\title{
ANALYSIS OF THE LOW-LEVEL WASTE RADIONUCLIDE INVENTORY FOR THE RADIOACTIVE WASTE MANAGEMENT COMPLEX PERFORMANCE ASSESSMENT
}

L. E. Plansky and S. A. Hoiland

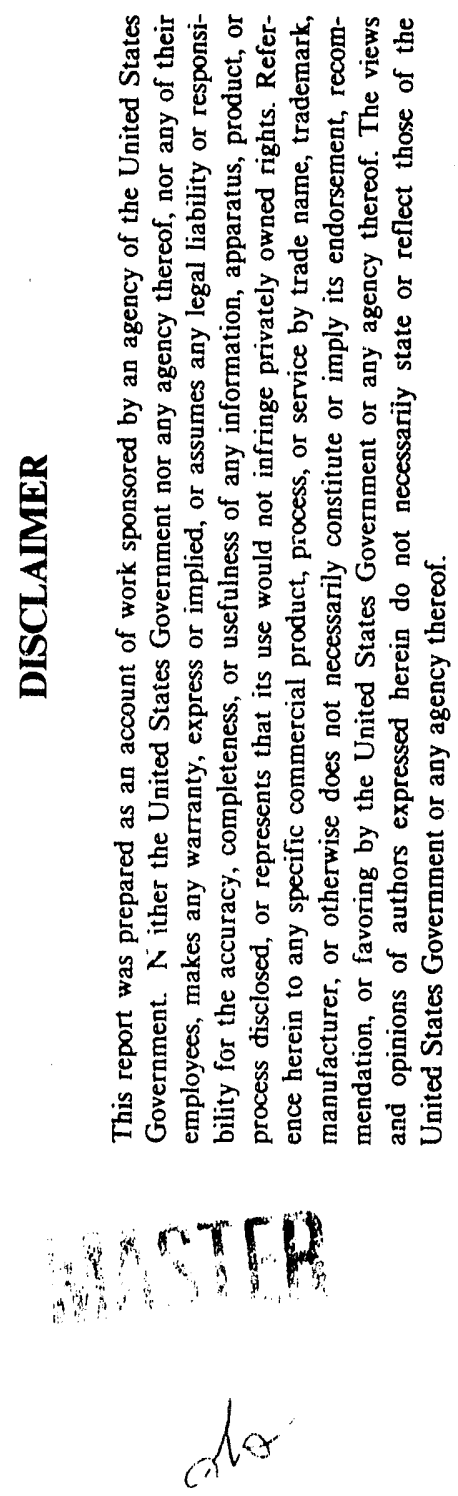

Prepared for the

U.S. Department of Energy

Waste Management Operations Technical Support Under DOE Contract No. DE-AC07-76ID01570
Idaho National Engineering Laboratory

Idaho Falls, Idaho 83415
Published February 1992 


\section{ABSTRACT}

This report summarizes the results of a study to improve the estimates of the radionuclides in the low-level radioactive waste (LLW) inventory which is buried in the Idaho National Engineering Laboratory (INEL) Radioactive Waste Management Complex (RWMC) Subsurface Disposal Area (SDA). The work is done to support the RWMC draft performance assessment (PA). Improved radionuclide inventory estimates are provided for the INEL LLW generators. Engineering, environmental assessment or other research areas may find use for the information in this report. It may also serve as a LLW inventory baseline for data quality assurance. The individual INEL LLW generators, their history and their activities are also described in detail. 
-
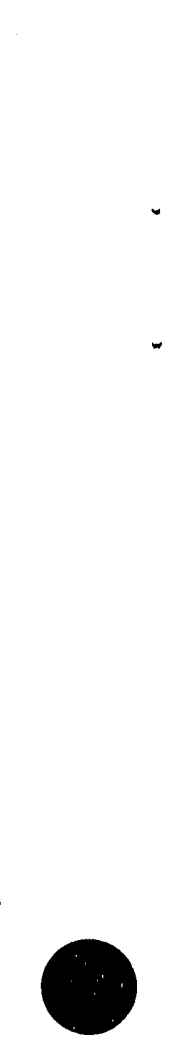

• 


\section{EXECUTIVE SUMMARY}

DOE Order 5820.2A, Chapter III (DOE 1988) addresses the management of low-level radioactive wastes and establishes the requirements for performance assessments of low-level waste (LLW) disposal sites such as the Subsurface Disposal Area located at the Radioactive Waste Management Complex at the Idaho National Engineering Laboratory. A draft performance assessment (PA) has been completed which indicates that the SDA conforms to these requirements (Maheras et al 1990).

This report summarizes the results of a study to improve the estimates of the radionuclides in the LLW inventory which is buried in the Idaho National Engineering Laboratory Radioactive Waste Management Complex Subsurface Disposal Area. The work is done to support the RWMC draft PA. Improved radionuclide inventory estimates are provided for the INEL LLW generators. Engineering, environmental assessment or other research areas may find use for the information in this report. It may also serve as a LLW inventory baseline for data quality assurance. The individual INEL LLW generators, their history and their activities are also described in detail. The offsite generators of the Interim Burial Ground (IBG) period (1961 to 1963) and Rocky Flats Operations (RFO) are not included. The IBG period wastes constitute 6000 cubic meters in volume with limited radionuclide identification and associated activity data available. Current plans and proposals for the buried RFO transuranic wastes (TRU) are that they will be retrieved or remediated.

LLW generated at the INEL consists primarily of protective clothing, paper, rags, packing material, glassware, tubing and other general use items (EG\&G 1984). Also included are contaminated equipment (such as glove boxes and ventilation ducts), process wastes (such as filter cartridges and sludges), and fuel hardware scrap. These materials are either contaminated with fission products or activation products from nuclear reactions.

Prior to 1971, developing disposal procedures, assay methodologies. lack of waste characterization requirements, and limited record keeping are responsible for uncertainties in the radionuclides contained in the low-level radioactive waste that was disposed up to that time. The uncertainty affects determination of the radionuclides and the amounts disposed (including Curies and mass) during the time period 1952 to 1971. During this period the disposal of LLW at the RWMC SDA was not subject to the same strict disposal guidelines as today. Formal disposal procedures, record keeping and practices were set in place only in 1961 (Rodgers 1985). Little information was recorded on the radionuclides present in the LLW until 1971. Radionuclide inventory information has been required before disposal since 1971. It is of primary importance to improve the LLW inventory estimates of the waste buried in the RWMC SDA. Exact knowledge of the radionuclides is also required. Such data are the basis for performance assessment. They are also important in compliance, health effects and risk assessment evaluations.

The LLW inventory that the present PA uses as its source term is the Radioactive Waste Management Information System (RWMIS) data for the years 1964 to 1988. The starting year of 1964 was chosen while waste disposed before that time was primarily TRU waste from RFO which is planned for retrieval or remediation. The latest RWMIS annual report, which includes the year 1990 , was released in August 1991 (Litteer 1991). The RWMIS is described in Appendix A. A listing of the radionuclides in the 1989 RWMIS database is given in Appendix B.

A series of tasks needed to obtain information and data for this study was identified and undertaken. The tasks comprising this study include: 
- Determine the sources of information and data

- $\quad$ Compare the RWMC PA LLW inventory to that given in the RWMIS

- Determine the significant generators using the RWMIS database

- Develop and send a questionnaire to INEL generators and analyze generator response

- Corroboration of what is reported by staff or available records

- Reviews of records and staff familiar with disposal operations at the RWMC

- Coordination with related programs in progress such as the Environmental Restoration Program (ERP)

- Peer review of the results obtained

The primary sources of information for this report have been the 1989 RWMISa annual report (Litteer 1990), the performance assessment data verification work given in (Plansky 1991), the INEL Site Development Plan (DOE-ID 1990), the draft performance assessment (Maheras 1990), and the RWMC History Report (Rodgers et al. 1985).

a. The differences up to 1990 in the latest inventory data reported in the 1990 RWMIS report (Litteer 1991) and the 1989 RWMIS report (Litteer 1990) used in this report are an 11 cubic meter volume increase for the year 1988 by ANL-W, and the inclusion of the SMC LLW of 124 cubic meters of volume and an activity of less than 1 Curie for the years 1986 to 1990. 


\section{Summary of Results}

\section{LLW Considered by the PA}

The LLW disposed during the years 1964 to 1988 is used as the source term in the PA. This LLW represents a volume of approximately 105,000 cubic mieters and 10 million Curies (Maheras 1990). The radionuclides considered by the PA are mostly beta-gamma emitters (Maheras 1990). The LLW inventory of the RWMIS database for the year 1988 (Litteer 1989) was the baseline data used. This database contained the disposed LLW data up to and including the year 1988.

In addition to the INEL LLW generated and disposed at the RWMC SDA from 1964 to 1988, the present PA includes radioactive wastes from: Argonne National Laboratory East (ANL-E) (1980 to 1988); RFO (minor amounts--1971 to 1973); and, the waste stored on Pad-A (1972 to 1978). Other minor generators of LLW included are the off site generators Brookhaven National Laboratory (BNL) and Bendix Field Engineering (BEN) (minor amounts--1983 and 1986). LLW from the decommissioned, INEL Organic Moderated Research Experiment (OMRE) is also included for the years 1964 and 1965. The Curie discrepancies between the PA and the RWMIS (circa 14,000 Ci) noted by Plansky (1991) have been resolved. The differences are generator changes present in the latest RWMIS database but which post-date the PA. Other than the noted discrepancies, the PA agrees with the 1988 RWMIS annual report (Litteer 1989) in volume and total Curies for the years considered to the degree of accuracy given in the RWMIS annual reports.

\section{Key LLW Generators}

The largest INEL generators of solid LLW are presently ANL-W, CPP, NRF, and TRA. They have also been the largest generators of LLW in the past along with TAN.

\section{Generator Agreement with RWMIS}

For the disposed LLW data entered in the RWMIS database, the INEL generators indicate that the disposed LLW data generally agree with the RWMIS data for the period 1971 to present.

The pre-1971 RWMIS data entries which the RWMIS reports were obtained from available reports and site-wide annual totals summarized by generators. These data include generator, volume and activity information, but no radionuclide information. The LLW disposal information kept before 1971 did not require radionuclide characterization. Disposal location entries were provided for on the waste shipping manifests, but they were often not filled out sufficiently. Disposal location was not recorded in the RWMIS database for pre-1971 LLW. These data have been required for LLW shipments since 1971. The RWMIS contains the burial location and radionuclide information since 1971.

Little or no radionuclide information is available for the pre-1961 disposed LLW. Some 300 pre-1960 shipping manifests have been found that have never been recorded. These are to be examined by ERP staff for possible inclusion in the RWMIS database. 


\section{Generlc Radionuclides}

A total volume of approximately 194,000 cubic meters and 11.6 million Curies of low-level radioactive waste from INEL and offsite generators has been disposed in trenches, pits and soil vaults at the RWMC SDA from 1952 to 1989 (Plansky 1991).

For the time period 1971 to 1989 , less than $2 \%$ of the activity was assigned a generic radionuclide classification, that is: as being mixed activation products (MAP), mixed fission products (MFP), or unidentified beta gamma or alpha emitting radionuclides UI-BG or UI-Alpha).

Approximately 4.6 million Curies of LLW were disposed in the RWMC SDA before 1971 which were assigned a generic radionuclide classification of UI-BG (Plansky 1991). This is about 1/3 of the total LLW buried since 1952. Generator based improvements for the radionuclide estimates assigned to these generic radionuclide classifications are an important source of improved radionuclide information. The generic assignments used in the RWMIS and the PA are: ${ }^{\mathrm{a}}$

$\begin{array}{ll}\text { Unidentified-Beta-Gamma (UI-BG) } & 100 \% \mathrm{Fe}-59 \\ \text { Unidentified-Alpha (UI-ALPHA) } & 100 \% \text { Po-210 } \\ \text { Mixed Activation Products (MAP) } & 100 \% \text { Co-60 } \\ \text { Mixed Fission Products (MFP) } & 100 \% \text { Cs- } 137 .\end{array}$

The generators and their approximate Curies of generic classified LLW disposed from 1952 to 1989 include:

TRA: $\quad 1,392,000 \mathrm{Ci}$ UI-BG and $84,500 \mathrm{Ci}$ of MAP/MFP radionuclides

NRF: $\quad 3,100,000 \mathrm{Ci}$ of UI-BG radionuclides

CPP: $\quad 100,000 \mathrm{Ci}$ of UI-BG and $25,000 \mathrm{Ci}$ of MAP/MFP radionuclides

ANL-W: $\quad 50,000 \mathrm{Ci}$ of UI-BG and $1,500 \mathrm{Ci}$ of MAP/MFP radionuclides

TAN: $\quad 83,000 \mathrm{Ci}$ of UI-BG radionuclides

RWMC: $\quad 61,000 \mathrm{Ci}$ of UI-BG radionuclides.

Maheras and Rood (1991) give analyses for the improvement of these generic classified radionuclides. They suggest that Niobium -94 be used as the predominant UI-BG radionuclide instead of $\mathrm{Fe}-59$. The present PA has does include the high, Ni-63 content shipments from NRF made since the beginning of the 1970's. For CPP and NRF, indications are that the radionuclide mix in the disposed LLW has not changed appreciably from what is generated today.

a. Most of the UI-BG LLW is from the pre-1971 time period. Most MAP/MFP LLW was reported after 1970. There was very little LLW classified as UI-ALPHA. 


\section{Inventory Improvement}

Improvements to the estimates of the disposed LLW are summarized immediately below. They are discussed in the individual generator sections in this report below. Details on their implementation are given in the last section of this report.

Improvements which can immediately be implemented by the PA are:

- The annual changes to the RWMIS since 1988

- Generator supplied changes to the RWMIS by CPP, TAN and LOFT/CTF present in the RWMIS but not included in the PA (those noted above which caused the discrepancy between the PA and RWMIS)

- Generator supplied recommendations from TAN for MFP and TAN generic radionuclides.

- Generator supplied recommendations from ANL-W and ANL-W generic radionuclides.

- Generator supplied recommendations from CPP and CPP generic radionuclides.

- The allocation of RWMC generic LLW to other INEL generators.

- The exclusion of the LLW in Pad-A. Pad-A is planned for remediation.

Improvements which require analysis and cooperation between other INEL staff before they can be considered further or implemented in the PA are:

- Obtain generator response from TRA and NRF

- Develop an improved radionuclide breakdown for the generic radionuclides in LLW disposals for which the generic radionuclide classification can not be resolved. This work has been started (Maheras and Rood 1991).

- Estimate TRA and NRF radionuclide improvements based on the improved radionuclide breakdown

- $\quad$ Reduced waste weights could be used. Shielded container weights were entered as the waste weights in many instances by NRF up to 1970. The RWMIS records containing these entries need to be identified and assessed for the potential improvement they may give.

- $\quad$ NRF and TRA Curies could be decreased for the shipment records for which liberal Curie estimating rules were used during the $1960 \mathrm{~s}$. Time away from core and Curic estimates due to shielding were conservative estimates. The RWMIS records containing these entries need to be identified and assessed for the potential improvement they may give. 
- RWMIS data entries - ouilier analysis. The historical shipping manifests and RWMIS best available data file contain approximately 45 records having some 5 million Curies of LLW. These records are suspect and could potentially reduce the total disposed LLW activity.

- The exclusion of the LLW in Pit-9. 'Pit-9 is planned for remediation. The LLW may be reburied in the pit, however.

\section{Changes Due to Inventory Related Findings of the Environmental Restoration Program (ERP)}

Staff of ERP have been examining the available pre-1971 shipping manifests which were obtained from the Federal Repository' in Seattle, Washington. After examination of the pre-1971 archives is completed, they plan on examining the post-1971 archives. One goal of their work is to suggest improvements to the RWMIS database.

The examination of the shipping archives will require the analysis of the findings. Specific issues may arise from such an examination. A statistical analysis of the pre-1971 shipping manifests against the RWMIS best available data file (the RWMIS BAD-File) is also being done.

Data input errors in pre-1971 shipping manifests have been found by ERP and Waste Management staff. Additionally, approximately 300 pre-1960 shipping records have been found for the generators CPP, SPERT and TRA which are not included in the RWMIS BAD-File. Present plans of ERP call for sub-contracting a detailed analyses of the shipping manifests and the identification of these and other questionable records for inclusion in the RWMIS database. A risk assessment effort which addresises the LLW by burial location is also planned as part of the ERP work. 


\section{CONTENTS}

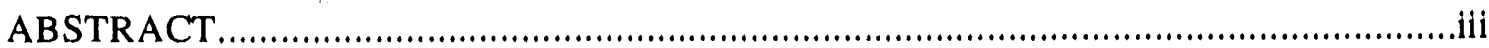

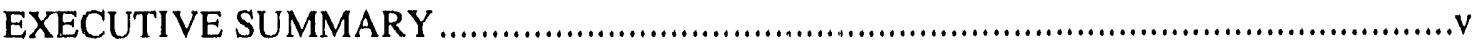

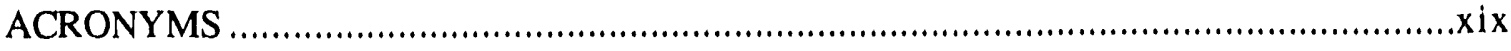

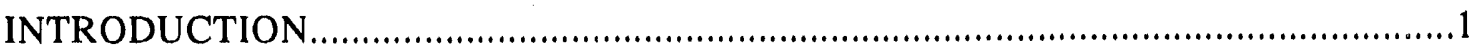

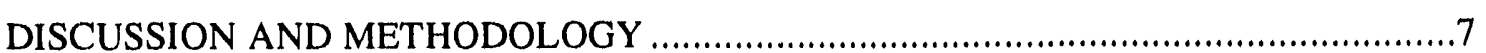

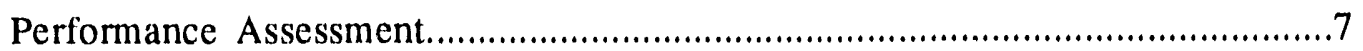

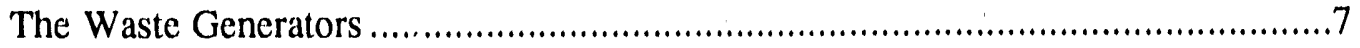

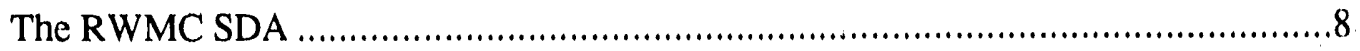

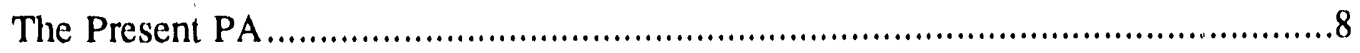

Methodology, Sources of Information, and Radionuclide

Inventory Improvements..................................................................

Determine Sources of Information and Data..................................................10

Compare the RWMC PA LLW Inventory to that

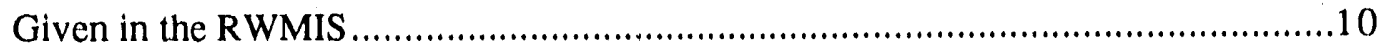

Using the RWMIS, Determine the Significant Generators .................................10

Develop and Send a Questionnaire to Operating INEL Generators and Analyze Generator Response.............................................................12

Corroboration of What is Reported by Staff or Available Records.......................12

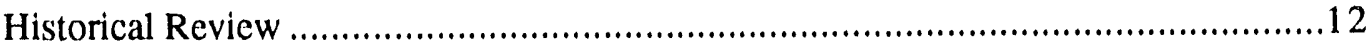

Coordination with the Environmental Restoration Program (ERP) .........................12

Peer Review of the Results Obtained...............................................................13

SOURCES OF INFORMATION AND GENERATOR ANALYSIS ..............................14

Radioactive Waste Information System (RWMIS) Changes...............................14

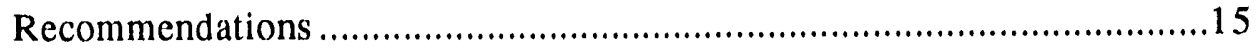

Preliminary Findings of the ERP RWMIS Database Analysis ..........................15

Recommendations ...................................................................17

GENERATOR: Radioactive Waste Management

Complex (RWMC/WMC)....................................................................18

Description and Historical Summary..................................................18

Operations Performed, Processes and Experiments..................................18

Affecting/Affected Facilities.................................................................20

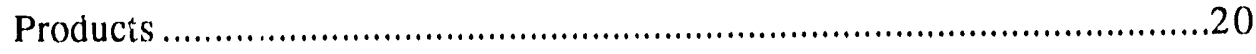

Radioactive Wastes and RWMIS Information......................................20

Questionnaire Response.............................................................2n

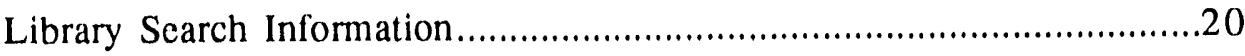




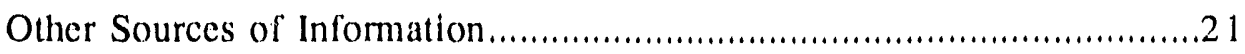

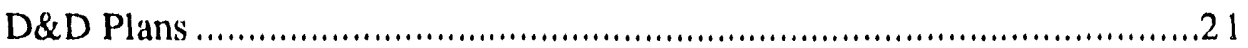

Error Sources and Specific Areas for Improving Information..................21

Justification of Improvements or Changes to the PA Inventory ...............21

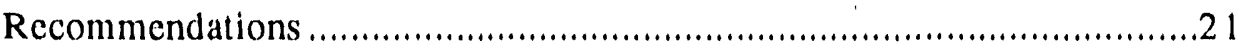

GENERATOR: Decontamination and Decommissioning (D\&D) ........................22

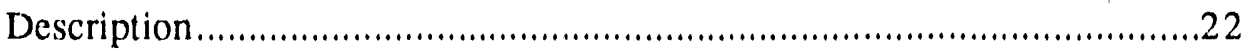

Operations Performed, Processes and Experiments................................22

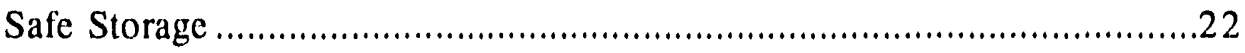

Entombment/In Place Stabilization......................................................22

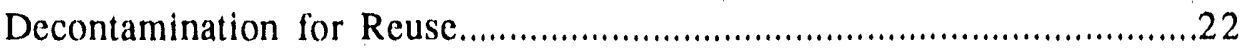

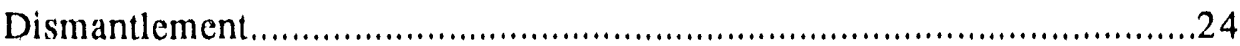

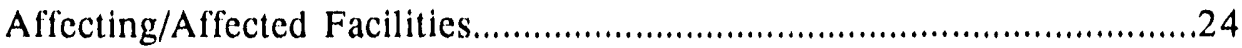

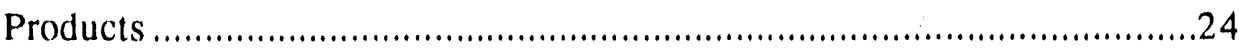

Radioactive Wastes and RWMIS Information.......................................24

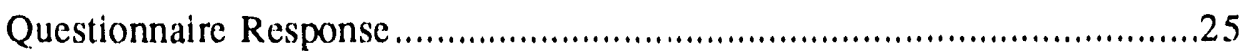

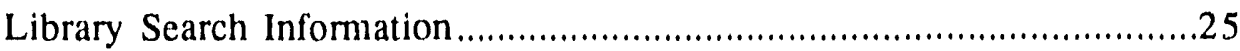

Other Sources of Information - Decontamination and

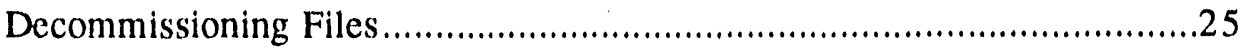

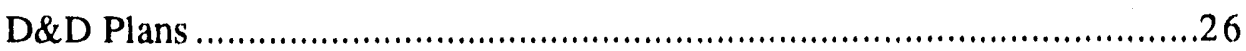

Error Sources and Specific Areas for Improving Information..................26

Justification of Improvements or Changes to the PA Inventory ................26

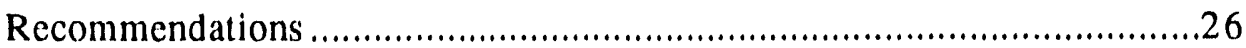

GENERATOR: Argonne National Laboratory-West (ANL-W) .........................27

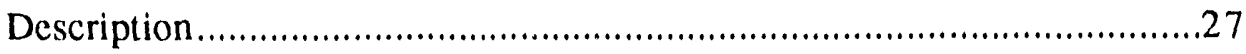

Operations Performed, Processes and Experiments....................................27

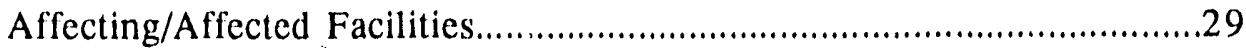

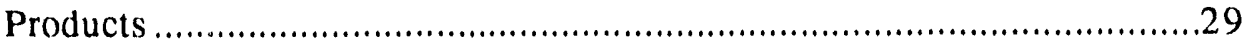

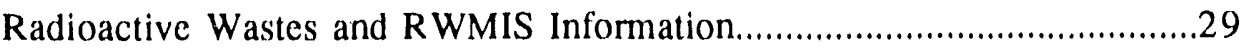

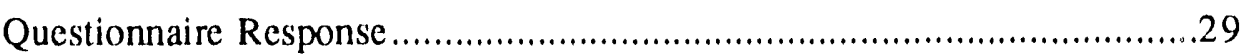

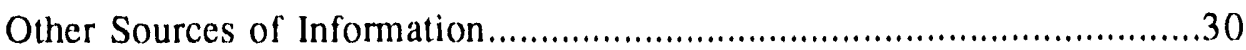

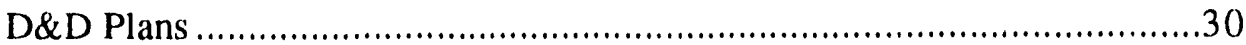

Error Sources and Specific Areas for Improving Information..................30

Justification of Improvements or Changes to the PA Inventory .................30

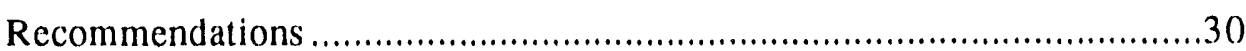

GENERATOR: Argonne National Laboratory-East (ANL-E)................................3 
Recommendations

GENERATOR: Central Faciitici, Area (CFA)/

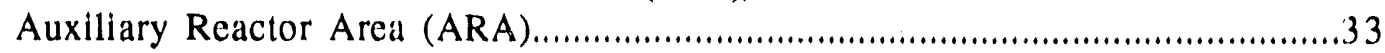

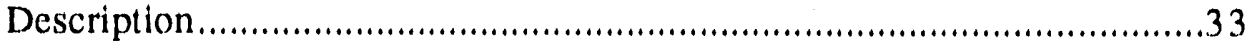

Operations Performed, Processes and Experiments.................................33

Affecting/Affected Facilities.............................................................. 36

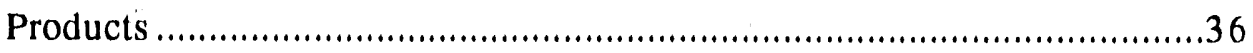

Radioactive Wastes and RWMIS Information..........................................36

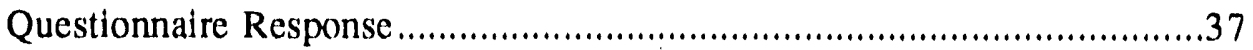

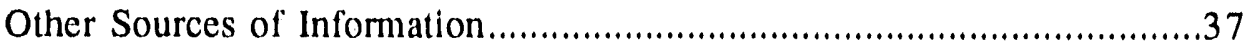

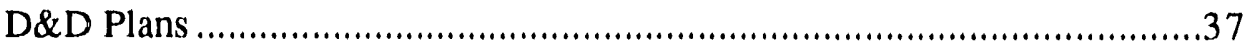

Error Sources and Specific Areas for Improving Ir.inrmation....................37

Justification of Improvements or Changes to the PA Inventory ..................38

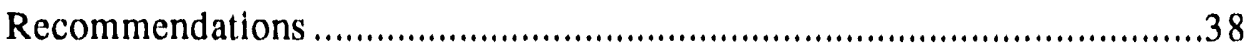

GENERATOR: Chemical Processing Plant (CPP) ..............................................39

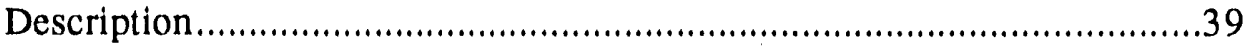

Operations Performed, Processes and Experiments...................................39

Affecting/Affected Facilities..................................................................39

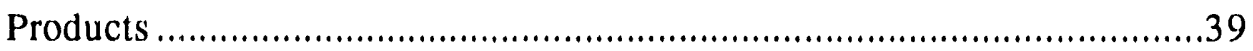

Radioactive Wastes and RWMIS Information........................................39

Questionnaire Response .............................................................41

Other Sources of Information.........................................................

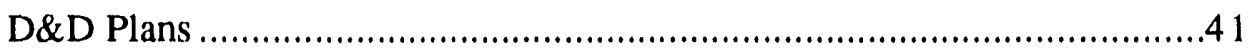

Error Sources and Specific Areas for Improving Information..................42

Justification of Improvements or Changes to the PA Inventory ................42

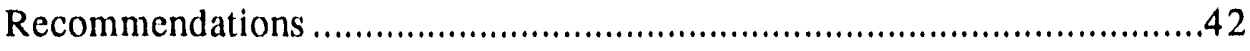

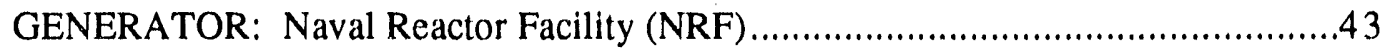

Description..........................................................................43

Operations Performed, Processes and Experiments...................................43

Affecting/Affected Facilities................................................................43

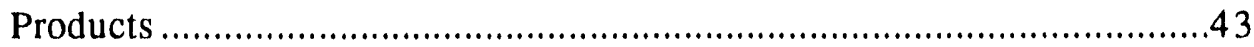

Radioactive Wastes and RWMIS Information.......................................43

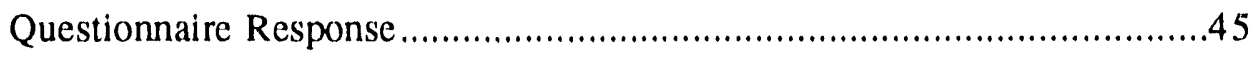

Other Sources of Information..........................................................45

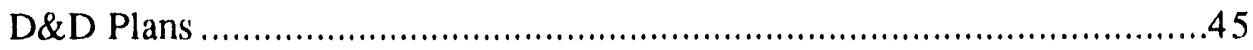

Error Sources and Specific Areas for Improving Information .................45 
Justification of Improvements or Changes to the PA Inventory..... .45

Recommendations

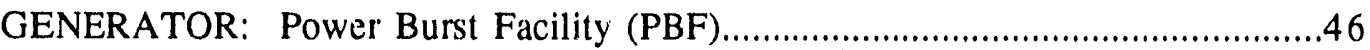

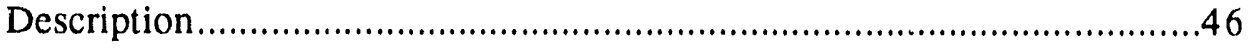

Operations Performed, Processes and Experiments....................................46

Affecting/Affected Facilities...............................................................49

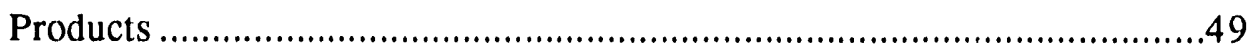

Radioactive Wastes and RWMIS Information........................................49

Questionnaire Response ......................................................................49

Library Search Information..........................................................50

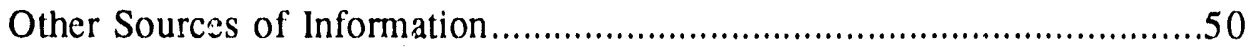

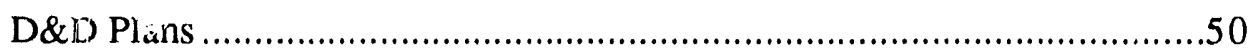

Error Sources and Specific Areas for Improving Information...................50

Justification of Improvements 01 Changes to the PA Inventory .................50

Recommendations …......................................................................5 50

GENERATOR: Waste Experimental Reduction Facility (WERF)..........................51

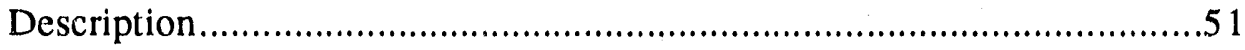

Operations Performed, Processes and Experiments...................................51

Affecting/Affected Facilities.................................................................51

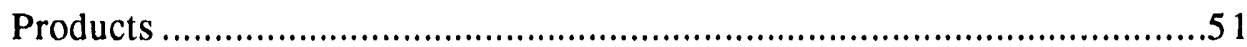

Radioactive Wastes and RWMIS Information........................................51

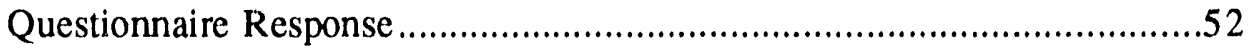

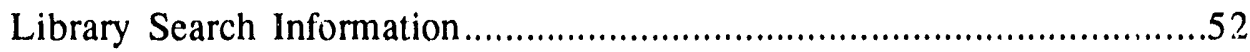

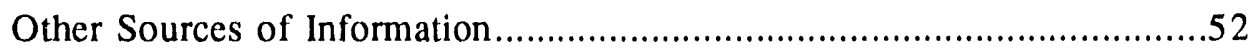

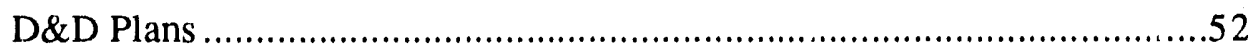

Error Sources and Specific Areas for Improving Information..................52

Justification of Improvements or Changes to the PA Inventory .................52

Recommendations ...................................................................5

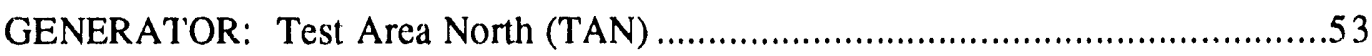

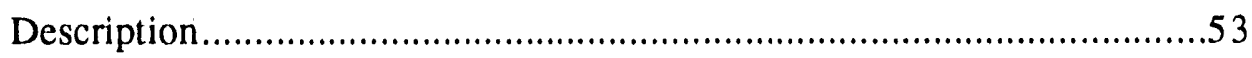

Operations Performed, Processes and Experiments..................................53

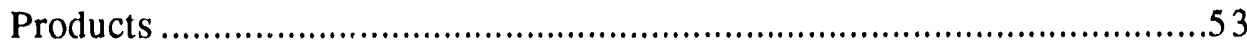

Radioactive Wastes and RWMIS Information.......................................55

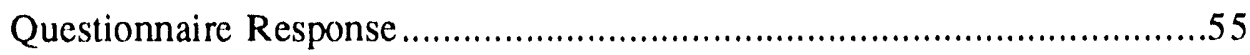

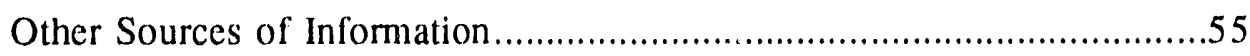

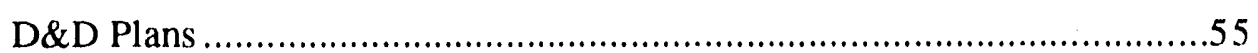


Error Sources and Specific Areas for Improving Information...................56

Justification of Improvements or Changes to the PA Inventory ................56

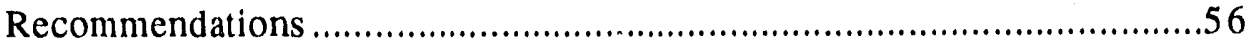

GENERATOR: Loss-of-Fluids Test (LOFT) Facility/

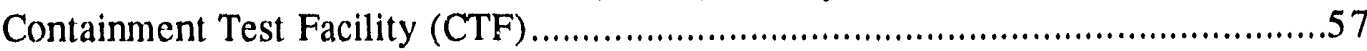

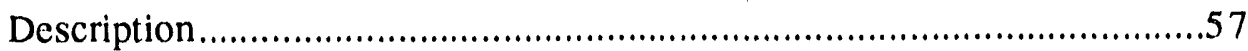

Operations Performed, Processes and Experiments...................................57

Affecting/Affected Facilities.............................................................57

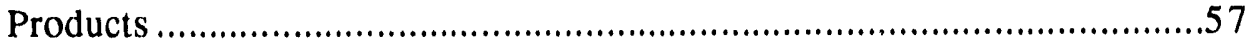

Radioactive Wastes and RWMIS Information..........................................57

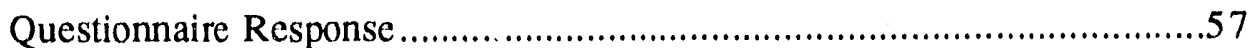

Other Sources of Information .........................................................58

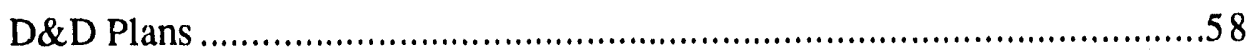

Error Sources and Specific Areas for Improving Information...................58

Justification of Improvements or Changes to the PA Inventory .................58

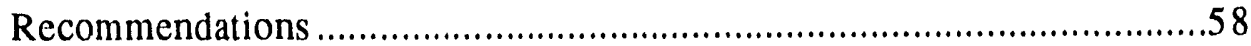

GENERATOR: Test Reactor Area (TRA) …..............................................59

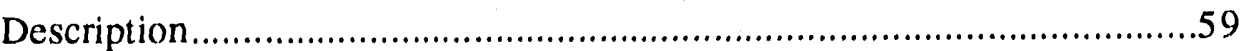

Operations Performed, Processes and Experiments...................................59

Affecting/Affected Facilities...................................................................59

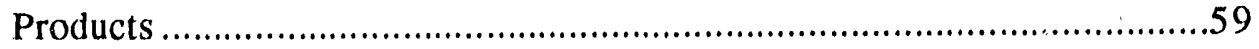

Radioactive Wastes and RWMIS Information..........................................61

Questionnaire Response...............................................................61

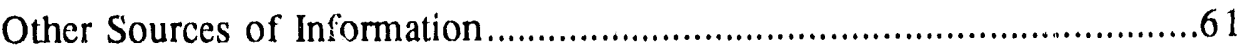

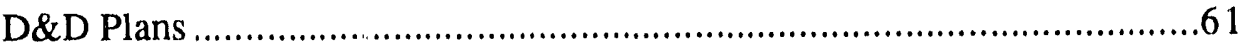

Error Sources and Specific Areas for Improving Information..................61

Justification of Improvemints or Changes to the PA Inventor ..................61

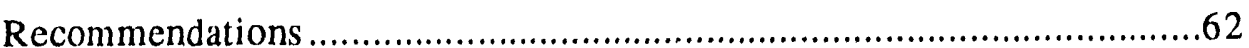

RADIONUCLIDE INVENTORY CHANGES FOR THE PA ...................................6

Revised Radionuclide Inventory for the PA..................................................63

Changes Due to Inventory Related Findings of the

Environmental Restoration Program (ERP) .......................................64

Changes not Requiring Interface with Other INEL Areas ..................................66

Annual Changes to the RWMIS since 1988 .........................................66

Generator Changes to the RWMIS by CPP, TAN and

LOFT/CTF Present in the RWMIS but not Included in the PA 66 
Generator Recommendations from TAN.

Generator Supplied Recommendations from ANL-W

and ANL-W Generic Radionuclides

Generator Supplied Recommendations from CPP

and CPP Generic Radionuclides

The Allocation of RWMC Generic LLW to Other

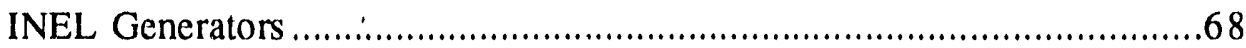

The Exclusion of Pad-A Radionuclides...................................................68

REFERENCES

APPENDIX A--A BRIEF HISTORY OF THE RADIOACTIVE WASTE

MANAGEMENT DATABASE (RWMIS)

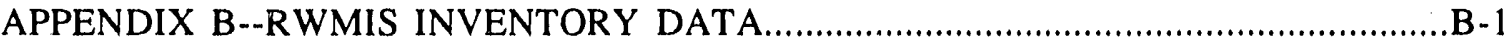

APPENDI. $\nvdash$ C--GENERATORS DISPOSING LLW IN THE RWMC SDA ….................... 1

APPENDIX D--THE TRENCH AND PIT DISPOSAL LOCATIONS

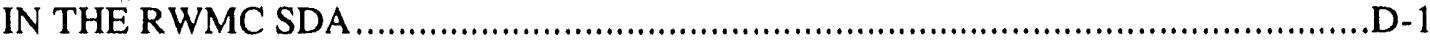

APPENDIX E--THE GENERATOR QUESTIONNAIRE ............................................

APPENDIX F--ANALYSIS OF THE GENERIC RADIONUCLIDES................................ 1

APPENDIX G--STAFF CONTACTS, REVIEWERS AND SOURCES

OF INFORMATION

\section{FIGURES}

1. Overview of INEL, RWMC and the SDA

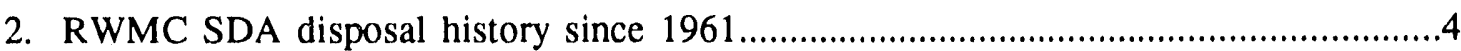

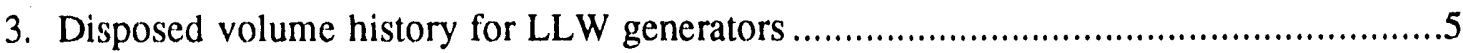

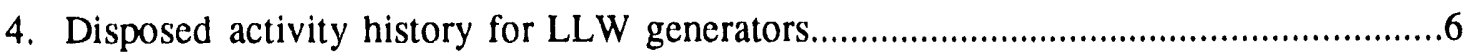

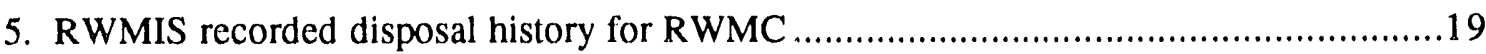

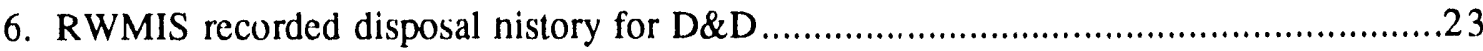

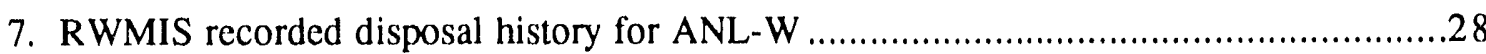




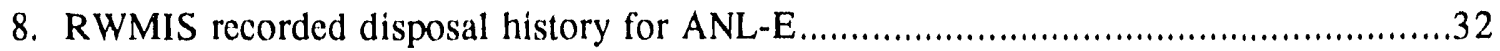

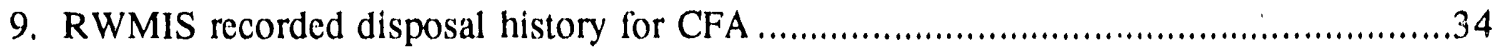

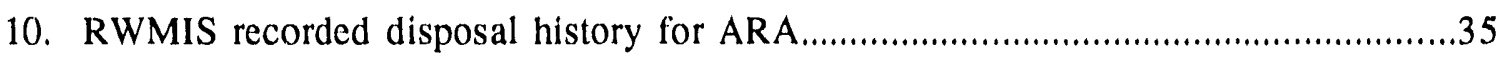

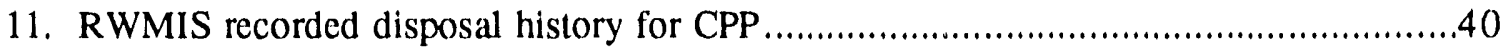

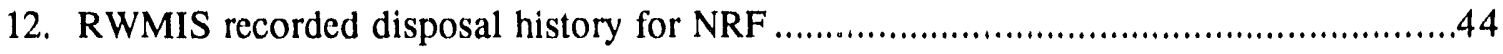

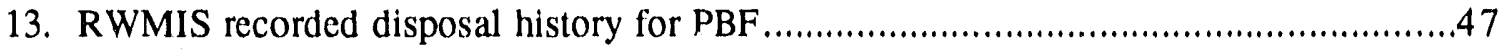

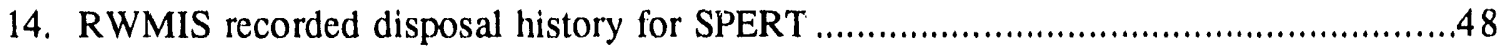

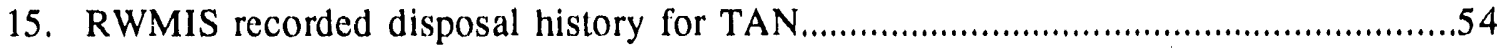

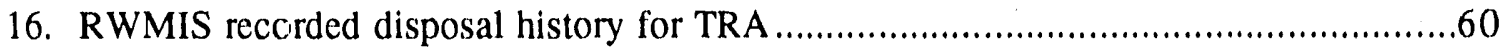




\section{ACRONYMS}

ANL-W

ANL-E

ANP

ARA

$\mathrm{Ci}$

CFA

CPP

D\&D

ERP

$\mathrm{g}$ or $\mathrm{gr}$

$\mathrm{h}$ or hr

IBG

IET

INEL

LLW

LOFT or CTF

NA or DNA

$\mathrm{nCi}$

NRF

PA

PBF

PER or SPERT

RFO

SDA

SL-1

RWMC or WMC

RWMIS

TAN

TRA

TRU

WAC

WERF
Argonne National Laboratory-West

Argonne National Laboratory-East

Aircraft Nuclear Propulsion

Auxiliary Reactor Areas

Curie, a unit of measurement

Central Facilities Area

Idaho Chemical Processing Plant

Decontamination and Decommissioning

Environmental Restoration Program

Gram, a unit of mass

Hour, a unit of time

Interim Burial Ground Period

Initial Engine Test

Idaho National Engineering Laboratory

Low-Level Waste

Containment of Fluids, or LOFT - Loss of Fluid Test

Not Applicable or Does Not Apply

NanoCurie(s), nano (10-9) Curies

Naval Reactor Facility

Performance Assessment

Power Burst Facility

Special Power Excursion Test Reactor

Rocky Flats Operations

Subsurface Disposal Area

U.S. Amy Stationary Low Power Reactor

Radioactive Waste Management Complex

Radioactive Waste Management Information System

Test Area North

Test Reactor Area

Transuranic Nuclide Contaminated Waste

Waste Acceptance Criteria

Waste Experimental Reduction Facility 


\section{ANALYSIS OF THE LOW-LEVEL WASTE RADIONUCLIDE INVENTORY FOR THE RADIOACTIVE WASTE MANAGEMENT COMPLEX PERFORMANCE ASSESSMENT}

\section{INTRODUCTION}

The INEL was established in 1949 as the National Reactor Testing Station (NRTS), a location where the U.S. Atomic Energy Commission (AEC) could build, test, and operate different types of nuclear reactors, support facilities, and equipment with maximum safety. As of October 1980, 52 reactors were built at the INEL of which 17 were operating or operable. Several service and support buildings have been constructed over the years. The RWMC SDA was opened in the southwestern comer of the INEL in 1952. The SDA is a controlled 96 acre area on the western part of the RWMC.

The INEL is located along the northwestern edge of the eastern Snake River Plain in southeastern Idaho (Figure 1). Lying at the foot of the Lost River, Lemhi, and Bitterroot Mountain ranges, the INEL comprises some contiguous 2305 square kilometers of the Snake River Plain. Portions of the area were once used by the military as a gunnery range. The INEL includes all the former military area and a large adjacent area withdrawn from the public domain for use by the DOE. Most of the land withdrawn from public domain lies in Butte County, Idaho, although it extends into Bingham, Bonneville, Jefferson, and Clark Counties.

Developing disposal procedures, assay methodologies, lack of waste characterization requirements, and limited record keeping in the early years (1952 to 1970) are responsible for uncertainties in the radioactive waste inventory that has been disposed at the RWMC SDA. Compounding this was the classified nature of some of the wastes buried. During the early years (1952 to 1970 inclusive) little or no information was recorded about what radionuclides were present in the LLW. Formal, documented procedures and record keeping of the waste shipments were not implemented until 1960-1961 (Rodgers 1985). Non-classified waste shipments were observed and witnessed by health physics personnel starting in 1962 . For many of the classified waste shipments, unauthorized personnel were not permitted to observe or record the waste burials. Characterization of the radionuclides present in the LLW disposed at the RWMC SDA was not required prior to 1971. Good characterization methods for the waste were not available at that time. Regular monitoring, characterization and recording of the radionuclides in the waste shipments was started in 1971. An unknown number of pre-1971 LLW shipping records were destroyed because the records retention time was exceeded. The shipping weights, volumes and activities were often rough estimates. In some instances the shipping weight of the waste container was taken as the waste weight, giving inflated values for the weight, or mass, of the actual waste.

LLW received at the SDA from 1952 to 1957 was disposed in trenches. No upper limit was established for the radiation level of the wastes which could be buried until 1957 (Rodgers 1985). The first trench was opened in July 1952 for burial of INEL generated waste. Trenches 1 through 10 were used between 1952 and 1957. These trenches were dug in the overburden down to the beginning of the basalt bedrock. LLW disposed in trenches typically had an activity of $500 \mathrm{mR}$ or more at 0.9 meters from the surface of the waste container (Rodgers 1985). Pits were used starting in 1957 while trenches continued to be used for RFO waste and on site generated LLW. INEL generated LLW disposed in pits generally had an activity of less than $500 \mathrm{mR} / \mathrm{h}$ at 0.9 meters from the surface of the waste container. For trench and pit burial starting in 1970, the radioactivity 


\section{Radioactive Waste Management Complex}

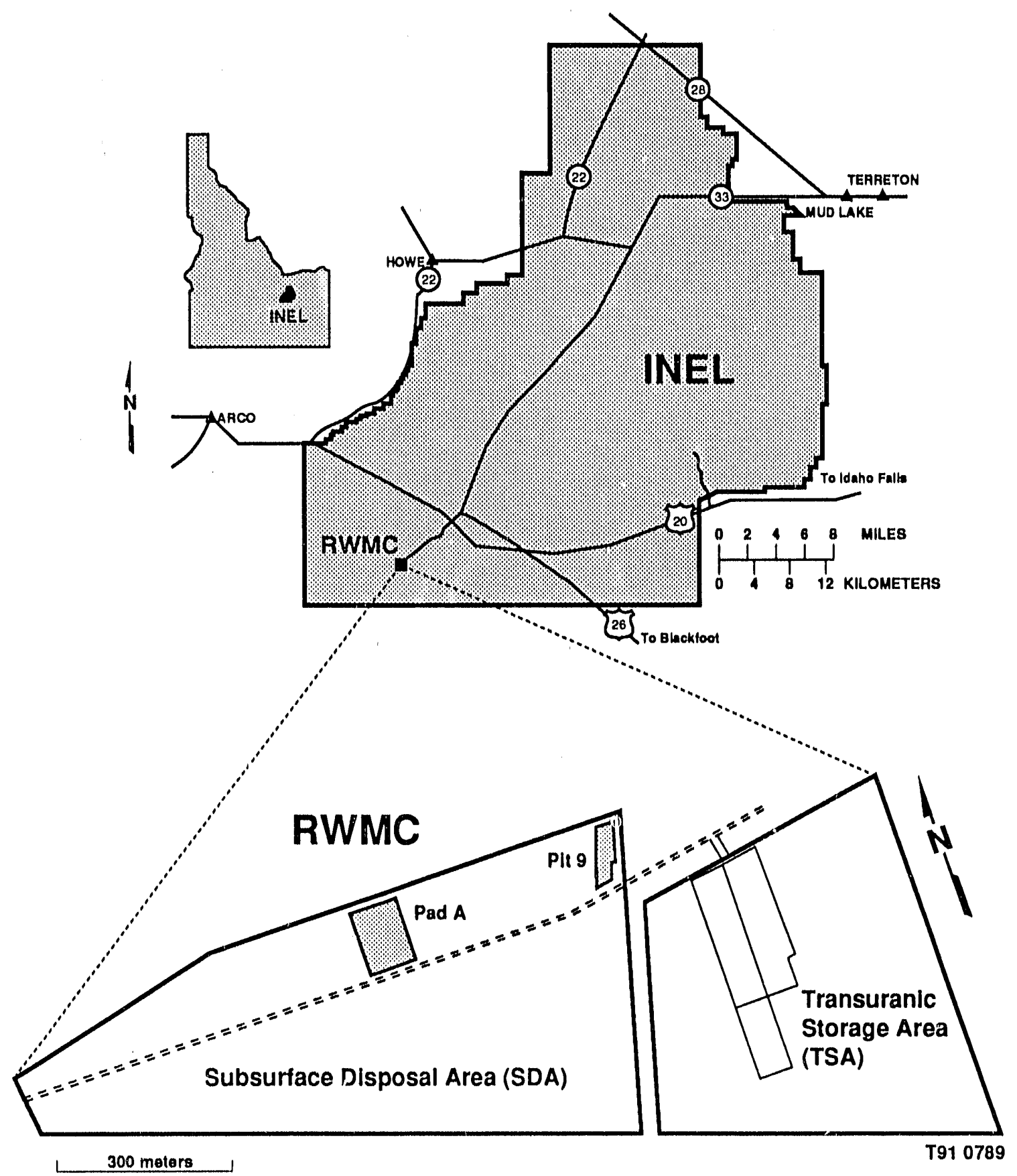

Figure 1. Overview of the INEL, RWMC and the SDA. 
concentration of transuranic radionuclides (TRU) was limited to less than $10 \mathrm{nCl}$ per gram (Rodgers 1985). Wastes from RFO usually excceded this limit. INEL LLW was normally placed in cardboard boxes and sealed. The sealed boxes were placed in metal Dempster Dumpsters, labeled as radioactive waste and disposed. Large items were buried without size reduction.

Presently, LLW containing transuranic isotopes with an activity of less than $10 \mathrm{nCl}$ per-gram is disposed. Two types of disposal locations are in use: pits and soil vaults. The former are for contact handled $(\mathrm{CH})$ LLW which has radiation levels less than $500 \mathrm{mR} / \mathrm{h}$ at 0.9 meters from the surface of the waste container. The latter are for remote handled (RH) LLW that has radiation levels more than $500 \mathrm{mR} / \mathrm{h}$ at 0.9 meters from the surface of the waste container. Figures 2,3 and 4 show the volume and activity disposal history of the INEL generators disposing LLW in the RWMC SDA from 1960 to 1989. Appendix D gives a summary of the LLW burial history. 


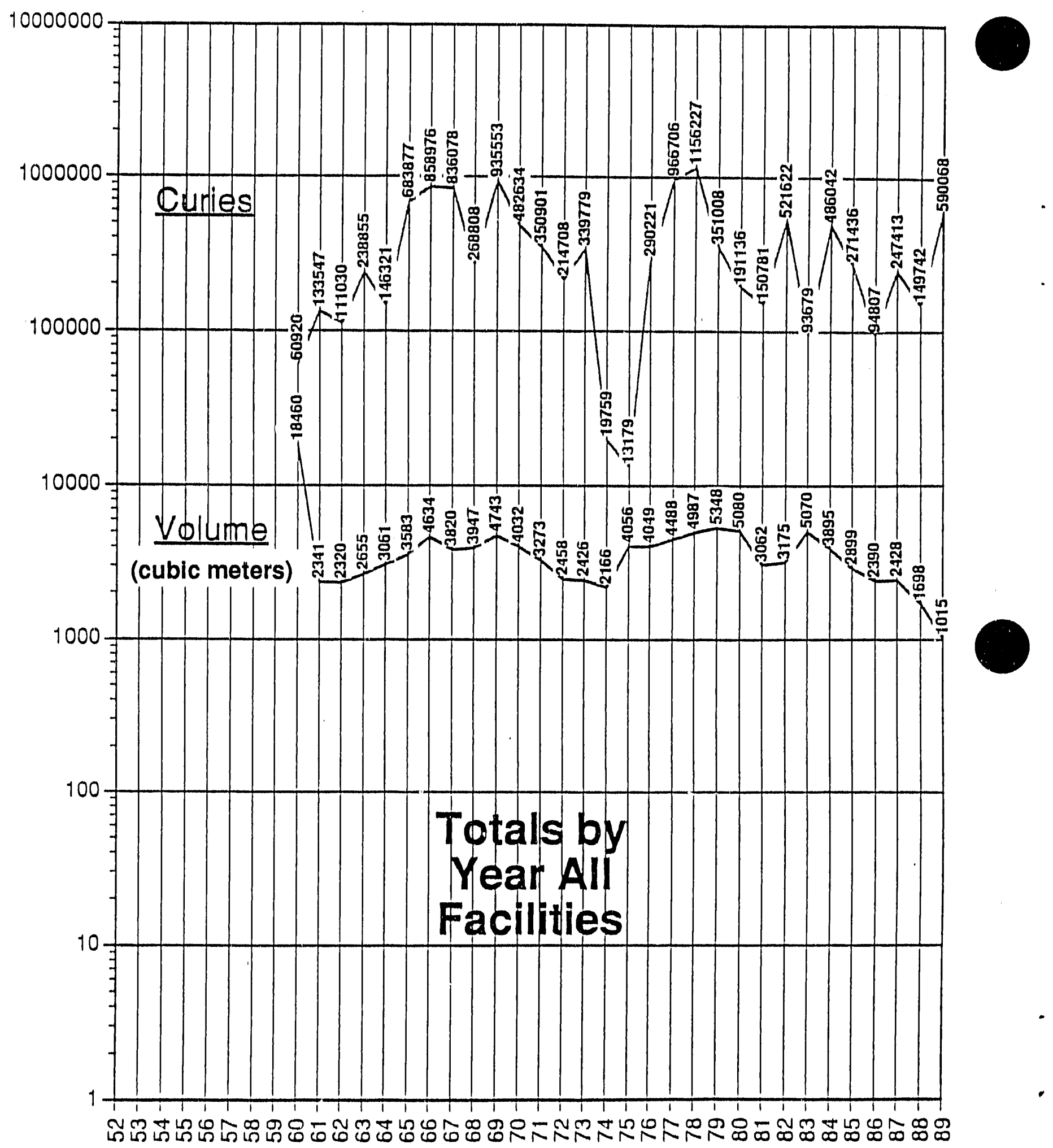

(WERF, RFO, AND LOFT EXCLUDED)

Figure 2. RWMC SDA disposal history since 1961. 


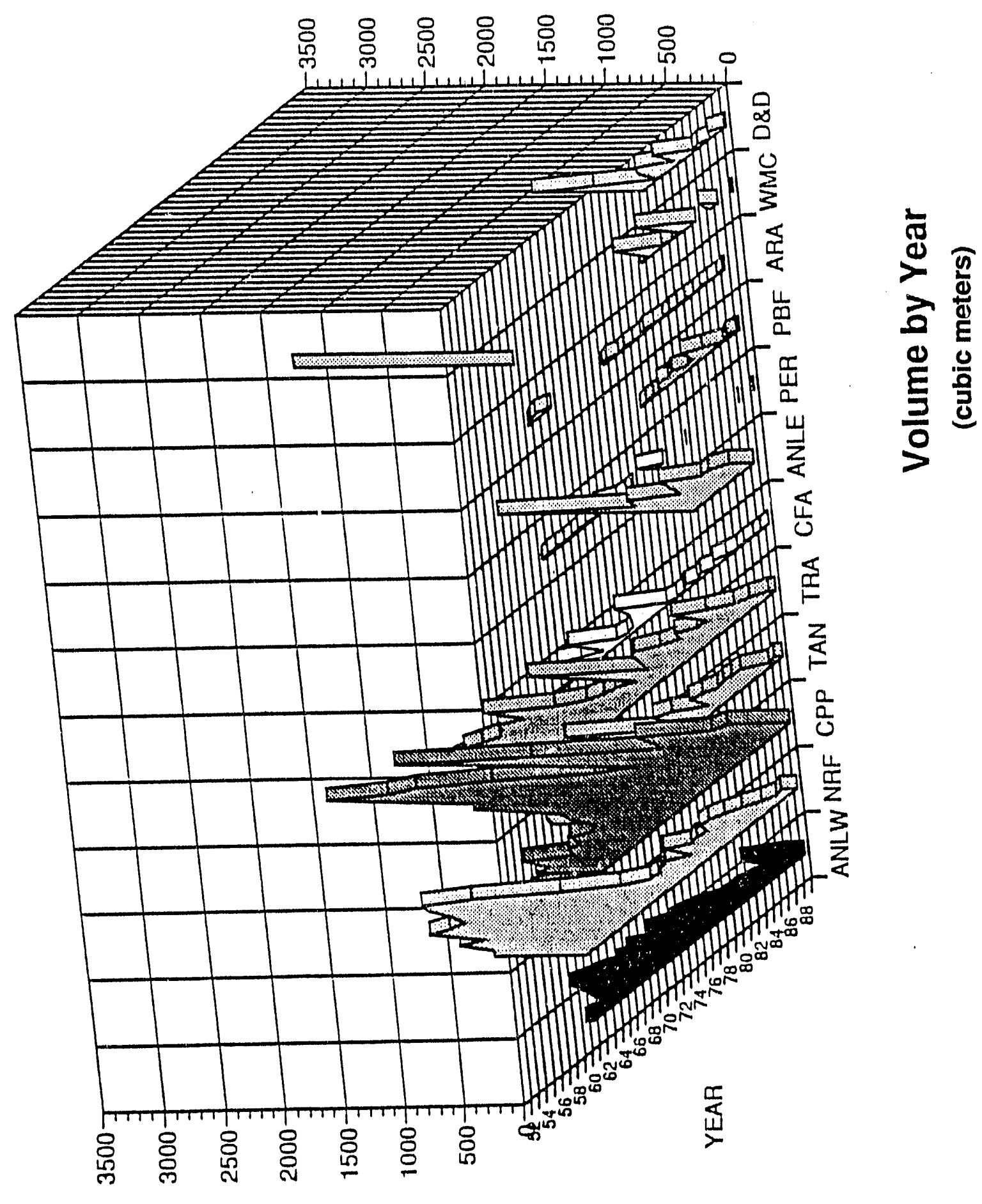

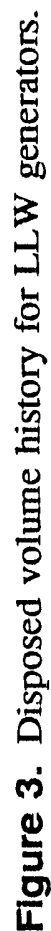




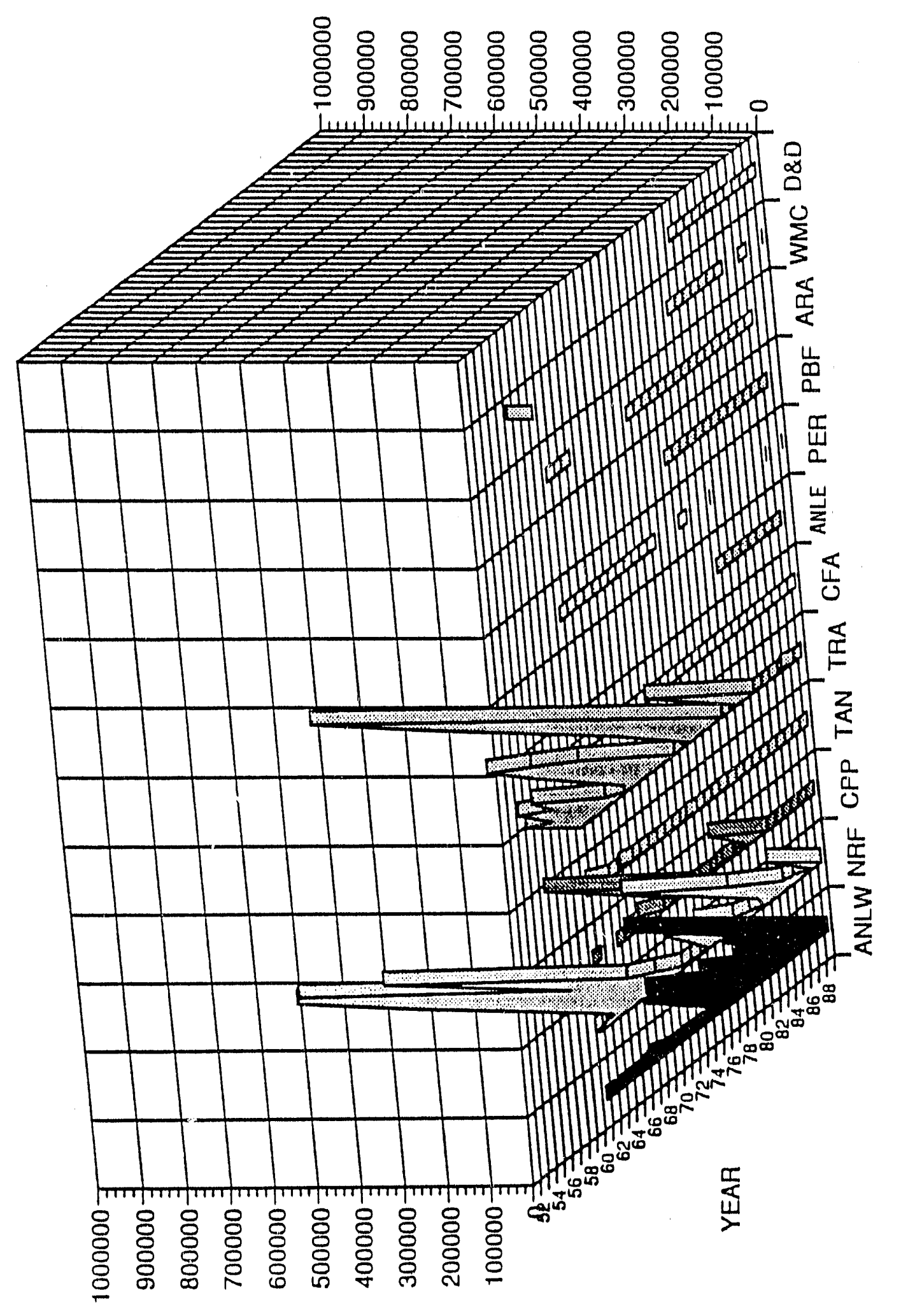

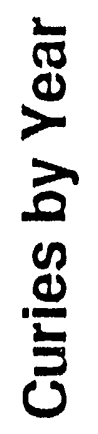

造 


\section{DISCUSSION AND METHODOLOGY}

\section{Performance Assessment}

Performance assessment is determining a measure of how well a system or facility performs its objective of isolating radionuclides and preventing their release into the biosphere. Performance assessment may be required to satisfy constraints or regulations. For a low-level radioactive waste disposal facility, a working definition of performance assessment is (Case 1988 and 1989):

A systematic analysis of a low-level radioactive waste disposal facility and its environs for the purpose of demonstrating compliance with specific radiological performance objectives (or regulations). The assessment addresses the current status of the facility and projects future conditions for as long as a potential for significant radiological impact exists.

The U.S. DOE (1988) defines performance assessment as:

A systematic analysis of the potential risks posed by waste management systems to the public and environment, and a comparison of those risks to established performance objectives.

Performance assessment is an iterative process which requires the repeated application of identifying data needs, data collection, analyses and modeling. A performance assessment is undertaken to demonstrate the safety of a disposal facility after operations cease and after the facility is closed. A performance assessment must frequently be done with available, incomplete information about a disposal facility, its design, its environment, and its buried waste.

Radionuclide behavior and transport are governed by the site characteristics, the waste, the waste containers, and the disposal system or facility in which the LLW is placed. Areas important to performance assessment for low-level radioactive waste disposal systems include the: geo-hydrologic character of the site; waste inventory; waste transport behavior; and, the disposal facility design including closure designs and actual closure. Site characterization is important in the near field, the area in the immediate vicinity of the waste and waste containers. The waste contains the radionuclides of the inventory. Final disposal facility design includes the determination of facility structure, geometry, materials, engineered barriers, covers, and in place monitoring systems. Waste containers, container failure, and the dynamics of radionuclide release from the containers into the biosphere are also key factors in a performance assessment.

\section{The Waste Generators}

The INEI, LLW generators which are currently operating are described in this report. Each generator has its own individual section together with any ancillary LLW generators related to them (such as ARA, which is described in its relation to CFA).

The waste generators which have disposed radioactive waste in the RWMC SDA from 1952 to present are given in Appendix C. This includes INEL generators which are disposing LLW and those which are no longer in operation that have disposed LLW in the RWMC SDA. Some of the INEL facilities are closed and decontamination and decommissioning is underway or has been completed. When applicable, this is noted in Appendix $\mathrm{C}$ as well as any prior names a generator or facility has had during its history. 
The primary off site generator has been the DOE operation at Rocky Flats, CO (RFO), RFO has disposed of some 63,352 cubic meters and $255,979 \mathrm{Cl}$ of predominantly transuranic (TRU) waste in the period 1954 to 1970. Small RFO LLW shipments, approximately 140() cubic meters and $90 \mathrm{Cl}$, were received and disposed in the RWMC SDA during 1971, 1972 and 1973. The RWMC PA includes these latter RFO shipments (Plansky 1991).

\section{The RWMC SDA}

The RWMC SDA is a controlled 96 acre area on the western part of the RWMC. Within the SDA are trenches, pits, soil vaults, and storage pad Pad-A. Support facilitics are external to the SDA itself. Table D-1 of Appendix D summarizes the waste burial history in these disposal locations in the SDA. Table D-2 of Appendix D gives the opening and closing dates of the trenches, pits, soil vaults, and storage pad, Pad-A.

Burial trenches were used between 1952 and 1981. Fifty-eight trenches were excavated. As one was filled and covered, another was prepared for conunued disposal operations. They were dug along predetermined centerlines and were scparated from adjacent trench centerlines by at most 4.9 meters. This allowed maximum use of available burial space without disturbing previously disposed waste. The width of the trenches was approximately 3.1 meters (those with collapsing walls were wider). The depth of a trench was approximately 4 meters and varied according to the depth of the basalt bedrock. Their length varied as the amount of usable free-run available the dimensions given may vary from trench to trench as well as over the burial history). Much of the high ruric count, remote handled LLW from ANL-W, CPP and NRF was disposed in the trenches before ths soil vault rows were opened in 1977.

Pits have been used from 1957 to the present. They are used for the disposal of beta-gamma contaminated LLW with radiation levels below $500 \mathrm{mR} / \mathrm{h}$ at $0.9 \mathrm{~m}$. Eighteen pits exist today - from Pit \#1 to Pit \#18. Pits 19 and 20 have also been identified for future waste disposal. Pits 1 through 16 have been closed. Pits are approximately 5 meters deep and 30 meters wide and vary in length.

Soil vaults are used to dispose of beta-gamma contaminated LLW with radiation levels greater than $500 \mathrm{mR} / \mathrm{h}$ at 0.9 meters. The soil vaults are cylindrical holes bored in the overburden. They are of varying depth and diameter between 0.4 meters and 2 meters arranged along a common centerline(s). The soil vaults are separated from previously disposed waste by a minimum of 0.6 meters.

Pad-A was used as an interim, above ground disposal pad for wastes of uranium and nitrate salts. These wastes were not TRU by current definition, but did contain more than $0.1 \mathrm{nCi} / \mathrm{gram}$ but less than $10 \mathrm{nCi} / \mathrm{gram}$ of TRU nuclides and had radiation levels less than $200 \mathrm{mR} / \mathrm{h}$ at the waste container surface. Pad-A was open from 1972 to 1978. The radioactive waste inventory presently reported for Pad-A is $70 \mathrm{Ci}$ and 10,400 -cubic meters.

\section{The Present PA}

The PA includes in its inventory the low-level waste disposed since 1964 in the pits, trenches, soil vaults, and Pad-A. The PA uses the reported RWMIS database (Plansky 1991; Litteer 1989) for the years 1964 to 1988 as its inventory. This was the baseline at the time the original PA was done 
(in the 1988 to 1989 time frame). The LLW in the inventory is divided into waste from two separate time periods for performance assessment: from 1964 through 1970; and, from 1971 to present (Maheras 1990). The first period is the period where little radionuclide information exists. The second period is the post 1970 period when radionuclide data was required prior to disposal and data entry in the RWMIS database.

In addition to the INEL LLW generators, the present PA includes wastes shipped from Argonne National Laboratory East (ANL-E) (1980 to 1988), RFO (minor amounts - 1971 to 1973), and the wastes stored on Pad A (1972 to 1978 and 1983). Other sources include the off site generators Brookhaven National Laboratory (BNL) and Bendix Field Engineering (BEN) (minor amounts - 1983 and 1986), and the closed, INEL Organic Modulated Research Reactor (OMRR) ( 565 cubic meters and $2,031 \mathrm{Ci}$ are included for the years 1964 to 1965).

A volume of approximately 105,000 cubic meters and 10 million Curies is included in the PA. The radionuclides considered are mostly beta-gamma emitters (Maheras 1990). The fission and activation radionuclides present in the time period 1964 to 1970 were estimated in the PA using the known radionuclides in the period 1971 to 1980 . The alpha emitting radionuclides in this period were estimated using the known alpha emitting radionuclides in the period 1979 to 1980 . For the time period 1971 to 1988 , less than $2 \%$ of the activity was declared as being mixed activation products, mixed fission products, or unidentified alpha or beta gamma emitting radionuclides. Approximately $1 / 3$ of the LLW buried before 1971 was classified as unidentified beta-gamma.

\section{Methodology, Sources of Information, and Radionuclide Inventory Improvements}

The methodology used for this study included:

- Determine sources of information and data

- Compare the RWMC PA LLW inventory to that given in the RWMIS

- Using the RWMIS, determine the significant generators

- Develop and send a questionnaire to operating INEL generators and analyze generator response

- Corroboration of what is reported by staff or available records

- Historical reviews of records and interviews with available staff familiar with disposal operations at the RWMC

- Coordination with related programs in progress such as the Environmental Restoration Program (ERP)

- $\quad$ Peer review of the results obtained

- Documentation of the results. 


\section{Determine Sources of Information and Data}

The most useful sources of information are: the present PA; the RWMIS database and the RWMIS annual report (RWMIS is taken as the baseline for comparison) including its radionuclide data; generator response to prepared questionnaire; available historical records and documents, including records of the ERP Program; and interviews with staff of the RWMC, ERP, and generators. These sources of information are described in this report.

\section{Compare the RWMC PA LLW Inventory to that Given in the RWMIS}

A detailed comparison of the present PA LLW inventory with that of the RWMIS is documented by Plansky (1991). This analysis shows that the present PA uses the inventory data of the RWMIS with the exception of revisions to activity values by the generators CPP, TAN, SMC and LOFT. These revisions post-dated the PA. The volumes match the RWMIS volumes well; six of the 25 years the PA covers have had the disposed Curies revised, primarily by CPP.

Generic classifications were assigned to radionuclides by R'WMIS which were not identified by the shipper. The PA presently uses the following assignment for these radionuclide classifications:

$\begin{array}{lll}\text { - } & \text { Unidentified-Beta-Gamma (UI-BG) } & 100 \% \text { Fe-59 } \\ \text { - } & \text { Unidentified-Alpha (UI-ALPHA) } & 100 \% \text { Po-210 } \\ \text { - } & \text { Mixed Activation Products (MAP) } & 100 \% \text { Co-60 } \\ \text { Mixed Fission Products (MFP) } & 100 \% \text { Cs-137 }\end{array}$

Maheras and Rood (1991, summarized in Appendix $F$ of this report) suggest a more conservative breakdown for the radionuclides of these generic classifications.

The original estimates of Curies and volume for LLW shipments to the RWMC SDA were done by the'generators. In some cases (primarily in the 1960s with some cases of continual use through 1980 s by other generators) shielded wastes were assigned a Curie value depending on the thickness of the lead shielding - times 10 for every inch of lead. For example, if a cask was evaluated as having $20 \mathrm{Ci}$ at 1 meter (circa $3 \mathrm{feet}$ ) from the cask and had four inches of shielding, the reported Curies were 20,000. In other instances, the estimation of Curies was done assuming that the LLW to be disposed had been removed from the core for only one month, when it may have been in storage at the generator longer. Both practices can be a cause for overestimating Curies.

\section{Using the RWMIS, Determine the Significant Generators}

Based on the inventory volume and Curie data as recorded in RWMIS, several facilities had peak years when comparatively large volumes of waste were shipped to the RWMC (Plansky 1991). Several facilities had peak years when large LLW volumes and/or Curie quantities were contained in the waste disposed in the RWMC SDA: 
Volume

- NRF: 1961-1973

- CPP: 1974-1979, 1982-1985

- TAN: 1963-1970, 1976-1980

- TRA: $1961-1970,1974-1976,1985-1986$

- WMC: 1960

Curies

- NRF: $\quad$ 1965-1971, 1976-1980, 1983-1985

- CPP: $1966-1969,1973-1976,1978-1982$

- TRA: $1961-1965,1968-1972,1976-1978,1982$

- WMC: 1960

- $\quad$ ANL-W: $1966-1971,1977-1989$

Using this information, the work in this report was prioritized relative to these significant LLW generators. High priority is given to the generators that had large shipment volumes or high number of Curies in the 1952 to 1971 time period (it may be possible that some high volume peaks could be caused by generator initiated D\&D efforts before the D\&D program began, this is true in the 1960s for CFA). The priority generators are:

- NRF: 1961-1973 (high volume quantities 1961-1973; high Curie quantities 19651971)

- TAN: 1962-1970 (high volume quantities)

- TRA: 1961-1972 (high volume quantities 1961-1970; high Curie quantity 19611965 and 1968-1972)

- WMC: 1960 - high vo!ume and high Curies (these are totals from all INEL generator records from earlier years)

- $\quad$ ANL-W: 1966-1971 - high Curie quantities

- CPP: 1966-1971 - high Curie quantities 


\section{Develop and Send a Questionnaire to Operating INEL Generators and Analyze Generator Response}

A questionnaire was developed and sent to the presently operating LLW INEL generators for current and historical inventory review and response. An example of this questionnaire is given in Appendix E. Included in the questionnaire are questions relating to past processes, disposed wastes, radionuclides, activities and weights as well as the existence of other sources of information or disposal records. If differences in disposal data were reported between the generator and the RWMIS database, the RWMIS database was taken as the standard for comparison. The responses received from the generators reported good agreement with the RWMIS database.

\section{Corroboration of What is Reported by Staff or Available Records}

To a limited extent, it may be possible to corroborate the information obtained from the various sources. This means identifying and examining available information independently to verify or support the information obtained from RWMIS, the generators or INEL staff. Information gathered should support existing information as well as the generator responses to the questionnaire. Specific information areas to examine would relate to the generators, projects, reactors, and experiments. Sources of information for this were: reports and technical papers available through the INEL library; and, available D\&D characterization reports.

Library search for a selection of INEL generators was done. A large, active generator, a large, inuperational generator, a small generator and the D\&D program were selected for examination to see what type of information could be found. (These were: TRA (including MTR, ETR and ATR); PBF and the SPERT reactors; and, the ARA reactors.) Little radionuclide specific information was found in reports or technical papers. Library search was subsequently used only to address specific questions. The D\&D characterization reports for the generators were examined. The D\&D characterization reports confirmed the reported radionuclides for the D\&D program.

\section{Historical Review}

A review was performed of historical sources of information including: INEL Site Development Plan (DOE-ID 1990); the examination of old shipping records; and interviews with personnel with hands on experience with the RWMIS database, the generators or waste disposal at the RWMC. This provided background information. Generator specific information is contained within the individual generator sections of this report.

\section{Coordination with the Environmental Restoration Program (ERP)}

Staff of ERP are examining the pre-1971 LLW shipping records (manifests) available from the federal repository in Seattle, WA. The time frame is from 1952 to and including 1970. One goal of the work is to verify data entries for the disposed volumes and Curies against the RWMIS BADFile. The shipping manifests for the pre-1971 period were also examined by Waste Management Department staff. The examinations underway may provide adjustments to the present RWMIS database and PA inventory data. Records for post-1971 may be examined by ERP staff after the present work is done. Interim results are discussed in the write up for the ERP in this report. 


\section{Peer Review of the Results Obtained}

The results and analyses of this report will undergo successive peer reviews. The individual generator descriptions and analyses have also been reviewed by the individual generators or staff familiar with the generator operations. 


\section{SOURCES OF INFORMATION AND GENERATOR ANALYSIS}

This, section describes the sources of information for improving the RWMC SDA LLW inventory data. In addition to generator interviews and/or their response to the questionnaire, these are:

- Regular updates to the quarterly and annual disposed LLW added to RWMIS data.

- Generator updates and corrections to the RWMIS data as they occur, these changes usually originate at the generator(s).

- Inventory related findings obtained from examining the ERP waste shipment archives.

- Interviews with available staff who have a close working knowledge of early disposal operations and the original RWMIS database.

- The radio-chemical facility characterization reports issued by the D\&D Program prior to facility decontamination and decommissioning.

- Obtaining an improved breakdown for the generic radionuclide classifications used by RWMIS.

These areas are discussed in the following sections. The RWMIS and ERP information are discussed first. This is followed by a summary for each LLW generator. RWMC and D\&D precede the INEL generators, which are given thereafter in alphabetical order. Results from interviews and library search are included within the individual discussions. A library search was made to address specific issues or questions as they arose. For the most part, the reports and papers in the library files addressed very specific research or facility areas. Only in a few instances were the radionuclides present in experiments reported in the literature. The RWMIS data used are those data which were available for the latest full calendar year which ended in 1989. These data are summarized in Litteer (1990) and are given in detail in Appendix B. The time period of the RWMIS data used is the time period from 1961 to 1989 unless otherwise noted. The differences in the latest inventory data reported in the 1990 RWMIS annual report (Litteer 1991) and the 1989 RWMIS annual report (Litteer 1990) used in this report are an 11 cubic meter volume increase for the year 1988 by ANLW and the inclusion of the SMC LLW of 124 cubic meters of volume and an activity of less than 1 Curie for the years 1986 to 1990 .

\section{Radioactive Waste Information System (RWMIS) Changes}

Improvements in the PA inventory due to changes in the RWMIS are given in the table below. NVC, indicates that no volume change took place. An entry indicates the revised, new total(s) for Curies and/or volume. The first two entries for 1989 and 1990 are for the years not included in the PA since it was originally done in 1989. The 1971 to 1988 changes for CPP are changes in Curies only. An additional $14,237 \mathrm{Ci}$ were reported by CPP for these years over what had previously been reported. The present PA includes Pad-A wastes. The LLW of Pad-A can be considered for removal from the PA assessment, as Pad-A is planned for remediation. The last two entries (marked "*") for LOFT/CTF and TAN are small changes in Curies ( +3 for LOFT/CTF, and +33 for TAN over what was 
reported in 1988 as the PA was started). The differences in the latest inventory data reported in the 1990 RWMIS annual report (Litteer 1991) and the 1989 RWMIS annual report (Litteer 1990) used in this report are an 11 cubic meter volume increase for the year 1988 by ANLW, and the inclusion of the SMC LLW of 124 cubic meters of volume and an activity of less than 1 Curie for the years 1986 to 1990 .

\begin{tabular}{llll} 
Year(s) & Generator & Curies & $\begin{array}{r}\text { Volume } \\
(\mathrm{cu} / \mathrm{m})\end{array}$ \\
\hline 1989 & All INEL & 590065 & 1342 \\
1990 & All INEL & 207540 & 1762 \\
$1971-1988$ & CPP & 614483 & NVC \\
$1972-1983$ & Pad-A & 70 & 10,700 \\
$1967-1969$ & Pit-9 & 13 & 1132 \\
1986 & LOFT/CTF* & 277 & NVC \\
PRE-1980 & TAN* & 101380 & NVC
\end{tabular}

\section{Recommendations}

An update to the PA must include the radionuclide changes for the last two years as well as the approximately $14,200 \mathrm{Ci}$ changes to CPP disposed LLW from pre-1988. These changes are included in the latest RWMIS database (Litteer 1991). The RWMIS data for 1991 should also be included. The data for 1991 should be ready for use by mid-1992. Consideration should be given to omitting the Pad-A inventory from the present PA. Pit-9 is also being considered for remediation and the same considerations may apply to it.

\section{Preliminary Findings of the ERP RWMIS Database Analysis}

Staff of the ERP have been examining the original LLW shipping manifests retrieved from the federal repository for the period 1952 to 1970. An assessment of the accuracy and completeness of the shipping records contained in the RWMIS database for this time period is also being done. Goals for the assessment are to estimate: the accuracy of the RWMIS electronic records relative to the original hard copy shipping records; the internal consistency of the RWMIS electronic records; the completeness of the RWMIS electronic database; and, characterization of the RWMIS electronic database.

The examination being done may generate issues to be resolved as well as provide adjustments to the present RWMIS and PA inventory data when the results become available. The pre-1971 RWMIS data reported was obtained from annual summaries provided by the generators as well as available publications. The pre-1971 shipping manifests were not used to develop the summary data which the RWMIS regularly reports (Litteer 1991, for example). The pre-1971 shipping manifests were entered into an electronic database known as the RWMIS Best-Available - 
Data file (BAD-File), Indications are that the pre-1971 shipping manifest data and the BAD-File can be improved and the two files brought more in agreement with the present RWMIS data. This will increase the overall credibility of both databases - the RWMIS, and the pre-1971 shipping manifests (Barnard 1991).

The pre-1971 shipping manifests for the LLW disposed in the RWMC SDA trenches and pits have been examined by the authors, Observations noted include:

- The radionuclides present in the LLW were not always entered on the shipping manifests, the nuclides noted most were Co-60, U-238, U-235, Cs-137, and Sr-90

- LLW weights were entered as the weight of the shipping cask by NRF in the 1960 s

- $\quad$ Fuel rods (spent and prototype) are contained in some of the LLW shipments (at least fifteen have been noted) as well as fucl samples for testing

- $\quad$ Some disposed shipments contain 10 to 50 gram amounts of U-235

- Order of magnitude errors in data entry have been found

- Records were found for which the Acid Pit was noted as their disposal location

- $\quad$ Buried scrap from the SL-1 accident

- Buried reactor vessels, piping, shielding, resin columns, resin tanks, core reflectors, control rods and hardware

- $\quad$ Buried, contaminated jet engines and delivery vehicles

- A buried gasoline tank which is noted to possibly contain gasoline

- Approximately 300 previously unrecorded records from pre-1960 were found

- Wastes were disposed which are now considered hazardous, for example: powdered zirconium metal; zirconium cladding; iridium; lead; asbestos; batteries; acids; cyanide; cadmium; nickel; and, mercury.

It is not possible at this time to identify definite changes to the radionuclide inventory pending completion of the ERP work. Preliminary observations of interest to the PA work are:

- Data input errors in transcribing from the shipping manifests to the RWMIS electronic database were found.

- Shipping cask weights were entered on the shipping manifests as the waste weight by NRF up to 1970.

- Pre-1960 shipping records have been found (approximately 300) for CPP, SPERT and TRA, which have never been recorded. 
- Approximately $45 \mathrm{LLW}$ shipments of high Curle value (above 50,00)( $\mathrm{Cl}$ ) exist in the BAD-File which may be crrors or overestimation results, if this is true and the data was used in the RWMIS reported data, perhaps 2 to 3 million Curies could be reduced from the present total disposed LLW inventory of 11.6 million Curies.

\section{Recommendations}

The pre-1971 archives being examined are an good source of information, data and issues for further resolution. This also applies to the post-1971 archives. These flles are being examined by staff of ERP. Work is concentrating on the pre-1971 files. This is being done on a burial location basis for the pre-1971 shipping manifests. Performance assessment staff need to keep appraised of this work. Review of the ERP work and its lindings should be done and applicable results should be incorporated in the PA. 


\section{GENERATOR: Radioactive Waste Management Complex (RWMC/WMC)}

\section{Description and Historlcal Summary}

The Radioactive Waste Management Complex (RWMC) at INEL is responsible for the disposal of INEL generated LLW in accordance with DOE Order 5820.2A (U.S. DOE 1988), the INEL LLW Acceptance Criteria (LLW WAC) and safety requirements, Interim storage of TRU waste is also done at the RWMC. The RWMC charter includes the definition, cooperative development and application of technologies for waste management as well as participating in remediation activities.

The RWMC was established for LLW disposal in 1952. Many of the waste shipment records prior to 1960 were destroyed because of records retention practices. The RWMC itself is a minor generator of LLW. The LLW disposal history for the RWMC is shown in Figure 5. The data for the year 1960) are summary data for all INEL generated LLW disposed from 1952 to 1960 that were credited to the RWMC.

\section{Operations Performed, Processes and Experiments}

Excluding administrative work, data entry and information processing, the operations performed at the RWMC are: receipt inspection/examination of waste shipments, followed by acceptance or rejection of shipments; temporary storage of TRU waste; handling of waste shipments; and, LLW disposal. Waste package recovery and monitoring experiments are also performed.

LLW contaminated with transuranic isotopes of activity less than $100 \mathrm{nCl}$ per gram but greater than $10 \mathrm{nCl}$ per-gram is currently excluded from disposal in the SDA and is placed in interim storage at the RWMC. LLW contaminated with transuranic isotopes of less than or equal to $10 \mathrm{nCl}$ per gram is disposed at the RWMC. Two types of disposal methods are presently in operation - pits and soil vaults. Pits are used to dispose of contact handled (CH) LLW, which has activity levels less than $500 \mathrm{mR} / \mathrm{h}$ at 0.9 meters from contact with the waste container. Soll vaults are used to dispose of remote handled (RH) LLW, which has radiation levels of greater than $500 \mathrm{mR} / \mathrm{h}$ at 0.9 meters from contact with the waste container.

TRU waste is no longer disposed at the RWMC. Since 1971 TRU waste has been stored on above-grade, asphalt pads. This TRU waste is to be characterized, certified, repackaged and transported for disposal at the Waste Isolation Pilot Plant (WIPP) Facility. A limited amount of LLW waste is produced at the RWMC. This is generated by clcanup as well as waste retricval tests. Chemical waste produced at the RWMC originates from cleaning matcrials. None of this waste is presently hazardous, Low-level waste may be generated at the Stored Waste Examination Pilot Plant (SWEPP). These wastes could be generated by the waste examination and assaying performed at SWEPP. 


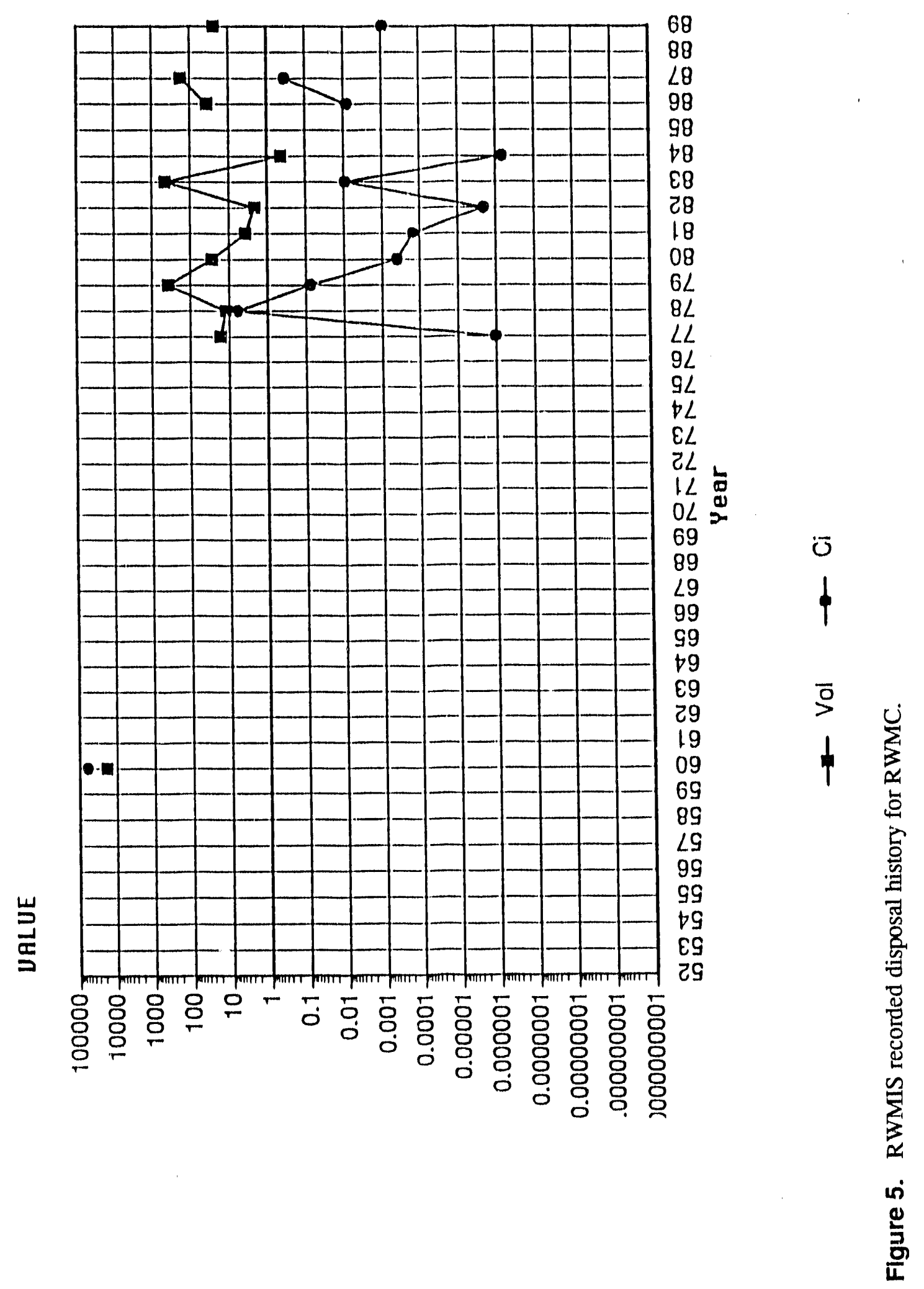




\section{Affecting/Affected Facllitles}

The RWMC supports all INEL facilities in the disposal and interim storage of LLW. It also works with other INEL technical groups in the definition, preparation and implementation of waste acceptance criteria and procedures for low-level and TRU waste management.

\section{Products}

NA.

\section{Radioactive Wastes and RWMIS Information}

Wastes generated at the RWMC are a result of the recovery or cleanup of contamination removed from the exterior of waste packages, decontamination of transport vehicles, or the decontamination of facilities, solls, or storage pads at the RWMC caused by leakage from a waste package. A small amount of LLW may result from testing and experiments. Examples of these are waste package retrieval, and the Vapor Vacuum Extraction Demonstration experiments which have been performed at the RWMC.

The RWMIS records include $6 \mathrm{Cl}$ and 1085 cubic meters of LLW which were disposed in the RWMC SDA since 1971. The radionuclides present in the RWMC LLW are reported by RWMIS to be mostly Cs-137 and Sr-90. Minor amounts of actinides are reported. The RWMC was also "credited" with an INEL overall cumulative LLW generation of $60920 \mathrm{Cl}$ and 18460 cubic meters in the year 1960. This LLW is classifled as unidentified beta-gamma. Records for this data do not exist. The data are an overall INEL summary record for wastes disposed between 1952 and 1960. MFP and MAP are represented by an activity of approximately $0.2 \mathrm{Cl}$ of the total $6 \mathrm{Cl}$ reported by the RWMIS. The radionuclides in the RWMC LLW are given in Appendix B.

\section{Questionnaire Response}

The generator response to the questionnaire indicates that the LLW disposed in the RWMC SDA agrees with the records contained in the RWMIS. The primary wastes at the RWMC have come directly from RWMC-external generators. Wastes generated at the RWMC are a result of the recovery or cleanup of contamination removed from the exterior of waste packages, decontamination of transport vehicles, or the decontamination of facilities at the RWMC caused by leakage from a waste package. Contaminated soll and asphalt as well as amounts of wood, steel and decontamination materials have been generated.

\section{Library Search Information}

There have been numerous studies dealing with the buried waste inventory. A library search of available documents was completed. No significant references were found which address specific radionuclides in addition to those already used in this report. 


\section{Other Sources of Information}

Interviews and peer reviews of the present report have been done with avallable INEL personnel who are famillar with past operations at the INEL, the RWMC SIA and the RWMIS.

\section{D\&D Plans}

The RWMC is planned to provide waste management capability to the INEL at least through the year 2000. Remediation plans for various aspects of the RWMC are presently being defined. To date, Pits 1-10 and Trenches 1-10 are planned to undergo remediation. The TRU waste at the RWMC is planned for removal and disposal at WIPP.

\section{Error Sources and Speciflc Areas for Improving Information}

The RWMC was credited with $60920 \mathrm{Cl}$ and 18460 cubic meters of LLW in 1960. This is a summary record accredited to the RWMC for LLW from all INEL generators for years prior to 1961. Records for 1960) and before are reported to have been destroyed. The LLW is classified as unidentifled beta-gamma. This is the most significant source of error for the RWMC. It is a potential source of improving radionuclide information if information can be found.

\section{Justification of Improvements or Changes to the PA Inventory}

As a LLW generator, the RWMC has produced a small percentage of the total INEL LLW, adjustments to the RWMC generated LLW are not necessary.

\section{Recommendations}

Allocate the RWMC generic radionuclides to the INEL generators. Classify it as $50 \%$ Cs- 137 and $50 \% \mathrm{Sr}-90$. 


\section{GENERATOR: Decontamination and Decommissioning (D\&D)}

\section{Description}

The Decontamination and Decommissioning (D\&D) program at the INEL is responsible for implementing the Surplus Facilities Management program (SFMP) and the Defense Facilities Decommissioning Program (DFDP) for the DOE-ID office. The D\&D program is administered by the Environmental Restoration Program of EG\&G Idaho. The D\&D program started formally in 1978 and continues to the present. The first shipments of LLW to the RWMC SDA from D\&D were in 1978. This is during the period where improved records were kept for the disposed LLW. As a LLW generator D\&D has produced a small percentage of the total LLW which has been disposed in the RWMC SDA. The D\&D program, due to its nature, could produce significant amounts of volume of varied radionuclide activity (due to decay) in its future operations. The LLW disposal history for the D\&D program is shown in Figure 6.

\section{Operations Performed, Processes and Experiments}

The activities of the D\&D program are: radiological, chemical and physical characterization; analyses to determine the selection of preferred D\&D alternatives; $D \& D$ project planning, engineering and disposition; and the establishment and maintenance of D\&D project data files. Surveillance and maintenance of contaminated, excess facilities are also performed. Through 1990, 25 facilities have been completed; another 45 remain to be decontaminated and decommissioned.

Four types of facility decommissioning alternatives exist when performing D\&D work:

\section{Safe Storage}

Leave the facility in place. Loose contamination is removed, temporary physical barriers and protective systems are installed and surveillance is performed. An exclusion area is maintained around the immediate site. The site is unavailable for other uses.

\section{Entombment/In Place Stabllization}

The facility is left in place. Loose contamination is removed, permanent physical barriers and protective systems are installed and surveillance is performed. An exclusion area is maintained around the immediate site. Unrestricted use of most of site is permitted.

\section{Decontamination for Reuse}

The facility is left in place. Contamination is completely removed from facility areas which may possibly be reused. Permanent physical barriers are provided for the remaining contaminated areas. Surveillance is performed until a new tenant moves into the area. An exclusion area is maintained around the immediate site. Unrestricted use of decontaminated areas is permitted. 


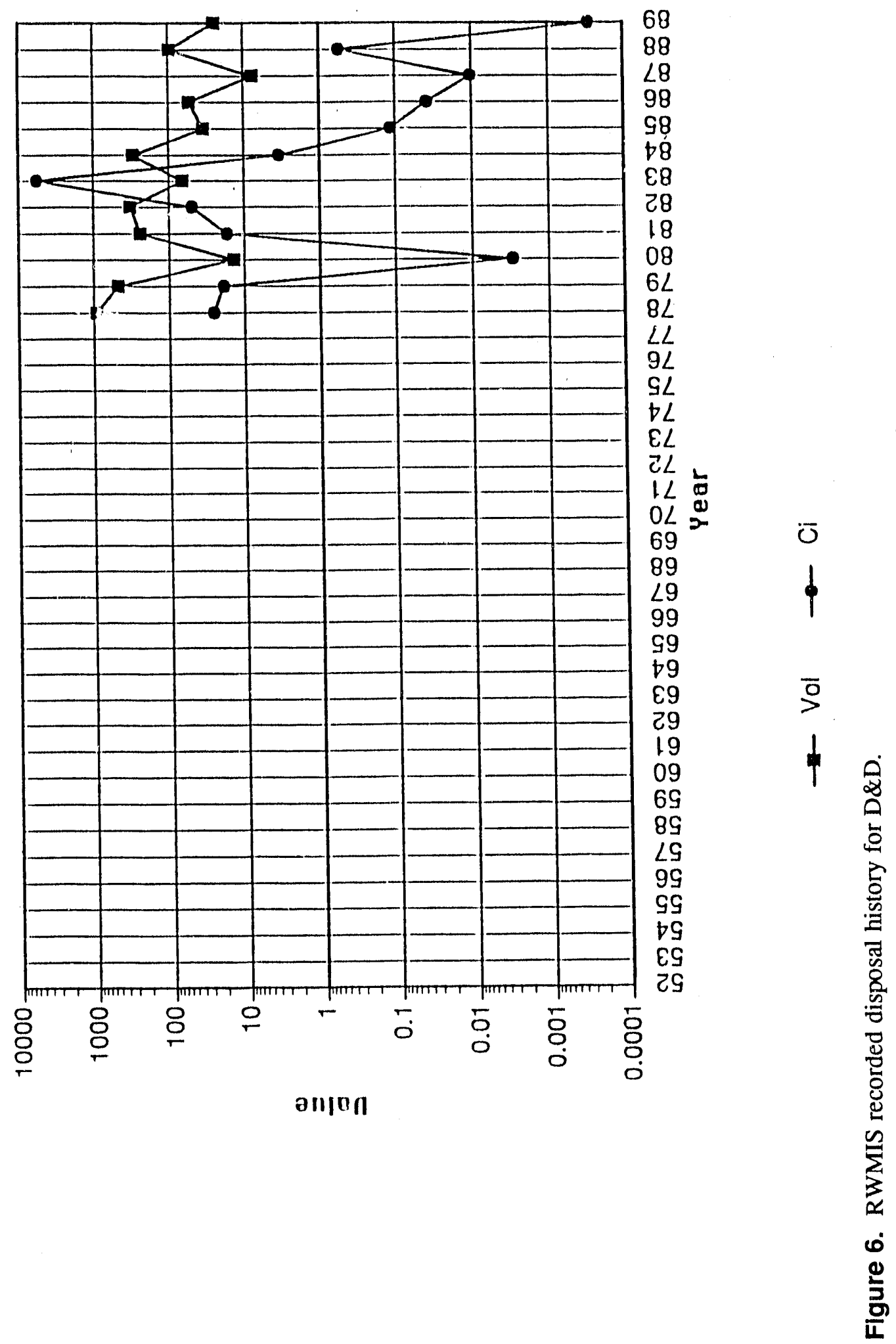




\section{Dismantlement}

Fully decontaminate or remove facility. Contamination is reduced to the unrestricted level, no surveillance is performed and unrestricted use is permitted.

All work is done according to EPA RCRA, CERCLA and SARA requirements. Rigid quality assurance requirements exist for D\&D work. Included in the satisfactory completion of a D\&D project are the: initial characterization and decision analysis; decontamination and decommissioning plan; decommissioning operations description; regulatory documentation; and, final compiled information and data package. D\&D work for NRF and ANL-W facilities is not included in the present EG\&G D\&D long range plan (Sekot 1990). Only a few reports are on file for CPP facilities. These latter two facilities managed by other INEL contractors.

\section{Affecting/Affected Facilities}

The D\&D program affects most INEL programs which have existed or are in planning. D\&D plans are now a requirement in the design of new nuclear facilities and systems.

Radioactively contaminated facilities for which decommissioning has been completed are presented in the D\&D long range plan (Sekot 1990). The INEL Site Development Plan (DOE-ID 1990) lists the following facilities as undergoing decontamination and decommissioning: BORAX-V, in progress; EBR-1 NaK coolant; SL-1 demolition equipment; MTR cleanup; TAN-607 DECON SHOP cleanup; and ICPP cleanup. Facilities for which decontamination and decommissioning is planned are: MTR-611 plug storage facility; BORAX-V reactor facility; ARA-II cleanup; WRRTF hot waste tank cleanup and remediation; ARA-I cleanup; TTAF cleanup; and ETR cleanup.

\section{Products}

The products of the D\&D program are used, scrap material which can go to a sanitary landfill; decontamination liquids (consolidated at ICPP before disposal); reactor fuels which are reprocessed at the ICCP; low-level radioactive waste for reduction and/or disposal (scrap material, equipment, contaminated soil); a limited amount of TRU waste (e.g., plutonium present in the NaK coolant) for eventual disposal at WIPP; and, salvage materials, facilities, and equipment for resale or reuse. No hazardous wastes have been disposed by the D\&D program at the RWMC SDA.

\section{Radloactive Wastes and RWMIS Information}

The RWMIS records include $5693 \mathrm{Ci}$ and 2530 cubic meters of LLW which were disposed in the RWMC SDA from 1978 to 1989. These data are shown in Figure 6 by year. The radionuclides present in the D\&D LLW are reported to be predominantly: Co-60; Cs-137; Mn-54; Fe-55; Sr-90; Nb-95; Ni-59; Ni-63. Minor amounts of actinides are also reported. MFP, MAP and UI-BG are represented by an activity of circa $8 \mathrm{Ci}$ of the total $5693 \mathrm{Ci}$ reported by the RWMIS. A detailed list of the radionuclides disposed by D\&D in the RWMC SDA is given in Appendix B. 


\section{Questionnaire Response}

Generator response to the questionnaire indicates that LLW disposed in the RWMC SDA from D\&D work agrees with the records contained in the RWMIS. Final reports and project information files are kept as records in the D\&D program office. The $D \& D$ program is confident radionuclides reported in RWMIS are correct.

Reported wastes include: steel pipe; concrete and steel structural materials; soil; small amounts of solidified sludge; and, reactor vessels. No chemicals have been disposed at the RWMC SDA. Except for large components which cannot be reduced, the wastes are shipped to the RWMC SDA in $4 \times 4 \times 4$ foot, $2 \times 4 \times 8$ foot, or $4 \times 4 \times 8$ foot metal boxes. Shielding is rarely used. Concrete grouting is used when necessary for radiation protection. The radionuclides present are mostly Co-60 and Cs137 with small amounts of radionuclides of silver, europium, and strontium.

\section{Llbrary Search Information}

Many of the reports done by the D\&D program are available in the INEL Technical Library. However, the best source for these reports is the D\&D program itself. Some files were reported to be available from personnel still in the program, other files exist in personal staff records. The D\&D program is subject to comprehensive, structured documentation requirements.

\section{Other Sources of Information - Decontamination and Decommissioning Files}

The decontamination and decommissioning (D\&D) files for INEL LLW generators were examined. Major focus was on Test Area North ('TAN) and the Test Reactor Area (TRA). D\&D reports for less significant areas such as BORAX, the Auxiliary Reactor Area (ARA), SPERT, and the Idaho Chemical Processing Plant (ICPP) were also examined.

Examination of D\&D characterization reports for TAN show that Cs-137, Co-60, Sr-90, Mn54, Fe-55, Ni-63, and Ni-59 are present in significant amounts. Other radionuclides detected in minor amounts include U-235, Cs-134, Eu-152, Eu-154, Eu-155, Ra-226, Th-228, Pu-238, Pu-239, $\mathrm{Pu}-240$ and Am-241.

D\&D characterization reports for TRA, including the decontamination and decommissioning of the Materials Testing Reactor and the Engineering Test Reactor, show significant amounts of Cs137, Co-60, and Sr-90. Minor amounts of Cs-134, Po-210, Zr-95, Ru-103, Cr-51, Ce-141, Ce-144, Be-10, C-14, Ra-226, Th-228, H-3, Na-24, U-235, Mn-54, Pu-238, Pu-239, Pu-240, Am-241, Ag-108, $\mathrm{Nb}-95, \mathrm{Sb}-125$, and $\mathrm{Hf}-181$ are also reported.

Radionuclides reported within D\&D reports for the BORAX facility include Cs-137, Co-60, U-235, Cs-134, Sr-90, Pu-238, Pu-239, Pu-240, U-238, U-235, and U-234.

Examination of the D\&D reports for areas within ARA show Cs-137 and Co-60 to be major radionuclides. Small amounts of Eu-154, U-235, Sr-90, Ag-108, Pu-238, Pu-239, Pu-240, U-238, U234, U-233, U-235, and U-236 are reported as well.

Major radionuclides reported within the SPERT D\&D documents include both Cs-137 and Co-60. Radionuclides detected in negligible amounts include U-235, Sr-90, Pu-238, PU-239, Pu240, U-238, and U-234. 
D\&D reports for CPP show that Cs-137, Co-60, Eu-155, Eu-154, and Eu-152 are present in significant amounts, with Eu activity levels exceeding Cs levels in some areas. Also reported at CPP are Sr-90, Cs-134, Sb-125, Ce-144, Mn-54, Nb-95, Ru-106, Zr-95, Co-57, Pu-238, Pu-239, Pu-240, U-233, U-234, U-235, U-236, U-238, and Am-241.

The information found in the examined D\&D reports agrees with the data reported in the RWMIS.

\section{D\&D Plans}

NA.

\section{Error Sources and Speciflc Areas for Improving Information}

Prior to the D\&D of a facility, detailed radio-chemical analyses of the prospective D\&D materials are conducted. The results of these analyses are reported in the initial decision and characterization documents required by the $D \& D$ program before $D \& D$ work is started. Very early D\&D projects were developing the documentation requirements and $D \& D$ procedures. It may be that some of the early D\&D work was not reported to the degree of detail as later work. Potassium40 was reported as a significant natural background emitter in the INEL region.

\section{Justification of Improvements or Changes to the PA Inventory}

Adjustments to the LLW inventory adjustments for D\&D are not necessary. As a LLW generator, D\&D has produced a small percentage of the INEL total LLW. The D\&D program, due to its nature, could produce significant amounts of both volume and activity in future work.

\section{Recommendations}

The D\&D files should be examined by performance assessment staff (not solely waste management staff) who are familiar with radiation contamination, reactors and fuels. Nuclear engineering and health physics staff may gain addit information. 


\section{GENERATOR: Argonne National Laboratory-West (ANL-W)}

\section{Description}

Argonne National Laboratory West (ANL-W) is an INEL complex which provides basic support for the Integral Fast Reactor (IFR) research and development program. ANL-W is and has been a significant LLW generator. Volumes of LLW generated at ANL-W since 1960 have remained fairly constant, with an average of approximately 280 cubic meters/yr. The annually disposed Curies have varied widely, however, with some stabilization occurring after 1977. From 1960 to 1989. Curies have ranged from $3 . \mathrm{Ci}$ reported in 1963 to $463321 \mathrm{Ci}$ reported in 1989. The LLW disposal history for ANL-W is shown in Figure 7.

\section{Operations Performed, Processes and Experiments}

ANL-W operates four major facilities at the INEL in support of the IFR. They include the Experimental Breeder Reactor II (EBR-II), the Transient Reactor Test Facility (TREAT), the Zero Power Physics Reactor (ZPPR), and the Hot Fuel Examination Facilities (HFEF), A fifth facility, the Fuel Cycle Facility (FCF), will soon be operable.

EBR-II consists of a sodium-cooled reactor, an intermediate closed loop of secondary sodium, and a steam plant that produces electrical power. The original emphasis in the design and operation of EBR-II was to demonstrate a complete breeder reactor power plant with on-site reprocessing of metallic fuel. After 1969, the emphasis at EBR-II was then shifted to irradiation testing of fuels and materials for larger liquid metal reactors. EBR-II is now a central part of the Integral Fast Reactor Program (IFR). It also is a power producer for the INEL (it is connected to the North West power grid).

TREAT is a uranium-oxide-fueled, graphite-moderated, air-cooled reactor designed to produce short controlled bursts of nuclear energy. The purpose is to simulate accident conditions leading to fuel damage, while leaving the reactor's driver fuel undamaged.

ZPPR is the national facility for testing physics properties of advanced fast-spectrum reactors, large breeder reactors, space reactors, or gas-cooled fast reactors. Testing is achieved by assembling and operating a reactor that closely resembles the particular design that is under consideration. The ZPPR critical assembly is put together from rectangular building blocks of fuel, coolant, and structural materials. ZPPR is operated at very low power, the materials therefore do not become highly radioactive and can be used over and over again.

HFEF and the Fuel Cycle Facility (FCF) consist of two large buildings, each containing an air atmosphere and an argon-gas-atmosphere hot cell. The argon gas cells are utilized for work involving exposure of materials such as sodium and plutonium that would react chemically with air. FCF was originally the Fuel Cycle Facility for EBR-II. During operations at EBR-II, it contained a remotely operated production line for the reprocessing, fabrication and recycling of spent fuel. This project was discontinued in 1969 . The facility was subsequently used for the examination of fuels and materials irradiation experiments and other support for EBR-II and TREAT reactors. The facility is now being modified for use in demonstrating the new remote reprocessing and fabrication 

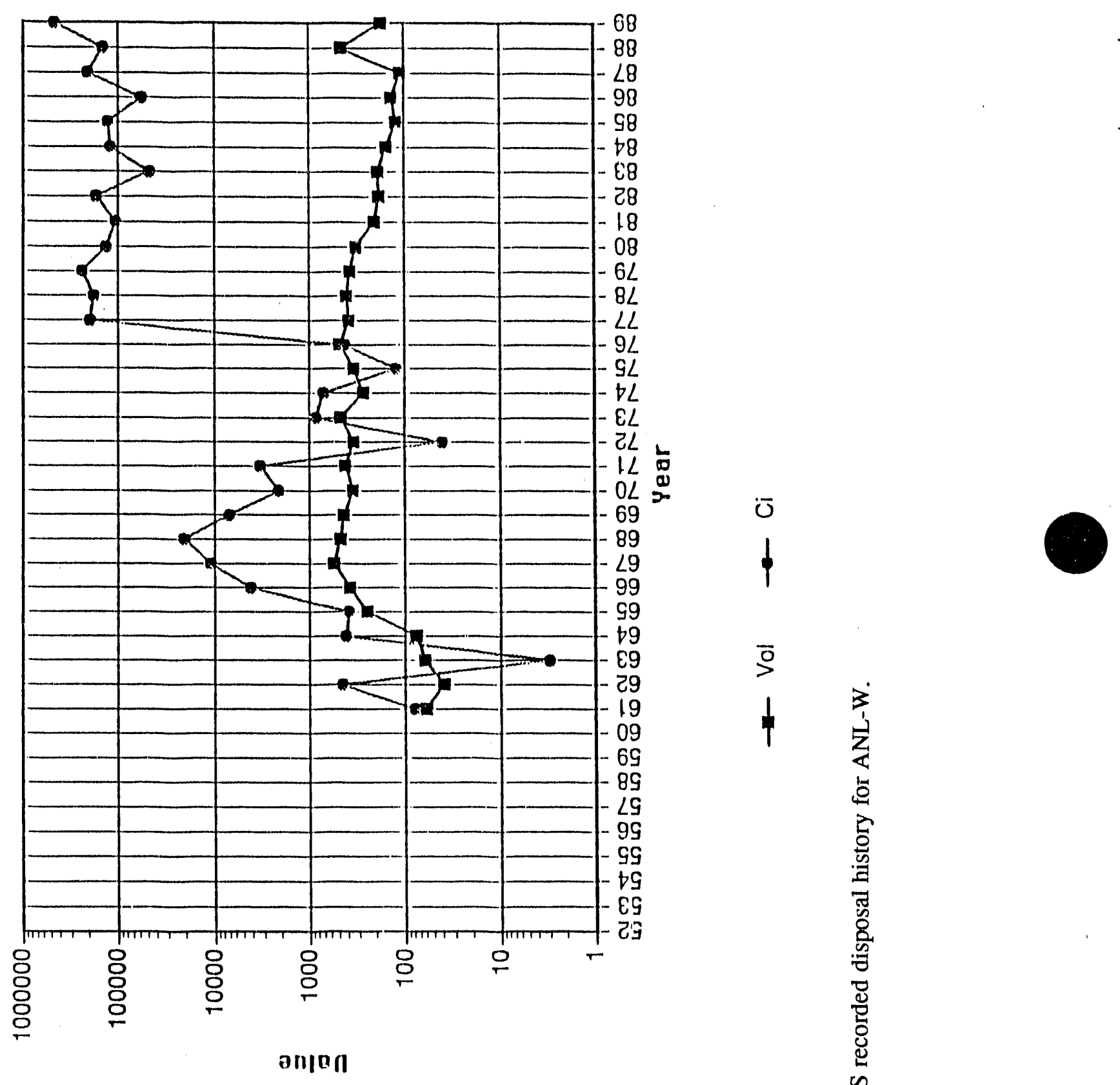

$\frac{7}{1}$

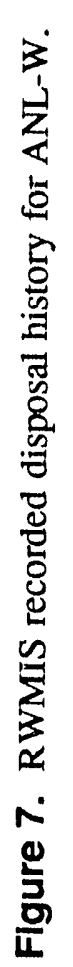


fuel cycle process for the IFR program. HFEF began operations in 1975. It has several features well suited for examining irradiation experiments. The argon-gas-atmosphere hot cell is designed for containment of any plutonium contamination released during experiments. The main cell is arranged for vertical handling, examination and cutup of long fucl elements. Much of the in-cell examination equipment for fuel elements is automated or semi-automated.

Several support facilities also exist at ANL-W. The Fuel Manufacturing Facility (FMF) contains the entire operation of manufacturing metallic fuel elements and complete fuel subassemblies for EBR-II within a single building. The Sodium Process Facility (SPF) is a facility designed and built to convert elemental sodium to $50 \%$ sodium hydroxide. The Radioactive Scrap and Waste Facility (RSWF) operates as a mixed waste storage facility. The Radioactive Liquid Waste Treatment Facility (RLWTF) is used to evaporate all liquid waste suspected of containing radioactivity.

\section{Affecting/Affected Facillties}

NA.

\section{Products}

NA.

\section{Radioactive Wastes and RWMIS Information}

The RWMIS records include $2225866 \mathrm{Ci}$ and 8233 cubic meters of LLW which were disposed by A.NL.-W in the RWMC SDA since 1961. A wide variety of radionuclides are contained in ANL-W LLW. The primary radionuclide. include: Cs-137, Sb-125, Co-60, Cs-134, Cr-51, Fe-59, Mn-54, Ta-182, Ce-144, Ce-141, Co-58, Sr-90, and H-3. Other radionuclides are present in minor amounts. UI-BG and UI-ALPHA constitute approximately $49360 \mathrm{Ci}$ MAP is represented by an activity of approximately $420 \mathrm{Ci}$ and MFP is represented by an activity of approximately $1080 \mathrm{Ci}$. Known radionuclides in the ANL-W LLW are given in Appendix B.

\section{Questionnaire Response}

Generator response indicates that the ANL-W inventory agrees with what is reported in the RWMIS, Log books and records exist at some ANL-W facilities. EBR-II elirninated the classification MAP/MFP radionuclides and reported the actual radionuclides for each year since 1971. HFEF-FCF gave specific radionuclides for the MAP/MFP radionuclides of: 40\% MAP; $60 \%$ MFP; MAP, Co-58 (50\%) and Mn-54 (50\%); and, MFP, Cs-137 (20\%), Ce144 (50\%), Sr$90(20 \%)$ and Cs-134 (10\%). This distribution is to be applied for all years. RLWTF gave specific nuclides likely to be present in MAP and MFP of: Na-22; Mn-54; Co-58; Co-60; Cs-134; Cs-137; Ce-144; Eu-154; and, Eu-155. ZPPR reports minor amounts of MFP as U-238 and U235 and minor amounts MAP being Fe-59 and Al-28. 


\section{Other Sources of Information}

Additional sources of information are: past INEL and RWMC staff familiar with ANL-W operations and low-level wastes; INEL Library; the historical records contained in the files of the ERP, which are presently being examined.

\section{D\&D Plans}

Experimental Breeder Reactor 1 (EBR-1) has been decontaminated and decommissioned, as has Zero Power Reactor 3 (ZPR-III), and the Heat Transfer Reactor Experiment Dolly (HTRE-CTF and HTRE-P-102). No other information on D\&D plans for ANL-W facilities was avaliable.

\section{Error Sources and Specific Areas for Improving Information}

The most significant source of error and area for improving the radionuclide inventory is the present breakdown of UI-BG and MAP/MFP.

\section{Justiflcation of Improvements or Changes to the PA Inventory}

With the exception of the UI-BG and MAP/MFP radionuclides the data from ANL-W appear to be good. Generator recommended a breakdown for ANL-W generic radionuclides.

\section{Recommendations}

The approximate $50,000 \mathrm{Ci}$ of pre-1971 UI-BG LLW and the 1,500 Curies of post-70 MAP/MFP radionuclides should be split as 40\% MAP and 60\% MFP. The MAP should be Co-58 $(50 \%)$ and $\mathrm{Mn}-54(50 \%)$. The MFP should be Cs-137 (20\%), Ce-144 (50\%), Sr-90 (20\%) and Cs-134 (10\%). 


\section{GENERATOR: Argonne National Laboratory-East (ANL-E)}

Argonne National Laboratory East (ANL-E) is a facility external to the INEL. No information or generator response has been obtained to date. ANL-E is a minor generator of LLW. The LLW disposal history for ANL,-E is shown in Figure 8.

The RWMIS records include $1446 \mathrm{Cl}$ and 5001 cuble meters of LLW which were disposed in the RWMC SDA since 1980. A variety of radionuclides are contained in ANL-E waste, the predominant ones (in small concentrations) being Co-60, Co-57, Mn-54, Cs-137, Sr-90, Ra-226, H-3 $(120 \mathrm{Ci})$ and Th-228 $(9 \mathrm{Ci})$. ANL-E LLW has been buried since the improved RWMIS has been used. The RWMIS and PA radionuclide information can assumed to be correct.

\section{Recommendations}

None. 


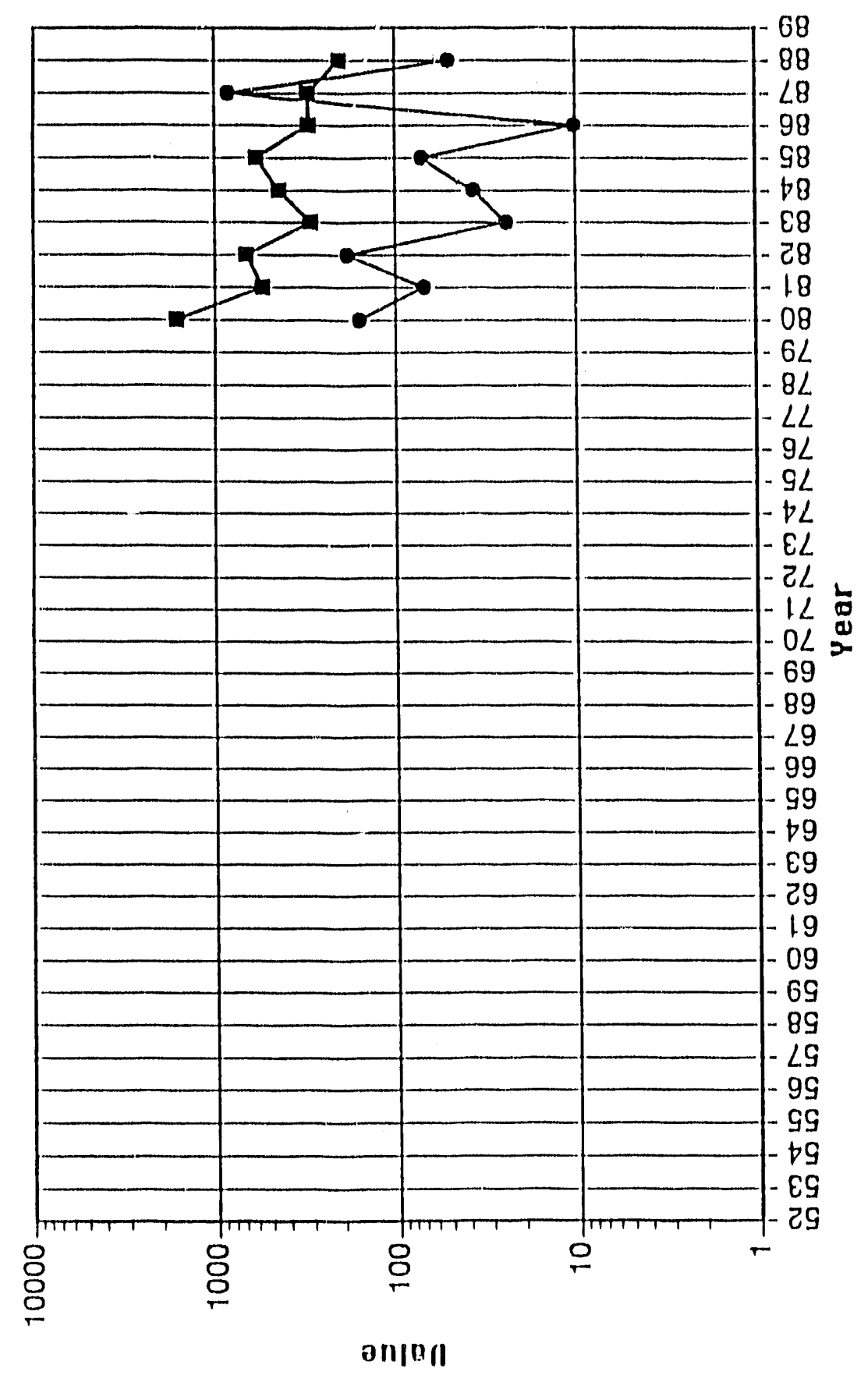

0
1

$\frac{0}{1}$

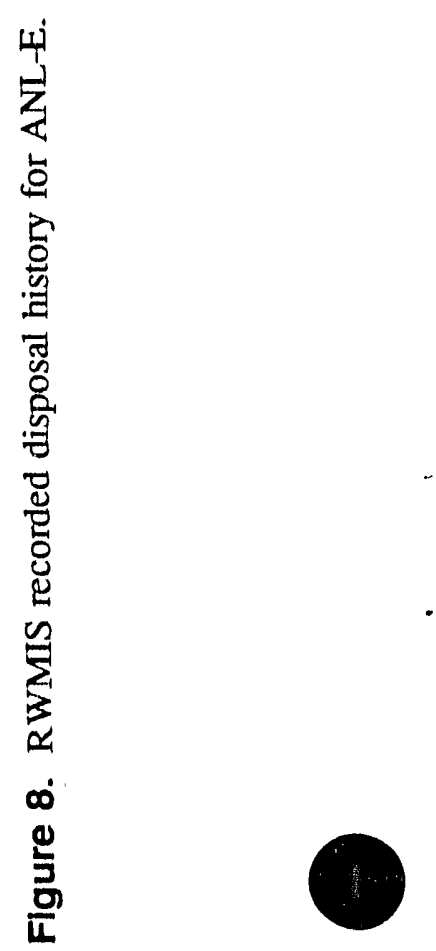




\section{GENERATOR: Central Facilities Area (CFA)/ Auxiliary Reactor Area (ARA)}

\section{Description}

The Central Facilities Area (CFA) is an INEL location providing centralized support services for programmatic and non-programmatlc efforts of INEL contractors. The Auxillary Reactor Area (ARA), previously known as the Army Reactor Area, was established as a working area to develop a compact power reactor capable of being moved with a minimal amount of time between shutdown and start-up. ARA has supported materials testing, environmental monitoring and hot cell operations. Most of the ARA facilities have been decontaminated and decommissioned. Minor amounts of LLW have been generated by CFA and ARA. The LLW disposal history for CFA and ARA is shown in Flgures 9 and 10.

\section{Operations Performed, Processes and Experiments}

The original facilities at CFA were built in the 1940s and 195()s. The facilities were initially used to house Naval Gunnery Range personnel and, later, National Reactor Testing Station personnel. The facilities have been modified over the past 30 years to fit the needs of the INEL. CFA now provides four major types of functional space: craft, office, services, and laboratory. Included at CFA are administrative offices, craft shops, warchouses, transportation facilities, hazardous waste storage facilities, and site service staging areas, as well as facilities for the Radiological and Environmental Sciences Laboratory and the United States Geological Survey. The security, fire protection, medical, laundry, and cafeterla services at CFA, together with services at other areas, combine to provide self-sufficiency at the INEL.

The ARA encompasses four satellite areas: ARA-I, ARA-II, ARA-III, and Reactive Storage and Treatment Area (RSTA, formerly ARA-IV). These facilitles were constructed in 1957 to test U.S. Army portable power reactors. In 1965, the Army Reactor Program was phased out and all reactors have since been removed. Use of the ARA is being discontinued due to the lack of mission activity in the area. Remote location and the high operating costs associated are credited with its closure. Since 1966, work at ARA has included a variety of technical support services for INEL research and development programs that use the metallurgy laboratory, the instrument development laboratory, and the hot cell facility.

Specific work reported at ARA-I included designing, testing, and treating materials as well as making fatigue measurements on irradiated materials, studying thermonuclear reactor design and feasibility, applying crystal growth processes related to geothermal rescarch, and studying neutron irradiation effects.

The decontamination and decommissioning assessment has been completed at ARA-I and the hot cell project is idle. ARA-II originally housed the Stationary Low Power Reactor-1 (SL-1), an Army-operated reactor that was accidentally destroyed during shutdown in 1961. Following the accident, the three main buildings were converted to offices and a welding shop. The reactor has been dismantled at ARA.II and decontamination and decommissioning is scheduled for FY 1991. 


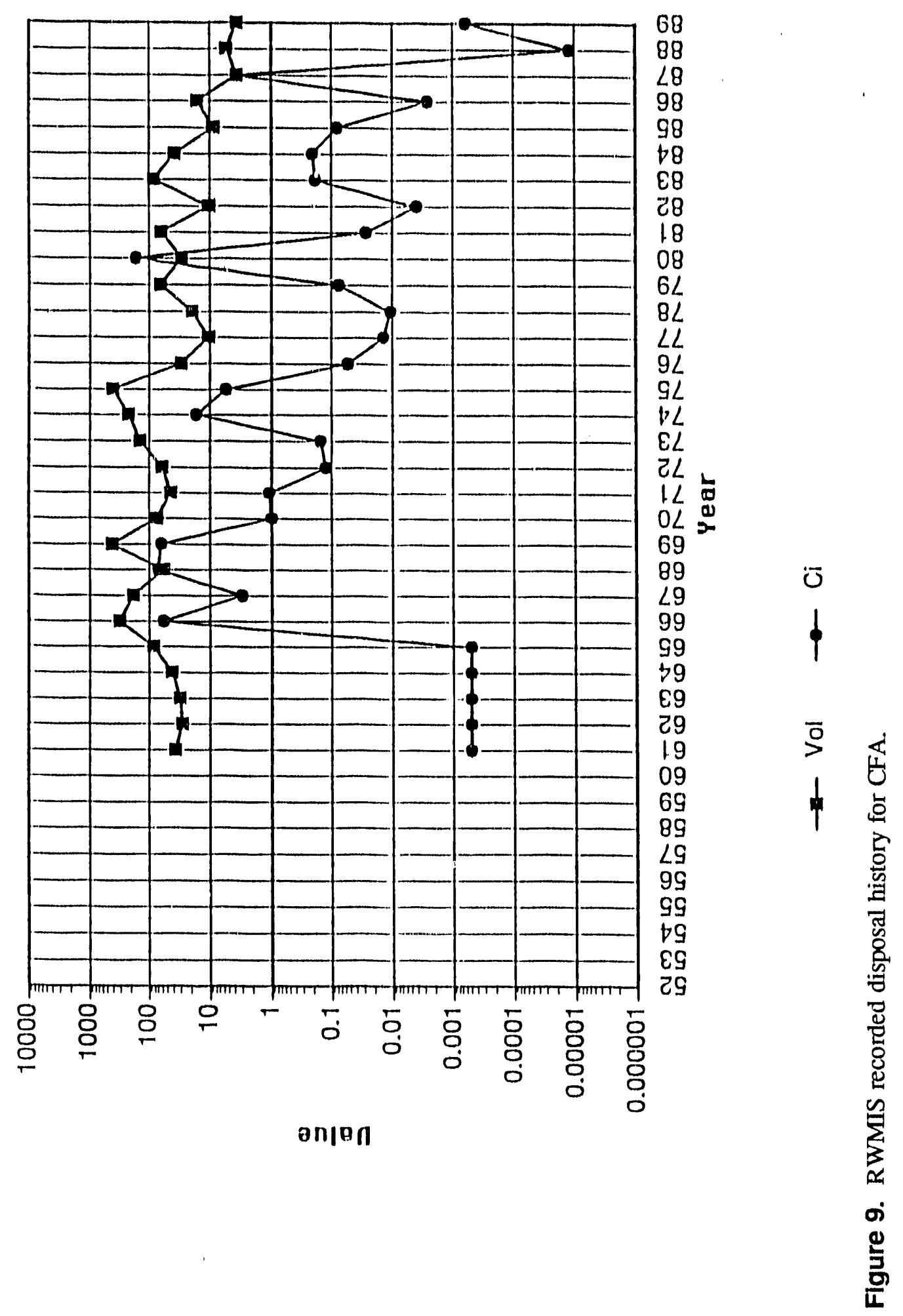




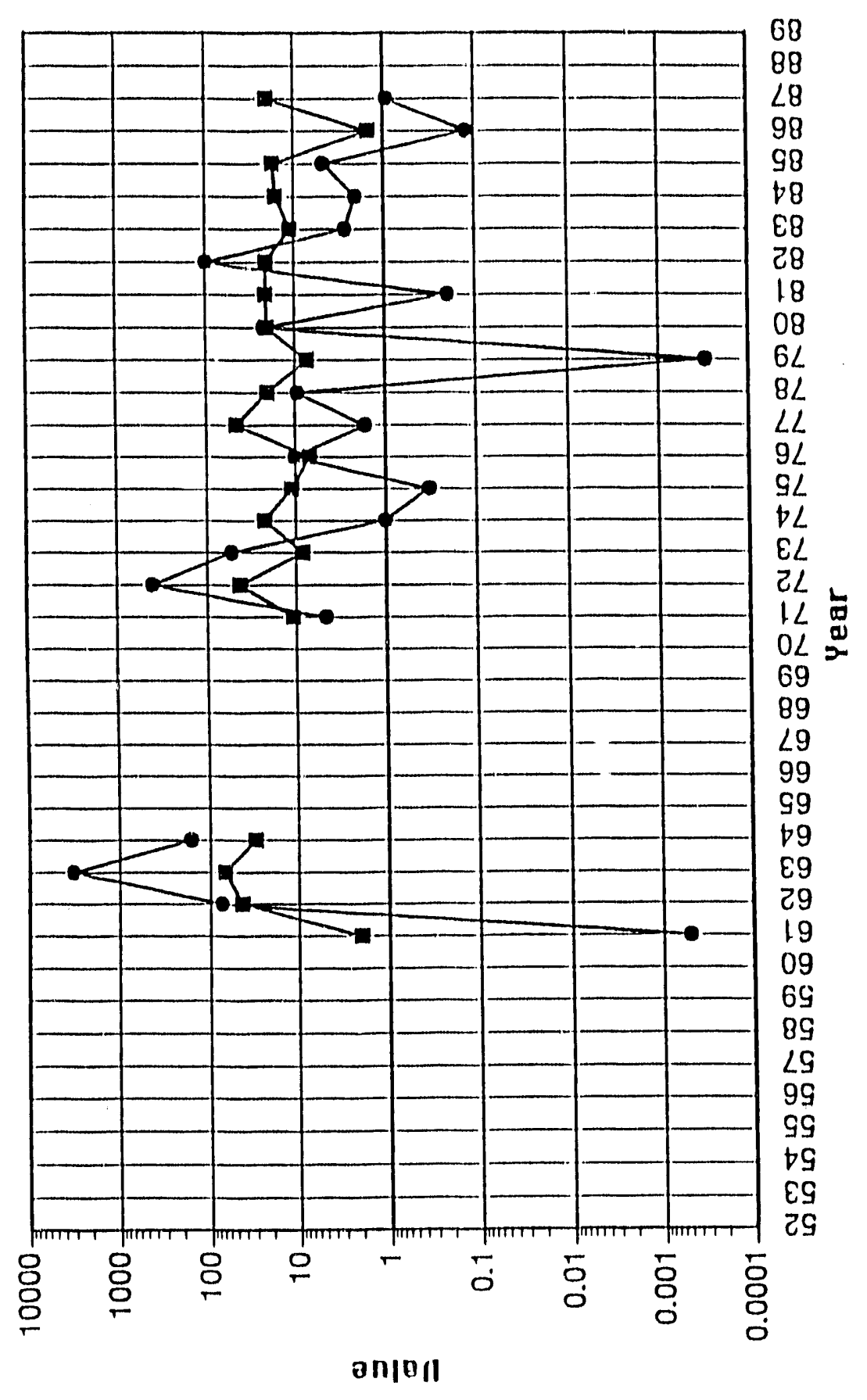

0
1

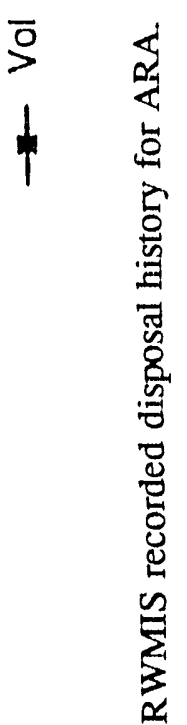

움 
The SL-1 surplus area is located about 4.5 miles north of the southern INEL boundary. The area contains most of the SL-1 dismantled reactor building, contaminated equipment, contaminated dirt and gravel, and decontamination waste.

ARA-III originally housed the Army Gas Cooled Reactor Experiment, a water-moderated, nitrogen-cooled, direct- and closed-cycle reactor generating heat, but no electricity. This project was the forcrunner of the Mobile Low Power Plant-1 Program which was eventually phased-out in 1965. The reactor has been removed from ARA-III and is ready for decontamination and decommissioning.

The Reactive Treatment and Storage Area (RSTA) of the ARA complex housed the Nuclear Effects Reactor used to test the performance of new detection instruments being developed for reactor control purposes. Following the program phase-out and reactor transfer to Lawrence Livermore National Laboratory in 1970, all utilities were terminated and the tanks, machinery, and electrical equipment were elther abandoned or moved to other facilities. The facility was characterized in FY1983 and decontaminated and decommissloned in FY1988. Currently, RSTA is not occupled by personnel but is used for remote testing.

The Experimental Organic Cooled Reactor (EOCR) and the Organic Moderated Reactor Experiment (OMRE), now known as the Security Training Facility (STF), is located approximatcly 2.5 miles east of CFA. The STF was originally bult to house the organic reactor program, which addressed coolant and fuel element technology for advanced organic reactor concepts. Work was halted at this area September 1962 and the physical facilities were declared excess. Facility reactors were never used. Since 1979 the facility has been used for material storage, for security force practice maneuvers and occasional destructive testing of reactor components or hazardous materials. Decontamination and decommissioning has been completed at OMRE.

\section{Affecting/Affected Facillties}

NA.

\section{Products}

NA.

\section{Radioactlve Wastes and RWMIS Information}

The RWMIS records include $385 \mathrm{Ci}$ and 2504 cubic meters of LLW generated at CFA which were disposed in the RWMC SDA since 1961. CFA LLW predominantly consists of UI-BG and Co60. UI-BG constitutes approximately $190 \mathrm{Cl}$ of the total $385 \mathrm{Ci}$ reported for CFA. $\mathrm{Co}-60$ is represented by an activity of approximately $160 \mathrm{Ci}$. Minor amounts of Cs-137, Ba-133, H-3, Na-22, Fe-59, Ra226, U-235, U-238, Ta-182 and UI-ALPHA are also reported. Activity levels for MFP and MAP are negligible for CFA.

Radioactive wastes from operations conducted at ARA include $4025 \mathrm{Ci}$ and 442 cubic meters of LLW which were disposed in the RWMC SDA since 1961. The LLW is primarily characterized as UI-BG, which is represented by an activity of approximately $3400 \mathrm{Ci}$ of the total $4(034 \mathrm{Ci}$ reported 
for ARA. Co-60 and Cr-51 are present with activity greater than $50 \mathrm{Ci}$. Small amounts of Ag-110, Mn-54, Zn-65, Cs-137, U-235, U-238, Ce-141, Zr-95, Nb-95, Am-241, Fe-59, Ni-59, Pu-239, Ce-144, Cs-134, and Pu-240 are also reported. Activity levels for MFP, MAP, and UI-ALPHA are negligible.

The RWMIS records include $2434 \mathrm{Ci}$ and 1364 cubic meters of LLW generated at EOCR/OMRE/STF and disposed in the RWMC SDA from 1961 to 1965. The greater part of the activity occurs in 1965 . The LLW is identified as UI-BG.

The RWMIS records for SL-1 include $599 \mathrm{Ci}$ and 2319 cubic meters of LLW which were disposed in the RWMC SDA in 1961 and 1962. The LLW generated at SL-1 is identified as UI-BG.

Known radionuclides in the LLW generated by CFA, ARA, EOCR/OMRE/STF, and SL-1 are given in Appendix B.

\section{Questionnaire Response}

Waste generated at the ARA reactors from 1980 to the present was noted to contain Cs, Co, I, $\mathrm{Xr}, \mathrm{Zn}, \mathrm{Pu}, \mathrm{U}, \mathrm{Pb}$, and silver zeolite. Some of the RWMIS data for CFA/ARA MFP waste was noted as containing all of the isotopes associated with the fission of fuel. Chemicals included in waste packages shipped from ARA to the RWMC include Turco, Radiac wash, and alcohol. Wastes disposed in the past in the RWMC SDA include buried resin columns used to decontaminate warm waste. Most of these latter wastes are presently considered as hazardous wastes and burial would not be permitted at the RWMC SDA today.

\section{Other Sources of Information}

Additional sources of information are: past INEL and RWMC staff familiar with CFA and ARA operations and low-level wastes; INEL Library; historical record contained in the files of the ERP which are presently being examined; and, records currently stored in Records Storage.

\section{D\&D Plans}

Reactors at ARA-I and ARA-III have been removed and the areas are ready for decontamination and decommissioning. The reactor at ARA-II has been dismantled and decontamination and decommissioning is scheduled for FY 1991. Decontamination and decommissioning was completed at RSTA in FY 1988. EOCR and OMRE were never used. The reactors have been dismantled. The LLW disposed at the RWMC SDA following early D\&D operations at CFA were apparently entered into the RWMC database as waste generated by CFA and not by the D\&D program.

\section{Error Sources and Specific Areas for Improving Information}

The most obvious source of improvement is to examine the fuel(s) used in the reactor operations. The fission product distributions for fuels are normally known. This indicates that the fuels used in the ARA reactors could be determined and a radionuclide summary be made. Verification of information gathered from the generator response may be attained by locating records currently stored in Records Storage. Past INEL and RWMC staff familiar with CFA and ARA 
operations and their L,LW can be interviewed. The historical record contained in the files of the ERP which are presently being examined is also a source of information.

\section{Justification of Improvements or Changes to the PA Inventory}

Since the CFA and ARA facilities did not produce large amounts of LLW, adjustments to the LLW inventory are not necessary at this time.

\section{Recommendations}

None. 


\section{GENERATOR: Chemical Processing Plant (CPP)}

\section{Description}

The Idaho Chemical Processing Plant (ICPP) is an INEL facility for processing fuel, receiving and storing fuel, and managing radioactive and hazardous wastes. ICPP is and has been a significant LLW generator. The volumes of LLW from ICPP vary widely between 207 and 3111 cubic meters per year since 1960. The annually disposed Curies have also varied widely between 37 and $326260 \mathrm{Ci}$ per year. High LLW Curie production occurred during the years 1973 and 1982. The LLW disposal history for CPP is shown in Figure 11.

\section{Operations Performed, Processes and Experiments}

In 1953, the ICPP began operation and has served as an engineering-scale demonstration facility to process highly enriched spent reactor fuel for the recovery of uranium and krypton gas. The first successful processing of stainless steel-clad fuels took place at ICPP. Processing of zirconium and stainless steel alloy fuels has subsequently become the principal production responsibility. Excluding administrative work, data entry and information processing, other operations performed at CPP include:

- Reprocessing Naval fuel

- $\quad$ Receiving, storing and reprocessing other DOE assigned fuels

- ' Recovering high-enriched uranium and special isotopes

- Managing radioactive and hazardous wastes.

\section{Affecting/Affected Facilities}

NA, not applicable for this generator.

\section{Products}

NA, not applicable for this generator.

\section{Radioactive Wastes and RWMIS Information}

The RWMIS records include $614739 \mathrm{Ci}$ and 31712 cubic meters of LLW which were disposed in the RWMC SDA since 1961. The CPP LLW contains a wide variety of radionuclides, including: Ce-144, Cs-137, Nb-95, Pr-144, Rh-106, Ru-106, Sb-125, Sr-90, Y-90, Sr-95, Zr-95, Nb95, Ce-141, Co-58, Co-60, Cs-134, Eu-152, Eu-154, Eu-155, Mn-54, Cr-51, Fe-59, Fe-55, and Mn56. MFP is represented by an activity of approximately $1860 \mathrm{Ci}$ and MAP is represented by an activity of $23070 \mathrm{Ci}$. UI-BG constitutes approximately $99790 \mathrm{Ci}$. Known radionuclides in the CPP LLW are given in Appendix B. 


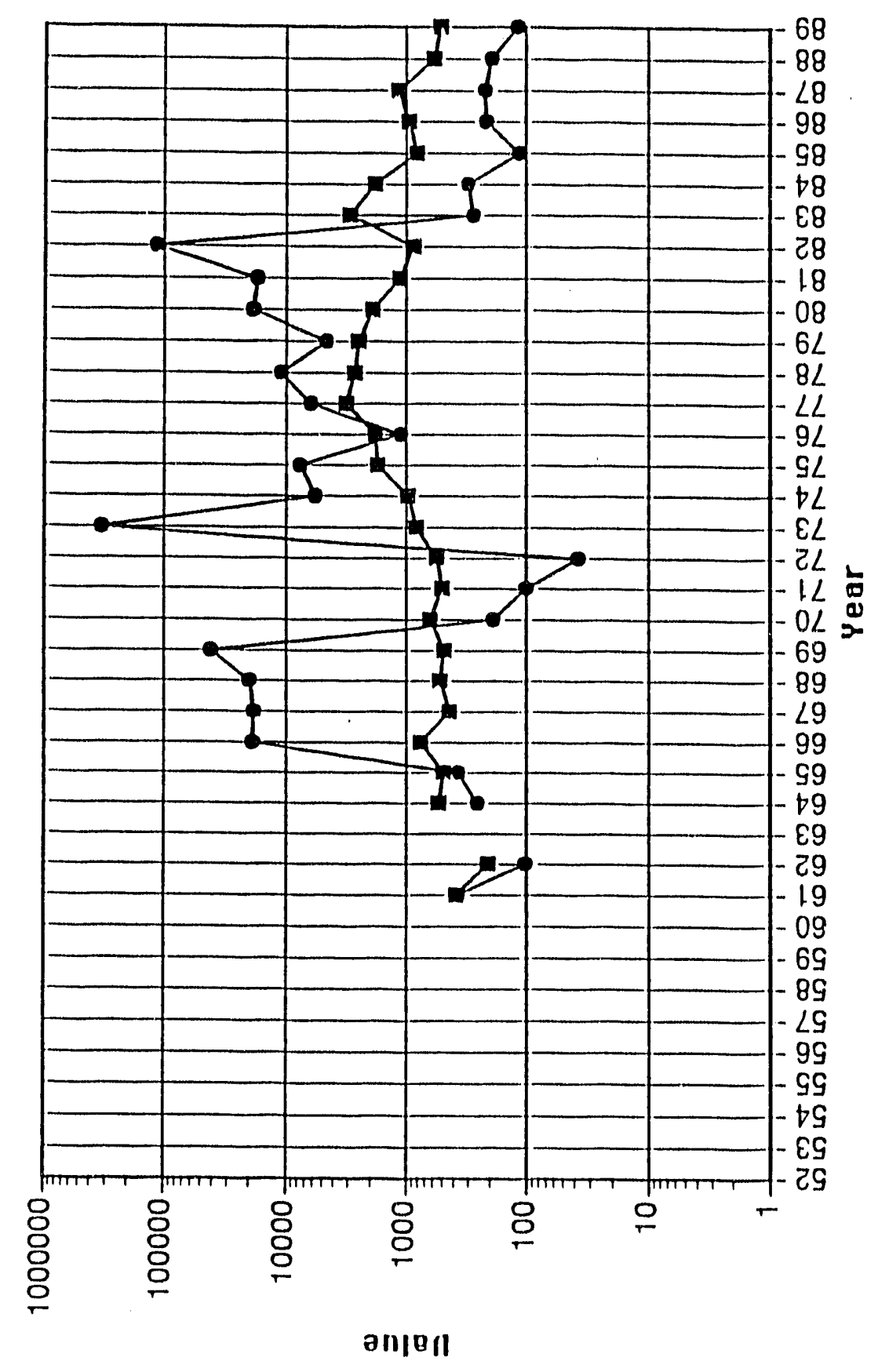

$\overline{0}$
$\phi$

항

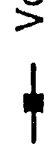

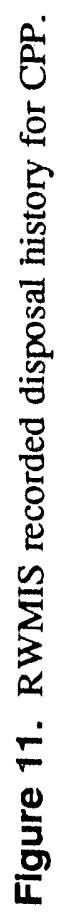

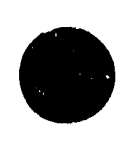




\section{Questionnaire Response}

Process history, which includes the processing of aluminum fuel, zirconium fuel, graphite, and stainless steel clad fuel, has shown almost the same radionuclide breakdown and concentrations throughout operations. Isotopic breakdowns are performed in cach process run to ensure consistency in the process. Differences may occur in the years 1981 and 1982 where the concentrations increased for CPP-603 waste (due to sludge removal from the basins). The isotopes, however, are believed to be the same.

Most waste is in combustible or compactible form and is packaged in cardboard boxes for further reduction at WERF. Non-compactible waste is primarily structural steel from demolition, glass, soils, and concrete, packaged in wood boxes.

The generator response indicates that no chemicals, explosives, or explosive mixtures have been shipped to RWMC. Aerosol cans and batteries may have been sent to the RWMC in the past.

The generic LLW includes approximately 100,000 $\mathrm{Ci}$ identified as UI-BG radionuclides and 25,000 $\mathrm{Ci}$ identified as MAP/MFP radionuclides. The UI-BG radionuclides are from the pre-1971 time period. The MAP/MFP radionuclides are from the time period since 1971. These generic radionuclides represent approximately $20 \%$ of the total activity disposed at the RWMC SDA by CPP. CPP staff have provided a standard radionuclide breakdown for the LLW of: Sr-90 (10\%); Y-90 (10\%); Zr-95 (3.1\%); Nb-95 (3.1\%); Cs-137 (10\%); Ce-144 (19.7\%); Pr-144 m(19.7\%); Sb-125 $(4.4 \%)$; Ru-106 (10\%); and, Rh-106 (10\%). This radionuclide breakdown for the $100,000 \mathrm{Ci}$ of UIBG or the $25,000 \mathrm{Ci}$ of MAP/MFP radionuclides is to be used for all years. The CPP response notes that the radionuclide mix in the disposed LLW has not changed appreciably since 1952.

\section{Other Sources of Information}

Additional sources of information are: past INEL and RWMC staff familiar with CPP operations and low-level wastes; INEL Library; documents located at CPP-608 and CPP-666; and the historical records contained in the files of the ERP which are presently being examined.

\section{D\&D Plans}

Completed decontamination and decommissioning projects at ICPP include the CPP BIF Filter Room (1984), CPP Cells A, B, C, D, and L (1984), CPP 631 Radioactive Lanthanum-140 (RALA) Off-Gas Cell (1986), and the CPP 633 (NaK) Furnace (1983).

Facilities at ICPP that are scheduled to be decommissioned include the Fuel Element Cutting Facility (FECF), the Waste Calcining Facility (WCF), RALA Off-Gas Vault and High Vacuum Cell (equipment removed during previous D\&D work), the Stored Fuel Exterior Waste Tank and Vault, the Electrolytic Dissolution System, the ROVER Graphite Fuel Processing System, and areas within CPP-603. Surplus facilities at ICPP for which decontamination and decommissioning has not been completed include CPP-603 FECF, CPP-740 Basin Filter System, CPP-603 SFE-20 Waste Tank and CPP-633 WCF. 
Error Sources and Specific Areas for Improving Information

Past INEL and RWMC staff familiar with CPP operations and low-level wastes can be interviewed. Documents located at CPP-609 and CPP-666 can be reviewed for pertinent information. The historical record contained in the files of the ERP which are presently being examined is also a source of information.

\section{Justiflcation of Improvements or Changes to the PA Inventory}

Adjustments to the LLW inventory can be made at this time. These changes are based upon generator changes to the RWMIS for the years 1971 through 1990 and generator recommendations for allocating their disposed generic radionuclides.

\section{Recommendations}

As per the generator response, the 125,000 Curies of generic classified LLW should be split as being: Sr-90 (10\%), Y-90 (10\%), Zr-95 (3.1\%), Nb-95 (3.1\%), Cs-137 (10\%), Ce-144 (19.7\%), Pr144 (19.7\%), Sb-125 (4.4\%), Ru-106 (10\%), and Rh-106 (10\%). 


\section{GENERATOR: Naval Reactor Facility (NRF)}

\section{Description}

The Naval Reactor Facility (NRF) at the INEL is a reactor development and training facility for the NAVY, operated by Westinghouse Electric Company (WEC). Information about the work performed at NRF is limited. Reactor research, testing, and development are done at various nuclear facilities at the INEL in support of NRF. This includes the design of advanced propulsion systems, new systems for present nuclear systems, and the design of advanced equipment for future use. The Extended Core Facility (ECF) is part of the NRF. NRF also has special training simulator systems in place for training members of the Navy Nuclear Fleets. NRF is and has been a significant LLW generator. The volume of LLW from NRF has varied around approximately 500 cubic meters per year since 1960. The annual disposed Curies have varied widely between 10000 and $1,000,000 \mathrm{Cl}$ per year. There have been six periods of high LLW Curie production, two pre-1974 and four post1974. The LLW disposal history for NRF is shown in Figure 12.

\section{Operations Performed, Processes and Experiments}

NRF was established in the late 1940s. It was constructed to support the Navy in developing nuclear power systems for naval weapons systems. Research and development began at the NRF in 1951.

\section{Affecting/Affected Facllitles}

NRF uses the capabilities and facilities of various INEL generators. Two major facilities are used to support NRF, they are: TRA for components and fuel development; and, the CPP for fuel reprocessing of the spent fuel reactor systems.

\section{Products}

Reactor power systems including training in their use.

\section{Radioactive Wastes and RWMIS Information}

The RWMIS records include $4356556 \mathrm{Ci}$ and 21140 cubic meters of LLW which were disposed in the RWMC SDA since 1961. The NRF LLW contains a wide variety of radionuclides. The majority of radionuclides are: Co-58; Co-60; Fe-55; Cs-134; Cs-137;Sr-89; Sr-90; Ni-59; Ni-63; Sb-125; Sn-119; Zr-95; Mn-54. Minor amounts of actinides are present in the LLW. MFP, MAP and UI-ALPHA are present in minimal amounts. UI-BG constitutes some 3,100,000 $\mathrm{Ci}$ for the period 1961 to 1970 , approximately $3 / 4(71 \%)$ of the total reported NRF Curies. Known radionuclides reported in the RWMIS for NRF LLW are given in Appendix B. 


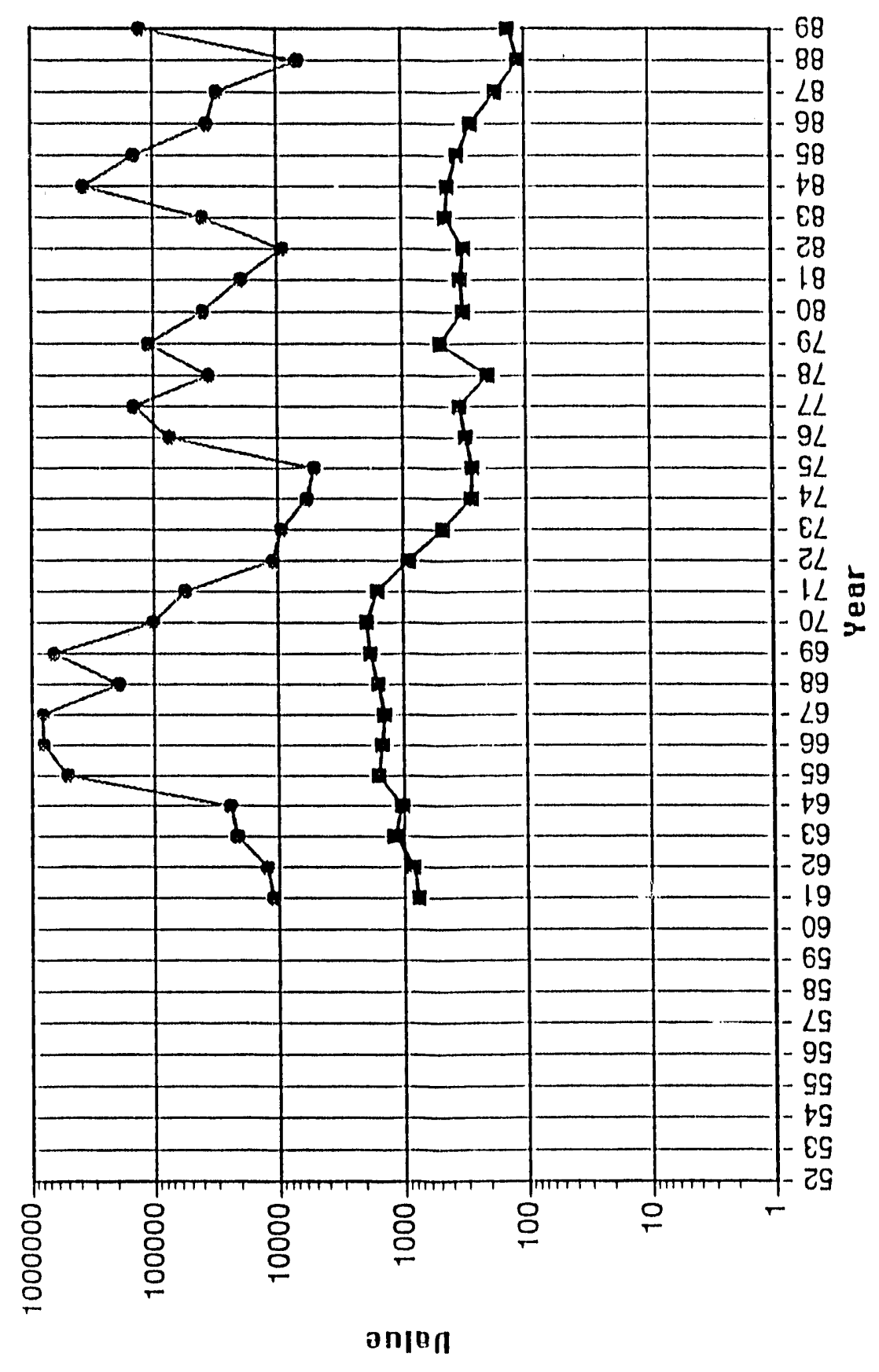

0
1

$\overline{0}$

$>$

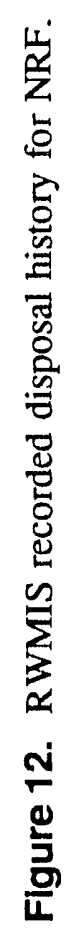


Questionnaire Response

To date, no generator response has been recelved from NRF.

\section{Other Sources of Information}

Additional sources of information may be: past INEL and RWMC staff familiar with NRF operations and low-level wastes; and, the historical records contained in the files of the ERP.

\section{D\&D Plans}

Unknown. NRF facilities are not reported in the EG\&G Site Development Plans or the INEL D\&D plan.

\section{Error Sources and Speciflc Areas for Improving Information}

To date, the generator has not responded to the questionnaire. Library material for NRF that identifies specific radionuclides is not available. Fission product distributions for fuels are normally available in published tables. The fuels used in the NRF reactors could possibly be analyzed to obtain improved radionuclide data.

\section{Justiflcation of Iinprovements or Changes to the PA Inventory}

Adjustments to the LLW inventory cannot be made at this time. Generator assistance is needed for specific radionuclide identification. The NRF LLW is reported to have approximately $3,100,000 \mathrm{Ci}$ of UI-BG LLW.

\section{Recommendations}

Obtain generator response to the questionnaire. Indications are that the processes have not changed significantly for NRF, Radionuclides generated and disposed in the 1960 (or earlier) to 1971 time period could possibly be estimated by those produced since 1970. Generator review is needed with such an assumption. Obtain additional background information from NRF if possible. 


\section{GENERATOR: Power Burst Facility (PBF)}

\section{Description}

The Power Burst Facility (PBF) is and has been a minor LLW generator. The PBF reactor is presently in standby mode. Funding for research is expected in 1992. Its charter currently includes the Boron Neutron Capture Therapy (BNCT) program, the development of waste management technologies, waste process research, waste reduction, and the storage of radioactive, mlxed wastes, It also particlpates in identifying cleanup and remediation tasks. The earller SPERT (Speclal Power Excursion Reactor Test) reactor faclities in the present PBF area produced LLW which was disposed before 1971 and were not required to report the radionuclides in the LLW. The waste reported for PBF and the SPERT program facilities are, respectively: $573 \mathrm{Cl}$ and 950 cubic meters; and, $24 \mathrm{Cl}$ and 509 cubic meters of LLW. The LLW disposal history for PBF and SPERT are shown in Figures 13 and 14

\section{Operations Performed, Processes and Experiments}

The Power Burst Facility (PBF) at the INEL currently provides facilities for research and development for waste reduction programs and the BNCT program. The PBF was orlginally constructed for the SPERT (the SPERT 1 to 4 reactor installations) in the late 1950)s. It presently includes five unique operations: PBF Control Center Area; PBF Reactor Area, which is tue only operational reactor in the PBF area: Waste Engineering Development Facility (WEDF), which was the SPERT-2 facility; Waste Experimental Reduction Facility (WERF), at SPERT-3; and, the Radioactive Mixed Waste Storage Facility (RMWSF), at SPERT-4. The reactor at the PBF facility is in standby status. Upon recelpt of funding, it is to start up for use by the BNCT program. The WEDF is an engineering and development center for waste technology applications. The WERF is a LLW processing and reduction facllity (WERF is discussed separately in this report). It processes approximately $60 \%$ of the LLW from the INEL generators and produces relatively high volumes of very low activity LLW for disposal in the RWMC SDA. The RMWSF is a Resource Conservation and Recovery Act (RCRA) storage facility for radioactive mixed waste.

The reactors of the four original SPERT programs have been decontaminated and decommissioned. The earlier SPERT facilities were involved in research and experiments in the areas:

- Thermal fucls bchavior

- Severe fuel damage

- Reactor safety

- Reactor transients

- Alternative moderators

- Flow, temperature and pressure transients

- Alternative reactor core designs. 


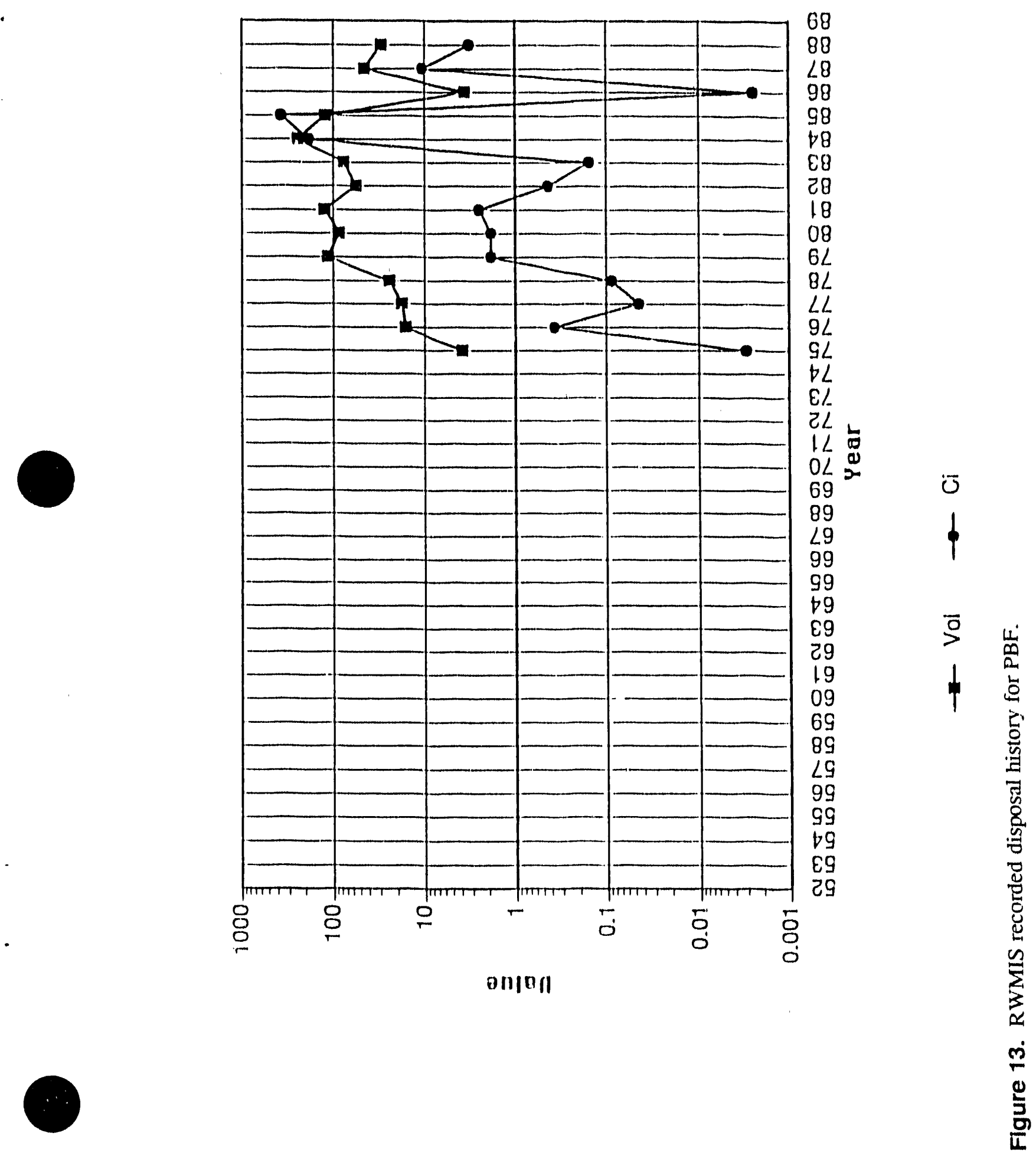



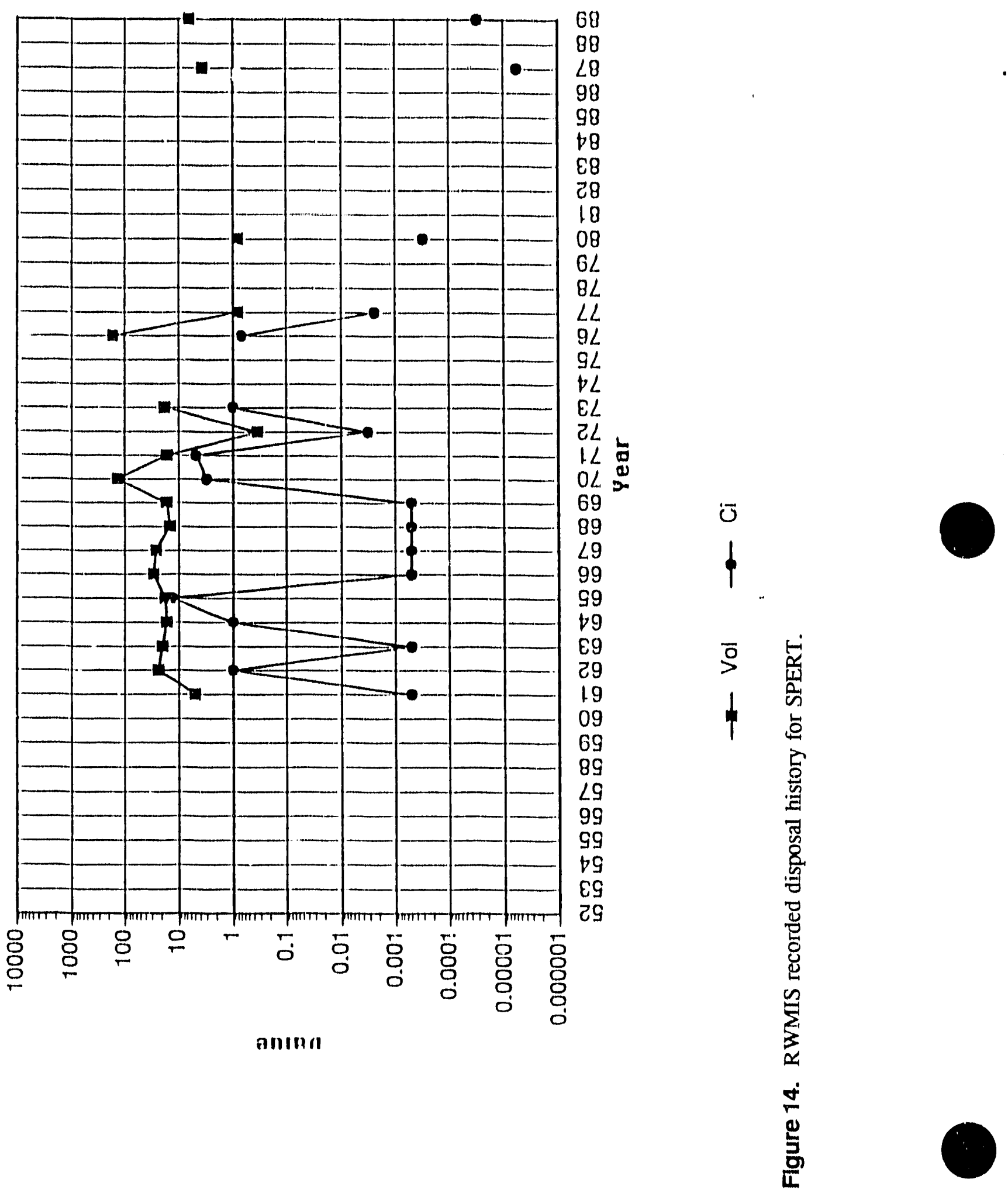
Excluding administrative work, data entry and information processing, the operations performed at the present PBF facllity are:

- Enginecring and development for waste technology applications

- Waste processing and reduction facility (WERF)

- Radioactive mixed waste storage

- BNCT research.

\section{Affecting/Affected Facilities}

NA.

\section{Products}

NA. The present PBF facility is used for irradiation, no products are produced.

\section{Radloactlve Wastes and RWMIS Information}

Radioactive wastes from operations and experiments done at the PBF and its predecessor SPERT facilities include: Cs-134; Cs-137; Co-60; Noble gasses; 1-129; I-131; Te-127. Minor amounts of actinides and lanthanides are reported. MFP and MAP are represented by an activity of approximately $192 \mathrm{Cl}$ of the total $573 \mathrm{Cl}$ reported for the $\mathrm{PBF}$. The radionuclides for $\mathrm{PBF}$ and the SPERT facilities are given in Appendix B. The RWMIS records for $\mathrm{PBF}$ include $573 \mathrm{Cl}$ and 950 cubic meters of LLW which were disposed in the RWMC SDA since 1975. The earlier SPERT reastor facilities include $24 \mathrm{Cl}$ and $5(99$ cubic meters for the period 1960 to 1989 (most is from the period 1960 to 1977).

\section{Questlonnaire Response}

Formal record keeping requirements were not in place at the PBF or its predecessor facilities during its early years of operation. Best estimates of the LLW that was disposed in the RWMC SDA were made by staff familiar with the PBF/SPERT work. Some of the RWMIS data for MFP waste is noted as most likely being Cs-137 (circa 175 Curies). Wastes disposed in the RWMC SDA include: acetone; alcohol; lead; cadmium; dry-cell batteries; aerosol cans; and, cleaning agents. These are now considered hazardous. The generator response to the questionnalre indicates that the LLW disposed in the RWMC SDA should be reconstructible from, or agrec with, the records contained in the RWMIS. 


\section{Library Search Information}

Avallable documents and papers agree with the radionuclides noted in RWMIS and the generator response.

\section{Other Sources of Information}

Noted above.

\section{D\&D Plans}

The majority of the earlior SPERT facilities and their reactors have been decontaminated and decommissioned. The PBF will start up upon recelpt of funding for its BNCT program; BNCT work and research is to continue indefinitcly.

\section{Error Sources and Speciflc Areas for Improving Information}

Although large LLW volumes and activity were/are not generated by the PBF and its predecessor facilities, a large percentage of what they did generate was reported as MFP-MAP LLW.

\section{Justification of Improvements or Changes to the PA Inventory}

The PBF and lts predecessor facilitics have been minor generators. Further refinement of the radionuclide data is a low priority. Adjustments to the LLW inventory are not necessary al this time.

\section{Recommendations}

None. 


\section{GENERATOR: Waste Experimental Reduction Facility (WERF)}

\section{Description}

WERF is and has been a minor LLW generator. It has been reducing the volume of LLW produced by INEL generators since 1985. It is a conversion of the old SPERT-3 facility. The amounts of disposed LLW reported for WERF are $1.1 \mathrm{Ci}$ and 1246 cubic meters from 1985 to 1989.

\section{Operations Performed, Processes and Experiments}

WERF is part of the Waste Reduction Operations Complex (WROC) at the INEL which provides facilities for research and development for waste reduction programs and waste technology. WERF is a waste processing and reduction facility. It processes approximately $60 \%$ of the volume of low activity LLW from the INEL generators for disposal in the RWMC SDA. It also participates in identifying cleanup and remediation tasks. No reactors are present at WERF.

Excluding administrative work, data entry and information processing, the operations performed at the present WERF facility are the following:

- Size reduction of wastes, via mechanical (compaction, crushing, sawing), melting and casting, or incineration

- Incineration of hazardous mixed wastes to eliminate the hazardous characteristic or components

- Packaging and transport to the RWMC SDA.

A variety of WERF improvement studies are being done or planned.

\section{Affecting/Affected Facillties}

WERF processes LLW from all INEL generators. Only LLW which meets the WERF waste acceptance criteria can be processed by the facility.

\section{Products}

The LLW which is reduced or processed by WERF, upon meeting the RWMC Waste Acceptance Criteria, is shipped for disposal in the RWMC SDA.

\section{Radloactive Wastes and RWMIS Information}

Radioactive wastes from operations at WERF are reported all as being MFP and MAP. The RWMIS records include $1.1 \mathrm{Ci}$ and 1246 cubic meters of this MAP/MFP LLW which were disposed in the RWMC SDA since 1985. 


\section{Questlonnalre Response}

WERF classifies its LLW as MFP/MAP. Radionuclides present in the waste from INEL generators may have been characterized by the generators before shipping to WFRF. WERF processing began after improved RWMIS information requirements were established. This means that the waste shipment Curies and volumes should be accurately reflected in the RWMIS.

\section{Library Search Information}

NA.

\section{Other Sources of information}

NA.

D\&D Plans

NA.

Error Sources and Specific Areas for Improving Information

NA.

Justiflcation of Improvements or Changes to the PA Inventory

Adjustments to the LLW inventory are not necessary.

\section{Recommendations}

None. 


\section{GENERATOR: Test Area North (TAN)}

\section{Description}

Test Area North (TAN) is an INEL location for the support of research and development programs. TAN presently generates a small amount of LLW. The volumes from TAN have remained fairly constant over time--approximately 300 cubic meters per year since 1960 . The annually disposed Curies, however, have varied widely, circa: $10 \mathrm{Ci}$ per year since $1980 ; 1000 \mathrm{Ci}$ per year for 1964 to 1979 ; and $10000 \mathrm{Ci}$ per year during the period 1961 to 1963 . The LLW disposal history for TAN is shown in Figure 15.

\section{Operations Performed, Processes and Experiments}

TAN was established in 1954, with sustained growth during 1961. TAN was originally built to support the Aircraft Nuclear Propulsion Program (ANP). TAN presently includes one major facility, the Technical Support Facility (TSF). TAN has three primary satellite areas: the Initial Engine Test Facility (IET), the old ANP facility; the Containment Test Facility (CTF); and, the Water Reactor Research Test Facility (WRRTF). The Process Experimental Pilot Plant (PREPP), for waste volume reduction, is being phased out. The Special Manufacturing Capabilities (SMC) is located in the old aircraft hanger complex of TAN which was the main LOFT facility. The Loss of Containment Test Program (LOFT or CTF) uses the rernaining portions of the previous LOFT facility (LOFT is written up separately in this report). PREPP, SMC and CTF/LOFT are contained within the TAN satellite areas.

Activities at TAN are expected to increase in the future due to dry storage of TMI core debris and other NRC fuel assemblies. TAN also participates in identifying cleanup and remediation tasks. LOFT/CTF are discussed separately in this report. The Process Experimental Pilot Plant (PREPP) was placed in standby in 1991 and is planned to be closed. Included under the spent fuel work are a variety of programs dealing with casks and transportation systems, cask testing and monitoring; and, rod consolidation. Excluding adninistrative work, data entry and information processing, the facilities or development programs active at TAN are:

- Management of TMI-2 core debris

- TAN Hot Shop

- Spent Fuel Programs (various programs are active)

- $\quad$ Containment Test Facility (CTF)

- Water Reactor Research Test Facility (WRRTF)

- $\quad$ Special Manufacturing Capabilities (SMC).

\section{Products}

The SMC within TAN is a production facility for the U.S. ARMY. 

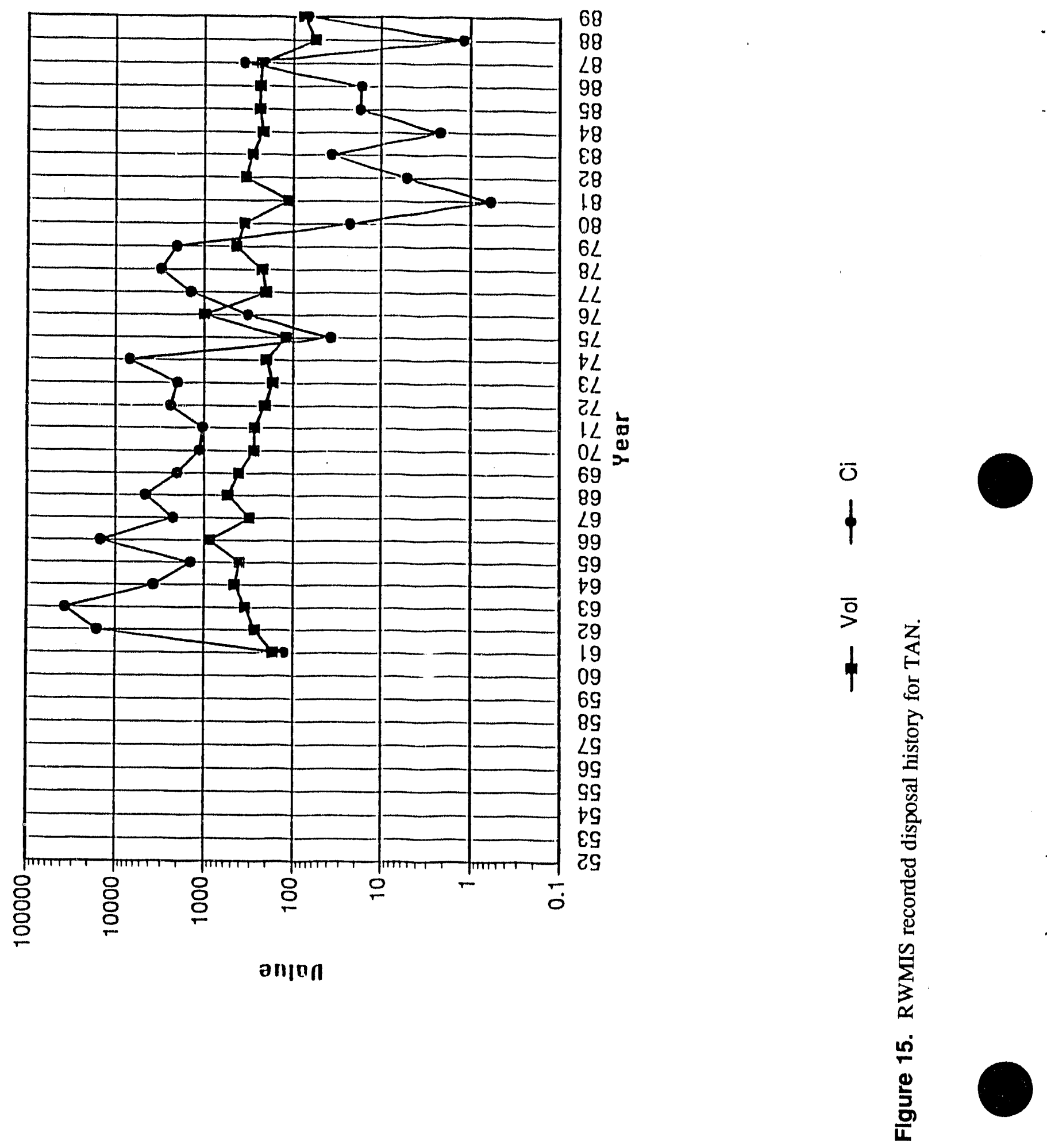
Radloactive Wastes and RWMIS Information

The RWMIS records include $101915 \mathrm{Ci}$ and 9020 cubic meters of LLW which were disposed in the RWMC SDA since 1961. The greater part of the activity is pre-1980. The radionuclides present in the LLW are Co-60, Co-58, Fe-59, Ni-59, Rb-86, Cs-134, Cs-137, Sr-90, Ce-144, Rh-106, $\mathrm{Ru}-106, \mathrm{Y}-90, \mathrm{Hf}-181$. Minor amounts of $\mathrm{Mn}, \mathrm{Ra}, \mathrm{Cm}$, and actinides are reported. MFP and MAP are repiesented by an activity of approximately $500 \mathrm{Ci}$ of the total $101915 \mathrm{Ci}$ reported for TAN. UIBG are approximately $82700 \mathrm{Cl}$. The generic radionuclides represent approximately $2 \%$ of the total generic radionuclides for all INEL LLW disposed at the RWMC SDA. Known radionuclides in the TAN LLW are given in Appendix B. SMC LLW consists of 124 cubic meters volume and an activity of less than 1 Curie for the years 1986 to 1990.

\section{Questionnaire Response}

Generator response indicates that the radionuclides listed in the RWMIS as MAP were Co-57 and Co-60 (mostly Co-60) while those listed as MFP were Cs-137 and Sr-90 (70\% Cs-137). The RWMIS radionuclide data since 1987 agree with TAN records. No indication of agreement prior to 1987 was given in the generator response. TAN staff have provided a radionuclide breakdown for the MAP/MFP radionuclides of: MAP, mostly Co-60 (100\%); and, MFP, 70\% Cs-137 and 30\% Sr-90. The $82,700 \mathrm{Ci}$ of pre-1971 UI-BG radionuclides are reported to be Cs- 137 .

Other wastes disposed by TAN in the RWMC SDA include: combustible material (wood, paper); asbestos blankets, tiles and pipe wrapping; radioactively contaminated mercury, boron and PCBs; batteries, lead sheets, shot and bricks; zirconium and cladding. Also reported were cleaning agents such as alcohol, Tri-Chlor, and Meta-Chlor and aerosol cans.

Specific work reported at TAN-607 includes: testing and evaluation of SL-1 material damage, 1961 to 1963; characterization / examination of the PM-2A tanks and the Greenland Reactor; 1963 to 1965 ; storage of spent fuel assemblies, 1975 to 1986 ; characterization/examination of the TMI-2 core and core materials including resin liners, 1982 to 1990; and, rod consolidation studies for the DRCT (Dry Rod Consolidation Technology) program, in 1987.

\section{Other Sources of Information}

Generator response notes log books at TAN and the presence of staff from earlier years who are still working at the INEL.

\section{D\&D Plans}

The original facilities of the ANP and IET have been decontaminated and decommissioned. The ANP reactors, ITRE-2 and HTRE-3 are scheduled for decontamination and decommissioning. Most of the LOFT program facilities have also been decontaminated and decommissioned. Activities at TAN are expected to decrease in the future, with a significant percent of its facilities to be decontaminated and decommissioned. IET is being considered for potential use in new programs. The D\&D Long Range Plan (Sekot 1990) and the INEL Site Development Plan (DOE-ID 1991) describe the D\&D plans for TAN. 
Error Sources and Speciflc Areas for Improving Information

As with most INEL generators, formal record keeping was not done in the earlier time periods. Logbooks are reported to exist at TAN. Shipping data from 1983 are reported to be available.

\section{Justlfication of Improvements or Changes to the PA Inventory}

Changes have been suggested by TAN staff.

\section{Recommendations}

Adjustments to the LLW inventory for use in the PA can be made at this time. These changes are based upon generator response. All TAN MAP radionuclides should be considered as being Co60 (this requires no change from what is presently done). All TAN MFP radionuclides should be split: $70 \%$ Cs-137 and 30\% Sr-90. All TAN UI-BG radionuclides should be assigned as being 70\% Cs-137 and 30\% Sr-90. Changes lowering the reported Curies for the years 1983 to 1987 are also possible. The Curies for these years have been reduced up to $50 \%$. 


\section{GENERATOR: Loss-of-Fluids Test (LOFT) Facility/ Containment Test Facility (CTF)}

\section{Description}

The Containment Test Facility (CTF), formerly known as the Loss-of-Fluids Test (LOFT) Facility is one of three satellite areas within the complex of Test Area North (TAN). The LOFT/CTF is an INEL facility used to perform loss-of-coolant expcriments (LOCEs) that simulate loss-ofcoolant accidents (LOCAs) as part of the nation's power water reactor program. The LOFT/CTF generates minor amounts of LLW.

\section{Operations Performed, Processes and Experiments}

The LOFT/CTF was established in the mid-1960's. LOFT/CTF was originally built to support the Power Water Reactor Program. The LOFT/CTF area includes the CTF Containment and Service Building (TAN-650), the CTF Containment Vessel, the CTF Reactor Control and Equipment Building (TAN-630), an aircraft hangar, and support facilities. Most of the LOFT/CTF program facilities have been decontaminated and decommissioned. The present LOFT/CTF activities also include cleanup and remediation work.

Excluding administrative work and data entry and information processing, the operations, research and development program at LOFT/CTF is the Augmented Operator Capability (AOC) Program. The AOC program includes alements to improve the ability of LOFT/CTF and commercial reactor operations personnel to recognı.c and correctly respond to emergency conditions in light water reactors.

\section{Affecting/Affected Facillities}

NA. ,

\section{Products}

None.

\section{Radloactlve Wastes and RWMIS Information}

The RWMIS records include $305 \mathrm{Ci}$ and 1157 cubic meters of LLW which were disposed in the RWMC SDA since 1981. The greater part of the activity occurs from 1985 to 1987 . The primary radionuclides present in the LLW include Co-58 and Co-60. Minor amounts of $\mathrm{Ag}-110, \mathrm{Cr}$ 51, Mn-54, and Cs-137 are also reported. Activity levels for MFP and MAP are negligible for LOFT/CTF. Known radionuclides in the LOFT/CTF LLW are given in Appendix B.

\section{Questionnaire Response}

No generator response has been received to date from LOFT/CTF. 


\section{Other Sources of Information}

Staff personnel of LOFT/CTF who are still working at the INEL.

\section{D\&D Plans}

Most of the LOFT/CTF facilities have been decontaminated and decommissioned. The INEL Site Development Plan (DOE-ID 1990) and the D\&D Program Long Range Plan (Sekot 1990) describe the $D \& D$ plans for the remaining facilities.

Error Sources and Speclfic Areas for Improving Information

NA.

\section{Justification of Improvements or Changes to the PA Inventory}

LOFT/CTF LLW shipments began in 1981. This was after the inauguration of the improved RWMIS data input requirements. Unless present or past staff of the LOFT/CTF project can show gross errors in the RWMIS data, no changes are indicated. The small quantities of LLW also support this.

\section{Recommendations}

None, the LOFT/CTF radionuclide data can be assumed accurate. 


\section{GENERATOR: Test Reactor Area (TRA)}

\section{Description}

Test Reactor Area (TRA) is an INEL location for the support of research and development programs dealing with reactor fuels, materials used in nuclear environments, and clectronic systems. TRA is and has been a significant LLW generator. The volumes from TRA have been fairly constant over time -- approximately 500 cubic meters/yr, since 1960. The annually disposed Curies have: varied widely between 100 and $100,000 \mathrm{Ci}$ per year. There have been four periods of high LLW Curie production, two pre-1974 and two post-1974. The LLW disposal history for TRA is shown in Figure 16.

\section{Operations Performed, Processes, and Experiments}

TRA was established in 1952. It was constructed to support government and private agencies in conducting experiments associated with development, testing, and analysis of materials and fuels used in nuclear reactor applications. TRA presently includes one major facility and reactor, the Advanced Test Reactor (ATR). Support functions located at TRA include the: TRA hot cells; Advanced Reactivity Measurement Facility/Coupled Fast Reactivity Measurement Facility (ARMF/CFRMF); Hydraulic Test Facility; Neutron Radiography Facility; Radiation Measurements Laboratory (RML); Chemistry and Physics Laboratory; TRA Warm Waste Treatment Facility (TRAWWTF); New Production Reactor (NPR) instruments and fabrication; and Test Train Assembly Facility (TTAF). Other research done at the TRA involves environmental restoration and tritium research.

The Materials Test Reactor (MTR) and the Engineering Test Reactor (ETR) facilities are not in operation. Portions of the MTR/ETR facilities have been decontaminated and decommissioned (decontamination and decommissioning still continues for these facilities). Some 25 structures and facilities at TRA have been identified for D\&D.

Activity at the TRA is expected to increase over the next five years. New research is planned in the chemical and physical sciences. TRA also participates in identifying cleanup and remediation tasks. There is a Sanitary Waste and Radioactive Effluent Zone, a Low-Level Liquid Radioactive Waste Retention Basin, a sewage plant, and a canal at ATR for the interim storage of radioactive wastes. Solid low-level wastes are sent to WERF and the RWMC SDA for reduction and/or disposal. High level waste from reactor fuel change-outs is sent to the CPP for reprocessing (other wastes resulting from this reprocessing may also produced at CPP).

\section{Affecting/Affected Facillities}

NA.

\section{Products}

NA. 


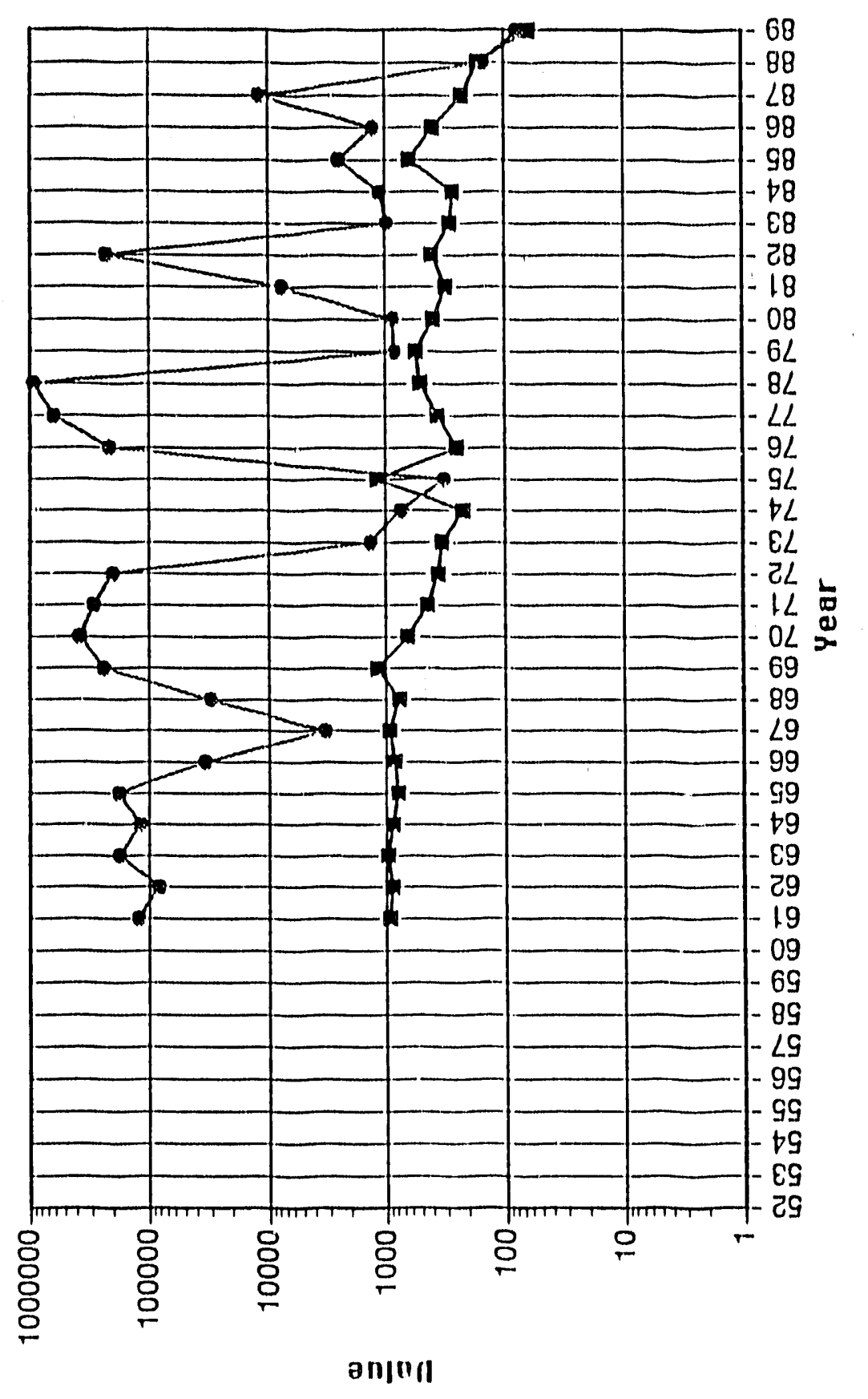

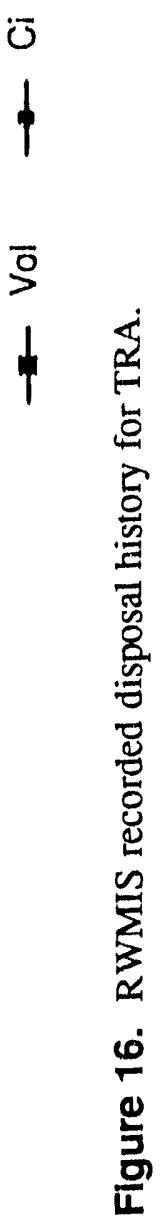




\section{Radioactive Wastes and RWMIS Information}

The RWMIS records include $3883667 \mathrm{Cl}$ and 15973 cubic metors of LLW which were disposed in the RWMC SDA since 1961. The TRA LLW contains a wide varicty of radionuclicles. The majority of radionuclides are: Cs-134; Cs-137; Co-60; Fe-59; N1-59; Mn-54; Mn-56; Cr-51; Zn65: Ce-141; Ce-144; W-187; Ba-140; La-140; Nb-95; Zr-95; Sc-46; Hr-181; 1-131; Ag-110. MFP and MAP are represented by an activity of approximately 84500$) \mathrm{Cl}$ of the total $3883667 \mathrm{Cl}$ reported for TRA $(2 \%)$, UI-BG constltutes some $13920(0) \mathrm{Cl}$, approximately $1 / 3(36 \%)$ of the total reported TRA Curles. Known radionuclides reported in the RWMIS for the TRA LLW are given in Appendix B.

\section{Questlonnalre Response}

To date, no generator response has been recelved from TRA.

\section{Other Sources of Information}

Additional sources of information are: past INEL and RWMC staff famillar with TRA operations and low-level wastes; INEL Library; and the historical record contained in the files of the ERP which are presently being examined.

\section{D\&D Plans}

The Matcrials Test Reactor (MTR) and the Enginecring Test Reactor (ETR) facilities arc incperative and decontamination and decommissioning is in progress. Approximately 25 TRA structures or facilities have been iddentified for decontamination and decommissioning. The INEL Site Development Plan (DOE-ID 1991) and the D\&D Long Range Plan (Sekot 1990) describe the D\&D plans for ThA.

\section{Error Sources and Specific Areas for Improving Information}

To date, the generator has not responded to the questionnaire. The primary source of improvement is to determine the breakdown in the approximately 1 million Curies of UI-BG radionuclides. An additional source of information is to examine the fuel(s) used in the reactor operations. The fission product distributions for fuels are normally known.

\section{Justification of Improvements or Changes to the PA Inventor}

The primary area of improvement for TRA is to determine the breakdown of the UI-BG radionuclides disposed from 1960 through 1970. Adjustments to the LLW inventory cannot be made at this time without this. 


\section{Recommendations}

Obtain a generator response to the yuestionnalre and get thetr assistance in lmproving the radionuclide breakdown of the UI-BC and MAP/MFP LLW. Radionuclides generaled and disposed In the 1960 (or carlicr) to 1971 thme perlod mily possibly be represented by those produced since 1970. Generator review is needed with such an assumption. Signiflicant TRA canal shlpments are expected to be dlsposed at the RWMC SDA In 1991 and 1992. PA staft should Include estimates of these planned shipments. 


\section{RADIONUCLIDE INVENTORY CHANGES FOR THE PA Revised Radionuclide Inventory for the PA}

Improvements to the estimates of the disposed LLW are summarized immediately below. Detalls on the implementation of those which can be immediately incorporated are glven in the next section. Changes which are not the result of RWMIS updates or generator recommendations will require generator concurrence.

Improvements which can immediately be implemented by the PA are:

- The annual changes to the RWMIS since 1988

- Generalor supplled changes to the RWMIS by CPP, TAN and LOFT/CTF present in the RWMIS but not included in the PA (those noted above which caused the discrepancy between the PA and RWMIS)

- Generator supplled recommendations from TAN for MFP and TAN generic radlonuclides.

- Generator supplied recommendations from ANL-W and ANL-W generic radionuclides.

- Generator supplied recommendations from CPP and CPP generic radionuclides.

- The allocation of RWMC generic LLW to other INEL generators,

- The exclusion of the LLW in Pad-A. Pad-A is planned for remediation. 
Improvements which require analysis and cooperatton between other INEL staff before they can be considered further or implemented in the PA are:

- Obtain generator response from TRA and NRF

- Develop an improved radionuclide breakdown for the generic radionuclides in LLW disposals for which the generic radionuclide classification can not be resolved. This work has been started (Maheras and Rood 1991).

- Estimate TRA and NRF radionuclide improvements based on the improved radionuclide breakdown

- Reduced waste weights could be used. Shielded container weights were entered as the waste weights in many instances by NRF up to 1970. The RWMIS records containing these entries need to be identified and assessed for the potential improvement they may give.

- NRF and TRA Curies could possibly be decreased for the shipment records for which liberal Curie estimating rules were used during the 1960s. Time away from core and Curie estimates due to shiclding were conservative estimates. The RWMIS records containing these entries need to be identified and assessed for the potential improvement they may give.

- Significant TRA canal shipments are expected to be disposed at the RWMC SDA in 1991, 1992, and later. PA staff should kecp abreast of include estimates of these planned shipments in the LLW forecasts used in the PA.

- RWMIS data entries - outlier analysis. The historical shipping manifests and RWMIS best avallable data file contain approximately 45 records having some 5 million Curies of LLW. These records are suspect and could potentially reduce the total disposed LLW activity.

- The exclusion of the LLW in Pit-9. Pit-9 is planned for remediation. The LLW may be reburied in the pit, however.

\section{Changes Due to Inventory Related Findings of the Environmental Restoration Program (ERP)}

Staff of ERP have been examining the avallable pre-1971 shipping manifests which were obtained from the Federal Repository in Scattle, Washington. After examination of the pre-1971 archives is completed, they plan on examining the post-1971 archives. One goal of their work is to suggest improvements to the RWMIS database.

The examination of the shipping archives will require the analysis of the findings. Specific issues may arise from such an examination. A statistical analysis of the pre-1971 shipping manifests against the RWMIS best available data file (the RWMIS BAD-File) is also being done. 
Data input errors in pre-1971 shipping manifests have been found by ERP and Waste Management staff. Additionally, approximately 300 pre-1960 shipping records have been found for the generators CPP, SPERT and TRA which are not included in the RWMIS BAD-File. Present plans of ERP call for sub-corrtracting a detailed analyses of the shipping manifests and the identification of these and other questionuible records for inclusion in the RWMIS database. A risk assessment effort which addresses the LLW Lurial locations is also planned as part of the ERP work. 


\section{Changes not Requiring Interface with Other INEL Areas}

Changes which can immediately be implemented by the PA are:

\section{Annual Changes to the RWMIS since 1988}

Update to the PA must include the radionuclide changes for the years 1989 and 1990 as well as the approximately $14,200 \mathrm{Ci}$ changes to CPP disposed LLW from pre-1988. These latter changes are included in the latest RWMIS database (Litteer 1991). The RWMIS data for 1991 should also be included. The data for 1991 should be ready for use by mid-1992.

\section{Generator Changes to the RWMIS by CPP, TAN and LOFT/CTF Present in the RWMIS but not Included In the PA}

The changes for CPP, TAN and LOFT are also included in the latest RWMIS for all years. These changes affect only the reported Curies. No changes in volume are to be made, the volumes have .emained the same.

\section{Generator Recommendations from TAN}

Generator response to the questionnaire resulted in a revised breakdown for the generic radionuclides. These changes are:

All TAN MAP radionuclides should be classified as Co-60 (this is no change from what is presently done).

All TAN MFP radionuclides should be split: $70 \%$ Cs-137 and 30\% Sr-90.

All TAN UI-BG radionuclides should be assigned as $70 \%$ Cs-137 and 30\% Sr-90.

Changes to the reported Curies (no volume changes) for the years 1983 to 1987 were reported for building TAN 607 . These changes have not been included in the RWMIS. The revised data are (a 0.0 increment indicates no change):

\begin{tabular}{llcc} 
Year & Nuclides & Increment & New Total Curies \\
\hline 1983 & Rh-106 & 0.0 & 0.150 \\
Ru-106 & 0.0 & 0.150 \\
Y-90 & 0.0 & 0.150 \\
Cs-134 & 0.0 & 0.601 \\
Cs-137 & -22.21 & 7.800 \\
Sr-90 & +3.20 & 3.350 \\
MFP & -5.35 & 0.0 \\
& & & -12.20
\end{tabular}




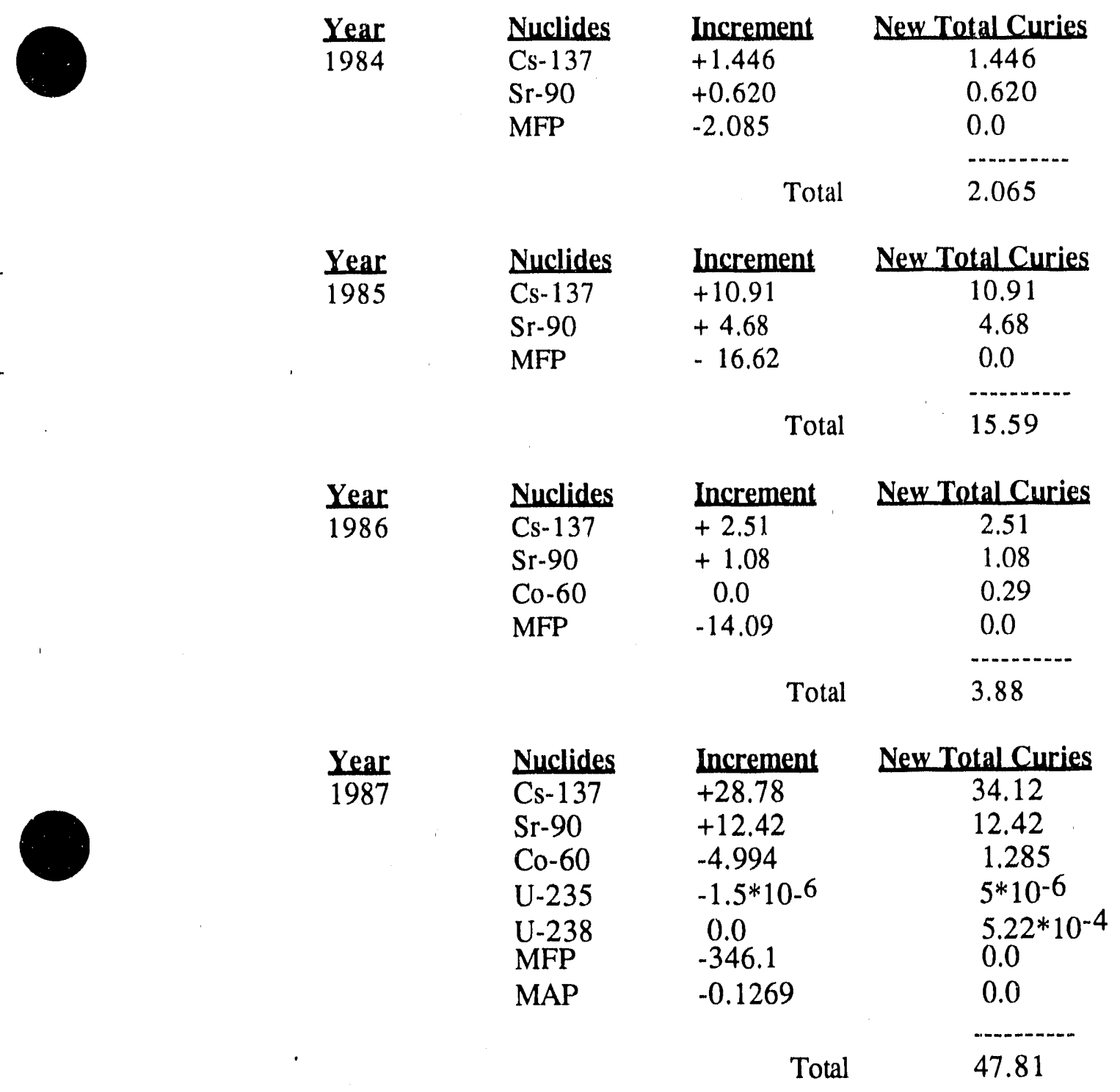

Generator Supplied Recommendations from ANL-W and ANL-W Generic Radionuclides.

The approximate 50,000 $\mathrm{Ci}$ of pre-1971 UI-BG LLW and the 1,500 Curies of post-70 MAP/MFP radionuclides should be split as $40 \%$ MAP and 60\% MFP. The MAP should be Co-58 (50\%) and Mn-54 (50\%). The MFP should be Cs-137 (20\%), Ce-144 (50\%), Sr-90 (20\%) and Cs-134 (10\%).

\section{Generator Supplied Recommendations from CPP and CPP Generic Radionuclides.}

As per generator recommendations, all of the approximate 125,000 Curies of generic classified LLW (MAP, MFP and UI-BG) disposed since 1952 should be allocated as:

$$
\begin{aligned}
& \text { Sr-90 (10\%) } \\
& \text { Y-90 (10\%) }
\end{aligned}
$$




$\begin{array}{ll} & \text { Zr-95 (3.1\%) } \\ & \text { Nb-95 }(3.1 \%) \\ & \text { Cs-137 (10\%) } \\ & \text { Ce-144 (19.7\%) } \\ & \text { Pr-144 (19.7\%) } \\ & \text { Sb-125 (4.4\%) } \\ & \text { Ru-106 (10\%) } \\ \text { and, } & \text { Rh-106 (10\%) }\end{array}$

The Allocation of RWMC Generic LLW to Other INEL Generators.

The approximate 61,000 Curies of UI-BG generic LLW attributed to the RWMC should be allocated to the major INEL generators in operation up to 1961. The generators are: TAN, CPP, ANL-W, TRA, and NRF. Assignment should be done according to the generators' percent of their reported UI-BG and their recommendations for radionuclide assignments as described in this report above.

\section{The Exclusion of Pad-A Radionuclides}

The radionuclide inventory of Pad-A is included in the PA. Pad-A is to be remediated, therefore consider excluding its inventory of LLW from the PA. (Remediation is also planned for Pit-9 and the same may apply to the Pit-9 LLW radionuclides. Present Pit-9 remediation plans may result in the Pit-9 LLW being left in place, however).

Pad-A is classified as disposed LLW for reporting purposes and in the RWMIS database. PadA has some 10,400 cubic meters and $70 \mathrm{Ci}$ of radioactive wastes stored upon it. (Comparisons of disposed waste using the RWMIS annual report data often lead to these Pad-A differences in volume and Curies. The RWMIS annual report includes them as disposed LLW without noting it.) 


\section{REFERENCES}

US-DOE, "Radioactive Waste Management," DOE Order 5820.2A, September 26, 1988.

DOE-ID, INEL Site Development Plan, April 1990.

DOE-ID, INEL Low-Level Radioactive Waste Acceptance Criteria, DOE/ID-10112, Rev. 4, October 1991.

Barnard, C., Radioactive Waste Management Information System and Accuracy Assessment Sampling Design Letter Report, EG\&G, Internal Memo CJB-12-91, from Cathy Barnard to Yusef Noorani, June 17, 1991.

Card, D. H., History of Buried Transuranic Waste al INEL, EG\&G Idaho Inc., WMP 77-3, March 1977.

Case, M. J., and Otis, M. D., Guidelines for Radiological Assessment of DOE Low-level Radioactive Waste Dispesal Sites, DOE/LLW-62T, July 1988.

Case, M. J. et. al., Recommended Format and Content for DOE Low-Level Waste Disposal Facility Radiological Performance Assessment Reports, DOE/LLW-81, April 1989.

Litteer, D. L. et al., Radioactive Waste Management Information for 1988 and Record-to-Date, DOEID-10054(88), July 1989.

Litteer, D. L. et al., Radieactive Waste Management Information for 1989 and Record-to-Date, DOEID-10054(89), June 1990.

Litteer, D. L. et al., Radioactive Waste Management Information for 1990 and Record-to-Date, DOEID-10054(91), July 1991.

Maheras, S. J. et al., Draft Radioactive Waste Management Com;'ex Performance Assessment, EGGWM-8773, June 1990.

Maheras, S. J. and Rood, A. S., "Intruder Dose Calculations for Mixed Fission Products and Mixed Activation Products Disposed of at the Radioactive Waste Management Complex," May 1991. (Attached in part as Appendix F in this report.)

Maheras, S. J. and Rood, A. S., "Intruder Dose Calculations for Unidentified Alpha Radionuclides Disposed of at the Radioactive Waste Management Complex," May 1991. (Attached as Appendix F in this report.)

Plansky, L. E., "Radioactive Waste Management Complex Low-Level Waste Inventory for Performance Assessment: Volume and Curie Verification," EG\&G Internal Memo LEP-03-91, from L. E. Plansky to Distribution, March 4, 1991.

Plansky, L. E., "Low-Level Waste Radionuclide Inventory Analysis for Performance Assessment," Engineering Design Fille \#504, EG\&G Waste Management, February 1992. 
Rodgers, A. D. et al. A History of the Radioactive Waste Management Complex at the Idahe National Engineering Laboratory, WM-F1-81-003, Rev. 3, July 1985.

Schmalz, B. L., Radionuclide Distribution in Soil Mantle of the Lithosphere as a Consequence of Waste Disposal at the National Reactor Test Station. ID0-10049, October 1972.

Sekot, M., Idahe National Engineering Laboratory Decontamination and Decommissioning Lonf:Range Plan. Draft PR-W-79-005, Rev. 8, September 1990.

Anon. Environmental and Other fivglitations of Low-Level Waste at the Radioactive Waste Management Complex. EGG-WM $652 \% 19 \$ 4$. 
APPENDIX A

A BRIEF HISTORY OF THE RADIOACTIVE WASTE MANAGEMENT DATABASE (RWMIS)

A-1 
•

•

-

$$
\text { A-2 }
$$




\section{APPENDIX A \\ A BRIEF HISTORY OF THE RADIOACTIVE WASTE MANAGEMENT DATABASE (RWMIS)}

The RWMIS was implemented in January 1971. At that time, 1952 to 1970 data was placed into the database. These data that were input into RWMIS were based on records kept at the RWMC. During 1971 - 1986 RWMIS data was input on a shipment basis (allowing more than one container per shipment). Since 1986, RWMIS data has been input on a container basis. The information given below apply to the official data the RWMIS reports (Litteer, 1989, 1990, and 1991) unless otherwise noted.

For the period 1952 to 1970 , the RWMIS data may be summarized as follows:

Summary data based on RWMC records

- Annual volume disposed by area

- $\quad$ Annual curies disposed by area

- Details on nuclides limited (mostly unidentified beta-gamma)

The confidence of data accuracy, that records in RWMIS reflect what is actually disposed at the RWMC for the period 1952 to 1970 is:

- Disposed volume - $70 \%$ (only data source RWMC logbooks and records)

- $\quad$ Disposed curies - $70 \%$ (only data source RWMC logbooks and records)

- $\quad$ Specific nuclides - $10 \%$ (not recorded)

- $\quad$ Specific locations - 0\% (not recorded)

For the period 1971 to 1984 , the RWMIS is more detailed and may be summarized as:

- Generator area and building

- $\quad$ Shipment total volume

- Shipment total weight

- Shipment total curies

- $\quad$ Nuclides in shipment (curies and grams of each nuclide)

- Generic shipment description

- Type of containers in shipment

- Number of each type of container in shipment (generic description of contents by type of container) 
- Disposal location and date

The confidence of data accuracy, that records in RWMIS reflect what is actually disposed at the RWMC for the period 1971 to 1984 is:

- $\quad$ Disposed volume $-85 \%$

- Disposed curies - $85 \%$

- Specific nuclides - 75\% (MFP, MAP, unidentified beta-gamma, unidentified alpha)

- $\quad$ Specific locations - $50 \%$

The above confidence bands are based on expert judgement. The lack of formal quality assurance procedures, shipment observation and recording errors, and shipment characterization errors are responsible for the uncertainty in the RWMIS data for the years prior to 1984.

In 1984, the RWMIS underwent revision to enhance the data. The shipment numbers were included instead of generic descriptions. The containers were listed individually and information included:

- Container number

- Content code instead of generic waste description

- Dose rate at contact

- Volume percent metal

- Volume percent combustible

- Disposal location and date

- Container basis

The RWMIS data is taken as the standard in this report. All comparisons are made against the RWMIS. The RWMIS has two LLW data files within it. The first is the file of reported data which has been entered according to established RWMIS procedures. The second is the "best-available" data file, also called the BAD-FILE. This latter file contains records of questionable value, 
APPENDIX B

RWMIS INVENTORY DATA

B-1 
$\bullet$

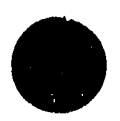

-

B-2 


\begin{tabular}{|c|c|c|}
\hline QENERATINO & OEHERATINO & DISPOSAL. \\
\hline AREA & BUILDINO & YEAR \\
\hline & …......... & \\
\hline ALE & 306 & 86 \\
\hline
\end{tabular}
$\begin{array}{ll}\text { ANNUAL } & \text { ANNUAL. } \\ \text { VOLUME } & \text { WEIOHT }\end{array}$

$1.359 E+01$ QRAMS

4. $720 E+06$ CUBIC METERS

ANNUAL
CURIES
$2.372 E-01$

NUCLIDE

$A M-241$

$A M-243$

C. 14

CD. 109

$\mathrm{CO}-60$

EU-152

EU- 154

$K-40$

MAP

HFP

$N A-22$

$N P-237$

PU- 239

$P U-240$

$R A-226$

TC- 99

$\mathrm{U} \cdot 235$

U-238
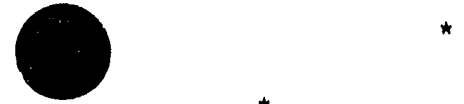

$\star$

317

80
81

*

1

$1.621 E+03$
$5.506 E+02$ $.204 E+08$

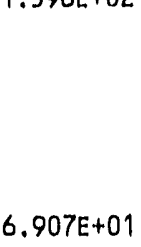

CO- 5

CO- 60

CS -137

EU- 152

$1-125$

MFP

$M N-54$

NA- 22

PU- 239

PU- 240

TH- 232

$\mathrm{U}-233$

$U-235$

U- 238

ZN-65

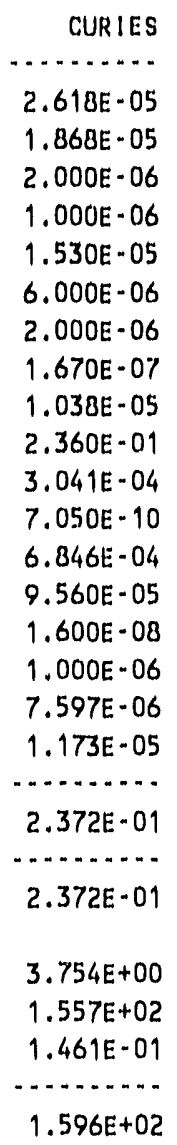

4.570E-01

$7.448 \mathrm{E}+00$

$1.000 E-03$

$2.500 \mathrm{E}-03$

2.000E-02

$4.324 E+01$

$1.725 E+01$

2. 180E- 04

$1.325 E-02$

$5.962 E-03$

$1.090 E-15$

$3.788 \mathrm{E}-05$

1. $891 \mathrm{E}-04$

1.378E-02

$6.100 E=01$

$6.907 E+01$ 


\begin{tabular}{|c|c|c|c|c|c|c|c|}
\hline $\begin{array}{l}\text { GENERATINO } \\
\text { AREA }\end{array}$ & $\begin{array}{l}\text { DENERATING } \\
\text { BUILDINO }\end{array}$ & $\begin{array}{l}\text { DISPOSAL } \\
\text { YEAR }\end{array}$ & $\begin{array}{c}\text { ANNUAL } \\
\text { VOLUME } \\
\text { CUBIC METERS }\end{array}$ & $\begin{array}{l}\text { ANNUAL. } \\
\text { WEIOHT } \\
\text { GRAMS }\end{array}$ & $\begin{array}{l}\text { ANNUAL } \\
\text { CURIES }\end{array}$ & NUCL IDE & CURIES \\
\hline . & $\ldots \ldots \ldots$ & $\cdots \ldots$ & $\ldots \ldots \ldots$ & . & , n n & . & …........ \\
\hline \multirow[t]{45}{*}{ ALE } & 317 & 82 & $6.766[\mathrm{E}+02$ & $3.069 E+08$ & $1.852 E+02$ & $A O-110$ & $1.250 E-02$ \\
\hline & & & & & & $A H-241$ & $1.329 E-02$ \\
\hline & & & & & & $B E-7$ & $3.511 \mathrm{E}-01$ \\
\hline & & & & & & $c \cdot 14$ & $1.607 E-03$ \\
\hline & & & & & & $C D \cdot 104$ & $1.500 E-07$ \\
\hline & & & & & & $C D \cdot 109$ & $1.747 E=04$ \\
\hline & & & & & & $C E-144$ & $8.000 E-06$ \\
\hline & & & & & & $C M-244$ & $1.000 E-06$ \\
\hline & & & & & & 60.57 & $4.314 E+00$ \\
\hline & & & & & & $\cos 58$ & $1.310 E=04$ \\
\hline & & & & & & $\mathrm{Co} \cdot 60$ & $4.414 E+01$ \\
\hline & & ! & & & & $C R \cdot 51$ & $7.600 \mathrm{E}-02$ \\
\hline & & & & & & $\operatorname{cs}-134$ & $3.050 E-04$ \\
\hline & & & & & & cs-137 & $2.547 E-03$ \\
\hline & & & & & & $E U=152$ & $1.650 E-03$ \\
\hline & & & & & & EU- 154 & $4.500 E-04$ \\
\hline & & & & & & $F E-59$ & $7.431 E-03$ \\
\hline & & & & & & $H-3$ & $1.195 \mathrm{E}-02$ \\
\hline & & & & & & $1-125$ & $9.300 \mathrm{E}-03$ \\
\hline & & & & & & MFP & $4.232 E+01$ \\
\hline & & & & & & $M N-53$ & $1.000 E-03$ \\
\hline & & & & & & $M N=54$ & $9.208 E+01$ \\
\hline & & & & & & $N A-22$ & $7.018 E-03$ \\
\hline & & & & & & $N 1-63$ & $2.500 E-04$ \\
\hline & & & & & & $N P-237$ & $7.355 E-05$ \\
\hline & & & & & & $P B-210$ & $9.100 \mathrm{E}-06$ \\
\hline & & & & & & $P B-212$ & $2.000 E-0.5$ \\
\hline & & & & & & PU-238 & $3.043 E-05$ \\
\hline & & & & & & PU-239 & $4.472 E-02$ \\
\hline & & & & & & $P U-240$ & $1.836 E-02$ \\
\hline & & & & & & PU-242 & $9.498 E-06$ \\
\hline & & & & & & $R A-226$ & $4.785 E-03$ \\
\hline & & & & & & $s-35$ & $2.050 \mathrm{E}-02$ \\
\hline & & & & & & $S R-90$ & $2.000 E-06$ \\
\hline & & & & & & TC-99 & $2.000 E-06$ \\
\hline & & & & & & $T H-232$ & $2.107 E-04$ \\
\hline & & & & & & $U \cdot 233$ & $2.983 E-06$ \\
\hline & & & & & & $U-235$ & $1.126 E-02$ \\
\hline & & & & & & $U \cdot 238$ & $1.770 E+00$ \\
\hline & & & & & & $2 N-65$ & $8.601 E-03$ \\
\hline & & & & & & & 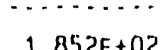 \\
\hline & & " & & & & & $1.852 E+02$ \\
\hline & & 83 & $2.990 \mathrm{E}+02$ & $1.366 E+08$ & $2.389 E+01$ & $B E \cdot 7$ & $3.320 \mathrm{OE}-05$ \\
\hline & & & & & & $C-14$ & $4.000 E-06$ \\
\hline & & & & & & CD. 109 & $1.370 F-03$ \\
\hline
\end{tabular}




\begin{tabular}{lll}
$\begin{array}{c}\text { GENERATING } \\
\text { AREA }\end{array}$ & $\begin{array}{l}\text { GENERATING } \\
\text { BUILDING }\end{array}$ & $\begin{array}{c}\text { DISPOSAL } \\
\text { YEAR }\end{array}$ \\
\hdashline & \multicolumn{1}{c}{ CUB } \\
ALE & 317 & 83
\end{tabular}

ANNUAL
VOLUME
CUBIC METERS

ANNUAL

WEIGHT GRAMS

ANNUAL

CURIES

NUCLIDE

CURIES

$\mathrm{CO}-57$

CO-58

Co. 60

CS- 134

CS -137

EU- 152

FE-59

$\mathrm{H}-3$

MFP

MN -54

NA-22

NP -237

PU -238

PU-239

PU -240

RA -225

SR -90

TH- 232

$\mathrm{U}-233$

$U-235$

$U-238$

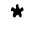

84

$4.422 E+02$

$2.301 E+08$

$3.677 E+01$

AM- 24

AM- 243

C- 14

CD- 109

CF -252

CO- 60

CS- 137

EU- 152

FE-59

$\mathrm{H}-3$

MFP

MN -54

NA- 22

NP- 237

$\mathrm{P}-32$

PA- 231

PM- 147

PU-238

PU-239

$P U-240$

$\mathrm{PU}-242$

$R A-226$

$1.002 E-04$

$1.040 E-07$

5. 470 E -02

1. 000 E-09

2. 100E-04

$1.000 E-03$

3. $000 \mathrm{E}-02$

$4.513 E+00$

$1.871 \mathrm{E}+01$

2.330E-01

2. 500E-02

7.755E-04

5.063E-09

$9.336 \mathrm{E}-02$

2.020E-01

2.000E-06

1. 100E-05

3. 088E-05

4.735E-09

1.691E-03

2.007E-02

2.389E+01

6.045E-06

$9.250 E-07$

2. $434 E-04$

1. $120 E-03$

$9.945 \mathrm{E}-11$

1.104E-01

8.048E-02

1.000E-05

1.001E-02

2.589E-02

$3.625 E+01$

1.006E-02

2. 001E-02

1.346E-05

1. $.000 E-03$

4. $720 \mathrm{E}-03$

6. 000 E- 03

1.740E-02

5.218E-02

2.031E-02

$9.922 E-07$

1.426E-04 


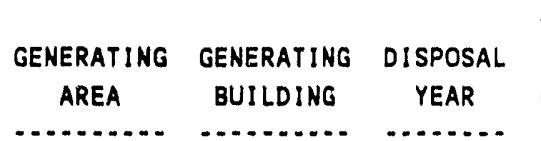

ALE 317

84

\begin{abstract}
ANNUAL

$$
\text { VOLUME }
$$
CUBIC METERS

WEIGHT

GRAMS
\end{abstract}

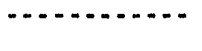

...........

CLRIES

NUCLIDE

RA- 228

RN-222

$\mathrm{SR}=90$

TH- 232

$U-233$

$U-235$

$U-238$

$v-48$

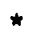

85

\begin{abstract}
$5.924 E+02$
\end{abstract}

\begin{abstract}
$7.074 E+01$
\end{abstract}
$N / A$

AM-241

$A M-243$

$B A-133$

$B K-249$

C- 14

CF-249

CF- 252

CM- 244

CO- 60

CS-134

CS -137

EU-152

EU-154

FE-59

$\mathrm{H}-3$

$K-40$

MFP

MN-54

NP- 237

NP- 239

$P-32$

PB- 212

PU-236

PU-238

PU-239

PU- 240

PU- 242

RA- 226

RN-222

RU- 106

SR -90

TH -228

TH-232

U-233
CURIES

1. 000 E- 03

$1.000 E-06$

3.282E- 04

3.581E-03

1.360E-05

$9.484 E-04$

$1.363 E-01$

2.501E-02

$3.677 E+01$

$0.000 E+00$

1.091E-01

$1.297 \mathrm{E}-03$

$1.000 E-06$

1.700 E- 02

5.000E- 07

2.055E-04

4.296E-04

$9.991 E-08$

$6.400 E+00$

$1.330 E-01$

$1.993 E+01$

$1.175 E-03$

2.570E- 01

3.511E-01

$2.097 E+01$

$1.000 E-06$

$1.908 E+01$

$3.200 E+00$

5.133E-04

$1.000 E-06$

$7.500 E-03$

$4.000 E-03$

$1.012 E-07$

1.796E-05

$6.153 E-02$

5.583E-03

2.104E- 04

$1.849 E-04$

1.000 E- 03

5.000E-07

$1.000 E-07$

$1.003 E-03$

$2.708 \mathrm{E}-03$

$1.820 \mathrm{E}-03$ 
1SCHEDULE NO. SUSS411

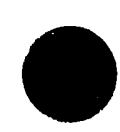

GENERATING GENERATING DISPOSAL

AREA

ALE

317
IDAHO OPERATIONS OFFICE

U.S. DEPARTMENT OF ENERGY

RUN DATE: 04/03/91

INEL WASTE MANAGEMENT INFORMATION SYSTEM

ANNUAL SUMMARY FOR ALE

PAGE

5
$2.922 E \times 02$

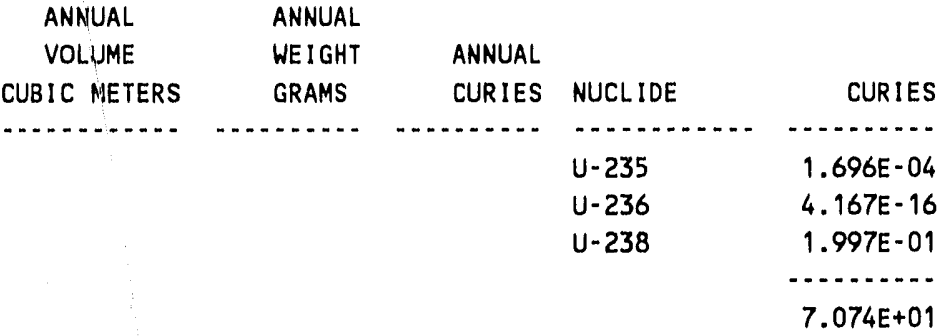

$1.157 E+08 \quad 9.887 E+00$
$A C-227$

$A G-110$

$A G=110 M$

AM- 241

$A M-243$

$\mathrm{BE}-7$

BK- 249

C- 14

CD -109

CF -249

CF -250

CF -252

CM-243

CO- 56

CO-57

CO- 60

CR-51

CS -137

EU- 152

EU-154

FE-59

$\mathrm{H}-3$

HG-203

K-40

MFP

$M N-54$

NA-22

NP -237

$\mathrm{P}-32$

PB- 210

PB- 212

PU-236

PU- 238

PU-239

PU-240

PU-241

PU-242

RA- 2.25

RA- 226

RA- 228
$7.074 E+01$

1.593E-02

$1.314 E-06$

$1.259 E-06$

5.269E-02

2.055E-04

6.584E-04

2.366E-08

1. $083 E-03$

5.841E- 04

4.091E-06

$1.080 E-04$

2. 505E-05

5. 000 E- 07

7.822E-06

$1.250 E-05$

$1.347 \mathrm{E}+00$

2. $215 \mathrm{E}-03$

$1.801 E-02$

$1.000 E-01$

$1.000 \mathrm{E}-05$

8.143E-06

2.277E-02

$1.000 E-06$

2.116E-05

6. $216 E+00$

$7.881 E-04$

$1.485 E-05$

7.578E-04

5. 000 E- 05

1.000 E- 06

3. $000 E-06$

$1.141 E-06$

1.358E-05

6.666E-02

6.995E-04

1.550 E- 04

5.953E-05

$1.500 E-06$

$1.000 E+00$

$2.000 E-06$ 


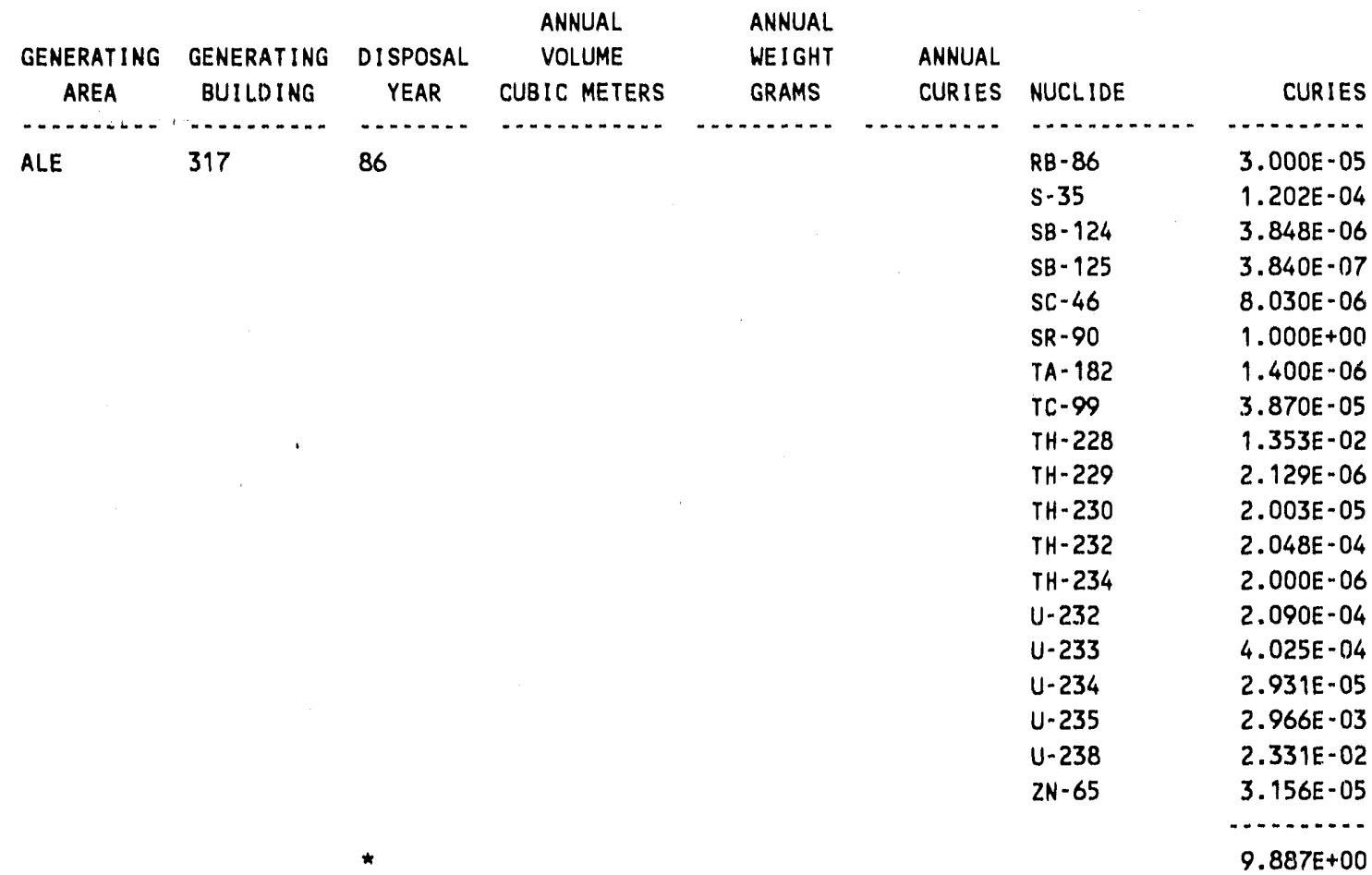




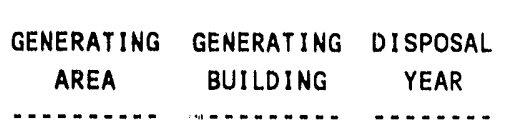

$\begin{array}{ll}\text { ANNUAL } & \text { ANNUAL } \\ \text { VOLUME } & \text { WEIGHT } \\ \text { GIC METERS } & \text { GRAMS }\end{array}$ 87 317 CUBIC METERS ........

...

\begin{tabular}{|c|c|c|}
\hline \multicolumn{3}{|l|}{ ANNUAL } \\
\hline CURIES & NUCL IDE & CURIES \\
\hline & $\cdots$ & 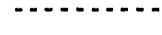 \\
\hline & PU-242 & $2.588 \mathrm{E}-05$ \\
\hline & $R A-226$ & $6.998 E-03$ \\
\hline & $R A-228$ & $1.000 \mathrm{E}-07$ \\
\hline & $s-35$ & $1.000 \mathrm{E}-05$ \\
\hline & TC-99 & $1.110 \mathrm{E}-05$ \\
\hline & $T H-228$ & $8.230 E+00$ \\
\hline & $T H-230$ & $8.788 E-06$ \\
\hline & $T H-232$ & $2.916 \mathrm{E}-03$ \\
\hline & $U-232$ & $2.090 E-04$ \\
\hline & $U-233$ & $7.415 E-04$ \\
\hline & $U-234$ & $3.403 E-04$ \\
\hline & $U-235$ & $6.864 E-04$ \\
\hline & $U-238$ & $4.215 E-02$ \\
\hline & $2 N-65$ & $2.565 E-05$ \\
\hline & $2 R-95$ & $2.400 E-10$ \\
\hline & & $8.404 E+02$ \\
\hline
\end{tabular}

88

\section{2. $039 \mathrm{E}+02$}

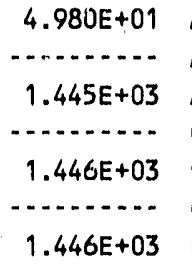

$A G-110$

AM-241

AM-243

C- 14

CA- 45

$C D-109$

CO- 60

CS -137

EU- 152

$\mathrm{H}-3$

MFP

$M N-54$

NP- 237

PU- 238

PU- 239

PU -240

PU-241

PU -242

$R A-226$

SR -90

TC-99

$T H-228$

TH-232

U-232

$U-234$

U -235

U-238

$\mathrm{ZN}-65$
$1.430 E-06$

3.501E-03

2.040E-04

$1.211 \mathrm{E}-02$

$1.015 \mathrm{E}-03$

$1.700 E-05$

1.169E-02

5.910E-03

$1.000 E-05$

4.694E+01

$1.223 E-01$

$9.200 E-09$

4.900E- 05

2.114E-04

1.456E-02

$1.441 \mathrm{E}-03$

$2.127 E-02$

4.087E-05

1.005E-01

$3.000 E-06$

1. 000 E-06

1. 000 E- 05

$1.824 E-04$

2. $218 \mathrm{E}+00$

$3.630 \mathrm{E}-04$

3. $458 \mathrm{E}-05$

3. $459 \mathrm{E}-01$

1.306E-03 
IDAHO OPERATIONS OFFICE

U.S. DEPARTMENT OF ENERGY

INEL WASTE MANAGEMENT INFORMATION SYSTEM

ANNUAL SUMMARY FOR ALE
RUN DATE : 04/03/91

PAGE

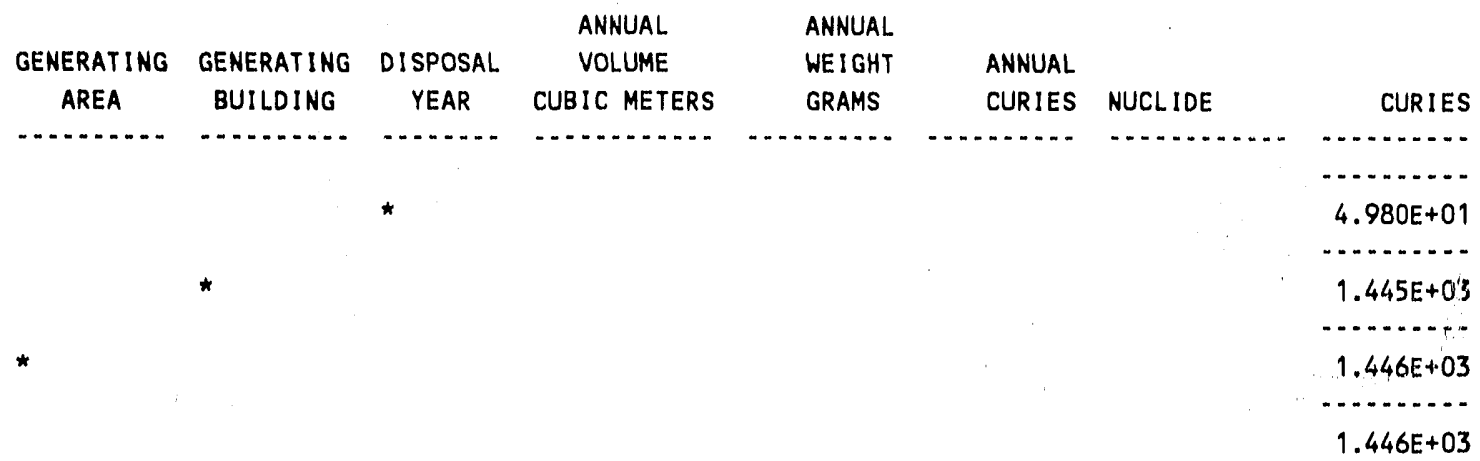




\begin{tabular}{|c|c|c|c|c|c|c|c|}
\hline $\begin{array}{l}\text { GENERATING } \\
\text { AREA }\end{array}$ & $\begin{array}{l}\text { GENERATING } \\
\text { BUILDING }\end{array}$ & $\begin{array}{l}\text { DISPOSAL } \\
\text { YEAR }\end{array}$ & $\begin{array}{c}\text { ANNUAL } \\
\text { VOL.UME } \\
\text { CUBIC METERS }\end{array}$ & $\begin{array}{l}\text { ANNUAL } \\
\text { WEIGHT } \\
\text { GRAMS }\end{array}$ & $\begin{array}{l}\text { ANNUAL } \\
\text { CURIES }\end{array}$ & NUCLIDE & CURIES \\
\hline (........... & .................. & $\ldots \ldots$ & . & 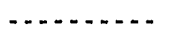 & 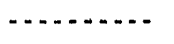 & $\ldots \ldots$ & - \\
\hline \multirow[t]{31}{*}{ ANL } & NONE & 71 & $3.211 E+01$ & $1.178 E+07$ & $5.385 E+01$ & $B E-10$ & $4.290 E+00$ \\
\hline & & & & & & CS- 137 & $3.051 E+01$ \\
\hline & & & & & & MFP & 5.770E-03 \\
\hline & & & & & & PO-210 & $1.100 E-01$ \\
\hline & & & & & & SB- 125 & $1.610 E+01$ \\
\hline & & & & & & $U-235$ & $1.485 E-04$ \\
\hline & & & & & & $U-238$ & $9.181 E-04$ \\
\hline & & & & & & $U N-I D-B+G$ & $2.834 E+00$ \\
\hline & & & : & & & & n. \\
\hline & & * & & & & & $5.385 E+01$ \\
\hline & & & & & & & n. \\
\hline & * & & & & & & $5.385 E+01$ \\
\hline & 000 & 61 & $6.000 E+01$ & $0.000 E+00$ & $7.900 E+01$ & $U N-1 D-B+G$ & $7.900 E+01$ \\
\hline & & 62 & $3.900 E+01$ & $0.000 E+00$ & $4.540 E+02$ & $U N-1 D-B+G$ & $4.540 E+02$ \\
\hline & & 63 & $6.200 E+01$ & $0.000 E+00$ & $3.000 E+00$ & $U N-1 D-B+G$ & $3.000 E+00$ \\
\hline & & 64 & $7.600 E+01$ & $0.000 E+00$ & $4.150 E+02$ & $U N-I D-B+G$ & 4. $150 E+02$ \\
\hline & & 65 & $2.460 \mathrm{E}+02$ & $0.000 E+00$ & $3.890 \mathrm{E}+02$ & $U N-1 D-B+G$ & $3.890 E+02$ \\
\hline & & 66 & $3.820 E+02$ & $0.000 E+00$ & $4.159 E+03$ & $U N-1 D-B+G$ & $4.159 E+03$ \\
\hline & & 67 & $5.550 E+02$ & $0.000 E+00$ & $1.102 E+04$ & $U N-I D-B+G$ & $1.102 E+04$ \\
\hline & & 68 & $4.800 E+02$ & $0.000 E+00$ & $2.079 E+04$ & $U N-1 D-B+G$ & $2.079 E+04$ \\
\hline & & 69 & $4.380 E+02$ & $0.000 E+00$ & $7.000 E+03$ & $U N-I D-B+G$ & $7.000 E+03$ \\
\hline & & 70 & $3.490 E+02$ & $0.000 E+00$ & $2.122 E+03$ & $U N-I D-B+G$ & $2.122 E+03$ \\
\hline & * & & & & $4.643 E+04$ & & $4.643 E+04$ \\
\hline & 601 & 71 & $3.625 \mathrm{E}+00$ & $1.814 E+05$ & $1.000 E-03$ & MFP & $1.000 E-03$ \\
\hline & 704 & 87 & $6.937 E+00$ & $1.871 E+06$ & $1.437 \mathrm{E}-02$ & PU-239 & $8.289 E-04$ \\
\hline & & & & & & $P U-240$ & $5.683 E-04$ \\
\hline & & & & & & $U-235$ & $1.157 E-02$ \\
\hline & & & & & & $U-238$ & $1.406 E-03$ \\
\hline & & * & & & & & $137 E_{0}-0 ?$ \\
\hline & & 88 & $2.823 E+01$ & $6.835 E+06$ & $2.202 E-02$ & PU-239 & $1.040 E-04$ \\
\hline & & & & & & $P U-240$ & T.288E-05 \\
\hline
\end{tabular}




\begin{tabular}{|c|c|c|c|c|c|c|c|}
\hline $\begin{array}{c}\text { GENERATING } \\
\text { AREA }\end{array}$ & $\begin{array}{l}\text { GENERATING } \\
\text { BUILDING }\end{array}$ & $\begin{array}{l}\text { DISPOSAL } \\
\text { YEAR }\end{array}$ & $\begin{array}{c}\text { ANNUAL } \\
\text { VOLUME } \\
\text { CUBIC METERS }\end{array}$ & $\begin{array}{l}\text { ANNUAL } \\
\text { WEIGHT } \\
\text { GRAMS }\end{array}$ & $\begin{array}{l}\text { ANNUAL } \\
\text { CURIES }\end{array}$ & NUCLIDE & CURIES \\
\hline (n) & , n & ............. & . & n............ & ............. & . & ............ \\
\hline \multirow[t]{36}{*}{ ANL } & 704 & 88 & & & & $U-235$ & $1.613 E-02$ \\
\hline & & & & & & $U-238$ & $5.712 E-03$ \\
\hline & & * & . & & & & $2.202 E-02$ \\
\hline & & 89 & $6.003 E+00$ & $1.594 E+06$ & $7.817 E-03$ & $U-235$ & $4.548 E-03$ \\
\hline & & & & & 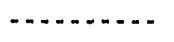 & $U-238$ & $3.269 E-03$ \\
\hline & * & & & & $4.421 E-02$ & & .............. \\
\hline & & * & & & & & $7.817 E-03$ \\
\hline & & & & & & & n \\
\hline & * & & & & & & $4.421 E-02$ \\
\hline & 717 & 71 & $2.067 E+01$ & $2.948 E+06$ & 2. $105 E+00$ & $\mathrm{CO}-60$ & $1.890 E+00$ \\
\hline & & & & & & MAP & $1.000 E-04$ \\
\hline & & & & & & MFP & $5.000 \mathrm{E}-03$ \\
\hline & & & & & & $U N-1 D-B+G$ & $2.100 E-01$ \\
\hline & & & & & & & 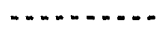 \\
\hline & & * & & & & & $2.105 E+00$ \\
\hline & * & & & & & & $2.105 E+00$ \\
\hline & 720 & 74 & $7.137 E-01$ & $2.835 E+05$ & $2.630 \mathrm{E}-03$ & MAP & $1.052 E-03$ \\
\hline & & & & & & MFP & $1.576 E-03$ \\
\hline & & & & & & PU-239 & $2.128 E-06$ \\
\hline & & & & & & & 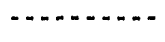 \\
\hline & & * & & & & & $2.630 E-03$ \\
\hline & & 75 & $1.493 E+01$ & $7.541 E+06$ & $1.459 E-01$ & CS- 137 & $1.650 \mathrm{E}-06$ \\
\hline & & & & & & MAP & $1.340 E-01$ \\
\hline & & & & & & MFP & $1.188 E-02$ \\
\hline & & & & & & PU-239 & $9.160 E-06$ \\
\hline & & & & & & & n. \\
\hline & & * & & & & & $1.459 E-01$ \\
\hline & & 76 & $2.549 E+00$ & $3.634 E+06$ & $1.231 \mathrm{E}-01$ & MAP & $1.230 \mathrm{E}-01$ \\
\hline & & & & & & U.235 & $3.298 \mathrm{E}-05$ \\
\hline & & & & & & $U-238$ & $8.232 E-05$ \\
\hline & & * & & & & & $1.231 \mathrm{E}-01$ \\
\hline & & 77 & $1.104 E+00$ & $3.402 E+05$ & $1.204 E-01$ & MAP & $1.200 \mathrm{E}-01$ \\
\hline & & & & & & $T H-232$ & $2.180 E-05$ \\
\hline & & & & & & $u-235$ & $3.683 E-04$ \\
\hline & & & & & & $U-238$ & $3.463 E-05$ \\
\hline & & $\star$ & & & & & $1.204 \mathrm{E}-01$ \\
\hline
\end{tabular}




\begin{tabular}{|c|c|c|c|c|c|c|c|}
\hline $\begin{array}{c}\text { GENERATING } \\
\text { AREA }\end{array}$ & $\begin{array}{l}\text { GENERATING } \\
\text { BUILDING }\end{array}$ & $\begin{array}{c}\text { DISPOSAL } \\
\text { YEAR }\end{array}$ & $\begin{array}{c}\text { ANNUAL } \\
\text { VOLUME } \\
\text { CUBIC METERS }\end{array}$ & $\begin{array}{l}\text { ANNUAL } \\
\text { WEIGHT } \\
\text { GRAMS }\end{array}$ & $\begin{array}{l}\text { ANNUAL } \\
\text { CURIES }\end{array}$ & NUCLIDE & CURIES \\
\hline 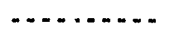 & 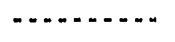 & $\ldots$ & - & n. & 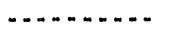 & - & - \\
\hline \multirow[t]{36}{*}{ ANL } & 720 & 80 & $9.062 E+00$ & $1.497 E+06$ & $5.572 E-02$ & $c 0-60$ & $1.429 E-02$ \\
\hline & & & & & & CS- 137 & $2.143 E-02$ \\
\hline & & & & & & MAP & $8.000 E-03$ \\
\hline & & & & & & MFP & $1.200 E-02$ \\
\hline & & & & & & & $\cdots$ \\
\hline & & * & & & & & $5.572 E-02$ \\
\hline & & 81 & $4.531 E+00$ & $1.542 E+06$ & $9.592 E-01$ & MAP & $3.834 E-01$ \\
\hline & & & & & & MFP & $5.714 E-01$ \\
\hline & & & & & & $N P-237$ & $4.371 E-03$ \\
\hline & & & & & & & (n) \\
\hline & & * & & & & & $9.592 E-01$ \\
\hline & & 82 & $1.812 E+00$ & $1.814 E+05$ & $1.737 \mathrm{E}-02$ & MAP & $6.680 E-03$ \\
\hline & & & & & & MFP & $1.002 E-02$ \\
\hline & & & & & & $U-235$ & $6.600 E-04$ \\
\hline & & & & & & $U-238$ & $7.700 E-06$ \\
\hline & & & & & & & n. \\
\hline & & * & & & & & $1.737 E-02$ \\
\hline & & 83 & $4.418 E+00$ & $8.168 E+05$ & $6.060 E-02$ & MAP & $2.510 E-02$ \\
\hline & & & & & & MFP & $3.550 E-02$ \\
\hline & & * & & & & & $6.060 \mathrm{E}-02$ \\
\hline & & 85 & $7.250 E+00$ & $3.768 E+06$ & $2.063 E+00$ & CS- 134 & $1.580 E-01$ \\
\hline & & & & & & Cs- 137 & $3.570 E-01$ \\
\hline & & & & & & MAP & $6.190 E-01$ \\
\hline & & & & & & MFP & $9.286 E-01$ \\
\hline & & * & & & & & $2.063 E+00$ \\
\hline & & 87 & $5.437 E+00$ & $1.249 E+06$ & $1.429 E+01$ & MAP & $1.429 E+01$ \\
\hline & & 88 & $9.062 E+00$ & $3.711 E+06$ & $2.595 E-01$ & MAP & $1.038 \mathrm{E}-01$ \\
\hline & & & & & n & MFP & $1.557 E-01$ \\
\hline & $\star$ & & & & $1.810 E+01$ & & n. \\
\hline & & * & & & & & $2.595 \mathrm{E}-01$ \\
\hline & * & & & & & & $1.810 E+01$ \\
\hline & 721 & 78 & $3.001 E+00$ & $4.990 E+05$ & $6.050 E+00$ & $C 0-60$ & $1.200 E+00$ \\
\hline & & & & & & $C R-51$ & $2.000 E-01$ \\
\hline & & & & & & FE-59 & $2.000 E-01$ \\
\hline & & & & & & MAP & $1.000 E-01$ \\
\hline & & & & & & MFP & $1.500 E-01$ \\
\hline
\end{tabular}




\begin{tabular}{|c|c|c|c|c|c|c|c|}
\hline $\begin{array}{l}\text { GENERATING } \\
\text { AREA }\end{array}$ & $\begin{array}{l}\text { GENERATING } \\
\text { BUILDING }\end{array}$ & $\begin{array}{l}\text { DISPOSAL } \\
\text { YEAR }\end{array}$ & $\begin{array}{c}\text { ANNUAL } \\
\text { VOLUME } \\
\text { CUBIC METERS }\end{array}$ & $\begin{array}{l}\text { ANNUAL } \\
\text { WE I GHT } \\
\text { GRAMS }\end{array}$ & $\begin{array}{l}\text { ANNUAL } \\
\text { CURIES }\end{array}$ & NUCLIDE & CURIES \\
\hline n & - & …...... & 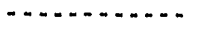 & (1) & , n & , n & n.......... \\
\hline \multirow[t]{38}{*}{ ANL. } & 721 & 78 & & & & $M N-54$ & $2.000 E-01$ \\
\hline & & & & & & $T A-182$ & $4.000 E+00$ \\
\hline & & & & & & $U-238$ & $3.300 E-07$ \\
\hline & & * & & & & & $6.050 E+00$ \\
\hline & & 79 & $3.624 E+00$ & $1.633 E+06$ & $4.100 E-01$ & $\mathrm{CO}-60$ & $2.050 E-01$ \\
\hline & & & & & n. & FE-59 & $2.050 E-01$ \\
\hline & * & & & & $6.460 E+00$ & & - \\
\hline & & * & & & & & $4.100 E-01$ \\
\hline & $\star$ & & & & & & $6.460 E+00$ \\
\hline & 746 & 75 & $6.881 E+01$ & $1.237 E+08$ & $3.096 E-04$ & CE-144 & $4.950 E-05$ \\
\hline & & & & & & CS-137 & $2.601 E-04$ \\
\hline & & * & & & & & 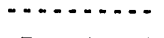 \\
\hline & & ${ }^{*}$ & & & & & $3.096 E-04$ \\
\hline & & 76 & $5.799 E+01$ & $5.034 E+07$ & $8.280 E-03$ & CE-144 & $1.560 E-03$ \\
\hline & & & & & , n. & CS -137 & $6.720 E-03$ \\
\hline & * & $*$ & & & $8.590 E-03$ & & n........... \\
\hline & & $n$ & & & & & $8.280 E-03$ \\
\hline & * & & & & & & $85005-03$ \\
\hline & 750 & 71 & $1328 \mathrm{~F}+02$ & $3758 \mathrm{~F}+07$ & & & \\
\hline & & & & & & CE-144 & $2.000 E=01$ \\
\hline & & & & & & $\begin{array}{l}n-2 \\
0.191\end{array}$ & $3.485 \mathrm{E}+01$ \\
\hline & & & & & & MFP & $3.880 E+00$ \\
\hline & & & & & & TH-232 & $1.090 E-04$ \\
\hline & & & & & & $U-235$ & $3.131 E-03$ \\
\hline & & & & & & $U-238$ & $7.089 E-04$ \\
\hline & & & & & & $U N-1 D-B+G$ & $2.851 E+03$ \\
\hline & & & & & & $Z R-N B-95$ & $1.500 E+00$ \\
\hline & & * & & & & & (n) \\
\hline & & & & & & & $\begin{array}{l}2.81<E+U S \\
\ldots . . . \ldots . . . .\end{array}$ \\
\hline & $\star$ & & & & & & $2.912 E+03$ \\
\hline & 752 & 71 & $1.957 E+01$ & $3.898 E+07$ & $2.490 E+02$ & CE- 141 & $2.050 E+01$ \\
\hline & & & & & & CE- 144 & $3.574 E+00$ \\
\hline & & & & & & Co-58 & 4. $000 E-01$ \\
\hline & & & & & & $c 0-60$ & $7.500 E+00$ \\
\hline & & & & & & $C R-51$ & $4.000 E+00$ \\
\hline & & & & & & CS -137 & $1.836 E+02$ \\
\hline & & & & & & MAP & $1.100 E+00$ \\
\hline & & & & & & MFP & $2.110 E+01$ \\
\hline
\end{tabular}




\begin{tabular}{|c|c|c|c|c|c|c|c|}
\hline $\begin{array}{c}\text { GENERATING } \\
\text { AREA }\end{array}$ & $\begin{array}{l}\text { GENEF,'TING } \\
\text { BUILDING }\end{array}$ & $\begin{array}{c}\text { DISPOSAL } \\
\text { YEAR }\end{array}$ & $\begin{array}{c}\text { ANNUAL } \\
\text { VOLUME } \\
\text { CUBIC METERS }\end{array}$ & $\begin{array}{l}\text { ANNUAL } \\
\text { WE I GHT } \\
\text { GRAMS }\end{array}$ & $\begin{array}{l}\text { ANNUAL } \\
\text { CURIES }\end{array}$ & NUCL IDE & CURIES \\
\hline 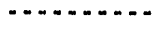 & - nat. & ........... & - nan & - n. & 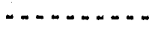 & (n) & . \\
\hline \multirow[t]{42}{*}{ ANL } & 752 & 71 & & & & $M N-54$ & $4.000 E-01$ \\
\hline & & & & & & NB-95 & $3.724 E+00$ \\
\hline & & & & & & $U N-1 D-B+G$ & $1.148 E+00$ \\
\hline & & & & & & $Z R-N B-95$ & $2.000 E+00$ \\
\hline & & $*$ & & & & & (n) \\
\hline & & * & & & & & $2.490 E+02$ \\
\hline & & 72 & $5.778 E+00$ & $9.026 E+05$ & $6.893 E+00$ & MAP & $3.551 E+00$ \\
\hline & & & & & & MFP & $3.340 E+00$ \\
\hline & & & & & & $U-235$ & $1.369 E-04$ \\
\hline & & & & & & $U-238$ & $1.707 E-03$ \\
\hline & & $\downarrow$ & & & & & . \\
\hline & & * & & & & & $6.893 E+00$ \\
\hline & & 73 & $3.175 E+01$ & $2.225 E+07$ & $4.090 E+01$ & $C E-144$ & $2.560 E+00$ \\
\hline & & & & & & Co-58 & $1.716 E-01$ \\
\hline & & & & & & $c 0-60$ & $7.080 E-01$ \\
\hline & & & & & & CS- 134 & $2.24,0 E+00$ \\
\hline & & & & & & CS- 137 & $2.888 E+01$ \\
\hline & & & & & & MAP & $1.213 E+00$ \\
\hline & & & & & & MFP & $1.685 E+00$ \\
\hline & & & & & & $M N-54$ & $7.440 E-02$ \\
\hline & & & & & & U. 235 & $7.239 E-04$ \\
\hline & & & & & & $U-238$ & $2.922 E-04$ \\
\hline & & & & & & UN-ID-ALPHA & $3.500 E-02$ \\
\hline & & & & & & $U N-I D-B+G$ & $3.331 E+00$ \\
\hline & & & & & & & n \\
\hline & & * & & & & & $4.090 E+01$ \\
\hline & & 74 & $1.672 E+01$ & $7.609 E+06$ & $5.325 E+02$ & CE- 144 & $5.625 E+00$ \\
\hline & & & & & & CS- 137 & $7.876 E+00$ \\
\hline & & & & & & MAP & $2.452 \mathrm{E}-01$ \\
\hline & & & & & & MFP & $3.709 E+02$ \\
\hline & & & & & & $S R-90$ & $1.479 E+02$ \\
\hline & & & & & & $U-235$ & $8.802 E-04$ \\
\hline & & & & & & $U-238$ & $7.712 \mathrm{E}-05$ \\
\hline & & & & & & & י מ \\
\hline & & * & & & & & $5.325 E+02$ \\
\hline & & 75 & $9.103 E+01$ & $3.170 E+07$ & $1.202 E+02$ & $A M-241$ & $1.850 E-07$ \\
\hline & & & & & & CE -144 & $2.844 E+01$ \\
\hline & & & & & & co- 60 & $4.910 \mathrm{E}-09$ \\
\hline & & & & & & CS- 137 & $3.984 E+01$ \\
\hline & & & & & & MAP & $3.289 E+00$ \\
\hline & & & & & & MFP & $8.702 E+00$ \\
\hline & & & & & & PU-239 & $8.782 E-02$ \\
\hline
\end{tabular}




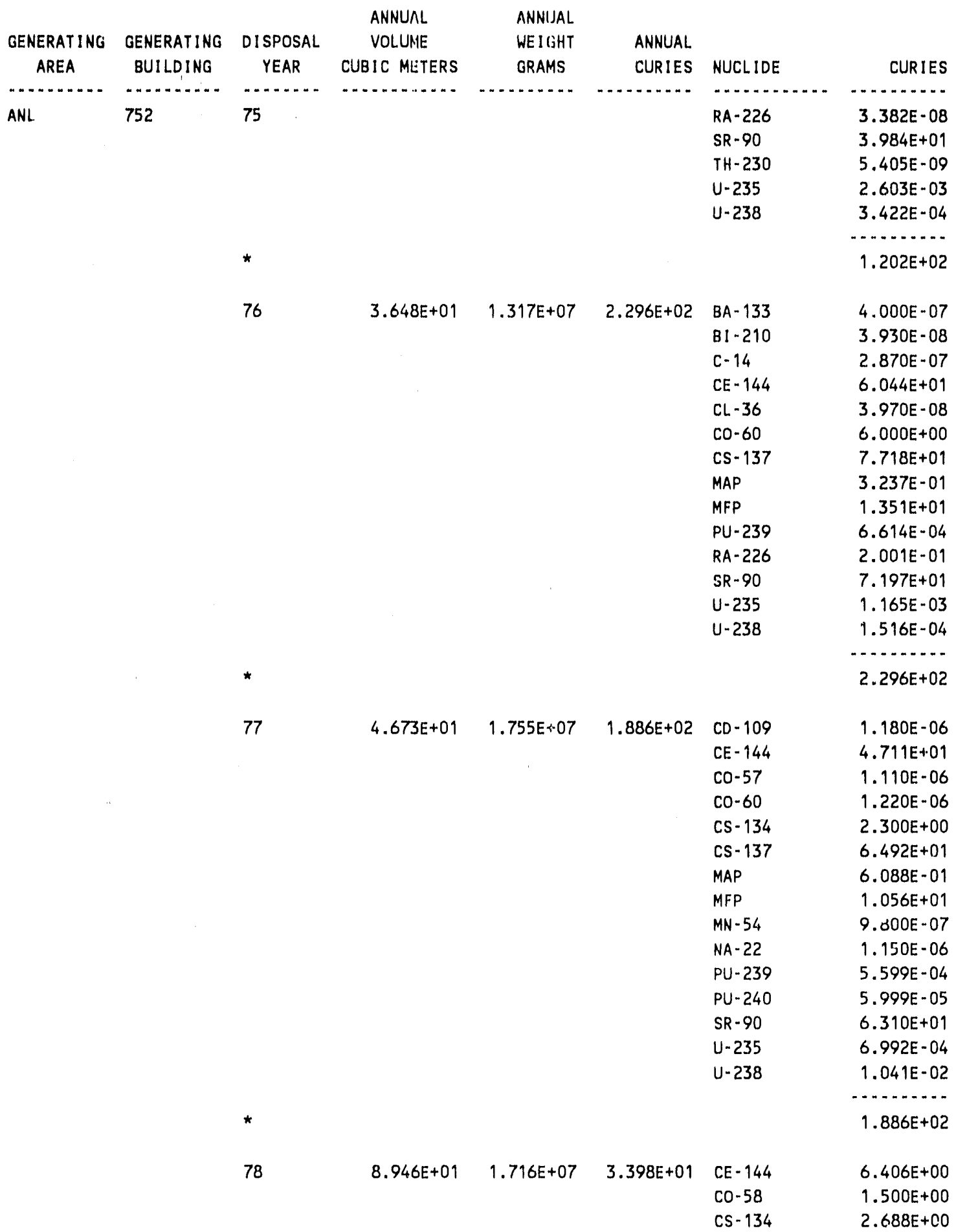




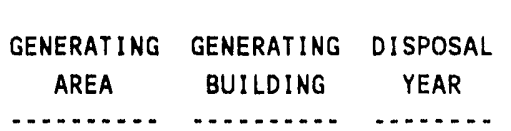

752

78

ANL

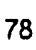

$\begin{array}{cl}\text { ANNUAL } & \text { ANNUAL } \\ \text { VOLUME } & \text { WEIGHT } \\ \text { CUBIC METERS } & \text { GRAMS }\end{array}$

$\star$

79

4.556E+01
$1.531 E+07$
ANNUAL CURIES NUCLIDE CURIES

CS -137

MAP

MFP

$M N-54$

PU -239

PU -240

SR -90

$\mathrm{U}-235$

$U-238$

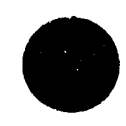

$7.586 E+06$
$2.871 E+01$

CE-144

CO- 58

CS -137

MAP

M.FP

$M N-54$

PU- 239

PU- 240

SR -90

$U-235$

$U-238$

81

\begin{tabular}{|c|c|c|c|c|}
\hline & & & SR-90 & $2.500 E+00$ \\
\hline & & & $U-235$ & $1.783 E-05$ \\
\hline & & & $U-238$ & $3.550 E-05$ \\
\hline & & & & ـ \\
\hline & & & & $2.871 E+01$ \\
\hline $1.634 E+01$ & $9.067 E+06$ & $9.195 E+00$ & $C D=109$ & $4.000 E-08$ \\
\hline & & & $c 0-58$ & $4.000 E-01$ \\
\hline
\end{tabular}

$7.419 E+00$

$3.031 E+00$

$6.015 E+00$

$1.500 E+00$

1.106E-03

2. 160E-04

$5.419 E+00$

2. $834 E-05$

$1.492 E-04$

$3.398 \mathrm{c}+01$

$4.450 E+00$

$4.300 E+00$

2.500E- 01

2. $290 E+00$

$6.580 E+00$

2.500E-01

2. 000 E- 03

$7.080 E+00$

1. $137 E+01$

$4.300 E+00$

$1.036 E-03$

$1.258 \mathrm{E}-04$

$6.580 E+00$

3.164E-05

8. 193E-07

$4.745 E+01$

$1.000 E+00$

$4.500 E+00$

$4.500 E+00$

$5.305 E+00$

$6.406 E+00$

4.5CDE+00

3.128E-04

$6.214 E-06$

$2.500 E+00$

$1.783 \mathrm{E}-05$

4. 000 E- 01 


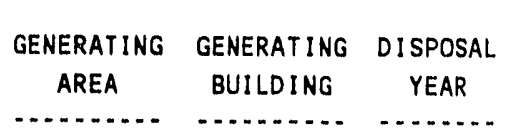
81 752

\begin{abstract}
ANNUAL VOLUME CUBIC METERS

\section{ANNUAL \\ WEIGHT} CUBIC METERS j
ANL
GRAMS CURIES NUCLIDE CURIES CO-60

CS $-137 \quad 1.000 E+00$

$H-3 \quad 1.100 E+00$

MAP 2.358E+00

MFP $\quad 3.537 E+00$

$M N-54 \quad 3.000 E-01$

PU-239 1.101E-04

PU-240 2.200E-06

RA-226 $1.000 E-06$

SR $-90 \quad 5.000 E-01$

TH-228 9.999E-09

U.235 $1.560 E-04$

U-238 2.187E-05

$9.195 E+00$

82

$1.790 E+01 \quad 1.186 E+07 \quad 1.311 E+01$

CS -137

MAP

MFP

PU-239

PU -240

$U-235$

U- 238

$2.381 E-04$

$5.243 E+00$

$7.864 E+00$

$2.600 E-04$

5. $000 \mathrm{E}-06$

$7.943 E-04$

1.707E-04

$1.311 E+01$

83

\section{$3.868 \mathrm{E}+01$}

$2.886 \mathrm{E}+07$

$1.449 E+01$

CS -137

$\mathrm{H}-3$

2. $35.45-03$

$1.200 \mathrm{E}+01$

$9.950 E-01$

MAP

$1.494 E+00$

PU-239

PU- 240

$\mathrm{U}-235$

U-238

$1.148 \mathrm{E}-03$

$1.932 \mathrm{E}-05$

$7.853 E-04$

$3.301 \mathrm{E}-04$

$1.449 E+01$

84

$1.518 E+01$

$3.734 E+06$

$5.381 E+00$

$H-3$

MAP

2.210E+00

$5.909 \mathrm{E}-01$

MFP $\quad 2.553 E+00$

PU-239 1.137E-08

PU-240 2.223E-10

U-235 1.554E-03

$U-238$

2.550E-02

$5.381 \mathrm{E}+00$ 


\begin{tabular}{|c|c|c|c|c|c|c|c|}
\hline GENERATING & GENERATING & DISPOSAL & $\begin{array}{l}\text { ANNUAL } \\
\text { VOLUME }\end{array}$ & $\begin{array}{l}\text { ANNUAL } \\
\text { WEIGHT }\end{array}$ & ANNUAL & & \\
\hline AREA & BUI LDING & YEAR & CUBIC METERS & GRAMS & CURIES & NUCLIDE & CURIES \\
\hline . n........... & - n. & n........ & n. & n............. & 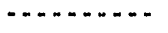 & - n....... & n........... \\
\hline \multirow[t]{42}{*}{ ANL } & 752 & 85 & $1.535 E+01$ & $3.769 \mathrm{E}+06$ & $1.664 E+02$ & MAP & $3.686 E+01$ \\
\hline & & & & & & MFP & $1.296 E+02$ \\
\hline & & & & & & $P U=239$ & $6.140 E-03$ \\
\hline & & & & & & PU-240 & $1.195 E-04$ \\
\hline & & & & & & $U-235$ & $2.592 E-04$ \\
\hline & & & & & & $U-238$ & $1.923 E-04$ \\
\hline & & & & & & & - n........... \\
\hline & & * & & & & & $1.664 E+02$ \\
\hline & & 86 & $1.899 E+01$ & $8.238 E+06$ & $4.069 E+01$ & MAP & $1.605 E+01$ \\
\hline & & & & & & MFP & $2.464 E+01$ \\
\hline & & & & & & PU-239 & $8.767 E-05$ \\
\hline & & & & & & PU-240 & $1.432 E-06$ \\
\hline & & & & & & $U-235$ & $3.672 E-04$ \\
\hline & & & & & & $U-238$ & $1.922 E-05$ \\
\hline & & & & & & & - \\
\hline & & * & & & & & $4.069 E+01$ \\
\hline & & 87 & $7.391 \mathrm{E}+00$ & $1.539 E+06$ & $4.207 E+01$ & CE-144 & $1.214 E+00$ \\
\hline & & & & & & CS- 134 & $5.952 E-01$ \\
\hline & & & & & & CS- 137 & $9.532 E+00$ \\
\hline & & & & & & MAP & $1.205 E+01$ \\
\hline & & & & & & MFP & $1.807 E+01$ \\
\hline & & & & & & NB-95 & $8.231 E-03$ \\
\hline & & & & & & PU-239 & $3.330 E-05$ \\
\hline & & & & & & PU-240 & $6.481 E-07$ \\
\hline & & & & & & $U-235$ & $1.950 E-04$ \\
\hline & & & & & & $U-238$ & $6.009 E-05$ \\
\hline & & & & & & $Z R-N B-95$ & $5.952 E-01$ \\
\hline & & & & & & $Z R-95$ & $4.852 E-03$ \\
\hline & & & & & & & 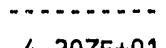 \\
\hline & & * & & & & & $4.207 E+01$ \\
\hline & & 88 & $2.775 E+00$ & $9.557 E+05$ & $6.370 E-01$ & $A M-241$ & $7.000 E-09$ \\
\hline & & & & & & $C E-144$ & $6.831 E-03$ \\
\hline & & & & & & CS -137 & $2.299 E-03$ \\
\hline & & & & & & MAP & $2.486 E-01$ \\
\hline & & & & & & MFP & $3.729 E-01$ \\
\hline & & & & & & NB-95 & $2.354 E-03$ \\
\hline & & & & & & PU-239 & $7.887 E-04$ \\
\hline & & & & & & $P U-240$ & $1.441 \mathrm{E}-05$ \\
\hline & & & & & & $U-235$ & $1.492 E-03$ \\
\hline & & & & & & $U-238$ & $3.198 E-04$ \\
\hline & & & & & & $2 R-95$ & $1.414 E-03$ \\
\hline & & * & & & & & $6.370 E-01$ \\
\hline
\end{tabular}




\begin{tabular}{|c|c|c|c|c|c|c|c|}
\hline $\begin{array}{c}\text { GENERATING } \\
\text { AREA }\end{array}$ & $\begin{array}{l}\text { GENERATING } \\
\text { BUILDING }\end{array}$ & $\begin{array}{l}\text { DISPOSAL } \\
\text { YEAR }\end{array}$ & $\begin{array}{c}\text { ANNUAL } \\
\text { VOLUME } \\
\text { CUBIC METERS }\end{array}$ & $\begin{array}{l}\text { ANNUAL } \\
\text { WEIGHT } \\
\text { GRAMS }\end{array}$ & $\begin{array}{l}\text { ANNUAL } \\
\text { CURIES }\end{array}$ & NUCLIDE & CURIES \\
\hline (n) & ……....... & - n...... & , n & n. & 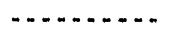 & , n & . \\
\hline \multirow[t]{41}{*}{ ANL } & 752 & 89 & $2.367 E+01$ & $1.693 E+07$ & $3.971 E+01$ & $C E-144$ & $5.833 E-01$ \\
\hline & & & & & . & CO-58 & $5.169 E-03$ \\
\hline & $\star$ & & & & $1.810 E+03$ & $c 0-60$ & $1.130 E-02$ \\
\hline & & & & & & CS -134 & $5.108 E-02$ \\
\hline & & & & & & CS -137 & $5.040 E-01$ \\
\hline & & & & & & $E U-155$ & $1.765 \mathrm{E}-02$ \\
\hline & & & & & & MAP & $1.528 E+01$ \\
\hline & & & & & & MFP & $2.292 E+01$ \\
\hline & & & & & & $M N-54$ & $1.117 E-01$ \\
\hline & & & & & & NB - 95 & $2.281 E-02$ \\
\hline & & & & & & $P()-239$ & $6.550 E-03$ \\
\hline & & & & & & RH- 106 & $7.600 E-05$ \\
\hline & & & & & & $R U-106$ & $1.809 E-01$ \\
\hline & & & & & & $S B-125$ & $7.906 E-03$ \\
\hline & & & & & & $U \cdot 235$ & $6.456 E-04$ \\
\hline & & & & & & $U-238$ & $1.331 \mathrm{E}-04$ \\
\hline & & & & & & $2 R-95$ & $9.674 E-03$ \\
\hline & & * & & & & & $3.871 E+01$ \\
\hline & & & & & & & 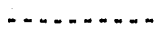 \\
\hline & * & & & & & & $1.810 E+03$ \\
\hline & 764 & 82 & $7.249 E+00$ & $7.257 E+05$ & $4.800 \varepsilon-04$ & MAP & $2.000 E-04$ \\
\hline & & & & & & MFP & $2.800 E-04$ \\
\hline & & & & & & & (n) \\
\hline & & * & & & & & $4.800 E-04$ \\
\hline & & 83 & $1.812 E+00$ & $3.629 E+05$ & $2.400 E-04$ & MAP & $1.000 E-04$ \\
\hline & & & & & .............. & MFP & $1.400 E-04$ \\
\hline & * & & & & $7.200 E-04$ & & n. n. \\
\hline & & * & & & & & $2.400 E-0.4$ \\
\hline & & & & & & & 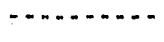 \\
\hline & $\star$ & & & & & & $7.200 E-04$ \\
\hline & 765 & 71 & $1.984 E+02$ & $4.070 E+07$ & $9.239 E+01$ & $C E-141$ & $1.376 E+00$ \\
\hline & & & & & & CE $-141-144$ & $3.000 E+00$ \\
\hline & & & & & & CE - 144 & $3.350 E+01$ \\
\hline & & & & & & Co- 60 & $4.128 E+00$ \\
\hline & & & & & & $C R=51$ & $2.202 \mathrm{E}+00$ \\
\hline & & & & & & $C S-137$ & $3.850 E+01$ \\
\hline & & & & & & MAP & $1.701 \mathrm{E}-01$ \\
\hline & & & & & & MFP & $9.235 E+00$ \\
\hline & & & & & & $M N-54$ & $2.752 \mathrm{E}-01$ \\
\hline & & & & & & $U-235$ & $2.397 E-05$ \\
\hline & & & & & & $U-238$ & $1.001 E-05$ \\
\hline
\end{tabular}




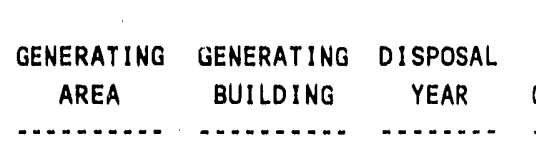

*

ANL

765

72

$\begin{array}{cl}\text { ANNUAL } & \text { ANNUAL } \\ \text { VOLUME } & \text { WEIGHT } \\ \text { CUBIC METERS } & \text { GRAMS }\end{array}$
........... (...........

$2.870 E+02$

$2.752 E+07$
ANNUAL CURIES

NUCLIDE

CURIES

.............

$9.239 E+01$

$3.333 E+01$

CE- 141

$7.000 E-01$

CO- 58

CO- 60

CR-51

8.060E-01

CS-137

MAP

MFP

$7.300 \mathrm{E}+00$

$M N-54$

$1.846 \mathrm{E}+00$

$9.152 E+00$

PU- 239

$U-235$

4.600E- 01

$U-238$

$6.140 E-04$

1.647E-05

UN-1D-ALPHA

$1.166 \mathrm{E}-03$

$U N-1 D-B+G$

2. $000 E-01$

$1.366 E+00$

$3.333 E+01$

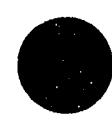

2. $832 E+0$

?.641E+07

$8.088 E+02$

CE -144

CO- 60

CS -134

CS- 137

$\mathrm{H}-3$

MAP

MFP

MN -54

PU- 239

U- 235

$U-238$

UN-ID - ALPHA

$U N-I D-B+G$

$3.619 E+01$

9.000E+00

4. $928 E+01$

$6.200 E+02$

2.300E- 01

9. $239 E+00$

$9.291 E+00$

$5.000 E+00$

$9.990 E-03$

$4.386 E-04$

$5.028 E-05$

4.011E-01

$7.013 E+01$

8.088E+02

74

$2.027 E+02 \quad 1.673 E+07 \quad 1.749 E+02$

CS -137
MAP
MFP

4.500E-05

$8.832 E+01$

PU-239

$8.660 \mathrm{E}+01$

U- 235

2.000E-06

$1.749 E+02$

4.774E-01

7.133E-01

MFP

$7.429 E-04$ 


\begin{tabular}{|c|c|c|c|c|c|c|c|}
\hline & & & ANNUAL & ANNUAL & & & \\
\hline $\begin{array}{l}\text { GENERAT ING } \\
\text { AREA }\end{array}$ & GENERATING & $\begin{array}{l}\text { DISPOSAL } \\
\text { YEAR }\end{array}$ & $\begin{array}{l}\text { VOLLUME } \\
\text { CUBIC METERS }\end{array}$ & $\begin{array}{l}\text { WEIGHT } \\
\text { GRAMS }\end{array}$ & $\begin{array}{l}\text { ANNUAL } \\
\text { CURIES }\end{array}$ & NUCL IDE & CURIES \\
\hline ............. & .... & $\ldots . .$. & …......... & 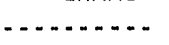 & ............ & ............... & ........... \\
\hline & & & & & & & n \\
\hline & & * & & & & & $1.191 E+00$ \\
\hline \multirow[t]{41}{*}{ ANL } & 765 & 76 & $3.110 \mathrm{E}+02$ & $6.048 E+07$ & $1.769 E+02$ & $B A-140$ & $3.500 E+00$ \\
\hline & & & & & & CE- 144 & $2.342 E+01$ \\
\hline & & & & & & $\mathrm{CO}-58$ & $2.831 E+01$ \\
\hline & & & & & & CS -137 & $3.433 E+01$ \\
\hline & ' & & & & & $L A=140$ & $3.500 E+00$ \\
\hline & & & & & & MAP & $6.490 E+00$ \\
\hline & & & & & & MFP & $1.511 E+01$ \\
\hline & & & & & & $M N-54$ & $2.831 E+01$ \\
\hline & & & & & & PU-239 & $2.163 E-03$ \\
\hline & & & & & & $S R-90$ & $3.393 E+01$ \\
\hline & & & & & & $U-235$ & $2.714 E-05$ \\
\hline & & & & & & $U-238$ & $3.325 E-06$ \\
\hline & & & & & & & (n. \\
\hline & & * & & & & & $1.769 E+02$ \\
\hline & & 77 & $2.760 E+02$ & $6.590 E+07$ & $1.838 E+05$ & $C E-144$ & $4.370 E+00$ \\
\hline & & & & & & $c 0-58$ & $1.006 E+05$ \\
\hline & & & & & & $c 0-60$ & $1.494 E+03$ \\
\hline & & & & & & $C R=51$ & $1.198 E+04$ \\
\hline & & & & & & $c s-137$ & $6.640 E+00$ \\
\hline & & & & & & FE-59 & $1.171 E+03$ \\
\hline & & & & & & MAP & $1.553 E+01$ \\
\hline & & & & & & MFP & $1.201 E+01$ \\
\hline & & & & & & $M N-54$ & $6.848 E+04$ \\
\hline & & & & & & $P U-239$ & $8.659 E-03$ \\
\hline & & & & & & $P U-240$ & $1.440 E-03$ \\
\hline & & & & & & $S R=90$ & $5.640 E+00$ \\
\hline & & & & & & $U-235$ & $1.028 E-04$ \\
\hline & & & & & & $U-238$ & $5.736 E-06$ \\
\hline & & & & & & & 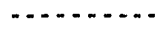 \\
\hline & & * & & & & & $1.838 E+05$ \\
\hline & & 78 & $2.796 E+02$ & $1.201 E+08$ & $8.361 E+04$ & $C E-144$ & $7.300 E+01$ \\
\hline & & & & & & $\mathrm{CO}-58$ & $4.578 E+04$ \\
\hline & & & & & & $C 0-60$ & $6.330 E+02$ \\
\hline & & & & & & $C R-51$ & $4.420 E+03$ \\
\hline & & & & & & CS- 134 & $7.802 E+01$ \\
\hline & & & & & & CS -137 & $9.444 E+01$ \\
\hline & & & & & & $F E-59$ & $4.670 E+02$ \\
\hline & & & & & & MAP & $6.439 E+00$ \\
\hline & & & & & & MFP & $2.404 E+01$ \\
\hline & & & & & & $M N-54$ & $3.195 E+04$ \\
\hline & & & & & & PU-239 & $1.056 E-02$ \\
\hline
\end{tabular}




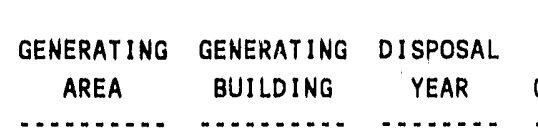

ANL

765

78 $\begin{array}{ll}\text { ANNUAL } & \text { ANNUAL } \\ \text { VOLUME } & \text { WEIGHT }\end{array}$

CUBIC METERS GRAMS

*

79

$1.482 E+02$
$5.878 E+07$
$1.565 E+05$

CE-144

CO- 58

CO-60

$C R-51$

CS- 134

CS -137

FE-59

MAP

MFP

$M N-54$

PU-239

PU -240

$S R-90$

U -235

$U-238$

*
$6.680 E+07$
80

$1.775 E+02$

CO-58

Co-60

$C R-51$

CS- 137

FE- 59

KR-85

MAP

MFP

MN-54

PU-239

PU -240

$U-235$

U-238

81

\section{$1.524 E+02 \quad 5.220 E+07 \quad 5.277 E+04$}

CE- -144

$\mathrm{CO}-58$

CO-60

$\mathrm{CR}-51$

CS- 137
CURIES

2.127E-03

8.000E+01

4.656E-04

5.347E-05

(3).3.....

$5.150 E+01$

$8.420 E+04$

$1.480 E+03$

$6.357 E+03$

$9.600 E+00$

$2.450 E+01$

$7.330 E+02$

$7.054 E+00$

$9.686 E+00$

$6.364 E+04$

$7.251 \mathrm{E}-03$

3.945E-04

2. $150 E+01$

4.325E-05

6.334E-06

-.........

$1.565 E+05$

$5.498 E+04$

$3.892 E+03$

$5.846 E+03$

$2.825 E+00$

$6.010 E+02$

1.500E-01

$4.984 E+00$

$6.924 E+00$

$3.522 E+04$

$3.837 \mathrm{E}-03$

$6.929 E-05$

$1.298 E-05$

$1.177 E-06$

$1.006 E+05$

$1.000 E+00$

$2.929 E+04$

$1.533 E+03$

$1.099 E+03$

$4.000 E+00$ 


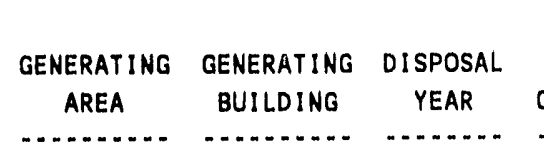

81

ANL 765
82 $1.064 E+02$
$3.528 E+07$
1.138E+05

CE- 144

CO- 57

Co-58

CO- 60

$C R-51$

CS- 134

CS- 137

EU- 155

$\mathrm{FE}-59$

$\mathrm{H}-3$

MAP

MFP

$M N-54$

PU-239

PU -240

SR -90

U. 235

$U-238$

83

$7.275 E+0$
$2.600 E+07$
$3.955 E+04$
Co. 58

CO- 60

CR-51

FE-59

MAP

MFP

MN-54

$\mathrm{NP}-237$

PU- 239

PU- 240

$\mathrm{U}-235$

U-238

\section{PAQE 22}

\section{CURIES}

$1.647 \mathrm{E}+02$

$6.527 E+00$

$9.288 E+00$

$2.066 E+04$

$1.948 \mathrm{E}-03$

$3.805 E-05$

$4.059 E-06$

3. $999 E-05$

5.277E+04

$3.000 E+00$

3.510E-04

$6.333 E+04$

$1.109 E+04$

2.907E+03

6.000E-01

1.203E+00

$9.630 \mathrm{E}-04$

$3.520 E+02$

$1.9144 \mathrm{E}-01$

$3.194 E+01$

4.803E+01

$3.601 E+04$

6.747E-04

$1.324 E-05$

$1.200 E+00$

4.673E-08

$4.299 E-05$

$1.138 \mathrm{E}+05$

$2.035 E+04$

$3.916 E+03$

$7.040 E+02$

$1.190 E+02$

$1.894 E+00$

$2.835 E+00$

$1.446 E+04$

2.115E-05

1.541E-03

5.445E-05

5.877E-08

2.661E-06

(3.......

$3.955 E+04$ 


\begin{tabular}{|c|c|c|}
\hline GENERAT ING & GENERATING & DISPOSAL \\
\hline AREA & BUILDING & YEAR \\
\hline
\end{tabular}

ANL 765

84
85

86

$8.439 E+01$
ANNUAL

$$
\text { VOLUME }
$$

CUBIC METERS

$6.625 E+01$

ANNUAL

WEIGHT GRAMS

ANNUAL .......... CURIES

NUCLIDE CURIES $1.003 E+05$ CE -144

$7.850 E+00$

CO. 58

CO. 60

CR-51

CS -134

CS -137

FE-59

MAP

MFP

MN -54

PU-239

PU. 240

SR -90

U -235

$U-238$

4.723E+04

$1.494 E+04$

$1.779 E+03$

$1.570 E+00$

3. $140 E+00$

2. $830 E+02$

$1.371 E+00$

$2.058 E+00$

$3.608 E+04$

$7.950 E-04$

5.753E-05

3. 140E+00

2.351E-05

1.827E-06

$1.003 E+05$

$2.974 E+0$

$1.023 E+05$

Co-58

CO- 60

CR-51

FE-59

MAP

MFP

MN-54

PU-239

PU-240

U -235

U-238

4.540E+04

2. $030 E+04$

2. $254 E+03$

3.320E+02

8.600E- 01

$1.289 E+00$

$3.396 E+04$

2. $134 \mathrm{E}-04$

$3.989 E-06$

2.906E-06

4. $499 \mathrm{E}-08$

.........

$1.023 E+05$

$1.557 E+04$

4.043E+03

4. $210 E+02$

9.300E+01

CR -51

FE-59

$3.105 E+00$

MAP

$4.657 E+00$

MFP

PU-239

$1.374 E+04$

$1.453 E-04$

PU- 240

U- 235

$2.828 E-06$

$3.585 \mathrm{E}-06$

$4.848 \mathrm{E}-08$

$U-238$

$3.387 \mathrm{E}+04$ 

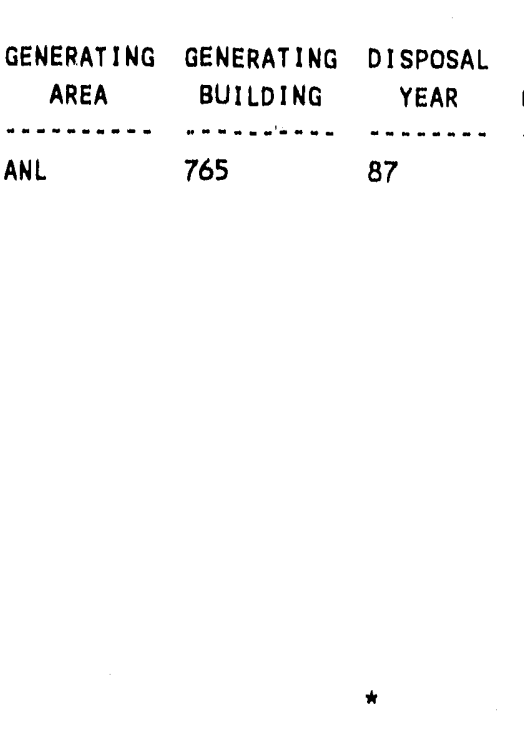

88

89 $\begin{array}{ll}\text { ANNUAL } & \text { ANNUAL } \\ \text { VOLUME } & \text { WEIGHT }\end{array}$ CUBIC METERS GRAMS -...........

$5.858 \mathrm{E}+01$ ............ $4.955 E+07$
NUCL.IDE

Co-58

CO- 60

CR-51

FE-59

MAP

MFP

MN-54

PU- 239

PU-240

SB- 124

TA -182

U. 235

$U-238$

$4.059 E+02$

$3.206 E+08$

$6.830 E+04$

CE -144

CO- 58

CO- 60

CR- 51

CS- 134

CS -137

FE- 59

MAP

MFP

MN -54

PU-239

PU -240

$S R-90$

$T A-182$

$U-235$

$U-238$

$1.911 E-04$ 


$\begin{gathered}\text { GENERATING } \\ \text { AREA }\end{gathered}$
$\begin{gathered}\text { GENERATING } \\ \text { BUILDING }\end{gathered}$ $\begin{gathered}\text { DISPOSAL } \\ \text { YEAR }\end{gathered}$

ANL
89

71

767

765

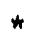

ANNUAL

VOLUME

CUBIC METERS

C............

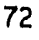

$\star$

73

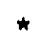

75

*

76

$1.039 E+0$

72

$4.333 E+00$

$1.340 E+01$
ANNUAL

WEIGHT

ORAMS

ANNUAL

CURIES NUCLIDE

PU-240

RU-106

SB- 125

$2.011 E+00$

$8.619 E+05$

$1.510 E+00$

CO. 58

CO- 60

CR -51

CS -137

MAP

MFP

$M N-54$

4.220E +00

$5.443 E+05$

$1.500 E-02$

MFP

4. $082 E+05$

3. 100E-02

MAP

MFP

$1.769 E+06$

5.880E-0

MAP

MFP

PU-239

3.530E-01

1.362E-06

$5.880 \mathrm{E}-01$

1.700E-01

$1.480 E-02$

$2.400 E-01$

$5.718 \mathrm{E}-01$

MAP

MFP

$R A-226$

1.726E-01

$2.000 E-03$

SR-90

U- 235

U- 238

2.400E- 01

5.933E-05

$7.159 E-07$

$1.411 E+00$ 


\begin{tabular}{|c|c|c|c|c|c|c|c|}
\hline $\begin{array}{c}\text { GENERATING } \\
\text { AREA }\end{array}$ & $\begin{array}{l}\text { GENERATING } \\
\text { BUILDING }\end{array}$ & $\begin{array}{c}\text { DISPOSAL } \\
\text { YEAR }\end{array}$ & $\begin{array}{c}\text { ANNUAL } \\
\text { VOLUME } \\
\text { CUBIC METERS }\end{array}$ & $\begin{array}{l}\text { ANNUAL } \\
\text { WEIGHT } \\
\text { GRAMS }\end{array}$ & $\begin{array}{l}\text { ANNUAL } \\
\text { CURIES }\end{array}$ & NUCLIDE & CURIES \\
\hline ……… & n............. & …….... & - & n. & (............. & . & $\cdots$ \\
\hline \multirow{37}{*}{ ANL } & 767 & 77 & $1.402 E+01$ & $1.815 E+06$ & $2.250 E-01$ & MAP & $1.650 E-01$ \\
\hline & & & & & & MFP & $6.000 E-02$ \\
\hline & & & & & & PU-239 & $6.000 E-06$ \\
\hline & & & & & & & 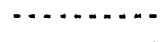 \\
\hline & & * & & & & & $2.250 E-01$ \\
\hline & & 79 & $3.625 E+00$ & $2.268 \mathrm{E}+05$ & $1.000 E-01$ & CS- 137 & $1.000 E-01$ \\
\hline & & 83 & $1.586 E+00$ & $1.089 E+06$ & $4.405 E-03$ & MAP & $1.760 E-03$ \\
\hline & & & & & & MFP & $2.640 \mathrm{E}-03$ \\
\hline & & & & & & $P U=239$ & $5.000 E-06$ \\
\hline & & & & & & $P U-240$ & $9.600 E-08$ \\
\hline & & & & & & & (1) \\
\hline & & ${ }^{*}$ & & & & & $4.405 E-05$ \\
\hline & & 86 & $1.982 \mathrm{E}-01$ & $4.540 E+04$ & $1.000 E-02$ & MAP & $4.000 E-03$ \\
\hline & & & & & n. & MFP & $6.000 E-03$ \\
\hline & * & & & & $3.895 E+00$ & & מ \\
\hline & & * & & & & & $1.000 E-02$ \\
\hline & & & & & & & $\cdots+\ldots$ \\
\hline & $\star$ & & & & & & $3.895 E+00$ \\
\hline & 768 & 73 & $4.984 E+00$ & $2.359 E+05$ & $6.460 E-02$ & MAP & $5.814 E-02$ \\
\hline & & & & & & MFP & $6.459 E-03$ \\
\hline & & & & & & PU-239 & $8.154 E-07$ \\
\hline & & & & & & & ( \\
\hline & & 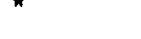 & & & & & $6.460 E-02$ \\
\hline & & 74 & $6.230 E+00$ & $3.220 E+05$ & $1.450 E-02$ & MAP & $1.305 E-02$ \\
\hline & & & & & & MFP & $1.450 E-03$ \\
\hline & & & & & & & 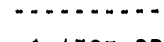 \\
\hline & & * & & & & & $1.450 E-02$ \\
\hline & & 77 & $2.832 E-01$ & $2.835 E+05$ & $2.690 \mathrm{E}-01$ & $c 0-60$ & 2.690: -01 \\
\hline & & 78 & $8.156 E+00$ & $5.670 E+05$ & $2.120 E-01$ & $C S-137$ & $1.000 E-01$ \\
\hline & & & & & & MAP & $1.000 E-01$ \\
\hline & & & & & & $U-235$ & $3.030 E-04$ \\
\hline & & & & & & $U \cdot 238$ & $1.174 \mathrm{E}-02$ \\
\hline & & * & & & & & $2.120 E-01$ \\
\hline & & 80 & $7.249 E+00$ & $1.043 E+07$ & $5.341 E-01$ & MAP & $3.100 E-01$ \\
\hline & & & & & & MFP & $2.150 E-01$ \\
\hline & & & & & & $U-235$ & $1.070 E-04$ \\
\hline & & & & & & $U \cdot 238$ & $9.041 \mathrm{E}-03$ \\
\hline
\end{tabular}




\begin{tabular}{|c|c|c|c|c|c|c|c|}
\hline $\begin{array}{c}\text { GENERATING } \\
\text { AREA }\end{array}$ & $\begin{array}{l}\text { GENERATING } \\
\text { BUILDING }\end{array}$ & $\begin{array}{l}\text { DISPOSAL } \\
\text { YEAR }\end{array}$ & $\begin{array}{c}\text { ANNUAL } \\
\text { VOLUME } \\
\text { CUBIC METERS }\end{array}$ & $\begin{array}{l}\text { ANNUAL } \\
\text { WE!GHT } \\
\text { GRAMS }\end{array}$ & $\begin{array}{l}\text { ANNUAL } \\
\text { CURIES }\end{array}$ & NUCLIDE & CURIES \\
\hline - & . & * & 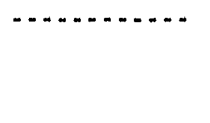 & n & n. & . & $5.341 \mathrm{E} \times 01$ \\
\hline ANL & 768 & * & $9.062 E-01$ & $2.268 E+05$ & $7.143 E-01$ & $\begin{array}{l}\text { MAP } \\
\text { MFP } \\
U-235\end{array}$ & $\begin{array}{r}2.857 E-01 \\
4.286 E-01 \\
3.210 E-07 \\
\cdots . .1 \\
7.143 E-01\end{array}$ \\
\hline & & $\star$ & $9.911 E+00$ & $3.125 E+06$ & $3.458 E-01$ & $\begin{array}{l}\text { MAP } \\
\text { MFP }\end{array}$ & $\begin{array}{r}1.383 E-01 \\
2.075 E-01 \\
\cdots \ldots \ldots \ldots \\
3.458 E-01\end{array}$ \\
\hline & & 84 & $3.568 E+00$ & $1.060 E+06$ & $\begin{array}{c}2.091 E-01 \\
\ldots\end{array}$ & $\begin{array}{l}\text { MAP } \\
\text { MFP }\end{array}$ & $\begin{array}{l}8.311 E-02 \\
1.260 E=01\end{array}$ \\
\hline & * & 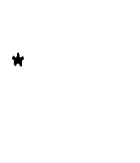 & . & & $2.364 E+00$ & & $\begin{array}{r}2.091 E-01 \\
2.364 E+00\end{array}$ \\
\hline & 770 & * & $5.777 E+00$ & $3.447 E+05$ & $2.320 E-01$ & $\begin{array}{l}\text { MAP } \\
\text { MFP } \\
\text { PU-239 }\end{array}$ & $\begin{array}{r}9.280 E-02 \\
1.392 E-01 \\
8.154 E-07 \\
\cdots .2 . . . \\
2.320 E-01\end{array}$ \\
\hline & & $\star$ & $5.466 E+00$ & $1.610 E+06$ & $2.814 E-03$ & $\begin{array}{l}\text { MAP } \\
\text { MFP }\end{array}$ & $\begin{array}{r}1.125 E-03 \\
1.689 E-03 \\
\ldots .2 \ldots-. .2 \\
2.814 E-03\end{array}$ \\
\hline & & * & $2.889 \mathrm{E}+00$ & $4.083 E+05$ & $8.000 E-03$ & $\begin{array}{l}\text { MAP } \\
\text { MFP }\end{array}$ & $\begin{array}{r}1.000 E-03 \\
7.000 E-03 \\
\ldots . .2 .0 . \\
8.000 E-03\end{array}$ \\
\hline & & * & $8.971 E+01$ & $6.177 E+07$ & $6.125 E-01$ & $\begin{array}{l}C O-60 \\
C S-137 \\
N A-22\end{array}$ & $\begin{array}{r}1.276 E-02 \\
5.180 E-01 \\
8.176 E-02 \\
\cdots \\
6.125 E-01\end{array}$ \\
\hline & * & 80 & $2.900 E+01$ & $5.443 E+06$ & $\begin{array}{r}2.000 E-01 \\
1.055 E+00\end{array}$ & $\begin{array}{l}\text { CS }-137 \\
\text { NA- } 22\end{array}$ & $\begin{array}{l}1.000 E-01 \\
1.000 E-01\end{array}$ \\
\hline
\end{tabular}




\begin{tabular}{|c|c|c|c|c|c|c|c|}
\hline & & & ANNUAL & ANNUAL & & & \\
\hline $\begin{array}{l}\text { OENERATING } \\
\text { AREA }\end{array}$ & $\begin{array}{l}\text { GENERATING } \\
\text { BUILDING }\end{array}$ & $\begin{array}{l}\text { DISPOSAL } \\
\text { YEAR }\end{array}$ & $\begin{array}{l}\text { VOLUME } \\
\text { CUBIC METERS }\end{array}$ & $\begin{array}{l}\text { WEIGHT } \\
\text { GRAMS }\end{array}$ & $\begin{array}{l}\text { ANNUAL } \\
\text { CURIES }\end{array}$ & NUCL IDE & CURIES \\
\hline \multirow[t]{4}{*}{ ……… } & n. & $\ldots \ldots$ & - & (............ & 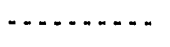 & , n... & (........... \\
\hline & & 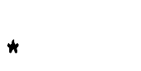 & & & & & $2.000 E-01$ \\
\hline & & & & & & & ........... \\
\hline & * & & & & & & $1.055 E+00$ \\
\hline \multirow[t]{34}{*}{ ANL } & 771 & 75 & $4.814 E-01$ & $9.072 E+05$ & $2.080 E-03$ & MFP & $2.078 \mathrm{E}-03$ \\
\hline & & & & & & PU-239 & $1.890 E-06$ \\
\hline & & & & & & & (n) \\
\hline & & * & & & & & $2.080 E-03$ \\
\hline & & 76 & $1.252 E+01$ & $2.359 E+07$ & $6.191 E+00$ & $C E-144$ & $1.180 E+00$ \\
\hline & & & & & & CS-137 & $1.260 E+00$ \\
\hline & & & & & & MFP & $3.250 E+00$ \\
\hline & & & & & & SR-90 & $5.000 E-01$ \\
\hline & & & & & & $U-235$ & $4.601 E-04$ \\
\hline & & & & & & $U-238$ & $7.206 E-05$ \\
\hline & & & & & & & n...non \\
\hline & & $\star$ & & & & & $6.191 E+00$ \\
\hline & & 83 & $5.947 E-01$ & $5.897 E+05$ & $5.790 E-06$ & $c 0-60$ & $1.150 \mathrm{E}-06$ \\
\hline & & & & & & CS- 137 & $4.640 E-06$ \\
\hline & & & & & & & (n) \\
\hline & & $\star$ & & & & & $5.790 E-06$ \\
\hline & & 89 & $9.170 E+00$ & $2.702 E+06$ & $1.501 E+00$ & CS-137 & $1.501 \mathrm{E}+00$ \\
\hline & & & & & , n. & & n. \\
\hline & $\star$ & & & & $7.694 E+00$ & & $7.694 E+00$ \\
\hline & 772 & 79 & $1.812 E+00$ & $1.361 \mathrm{E}+05$ & $1.000 E-01$ & MAP & $4.000 E-02$ \\
\hline & & & & & & MFP & $6.000 E-02$ \\
\hline & & & & & & & n............. \\
\hline & & * & & & & & $1.000 E-01$ \\
\hline & & 81 & $3.625 E+00$ & $6.129 E+05$ & $2.400 E-04$ & MAP & $1.000 E-04$ \\
\hline & & & & & & MFP & $1.400 E-04$ \\
\hline & & & & & & & . \\
\hline & & * & & & & & $2.400 E-04$ \\
\hline & & 82 & $3.625 E+00$ & $6.804 E+05$ & $4.800 E-03$ & MAP & $1.920 E-03$ \\
\hline & & & & & 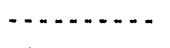 & MFP & $2.880 E-03$ \\
\hline & $\star$ & & & & $1.050 E-01$ & & ........... \\
\hline & & * & & & & & $4.800 E-03$ \\
\hline & & & & & & & $\ldots$ \\
\hline & * & & & & & & $1.050 E-01$ \\
\hline & 774 & 71 & $6.117 E+00$ & $5.443 E+05$ & $1.000 E-03$ & MFP & $1.000 E-03$ \\
\hline
\end{tabular}




\begin{tabular}{ccc}
$\begin{array}{l}\text { GENERATING } \\
\text { AREA }\end{array}$ & $\begin{array}{c}\text { GENERATING } \\
\text { BUILDING }\end{array}$ & $\begin{array}{c}\text { DISPOSAL } \\
\text { YEAR }\end{array}$ \\
\hdashline & $\ldots$ & 72
\end{tabular}

ANNUAL ANNUAL

VOLUME WEIGHT

CUBIC METERS GRAMS

1..........

$1.172 E+01$

$1.077 E+06$

ANNUAL

CURIES NUCLIDE

CURIES

$0.524 E-02$

MFP

$U-235$

$U-238$

$5.010 \mathrm{E}-02$

$6.206 E-04$

4.452E-02

-..........

$9.524 E-02$

73

$4.078 E+00$

$3.629 E+05$

$2.000 E-03$

MAP

$1.900 E-03$

$1.000 E-04$

$2.000 \mathrm{E}-03$

74

$3.738 E+00$

$1.497 E+05$

2.000E-06 MAP

MFP

$1.000 E-06$

$1.000 E-06$

1..........

$2.000 E-06$

79

$5.437 E+00 \quad 1.817 E+06$

8.531E-02 MAP

$T H-232$

$U-235$

U- 238

$2.060 \mathrm{E}-03$

$3.270 E-09$

2.340E-07

8.325E-02

$8.531 E-02$

80

$1.812 E+00 \quad 1.361 E+05 \quad 2.400 E-04$

CE- 144

CS -137

SB- 125

$8.000 \mathrm{E}-05$

8.000E-05

8.000E-05

$2.400 E-04$

9.601E-06

$3.400 E-07$

4.800E-08

3.300E-09

9.992E-06

9.600E-05

$1.440 E-04$

..........

$2.400 E-04$

1.500E-05

2.250E-05

$3.750 E-05$ 


\begin{tabular}{|c|c|c|c|c|c|c|c|}
\hline & & & ANNUAL & ANNUAL & & & \\
\hline GENERATI ING & GENERAT I NG & DISPOSAL & VOLUME & WEIGHT & ANNUAL & & \\
\hline AREA & BUILDING & YEAR & CUBIC METERS & GRAMS & CUR IES & NUCL IDE & CURIES \\
\hline ימוn & , & n...... & 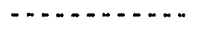 & 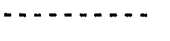 & ............. & n. & , n n \\
\hline & * & & & & & & $1.841 \mathrm{E}-01$ \\
\hline \multirow[t]{30}{*}{ ANL } & 775 & 72 & $5.437 E+00$ & $5.443 E+05$ & $1.000 E-05$ & MFP & $1.000 E-05$ \\
\hline & & 79 & $1.982 E-01$ & $1.134 E+05$ & $1.245 \mathrm{E}-02$ & $T H-232$ & $1.090 E-06$ \\
\hline & & & & & - & U-235 & $1.770 E-04$ \\
\hline & * & & & & $1.246 E-02$ & $U-238$ & $1.227 E-02$ \\
\hline & & * & & & & & $1.245 \mathrm{E}-02$ \\
\hline & & & & & & & כ0 \\
\hline & ^ & & & & & & $1.246 E-02$ \\
\hline & 776 & 71 & $5.777 \mathrm{E}+00$ & $3.629 E+05$ & $1.000 E-04$ & $U-238$ & $1.000 E-04$ \\
\hline & & 72 & $5.777 E+00$ & $5.443 E+05$ & $1.000 E-03$ & MFP & $1.000 E-03$ \\
\hline & & 74 & $7.930 E-01$ & $3.062 E+05$ & $6.250 E-05$ & MAP & $3.125 E-05$ \\
\hline & & & & & & MFP & $3.125 E-05$ \\
\hline & & * & & & & & $6.250 E-05$ \\
\hline & & 75 & $9.912 E-01$ & $3.130 E+05$ & $1.250 E-04$ & MAP & $5.000 E-05$ \\
\hline & & & & & & MFP & $7.500 E-05$ \\
\hline & & & & & & & . \\
\hline & & * & & & & & $1.250 E-04$ \\
\hline & & 76 & $9.346 E-01$ & $6.278 E+05$ & $4.310 E-02$ & MAP & $2.500 E-05$ \\
\hline & & & & & & MFP & $3.800 E-05$ \\
\hline & & & & & & $U-235$ & $6.070 E-04$ \\
\hline & & & & & & $U-238$ & $4.243 E-02$ \\
\hline & & * & & & & & $4.310 E-02$ \\
\hline & & 77 & $1.643 E+00$ & $1.170 E+06$ & $2.098 E-02$ & MAP & $8.000 E-04$ \\
\hline & & & & & & MFP & $1.200 E-03$ \\
\hline & & & & & & $T H-232$ & $1.000 E-06$ \\
\hline & & & & & & $U-235$ & $2.645 E-04$ \\
\hline & & & & & & $U-238$ & $1.871 E-02$ \\
\hline & & * & & & & & $2.098 \mathrm{E}-02$ \\
\hline & & 79 & $1.982 E-01$ & $2.540 E+05$ & $6.444 E-02$ & U.235 & $8.988 E-04$ \\
\hline & & & & & & $U-238$ & $6.354 E-02$ \\
\hline & & $\star$ & & & & & $6.444 E-02$ \\
\hline
\end{tabular}




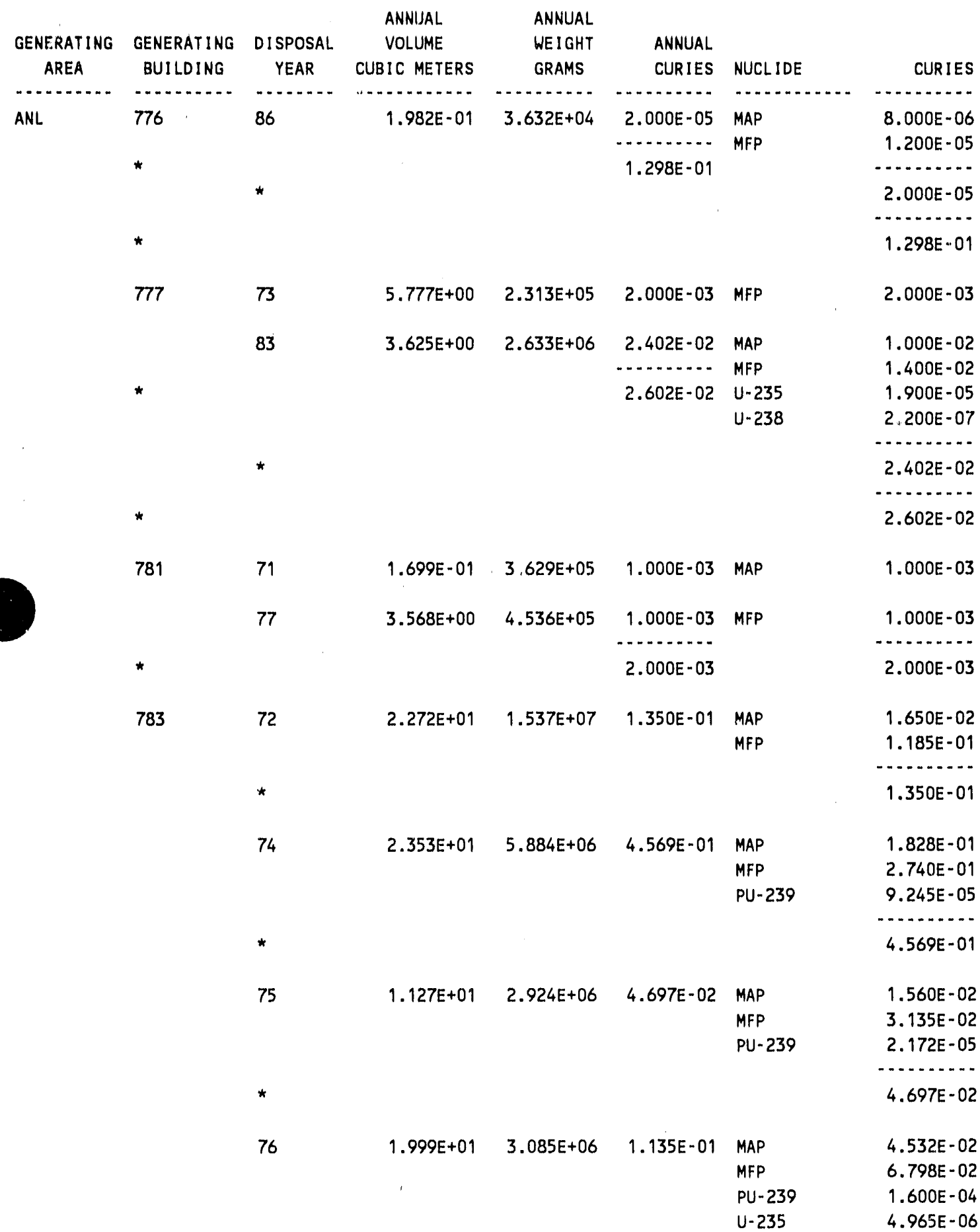




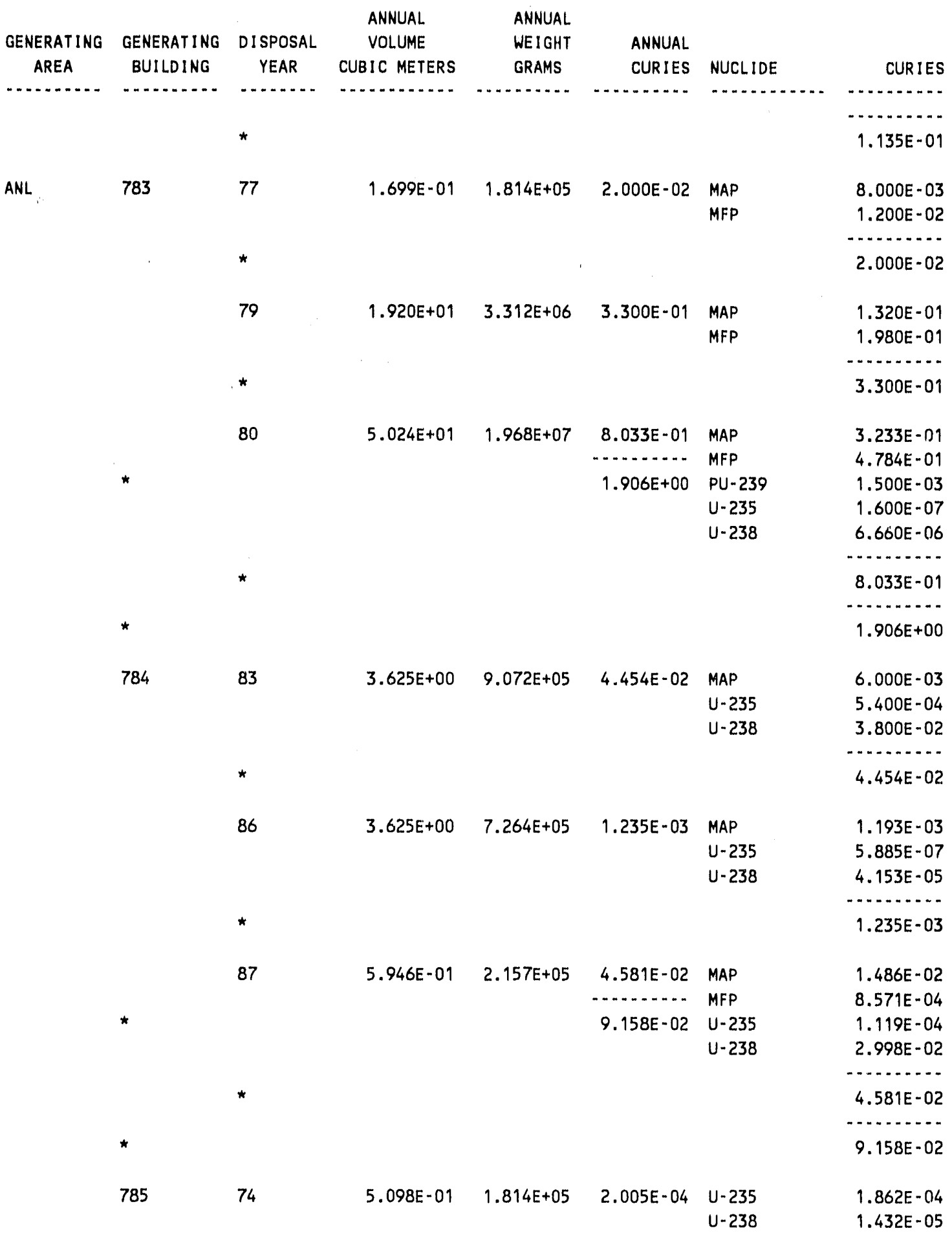




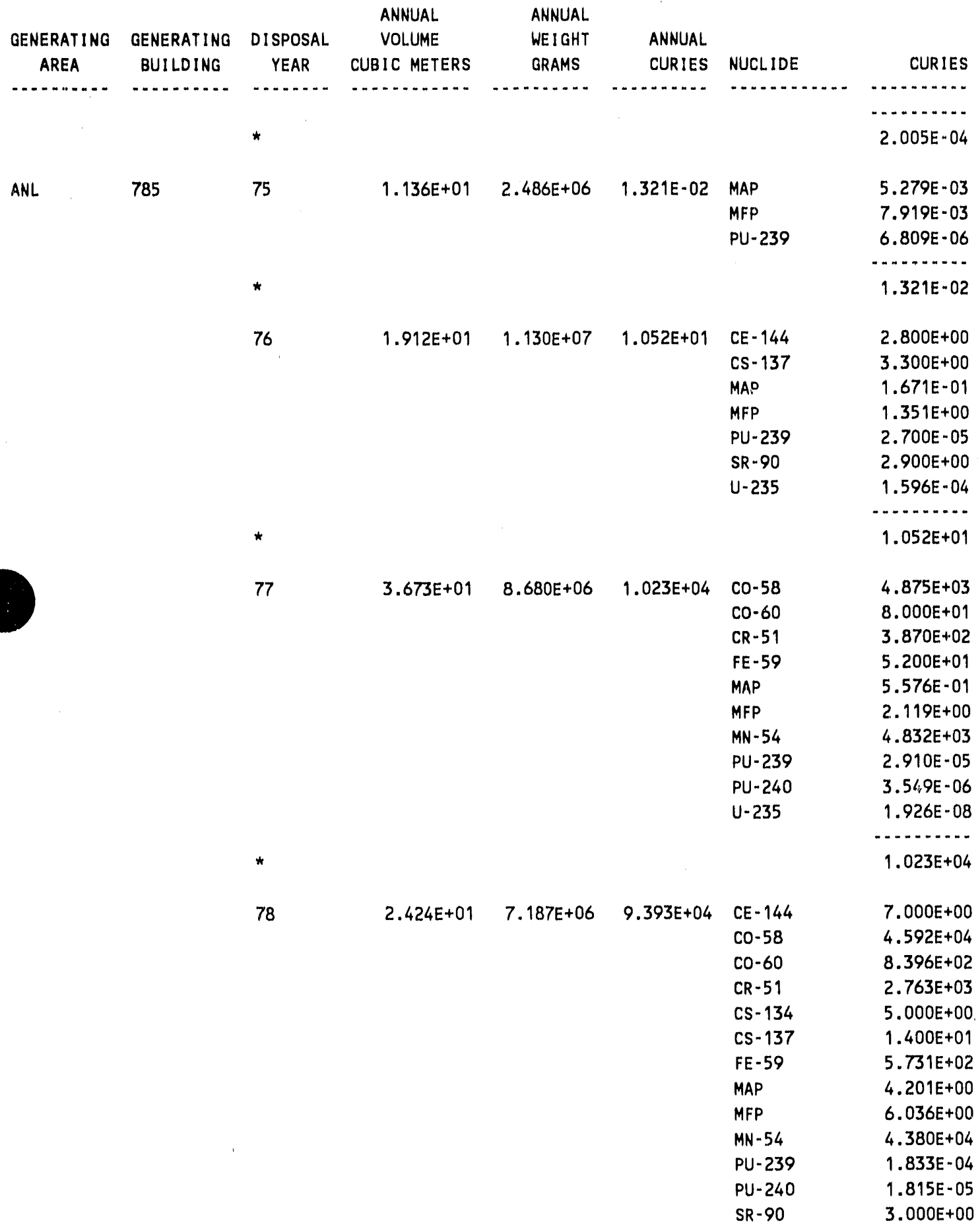




\begin{tabular}{|c|c|c|c|c|c|c|c|}
\hline \multirow[b]{2}{*}{ GENERATING } & \multirow[b]{2}{*}{ GENERATING } & \multicolumn{2}{|r|}{ ANNUAL } & ANNUAL & \multirow[b]{2}{*}{ ANNUAL } & \multirow[b]{3}{*}{ NUCLIDE } & \multirow[b]{3}{*}{ CURIES } \\
\hline & & DISPOSAL & VOLUME & WEIGHT & & & \\
\hline AREA & BUILDING & YEAR & CUBIC METERS & GRAMS & CURIES & & \\
\hline (n) & 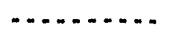 & $\ldots$ & $\ldots$ & (n. & 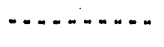 & , n & . \\
\hline & & * & & & & & $9.393 E+04$ \\
\hline \multirow[t]{41}{*}{ ANL. } & 785 & 79 & $2.529 E+01$ & $1.525 E+08$ & $7.780 E+04$ & $C E-144$ & $4.000 E+00$ \\
\hline & & & & & & 00.58 & $4.601 E+04$ \\
\hline & & & & & & $C 0-60$ & $5.460 E+02$ \\
\hline & & & & & & $C R-51$ & $5.242 E+03$ \\
\hline & & & & & & CS -134 & $6.000 E-01$ \\
\hline & & & & & & CS -137 & $3.200 E+00$ \\
\hline & & & & & & FE-59 & $4.15 C E+02$ \\
\hline & & & & & & MAP & $2.555 E+00$ \\
\hline & & & & & & MFP & $3.592 E+00$ \\
\hline & & & & & & $M N-54$ & $2.557 E+04$ \\
\hline & & & & & & PU-239 & $2.413 E-04$ \\
\hline & . & & & & & $P U-240$ & $1.340 E-05$ \\
\hline & & & & & & SR-90 & $2.200 E+00$ \\
\hline & & & & & & & (n................ \\
\hline & & * & & & & & $7.780 E+04$ \\
\hline & & 80 & $1.600 E+01$ & $9.92 .5 E+06$ & $3.153 E+04$ & $C E-144$ & $4.000 E+00$ \\
\hline & & & & & & Co-58 & $1.535 E+04$ \\
\hline & & & & & & $C 0-60$ & $4.700 E+02$ \\
\hline & & & & & & $C R-51$ & $1.746 E+03$ \\
\hline & & & & & & CS -134 & $1.000 E+00$ \\
\hline & & & & & & CS -137 & $1.100 E+01$ \\
\hline & & & & & & FE-59 & $2.300 E+02$ \\
\hline & & & & & & MAP & $6.476 E+00$ \\
\hline & & & & & & MFP & $6.804 E+00$ \\
\hline & & & & & & $M N-54$ & $1.370 E+04$ \\
\hline & & & & & & PU-239 & $6.425 E-04$ \\
\hline & & & & & & PU-240 & $1.304 E-05$ \\
\hline & & & & & & $S R-90$ & $4.000 E+00$ \\
\hline & & & & & & & 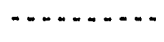 \\
\hline & & * & & & & & $3.153 E+04$ \\
\hline & & 81 & $1.976 E+01$ & $7.322 E+06$ & $5.374 E+04$ & CE-144 & $7.500 E+00$ \\
\hline & & & & & & Co. 58 & $3.302 E+04$ \\
\hline & & & & & & $c 0-60$ & $1.265 E+03$ \\
\hline & & & & & & $C R-51$ & $1.462 E+03$ \\
\hline & & & & & & CS- 134 & $5.500 E+00$ \\
\hline & & & & & & CS -137 & $1.290 E+01$ \\
\hline & & & & & & $\mathrm{FE}-59$ & $1.940 E+02$ \\
\hline & & & & & & MAP & $6.391 E+00$ \\
\hline & & & & & & MFP & $9.576 E+00$ \\
\hline & & & & & & $M N-54$ & $1.775 E+04$ \\
\hline & & & & & & PU-239 & $2.624 E-03$ \\
\hline
\end{tabular}




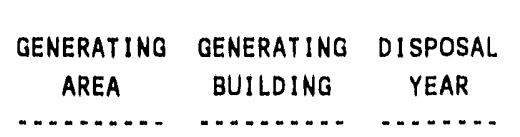

ANL 785

\begin{abstract}
ANNUAL VOLUME CUBIC METERS

ANNUAL

WEIGHT GRAMS
\end{abstract} C...........

(............
(n)

CURIES

NUCLIDE

$\mathrm{PU}-240$

$R A-226$

$S R-90$

TC- 99

U. 235

U-238

*

82

$1.739 E+01$

1.237E+07

CE -144

CO- 58

CO- 60

CR -51

CS- 134

CS- 137

FE- 59

MAP

MFP

$M N-54$

PU-239

PU- 240

$S R-90$

TA-182

$U-235$

$U-238$

*

83

\begin{abstract}
$4.398 E+01 \quad 1.302 E+07$
\end{abstract}

\begin{abstract}
$8.176 E+03$
\end{abstract}
CE- 144

CO- 58

CO- 60

CR-51

CS. 134

CS- 137

FE-59

MAP

MFP

MN-54

PU- 239

PU -240

SR-90

U. 235

U- 238
CURIES

$1.572 E-04$

$4.000 E-08$

$5.500 E+00$

3.230E - 08

$9.300 E-06$

$9.001 \mathrm{E}-07$

$5.374 E+04$

$1.800 E+01$

2.541E+04

$6.093 E+03$

$6.560 \mathrm{E}+02$

$3.600 E+00$

$7.200 E+00$

$1.530 E+02$

$3.353 E+00$

$5.317 E+00$

2. 136E+04

2. $600 \mathrm{E}-03$

5.309E-05

$7.200 E+00$

$4.000 E+00$

7.230E-06

$1.120 E-06$

-.........

$5.372 E+04$

$5.085 E+02$

$3.563 E+03$

$8.850 E+02$

$9.500 E+C 1$

$1.017 E+02$

2. $034 E+02$

2. $600 E+01$

$1.046 E+01$

$1.668 E+01$

$2.563 E+03$

$1.026 \mathrm{E}-02$

2.635E-03

$2.034 E+02$

3.685E-04

8. $408 E-03$

8. $176 E+03$ 


\begin{tabular}{|c|c|c|}
\hline GENERAT ING & GENERATING & DISPOSAL \\
\hline AREA & BUILDING & YEAR \\
\hline . & 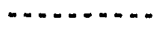 & 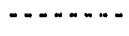 \\
\hline ANL & 785 & 84 \\
\hline
\end{tabular}

$\begin{array}{ll}\text { ANNUAL } & \text { ANNUAL } \\ \text { VOLUME } & \text { WEIGHT }\end{array}$ CUBIC METERS

$1.288 E+01$
WEIGHT GRAMS

4.804E+0
ANNUAL

CURIES
$1.895 E+04$

NUCL. IDE

CE - 144

CO- 58

CO- 60

$C R-51$

CS -134

CS -137

FE-59

MAP

MFP

$M N-54$

PU-239

PU -240

$S R=90$

TA- 182

U-235

U-238

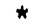

85

$2.172 E+01$

$7.550 E+06$

$2.423 E+04$

CE- 144

CO. 58

CO- 60

CR-51

CS -134

CS -137

FE -59

MAP

MFP

$M N-54$

PU- 239

PU- 240

$S R-90$

TA- 182

U. 235

U- 238

86
$8.353 E+0$
$4.610 E+06$

\section{$2.336 E+04$}

CE -144

CO- 58

CO- 60

CR-51

CS -134

CS -137

FE-59

MAP

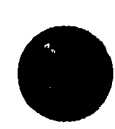
............

$3.906 E+02$

$7.589 E+03$

$2.343 E+03$

1. $710 E+02$

$7.812 E+01$

$1.562 \mathrm{E}+02$

6.300E+01

$4.748 \mathrm{E}+00$

$7.121 \mathrm{E}+00$

$7.938 E+03$

$8.001 E-03$

1.477E-04

$1.562 E+02$

5.700E+01

1.571E-04

3.146E-05

$1.895 E+04$

4. $600 E+01$

$1.110 E+04$

$3.195 E+03$

3.200E+02

$9.200 \mathrm{E}+00$

$1.840 E+01$

$1.150 E+02$

2. $333 E+00$

$3.500 E+00$

9.190E+03

$3.848 E-03$

$9.699 E-04$

$1.840 E+01$

2.080E+02

$9.864 \mathrm{E}-05$

$1.165 \mathrm{E}-05$

............

$1.365 E+02$

$7.402 E+03$

$9.725 E+03$

$2.381 E+02$

2. $770 E+01$

$5.440 E+01$

$2.600 E+01$

$2.876 E+00$ 

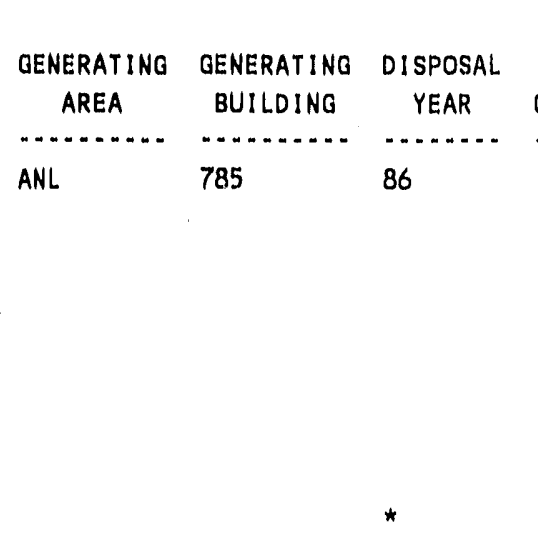

87

$6.065 E+00$
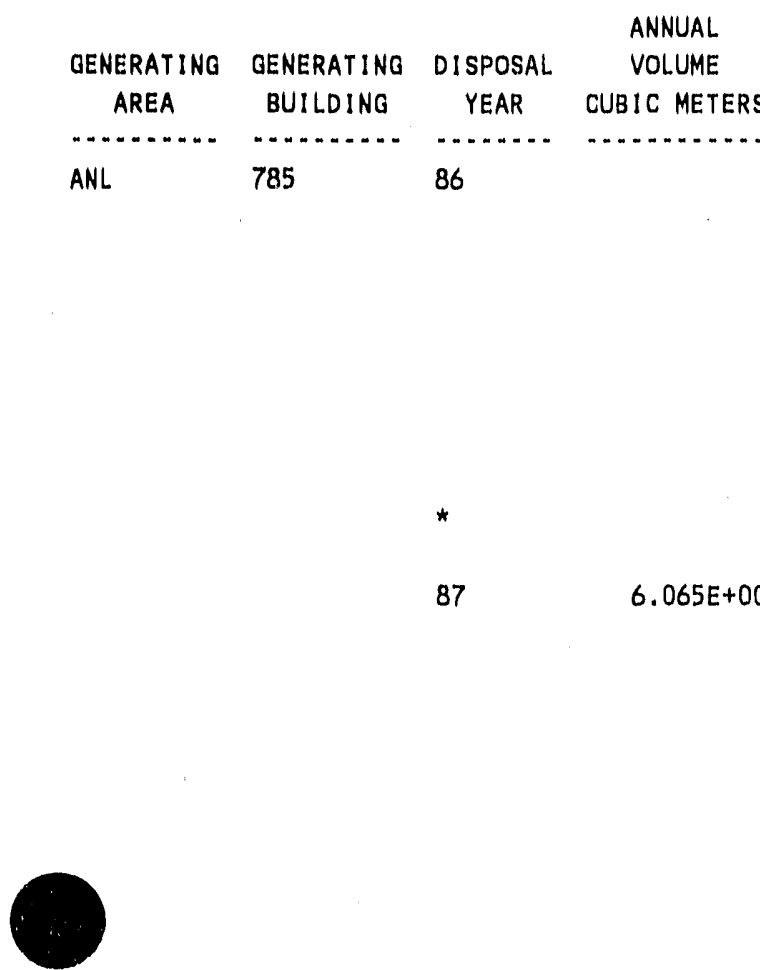

88
ANNUAL WEI IOHT QRAMS ANNUAL

\begin{tabular}{|c|c|c|}
\hline CURIES & NUCLIDE & CURIES \\
\hline & $\cdots$ & n \\
\hline & MFP & $4.315 E+00$ \\
\hline & $M N-54$ & $4.713 E+03$ \\
\hline & PU-239 & $1.437 E-02$ \\
\hline & $P U-240$ & $2.281 E-04$ \\
\hline & $S R-90$ & $5.440 E+01$ \\
\hline & $T A-182$ & $9.784 E+02$ \\
\hline & $U-235$ & $1.135 E-04$ \\
\hline & $U-238$ & $1.954 E-05$ \\
\hline & & . \\
\hline
\end{tabular}

CO- 58

CO- 60

CR -51

CS. 134

CS -137

FE- 59

MAP

MFP

$M N-54$

PU- 239

PU -240

$S R-90$

TA- 182

$U-235$

U. 238

$6.000 E+00$

$2.027 E+04$

$2.822 E+03$

$9.240 E+02$

$1.200 E+00$

$2.400 E+00$

9.600E+01

6.857E- 01

$1.029 E+00$

$1.183 E+04$

$6.265 E-04$

$1.271 E=05$

$2.400 E+00$

$1.900 E+02$

$2.247 \mathrm{E}-08$

1.865E-09

$3.615 E+04$

CE- 144

CO- 58

CO-60

$\mathrm{CR}-51$

CS- 134

CS -137

FE- 59

MAP

MFP

MN-54

PU-239

PU- 240

SR -90

TA- 182

U- 235

U- 238

$3.000 E+00$

$3.446 E+04$

$1.246 E+04$

$1.160 E+03$

6.000E - 01

1. $2.00 E+00$

$1.810 E+02$

6.096E-01

$9.143 E-01$

$2.570 E+04$

4.476E-04

$6.208 E-06$

$1.200 E+00$

$3.373 E+02$

5.334E- 07

5.259E-03 


\begin{tabular}{|c|c|c|c|c|c|c|c|}
\hline GENERATING & GENERATING & DISPOSAL & $\begin{array}{c}\text { ANNUAL } \\
\text { VOLUME } \\
\text { CUBIC METERS }\end{array}$ & $\begin{array}{l}\text { ANNUAL } \\
\text { WEI GHT }\end{array}$ & ANNUAL & & \\
\hline AREA & BUILDING & YEAR & CUBIC METERS & GRAMS & CURIES & NUCL IDE & CURIES \\
\hline \multirow[t]{2}{*}{. } & (n) & $\cdots$ & and & 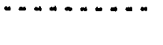 & …다. & 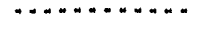 & $\cdots$ \\
\hline & & * & & & & & $7.429 E+04$ \\
\hline \multirow[t]{39}{*}{ ANL } & 785 & 89 & $7.985 E+00$ & $1.215 E+07$ & $4.316 E+05$ & $C E-144$ & $6.000 E+00$ \\
\hline & & & & & $\cdots \cdots$ & $\mathrm{CO}-58$ & $7.303 E+0.4$ \\
\hline & * & & & & $9.377 E+05$ & $c 0.60$ & $3.068 E+05$ \\
\hline & & & & & & $C R=51$ & $2.959 E+03$ \\
\hline & & & & & & CS- 134 & $1.200 E+00$ \\
\hline & & & & & & CS. 137 & $2.400 E+00$ \\
\hline & & & & & & $\mathrm{FE}-59$ & $5.260 E+02$ \\
\hline & & & & & & MAP & $4.334 E-01$ \\
\hline & & & & & & MFP & $6.500 E-01$ \\
\hline & & & & & & $M N-54$ & $4.823 E+04$ \\
\hline & & & & & & PU.239 & $4.539 E-04$ \\
\hline & & & & & & $P U \cdot 240$ & $1.283 E-04$ \\
\hline & & & & & & $S R=90$ & $2.400 E+00$ \\
\hline & & & & & & $T A-182$ & $3.000 E-01$ \\
\hline & & & & & & $U-235$ & $6.960 E-07$ \\
\hline & & & & & & U. 238 & $4.865 E-05$ \\
\hline & & & & & & & $\ldots \ldots$ \\
\hline & & * & & & & & $4.316 E+05$ \\
\hline & ^ & & & & & & $03775+05$ \\
\hline & & & & & & & \\
\hline & 787 & 73 & $1.801 E+01$ & $1.011 E+06$ & $2.171 \mathrm{E}=04$ & MAP & $2.550 E-05$ \\
\hline & & & & & & MFP & $1.275 E-05$ \\
\hline & & & & & & $U-235$ & $1.668 E-04$ \\
\hline & & & & & & $U-238$ & $1.199 E-05$ \\
\hline & & & & & & & n.............. \\
\hline & & * & & & & & $2.171 E=04$ \\
\hline & & 74 & B. $275 E+00$ & $1.660 E+06$ & $2.979 E-05$ & MAP & $2.277 \mathrm{E}-05$ \\
\hline & & & & & & $U-235$ & $7.012 E-06$ \\
\hline & & & & & & & ……....... \\
\hline & & * & & & & & $2.979 E-05$ \\
\hline & & 75 & $3.653 E+00$ & $2.874 E+06$ & $6.420 E-04$ & MAP & $9.600 E-07$ \\
\hline & & & & & & MFP & $2.750 E-05$ \\
\hline & & & & & & $U-235$ & $5.476 \mathrm{E}-04$ \\
\hline & & & & & & $41-238$ & $6.594 E-05$ \\
\hline & & * & & & & & $6420 E-04$ \\
\hline & & & & & & & \\
\hline & & 76 & $1.059 E+01$ & $4.196 E+06$ & $1.078 \mathrm{E}-01$ & MAP & $5.000 E-05$ \\
\hline & & & & & & MFP & $7.500 E-05$ \\
\hline & & & & & & $U-235$ & $1.813 E-03$ \\
\hline
\end{tabular}




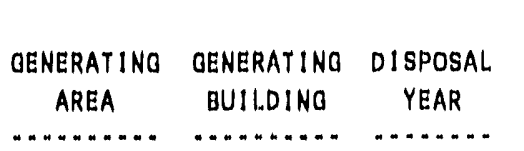

ANNUAL

VOLUME
ANL 787

76

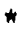

77

79

82

83

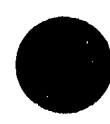

$1.360 E+00$

$6.804 E+05$

WEIOHT

GRAMS

84

$1.557 E+00 \quad 1.042 E+06$

ANNUAL

CURIES NUCLIDE

...............

U. 238

CURIES

$1.0508-01$

............

$1.078 E \cdot 01$

$6.735 E-04$

$5.261 E \times 05$

..........

$7.261 \mathrm{E}-04$

$1.000 E-03$

$1.000 E-04$

$1.400 E-04$

$\begin{array}{ll}U \cdot 235 & 1.539 E-06 \\ U \cdot 238 & 1.630 E-07\end{array}$

U.238 $\quad 1.630 E-07$

$2.417 E-04$

$2.752 E-04$

$4.029 E-04$

$\begin{array}{ll}U-235 & 1.326 E-04 \\ U-238 & 2.044 E-03\end{array}$

$\begin{array}{ll}U-235 & 1.326 E-04 \\ U-238 & 2.044 E-03\end{array}$

$2.855 E-03$

1.101E-02

MFP

TH-234

U-235

U- 238

T.308 - 07

$1.308 \mathrm{E}-07$

$9.323 E-03$

$U N=1 D=B+G$

$1.190 E-03$

$1.101 \mathrm{E} \cdot 02$

$4.102 E=04$

$1.088 E-04$

$5.190 E-04$

86

$4.955 E+00$

$1.791 E+06$

1.421E-02 MAP

1.392E-01 PU-239

PU- 240

U-235

U. 238

$2.762 E=03$

$4.143 E-03$

$4.482 E-04$

$1.678 E-04$

$2.575 E-03$

4.119E-03

$1,421 E$ 


\begin{tabular}{|c|c|c|c|c|c|c|c|}
\hline OENERATINO & GENERATINO & DISPOSAL & $\begin{array}{l}\text { ANNUAL } \\
\text { VOLUME }\end{array}$ & $\begin{array}{l}\text { ANNUAL } \\
\text { WEIOHT }\end{array}$ & ANNUAL. & & \\
\hline AREA & BUILDINO & YEAR & CUBIC METERS & ORAMS & CURIES & NUCL IDE & CURIES \\
\hline 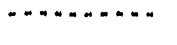 & n & $\ldots . . . \cdots$ & " & n & 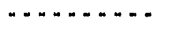 & 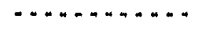 & $\cdots+\ldots+\cdots$ \\
\hline & $\star$ & & & & & & $1.392 E-01$ \\
\hline \multirow[t]{31}{*}{ ANL } & 790 & 73 & $1.144 E+02$ & $1.727 \mathrm{E}+07$ & $7.211 \mathrm{E}-02$ & MFP & $7.211 \mathrm{E}-02$ \\
\hline & & 75 & $6.683 E+00$ & $1.123 E+06$ & $3.629 E-02$ & MAP & $5.390 \mathrm{E}-03$ \\
\hline & & & & & n........ & MFP & $3.088 \mathrm{E}-02$ \\
\hline & * & & & & $1.084 \mathrm{E}=01$ & PU- 2.39 & $1.056 E-05$ \\
\hline & & & & & & & $\cdots+\cdots+\cdots$ \\
\hline & & * & & & & & $3.629 \mathrm{E}-02$ \\
\hline & $\star$ & & & & & & 1 - $845-01$ \\
\hline & 792 & 79 & $4.758 E+00$ & $3.856 E+05$ & $2.468 \mathrm{E}-06$ & $T H-232$ & $1.526 \mathrm{E}-06$ \\
\hline & & & & & & $U=235$ & $9.416 E-07$ \\
\hline & & & & & & & and \\
\hline & & * & & & & & $2.468 \mathrm{E}-06$ \\
\hline & & 84 & $2.764 E+01$ & $3.325 E+07$ & $4.409 E-02$ & MAP & $1.715 E-02$ \\
\hline & & & & & ……… & MFP & $2.690 \mathrm{E}-02$ \\
\hline & $\star$ & & & & $4.410 E-02$ & $U-235$ & $4.241 E-05$ \\
\hline & & & & & & $U=238$ & $2.407 E-07$ \\
\hline & & & & & & & 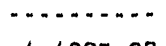 \\
\hline & & * & & & & & $4.409 E-02$ \\
\hline & $\star$ & & & & & & $4.410 E-02$ \\
\hline & 793 & 76 & $7.930 E-01$ & $1.361 \mathrm{E}+05$ & $1.500 E-03$ & MFP & $1.500 E-03$ \\
\hline & & 77 & $1.020 E+00$ & $2.268 \mathrm{E}+05$ & $5.000 E-02$ & MFP & $5.000 \mathrm{E}-02$ \\
\hline & & 78 & $3.625 \mathrm{E}+00$ & $1.814 E+05$ & $1.000 E-02$ & MAP & $4.000 E-03$ \\
\hline & & & & & & MFP & $6.000 E-03$ \\
\hline & & * & & & & & $1.000 \mathrm{E}-02$ \\
\hline & & 79 & $2.628 \mathrm{E}+01$ & $9.525 E+06$ & $1.590 \mathrm{E}+00$ & CS -137 & $7.900 E-01$ \\
\hline & & & & & & $\mathrm{H}-3$ & $1.000 E-02$ \\
\hline & & & & & & $N A-22$ & $7.900 E-01$ \\
\hline & & & & & & $U-235$ & $2.739 E-06$ \\
\hline & & * & & & & & $1.590 \mathrm{E}+00$ \\
\hline & & 81 & $5.436 \mathrm{E}+00$ & $2.041 E+06$ & $1.548 \mathrm{E}-01$ & CS -137 & $1.190 \mathrm{E}-01$ \\
\hline & & & & & & MAP & $1.429 E-02$ \\
\hline & & & & & & MFP & $2.143 E-02$ \\
\hline
\end{tabular}




\begin{tabular}{|c|c|c|c|c|c|c|c|}
\hline \multirow{2}{*}{$\begin{array}{l}\text { QENERATING } \\
\text { AREA }\end{array}$} & \multirow{2}{*}{$\begin{array}{l}\text { QENERATING } \\
\text { BUILDING } \\
\ldots . . . . . . .\end{array}$} & $\begin{array}{l}\text { DISPOSAL } \\
\text { YEAR }\end{array}$ & $\begin{array}{l}\text { ANNUAL } \\
\text { VOLUME }\end{array}$ & $\begin{array}{l}\text { ANNUAL } \\
\text { WEIGHT } \\
\text { GRAMS }\end{array}$ & ANNUAL & NUCL.1DE & CURIES \\
\hline & & 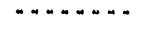 & 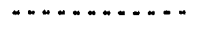 & 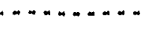 & 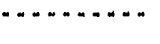 & -......... & 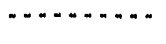 \\
\hline & & * & & & & & $1.548 \mathrm{E}-01$ \\
\hline \multirow[t]{30}{*}{ ANL } & 793 & 82 & $2.175 E+01$ & $5.897 E+06$ & $9.758 E-02$ & MAP & $3.903 E-02$ \\
\hline & & & & & & MFP & $5.855 \mathrm{E}-02$ \\
\hline & & * & & & & & $9.758 \mathrm{E}-02$ \\
\hline & & 83 & $3.625 E+00$ & $6.804 E+05$ & $1.310 E-01$ & MAP & $5.200 E-02$ \\
\hline & & & & & & MFP & $7.900 E-02$ \\
\hline & & * & & & & & $1.310 E-01$ \\
\hline & & 84 & $1.991 E+01$ & $6.376 E+06$ & $6.169 E-01$ & CS-137 & $1.600 E-02$ \\
\hline & & & & & & MAP & $2.301 E-01$ \\
\hline & & & & & & MFP & $3.452 E-01$ \\
\hline & & & & & & U.235 & $3.634 E-04$ \\
\hline & & & & & & U. 238 & $2.524 E-02$ \\
\hline & & * & & & & & $6.169 \varepsilon-01$ \\
\hline & & 85 & $1.269 E+01$ & $3.786 E+06$ & $6.714 E-01$ & MAP & $3.352 E-01$ \\
\hline & & & & & & MFP & $3.362 E-01$ \\
\hline & & * & & & & & $6.714 E-01$ \\
\hline & & 86 & $8.241 E+00$ & $3.201 E+06$ & $1.112 E+02$ & $H-3$ & $1.100 E+02$ \\
\hline & & & & & & MAP & $8.572 E-02$ \\
\hline & & & & & & MFP & $1.057 E+00$ \\
\hline & & . & & & & & . \\
\hline & & * & & & & & $1.112 E+02$ \\
\hline & & 87 & $7.646 E+00$ & $1.838 E+06$ & $1.583 E+00$ & MAP & 6.333E-01 \\
\hline & & & & & & MFP & $9.500 E-01$ \\
\hline & & * & & & & & $1.583 E+00$ \\
\hline & & 88 & $3.823 \mathrm{E}+00$ & $1.397 E+06$ & $1.429 E-01$ & MAP & $5.714 E-02$ \\
\hline & & & & & & MFP & $8.572 E-02$ \\
\hline & * & & & & $1.162 E+02$ & & . \\
\hline & & * & & & & & $1.429 E-01$ \\
\hline & * & & & & & & $1.1625+02$ \\
\hline & 794 & 78 & $2.266 E-01$ & $2.268 E+04$ & $1.500 E+00$ & Co.58 & $5.000 E \cdots 01$ \\
\hline & & & & & & $100-60$ & $2.500 E-01$ \\
\hline
\end{tabular}




\begin{tabular}{|c|c|c|c|c|c|c|c|}
\hline GENERATING & OENERATING & DISPOSAL. & $\begin{array}{l}\text { ANNUAL. } \\
\text { VOL.UME }\end{array}$ & $\begin{array}{l}\text { ANNUAL } \\
\text { WEIGHT }\end{array}$ & ANNUAL & & \\
\hline AREA & BUILDING & YEAR & CUBIC METERS & GRAMS & CURIES & NUCLIDE & CURIES \\
\hline n.......... & $\ldots \ldots$ & $\ldots \ldots$ & 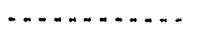 & 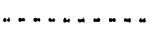 & anom & , & , n \\
\hline \multirow[t]{39}{*}{ ANL. } & 794 & 78 & & & & MAP & $2.500 E-01$ \\
\hline & & & & & & $M N-54$ & $5.000 E-01$ \\
\hline & & & & & & & - n \\
\hline & & * & & & & & $1.500 E+00$ \\
\hline & & $1 / 2$ & $1.812 E+00$ & $5.443 E+05$ & $6.094 \mathrm{E}-02$ & MAP & $1.900 E-03$ \\
\hline & & & & & n n & MFP & $2.860 E-03$ \\
\hline & * & & & & $1.561 E+00$ & $U \cdot 235$ & $7.918 E-04$ \\
\hline & & & & & & $U-238$ & $5.539 E-02$ \\
\hline & & & & & & & n........... \\
\hline & & * & & & & & $6.094 \mathrm{E}-02$ \\
\hline & & & & & & & 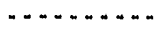 \\
\hline & * & & & & & & $1.561 E+00$ \\
\hline & 797 & 87 & $3.625 E+00$ & $4.812 E+05$ & $4.048 E-02$ & MAP & $1.619 E-02$ \\
\hline & & & & & & MFP & $2.429 E-02$ \\
\hline & & & & & & PU-239 & $1.394 E-06$ \\
\hline & & & & & & PU-240 & $2.713 E-08$ \\
\hline & & $\star$ & & & & & $4.048 \mathrm{~B}-02$ \\
\hline & & 88 & $1.676 E+01$ & $1.385 E+06$ & $3.181 E+00$ & $C E-144$ & $6.430 E-04$ \\
\hline & & & & & …......... & $c 0-60$ & $6.155 E-06$ \\
\hline & * & & & & $3.222 E+00$ & CS -137 & $9.946 E-04$ \\
\hline & & & & & & MAP & $1.271 E+00$ \\
\hline & & & & & & MFP & $1.908 E+00$ \\
\hline & & & & & & NB- 95 & $2.210 E-04$ \\
\hline & & & & & & $2 R-95$ & $1.320 E-04$ \\
\hline & & & & & & & n............ \\
\hline & & * & & & & & $3.181 E+00$ \\
\hline & & & & & & & (n) \\
\hline & * & & & & & & $3.222 E+00$ \\
\hline & 798 & 84 & $5.947 E+00$ & $2.043 E+07$ & $9.179 E-01$ & MAP & $3.667 E-01$ \\
\hline & & & & & & MFP & 5.500E-01 \\
\hline & & & & & & PU-239 & $1.130 E-03$ \\
\hline & & & & & & PU-240 & $2.209 E-05$ \\
\hline & & & & & & $U-235$ & $5.513 E-06$ \\
\hline & & & & & & $U-238$ & $4.226 E-07$ \\
\hline & & * & & & & & 0 \\
\hline & & 85 & $7.759 E+00$ & $2.070 E+07$ & $6.173 E-01$ & MAP & $2.466 E-01$ \\
\hline & & & & & & MFP & $3.700 E-01$ \\
\hline & & & & & & PU-239 & $6.588 E-04$ \\
\hline & & & & & & $P U-240$ & $1.289 E-05$ \\
\hline
\end{tabular}



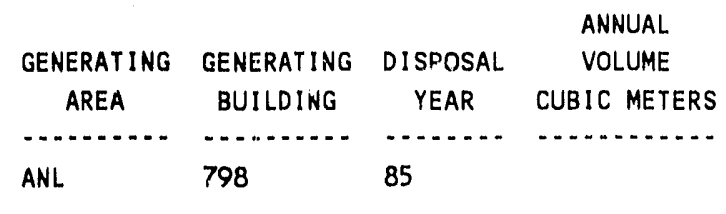

ANNUAL

\begin{tabular}{|c|c|c|}
\hline GENERAT ING & GENERATING & DISPOSAL \\
\hline AREA & BUILDING & YEAR \\
\hline - & - & \\
\hline & 798 & 85 \\
\hline
\end{tabular}

WEIGHT
GRAMS
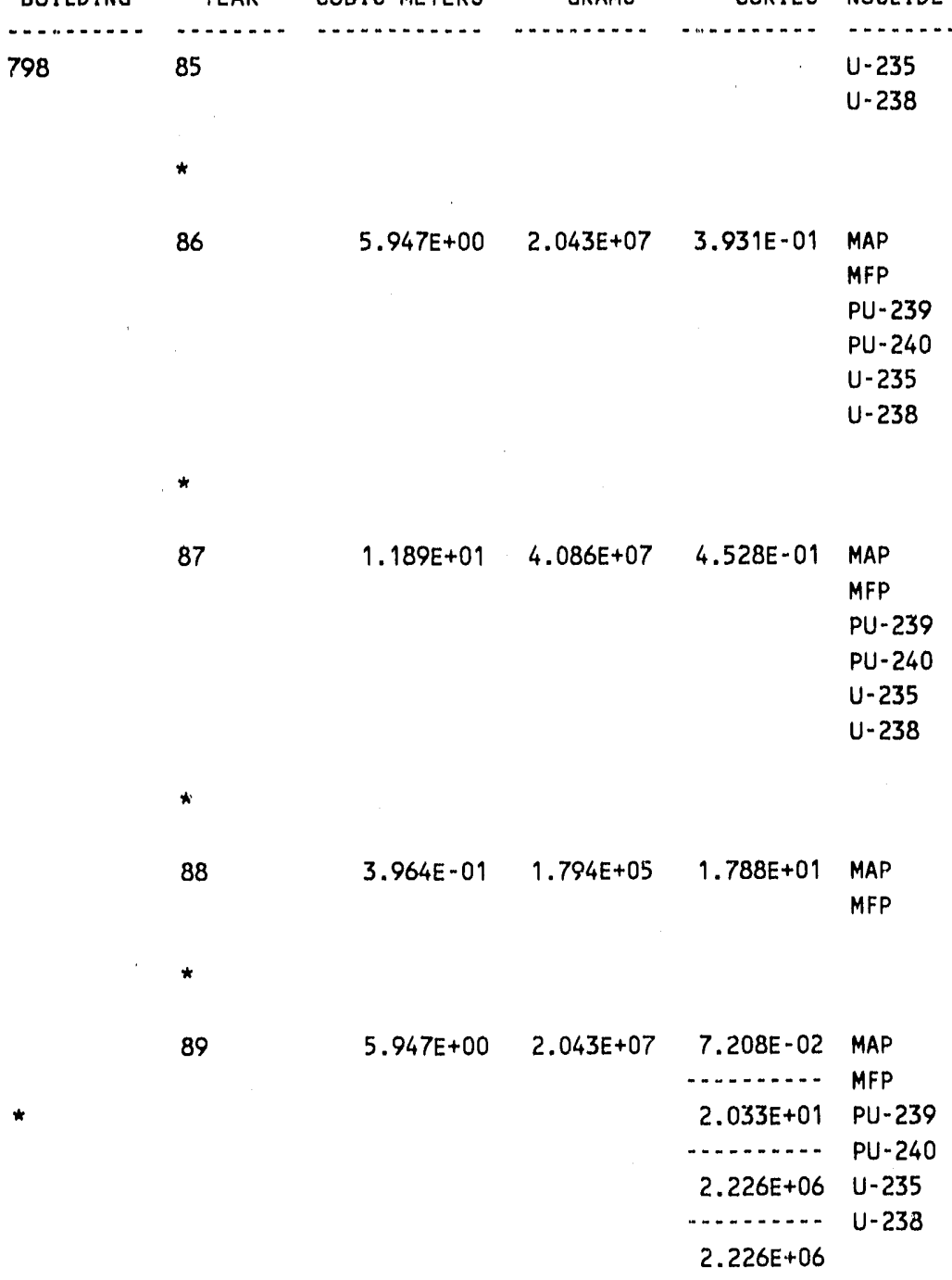

ANNUAL. CURIES NUCLIDE CURIES

$U-235 \quad 1.221 E-05$

9.357E-07

$6.173 E-01$

1.571E-01

2.358E-01

$1.862 E-04$

3.702E-06

$1.049 E-05$

$8.044 \mathrm{E}-07$

$3.931 E-01$

1.810E-01

2.714E-01

$3.984 E-04$

$7.672 E-06$

$1.549 \mathrm{E}-05$

1. 188E-06

$4.528 \mathrm{E}-01$

$7.153 E+00$

1.072E+01

. .........

$1.788 E+01$

$2.857 \mathrm{E}-02$

4.286E-02

$6.301 E-04$

$1.158 \mathrm{E}-05$

8.935E-06

6.845E-07

7.208E-02

...........

$2.033 E+01$

-.........-

$2.226 E+06$

$2.226 E+06$ 
IDAHO OPERATIONS OFFICE

U.S. DEPARTMENT OF ENERGY

INEL WASTE MANAGEMENT INFORMATION SYSTEM

ANNUAL SUMMARY FOR ARA
RUN DATE: $04 / 03 / 91$

PAGE 44

\begin{tabular}{|c|c|c|c|c|c|c|c|}
\hline & & & ANNUAL & ANNUAL & & & \\
\hline $\begin{array}{l}\text { GENERATING } \\
\text { AREA }\end{array}$ & $\begin{array}{l}\text { GENERATING } \\
\text { BUILDING }\end{array}$ & $\begin{array}{l}\text { DISPOSAL } \\
\text { YEAR }\end{array}$ & $\begin{array}{l}\text { VOL.UME } \\
\text { CUBIC METERS }\end{array}$ & $\begin{array}{l}\text { WEIGHT } \\
\text { GRAMS }\end{array}$ & $\begin{array}{l}\text { ANNUAL } \\
\text { CURIES }\end{array}$ & NUCL.IDE & CURIES \\
\hline n. & . & $\ldots$ & - & . & . & 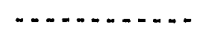 & . \\
\hline \multirow[t]{34}{*}{ ARA } & NONE & 71 & $6.627 E+00$ & $4.872 E+05$ & $3.359 E+00$ & $A G-110$ & $2.338 E-02$ \\
\hline & & & & & & $C 0-60$ & $2.672 E-01$ \\
\hline & & & & & & $C R-51$ & $6.680 \mathrm{E}-02$ \\
\hline & & & & & & MFP & $2.900 E-02$ \\
\hline & & & & & & $M N-54$ & $3.006 \mathrm{E}-01$ \\
\hline & & & & & & $2 N-65$ & $2.672 E+00$ \\
\hline & & & & & & & - \\
\hline & & * & & & & & $3.359 E+00$ \\
\hline & & & & & & & . \\
\hline & * & & & & & & $3.359 \mathrm{E}+00$ \\
\hline & 000 & 61 & $2.000 E+00$ & $0.000 E+00$ & $5.000 E-04$ & $U N-I D-B+G$ & $5.000 E-04$ \\
\hline & & 62 & $4.300 E+01$ & $0.000 E+00$ & $7.300 E+01$ & $U N-1 D-B+G$ & $7.300 E+01$ \\
\hline & & 63 & $6.700 E+01$ & $0.000 E+00$ & $3.182 E+03$ & $U N-I D-B+G$ & $3.182 E+03$ \\
\hline & & 64 & $3.000 E+01$ & $0.000 E+00$ & $1.590 E+02$ & $U N-I D-B+G$ & $1.590 E+02$ \\
\hline & & & & & - & & , n \\
\hline & * & & & & $3.414 E+03$ & & $3.414 E+03$ \\
\hline & 601 & 77 & $1.189 E+00$ & $1.134 E+05$ & $2.510 E-05$ & CS -137 & $2.510 E-05$ \\
\hline & 602 & 77 & $2.082 E-01$ & $4.082 E+04$ & $3.000 E-04$ & MAP & $1.500 \mathrm{E}-04$ \\
\hline & & & & & & MFP & $1.500 \mathrm{E}-04$ \\
\hline & & * & & & & & 3.000 E-04 \\
\hline & & & & & & & $\ldots$ \\
\hline & * & & & & & & $3.000 \mathrm{E}-04$ \\
\hline & 606 & 77 & $3.625 E+00$ & $2.268 E+05$ & $1.000 E-03$ & CS -137 & $1.000 E-03$ \\
\hline & 607 & 77 & $2.832 E-02$ & $1.670 E+02$ & $5.627 E-05$ & $U-235$ & $7.918 E-07$ \\
\hline & & & & & & $U-238$ & $5.548 E-05$ \\
\hline & & & & & & & n \\
\hline & & * & & & & & 5.627E-05 \\
\hline & & 78 & $2.832 E-02$ & $3.120 E+02$ & $1.049 E-04$ & $U-235$ & $1.284 E-06$ \\
\hline & & & & & , n & $U-238$ & $1.036 E-04$ \\
\hline & * & & & & $1.612 E-04$ & & $\ldots$ \\
\hline & & * & & & & & $1.049 \mathrm{E}-04$ \\
\hline & & & & & & & . \\
\hline & * & & & & & & $1.612 E-04$ \\
\hline & 608 & 72 & $1.416 E+00$ & $3.629 E+06$ & $1.000 E-03$ & $U N-I D-B+G$ & $1.000 E-03$ \\
\hline
\end{tabular}




\begin{tabular}{|c|c|c|c|c|c|c|c|}
\hline $\begin{array}{c}\text { GENERATING } \\
\text { AREA }\end{array}$ & $\begin{array}{l}\text { GENERATING } \\
\text { BUILDING }\end{array}$ & $\begin{array}{l}\text { DISPOSAL } \\
\text { YEAR }\end{array}$ & $\begin{array}{c}\text { ANNUAL } \\
\text { VOLUMEE } \\
\text { CUBIC METERS }\end{array}$ & $\begin{array}{l}\text { ANNUAL } \\
\text { WEIGHT } \\
\text { GRAMS }\end{array}$ & $\begin{array}{l}\text { ANNUAL } \\
\text { CURIES }\end{array}$ & NUCL IDE & CURIES \\
\hline . & (............ & n......... & ............... & -........... & n.......... & …......... & 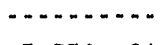 \\
\hline \multirow{34}{*}{ ARA } & 608 & 82 & $5.437 E+00$ & $1.270 E+06$ & $\begin{array}{c}5.250 \mathrm{E}-04 \\
\ldots\end{array}$ & MFP & $\begin{array}{r}5.250 E-04 \\
-\end{array}$ \\
\hline & * & & & & $1.525 E-03$ & & $1.525 E-03$ \\
\hline & 610 & 85 & $2.572 E+00$ & $1.424 E+06$ & $1.950 E-02$ & MFP & $1.950 \mathrm{E}-02$ \\
\hline & & 86 & $5.946 E-01$ & $1.020 E+06$ & $7.700 E-04$ & MFP & 7.700 E -04 \\
\hline & * & & & & $2.027 E-02$ & & $2.027 E-02$ \\
\hline & & & & & & & \\
\hline & 626 & 71 & $4.135 E+00$ & $5.443 E+05$ & $1.275 E+00$ & CE- 141 & $2.110 E-01$ \\
\hline & & & & & & $U N-I D-B+G$ & $6.375 E=0 /$ \\
\hline & & & & & & ZR-NB-95 & $1.063 E+00$ \\
\hline & & * & & & & & $1.275 E+00$ \\
\hline & & 72 & $4.068 E+01$ & $1.075 E+06$ & $4.013 E+02$ & $A M-241$ & $1.000 E-05$ \\
\hline & & & & & & $\mathrm{CO}-60$ & $6.010 E+01$ \\
\hline & & & & & & $C R-51$ & $1.629 E+02$ \\
\hline & & & & & & CS -137 & $1.200 E+01$ \\
\hline & & & & & & FE-59 & $6.812 E+01$ \\
\hline & & & & & & N1-59 & $9.200 E+01$ \\
\hline & & & & & & PU-239 & $9.900 E-04$ \\
\hline & & & & & & $U N-I D-B+G$ & $6.176 E+00$ \\
\hline & & * & & & & & $4.013 E+02$ \\
\hline & & 73 & $8.279 E+00$ & $8.754 E+05$ & $5.206 E+01$ & $10-60$ & $1.059 E+01$ \\
\hline & & & & & & $C R-51$ & $8.311 E-01$ \\
\hline & & & & & & CS -137 & $3.000 E+00$ \\
\hline & & & & & & FE-59 & $1.210 E+01$ \\
\hline & & & & & & MFP & $5.600 E-02$ \\
\hline & & & & & & NI -59 & $2.300 E+01$ \\
\hline & & & & & & UN-ID-ALPHA & $9.750 E-06$ \\
\hline & & & & & & $U N-I D-B+G$ & $2.475 E+00$ \\
\hline & & * & & & & & $5.206 E+01$ \\
\hline & & 74 & $2.223 E+01$ & $2.149 E+06$ & $1.012 E+00$ & MAP & $2.262 \mathrm{E}-02$ \\
\hline & & & & & & MFP & $6.787 E-02$ \\
\hline & & & & & & UN-ID-ALPHA & $1.550 E-06$ \\
\hline & & & & & & $U N-I D-B+G$ & $9.220 E-01$ \\
\hline & & * & & & & & $1.012 E+00$ \\
\hline & & 75 & $1.096 E+01$ & $1.044 E+06$ & $3.300 E-01$ & MAP & $9.000 E-02$ \\
\hline
\end{tabular}




\begin{tabular}{|c|c|c|c|c|c|c|c|}
\hline $\begin{array}{l}\text { GENERATING } \\
\text { AREA }\end{array}$ & $\begin{array}{l}\text { GENERAT ING } \\
\text { BUILDING }\end{array}$ & $\begin{array}{l}\text { DISPOSAL } \\
\text { YEAR }\end{array}$ & $\begin{array}{c}\text { ANNUAL } \\
\text { VOL.UME } \\
\text { CUBIC METERS }\end{array}$ & $\begin{array}{l}\text { ANNUAL } \\
\text { WEIGHT } \\
\text { GRAMS }\end{array}$ & $\begin{array}{l}\text { ANNUAL } \\
\text { CURIES }\end{array}$ & NUCLIDE & CURIES \\
\hline 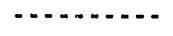 & n............. & n...... & 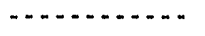 & $\cdots$ & $\cdots$ & - n. & - n........... \\
\hline \multirow[t]{38}{*}{ ARA } & 626 & 75 & & & & MFP & $9.000 \mathrm{E}-02$ \\
\hline & & & & & & $U-235$ & $2.354 E-05$ \\
\hline & & & & & & $U-238$ & $8.325 E-08$ \\
\hline & & & & & & $U N-1 D-B+G$ & $1.500 E-01$ \\
\hline & & * & & & & & 3 \\
\hline & & $*$ & & & & & $3.300 E-01$ \\
\hline & & 76 & $6.760 E+00$ & $1.561 E+06$ & $1.004 E+01$ & MAP & $5.018 E+00$ \\
\hline & & & & & & MFP & $5.018 \mathrm{E}+00$ \\
\hline & & & & & & U-235 & $6.292 E-04$ \\
\hline & & & & & & $U-238$ & $4.226 E-04$ \\
\hline & & & & & & & - \\
\hline & & * & & & & & $1.004 E+01$ \\
\hline & & 77 & $3.939 E+01$ & $4.764 E+06$ & $1.637 E+00$ & MAP & $2.377 E-01$ \\
\hline & & & & & & MFP & $1.399 E+00$ \\
\hline & & & & & & $U-235$ & $1.380 E-04$ \\
\hline & & & & & & $U-238$ & $1.519 E-04$ \\
\hline & & & & & & & (n) \\
\hline & & * & & & & & $1.637 E+00$ \\
\hline & & 78 & $8.713 E+00$ & $1.805 E+06$ & $9.381 E+00$ & MAP & $7.707 E+00$ \\
\hline & & & & & & MFP & $1.674 E+00$ \\
\hline & & & & & & & 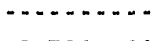 \\
\hline & & * & & & & & $9.381 E+00$ \\
\hline & & 79 & $3.625 E+00$ & $4.536 E+05$ & $1.427 E-04$ & $U-235$ & $6.848 E-05$ \\
\hline & & & & & & $U-238$ & $7.426 E-05$ \\
\hline & & * & & & & & $1427 E-04$ \\
\hline & & 80 & $20385+01$ & $5013 F+06$ & $230<\mathrm{F}+01$ & MAP & $0513 F+00$ \\
\hline & & 80 & $2.028 t+01$ & $3.013 E+00$ & C. 2045.701 & MFP & $1.253 E+01$ \\
\hline & & & & & & & . \\
\hline & & * & & & & & $2.204 E+01$ \\
\hline & & 81 & $2.093 E+01$ & $2.722 E+06$ & $2.022 E-01$ & MAP & $5.127 \mathrm{E}-02$ \\
\hline & & & & & & MFP & $1.510 E-01$ \\
\hline & & & & & & & - \\
\hline & & * & & & & & $2.022 E-01$ \\
\hline & & 82 & $1.504 E+01$ & $2.776 E+06$ & $9.784 E+01$ & $C E-144$ & $7.986 \mathrm{E}+00$ \\
\hline & & & & & & $c 0-60$ & $4.117 E+00$ \\
\hline & & & & & & CS- 134 & $1.211 E+01$ \\
\hline & & & & & & CS -137 & $5.029 E+01$ \\
\hline & & & & & & MAP & $1.548 \mathrm{E}-01$ \\
\hline
\end{tabular}




\begin{tabular}{|c|c|c|c|c|c|c|c|}
\hline $\begin{array}{c}\text { GENERAT ING } \\
\text { AREA }\end{array}$ & $\begin{array}{l}\text { GENERATING } \\
\text { BUILDING }\end{array}$ & $\begin{array}{l}\text { DISPOSAL } \\
\text { YEAR }\end{array}$ & $\begin{array}{l}\text { ANNUAL } \\
\text { VOLUME } \\
\text { CUBIC METERS }\end{array}$ & $\begin{array}{l}\text { ANNUAL } \\
\text { WEIGHT } \\
\text { GRAMS }\end{array}$ & $\begin{array}{l}\text { ANNUAL } \\
\text { CURIES }\end{array}$ & NUCL IDE & CURIES \\
\hline 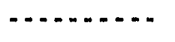 & - & $\ldots \ldots$ & , n & . n.............. & …......... & - & - \\
\hline \multirow[t]{39}{*}{ ARA } & 626 & 82 & & & & MFP & $1.152 E+00$ \\
\hline & & & & & & NB -95 & $1.117 E+01$ \\
\hline & & & & & & PU-239 & $5.770 E-03$ \\
\hline & & & & & & $U-235$ & $7.062 E-06$ \\
\hline & & & & & & $U-238$ & $3.410 E-04$ \\
\hline & & & & & & $U N-1 D-B+G$ & $5.134 E+00$ \\
\hline & & & & & & $2 R-95$ & $5.723 E+00$ \\
\hline & & & & & & & (1) \\
\hline & & * & & & & & $9.784 E+01$ \\
\hline & & 83 & $1.091 \mathrm{E}+01$ & $2.127 E+06$ & $2.659 E+00$ & MAP & $2.583 E-01$ \\
\hline & & & & & & MFP & $2.400 E+00$ \\
\hline & & & & & & PU-239 & $2.056 E-06$ \\
\hline & & & & & & $P U-240$ & $5.115 E-07$ \\
\hline & & & & & & $U-235$ & $1.407 E-05$ \\
\hline & & & & & & $U-238$ & $3.246 E-04$ \\
\hline & & * & & & & & $2.659 E+00$ \\
\hline & & 84 & $1.590 E+01$ & $3.107 E+06$ & $2.005 E+00$ & CE- 144 & $6.200 E-04$ \\
\hline & & & & & & $\mathrm{CO}-60$ & $3.190 E-04$ \\
\hline & & & & & & CS- 134 & $9.410 \mathrm{E}-04$ \\
\hline & & & & & & CS -137 & $5.907 E-03$ \\
\hline & & & & & & MAP & $3.987 E-01$ \\
\hline & & & & & & MFP & $1.595 E+00$ \\
\hline & & & & & & NB - 95 & $8.670 E-04$ \\
\hline & & & & & & $U-235$ & $2.882 E-05$ \\
\hline & & & & & & $U-238$ & $1.993 E-03$ \\
\hline & & & & & & $U N-1 D-B+G$ & $4.000 E-04$ \\
\hline & & & & & & $2 R-95$ & $4.450 E-04$ \\
\hline & & * & & & & & $2.005 E+00$ \\
\hline & & 85 & $1.448 E+01$ & $3.175 E+06$ & $4.576 E+00$ & CE- 144 & $3.784 E-01$ \\
\hline & & & & & & co- 60 & $1.949 E-01$ \\
\hline & & & & & & CS- 134 & $5.743 E-01$ \\
\hline & & & & & & CS- 137 & $2.384 E+00$ \\
\hline & & & & & & NB -95 & $5.294 E-01$ \\
\hline & & & & & & $U N-I D-B+G$ & $2.434 E-01$ \\
\hline & & & & & & ZR-95 & $2.718 E-01$ \\
\hline & & * & & & & & $4.576 E+00$ \\
\hline & & 86 & $8.400 E-01$ & $5.715 E+05$ & $1.200 \mathrm{E}-01$ & CE- 144 & $9.924 E-03$ \\
\hline & & & & & & $c 0-60$ & $5.112 E-03$ \\
\hline & & & & & & CS- 134 & $1.506 \mathrm{E}-0$ \\
\hline
\end{tabular}




\begin{tabular}{|c|c|c|c|c|c|c|c|}
\hline $\begin{array}{c}\text { GENERATING } \\
\text { AREA }\end{array}$ & $\begin{array}{l}\text { GENERATING } \\
\text { BUILDING }\end{array}$ & $\begin{array}{l}\text { DISPOSAL } \\
\text { YEAR }\end{array}$ & $\begin{array}{c}\text { ANNUAL } \\
\text { VOLUME } \\
\text { CUBIC METERS }\end{array}$ & $\begin{array}{l}\text { ANNUAL } \\
\text { WEIGHT } \\
\text { GRAMS }\end{array}$ & $\begin{array}{l}\text { ANNUAL } \\
\text { CURIES }\end{array}$ & NUCLIDE & CURIES \\
\hline n.t. & n.......... & -........ & - n n n & - n & - n & 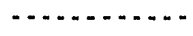 & - n \\
\hline \multirow[t]{25}{*}{ ARA } & 626 & 86 & & & & CS -137 & $6.251 E-02$ \\
\hline & & & & & & NB- 95 & $1.388 E-02$ \\
\hline & & & & & & $U N-1 D-B+G$ & $6.384 E-03$ \\
\hline & & & & & & $2 R-95$ & $7.128 E-03$ \\
\hline & & & & & & & . \\
\hline & & $\star$ & & & & & $1.200 E-01$ \\
\hline & & 87 & $1.994 E+01$ & $5.509 E+06$ & $9.220 E-01$ & MAP & $5.312 E-01$ \\
\hline & & & & & , n. & MFP & $3.908 E-01$ \\
\hline & * & & & & $6.074 E+02$ & & n......... \\
\hline & & * & & & & & $9.220 \mathrm{E}-01$ \\
\hline & & & & & & & $\cdots$ \\
\hline & * & & & & & & $6.074 E+02$ \\
\hline & 627 & 77 & $2.870 E-01$ & $3.493 E+04$ & $2.203 E-03$ & $U-235$ & $5.992 E-05$ \\
\hline & & & & & & $U-238$ & $2.143 E-03$ \\
\hline & & * & & & & & $2.203 \mathrm{E}-03$ \\
\hline & & 78 & $1.138 E+01$ & $9.344 E+05$ & $2.641 \mathrm{E}-03$ & MAP & $2.125 E-03$ \\
\hline & & & & & & MFP & $3.750 E-04$ \\
\hline & & & & & & $U-235$ & $4.708 E-05$ \\
\hline & & & & & & $U-238$ & $9.391 E-05$ \\
\hline & & & & & & & - \\
\hline & & * & & & & & $2.641 \mathrm{E}-03$ \\
\hline & & 79 & $3.625 E+00$ & $4.536 E+05$ & $1.576 E-04$ & $U-235$ & $8.132 E-05$ \\
\hline & & & & & $\cdots$ & $U-238$ & $7.626 E \cdot 05$ \\
\hline & $\star$ & & & & $5.001 E-03$ & & . \\
\hline & & * & & & ............... & & $1.576 E-04$ \\
\hline \multirow[t]{3}{*}{ ઔ } & & & & & $4.025 E+03$ & & . \\
\hline & * & & & & …… & & $5.001 E-03$ \\
\hline & & & & & $4.025 E+03$ & & , n \\
\hline \multirow[t]{2}{*}{ * } & & & & & & & $4.025 E+03$ \\
\hline & & & & & & & $4.025 E+03$ \\
\hline
\end{tabular}




\begin{tabular}{|c|c|c|c|c|c|c|c|}
\hline & & & ANNUAL & ANNUAL & & & \\
\hline GENERATING & GENERATING & DISPOSAL & VOLUME & WEIGHT & ANNUAL & & \\
\hline AREA & BUILDING & YEAR & CUBIC METERS & GRAMS & CURIES & NUCLIDE & CURIES \\
\hline ……… & $\ldots+\ldots$ & ……. & (n) & 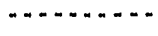 & n........... & - & ............... \\
\hline \multirow{8}{*}{ BEN } & 036 & 86 & $6.246 E-01$ & $3.194 E+05$ & $4.824 E-02$ & $C D-109$ & $1.100 E-06$ \\
\hline & & & & & & $\mathrm{CO}-57$ & $1.500 E-05$ \\
\hline & & & & & & $c 0-60$ & $1.000 E-02$ \\
\hline & & & & & & CS- 137 & $1.400 \mathrm{E}-02$ \\
\hline & & & & & & $M N=54$ & $1.000 \mathrm{E}-05$ \\
\hline & & & & & & $N A-22$ & $1.500 E-05$ \\
\hline & & & & & & $R A-226$ & $2.300 E-02$ \\
\hline & & & & & & $T H=228$ & $1.200 E-03$ \\
\hline & & & & & & & $\ldots \ldots$ \\
\hline & & * & & & & & $4.824 E-02$ \\
\hline & & & & & & & ............... \\
\hline & * & & & & & & $4.824 E-02$ \\
\hline & & & & & & & $\ldots \ldots$ \\
\hline \multirow[t]{2}{*}{ * } & & & & & & & $4.824 E-02$ \\
\hline & & & & & & & $4.824 E-02$ \\
\hline
\end{tabular}


IDAHO OPERATIONS OFFICE

U.S. DEPARTMENT OF ENEROY

INEL. WASTE MANAGEMENT INFORMATION SYSTEM

ANNUAL SUMMARY FOR BNL.
RUN DATE: 04/03/91

PAGE

50

\begin{tabular}{|c|c|c|c|c|c|c|c|}
\hline $\begin{array}{c}\text { GENERATING } \\
\text { AREA }\end{array}$ & $\begin{array}{l}\text { GENERATING } \\
\text { BUILDING }\end{array}$ & $\begin{array}{c}\text { DISPOSAL } \\
\text { YEAR }\end{array}$ & $\begin{array}{c}\text { ANNUAL } \\
\text { VOLUME } \\
\text { CUB!C METERS }\end{array}$ & $\begin{array}{l}\text { ANNUAL } \\
\text { WEIGHT } \\
\text { GRAMS }\end{array}$ & $\begin{array}{l}\text { ANNUAL. } \\
\text { CURIES }\end{array}$ & NUCL IDE & CURIES \\
\hline 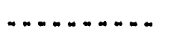 & ……… & ......... & 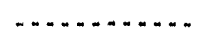 & n.......... & . n. & - & 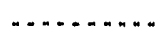 \\
\hline \multirow[t]{10}{*}{ BNL } & 445 & 83 & $4.655 E+00$ & $3.084 E+06$ & $1.897 E-01$ & $A M-241$ & $1.200 \mathrm{E} \times 06$ \\
\hline & & & & & & $c-14$ & $5.000 E-06$ \\
\hline & & & & & & $c 0.60$ & $1.230 E-02$ \\
\hline & & & & & & $H \cdot 3$ & $1.774 E-01$ \\
\hline & & & & & & $U=238$ & $2.000 E-09$ \\
\hline & & & & & & & n. \\
\hline & & * & & & & & $1.897 E-01$ \\
\hline & & & & & & & 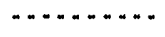 \\
\hline & * & & & & & & $1.897 E=01$ \\
\hline & & & & & & & ................. \\
\hline \multirow[t]{2}{*}{ * } & & & & & & & $1.897 E-01$ \\
\hline & & & & & & & $1.897 \mathrm{E}-01$ \\
\hline
\end{tabular}




\begin{tabular}{|c|c|c|c|c|c|c|c|}
\hline QENERATINO & QENERATING & DISPOSAL. & $\begin{array}{l}\text { ANNUAL } \\
\text { VOLUMEE }\end{array}$ & $\begin{array}{l}\text { ANNUAL. } \\
\text { WEIOHT }\end{array}$ & ANNUAL. & & \\
\hline AREA & BUILDING & YEAR & CUBIC METERS & GRAMS & CURIES & NUCL.IDE & CURIES \\
\hline$\ldots \ldots \ldots$ & $\ldots$ & $\ldots \ldots$ & a n & . & n.............. & $\ldots$ & $\ldots \ldots \ldots$ \\
\hline \multirow[t]{34}{*}{ CFA } & EBR & 74 & $3.283 E+01$ & $2.981 E+07$ & $1.612 E+01$ & Cs -137 & $1.602 E+01$ \\
\hline & & & & & & MFP & $1.010 E-01$ \\
\hline & & * & & & & & $1.612 E+01$ \\
\hline & & 75 & $3.158 E+02$ & $2.554 E+08$ & $5.276 \mathrm{E}+00$ & CS - 137 & $5.275 E+00$ \\
\hline & & & & & & MAP & $1.235 E-03$ \\
\hline & & & & & & MFP & $6.500 E-05$ \\
\hline & & & & & & & - \\
\hline & & * & & & & & $5.276 E+00$ \\
\hline & & 81 & $1.812 E+00$ & $2.268 \mathrm{E}+05$ & $1.500 E-04$ & MAP & $7.500 E-05$ \\
\hline & & & & & $\cdots$ & MFP & $7.500 E-05$ \\
\hline & * & & & & $2.139 E+01$ & & . \\
\hline & & * & & & & & $1.500 E \times 04$ \\
\hline & & & & & & & 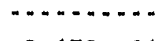 \\
\hline & * & & & & & & $2.139 E+01$ \\
\hline & EFS & 81 & $2.536 E+01$ & $8.391 E+06$ & $1.430 E-03$ & $B A-133$ & $1.070 E-03$ \\
\hline & & & & & & CS -137 & $3.600 E-04$ \\
\hline & & & & & & & 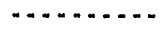 \\
\hline & & * & & & & & $1.430 E-03$ \\
\hline & & 86 & $2.265 E-01$ & $9.080 E+04$ & $3.000 E-04$ & MAP & $4.500 E-05$ \\
\hline & & & & & 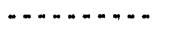 & MFP & $2.550 E-04$ \\
\hline & * & & & & $1.730 \mathrm{E}-03$ & & n.......... \\
\hline & & * & & & & & $3.000 E-04$ \\
\hline & & & & & & & 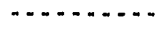 \\
\hline & * & & & & & & $1.730 E-03$ \\
\hline & NONE & 71 & $1.879 E+01$ & $1.172 E+06$ & $1.039 E+00$ & MFP & $1.039 E+00$ \\
\hline & ZPR & 74 & $9.834 E+01$ & $7.052 E+07$ & $1.410 E-02$ & MFP & $2.000 E-03$ \\
\hline & & & & & & UN-ID-ALPHA & $1.210 E-02$. \\
\hline & & * & & & & & $1.410 E-02$ \\
\hline & & & & & & & $\cdots$ \\
\hline & * & & & & & & $1.410 \mathrm{E}-02$ \\
\hline & 000 & 61 & $3.700 E+01$ & $0.000 E+00$ & $5.000 E-04$ & $U N-1 D-B+G$ & $5.000 E-04$ \\
\hline & & 62 & $2.800 E+01$ & $0.000 E+00$ & $5.000 E-04$ & $U N-I D-B+G$ & $5.000 E-04$ \\
\hline & & 63 & $3.100 E+01$ & $0.000 E+00$ & $5.000 E-04$ & $U N-1 D-B+G$ & $5.000 E=04$ \\
\hline & & 64 & $4.200 E+01$ & $0.000 E+00$ & $5.000 E-04$ & $U N-I D-B+G$ & $5.000 E-04$ \\
\hline
\end{tabular}




\begin{tabular}{|c|c|c|c|c|c|c|c|}
\hline $\begin{array}{l}\text { QENERATING } \\
\text { AREA }\end{array}$ & $\begin{array}{l}\text { GENERATING } \\
\text { BUILDINO }\end{array}$ & $\begin{array}{c}\text { DISPOSAL } \\
\text { YEAR }\end{array}$ & $\begin{array}{c}\text { ANNUAL } \\
\text { VOLUME } \\
\text { CUBIC METERS }\end{array}$ & $\begin{array}{l}\text { ANNUAL } \\
\text { WE I QHT } \\
\text { GRAMS }\end{array}$ & $\begin{array}{l}\text { ANNUAL. } \\
\text { CURIES }\end{array}$ & NUCLIDE & CURIES \\
\hline 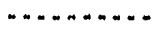 & n............ & $\ldots \ldots$ & $\ldots$ & (…… & $\ldots \ldots \ldots \ldots$ & n. & $\ldots+\ldots \ldots$ \\
\hline \multirow[t]{28}{*}{ CFA } & 000 & 65 & $8.400 E+01$ & $0.000 E+00$ & $5.000 E=04$ & $U N-1 D=B+Q$ & $5.000 E-04$ \\
\hline & & 66 & $3.110 \mathrm{E}+02$ & $0.000 E+00$ & $5.700 E+01$ & $U N-10 \cdot B+Q$ & $5.700 E+01$ \\
\hline & & 67 & $1.810 E+02$ & $0.000 E+00$ & $3.000 E+00$ & $U N=10-8+0$ & $3.000 E+00$ \\
\hline & & 68 & $5.700 E+01$ & $0.000 E+00$ & $7.000 E+01$ & $U N-1 D-B+C$ & $7.000 E+01$ \\
\hline & & 69 & $4.130 E+02$ & $0.000 \mathrm{E}+00$ & $6.300 E+01$ & $U N \cdot 1 D \cdot B+C$ & $6.300 E+01$ \\
\hline & & 70 & $7.300 E+01$ & $0.000 E+00$ & $1.000 E+00$ & $U N-1 D-B+Q$ & $1.000 E+00$ \\
\hline & * & & & & $1.940 E+02$ & & $1.940 E+02$ \\
\hline & 601 & 74 & $1.699 E-01$ & $1.701 E+05$ & $3.000 E \cdot 03$ & 100.60 & $1.500 E-03$ \\
\hline & & & & & & CS -137 & $1.500 E-03$ \\
\hline & & * & & & & & $3.000 E-03$ \\
\hline & * & & & & & & $3.000 \mathrm{E}-03$ \\
\hline & 609 & 72 & $1.136 E+00$ & $1.819 E+05$ & $1.010 E-03$ & MFP & $1.000 E-05$ \\
\hline & & & & & & $U N-1 D \cdot B+G$ & $1.000 E-03$ \\
\hline & & & & & & & a.......... \\
\hline & & * & & & & & $\begin{array}{r}1.010 E-03 \\
\ldots \ldots \ldots \ldots\end{array}$ \\
\hline & * & & & & & & $1.010 \mathrm{E}-03$ \\
\hline & 617 & 82 & $3.211 \mathrm{E}+00$ & $2.204 E+06$ & $9.380 E-04$ & MAP & $4.690 E-04$ \\
\hline & & & & & & MFP & $4.690 E-04$ \\
\hline & & * & & & & & $9.380 \mathrm{E}-04$ \\
\hline & & 83 & $1.223 E+01$ & $6.450 E+06$ & $5.355 E-03$ & MAP & $2.437 E-03$ \\
\hline & & & & & & MFP & $2.917 E-03$ \\
\hline & & $\star$ & & & & & $5.355 \mathrm{E}-03$ \\
\hline & & 84 & $8.603 E+00$ & $5.906 E+06$ & $7.288 E-03$ & MAP & $3.644 E-03$ \\
\hline & & & & & & MFP & $3.644 E-03$ \\
\hline & & * & & & & & $7.288 E-03$ \\
\hline & & 85 & $8.476 E+00$ & $4.046 E+06$ & $1.050 E-03$ & $H-3$ & $1.000 E-04$ \\
\hline & & & & & & MAP & $4.500 E-04$ \\
\hline & & & & & & MFP & $4.500 \mathrm{E}-04$ \\
\hline
\end{tabular}


U.S. DEPARTMENT OF ENERGY INEL WASTE MANAQEMENT INFORMATION SYSTEM

\begin{tabular}{|c|c|c|c|c|c|c|c|}
\hline $\begin{array}{l}\text { BENERATINO } \\
\text { AREA }\end{array}$ & $\begin{array}{l}\text { GENERATING } \\
\text { BUILDING }\end{array}$ & $\begin{array}{l}\text { DISPOSAL } \\
\text { YEAR }\end{array}$ & $\begin{array}{c}\text { ANNUAL } \\
\text { VOLUME } \\
\text { CUBIC METERS }\end{array}$ & $\begin{array}{l}\text { ANNUAL } \\
\text { WEIOHT } \\
\text { GRAMS }\end{array}$ & $\begin{array}{l}\text { ANNUAL. } \\
\text { CURIES }\end{array}$ & NUCL. IDE & CURIES \\
\hline ……........ & ................ & $\ldots . . . .$. & ............ & … & 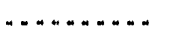 & . & 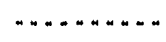 \\
\hline \multirow[t]{34}{*}{ CFA } & 617 & 85 & & & & $N A-22$ & $5.000 E-05$ \\
\hline & & * & & & & & $1.050 \mathrm{E}-03$ \\
\hline & & 86 & $1.201 E+01$ & $4.792 E+06$ & $2.180 \mathrm{E} \cdot 03$ & MAP & $1.090 E-03$ \\
\hline & & & & & & MFP & $1.090 \mathrm{E}-03$ \\
\hline & & & & & & & …............ \\
\hline & & * & & & & & \\
\hline & & 87 & $3.625 E+00$ & $1.823 E+06$ & $3.600 E+00$ & MAP & $1.800 E+00$ \\
\hline & & & & & n.......... & MFP & $1.800 E+00$ \\
\hline & * & & & & $3.617 E+00$ & & n............ \\
\hline & & * & & & & & $3.600 E+00$ \\
\hline & & & & & & & (n. \\
\hline & * & & & & & & $3.617 E+00$ \\
\hline & 633 & 74 & $5.664 E-01$ & $2.268 E+05$ & $1.000 E=03$ & $c 0.60$ & $5.000 E-04$ \\
\hline & & & & & & $F E-59$ & $5.000 E-04$ \\
\hline & & & & & & & 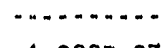 \\
\hline & & * & & & & & $1.000 E-03$ \\
\hline & * & & & & & & $1.000 \mathrm{E}-03$ \\
\hline & 638 & 80 & $2.266 E-01$ & $2.767 E+06$ & $1.640 E+02$ & $c 0.60$ & $1.640 E+02$ \\
\hline & 659 & 83 & $7.929 E=01$ & $5.443 E+05$ & $7.875 E-04$ & MAP & $3.937 E-04$ \\
\hline & & & & & & MFP & $3.937 E-04$ \\
\hline & & * & & & & & $7875 \mathrm{~F}-04$ \\
\hline & & & & & & & ......... \\
\hline & * & & , & & & & $7.875 E-04$ \\
\hline & 660 & 72 & $5.664 E-02$ & $2.268 \mathrm{E}+05$ & $2.500 E-02$ & MFP & $2.500 E-02$ \\
\hline & & 76 & $6.797 E-01$ & $3.629 E+05$ & $1.000 E-03$ & MAP & $5.000 E-04$ \\
\hline & & & & & ………n. & MFP & $5.000 E-04$ \\
\hline & * & & & & $2.600 \mathrm{E}-02$ & & ............. \\
\hline & & * & & & & & $1.000 E-03$ \\
\hline & & & & & & & ……....... \\
\hline & * & & & & & & $2.600 \mathrm{E}-02$ \\
\hline & 665 & 74 & $3.993 E+00$ & $9.979 E+05$ & $1.002 E-03$ & MAP & $5.000 E-04$ \\
\hline & & & & & & MFP & $5.000 E-04$ \\
\hline & & & & & & $U N-I D-B+G$ & $2.000 \mathrm{E}-06$ \\
\hline & & $\star$ & & & & & $1.002 \mathrm{E}-03$ \\
\hline
\end{tabular}




\begin{tabular}{|c|c|c|c|c|c|c|c|}
\hline $\begin{array}{c}\text { QENERATINO } \\
\text { AREA }\end{array}$ & $\begin{array}{l}\text { GENERATINO } \\
\text { BUILDING }\end{array}$ & $\begin{array}{l}\text { DISPOSAL } \\
\text { YEAR }\end{array}$ & $\begin{array}{c}\text { ANNUAL } \\
\text { VOLUME } \\
\text { CUBIC METERS }\end{array}$ & $\begin{array}{l}\text { ANNUAL } \\
\text { WE I GHT } \\
\text { GRAMS }\end{array}$ & $\begin{array}{l}\text { ANNUAL } \\
\text { CURIES }\end{array}$ & NUCLIDE & CURIES \\
\hline 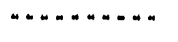 & n.............. & ……. & n........ & n............. & 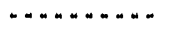 & 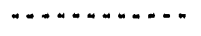 & n. n n n n n n \\
\hline \multirow[t]{32}{*}{ CFA } & 665 & 75 & $7.193 E+01$ & $2.903 E+07$ & $1.136 E-02$ & MAP & $3.603 E-03$ \\
\hline & & & & & & MFP & 7.757E-03 \\
\hline & & $\star$ & & & & & $1.136 E-02$ \\
\hline & & 76 & $3.398 E+00$ & $6.804 E+06$ & $1.400 E-04$ & MFP & $1.400 E-04$ \\
\hline & & 84 & $2.878 E+01$ & $1.437 E+07$ & $2.000 E-01$ & MAP & $5.000 E-02$ \\
\hline & & & & & n & MFP & $1.500 E-01$ \\
\hline & * & & & & $2.125 E-01$ & & $\ldots$ \\
\hline & & * & & & & & $2.000 E-01$ \\
\hline & & & & & & & , \\
\hline & * & & & & & & $2.125 E-01$ \\
\hline & 669 & 71 & $2.277 E+01$ & $1.814 E+06$ & $2.900 E-02$ & MFP & $2.600 E-02$ \\
\hline & & & & & & $U N-1 D-B+G$ & $3.000 E-03$ \\
\hline & & & & & & & ons \\
\hline & & * & & & & & $2.900 \mathrm{E}=02$ \\
\hline & & 72 & $5.454 E+01$ & $6.419 E+06$ & $8.075 E-02$ & MFP & $8.075 E-02$ \\
\hline & & 73 & $5.406 E+01$ & $4.241 E+06$ & $6.200 E-02$ & MFP & $6.200 E-02$ \\
\hline & & 74 & $3.596 E+01$ & $3.130 E+06$ & $1.213 E-02$ & MAP & $2.940 E-03$ \\
\hline & & & & & & MFP & $8.190 E-03$ \\
\hline & & & & & & $U N-1 D-B+G$ & $1.000 \mathrm{E}-03$ \\
\hline & & * & & & & & $1.213 E-02$ \\
\hline & & 75 & $5.987 E+00$ & $2.631 E+06$ & $9.500 E-03$ & MAP & $4.750 E-03$ \\
\hline & & & & & & MFP & $4.750 E-03$ \\
\hline & & & & & & & 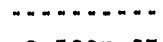 \\
\hline & & * & & & & & $9.500 E-03$ \\
\hline & & 76 & $8.723 E+00$ & $1.361 E+06$ & $2.250 E-03$ & MAP & $1.125 E-03$ \\
\hline & & & & & & MFP & $1.125 E-03$ \\
\hline & & * & & & & & $2.250 E-03$ \\
\hline & & 77 & $1.034 E+01$ & $3.901 E+06$ & $1.382 E-02$ & MAP & $6.912 E-03$ \\
\hline & & & & & & MFP & $6.912 E-03$ \\
\hline & & $\star$ & & & & & $1.382 E-02$ \\
\hline & & 78 & $2.775 E+00$ & $1.905 E+06$ & $3.000 E-03$ & MAP & $1.500 E-03$ \\
\hline & & & & & & MFP & $1.500 E-03$ \\
\hline
\end{tabular}




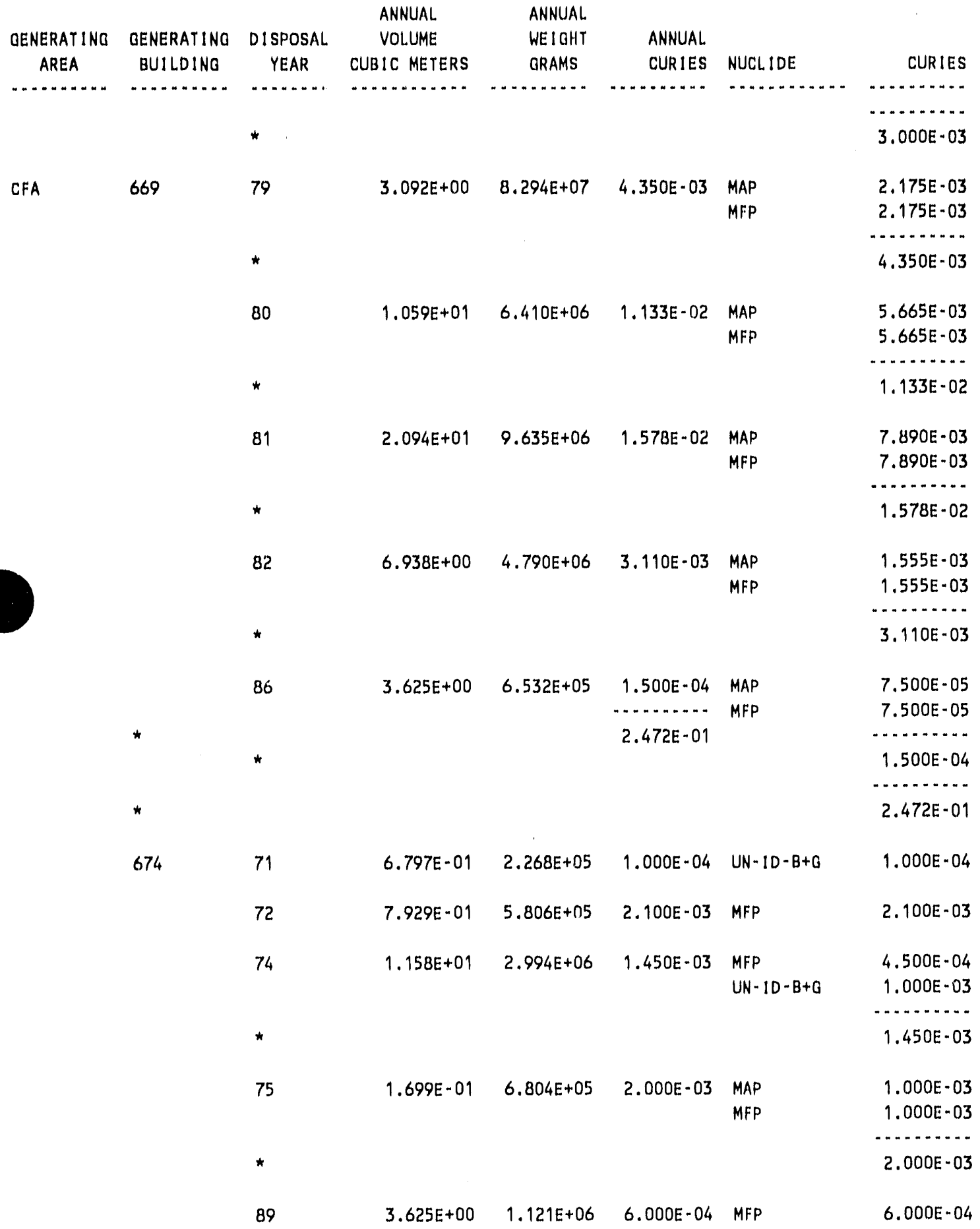




\begin{tabular}{|c|c|c|c|c|c|c|c|}
\hline $\begin{array}{l}\text { GENERATING } \\
\text { AREA }\end{array}$ & $\begin{array}{l}\text { GENERATING } \\
\text { BUILDING }\end{array}$ & $\begin{array}{l}\text { DISPOSAL } \\
\text { YEAR }\end{array}$ & $\begin{array}{c}\text { ANNUAL } \\
\text { VOLUME } \\
\text { CUBIC. METERS }\end{array}$ & $\begin{array}{l}\text { ANNUAL } \\
\text { WEIGHT } \\
\text { GRAMS }\end{array}$ & $\begin{array}{l}\text { ANNUAL } \\
\text { CURIES }\end{array}$ & NUCL IDE & CURIES \\
\hline \multirow{2}{*}{$\begin{array}{l}\text { AREA } \\
\cdots . . . . . . . .\end{array}$} & n-......... & , n....... & 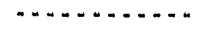 & , nancon. & …… & & … \\
\hline & * & & & & $6.250 \mathrm{E}-03$ & & $6.250 E-03$ \\
\hline \multirow[t]{25}{*}{ CFA } & 683 & 71 & $2.266 E-01$ & $9.072 E+05$ & $1.000 E=03$ & MFP & $1.000 E-03$ \\
\hline & & 72 & $1.699 \mathrm{E}-01$ & $2.268 E+05$ & $1.000 E-02$ & MAP & $1.000 E-02$ \\
\hline & & 73 & $7.312 E+01$ & $1.479 E+07$ & 5.235E-02 & MAP & $3.750 \mathrm{E}-04$ \\
\hline & & & & & 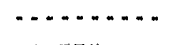 & MFP & $1.897 \mathrm{E}-02$ \\
\hline & ${ }^{*}$ & & & & $6.335 \mathrm{E}-02$ & $U N-1 D-B+G$ & $\begin{array}{c}3.300 \mathrm{E}-02 \\
\ldots \ldots \ldots \ldots\end{array}$ \\
\hline & & * & & & & & $5.235 E-02$ \\
\hline & * & & & & & & $6.335 \mathrm{E} \cdot 02$ \\
\hline & 685 & 72 & $2.832 E+00$ & $9.072 E+04$ & $1.000 E=04$ & MFP & $1.000 E-04$ \\
\hline & & 74 & $2.832 E+01$ & $5.443 E+06$ & $5.000 E-02$ & MAP & $2.500 E=03$ \\
\hline & * & & & & כח- כח & MFP & $\begin{array}{r}4.750 E-02 \\
\hdashline\end{array}$ \\
\hline & & * & & & $3.010 E-02$ & & $5.000 \mathrm{E}-02$ \\
\hline & * & & & & & & $5.010 E-02$ \\
\hline & 687 & 75 & $2.549 E+00$ & $1.270 E+07$ & $3.000 \mathrm{E}-03$ & MAP & $1.500 \mathrm{E}-03$ \\
\hline & & & & & & MFP & $1.500 \mathrm{E}-03$ \\
\hline & & * & & & & & $3.000 E-03$ \\
\hline & & 76 & $1.586 E+01$ & $7.984 E+06$ & $3.015 E-02$ & MAP & $1.507 \mathrm{E}-02$ \\
\hline & & & & & & MFP & 1.507E:02 \\
\hline & & * & & & & & $3.015 \mathrm{E}-02$ \\
\hline & & 78 & $1.812 E+00$ & $9.072 E+05$ & $1.000 E=04$ & MAP & $5.000 \mathrm{E}-05$ \\
\hline & & & & & & MFP & $\begin{array}{c}5.000 E-05 \\
-\end{array}$ \\
\hline & & * & & & & & $1.000 E=04$ \\
\hline & & 80 & $1.812 E+00$ & $2.132 E+06$ & $1.500 E-04$ & MAP & $7.500 E-05$ \\
\hline & $*$ & & & & . & MFP & $7.500 E-05$ \\
\hline & & * & & & $3.340 \mathrm{E}-02$ & & $1.500 E=04$ \\
\hline & $\star$ & & & & & & $3.340 \mathrm{E}-02$ \\
\hline
\end{tabular}




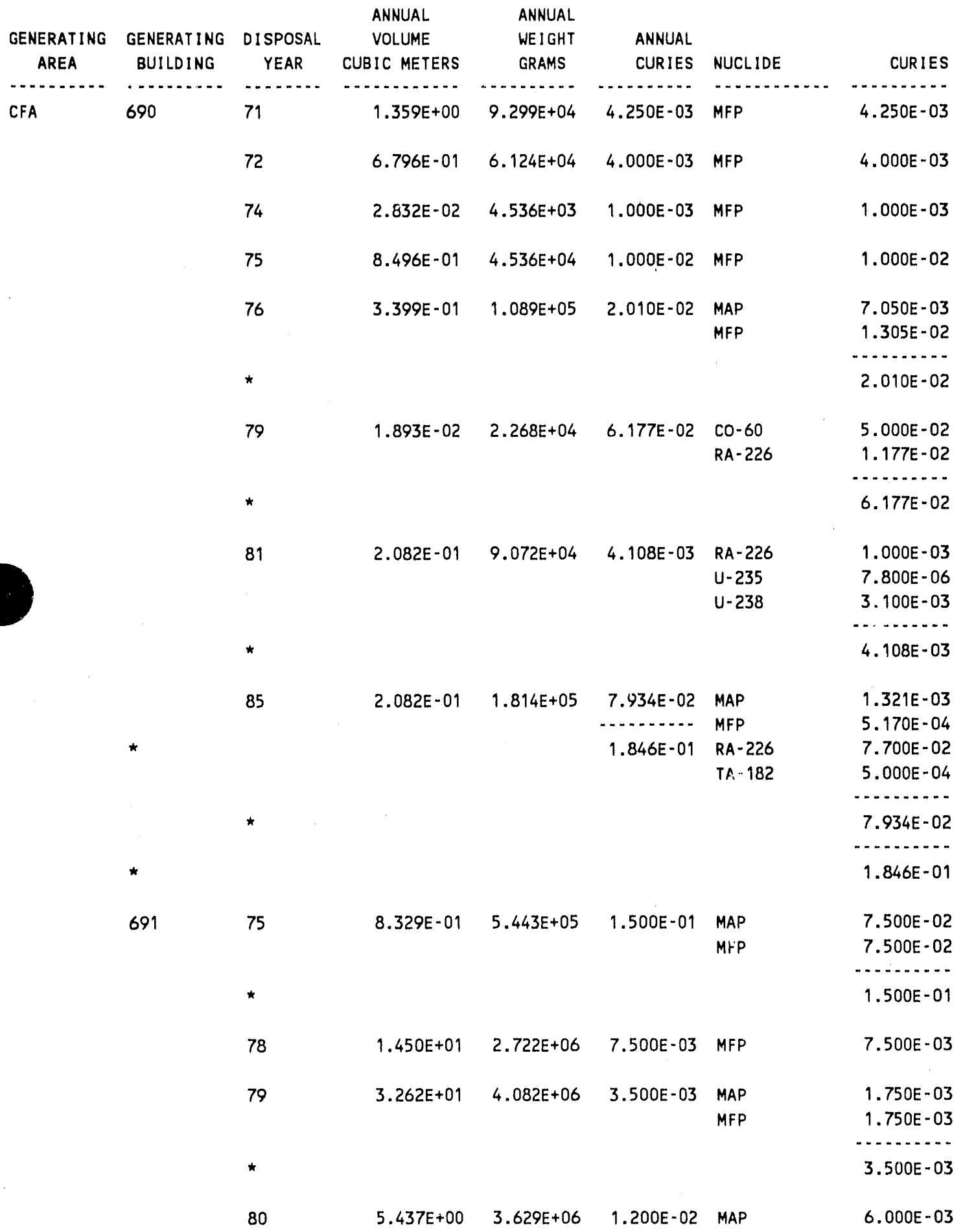




\begin{tabular}{|c|c|c|c|c|c|c|c|}
\hline $\begin{array}{l}\text { GENERATING } \\
\text { AREA }\end{array}$ & $\begin{array}{l}\text { GENERATING } \\
\text { BUILDING }\end{array}$ & $\begin{array}{l}\text { DISPOSAL } \\
\text { YEAR }\end{array}$ & $\begin{array}{c}\text { ANNUAL } \\
\text { VOLUME } \\
\text { CUBIC METERS }\end{array}$ & $\begin{array}{l}\text { ANNUAL } \\
\text { WE IGHT } \\
\text { GRAMS }\end{array}$ & $\begin{array}{l}\text { ANNUAL } \\
\text { CURIES }\end{array}$ & NUCL IDE & CURIES \\
\hline \multirow[t]{26}{*}{ CFA } & 691 & 80 & . & , nancon & , & MFP & $6.000 \mathrm{E}-03$ \\
\hline & & * & & & & & $1.200 \mathrm{E}-02$ \\
\hline & & 88 & $5.436 E+00$ & $2.871 E+06$ & $1.200 \mathrm{E}-05$ & MFP & $1.200 \mathrm{E}-05$ \\
\hline & * & & & & $1.730 E-01$ & & $1.730 E-01$ \\
\hline & 699 & 83 & $7.929 E-01$ & $5.443 E+05$ & $2.200 E-04$ & $\begin{array}{l}\text { MAP } \\
\text { MFP }\end{array}$ & $\begin{array}{l}1.100 E-04 \\
1.100 E-04\end{array}$ \\
\hline & & * & & & & & $2.2005-04$ \\
\hline & * & & & & & & $2.200 E-04$ \\
\hline & 766 & 73 & $1.410 E+01$ & $6.577 E+06$ & $3.850 E-02$ & $\begin{array}{l}\text { MAP } \\
\text { MFP }\end{array}$ & $\begin{array}{l}1.925 E-02 \\
1.925 E-02\end{array}$ \\
\hline & & & & & & MFP & מ. \\
\hline & & * & & & & & $3.850 E-02$ \\
\hline & & 74 & $6.457 E+00$ & $2.268 E+06$ & $5.000 E-03$ & MAP & $1.000 E-03$ \\
\hline & & & & & & MFP & $4.000 E-03$ \\
\hline & & * & & & & & $5.000 E-03$ \\
\hline & & 75 & $3.625 \mathrm{E}+00$ & $2.722 E+06$ & $1.200 E-03$ & MAP & $6.000 \mathrm{E}-04$ \\
\hline & & & & & & MFP & $6.000 E-04$ \\
\hline & & * & & & & & $1.200 E-03$ \\
\hline & & 79 & $2.839 E+01$ & $1.588 E+05$ & $6.000 E-03$ & MFP & $6.000 E-03$ \\
\hline & & 80 & $1.087 E+01$ & $2.268 E+06$ & $2.250 \mathrm{E}-03$ & MAP & $1.125 E-03$ \\
\hline & & & & & & MFP & $1.125 \mathrm{E}-03$ \\
\hline & & * & & & & & $2.250 E-03$ \\
\hline & & 81 & $1.450 E+01$ & $6.123 E+06$ & $5.850 E-03$ & MAP & $2.925 E-03$ \\
\hline & & & & & & MFP & $2.925 E-03$ \\
\hline & & * & & & & & $5.850 \mathrm{E}-03$ \\
\hline & & 83 & $6.887 E+01$ & $5.171 E+07$ & $1.770 E-01$ & co-60 & $8.850 \mathrm{E}-02$ \\
\hline & & & & & , n & Cs- 137 & $8.850 E-02$ \\
\hline & * & * & & & $2.358 \mathrm{E}-01$ & & $1.770 E-01$ \\
\hline
\end{tabular}



INEL WASTE MANAGEMENT INFORMATION SYSTEM

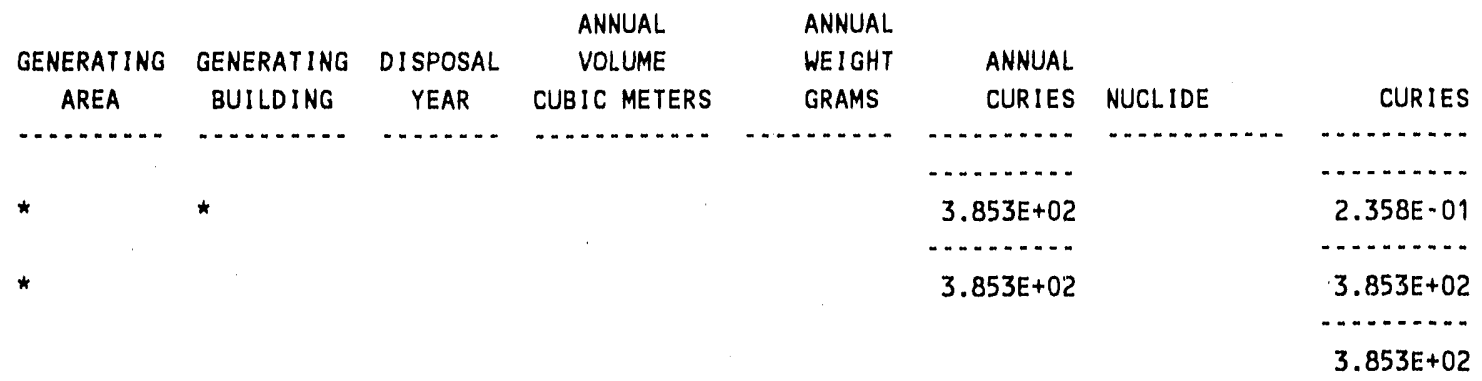




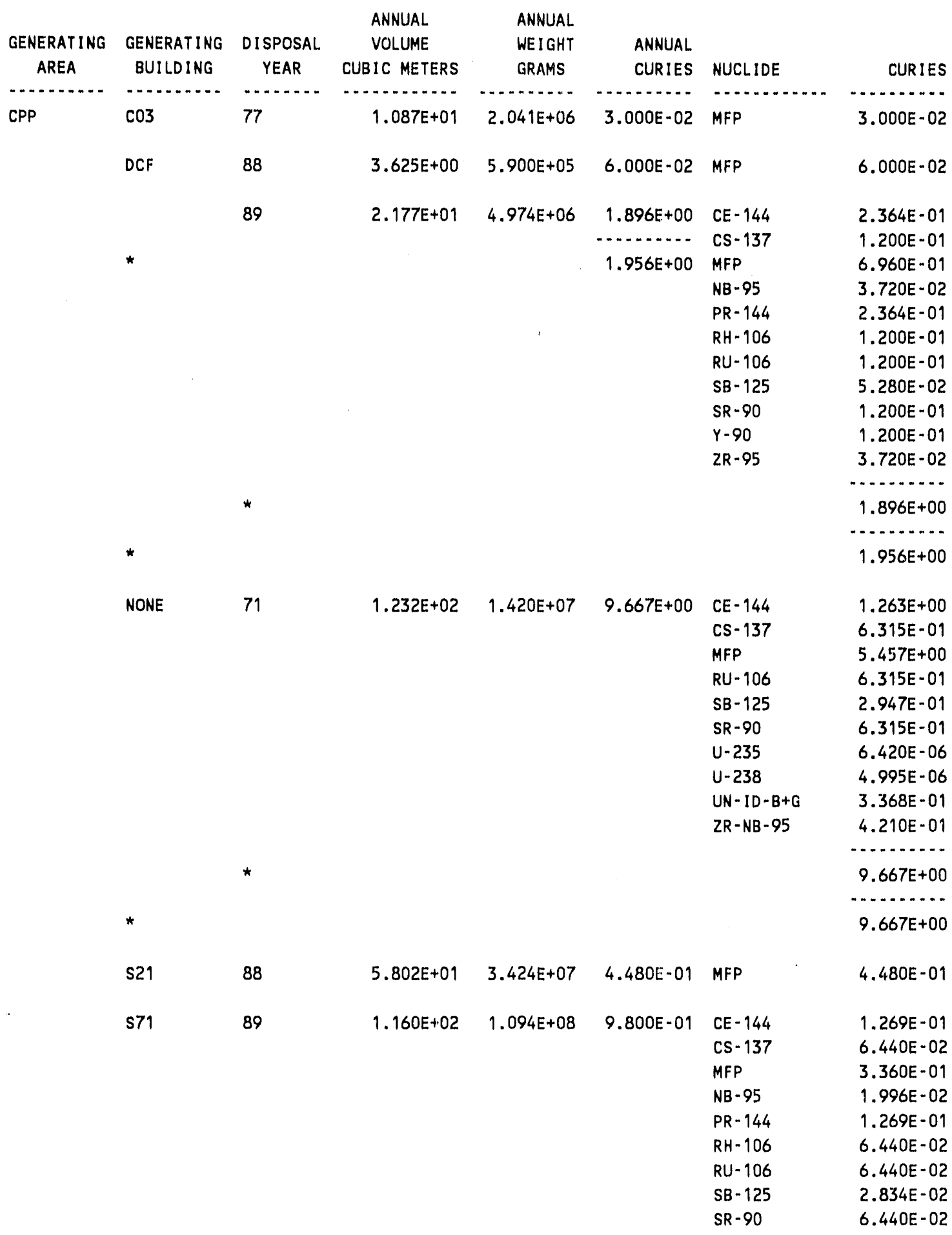




\begin{tabular}{|c|c|c|c|c|c|c|c|}
\hline $\begin{array}{c}\text { GENERATING } \\
\text { AREA }\end{array}$ & $\begin{array}{l}\text { GENERATING } \\
\text { BUILDING }\end{array}$ & $\begin{array}{l}\text { DISPOSAL } \\
\text { YEAR }\end{array}$ & $\begin{array}{c}\text { ANNUAL } \\
\text { VOLUME } \\
\text { CUBIC METERS }\end{array}$ & $\begin{array}{l}\text { ANNUAL } \\
\text { WEIGHT } \\
\text { GRAMS }\end{array}$ & $\begin{array}{l}\text { ANNUAL } \\
\text { CURIES }\end{array}$ & NUCLIDE & CURIES \\
\hline 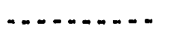 & $\ldots+\ldots$ & $\ldots \ldots$ & . & - & 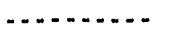 & • & ……… \\
\hline \multirow[t]{32}{*}{ CPP } & s71 & 89 & & & & $Y-90$ & $6.440 E-02$ \\
\hline & & & & & & $2 R-95$ & $1.996 \mathrm{E}-02$ \\
\hline & & & & & & & , n \\
\hline & & * & & & & & $9.800 E-01$ \\
\hline & & & & & & & (n) \\
\hline & * & & & & & & $9.800 \mathrm{E}-01$ \\
\hline & TFA & 88 & $2.538 E+01$ & $5.850 E+06$ & $1.254 E+00$ & MFP & $1.254 E+00$ \\
\hline & & 89 & $3.444 E+01$ & $2.582 E+07$ & $1.950 \mathrm{E}+00$ & $C E-144$ & $3.120 \mathrm{E}-01$ \\
\hline & & & & & (n) & CS- 137 & $1.584 \mathrm{E}-01$ \\
\hline & * & & & & $3.204 E+00$ & MFP & $3.660 E-01$ \\
\hline & & & & & & NB - 95 & $4.910 E-02$ \\
\hline & & & & & & $P R-144$ & $3.120 E-01$ \\
\hline & & & & & & $R H-106$ & $1.584 E-01$ \\
\hline & & & & & & $R U-106$ & $1.584 E-01$ \\
\hline & & & & & & $S B-125$ & $6.970 E-02$ \\
\hline & & & & & & SR -90 & $1.584 E-01$ \\
\hline & & & & & & $Y-90$ & $1.584 E-01$ \\
\hline & & & & & & $2 R-95$ & $4.910 E-02$ \\
\hline & & & & & & & - n \\
\hline & & * & & & & & $1.950 E+00$ \\
\hline & * & & & & & & $3.204 E+00$ \\
\hline & 000 & 61 & $3.830 E+02$ & $0.000 E+00$ & $3.720 E+02$ & $U N-I D-B+G$ & $3.720 \mathrm{E}+02$ \\
\hline & & 62 & $2.070 E+02$ & $0.000 E+00$ & $1.020 E+02$ & $U N-1 D-B+G$ & $1.020 E+02$ \\
\hline & & 64 & $5.380 E+02$ & $0.000 E+00$ & $2.540 E+02$ & $U N-I D-B+G$ & $2.540 E+02$ \\
\hline & & 65 & $4.910 E+02$ & $0.000 E+00$ & $3.710 E+02$ & $U N-1 D-B+G$ & $3.710 E+02$ \\
\hline & & 66 & $7.580 E+02$ & $0.000 E+00$ & $1.878 E+04$ & $U N-1 D-B+G$ & $1.878 E+04$ \\
\hline & & 67 & $4.370 E+02$ & $0.000 E+00$ & $1.842 E+04$ & $U N-1 D-B+G$ & $1.842 E+04$ \\
\hline & & 68 & $5.230 E+02$ & $0.000 E+00$ & $1.980 E+04$ & $U N-I D-B+G$ & $1.980 E+04$ \\
\hline & & 69 & $4.840 E+02$ & $0.000 E+00$ & $4.150 E+04$ & $U N-I D-B+G$ & $4.150 E+04$ \\
\hline & & 70 & $6.290 E+02$ & $0.000 E+00$ & $1.880 E+02$ & $U N-I D-B+G$ & $1.880 E+02$ \\
\hline & * & & & & $9.979 E+04$ & & $9.979 E+04$ \\
\hline & 600 & 76 & $6.117 E+00$ & $3.629 E+05$ & $2.100 E+01$ & CE- 144 & $3.927 E+00$ \\
\hline
\end{tabular}




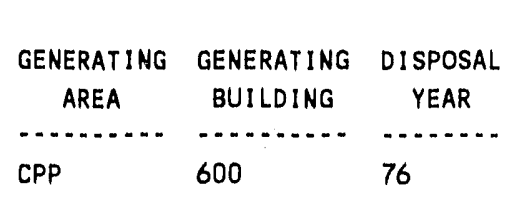

\begin{tabular}{|c|c|}
\hline ANNUAL & ANNUAL \\
\hline VOLUME & WEIGHT \\
\hline CUBIC METERS & GRAMS \\
\hline - & 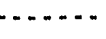 \\
\hline
\end{tabular}

\begin{tabular}{|c|c|c|}
\hline \multicolumn{3}{|l|}{ ANNUAL } \\
\hline CURIES & NUCL IDE & CURIES \\
\hline$\ldots . .$. & - & - n. n n n \\
\hline & CS- 137 & $1.974 E+00$ \\
\hline & MFP & $1.050 E+00$ \\
\hline & $P R-144$ & $3.927 E+00$ \\
\hline & $R H-106$ & $1.974 E+00$ \\
\hline & $R U-106$ & $1.974 E+00$ \\
\hline & SB- 125 & $9.240 \mathrm{E}-01$ \\
\hline & $S R-90$ & $1.974 E+00$ \\
\hline & $Y-90$ & $1.974 E+00$ \\
\hline & $2 R-N B-95$ & $1.302 E+00$ \\
\hline & & $\cdots$ \\
\hline & & $2.100 E+01$ \\
\hline & & , \\
\hline
\end{tabular}

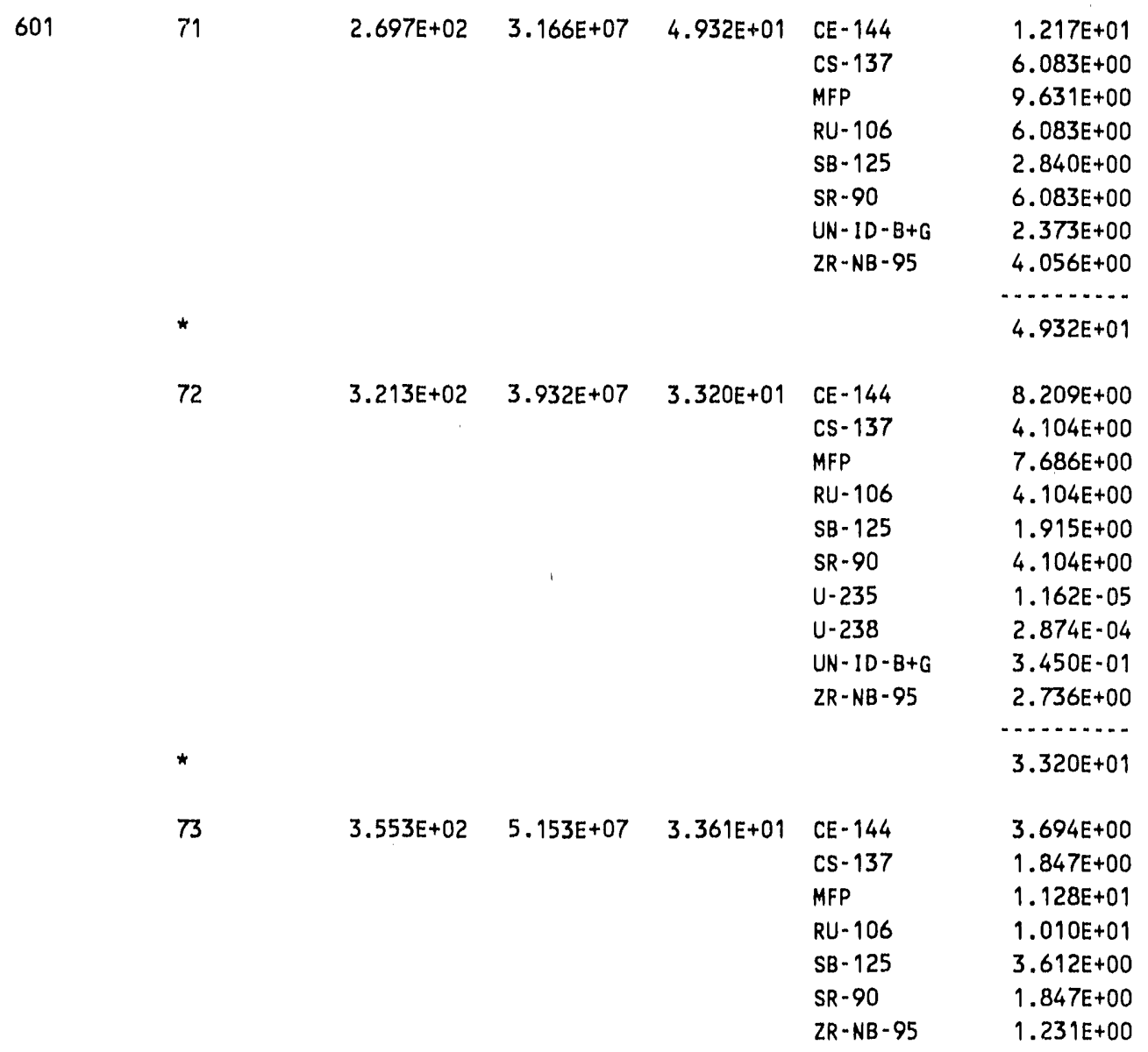




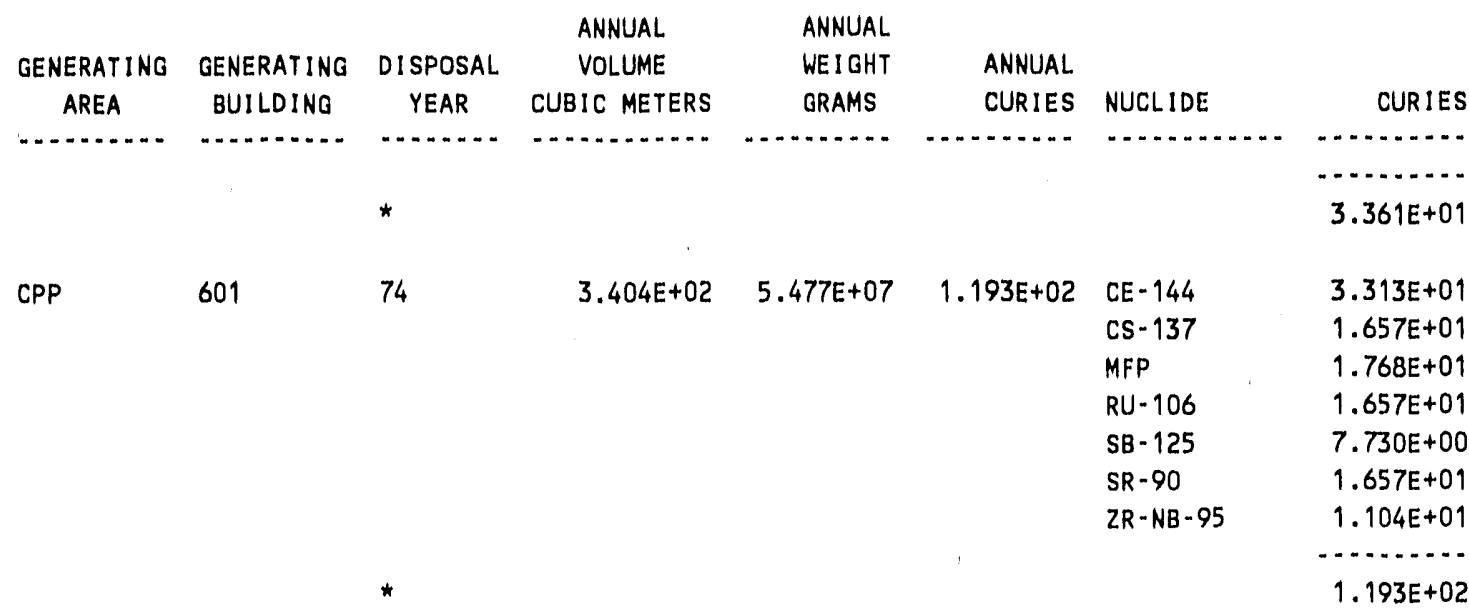

$3.942 E-01$

$S R-90$

$1.840 \mathrm{E}-01$

ZR-NB-95

$.942 . E-01$

2.628E-01

$5.216 E+00$

76

$2.804 E+02 \quad 3.171 E+07 \quad 6.464 E+00$

CE- 144

CS- 137

1. 180E+00

MFP

5.902E-01

RU- 106

$2.844 E+00$

SB- 125

5.902E- 01

$S R-90$

2.754E- 01

ZR-NB-95

$902 E-01$

$3.935 E-01$

$6.464 E+00$

77

$5.790 E+02 \quad 1.009 E+08 \quad 2.786 E+01$

CE- 144

CS- 137

$3.035 E+00$

MFP

$1.526 E+00$

NB- 95

$1.244 E+0$

$P R-144$

2.911E-01

$3.035 \mathrm{E}+00$

$\mathrm{RH}-106$

$1.371 E+00$

RU-106

SB- 125

$1.681 \mathrm{E}+00$

SR -90

7.142E- 01

$Y-90$

$1.526 E+00$

ZR-NB- 95

$1.526 \mathrm{E}+00$

ZR-95

4.242E- 01

2.911E-01 

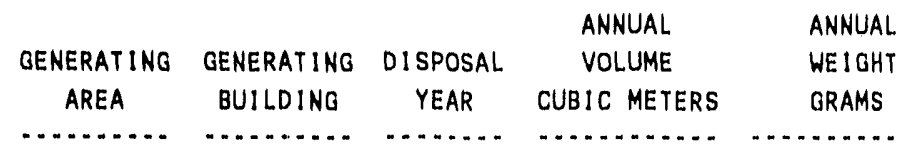

ANNUAL.

WEIGHT GRAMS

$1.230 E+03$
ANNUAL

CURIES NUCLIDE

CURIES

(..........

$2.786 E+01$

$6.025 E-01$

$9.038 E+01$

3.244E-01

3.244E-01

$1.528 \mathrm{E}-02$

$3.993 E+01$

$8.759 E+00$

$9.269 E-01$

$1.159 E+00$

$3.783 E+01$

$6.025 E-01$

$1.275 E+01$

$9.038 E+01$

$3.830 E+01$

$3.830 E+01$

$1.764 E+01$

$3.778 E+01$

$3.778 E+01$

$1.275 E+01$

........

$4.665 E+02$

79

$7.622 E+02 \quad 1.826 E+08$

$8.706 E+01$

$A M-241$

2.100E- 04

$1.424 E+01$

$7.055 E+00$

CS- 137

MAP

6.600E-02

MFP

$1.476 E+01$

NB- 95

$P R-144$

PU-238

PU-239

RH- 106

RU- 106

SB- 125

$S R-90$

$Y-90$

$2.360 E+00$

$1.424 E+01$

2. 100E-04

3. $684 \mathrm{E}-03$

$7.157 E+00$

$7.157 \mathrm{E}+00$

$3.350 E+00$

$7.157 E+00$

$7.157 \mathrm{E}+00$

ZR-95

2. $360 \mathrm{E}+00$

8.706E+01

$2.663 E+01$

$1.353 E+01$

$6.558 E+00$ 


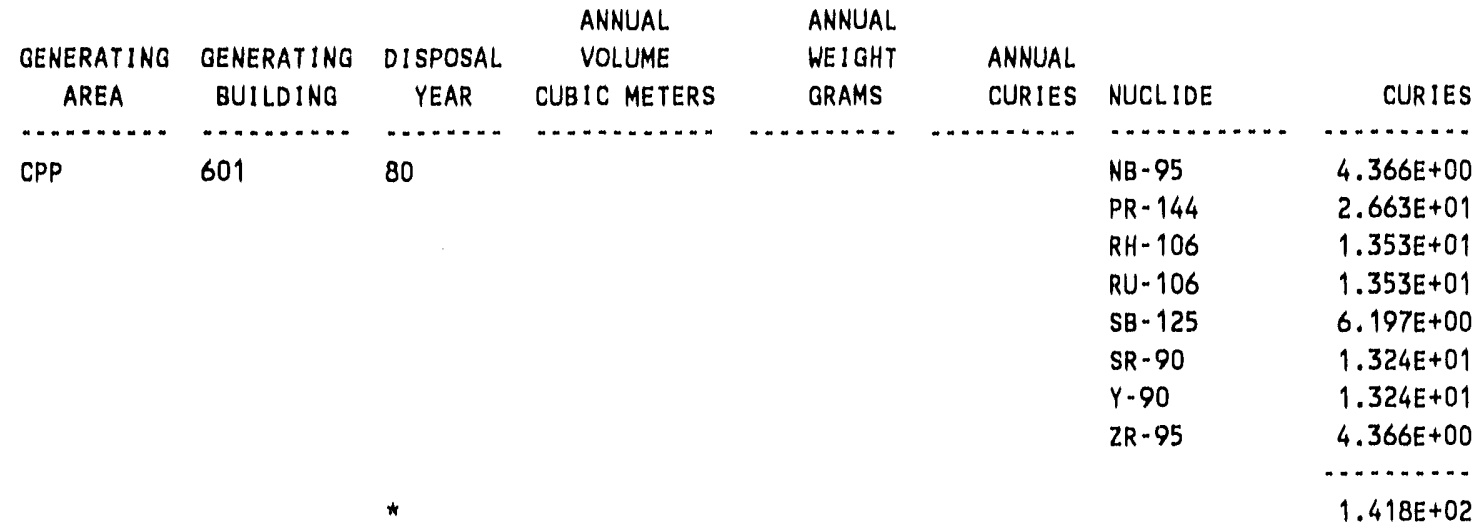

CE- 144

CS -137

MFP

NB-95

$P R-144$

RH- 106

RU- 106

$S B-125$

$S R-90$

$U-235$

$Y-90$

$2 R-95$

*

82

$3.658 E+0$

$1.494 E+07$

$3.494 E+01$

CE- 144

CS 137

MFP

NB- 95

$P R-144$

RH-106

RU- 106

SB- 125

$S R-90$

$Y-90$

$Z R-95$

$8.462 E+00$

$4.284 \mathrm{E}+00$

$9.437 E+00$

$1.351 E+00$

$8.462 E+00$

$4.284 E+00$

$4.284 E+00$

$1.917 E+00$

$4.284 E+00$

2.140E-05

$4.284 E+00$

$1.351 E+00$

$5.240 E+01$

$3.674 E+00$

$1.865 \mathrm{E}+00$

$1.629 E+01$

5.781E-01

$3.674 E+00$

$1.865 E+00$

$1.865 \mathrm{E}+00$

8.206E-01

$1.865 E+00$

$1.865 E+00$

5.781E-01

-.........

3.494E+01

83

$2.381 E+01$

$6.314 E+06$

$5.524 E+00$

CE- 144

rS- 137

MFP

NB-95

PR-144

$.083 E+00$

5.500E-01

2.437E-02

$\mathrm{RH}-106$

$1.705 E-01$

$1.083 E+00$

5.500E-01 


\begin{tabular}{|c|c|c|c|c|c|c|c|}
\hline \multirow{3}{*}{$\begin{array}{l}\text { QENERATING } \\
\text { AREA }\end{array}$} & \multirow{3}{*}{$\begin{array}{l}\text { GENERATING } \\
\text { BUILDING }\end{array}$} & \multirow[b]{2}{*}{ DISPOSAL } & \multirow{2}{*}{$\begin{array}{l}\text { ANNUAL } \\
\text { VOLUME }\end{array}$} & ANNUAL & \multirow[b]{2}{*}{ ANNUAL } & \multirow[b]{3}{*}{ NUCLIDE } & \multirow[b]{3}{*}{ CUR!ES } \\
\hline & & & & WEIGHT & & & \\
\hline & & YEAR & CUBIC PAETERS & GRAMS & CURIES & & \\
\hline 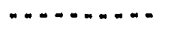 & 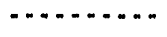 & n....... & n. n & 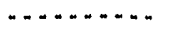 & 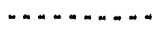 & 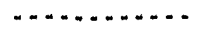 & - n......n. \\
\hline \multirow{40}{*}{ CPP } & 601 & 83 & & & & $R U-106$ & $5.500 E-01$ \\
\hline & & & & & & SB- 125 & $2.420 E-01$ \\
\hline & & & & & & SR - 90 & $5.500 E-01$ \\
\hline & & & & & & $Y-90$ & $5.500 E-01$ \\
\hline & & & & & & $2 R=95$ & $1.705 E-01$ \\
\hline & & & & & & & n. \\
\hline & & * & & & & & $5.524 E+00$ \\
\hline & & 84 & $2.175 E+01$ & $2.241 E+07$ & $1.920 \mathrm{E}-01$ & MFP & $1.920 E-01$ \\
\hline & & 87 & $7.250 E+00$ & $1.135 E+06$ & $2.880 E-01$ & MFP & $2.880 E-01$ \\
\hline & & 88 & $1.287 E+02$ & $3.773 E+07$ & $4.399 E+00$ & $C E-144$ & 5.910E-01 \\
\hline & & & & & & CS -137 & $1.500 E-01$ \\
\hline & & & & & & MFP & $2.899 E+00$ \\
\hline & & & & & & NB - 95 & $4.650 E-02$ \\
\hline & & & & & & $\mathrm{RH}-106$ & $1.500 E-01$ \\
\hline & & & & & & $R U-106$ & $1.500 E-01$ \\
\hline & & & & & & SB- 125 & $6.600 E-02$ \\
\hline & & & & & & $S R=90$ & $1.500 E-01$ \\
\hline & & & & & & $Y-90$ & $1.500 E-01$ \\
\hline & & & & & & $2 R-95$ & $4.650 E-02$ \\
\hline & & & & & & & - n. \\
\hline & & * & & & & & $4.399 E+00$ \\
\hline & & 89 & $8.881 E+01$ & $3.044 E+07$ & $2.022 E+01$ & CE -144 & $3.380 E+00$ \\
\hline & & & & & n n & CS 137 & $1.716 \mathrm{E}+00$ \\
\hline & * & & & & $1.088 E+03$ & MFP & $3.062 E+00$ \\
\hline & & & & & & NB-95 & $5.318 E-01$ \\
\hline & & & & & & $P R-144$ & $3.380 E+00$ \\
\hline & & & & & & $\mathrm{RH}-106$ & $1.716 E+00$ \\
\hline & & & & & & $R U-106$ & $1.716 E+00$ \\
\hline & & & & & & $S B-125$ & $7.549 E-01$ \\
\hline & & & & & & $S R-90$ & $1.716 E+00$ \\
\hline & & & & & & $Y-90$ & $1.716 E+00$ \\
\hline & & & & & & $2 R-95$ & $5.318 E-01$ \\
\hline & & & & & & & . \\
\hline & & * & & & & & $2.022 E+01$ \\
\hline & & & & & & & $\ldots$ \\
\hline & * & & & & & & $1.088 E+03$ \\
\hline & 602 & 71 & $6.665 E+00$ & $5.703 E+05$ & $3.652 E-01$ & MFP & $1.800 E-01$ \\
\hline & & & & & & PU-239 & $1.842 E-01$ \\
\hline & & & & & & $U-235$ & $1.947 E-04$ \\
\hline & & & & & & $U-238$ & $8.252 E-04$ \\
\hline
\end{tabular}




\begin{tabular}{|c|c|c|c|c|c|c|c|}
\hline GENERATING & GENERATING & DISFOSAL & $\begin{array}{l}\text { ANNUAL } \\
\text { VOLUME }\end{array}$ & $\begin{array}{l}\text { ANNUAL. } \\
\text { WE! GHT }\end{array}$ & ANNUAL & & \\
\hline AREA & BUILDING & YEAR & CUBIC METERS & GRAMS & CURIES & NUCL IDE & CURIES \\
\hline \multirow[t]{2}{*}{ 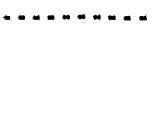 } & n. & $\cdots$ & 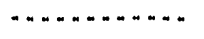 & (…… & …n....... & n............ & and \\
\hline & & * & & & & & $3.652 \mathrm{E}-01$ \\
\hline \multirow[t]{38}{*}{ CPP } & 602 & 72 & $2.832 E+00$ & $2.268 \mathrm{E}+06$ & $4.000 E \cdot 03$ & MFP & $4.000 E-03$ \\
\hline & & 73 & $5.777 E+00$ & $4.672 E+05$ & $3.753 E-02$ & MFP & $3.750 E-02$ \\
\hline & & & & & & U.235 & $1.691 E-05$ \\
\hline & & & & & & $U \cdot 238$ & $8.292 E-06$ \\
\hline & & & & & & & $\ldots$ \\
\hline & & * & & & & & $3.753 \mathrm{E}-02$ \\
\hline & & 74 & $8.609 E-01$ & $6.622 E+05$ & $1.000 E+02$ & MFP & $9.000 E-04$ \\
\hline & & & & & & $S R=90$ & $1.000 E+02$ \\
\hline & & $\star$ & & & & & $1.000 E+02$ \\
\hline & & 75 & $6.125 E+00$ & $4.812 E+06$ & $5.382 E-02$ & CF -141 & $4.886 E-03$ \\
\hline & & & & & & $C E-144$ & $6.395 E-03$ \\
\hline & & & & & & 60.58 & $6.598 E-05$ \\
\hline & & & & & & $c 0.60$ & $2.009 E-05$ \\
\hline & & & & & & Cs -137 & $2.678 E-04$ \\
\hline & & & & & & $L A=140$ & $2.399 E-04$ \\
\hline & & & & & & MFP & $4.830 E-03$ \\
\hline & & & & & & NB- 95 & $1.910 E-02$ \\
\hline & & & & & & PU-239 & $1.891 E-04$ \\
\hline & & & & & & PU-240 & $1.054 E-05$ \\
\hline & & & & & & $R U-103$ & $4.093 E-03$ \\
\hline & & & & & & $U-234$ & $1.760 E-04$ \\
\hline & & & & & & $U-235$ & $1.231 E-05$ \\
\hline & & & & & & $U-236$ & $2.280 E-06$ \\
\hline & & & & & & $U \cdot 238$ & $8.388 E-06$ \\
\hline & & & & & & $2 R-95$ & $1.352 \mathrm{E}-02$ \\
\hline & & & & & & & , n \\
\hline & & * & & & & & $5.382 E-02$ \\
\hline & & 76 & $8.128 E+01$ & $9.501 E+06$ & $1.299 E+00$ & $C E-141$ & $8.540 E-03$ \\
\hline & & & & & & CE- -144 & $4.739 E-02$ \\
\hline & & & & & & co- 58 & $1.145 E-04$ \\
\hline & & & & & & $c 0.60$ & $3.516 E-05$ \\
\hline & & & & & & CS -134 & $5.060 E-03$ \\
\hline & & & & & & Cs -137 & $3.817 E-02$ \\
\hline & & & & & & EU- 154 & $3.760 E-04$ \\
\hline & & & & & & $L A=140$ & $4.198 E-04$ \\
\hline & & & & & & MFP & $1.129 E+00$ \\
\hline & & & & & & NB- 95 & $3.342 E-02$ \\
\hline & & & & & & $R U-103$ & $7.163 E-03$ \\
\hline
\end{tabular}




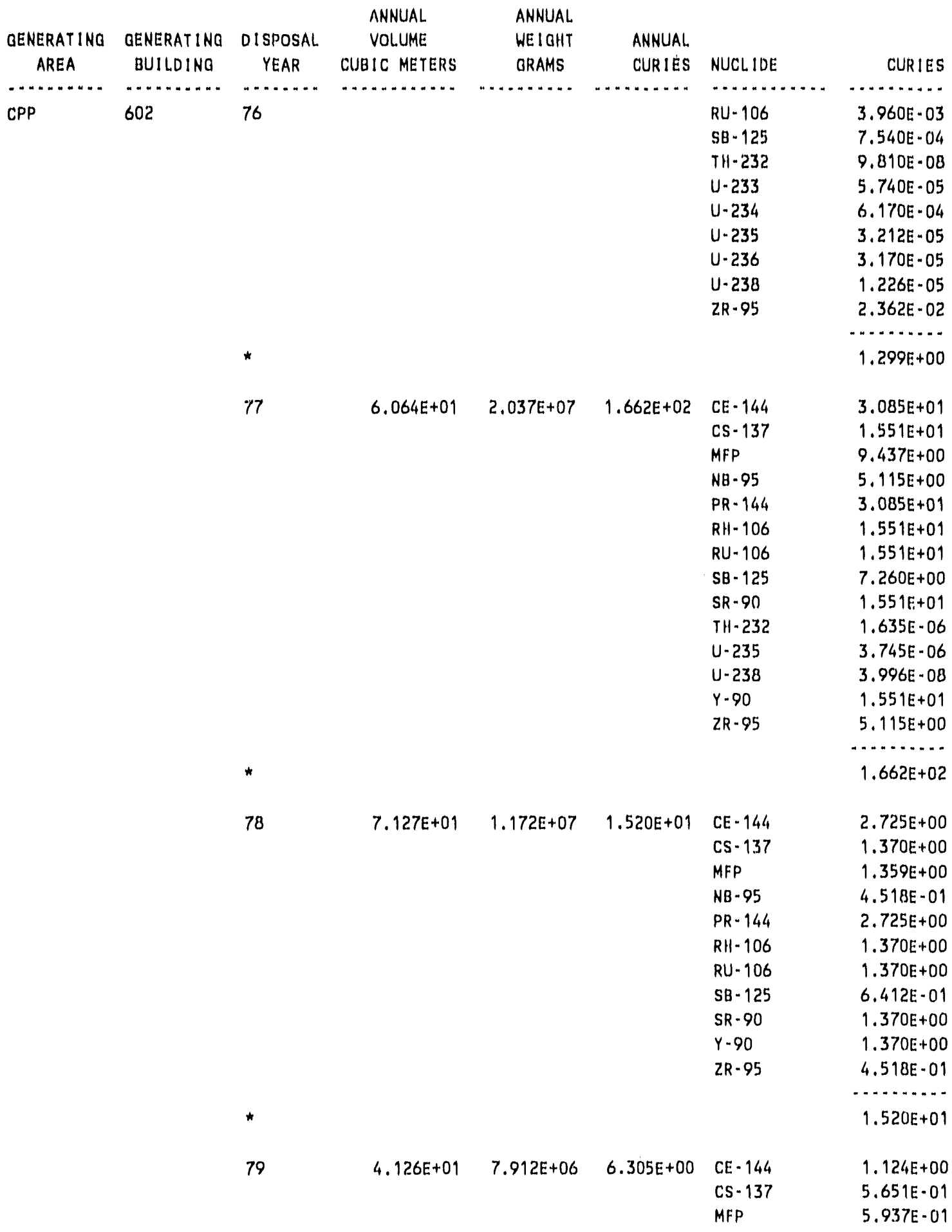




\begin{tabular}{|c|c|c|}
\hline QENERATINO & GENERATINO & DISPOSAL \\
\hline AREA & BUILDINO & YEAR \\
\hline 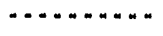 & n.......... & …..... \\
\hline CPP & 602 & 79 \\
\hline
\end{tabular}

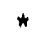

80 $1.815 E+01$

CUBIC METERS

2

ANNUAL ANNUAL

VOLUME WEIGHT

QRAMS

ANNUAL

CURIES

NUCL IDE

CURIES

NB. 95

PR-144

RHI 106

RU-106

SB- 125

SR 90

$U \cdot 234$

$U \cdot 235$

U. 236

$U \cdot 238$

$Y=90$

$2 R-95$

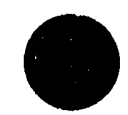

*

81

\begin{abstract}
$2.174 E+01 \quad 7.166 E+06$
\end{abstract}
8.850E-01 MFP

PU-239
(...........

$1.864 E-01$

$1.124 E+00$

$5.651 \mathrm{E}-01$

$5.651 \mathrm{E}-01$

$2.645 \mathrm{E}-01$

$5.651 \mathrm{E}-01$

$2.468 E-04$

8.703E-06

$4.216 E .06$

$2.726 \mathrm{E}-07$

5.651E-01

1.864E-01

...........

$6.305 E+00$

$6.472 E+01$

$1.588 E+00$

$1.494 E+01$

$4.394 E+02$

$1.752 E+00$

$1.821 E+00$

$1.392 E+00$

$9.151 E+00$

$5.115 E+00$

$6.472 E+01$

4.169E-0.2

1. 161E-02

$3.503 E-04$

8. 166E-02

4.607E-06

$1.551 \mathrm{E}+01$

$1.551 E+01$

$7.260 E+00$

$2.397 E+01$

1. 155E-05

$3.355 E-03$

$1.255 E-04$

$1.158 \mathrm{E}-04$

2.010E-05

$2.397 E+01$

$5.115 \mathrm{E}+00$

.....

$6.961 E+02$

8.799E- 01

$1.360 E-03$ 


\begin{tabular}{|c|c|c|c|c|c|c|c|}
\hline $\begin{array}{l}\text { QENERATINO } \\
\text { AREA }\end{array}$ & $\begin{array}{l}\text { GENERATING } \\
\text { BUILDING }\end{array}$ & $\begin{array}{c}\text { DISPOSAL } \\
\text { YEAR }\end{array}$ & $\begin{array}{c}\text { ANNUAL } \\
\text { VOLUME } \\
\text { CUBIC METERS }\end{array}$ & $\begin{array}{l}\text { ANNUAL. } \\
\text { WEI GHT } \\
\text { GRAMS }\end{array}$ & $\begin{array}{l}\text { ANNUAL } \\
\text { CURIES }\end{array}$ & NUCL.1DE & CURIES \\
\hline ……..... & ............ & . . . . . . . & -....... & ............ & … & ................ & 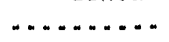 \\
\hline \multirow[t]{36}{*}{ CPP } & 602 & 81 & & & & $P U-240$ & $3.740 E-03$ \\
\hline & & * & & & & & $8.850 \mathrm{E}-01$ \\
\hline & & 86 & $2.878 E+01$ & $4.086 E+06$ & $3.303 E-01$ & MFP & $3.303 E-01$ \\
\hline & & 88 & $1.450 E+01$ & $2.838 E+06$ & $5.400 E-02$ & MFP & $5.400 E-02$ \\
\hline & & 89 & $1.813 E+00$ & $1.450 E+06$ & $1.400 E-02$ & MFP & $1.400 E-02$ \\
\hline & & & & & 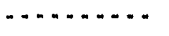 & & 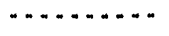 \\
\hline & * & & & & $9.868 E+02$ & & $9.868 E+02$ \\
\hline & 603 & 71 & $2.396 \mathrm{E}+01$ & $5.670 E+06$ & $3.737 E+01$ & CS- 137 & $2.782 E+01$ \\
\hline & & & & & & MFP & $2.705 E-01$ \\
\hline & & & & & & $S R-90$ & $9.275 E+00$ \\
\hline & & & & & & & …….... \\
\hline & & * & & & & & $3.737 E+01$ \\
\hline & & 72 & $1.372 \mathrm{E}+02$ & $5.257 E+07$ & $1.281 \mathrm{E}+00$ & MFP & $1.281 E+00$ \\
\hline & & 73 & $1.580 E+02$ & $2.247 E+07$ & $3.250 E+05$ & $c 0-58$ & $3.900 E+03$ \\
\hline & & & & & & $c 0-60$ & $1.982 E+05$ \\
\hline & & & & & & $C R-51$ & $7.897 E+04$ \\
\hline & & & & & & MAP & $2.307 E+04$ \\
\hline & & & & & & MFP & $3.055 E-01$ \\
\hline & & & & & & $M N-54$ & $2.080 \varepsilon+04$ \\
\hline & & * & & & & & $3.250 \mathrm{E}+05$ \\
\hline & & 74 & $1.484 E+02$ & $1.324 E+07$ & $2.130 E+00$ & MFP & $2.130 E+00$ \\
\hline & & 75 & $2.897 E+02$ & $5.552 E+07$ & $2.999 E+01$ & $C E-141$ & $5.400 E-01$ \\
\hline & & & & & & CE- 144 & $1.302 E+01$ \\
\hline & & & & & & $\mathrm{CO}-58$ & $2.700 E-01$ \\
\hline & & & & & & $\operatorname{co-} 60$ & $2.700 E-01$ \\
\hline & & & & & & CS- 134 & $5.400 E-01$ \\
\hline & & & & & & CS -137 & $8.330 E+00$ \\
\hline & & & & & & EU- 152 & $1.060 E+00$ \\
\hline & & & & & & EU- 154 & $1.080 E+00$ \\
\hline & & & & & & EU-155 & $5.400 E-01$ \\
\hline & & & & & & MAP & $1.325 E-02$ \\
\hline & & & & & & MFP & $2.979 E+00$ \\
\hline & & & & & & $M N-54$ & $2.700 E-01$ \\
\hline & & & & & & NB- 95 & $2.700 E-01$ \\
\hline & & & & & & RU- 106 & $5.400 E-01$ \\
\hline & & & & & & $2 R-95$ & $2.700 E-01$ \\
\hline
\end{tabular}




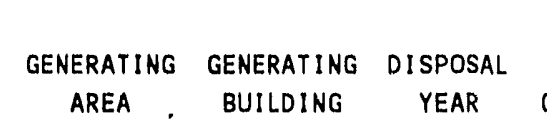

ANNUAL ANNUAL

VOLUME WEIGHT ........

$\star$

CPP

603

76

$7.677 E+02$

$1.972 E+08$

$6.871 E+0$

CE -141

CE -144

CO- 58

CO-60

CS -134

CS -137

EU- 152

EU- 154

EU- 155

MAP

MFP

MN-54

NB- 95

PR - 144

RH- 106

RU- 106

SR -89

SR - 90

$Y-90$

ZR-95

77

\section{$1.940 E+03$}

$4.993 E+08$
4.562E+03

CE- 141

CE-144

CO-58

CO- 60

CS -134

CS- 137

EU-132

EU-154

EU- 155

MFP

$M N-54$

NB-95

$P R-144$

$P U-238$

$\mathrm{PU}-239$

$\mathrm{PU}-240$

$\mathrm{RH}-106$

$\mathrm{RU}-106$

SB- 125

$S R-90$
CURIES

-

$2.999 E+01$

6. $600 \mathrm{E}-02$

$1.805 E+00$

3. $400 \mathrm{E}-02$

1.407E-01

4.170E-01

4. 102E+01

4.380E- 01

1.200E-01

$9.000 \mathrm{E}-02$

$5.000 E-04$

$7.770 E+00$

4.600E-02

$3.400 E-02$

$7.848 \mathrm{E}-01$

$2.600 \mathrm{E}-02$

$6.600 \mathrm{E}-02$

$1.008 \mathrm{E}-01$

$7.861 E+00$

$7.861 \mathrm{E}+00$

3.400E-02

$6.871 E+01$

$1.307 E+01$

$1.937 E+03$

$3.376 E+00$

$6.756 E+O C$

$1.150 E+01$

3. 130E+02

$1.712 E+02$

$8.357 E+01$

2. $001 E+01$

$1.162 E+02$

$6.227 E+00$

$1.353 E+01$

$1.810 E+03$

$1.800 \mathrm{E}-06$

3.476E-02

2. $462 E-04$

$1.080 E+01$

$1.080 E+01$

$1.834 E+00$

$1.866 E+01$ 


\begin{tabular}{|c|c|c|c|c|c|c|c|}
\hline GENERATING & GENERAT I NG & DISPOSAL & $\begin{array}{l}\text { ANNUAL } \\
\text { VOLUME }\end{array}$ & $\begin{array}{l}\text { ANNUAL } \\
\text { WEIGHT }\end{array}$ & ANNUAL & & \\
\hline AREA & BUILDING & YEAR & CUBIC METERS & GRAMS & CURIES & NUCL IDE & CURIES \\
\hline - & . & . & - & $\ldots$ & . n & . & . n \\
\hline \multirow[t]{44}{*}{ CPP } & 603 & 77 & & & & $U-234$ & $6.521 E-03$ \\
\hline & & & & & & U-235 & $6.875 E-04$ \\
\hline & & & & & & $U-236$ & $1.160 E-04$ \\
\hline & & & & & & $U-238$ & $1.002 E-04$ \\
\hline & & & & & & $Y-90$ & $2.764 E+00$ \\
\hline & & & & & & $2 R-95$ & $1.109 E+01$ \\
\hline & & & & & & & n. \\
\hline & & * & & & & & $4.562 E+03$ \\
\hline & & 78 & $8.711 E+02$ & $3.845 E+08$ & $5.725 E+03$ & $C E-141$ & 2. $101 E+01$ \\
\hline & & & & & & CE- 144 & $1.311 E+03$ \\
\hline & & & & & & Co- 58 & $4.361 E-01$ \\
\hline & & & & & & $C 0-60$ & $1.992 E+01$ \\
\hline & & & & & & CS- 134 & $9.178 E+01$ \\
\hline & & & & & & CS- 137 & $2.046 E+03$ \\
\hline & & & & & & EU-152 & $1.063 E+02$ \\
\hline & & & & & & EU-154 & $9.725 E+01$ \\
\hline & & & & & & $E U-155$ & $3.616 E+01$ \\
\hline & & & & & & MFP & $8.134 E+00$ \\
\hline & & & & & & $M N-54$ & $8.100 E-01$ \\
\hline & & & & & & NB-95 & $4.248 E+01$ \\
\hline & & & & & & PR- 144 & $1.311 E+03$ \\
\hline & & & & & & PU-238 & $3.022 E-02$ \\
\hline & & & & & & PU-239 & $2.872 E-02$ \\
\hline & & & & & & PU-240 & $2.560 E-03$ \\
\hline & & & & & & $\mathrm{RH}-106$ & $2.326 E+01$ \\
\hline & & & & & & $R U=106$ & $2.326 E+01$ \\
\hline & & & & & & $S B-125$ & $4.614 E+00$ \\
\hline & & & & & & $S R-90$ & $5.397 E+02$ \\
\hline & & & & & & $U-234$ & $7.673 E-03$ \\
\hline & & & & & & $U-235$ & $3.215 E-04$ \\
\hline & & & & & & $U-236$ & $1.268 E-04$ \\
\hline & & & & & & $U-238$ & $5.140 E-05$ \\
\hline & & & & & & $Y-90$ & $8.665 E+00$ \\
\hline & & & & & & $2 R-95$ & $3.305 E+01$ \\
\hline & & $\star$ & & & & & $5.725 \mathrm{~F}+03$ \\
\hline & & & & & & & \\
\hline & & 79 & $4.995 E+02$ & $1.784 E+08$ & $1.023 E+03$ & CE -144 & $1.276 E+02$ \\
\hline & & & & & & 100.60 & $3.830 E+00$ \\
\hline & & & & & & CS- 134 & $1.893 E+01$ \\
\hline & & & & & & $C S-137$ & $5.414 E+02$ \\
\hline & & & & & & $E U-152$ & $5.350 E+U 0$ \\
\hline & & & & & & $E U-154$ & $4.901 E+00$ \\
\hline & & & & & & EU-155 & $2.778 E+00$ \\
\hline & & & & & & MFP & $4.728 E+00$ \\
\hline
\end{tabular}



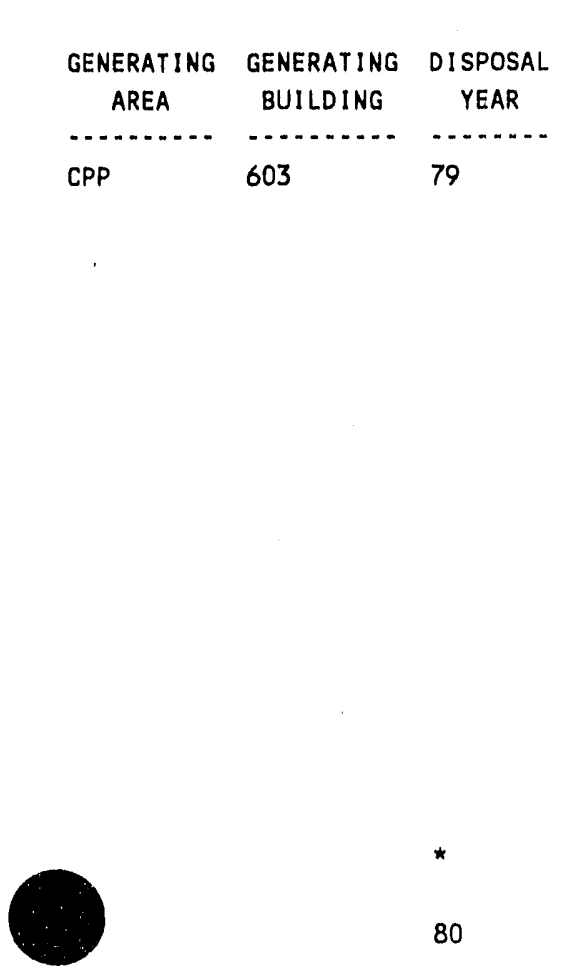

$\begin{array}{cc}\begin{array}{c}\text { ANNUAL } \\ \text { VOLUME }\end{array} & \begin{array}{c}\text { ANNUAL } \\ \text { WEIGHT } \\ \text { CUBIC METERS }\end{array} \\ \text { GRAMS }\end{array}$

$4.043 E+02 \quad 6.544 E+08 \quad 1.506 E+04$

\section{ANNUAL CURIES}

NUCL IDE

NB- 95

$P R-144$

$\mathrm{PU}-238$

PU-239

PU-240

PU -241

$\mathrm{PU}-242$

RH- 106

RU-106

$S B-125$

$S R-90$

U-234

$U-235$

$U-236$

$U-238$

$Y-90$

ZR-95

CURIES

-.........

$1.306 E+00$

$1.276 \mathrm{E}+02$

$4.169 E-02$

$2.690 \mathrm{E}-02$

$7.285 E-04$

8. 166E-02

4.607E-06

$1.121 E+01$

$1.121 E+01$

$1.949 E+00$

$7.970 E+01$

$1.023 E-02$

$3.766 E-04$

3.047E-04

6.690E-05

$7.970 E+01$

$6.485 \mathrm{E}-01$

$1.023 E+03$

CE- 141

CE- 144

CO- 60

$1.935 E+03$

CS- 134

CS- 137

EU- 152

EU- 154

EU-155

MFP

$5.394 E+01$

$3.268 \mathrm{E}+02$

$8.986 E+03$

$1.007 E+02$

$1.005 E+02$

$4.842 E+01$

NB-95

$3.588 E+00$

PR- 144

PU-238

PU-239

PU-240

PU-241

PU-242

$\mathrm{RH}-106$

RU-106

SB-125

$\mathrm{SR}-90$

$U-234$

$U-235$

$U-236$

$\mathrm{U}-238$

$Y-90$

$3.823 E+01$

$1.945 E+03$

7.253E- 01

3.043E-01

8. $489 E-03$

$1.340 E+00$

7.971E-05

$5.620 E+01$

$5.620 E+01$

$5.291 E+00$

8.618E+02

1. 134E-01

4. $416 E-03$

$3.228 \mathrm{E}-03$

7.533E- 04

$5.018 E+02$

ZR-95

2. $412 E+01$ 
IDAHO OPERATIONS OFFICE

U.S. DEPARTMENT OF ENERGY

INEL WASTE MANAGEMENT INFORMATION SYSTEM

ANNUAL SUMMARY FOR CPP
RUN DATE: 04/03/91

PAGE

74

\begin{tabular}{|c|c|c|c|c|c|c|c|}
\hline $\begin{array}{c}\text { GENERATING } \\
\text { AREA }\end{array}$ & $\begin{array}{l}\text { GENERATING } \\
\text { BUILDING }\end{array}$ & $\begin{array}{l}\text { DISPOSAL } \\
\text { YEAR }\end{array}$ & $\begin{array}{c}\text { ANNUAL } \\
\text { VOLUME } \\
\text { CUBIC METERS }\end{array}$ & $\begin{array}{l}\text { ANNUAL } \\
\text { WEIGHT } \\
\text { GRAMS }\end{array}$ & $\begin{array}{l}\text { ANNUAL } \\
\text { CURIES }\end{array}$ & NUCL. IDE & CURIES \\
\hline n & . & * & n & n & 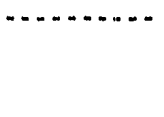 & - & $1.506 E+04$ \\
\hline CPP & 603 & 81 & $1.303 E+02$ & $6.636 E+07$ & $1.402 E+04$ & $\begin{array}{l}C E-144 \\
C D-58 \\
C O-60 \\
C R-51 \\
C S-137 \\
F E-59 \\
M F P \\
M N-54 \\
N B-95 \\
P R-144 \\
R H-106 \\
R U-106 \\
S B-125 \\
S R-90 \\
Y-90 \\
Z R-95\end{array}$ & $\begin{array}{r}3.016 E+00 \\
7.840 E+03 \\
1.400 E+02 \\
4.200 E+02 \\
1.519 E+00 \\
1.400 E+02 \\
2.705 E+00 \\
5.460 E+03 \\
4.946 E-01 \\
3.016 E+00 \\
1.519 E+00 \\
1.519 E+00 \\
7.020 E-01 \\
1.519 E+00 \\
1.519 E+00 \\
4.946 E-01 \\
\cdots .2 \cdots \\
1.402 E+04\end{array}$ \\
\hline & & * & $5.819 E+01$ & $2.288 E+07$ & $1.148 E+05$ & $\begin{array}{l}\text { CO-58 } \\
\text { CO-60 } \\
\text { CR-51 } \\
\text { FE-59 } \\
\text { MFP } \\
\text { MN-54 }\end{array}$ & $\begin{array}{r}6.429 E+04 \\
1.148 E+03 \\
3.444 E+03 \\
1.148 E+03 \\
1.170 E+00 \\
4.477 E+04 \\
\hdashline 1.148 E+05\end{array}$ \\
\hline & & 83 & $3.727 E+00$ & $2.545 E+06$ & $2.060 E-02$ & MFP & $2.060 E-02$ \\
\hline & & $\star$ & $3.205 E+01$ & $6.790 E+07$ & $1.484 E+00$ & $\begin{array}{l}\text { N/A } \\
\text { MFP }\end{array}$ & $\begin{array}{r}0.000 E+00 \\
1.484 E+00 \\
\cdots \\
1.484 E+00\end{array}$ \\
\hline & & 85 & $1.195 E+01$ & $1.996 E+06$ & $9.700 E-01$ & MFP & $9.700 E-01$ \\
\hline & & 87 & $4.502 E+00$ & $5.153 E+06$ & $1.950 E+(10$ & $\begin{array}{l}\text { CO- } 60 \\
\text { CS- } 134 \\
C S-137 \\
E U-152 \\
E U-154 \\
E U-155\end{array}$ & $\begin{array}{l}9.750 E-03 \\
5.850 E-03 \\
1.077 E+00 \\
3.260 E-01 \\
2.301 E-01 \\
4.836 E-02\end{array}$ \\
\hline
\end{tabular}




\begin{tabular}{|c|c|c|c|c|c|c|c|}
\hline GENERATING & GENERATING & DISPOSAL. & $\begin{array}{l}\text { ANNUAL } \\
\text { VOLUME }\end{array}$ & $\begin{array}{l}\text { ANNUAL } \\
\text { WEIGHT }\end{array}$ & ANNUAL. & & \\
\hline AREA & BUILDING & YEAR & CUBIC METERS & GRAMS & CURIES & NUCL IDE & CURIES \\
\hline - & n. & ........ & - n n & - n. & -........... & $\cdots+\cdots$ & \\
\hline CPP & 603 & 87 & & & & $\begin{array}{l}S R-90 \\
y-90\end{array}$ & $\begin{array}{l}1.264 E-C \\
1.264 E-C\end{array}$ \\
\hline
\end{tabular}

\begin{tabular}{|c|c|c|c|c|c|c|}
\hline & 88 & $1.269 E+01$ & $3.859 E+06$ & $2.540 E-01$ & MFP & $2.540 E-01$ \\
\hline & 89 & $7.250 E+00$ & $2.543 E+06$ & $4.440 E-01$ & $C E-144$ & $8.274 E-02$ \\
\hline \multirow{11}{*}{ * } & & & & . n. & CS-137 & $4.200 E-02$ \\
\hline & & & & $4.803 E+05$ & MFP & $2.400 E-02$ \\
\hline & & & & & NB-95 & $1.302 E-02$ \\
\hline & & & & & $P R-144$ & $8.274 E-02$ \\
\hline & & & & & $R H-106$ & $4.200 E-02$ \\
\hline & & & & & $R U-106$ & $4.200 E-02$ \\
\hline & & & & & SB- 125 & $1.848 \mathrm{E}-02$ \\
\hline & & & & & SR-90 & $4.200 E-02$ \\
\hline & & & & & $Y-90$ & $4.200 E-02$ \\
\hline & & & & & $2 R-95$ & \\
\hline & " & & & & & $4.440 E-01$ \\
\hline * & & & & & & - \\
\hline & & & & & & $4.803 E+05$ \\
\hline \multirow{19}{*}{604} & 71 & $3.556 E+01$ & $9.979 E+06$ & $2.347 E+00$ & CE- 144 & $3.420 E-01$ \\
\hline & & & & & CS-137 & $1.710 \mathrm{E}-01$ \\
\hline & & & & & MFP & $1.299 E+00$ \\
\hline & & & & & RU- 106 & $1.710 E-01$ \\
\hline & & & & & SB- 125 & $7.980 E-02$ \\
\hline & & & & & SR-90 & $1.710 E-01$ \\
\hline & & & & & ZR-NB-95 & \\
\hline & * & & & & & \\
\hline & & ? $5655+01$ & $44<6 F+06$ & & & \\
\hline & & & & 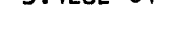 & mir & $3.428 \mathrm{E}-01$ \\
\hline & 73 & $6.491 E+01$ & $2.579 E+07$ & $4.362 E+00$ & CE- 144 & $1.215 E+00$ \\
\hline & & & & & CS- 137 & $6.075 E-01$ \\
\hline & & & & & MFP & $4.860 E-01$ \\
\hline & & & & & PU-239 & $1.500 E-01$ \\
\hline & & & & & $R U-106$ & $6.075 E-01$ \\
\hline & & & & & $S B-125$ & $2.835 \mathrm{E}-01$ \\
\hline & & & & & SR -90 & $6.075 E-01$ \\
\hline & & & & & $Z R-N B-95$ & $4.050 E-01$ \\
\hline & * & & & & & $4.362 . \mathrm{E}+00$ \\
\hline
\end{tabular}




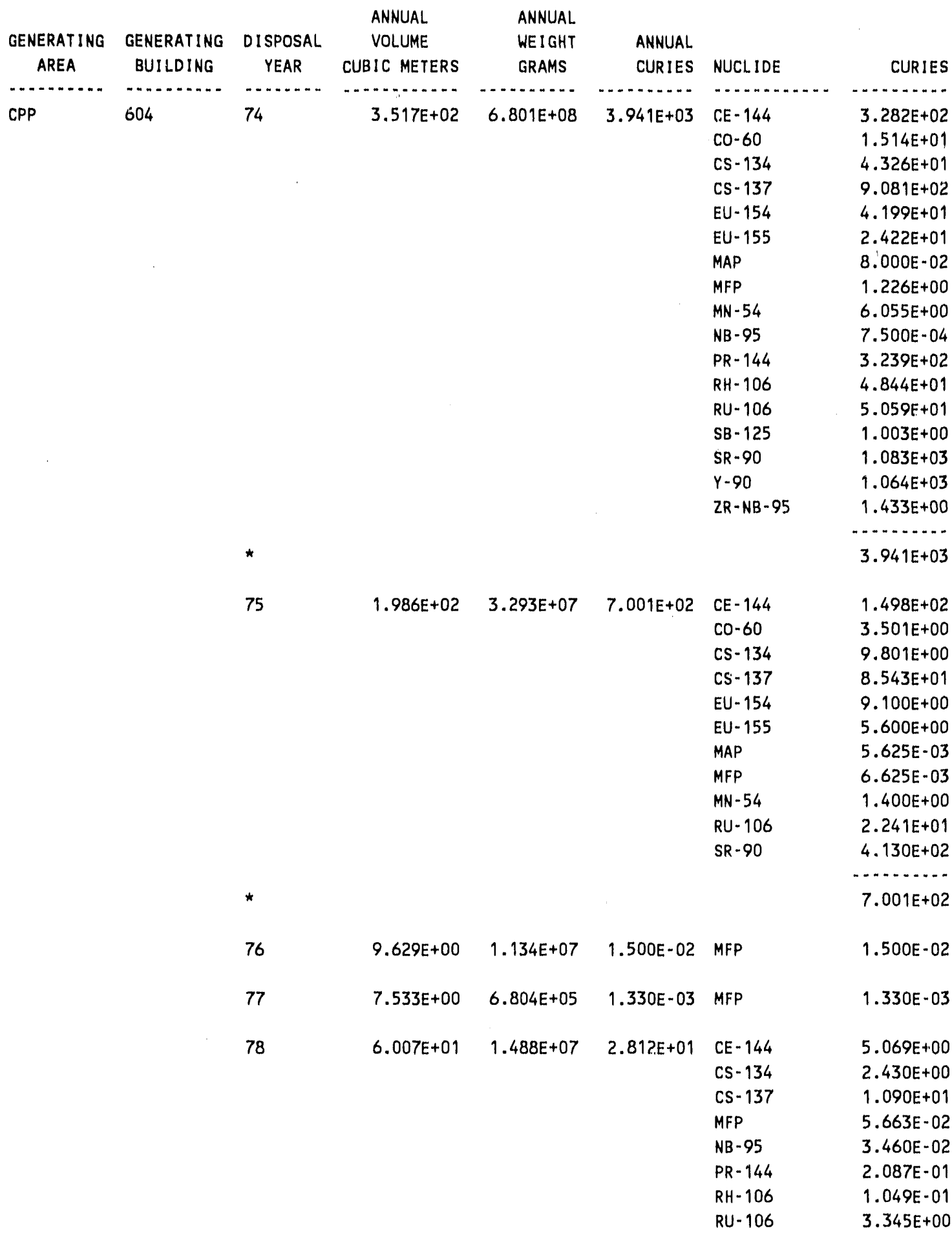




\begin{tabular}{|c|c|c|}
\hline GENERATINO & GENERATING & DISPOSAL. \\
\hline AREA & BUILDING & YEAR \\
\hline 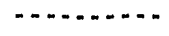 & - n & . n. \\
\hline CPP & 604 & 78 \\
\hline
\end{tabular}

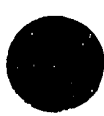

81

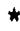

79

$1.087 E+01$

*
8.606E+01
VOLUME CUBIC METERS

C...........

..........

ANNUAL

CURIES

NUCLIDE

$\mathrm{SB}-125$

SR-89

$S R-90$

$Y-90$

ZR-95

$2.722 E+06$

5.700E-02 MFP

$2.567 \mathrm{E}+08$

$2.252 E+01$

CE-144

CS- 137

MFP

NB-95

$P R-144$

RH- 106

$\mathrm{RU}-106$

SB- 125

SR. -90

$Y-90$

$Z R-95$

$2.114 E+07$

1. 151E+02

CE- 144

CO- 60

CS -134

CS- 137

EU- 154

EU- 155

MFP

NB - 95

PR-144

RH- 106

RU- 106

SB- 125

SR 90

$Y-90$

2R-95

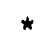

88
$3.444 E+01$

$1.818 \mathrm{E}+0$

\section{$2.978 E+01$}

CE- 144

CS -137

MFP

NB-95
CURIES

$5.891 E-01$

$1.890 E+00$

$3.345 E+00$

1.049E-01

$3.460 \mathrm{E}-02$

$2.812 E+01$

5.700E-02

$3.385 E+00$

$1.701 E+00$

$5.328 E+00$

5.611E-01

$3.385 E+00$

$1.701 \mathrm{E}+00$

$1.701 E+00$

7.964E-01

$1.701 E+00$

$1.701 E+00$

5.611E-01

$2.252 E+01$

1. $850 E+01$

4. $732 \mathrm{E}-02$

$6.151 E+00$

4.192E+01

$6.573 E-01$

2.746E-01

$1.380 E+00$

$1.960 E+00$

1.214E+01

$6.156 E+00$

$8.020 E+00$

$3.668 E+00$

$6.156 E+00$

$6.156 E+00$

$1.960 E+00$

1..........

$1.151 E+02$

$5.615 E+00$ $2.850 E+00$

$1.282 E+00$

$8.835 E-01$ 


\begin{tabular}{|c|c|c|c|c|c|c|c|}
\hline GENERATING & GENERAT ING & DISPOSAL. & $\begin{array}{l}\text { ANNUAL } \\
\text { VOLUME }\end{array}$ & $\begin{array}{l}\text { ANNUAL } \\
\text { WEIGHT }\end{array}$ & ANNUAL & & \\
\hline AREA & BUILDING & YEAR & CUBIC METERS & GRAMS & CURIES & NUCLLIDE & CURIES \\
\hline ……........ & $\ldots$ & ........ & ג & n & . & , n & $\ldots$ \\
\hline \multirow[t]{40}{*}{ CPP } & 604 & 88 & & & & $P R-144$ & $5.615 E+00$ \\
\hline & & & & & & RH- 106 & $2.850 E+00$ \\
\hline & & & & & & RU. 106 & $2.850 E+00$ \\
\hline & & & & & & $S B-125$ & $1.254 E+00$ \\
\hline & & & & & & $S R-90$ & $2.850 E+00$ \\
\hline & & & & & & $Y=90$ & $2.850 E+00$ \\
\hline & & & & & & $2 R-95$ & $8.835 E-01$ \\
\hline & & & & & & & 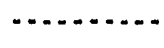 \\
\hline & & * & & & & & $2.978 E+01$ \\
\hline & & 89 & $3.081 E+01$ & $1.005 E+07$ & $1.029 E+01$ & $C E-144$ & $2.028 E+00$ \\
\hline & & & & & - & Cs. 137 & $1.029 E+00$ \\
\hline & * & & & & $4.854 E+03$ & NB. 95 & $3.191 \mathrm{E}-01$ \\
\hline & & & & & & $P R=144$ & $2.028 E+00$ \\
\hline & & & & & & RH- 106 & $1.029 E+00$ \\
\hline & & & & & & RU- 106 & $1.029 E+00$ \\
\hline & & & & & & SB- 125 & $4.529 E-01$ \\
\hline & & & & & & SR-90 & $1.029 \mathrm{E}+00$ \\
\hline & & & & & & $Y-90$ & $1.029 E+00$ \\
\hline & & & & & & $2 R-95$ & $3.191 E-01$ \\
\hline & & & & & & & (n) \\
\hline & & * & & & & & $1.029 E+01$ \\
\hline & & & & & & & מ \\
\hline & $\star$ & & & & & & $4.854 E+03$ \\
\hline & 605 & 73 & $6.587 E+01$ & $4.999 E+07$ & $7.040 E-01$ & MFP & $7.040 E-01$ \\
\hline & & 74 & $5.947 E+00$ & $1.089 \mathrm{E}+07$ & $3.000 E-01$ & MFP & $3.000 E-01$ \\
\hline & & 75 & $5.307 E+02$ & $1.424 E+08$ & $1.390 E+00$ & CE- 144 & $3.732 E-03$ \\
\hline & & & & & & $C 0.60$ & $7.465 E-03$ \\
\hline & & & & & & CS- 134 & $3.732 E-03$ \\
\hline & & & & & & CS: 137 & $1.232 \mathrm{E}-01$ \\
\hline & & & & & & MAP & $5.630 E-01$ \\
\hline & & & & & & MFP & $6.277 E-01$ \\
\hline & & & & & & $M N-54$ & $1.740 E-03$ \\
\hline & & & & & & RU- 106 & $4.928 E-02$ \\
\hline & & & & & & SR-90 & $1.008 E-02$ \\
\hline & & & & & & & 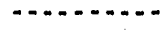 \\
\hline & & * & & & . & & $1.390 E+00$ \\
\hline & & 77 & $6.797 E-01$ & $2.722 E+05$ & $1.500 E-03$ & MFP & $1.500 E-03$ \\
\hline & & 80 & $1.087 E+01$ & $2.540 E+06$ & $7.190 E+00$ & $C E-144$ & $1.345 E+00$ \\
\hline & & & & & & $C S-137$ & $6.759 E-01$ \\
\hline & & & & & & MFP & $3.595 E-01$ \\
\hline
\end{tabular}




\begin{tabular}{|c|c|c|c|c|c|c|c|}
\hline $\begin{array}{l}\text { GENERATING } \\
\text { AREA }\end{array}$ & $\begin{array}{l}\text { GENERATING } \\
\text { BUILDING }\end{array}$ & $\begin{array}{c}\text { DISPOSAL } \\
\text { YEAR }\end{array}$ & $\begin{array}{c}\text { ANNUAL } \\
\text { VOLUME } \\
\text { CUBIC METERS }\end{array}$ & $\begin{array}{l}\text { ANNUAL } \\
\text { WEIGHT } \\
\text { GRAMS }\end{array}$ & $\begin{array}{l}\text { ANNUAL } \\
\text { CURIES }\end{array}$ & NUCL IDE & CURIES \\
\hline ............. & $\cdots$ & (.......... & - & $\ldots$ & - n. & n......... & 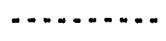 \\
\hline \multirow[t]{41}{*}{ CPP } & 605 & 80 & & & & NB-95 & $2.229 \mathrm{E}-01$ \\
\hline & & & & & & PR=144 & $1.345 E+00$ \\
\hline & & & & & & RH- 106 & $6.759 E-01$ \\
\hline & & & & & & $R U-106$ & $6.759 E-01$ \\
\hline & & & & & & $S B-125$ & $3.164 E-01$ \\
\hline & & & & & & SR-90 & $6.759 E-01$ \\
\hline & & & & & & $Y-90$ & $6.759 E-01$ \\
\hline & & & & & & $Z \cdot R-95$ & $2.229 E-01$ \\
\hline & & & & & & & , \\
\hline & & * & & & & & $7.190 E+00$ \\
\hline & & 81 & $2.174 E+01$ & $3.856 E+06$ & $8.242 E+00$ & CE-144 & 4. 403E-01 \\
\hline & & & & & & Cs- 137 & $2.235 E-01$ \\
\hline & & & & & & MFP & $6.007 E+00$ \\
\hline & & & & & & NB-95 & $6.928 E-02$ \\
\hline & & & & & & $P R-144$ & $4.403 E-01$ \\
\hline & & & & & & $R H-106$ & $2.235 E-01$ \\
\hline & & & & & & $R U-106$ & $2.235 E-01$ \\
\hline & & & & & & $S B-125$ & $9.834 E-02$ \\
\hline & & & & & & SR-90 & $2.235 E-01$ \\
\hline & & & & & & $Y-90$ & $2.235 E-01$ \\
\hline & & & & & & ZR-95 & $6.928 \mathrm{E}-02$ \\
\hline & & * & & & & & $8.242 E+00$ \\
\hline & & 88 & $1.088 E+01$ & $5.631 E+06$ & $1.980 E+01$ & $C E-144$ & $3.901 E+00$ \\
\hline & & & & & & CS -137 & $1.980 E+00$ \\
\hline & & & & & & NB- 95 & $6.138 E-01$ \\
\hline & & & & & & PR-144 & $3.901 E+00$ \\
\hline & & & & & & $\mathrm{RH}-106$ & $1.980 E+00$ \\
\hline & & & & & & RU- 106 & $1.980 E+00$ \\
\hline & & & & & & SB - 125 & $8.712 E-01$ \\
\hline & & & & & & SR-90 & $1.980 E+00$ \\
\hline & & & & & & $Y-90$ & $1.980 E+00$ \\
\hline & & & & & & $2 R-95$ & $6.138 E-01$ \\
\hline & & * & & & & & $1.980 E+01$ \\
\hline & & 89 & $2.538 E+01$ & $1.111 E+07$ & $5.217 E+01$ & CE-144 & $1.028 E+01$ \\
\hline & & & & & ............... & CS- 137 & $5.217 E+00$ \\
\hline & * & & & & $8.980 E+01$ & NB-95 & $1.617 E+00$ \\
\hline & & & & & & $P R-144$ & $1.028 E+01$ \\
\hline & & & & & & RH-106 & $5.217 E+00$ \\
\hline & & & & & & RU-106 & $5.217 E+00$ \\
\hline & & & & & & SB- 125 & $2.295 E+00$ \\
\hline & & & & & & SR-90 & $5.217 E+00$ \\
\hline
\end{tabular}




\begin{tabular}{|c|c|c|c|c|c|c|c|}
\hline $\begin{array}{c}\text { GENERATING } \\
\text { AREA }\end{array}$ & $\begin{array}{l}\text { GENERATING } \\
\text { BUILDING }\end{array}$ & $\begin{array}{l}\text { DISPOSAL } \\
\text { YEAR }\end{array}$ & $\begin{array}{c}\text { ANNUAL } \\
\text { VOLUME } \\
\text { CUBIC METERS }\end{array}$ & $\begin{array}{l}\text { ANNUAL } \\
\text { WEIGHT } \\
\text { GRAMS }\end{array}$ & $\begin{array}{l}\text { ANNUAL } \\
\text { CURIES }\end{array}$ & NUCLIDE & CURIES \\
\hline (n. & 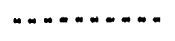 & $\ldots$ & . & ……........ & . & . & (............. \\
\hline \multirow[t]{31}{*}{ CPP } & 605 & 89 & & & & $Y-90$ & $5.217 E+00$ \\
\hline & & & & & & $2 R-95$ & $1.617 E+00$ \\
\hline & & * & & & & & 5 $3175+01$ \\
\hline & & & & & & & J.Cllte+U| \\
\hline & * & & & & & & $8.980 E+01$ \\
\hline & 606 & 71 & $5.211 E+00$ & $1.361 E+06$ & $1.000 E=03$ & MFP & $1.000 E-03$ \\
\hline & 607 & 76 & $7.250 E+00$ & $9.072 E+05$ & $6.000 E-03$ & MFP & $6.000 E-03$ \\
\hline & & 79 & $7.250 E+00$ & $1.814 E+06$ & $2.254 E-01$ & MFP & $2.254 E-01$ \\
\hline & & 81 & $1.087 E+01$ & $1.633 E+06$ & $1.500 \mathrm{E}-02$ & MFP & $1.500 E-02$ \\
\hline & & & & & - & & . n. \\
\hline & * & & & & $2.464 E-01$ & & $2.464 E-01$ \\
\hline & 608 & 71 & $1.087 E+01$ & $6.804 E+05$ & $4.500 E-03$ & MFP & $4.500 E-03$ \\
\hline & & 72 & $3.398 \mathrm{E}+00$ & $4.536 E+05$ & $5.000 E-02$ & MFP & $5.000 E-02$ \\
\hline & & 73 & $2.736 E+01$ & $4.037 E+06$ & $9.610 E-04$ & MFP & $9.610 E-04$ \\
\hline & & 74 & $1.118 E+01$ & $1.533 E+06$ & $2.046 E-03$ & MFP & $1.000 E-08$ \\
\hline & & & & & & $U-235$ & $1.434 E-04$ \\
\hline & & & & & & $U-238$ & $1.903 E-03$ \\
\hline & & * & & & & & $2.046 E-03$ \\
\hline & & 75 & $6.117 E+00$ & $4.536 E+05$ & $7.500 E-03$ & MAP & $3.750 E-03$ \\
\hline & & & & & & MFP & $3.750 E-03$ \\
\hline & & $\star$ & & & & & $7.500 E-03$ \\
\hline & . & 76 & $1.469 E+02$ & $3.683 E+07$ & $3.685 E-02$ & MFP & $3.685 E-02$ \\
\hline & & 84 & $1.087 E+01$ & $2.087 E+06$ & $2.400 E-02$ & MFP & $2.400 E-02$ \\
\hline & & & & & 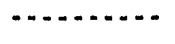 & & n. \\
\hline & * & & & & $1.259 E-01$ & & $1.259 E-01$ \\
\hline & 610 & 83 & $5.185 E+02$ & $1.607 E+08$ & $2.662 E+01$ & $C E-144$ & $4.844 E+00$ \\
\hline & & & & & & CS -137 & $2.429 E+00$ \\
\hline & & & & & & MFP & $2.063 E+00$ \\
\hline & . & & & & & NB-95 & $7.623 E-01$ \\
\hline & & & & & & $P R=144$ & $4.844 E+00$ \\
\hline & & & & & & $R H=106$ & $2.459 E+00$ \\
\hline
\end{tabular}



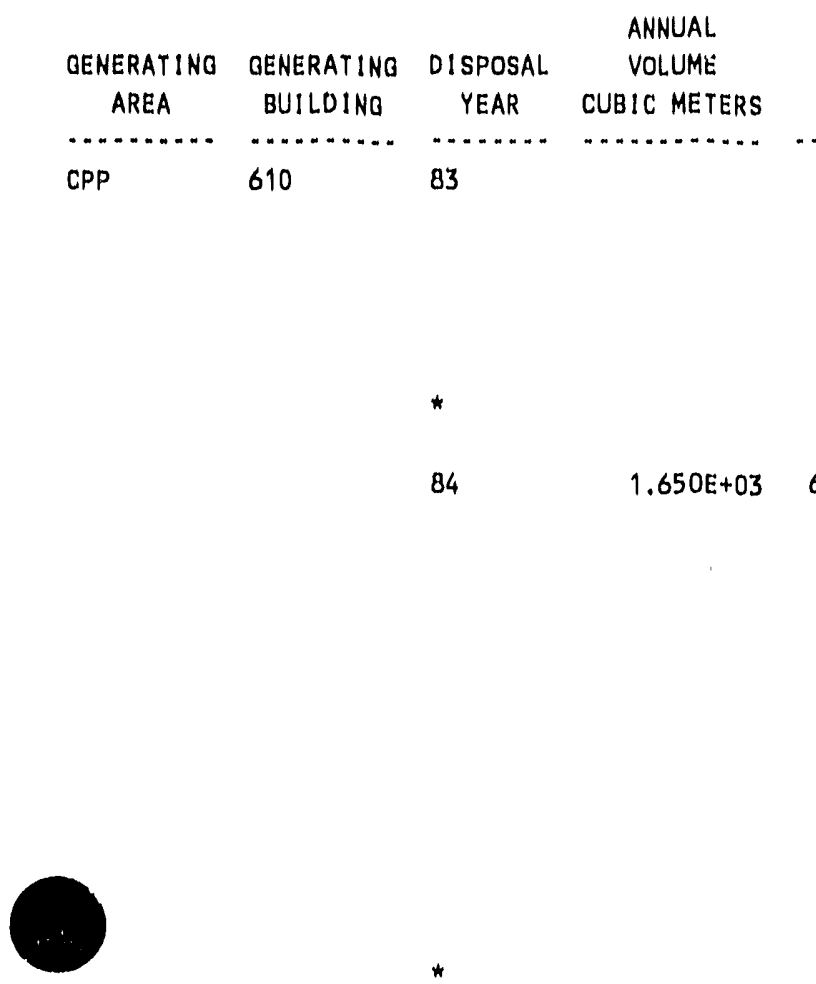

*

85

$7.785 E+02$

$2.517 E+0$

$1.038 E+02$

$N / A$

CE -144

CS- 137

MAP

MFP

NB- 95

$P R-144$

$\mathrm{RH}-106$

$\mathrm{RU}-106$

$S B-125$

$S R-90$

$Y-90$

$2 R-95$

86
$9.197 E+02$

\begin{abstract}
$2.747 E+08$
\end{abstract}
CE- 144

CS- 137

MFP

$N B-95$

$P R-144$

$\mathrm{RH}-106$

RU- 106
CURIES

..........

$2.459 E+00$

$1.082 E+00$

$2.459 E+00$

$2.459 E+00$

7.623E-01

$2.662 E+01$

$0.000 E+00$

$1.561 \mathrm{E}+01$

$7.429 E+00$

$2.414 E+01$

$2.457 E+00$

$1.561 \mathrm{E}+01$

$7.925 \mathrm{E}+00$

$7.925 E+00$

$3.487 E+00$

$7.925 \mathrm{E}+00$

$7.925 E+00$

$2.457 E+00$

. . . . .......

$1.029 E+02$

$0.000 E+00$

$1.766 E+01$

$8.965 \mathrm{E}+00$

$8.000 \mathrm{E}-03$

$1.418 E+01$

$2.779 E+00$

$1.766 E+01$

$8.965 E+00$

$8.965 E+00$

$3.945 E+00$

$8.965 E+00$

$8.965 E+00$

$2.779 E+00$

..........

$1.038 E+02$

$3.627 E+01$

$1.841 \mathrm{E}+01$

$2.962 E+01$

$5.708 E+00$

$3.627 E+01$

1. $841 E+01$

$1.84 \mathrm{IE}+01$ 
IDAHO OPERATIONS OFFICE

U.S. DEPARTMENT OF ENEROY

INEL WASTE MANAQEMENT INFORMATION SYSTEM

ANNUAL SUMMARY FOR CPP

\begin{tabular}{|c|c|c|c|c|c|c|c|}
\hline $\begin{array}{l}\text { OENERATINO } \\
\text { AREA }\end{array}$ & $\begin{array}{l}\text { OENERATINO } \\
\text { BUILDINA }\end{array}$ & $\begin{array}{l}\text { DISPOSAL } \\
\text { YEAR }\end{array}$ & $\begin{array}{c}\text { ANNUAL } \\
\text { VOLUME } \\
\text { CUBIC METERS }\end{array}$ & $\begin{array}{l}\text { ANNUAL } \\
\text { WEIOHT } \\
\text { GRAMS }\end{array}$ & $\begin{array}{l}\text { ANNUAL } \\
\text { CURIES }\end{array}$ & NUCL.IDE & CURIES \\
\hline (............. & n.............. & n... & 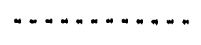 & n............ & 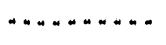 & . & $\ldots \ldots$ \\
\hline \multirow[t]{37}{*}{ CPP } & 610 & 86 & & & & $s B-125$ & B. 102E+00 \\
\hline & & & & & & $S R=90$ & $1.841 E+01$ \\
\hline & & & & & & $Y=90$ & $1.841 E+01$ \\
\hline & & & & & & $2 R-95$ & $5.708 E+00$ \\
\hline & & & & & & & ............. \\
\hline & & * & & & & & $2.138 E+02$ \\
\hline & & 87 & $1.117 E+03$ & $5.082 E+08$ & $2.141 \mathrm{E}+02$ & CE -144 & $2.656 \mathrm{E}+01$ \\
\hline & & & & & & $C 0.60$ & $1.760 E-01$ \\
\hline & & & & & & $\operatorname{cs} \cdot 13 / 4$ & $1.064 E-01$ \\
\hline & & & & & & Cs. 137 & $4.241 E+01$ \\
\hline & & & & & & $E U-152$ & $6.158 E+00$ \\
\hline & & & & & & EU-154 & $4.348 E+00$ \\
\hline & & & & & & $E U \cdot 155$ & $9.200 E-01$ \\
\hline & & & & & & MFP & $3.151 E+01$ \\
\hline & & & & & & $N B=95$ & $4.179 E+00$ \\
\hline & & & & & & $P R=144$ & $2.656 E+01$ \\
\hline & & & & & & RH= 106 & $1.348 E+01$ \\
\hline & & & & & & RU - 106 & $1.348 E+01$ \\
\hline & & & & & & SB- 125 & $8.256 E+00$ \\
\hline & & & & & & $S R=90$ & $1.588 \mathrm{E}+01$ \\
\hline & & & & & & $Y-90$ & $1.588 E+01$ \\
\hline & & & & & & $2 R-95$ & $4.179 E+00$ \\
\hline & & & & & & & $\cdots$ \\
\hline & & * & & & & & $2.141 E+02$ \\
\hline & & 88 & $1.813 E+00$ & $4.540 E+05$ & $1.400 E-02$ & MFP & $1.400 E-02$ \\
\hline & & & & & $\cdots$ & & $\ldots$ \\
\hline & $\star$ & & & & $6.612 E+02$ & & $6.612 E+02$ \\
\hline & 617 & 73 & $1.841 E+01$ & $7.938 E+06$ & $2.100 E-04$ & MFP & $2.100 E-04$ \\
\hline & & 76 & $6.162 E+01$ & $9.072 E+06$ & $1.100 E-02$ & MFP & $1.100 E-02$ \\
\hline & & 79 & $1.450 E+01$ & $4.536 E+06$ & $4.400 E-01$ & MFP & $4.400 E-01$ \\
\hline & & 81 & $2.174 E+01$ & $4.672 E+06$ & $3.390 E-01$ & MFP & $3.390 E-01$ \\
\hline & & & & & . & & n........ \\
\hline & $\star$ & & & & $7.902 E-01$ & & $7.902 E-01$ \\
\hline & 619 & 74 & $5.664 E+00$ & $9.072 E+05$ & $1.000 E-04$ & MFP & $1.000 E-04$ \\
\hline & 620 & 71 & $2.039 E+00$ & $3.629 E+05$ & $1.500 E-03$ & MFP & $1.500 E-03$ \\
\hline & & 73 & $2.050 E+01$ & $3.039 E+06$ & $3.813 \mathrm{E}-02$ & MFP & $3.750 E-02$ \\
\hline & & & & & & $U-235$ & $6.249 E-04$ \\
\hline
\end{tabular}

RUN DATE: 04/03/91

PAOE 82 


\begin{tabular}{|c|c|c|c|c|c|c|c|}
\hline \multirow{5}{*}{$\begin{array}{c}\text { GENERATING } \\
\text { AREA } \\
\ldots\end{array}$} & $\begin{array}{l}\text { QENERATING } \\
\text { BUI LDINO }\end{array}$ & $\begin{array}{l}\text { DISPOSAL } \\
\text { YEAR }\end{array}$ & $\begin{array}{c}\text { ANNUAL } \\
\text { VOL.UME } \\
\text { CUBIC METERS }\end{array}$ & $\begin{array}{l}\text { ANNUAL } \\
\text { WEIOHT } \\
\text { GRAMS }\end{array}$ & $\begin{array}{l}\text { ANNUAL } \\
\text { CURIES }\end{array}$ & NUCL IDE & CURIES \\
\hline & , n............ & $\cdots$ & 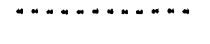 & , n........ & 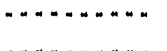 & 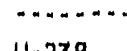 & a \\
\hline & * & & & & $3.963 E-02$ & $U \cdot 238$ & $\begin{array}{r}6.993 E-06 \\
\cdots\end{array}$ \\
\hline & & * & & & & & $3.813 \mathrm{E}-02$ \\
\hline & * & & & & & & $3.963 \mathrm{E}-02$ \\
\hline \multirow[t]{30}{*}{ CPP } & 621 & 76 & $1.903 E+01$ & $4.536 E+06$ & $4.000 E-03$ & MFP & $4.000 E-03$ \\
\hline & 627 & 71 & $1.514 E-02$ & $1.814 E+04$ & $9.630 E-07$ & $1 \mathrm{U}-235$ & $9.630 \mathrm{E}-07$ \\
\hline & & 72 & $2.365 \mathrm{E}-01$ & $3.856 E+04$ & $1.001 E+00$ & MFP & $1.000 E+00$ \\
\hline & & & & & & TH-232 & $1.090 \mathrm{E}-07$ \\
\hline & & & & & & U.235 & $5.211 \mathrm{E}-04$ \\
\hline & & & & & & $U=238$ & $6.184 E=06$ \\
\hline & & * & & & & & $1.001 E+00$ \\
\hline & & 73 & $2.266 \mathrm{E}+00$ & $6.804 E+05$ & $1.000 E-04$ & MFP & $1.000 \mathrm{E}-04$ \\
\hline & & 74 & $3.059 E+00$ & $1.724 E+06$ & $5.000 E-04$ & MFP & $5.000 E \cdot 04$ \\
\hline & & 75 & $2.086 E+01$ & $8.298 E+06$ & $1.358 E+01$ & $B A-140$ & $1.350 E+00$ \\
\hline & & & & & & $C E-141$ & $1.350 E+00$ \\
\hline & & & & & & CE- 144 & $2.025 E+00$ \\
\hline & & & & & & CS. 134 & $4.060 E-02$ \\
\hline & & & & & & CS -137 & $2.700 E+00$ \\
\hline & & & & & & $1 . A-140$ & $2.025 E+00$ \\
\hline & & & & & & MFP & $2.325 \mathrm{E}-02$ \\
\hline & & & & & & $R B-86$ & $7.600 E=04$ \\
\hline & & & & & & $R U \cdot 103$ & $2.029 E+00$ \\
\hline & & & & & & SE -75 & $4.556 E-03$ \\
\hline & & & & & & TH-232 & $9.911 E-03$ \\
\hline & & & & & & U-235 & $7.615 E-04$ \\
\hline & & & & & & U.238 & $2.496 E-05$ \\
\hline & & & & & & $2 R=45$ & 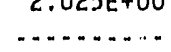 \\
\hline & & * & & & & & $1.358 E+01$ \\
\hline & & 76 & $3.172 E+00$ & $1.814 E+05$ & $6.830 E-04$ & $N P \cdot 237$ & $4.200 E=06$ \\
\hline & & & & & & $\mathrm{PU}-238$ & $6.200 E-04$ \\
\hline & & & & & & PU-239 & $4.100 E=05$ \\
\hline & & & & & & PU-240 & $1.700 E-05$ \\
\hline & & & & & & U.234 & $8.200 E-07$ \\
\hline & & . & & & & & $6.830 E-04$ \\
\hline
\end{tabular}


IDAHO OPERATIONS OFFICE

U.S. DEPARTMENT OF ENEROY

INEL WASTE MANAGEMENT INFORMATION SYSTEN

ANNUAL SUMMARY FOR CPP
RUN DATE: 04/03/91

PAQE

\begin{tabular}{|c|c|c|c|c|c|c|c|}
\hline QENERATING & QENERATINO & DISPOSAL & $\begin{array}{l}\text { ANNUAL } \\
\text { VOLUME }\end{array}$ & $\begin{array}{l}\text { ANNUAL } \\
\text { WEIOHT }\end{array}$ & ANA'UAL & & \\
\hline AREA & BUILDINO & YEAR & CUBIC METERS & QRAMS & CURIES & NUCLIDE & CURIES \\
\hline 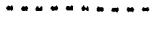 & , n. & (n)....... & , nan. & n......... & ……… & $\cdots+\cdots+\cdots+\cdots$ & $\ldots$ \\
\hline \multirow[t]{41}{*}{$\mathrm{CPP}$} & 627 & 77 & $3.798 E-02$ & $9.279 E+03$ & $1.026 \mathrm{E}=01$ & CS -137 & $4.020 E-02$ \\
\hline & & & & & & PU-239 & $4.690 E-05$ \\
\hline & & & & & & $S R=90$ & $4.020 E-02$ \\
\hline & & & & & & $U \cdot 234$ & 2. $130 \mathrm{E}-02$ \\
\hline & & & & & & $U-235$ & $7.169 E-04$ \\
\hline & & & & & & $U-236$ & $8.892 E-05$ \\
\hline & & & & & & $U-238$ & $6.920 E-06$ \\
\hline & & * & & & & & …............ \\
\hline & & $n$ & & & & & $1.026 E-01$ \\
\hline & & 79 & $3.645 E+01$ & $8.351 E+06$ & $6.663 E+00$ & $C E-144$ & $1.038 E+00$ \\
\hline & & & & & & CS- 137 & $5.217 E-01$ \\
\hline & & & & & & MFP & $1.390 E+00$ \\
\hline & & & & & & $N B-95$ & $1.720 E-01$ \\
\hline & & & & & & $P R-144$ & $1.038 E+00$ \\
\hline & & & & & & $R A-2.26$ & $1.657 \mathrm{E}-04$ \\
\hline & & & & & & RH- 106 & $5.217 E-01$ \\
\hline & & & & & & RU- 106 & $5.217 E-01$ \\
\hline & & & & & & $S B=125$ & $2.442 E-01$ \\
\hline & & & & & & SR -90 & $5.217 E-01$ \\
\hline & & & & & & $Y-90$ & $5.217 \mathrm{E}-01$ \\
\hline & & & & & & $2 R-95$ & $1.720 \mathrm{E}-01$ \\
\hline & & & & & & & $\cdots$ \\
\hline & & * & & & & & $6.663 E+00$ \\
\hline & & 81 & $1.450 E+01$ & $2.767 E+06$ & $5.680 E+00$ & CE- 144 & $1.045 E+00$ \\
\hline & & & & & & CS -137 & $5.255 E-01$ \\
\hline & & & & & & MFP & $3.689 \mathrm{E}-01$ \\
\hline & & & & & & $\mathrm{NB}-95$ & $1.733 E-01$ \\
\hline & & & & & & $P R=1144$ & $1.045 E+00$ \\
\hline & & & & & & RH -106 & $5.255 E-01$ \\
\hline & & & & & & $R U=106$ & $5.255 E-01$ \\
\hline & & & & & & SB- 125 & $2.460 E-01$ \\
\hline & & & & & & SR-90 & $5.255 E-01$ \\
\hline & & & & & & $U-238$ & $4.099 E-04$ \\
\hline & & & & & & $Y-90$ & $5.255 E-01$ \\
\hline & & & & & & $2 R-95$ & $1.733 E-01$ \\
\hline & & * & & & & & a \\
\hline & & & & & & & \\
\hline & & 87 & $7.250 E+00$ & $1.453 E+06$ & $1.200 E-02$ & MFP & $1.200 E-02$ \\
\hline & & 88 & $1.994 E+01$ & $4.949 E+06$ & $1.100 E-01$ & MFP & $1.100 E-01$ \\
\hline & & & & & 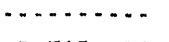 & & $\ldots$ \\
\hline & ^ & & & & $2.715 E+01$ & & $2.715 E+01$ \\
\hline
\end{tabular}



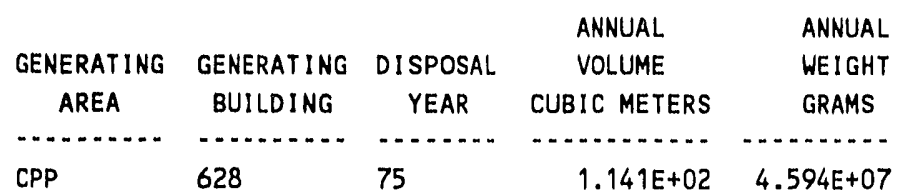

VOLUME WEIGHT

ANNUAL

METERS

$1.141 E+02 \quad 4.594 E+07 \quad 2.072 E+03$

CE -144

$4.560 E+02$

$\mathrm{CO}-60 \quad 9.625 \mathrm{E}+00$

CS- $134 \quad 2.695 \mathrm{E}+01$

CS-137 2.569E+02

EU-154 2.502E+01

Ell-155 $\quad 1.540 E+01$

MFP $1.216 E+01$

$M N-54 \quad 3.850 E+00$

RU-106 8.365E+01

SB-125 $\quad 1.029 E+01$

$S R-90 \quad 1.158 E+03$

ZR-NB-95 1.470E+01

-.........

$2.072 E+03$

77

$1.827 E+02 \quad 1.180 E+08 \quad 1.144 E+02$

Co- 60

1. 142E-01

CS-134 2.285E-01

CS-137 6.283E+01

EU-154 4.570E-01

MFP 1.677E-01

PU-238 2.285E-01

PU-239 1.069E-01

PU-240 7.403E-03

SR $-90 \quad 2.513 E+01$

$Y-90 \quad 2.513 E+01$

1.144E+02

78

$4.350 E+01$

$8.845 E+06$

3.110E-01 MFP

3.110E-01

*

630

71

$2.073 E+01$

$3.561 E+06$

2.187E+03

2.187E+03

72

$1.875 E+01$

$4.763 E+06$

1.205E-02 MFP

$1.205 E-02$

73

$2.804 E+00 \quad 1.814 E+06 \quad 1.000 E-05 \quad$ MFP

$6.750 E-03$

74

$3.858 E+01 \quad 1.398 E+07 \quad 8.520 E-01$ MFP

$1.000 E-05$

75

$1.057 E+02$

$3.590 E+07$

8.559E-01 MFP

$8.520 E-01$

76

$3.104 E+02$

$8.886 E+07$

$8.492 E+00$

CE -144

CS -137

MFP

PR-144

8.559E-01

$1.477 E+00$

7.397E-01

$3.097 E+00$

$4.301 E-01$ 


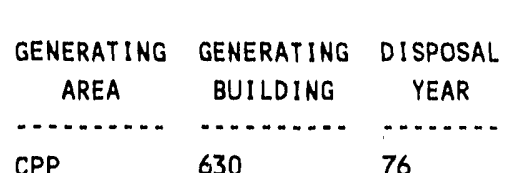

76

77

$2.313 E+02$

$3.723 E+07$

$6.921 E+00$

LE -144

CS- 137

MFP

$P R-144$

$\mathrm{RH}-106$

$\mathrm{RU}-106$

SB- 125

SR -90

$Y-90$

ZR-NB- 95

*

78

$2.681 \mathrm{E}+0$

$9.259 \mathrm{E}+0$

$6.220 E+01$

CE- 144

CS -134

CS-137

MFP

NB-95

$P R-144$

RH-106

RU-106

SB- 125

SR -90

$Y-90$

ZR-95

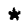

79
$2.399 E+02 \quad 1.657 E+08 \quad 2.864 E+02$

CE -144
CS- 137
MFP

MFP

PR- 144

RA- 226

RH- 106

RU- 106

SB- 125
CURIES

2. $162 \mathrm{E}-01$

7.397E- 01

3. $455 E-01$

7.397E-01

2. $162 \mathrm{E}-01$

4.916E- 01

$8.492 E+00$

$3.646 E-01$

$1.833 \mathrm{E}-01$

$5.068 \mathrm{E}+00$

3.646E- 01

$1.833 E-01$

$1.833 E-01$

8.580E-02

$1.833 E-01$

$1.833 E-01$

$1.209 E-01$

$6.921 E+00$

$1.065 E+01$

$1.472 E-02$

$6.641 E+00$

$6.530 E+00$

$1.764 E+00$

$1.065 E+01$

$5.375 E+00$

$5.375 E+00$

2. $508 E+00$

$5.459 E+00$

$5.459 \mathrm{E}+00$

$1.764 \mathrm{E}+00$

6. $220 E+01$

5.294E+01

2.661E+01

1. $739 E+01$

8. $776 E+00$

$5.294 \mathrm{E}+01$

$1.000 E-01$

$2.661 E+01$

$2.661 E+01$

$1.246 E+01$ 


\begin{tabular}{|c|c|c|}
\hline GENERATING & GENERATING & DISPOSAL \\
\hline AREA & BUILDING & YEAR \\
\hline - & - n & - n. \\
\hline$C P D$ & 630 & 79 \\
\hline
\end{tabular}

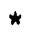

80

81

82

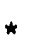

83

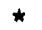

633

*
ANNUAL ANNUAL

VOLUUME WEIGHT CUBIC METERS GRAMS GRAMS

ANNUAL CURIES

(..........

NUCL IDE

SR -90

$Y-90$

2R-95

CE -144

CS- 137

MFP

NB-95

PR- 144

RH- 106

RU-106

SB- 125

SR-90

$Y-90$

ZR-95

$3.128 \mathrm{E}+01$

$2.131 E+07$

3.574E-01

MAP

MFP

CE -144

CS- 137

MFP

NB-95

$P R-144$

RH- 106

RU- 106

SB- 125

SR-90

$Y-90$

ZR- 95

MFP

$2.121 E+01$

$1.474 E+0$

$$
\text { .. }
$$

$8.697 E+02$

$3.398 E+00 \quad 9.072 E+05 \quad 2.250 E-02$ MFP

$7.873 E+00$

$2.041 E+06$

9.000E-01 MFP
$9.000 \mathrm{E}-01$

5.4P7E+01

$2.718 E+01$

$2.632 E+01$

$8.963 E+00$

$5.407 E+01$

$2.718 E+01$

2.718E+01

$1.272 E+01$

$2.718 \mathrm{E}+01$

$2.718 E+01$

$8.963 E+00$

$3.010 E+02$

3. $845 E+01$

2.014E+01

$7.304 \mathrm{E}+00$

$6.105 E+00$

$3.845 E+01$

2.014E+01

2. $014 E+01$

$8.665 E+00$

$1.851 E+01$

1.851E+01

6. $105 E+00$

......

$2.025 E+02$

$1.300 E+03$

3.561E-01

..........

3.574E- 01

9.076E-02

..........

8.697E+02

$2.250 E-02$ 


\begin{tabular}{|c|c|c|c|c|c|c|c|}
\hline $\begin{array}{c}\text { GENERATING } \\
\text { AREA }\end{array}$ & $\begin{array}{l}\text { GENERATING } \\
\text { BUILDING }\end{array}$ & $\begin{array}{l}\text { DISPOSAL } \\
\text { YEAR }\end{array}$ & $\begin{array}{c}\text { ANNUAL } \\
\text { VOLUME } \\
\text { CUBIC METERS }\end{array}$ & $\begin{array}{l}\text { ANNUAL } \\
\text { WEIGHT } \\
\text { GRAMS }\end{array}$ & $\begin{array}{l}\text { ANNUAL } \\
\text { CURIES }\end{array}$ & NUCL IDE & CURIES \\
\hline - & , n & $\ldots$ & , n & 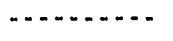 & - & ( n - n & . \\
\hline \multirow[t]{42}{*}{ CPP } & 633 & 73 & $4.339 E+01$ & $4.105 E+07$ & $1.216 E+03$ & CE- 144 & $3.649 E+02$ \\
\hline & & & & & & CS -137 & $1.824 E+02$ \\
\hline & & & & & & MFP & $9.730 E+01$ \\
\hline & & & & & & RU-106 & $1.824 E+02$ \\
\hline & & & & & & SB-125 & $8.513 E+01$ \\
\hline & & & & & & SR-90 & $1.824 E+02$ \\
\hline & & & & & & $Z R-N B-95$ & $1.216 E+02$ \\
\hline & & & & & & & n. \\
\hline & & * & & & & & $1.216 E+03$ \\
\hline & & 74 & $2.133 E+01$ & $3.910 E+07$ & $1.575 E+03$ & CE- 144 & $4.230 E+02$ \\
\hline & & & & & & CS -137 & $2.115 E+02$ \\
\hline & & & & & & MFP & $2.778 E+02$ \\
\hline & & & & & & $R U-106$ & $2.115 E+02$ \\
\hline & & ' & & & & SB- 125 & $9.870 E+01$ \\
\hline & & & & & & SR-90 & $2.115 E+02$ \\
\hline & & & & & & $2 R-N B-95$ & $1.410 E+02$ \\
\hline & & & & & & & 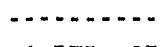 \\
\hline & & * & & & & & $1.575 E+03$ \\
\hline & & 75 & $8.270 E+00$ & $4.626 E+06$ & $1.155 E+03$ & CE- 144 & $2.970 E+02$ \\
\hline & & & & & & CS -137 & $1.485 E+02$ \\
\hline & & & & & & MFP & $2.442 E+02$ \\
\hline & & & & & & $R U-106$ & $1.485 E+02$ \\
\hline & & & & & & SB- 125 & $6.930 E+01$ \\
\hline & & & & & & SR -90 & $1.485 E+02$ \\
\hline & & & & & & $Z R-N B-95$ & $9.900 E+01$ \\
\hline & & & & & & & n. \\
\hline & & * & & & & & $1.155 E+03$ \\
\hline & & 76 & $1.728 E+01$ & $5.192 E+07$ & $9.900 E+02$ & CE- 144 & $2.597 E+02$ \\
\hline & & & & & & CS -137 & $1.300 E+02$ \\
\hline & & & & & & MFP & $6.930 E+01$ \\
\hline & & & & & & $P R-144$ & $6.171 E+01$ \\
\hline & & & & & & $\mathrm{RH}-106$ & $3.102 E+01$ \\
\hline & & & & & & $R U-106$ & $1.300 E+02$ \\
\hline & & & & & & $S B-125$ & $6.072 E+01$ \\
\hline & & & & & & $S R-90$ & $1.300 E+02$ \\
\hline & & & & & & $Y-90$ & $3.102 E+01$ \\
\hline & & & & & & $Z R-N B-95$ & $8.646 E+01$ \\
\hline & & & & & & ' & (n) \\
\hline & & * & & & & & $9.900 \mathrm{E}+02$ \\
\hline & & 77 & $6.066 E+01$ & $8.845 E+07$ & $1.327 E+03$ & CE- 144 & $2.480 E+02$ \\
\hline & & & & & & CS- 137 & $1.247 E+02$ \\
\hline & & & & & & MFP & $6.651 E+01$ \\
\hline
\end{tabular}




\begin{tabular}{cll}
$\begin{array}{l}\text { GENERATING } \\
\text { AREA }\end{array}$ & $\begin{array}{c}\text { GENERATING } \\
\text { BUILDING }\end{array}$ & $\begin{array}{c}\text { DISPOSAL } \\
\text { YEAR }\end{array}$ \\
\hline CPP & 633 & 77
\end{tabular}

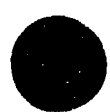

79

78 $8.457 E+02 \quad 4.841 E+08$

ANNUAL ANNUAL

VOLUME WEIGHT

CUBIC METERS GRAMS

C.........

(2......

ANNUAL

CURIES

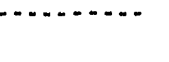

NUCL.IDE

NB. 95

$P R-144$

RH- 106

RU- 106

SB- 125

SR -90

$Y-90$

ZR-NB- 95

$2 R-95$

$8.844 E+01$

$1.862 E+08$

4.787E+03

CE- 144

CS -134

CS- 137

MFP

NB -95

PR-144

RH-106

RU- 106

SB- 125

$S R-90$

$Y-90$

ZR-95

4.84

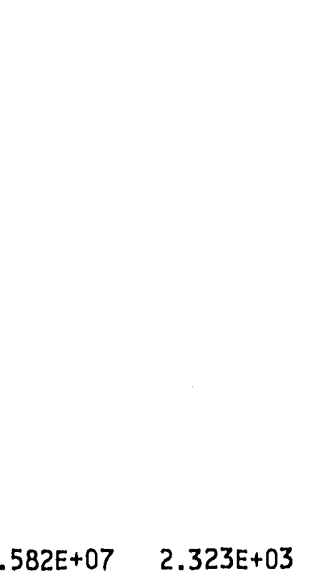

80
CE- 144

CS- 137

MFP

NB-95

CS. 134

CS- 137

MFP

NB-95

$P R-144$

RH-106

RU- 106

SB- 125

$S R-90$

$Y-90$

$Z R-95$
$1.321 E+02 \quad 3.582 E+07 \quad 2.323 E+03$

CURIES
$3.600 E+01$
$2.480 E+02$
$1.247 E+02$
$1.247 E+02$
$5.836 E+01$
$1.247 E+02$
$1.247 E+02$
$1.023 E+01$
$3.600 E+01$
$\cdots$
$1.327 E+03$

$8.948 E+02$

$1.368 \mathrm{E}-02$

4.510E+02

$2.401 E+02$

$1.483 E+02$

$8.948 E+02$

$4.498 E+02$

$4.498 \mathrm{E}+02$

2.105E+02

$4.499 E+02$

$4.499 E+02$

$1.483 \mathrm{E}+02$

$4.787 E+03$

$5.703 E+02$

7.022E-01

$3.464 E+02$

2.114E+02

$9.443 E+01$

$5.703 E+02$

2. $877 \mathrm{E}+02$

$2.877 E+02$

$1.343 E+02$

2.917E+02

$2.913 E+02$

$9.443 E+01$

3. $180 E+03$

4.470E+02

2.313E+02

$5.322 E+01$

$7.191 E+01$ 


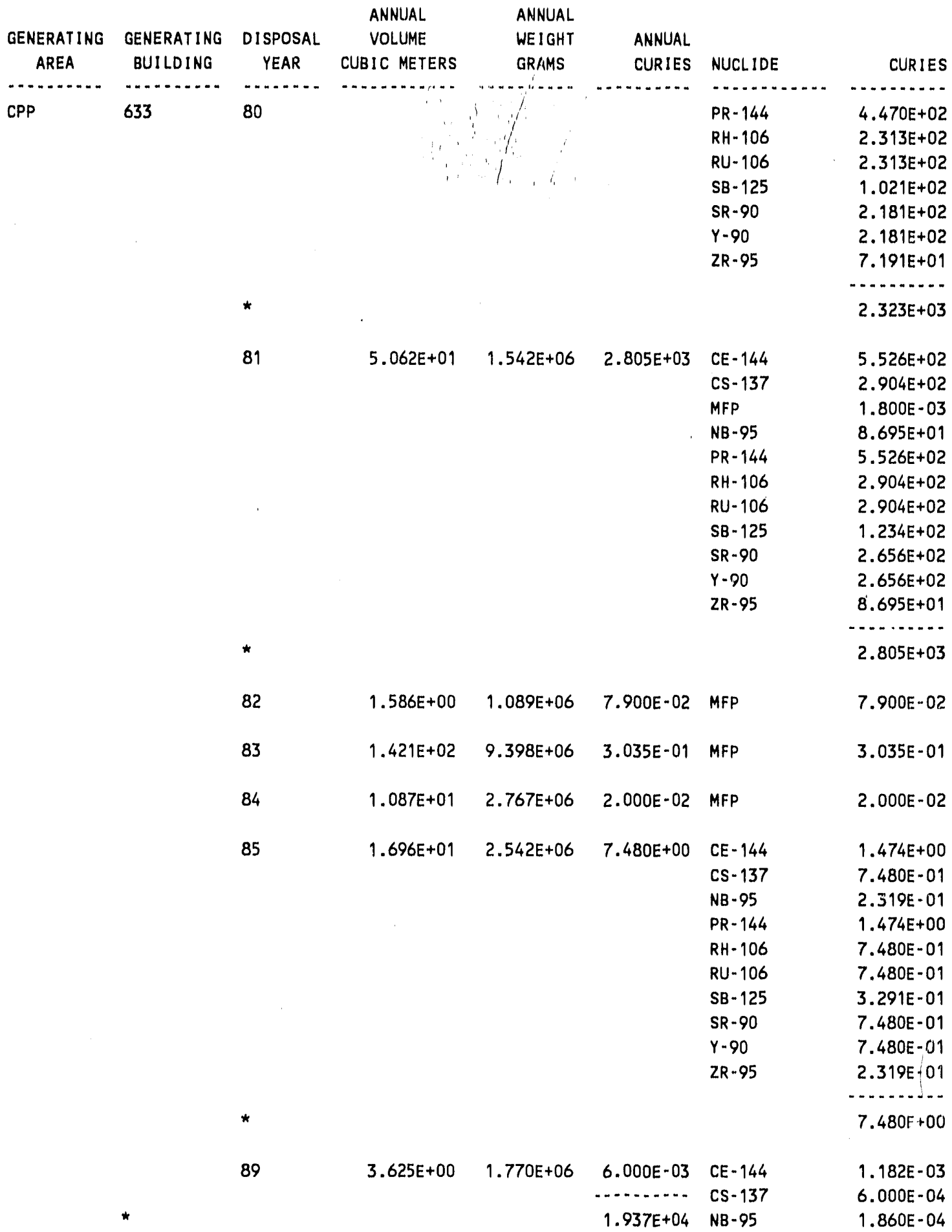




\begin{tabular}{cll}
$\begin{array}{c}\text { GENERATING } \\
\text { AREA }\end{array}$ & $\begin{array}{c}\text { GENERATING } \\
\text { BUILDING }\end{array}$ & $\begin{array}{c}\text { DISPOSAL } \\
\text { YEAR }\end{array}$ \\
\hline CPP & 633 & 89
\end{tabular}

\section{ANNUAL \\ ANNUAL}

VOLUME CUBIC METERS

WEIGHT GRAMS

ANAUAL CURIES

NUCLIDE

$P R-144$

RH- 106

RU -106

$S B-125$

$S R-90$

$Y-90$

ZR-95

*

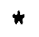

636

637

78

72

$\begin{array}{ccc}1.450 E+01 & 2.722 E+06 & 6.900 E-02 \\ 3.398 E-01 & 9.072 E+02 & 2.689 E-04\end{array}$
*

75

*

77

(

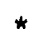

78

$4.899 E+00$

$1.161 E+06$

$3.638 E-03$

$\mathrm{TH}-232$

$\mathrm{U}-235$

U-238

*

79

U-238

MFP

U- 235

$U-238$

U-235

U. 238

(1)

$1.991 E+0$

$1.039 E+07$

$2.035 E-02$

MFP
$U-235$
$U-238$

$U-235$
$U-238$

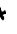

80
CURIES

$1.182 \mathrm{E}-03$

$6.000 E-04$

$6.000 E-04$

$2.640 \mathrm{E}-04$

$6.000 E-04$

$6.000 E-04$

$1.860 E-04$

...........

$6.000 \mathrm{E}-03$

$1.937 E+04$

$6.900 E-02$

$1.091 E-04$

$1.598 \mathrm{E}-04$

..........

$2.689 E-04$

1.800E-02

$9.750 E-04$

$1.485 E-04$

4.163E-05

(1..........

1.917E-02

$3.400 \mathrm{E}-04$

$2.690 \mathrm{E}-04$

$3.330 E-06$

C...........

$6.123 E-04$

3.000E-04

$1.304 \mathrm{E}-04$

4.560E-05

3.162E-03

..........

$3.638 \mathrm{E}-03$

$1.475 E-02$

$2.450 E-04$

$5.358 \mathrm{E}-03$

2.035E-02

$7.500 E-03$ 
IDAHO OPERATIONS OFFICE

RUN DATE: $04 / 03 / 91$

U.S. DEPARTMENT OF ENERQY

INEL WASTE MANAGEMENT INFORMATION SYSTEM

ANNUAL SUMMARY FOR CPP

PAGE

92

\begin{tabular}{|c|c|c|c|c|c|c|c|}
\hline $\begin{array}{l}\text { GENERATING } \\
\text { AREA }\end{array}$ & $\begin{array}{l}\text { GENERATING } \\
\text { BUILDING }\end{array}$ & $\begin{array}{l}\text { DISPOSAL } \\
\text { YEAR }\end{array}$ & $\begin{array}{c}\text { ANNUAL } \\
\text { VOLUME } \\
\text { CUB!C METERS }\end{array}$ & $\begin{array}{l}\text { ANNUAL } \\
\text { WEIGHT } \\
\text { GRAMS }\end{array}$ & $\begin{array}{l}\text { ANNUAL } \\
\text { CUR!ES }\end{array}$ & NUCL IDE & CURIES \\
\hline . n........ & . & $\ldots . . . .$. & ................ & ……. & 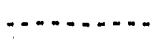 & 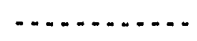 & ............ \\
\hline \multirow[t]{38}{*}{ CPP } & 637 & 81 & $2.582 E+01$ & $9.889 E+06$ & $1.115 E-02$ & MFP & $1.115 \mathrm{E}-02$ \\
\hline & & 83 & $3.625 E+00$ & $6.804 E+05$ & $1.960 E-02$ & $A M-241$ & $1.620 E-02$ \\
\hline & & & & & & $C F-252$ & $2.140 E-03$ \\
\hline & & & & & & $N P-237$ & $2.115 E-05$ \\
\hline & & & & & & PU-239 & $1.228 \mathrm{E}-03$ \\
\hline & & & & & & $U-238$ & $1.499 \mathrm{E}-05$ \\
\hline & & & & & & & (n.......... \\
\hline & & * & & & & & $1.960 E-02$ \\
\hline & & 89 & $3.625 E+00$ & $9.080 E+05$ & $6.000 E-03$ & MFP & $6.000 E-03$ \\
\hline & & & & & n. & & (n. \\
\hline & $\star$ & & & & 8.829E-02 & & $8.829 E-02$ \\
\hline & 640 & 71 & $5.664 E-02$ & $2.000 E+03$ & $6.680 E-04$ & $U-238$ & $6.680 E-04$ \\
\hline & & 72 & $1.008 E+01$ & $9.072 E+05$ & $6.530 E-01$ & MFP & $6.530 \mathrm{E}-01$ \\
\hline & & 73 & $5.515 \mathrm{E}+01$ & $6.486 E+06$ & $6.507 E+00$ & CE- 144 & $1.258 E+00$ \\
\hline & & & & & & CS -137 & $6.288 E-01$ \\
\hline & & & & & & MFP & $2.628 E+00$ \\
\hline & & & & & & $R U-106$ & $6.288 E-01$ \\
\hline & & & & & & $S B-125$ & $2.934 E-01$ \\
\hline & & & & & & $S R-90$ & $6.288 \mathrm{E}-01$ \\
\hline & & & & & & $U-235$ & $5.015 E-04$ \\
\hline & & & & & & $U-238$ & $2.144 E-02$ \\
\hline & & & & & & ZR-NB-95 & 4.192E-01 \\
\hline & & & & & & & n. \\
\hline & & $\star$ & & & & & $6.507 E+00$ \\
\hline & & 74 & $3.455 E+01$ & $5.353 E+06$ & $8.590 E-01$ & MFP & $8.590 E-01$ \\
\hline & & 75 & $1.854 E+02$ & $1.493 E+07$ & $3.655 E+03$ & $C E-144$ & $8.400 E-01$ \\
\hline & & & & & & $c 0-60$ & $2.188 E+03$ \\
\hline & & & & & & CS- 137 & $4.200 E-01$ \\
\hline & & & & & & FE- 55 & $3.600 E+02$ \\
\hline & & & & & & $F E-59$ & $1.846 E+02$ \\
\hline & & & & & & MFP & $6.512 E+00$ \\
\hline & & & & & & $M N-54$ & $3.600 E+02$ \\
\hline & & & & & & $M N-56$ & $5.538 \mathrm{E}+02$ \\
\hline & & & & & & $R U-106$ & $4.200 E-01$ \\
\hline & & & & & & $S B-125$ & $1.960 E-01$ \\
\hline & & & & & & $S R=90$ & $4.200 E-01$ \\
\hline & & & & & & $Z R-N B-95$ & $2.800 E-01$ \\
\hline & & $\star$ & & & & & $3.655 \mathrm{E}+03$ \\
\hline
\end{tabular}




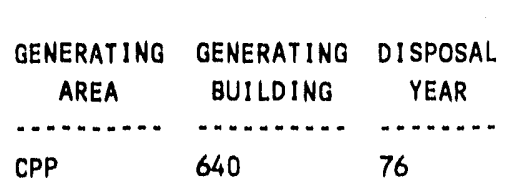

$\begin{aligned} & \text { ANNUAL } \\ & \text { VOLUME } \\ & \text { CUBIC METERS } \\ & 1.016 E+02\end{aligned}$

ANNUAL

GRAMS

ANNUAL

......... .

CURIES NUCLIDE

CURIES

$1.498 \mathrm{E}+07$

$1.082 E+01 \quad C E-144$

$1.425 E+00$

CS-137 7.144E-01

MFP $\quad 5.032 E+00$

PR-144 7.050E-01

RH-106 2.444E-01

RU-106 8.244E-01

SB-125 3.339E-01

SR-90 7.144E-01

$Y=90 \quad 3.544 E-01$

ZR-NB-95 4.737E-01

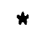

77

4.248E-01

$4.536 E+05$

$1.680 E+00 \quad C E-144$

CS- 137

MFP

$P R-144$

RH-106

$\mathrm{RU}-106$

SB- 125

$S R=90$

$Y-90$

$3.142 E-01$

1.579E-01

8. $400 E-02$

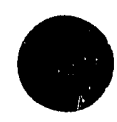

\begin{tabular}{|c|c|c|c|c|c|}
\hline & & & & $R U \cdot 106$ & $1.579 E-01$ \\
\hline & & & & $S B-125$ & $7.392 E-02$ \\
\hline & & & & $S R-90$ & $1.579 E-01$ \\
\hline & & & & $Y-90$ & $1.579 E-01$ \\
\hline & & & & ZR-NB-95 & $1.042 \mathrm{E}-01$ \\
\hline & & & & & $\cdots$ \\
\hline * & & & & & $1.680 E+00$ \\
\hline 82 & $1.784 E+00$ & $5.897 E+06$ & $1.000 \mathrm{E}-03$ & MFP & $1.000 E-03$ \\
\hline 84 & $2.718 \mathrm{E}+01$ & $1.397 E+07$ & $2.200 \mathrm{E}-01$ & $N / A$ & $0.000 E+00$ \\
\hline & & & & MFP & $2.200 E-01$ \\
\hline & & & & & - \\
\hline & & & & & $2.200 E-01$ \\
\hline 88 & $1.813 E+01$ & $5.562 E+06$ & $8.800 E-02$ & MFP & $8.800 E-02$ \\
\hline & & & - & & . \\
\hline & & & $3.676 E+03$ & & $3.676 E+03$ \\
\hline 77 & $3.738 \mathrm{E}+00$ & $9.072 E+05$ & $4.500 E-01$ & MFP & $4.500 E-01$ \\
\hline 84 & $6.097 E+01$ & $7.756 E+06$ & $1.961 E+02$ & CE- 144 & $3.861 E+01$ \\
\hline & & & & CS -137 & $1.960 E+01$ \\
\hline & & & & MFP & $9.300 \mathrm{E}-02$ \\
\hline & & & & NB - 95 & $6.076 E+00$ \\
\hline & & & & $P R-144$ & $3.861 E+01$ \\
\hline & & & & RH- 106 & $1.960 E+01$ \\
\hline & & & & $R U-106$ & $1.960 E+01$ \\
\hline
\end{tabular}




\begin{tabular}{|c|c|c|c|c|c|c|c|}
\hline $\begin{array}{l}\text { QENERATINQ } \\
\text { AREA }\end{array}$ & $\begin{array}{l}\text { GENERATING } \\
\text { BUILDING }\end{array}$ & $\begin{array}{l}\text { DISPOSAL } \\
\text { YEAR }\end{array}$ & $\begin{array}{c}\text { ANNUAL } \\
\text { VOLUME } \\
\text { CUBIC METERS }\end{array}$ & $\begin{array}{l}\text { ANNUAL } \\
\text { WEIGHT } \\
\text { GRAMS }\end{array}$ & $\begin{array}{l}\text { ANNUAL } \\
\text { CURIES }\end{array}$ & NUCLIDE & CURIES \\
\hline . & ................. & ........... & 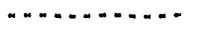 & n........... & n. & n........... & ............. \\
\hline \multirow[t]{36}{*}{ CPP } & 649 & 84 & & & & $S B-125$ & $8.624 E+00$ \\
\hline & & & & & & SR-90 & $1.960 E+01$ \\
\hline & & & & & & $Y-90$ & $1.960 E+01$ \\
\hline & & & & & & $2 R-95$ & $6.076 E+00$ \\
\hline & & * & & & & & $1.961 E+02$ \\
\hline & & 89 & $3.635 \mathrm{E}+00$ & $1.080 E+06$ & $6.000 E=03$ & MFP & $6.000 E-03$ \\
\hline & & & & & (1) & & . \\
\hline & ^ & & & & $1.965 E+02$ & & $1.965 E+02$ \\
\hline & 653 & 77 & $3.390 \mathrm{E}+01$ & $6.350 E+06$ & $4.000 E-03$ & MFP & $4.000 E-03$ \\
\hline & & 81 & $2.174 E+01$ & $5.761 E+06$ & $8.106 E+00$ & CE- 144 & $1.511 E+00$ \\
\hline & & & & & 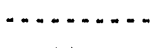 & CS- 137 & $7.596 E-01$ \\
\hline & * & & & & $8.110 E+00$ & MFP & $4.290 E-01$ \\
\hline & & & & & & NB - 95 & $2.505 E-01$ \\
\hline & & & & & & $P R-144$ & $1.511 E+00$ \\
\hline & & & & & & $\mathrm{RH}-106$ & $7.596 E-01$ \\
\hline & & & & & & $R U=106$ & $7.596 E-01$ \\
\hline & & & & & & $S B-125$ & $3.556 E-01$ \\
\hline & & & & & & $S R-90$ & $7.596 E-01$ \\
\hline & & & & & & $Y-90$ & $7.596 E-01$ \\
\hline & & & & & & $2 R-95$ & $2.505 E-01$ \\
\hline & & & & & & & - \\
\hline & & * & & & & & $8.106 E+00$ \\
\hline & $\star$ & & & & & & Q $110 \mathrm{E}+\mathrm{O}$ \\
\hline & & & & & & & \\
\hline & 656 & 79 & $2.492 E+00$ & $2.631 E+06$ & $1.500 \mathrm{E}-02$ & MFP & $1.500 E-02$ \\
\hline & 659 & 82 & $1.665 E+00$ & $1.143 E+06$ & $4.500 E-03$ & MFP & $4.500 E-03$ \\
\hline & & 83 & $1.154 E+01$ & $7.920 E+06$ & $5.924 E-02$ & MFP & $5.924 E-02$ \\
\hline & & 84 & $3.568 E+00$ & $2.041 E+06$ & $1.820 E-01$ & MFP & $1.820 E-01$ \\
\hline & & 87 & $7.250 E+00$ & $1.770 E+06$ & $1.200 E+00$ & MFP & $1.200 E+00$ \\
\hline & & 88 & $9.969 E+01$ & $2.395 E+07$ & $1.841 \mathrm{E}+01$ & $C E-144$ & $3.250 E+00$ \\
\hline & & & & & & CS -137 & $1.398 \mathrm{E}+00$ \\
\hline & & & & & & MFP & $4.430 E+00$ \\
\hline & & & & & & NB -95 & $4.334 E-01$ \\
\hline & & & & & & $P R-144$ & $2.258 \mathrm{E}+00$ \\
\hline & & & & & & $\mathrm{RH}-106$ & $1.398 E+00$ \\
\hline & & & & & & $R U-106$ & $1.398 \mathrm{E}+00$ \\
\hline
\end{tabular}




\begin{tabular}{|c|c|c|c|c|c|c|c|}
\hline OENERATING & GENERATING & DISPOSAL & $\begin{array}{l}\text { ANNUAL } \\
\text { VOLUME }\end{array}$ & $\begin{array}{l}\text { ANNUAL } \\
\text { WEIOHT }\end{array}$ & ANNUAL. & & \\
\hline AREA & BUILDING & YEAR & CUBIC METERS & QRAMS & CURIES & NUCLIDE & CURIES \\
\hline$\cdots$ & n. & ......... & 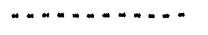 & $\cdots$ & n............ & ……........ & 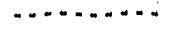 \\
\hline \multirow[t]{41}{*}{ CPP } & 659 & 88 & & & & $S B-125$ & $6.151 E-01$ \\
\hline & & & & & & $S R=90$ & $1.398 E+00$ \\
\hline & & & & & & $Y-90$ & $1.398 E+00$ \\
\hline & & & & & & $2 R-95$ & $4.334 E-01$ \\
\hline & & & & & & & $\ldots \ldots$ \\
\hline & & $\star$ & & & & & $1.841 E+01$ \\
\hline & & 89 & $1.269 E+02$ & $3.846 E+07$ & $2.564 E+01$ & CE- 144 & $3.488 E+00$ \\
\hline & & & & & $\cdots$ & Cs -137 & $1.771 E+00$ \\
\hline & * & & & & $4.549 E+01$ & MFP & $7.932 E+00$ \\
\hline & & & & & & $N B-95$ & $5.489 E-01$ \\
\hline & & & & & & $P R-144$ & $3.488 E+00$ \\
\hline & & & & & & $R H-106$ & $1.771 E+00$ \\
\hline & & & & & & $R U-106$ & $1.771 E+00$ \\
\hline & & & & & & SB- 125 & $7.791 E-01$ \\
\hline & & & & & & SR-90 & $1.771 E+00$ \\
\hline & & & & & & $Y-90$ & $1.771 E+00$ \\
\hline & & & & & & $2 R \cdot 95$ & $5.489 E-01$ \\
\hline & & & & & & & …........... \\
\hline & & * & & & & & $2.564 E+01$ \\
\hline & $\star$ & & & & & & and \\
\hline & " & & & & & & $4.549 E+01$ \\
\hline & 663 & 81 & $1.670 E+02$ & $2.801 E+07$ & $1.090 E+01$ & CE- 144 & $2.026 E+00$ \\
\hline & & & & & & CS -137 & $1.026 E+00$ \\
\hline & & & & & & MFP & $6.085 E-01$ \\
\hline & & & & & & NB -95 & $3.236 E-01$ \\
\hline & & & & & & $P R=144$ & $2.026 E+00$ \\
\hline & & & & & & RH- 106 & $1.026 E+00$ \\
\hline & & & & & & $R U-106$ & $1.026 E+00$ \\
\hline & & & & & & SB- 125 & $4.594 E-01$ \\
\hline & & & & & & $S R-90$ & $1.026 E+00$ \\
\hline & & & & & & $Y-90$ & $1.026 E+00$ \\
\hline & & & & & & $2 R-95$ & $3.236 E-01$ \\
\hline & & & & & & & . \\
\hline & & 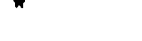 & & & & & $1.090 E+01$ \\
\hline & $\star$ & & & & & & $1.090 E+01$ \\
\hline & 666 & 87 & $3.625 E+00$ & $4.990 E+05$ & $2.700 E-01$ & MFP & $2.700 E-01$ \\
\hline & & 88 & $4.169 E+01$ & $9.943 E+06$ & $5.516 E+00$ & C.E- 144 & $7.328 E-01$ \\
\hline & & & & & & CS -137 & $3.720 E-01$ \\
\hline & & & & & & MFP & $1.796 E+00$ \\
\hline & & & & & & NB- 95 & $1.153 E-01$ \\
\hline & & & & & & $P R-144$ & $7.328 E-01$ \\
\hline
\end{tabular}


INEL WASTE MANAOEMENT INFORMATION SYSTEM

ANNUAL SUMMARY FOR CPP

\begin{tabular}{|c|c|c|c|c|c|c|c|}
\hline & & & ANNUAL. & ANNUAL. & & & \\
\hline QENERATINO & OENERATINO & DISPOSAL & VOLUME & WEIOHT & ANNUAL & & \\
\hline AREA & BUILDING & YEAR & CUBIC METERS & GRAMS & CURIES & NUCL. IDE & CURIES \\
\hline$\cdots$ & . & ........ & $\cdots \cdots$ & $\cdots$ & $\ldots \ldots \ldots$ & $\ldots \ldots \ldots \ldots$ & 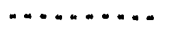 \\
\hline \multirow{39}{*}{ CPP } & 666 & 88 & & & & $R H=106$ & $3.720 \mathrm{E} \cdot 01$ \\
\hline & & & & & & $R U=106$ & $3.720 \mathrm{E}-01$ \\
\hline & & & & & & $S B=125$ & $1.637 \mathrm{E}-01$ \\
\hline & & & & & & $S R=90$ & $3.720 \mathrm{E}-01$ \\
\hline & & & & & & $Y=90$ & $3.720 E=01$ \\
\hline & & & & & & RR-95 & $1.153 E-01$ \\
\hline & & & & & & & $\cdots \cdots+\cdots$ \\
\hline & & * & & & & & $5.516 \mathrm{E}+00$ \\
\hline & & 89 & $1.088 \mathrm{E}+01$ & $2.582 E+06$ & $1.566 \mathrm{E}+00$ & CE- 144 & $2.364 E-01$ \\
\hline & & & & & 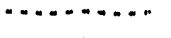 & CS -137 & $1.200 E-01$ \\
\hline & " & & & & $7.352 E+00$ & MFP & $3.660 E-01$ \\
\hline & & & & & & NB - 95 & $3.720 E-02$ \\
\hline & & & & & & $P R=144$ & $2.364 E-01$ \\
\hline & & & & & & $\mathrm{RH}=106$ & $1.200 E-01$ \\
\hline & & & & & & $R U-106$ & $1.200 E-01$ \\
\hline & & & & & & $S B-125$ & $5.280 E-02$ \\
\hline & & & & & & $S R=90$ & $1.200 E-01$ \\
\hline & & & & & & $Y-90$ & $1.200 E-01$ \\
\hline & & & & & & $2 R-95$ & $3.720 E-02$ \\
\hline & & $\star$ & & & & & $\ldots \ldots$ \\
\hline & & & & & & & $1.566 E+00$ \\
\hline & $\star$ & & & & & & $7.352 E+00$ \\
\hline & 672 & 89 & $3.444 E+01$ & $1.037 E+07$ & $9.000 E-02$ & $C E-144$ & $7.486 \mathrm{E} \cdot 03$ \\
\hline & & & & & & CS- 137 & $3.800 E-03$ \\
\hline & & & & & & MFP & $5.200 E-02$ \\
\hline & & & & & & NB-95 & $1.178 E-03$ \\
\hline & & & & & & $P R-144$ & $7.486 E-03$ \\
\hline & & & & & & $R H-106$ & $3.800 E-03$ \\
\hline & & & & & & $R U=106$ & $3.800 E-03$ \\
\hline & & & & & & $S B-125$ & 1. $172 E-03$ \\
\hline & & & & & & $S R-90$ & $3.800 E-03$ \\
\hline & & - & & & & $Y-90$ & $3.800 E-03$ \\
\hline & & & & & & $2 R-95$ & $1.178 \mathrm{E}-(13$ \\
\hline & & * & & & & & (n) \\
\hline & & & & & & & $9.000 E-02$ \\
\hline & $\star$ & & & & & & $9.000 E-02$ \\
\hline & 680 & 78 & $1.087 E+01$ & $6.804 E+05$ & $7.050 E-P ?$ & MFP & $7.050 E-02$ \\
\hline & 684 & 87 & $3.625 E+00$ & $6.356 E+05$ & $1.800 E-01$ & MFP & $1.800 E-01$ \\
\hline & & 88 & $1.088 E+02$ & $5.643 E+07$ & $1.114 E+02$ & $C E-144$ & $2.241 E+01$ \\
\hline
\end{tabular}




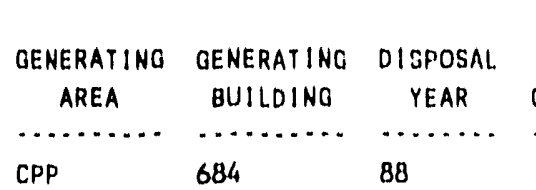

$\star$ $709 \quad 72$

715

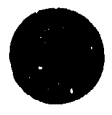

$$
73
$$

74

81

*

$\begin{array}{ll}716 & 75 \\ 743 & 83 \\ 749 & 82\end{array}$

89

$\begin{array}{cl}\text { ANNUAL } & \text { ANNUAL } \\ \text { VOLUME } & \text { WEIGHT } \\ \text { CUBIC METERS } & \text { GRAMS }\end{array}$
...........

ANNUAL

CURIES

NUCL IDE

CS-137

MFP

NB. 95

PR-144

$\mathrm{RH}-106$

$\mathrm{RU} \cdot 106$

$58-125$

SR -90

$Y-90$

$2 R \cdot 95$

$3.625 \mathrm{E}+00$

$1.820 E+06$

6.000E-02 MFP

$1.116 E+02$

$2.786 E+01 \quad 3.175 E+07 \quad 3.200 E-02$ MFP

$3.398 E+00 \quad 1.814 E+06 \quad 6.000 E-04 \quad$ MFP

$3.398 E+00 \quad 4.536 E+05 \quad 7.500 E-03 \quad$ MFP

$3.625 E+00$

$9.072 E+05 \quad 1.500 E \times 05$ MFP

8. $115 E-03$

8.115E-03

5.076E+01 1.415E+07 4.310E-02 MFP

4.078E+00 1.361E+07 1.100E-02 MFP

$7.294 E+02$

$3.267 E+08$

$1.529 E+02$

CE -144
CS. 137

MFP

$\mathrm{NB}-95$

$P R-144$

$\mathrm{RH}-106$

$\mathrm{RU}-106$

$S B-125$

$\mathrm{SR}-90$

$U-235$

$\mathrm{U}-238$

$Y-90$

ZR- 95
CURIES

-.........

$1.090 E+01$

$2.400 E+00$

$3.384 E+00$

$2.052 E+01$

$1.090 E+01$

$1.090 E+01$

$4.794 E+00$

$1.090 \mathrm{E}+01$

$1.090 E+01$

$3.378 E+00$

-.........

$1.114 E+02$

$6.000 E-02$

$1.116 \mathrm{E}+02$

3.200E-02

$6.000 E-04$

$7.500 E-03$

1.500E-05

8. $115 E-03$

4.310E-02

$1.100 E-02$

$2.780 E+01$

$1.411 E+01$

$9.677 E+00$

$5.446 E+00$

2. $780 E+01$

$1.411 E+01$

$1.411 E+01$

$6.209 E+00$

$1.411 E+01$

3. 101E-06

$1.081 E-03$

$1.411 E+01$

$5.446 E+00$

$1.529 E+02$ 


\begin{tabular}{|c|c|c|}
\hline OENERATINO & OENERATING & DISPOSAL. \\
\hline AREA & BUILDINO & YEAR \\
\hline$\cdots$ & 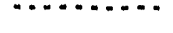 & $\ldots$ \\
\hline CPP & 749 & 83 \\
\hline
\end{tabular}

\section{$\star$}

\begin{tabular}{|c|c|c|c|c|}
\hline ANNUAL & ANNUAL & & & \\
\hline VOLUME & WE IOHT & ANNUAL & & \\
\hline CUBIC METERS & GRAMS & CURIES & NLICL IDE & CURIES \\
\hline$\cdots \cdots$ & $\cdots \ldots \ldots$ & (............ & $\ldots \ldots \ldots$ & ............. \\
\hline $2.189 \mathrm{E}+03$ & $2.380 E+09$ & $2.387 E+02$ & $B A-137 M$ & $1.686 E-01$ \\
\hline & & ג'. & $C E-144$ & $4.481 E+01$ \\
\hline & & $3.916 E+02$ & CS. 134 & $5.684 E-02$ \\
\hline & & , n & CS. 137 & $2.295 E+01$ \\
\hline & & $6.147 E+05$ & EU- 154 & $1.960 E-03$ \\
\hline & ' & (............... & $E U \cdot 155$ & $9.800 E-05$ \\
\hline & . & $6.147 E+05$ & MFP & $8.284 E+00$ \\
\hline & & & NB- 95 & $7.561 E+00$ \\
\hline & . & & $P M-147$ & $2.097 E-01$ \\
\hline & & & $P R=144$ & $4.481 E+01$ \\
\hline & & & $P U-238$ & $1.960 E-02$ \\
\hline & & & PU-241 & $5.880 E-03$ \\
\hline & & & RH- 106 & $2.288 E+01$ \\
\hline & & & $R U=106$ & $2.288 E+01$ \\
\hline & & & $S B-125$ & $1.041 E+01$ \\
\hline & & & $S M-151$ & $1.960 \mathrm{E}-03$ \\
\hline & & & SR-90 & $2.304 E+01$ \\
\hline & & & $Y-90$ & $2.304 E+01$ \\
\hline & & & $2 R=95$ & $7.539 E+00$ \\
\hline & & & & $\cdots+\ldots$ \\
\hline & & & & $2.387 E+02$ \\
\hline & & & & 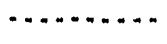 \\
\hline & & & & $3.916 E+02$ \\
\hline & & & & …........ \\
\hline & & & & $6.147 E+05$ \\
\hline & & & & $\cdots$ \\
\hline & & & & $6.147 E+05$ \\
\hline
\end{tabular}




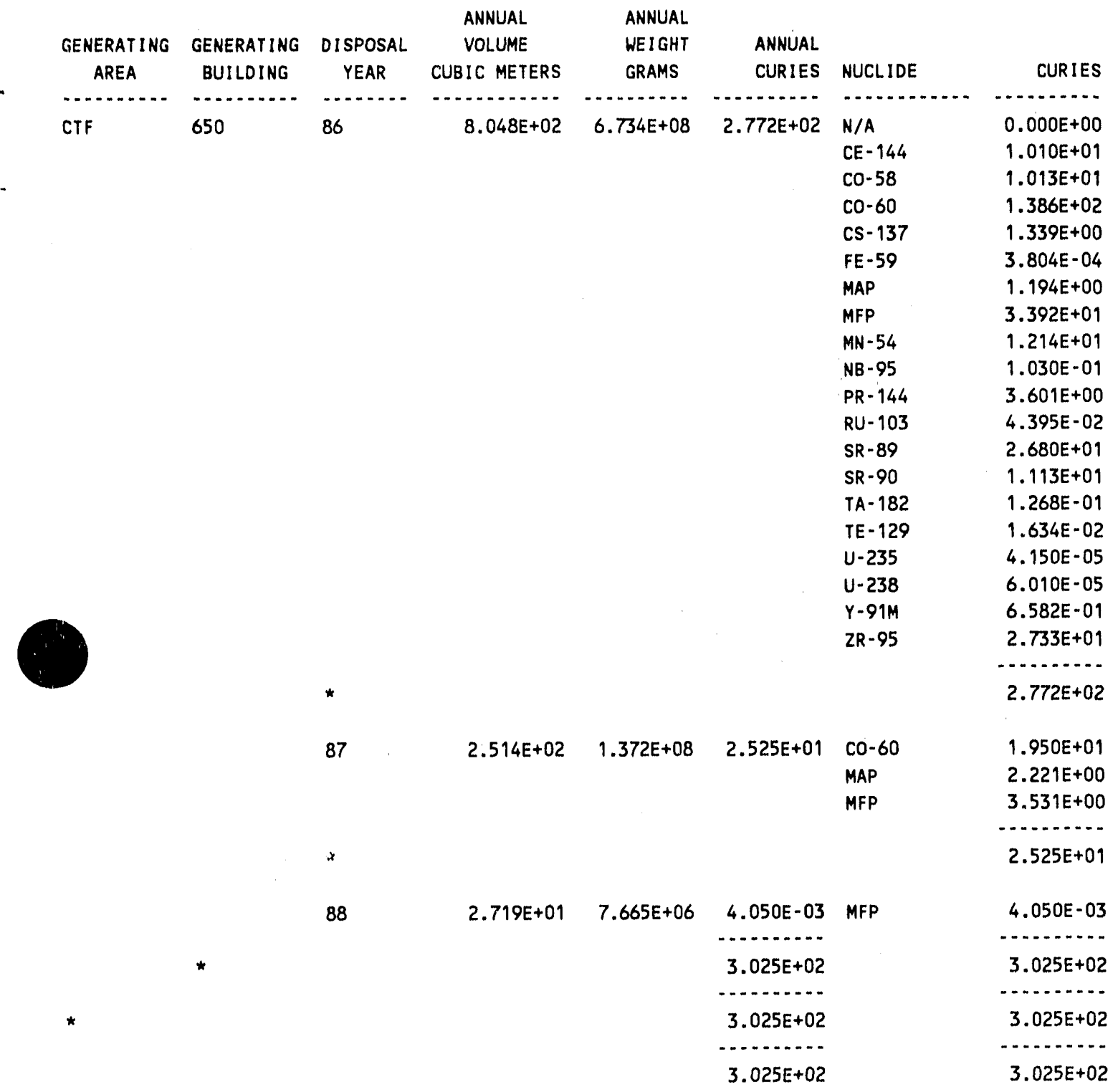




\begin{tabular}{|c|c|c|c|c|c|c|c|}
\hline & & & ANNUAL & ANNUAL & & & \\
\hline $\begin{array}{l}\text { GENERATING } \\
\text { AREA }\end{array}$ & $\begin{array}{l}\text { GENERATING } \\
\text { BUILDING }\end{array}$ & $\begin{array}{l}\text { DISPOSAL } \\
\text { YEAR }\end{array}$ & $\begin{array}{l}\text { VOLUME } \\
\text { CUBIC METERS }\end{array}$ & WEIGHT & $\begin{array}{l}\text { ANNUAL } \\
\text { CURIES }\end{array}$ & NUCLIDE & CURIES \\
\hline 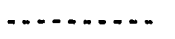 & . & $\ldots$ & (n, & . & $\ldots$ & , n & . \\
\hline \multirow[t]{36}{*}{$D+D$} & ARA & 87 & $4.162 E-01$ & $1.565 E+05$ & $2.000 E-03$ & $A G-108 M$ & $1.000 E-03$ \\
\hline & & & & & & $\mathrm{Co} \cdot 60$ & $1.000 \mathrm{E}-03$ \\
\hline & & & & & & & . \\
\hline & & * & & & & & $2.000 E-03$ \\
\hline & & & & & & & - . n........ \\
\hline & * & & & & & & $2.000 E-03$ \\
\hline & ARV & 80 & $1.812 E+00$ & $1.361 E+06$ & $1.000 E-03$ & MAP & $5.000 E-04$ \\
\hline & & & & & & MFP & $5.000 E-04$ \\
\hline & & & & & & & n. \\
\hline & & * & & & & & $1.000 E-03$ \\
\hline & & 89 & $7.250 E+00$ & $1.724 E+06$ & $6.419 E-05$ & CS -137 & $6.419 E-05$ \\
\hline & & & & & n...n........ & & ................. \\
\hline & * & & & & $1.064 \mathrm{E}-03$ & & $1.064 E-03$ \\
\hline & BOR & 80 & $1.178 E+01$ & $1.383 E+07$ & $1.950 E-03$ & MFP & $1.950 E-03$ \\
\hline & & 81 & $3.625 E+00$ & $1.814 E+06$ & $1.200 E-03$ & MAP & $6.000 E-04$ \\
\hline & & & & & . & MFP & $6.000 E-04$ \\
\hline & * & & & & $3.150 E-03$ & & - n. \\
\hline & & * & & & & & $1.200 E-03$ \\
\hline & & & & & & & - n \\
\hline & * & & & & & & $3.150 E-03$ \\
\hline & BRX & 85 & $2.800 \mathrm{E}-01$ & $1.905 E+05$ & $5.000 E-05$ & MAP & $2.500 E-05$ \\
\hline & & & & & & MFP & $2.500 E-05$ \\
\hline & & & & & & & n........... \\
\hline & & * & & & & & $5.000 E-05$ \\
\hline & & 89 & $9.342 E+00$ & $2.130 E+07$ & $2.126 \mathrm{E}-05$ & $\mathrm{CO}-60$ & $8.200 E-07$ \\
\hline & & & & & 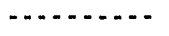 & CS -137 & $1.980 \mathrm{E}-05$ \\
\hline & * & & & & $7.126 E-05$ & $\mathrm{TH}-234$ & $6.400 E-07$ \\
\hline & & & & & & & $\cdots$ \\
\hline & & * & & & & & $2.126 \mathrm{E}-05$ \\
\hline & $\star$ & & & & & & $7.126 \mathrm{E}-05$ \\
\hline & CTF & 87 & $7.200 E+00$ & $2.951 E+06$ & $8.250 E-03$ & MFP & $8.250 E-03$ \\
\hline & HTR & 89 & $7.250 E+00$ & $2.631 E+06$ & $2.000 E-04$ & CO- 60 & $1.400 E-04$ \\
\hline & & & & & & CS- 137 & $6.000 E-05$ \\
\hline & & & & & & & .................. \\
\hline & & * & & & & & $2.000 E-04$ \\
\hline & * & & & & & & $2.000 E-04$ \\
\hline
\end{tabular}




\begin{tabular}{|c|c|c|c|c|c|c|c|}
\hline $\begin{array}{l}\text { GENERATING } \\
\text { AREA }\end{array}$ & $\begin{array}{l}\text { GENERATING } \\
\text { BUILDING }\end{array}$ & $\begin{array}{l}\text { DISPOSAL } \\
\text { YEAR }\end{array}$ & $\begin{array}{c}\text { ANNUAL } \\
\text { VOLUME } \\
\text { CUBIC METERS }\end{array}$ & $\begin{array}{l}\text { ANNUAL } \\
\text { WEIGHT } \\
\text { GRAMS }\end{array}$ & $\begin{array}{l}\text { ANNUAL } \\
\text { CURIES }\end{array}$ & NUCLIDE & CURIES \\
\hline , n & - & n........ & . & . & , n & $\cdots$ & , n \\
\hline \multirow[t]{30}{*}{$D+D$} & IET & 79 & $6.798 E+01$ & $1.025 E+08$ & $3.980 E+00$ & 00.60 & $1.660 E+00$ \\
\hline & & & & & & Cs-137 & $6.600 E-01$ \\
\hline & & & & & & MN-54 & $1.660 E+00$ \\
\hline & & * & & & & & $3.980 E+00$ \\
\hline & & 85 & $1.269 E+01$ & $7.350 E+06$ & $1.120 \mathrm{E}-02$ & MFP & $1.120 E-02$ \\
\hline & & 86 & $4.531 E+01$ & $2.571 E+07$ & $3.805 E-02$ & MFP & $3.805 E-02$ \\
\hline & & & & & (1) & & no \\
\hline & * & & & & $4.029 E+00$ & & $4.029 E+00$ \\
\hline & MTR & 85 & $2.114 E+01$ & $6.986 E+06$ & $1.024 E-01$ & $c 0-60$ & $1.024 E-01$ \\
\hline & OMR & 78 & $9.157 E+02$ & $4.299 E+08$ & $2.548 E+01$ & MAP & $2.166 E+01$ \\
\hline & & & & & & MFP & $3.813 E+00$ \\
\hline & & * & & & & & K. 548E+01 \\
\hline & & 79 & $3.388 E+02$ & 4. $144 E+08$ & $1.467 E+01$ & MAP & $7.335 E+00$ \\
\hline & & & & & & MFP & $7.335 E+00$ \\
\hline & & * & & & & & $1.467 E+01$ \\
\hline & & 82 & $5.799 E+01$ & $5.987 E+07$ & $2.816 E-03$ & $A M-241$ & $5.760 E-07$ \\
\hline & & & & & , n n & $\mathrm{CO}-60$ & $1.024 E-03$ \\
\hline & * & & & & $4.015 E+01$ & CS- 137 & $5.600 E-04$ \\
\hline & & & & & & EU-152 & $1.760 E-05$ \\
\hline & & & & & & $E U-155$ & $7.332 E=06$ \\
\hline & & & & & & $P U-238$ & $2.240 \mathrm{E}-06$ \\
\hline & & & & & & SR-90 & $5.760 \mathrm{E}-05$ \\
\hline & & & & & & U-235 & $1.472 E-05$ \\
\hline & & & & & & UN-ID-ALPHA & $1.132 E-03$ \\
\hline & & * & & & & & $2.816 \mathrm{E}-03$ \\
\hline & * & & & & & & $4.015 E+01$ \\
\hline & PER & 86 & $7.249 E+00$ & $1.02 i E+06$ & $1.000 E-06$ & U-235 & $1.000 \mathrm{E}-06$ \\
\hline & & 88 & $9.538 E+01$ & $6.255 E+07$ & $5.501 E-01$ & 00.60 & $5.501 E-01$ \\
\hline & * & & & & $5.502 E-01$ & & $5.502 E-01$ \\
\hline & PM2 & 81 & $1.715 E+02$ & $8.256 E+07$ & $1.620 E+01$ & MFP & $1.620 E+01$ \\
\hline
\end{tabular}




\begin{tabular}{|c|c|c|c|c|c|c|c|}
\hline $\begin{array}{c}\text { GENERATING } \\
\text { AREA }\end{array}$ & $\begin{array}{l}\text { GENERATING } \\
\text { BUILD̃INGG }\end{array}$ & $\begin{array}{c}\text { DISPOSAL } \\
\text { YEAR }\end{array}$ & $\begin{array}{c}\text { ANNUAL } \\
\text { VOLUME } \\
\text { CUBIC METERS }\end{array}$ & $\begin{array}{l}\text { ANNUAL } \\
\text { WEIGHT } \\
\text { GRAMS }\end{array}$ & $\begin{array}{l}\text { ANNUAL } \\
\text { CURIES }\end{array}$ & NUCLIDE & CURIES \\
\hline (n) & ............. & ......... & 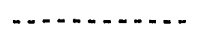 & . & 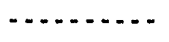 & 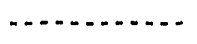 & ............. \\
\hline \multirow[t]{42}{*}{$D+D$} & PM2 & 82 & $2.215 E+02$ & $3.164 E+08$ & $1.791 \mathrm{E}-01$ & $c 0-60$ & $1.348 \mathrm{E}-02$ \\
\hline & & & & & - n & CS- 134 & $6.216 E-05$ \\
\hline & * & & & & $1.638 \mathrm{E}+01$ & CS- 137 & $6.709 E-02$ \\
\hline & & & & & & MFP & $1.000 E-03$ \\
\hline & & & & & & $S R-90$ & $9.751 \mathrm{E}-02$ \\
\hline & & & & & & & , n. \\
\hline & & * & & & & & $1.791 E-01$ \\
\hline & & & & & & & . \\
\hline & * & & & & & & $1.638 E+01$ \\
\hline & SPT & 79 & $6.614 E+01$ & $7.621 E+07$ & $2.750 E-03$ & MAP & $1.375 E-03$ \\
\hline & & & & & & MFP & $1.375 E-03$ \\
\hline & & & & & & & (1) \\
\hline & & * & & & & & $2.750 E-03$ \\
\hline & & 84 & $5.074 E+01$ & $6.078 E+07$ & $2.914 E-02$ & $\mathrm{co}-60$ & $2.184 \mathrm{E}-05$ \\
\hline & & & & & מ & CS- 137 & $1.051 \mathrm{E}-02$ \\
\hline & * & & & & $3.189 E-02$ & $P U-238$ & $4.805 E-06$ \\
\hline & & & & & & $P U-239-240$ & $1.400 E-05$ \\
\hline & & & & & & SR -90 & $1.878 E-03$ \\
\hline & & & & & & $U-234$ & $1.302 E-02$ \\
\hline & & & & & & $U-235$ & $1.004 E-03$ \\
\hline & & & & & & $U-236$ & $2.009 E-04$ \\
\hline & & & & & & $U-238$ & $2.489 E-03$ \\
\hline & & & & & & & a.n. \\
\hline & & * & & & & & $2.914 E-02$ \\
\hline & & & & & & & . \\
\hline & $\star$ & & & & & & $3.189 E-02$ \\
\hline & $S 1 G$ & 83 & $6.524 E+01$ & $1.288 E+08$ & $5.579 E+03$ & $\mathrm{CO}-60$ & $1.538 \mathrm{E}+03$ \\
\hline & & & & & & $F E-55$ & $6.100 E+01$ \\
\hline & & & & & & $H-3$ & $3.300 E+03$ \\
\hline & & & & & & MAP & $1.400 E+00$ \\
\hline & & & & & & NB-94 & $2.000 E+00$ \\
\hline & & & & & & $N 1-59$ & $4.000 E+00$ \\
\hline & & & & & & $N I-63$ & $6.730 E+02$ \\
\hline & & & & & & & n \\
\hline & & * & & & & & $5.579 E+03$ \\
\hline & & & & & & & (n) \\
\hline & $\star$ & & & & & & $5.579 E+03$ \\
\hline & TAN & 82 & $3.978 E+01$ & $1.814 E+07$ & $4.878 E+01$ & $10-60$ & $7.100 E-02$ \\
\hline & & & & & & CS- 134 & $8.100 E-02$ \\
\hline & & & & & & CS- 137 & $4.850 E+01$ \\
\hline & & & & & & $S R-90$ & $1.317 \mathrm{E}-01$ \\
\hline & & & & & & $U-235$ & $4.500 E-05$ \\
\hline
\end{tabular}


1SCHECDULE NO. SUSS411

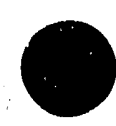

RUN DATE: 04/03/91

U.S. DEPARTMENT OF ENERGY

INEL WASTE MANAGEMENT INFORMATION SYSTEM

ANNUAL SUMMARY FOR D+D

PAGE 103

\begin{tabular}{|c|c|c|c|c|c|c|c|}
\hline GENERATING & GENERATING & DISPOSAL & $\begin{array}{l}\text { ANNUAL } \\
\text { VOLUME }\end{array}$ & $\begin{array}{l}\text { ANNUAL } \\
\text { WEIGHT }\end{array}$ & ANNUAL & & \\
\hline AREA & BUILDING & YEAR & CUBIC METERS & GRAMS & CURIES & NUCLIDE & CURIES \\
\hline 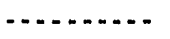 & . & . n......... & - & . & , n & , n & - \\
\hline \multirow[t]{14}{*}{$D+D$} & TAN & 82 & & & & UN-ID-ALPHA & $1.300 E-04$ \\
\hline & & * & & & & & $4.878 E+01$ \\
\hline & & & & & & & 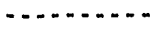 \\
\hline & * & & & & & & $4.878 E+01$ \\
\hline & 605 & 84 & $2.418 E+02$ & $1.657 E+08$ & $3.354 E+00$ & $c 0-60$ & $6.310 E-01$ \\
\hline & & & & & & CS -137 & $6.310 E-01$ \\
\hline & & & & & & MAP & $1.046 E+00$ \\
\hline & & & & & & MFP & $1.046 E+00$ \\
\hline & & & & & & & $\ldots$ \\
\hline & & * & & & & & $3.354 E+00$ \\
\hline & & & & & & & 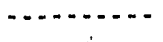 \\
\hline & * & & & & & & $3.354 E+00$ \\
\hline & 616 & 81 & $6.160 E+01$ & $6.440 E+07$ & $5.190 E-01$ & MFP & $5.190 \mathrm{E}-01$ \\
\hline & & & & & n. & & . n \\
\hline & & & & & $5.693 E+03$ & & $5.693 E+03$ \\
\hline & & & & & . & & n \\
\hline & & & & & $5.693 E+03$ & & $5.693 E+03$ \\
\hline
\end{tabular}




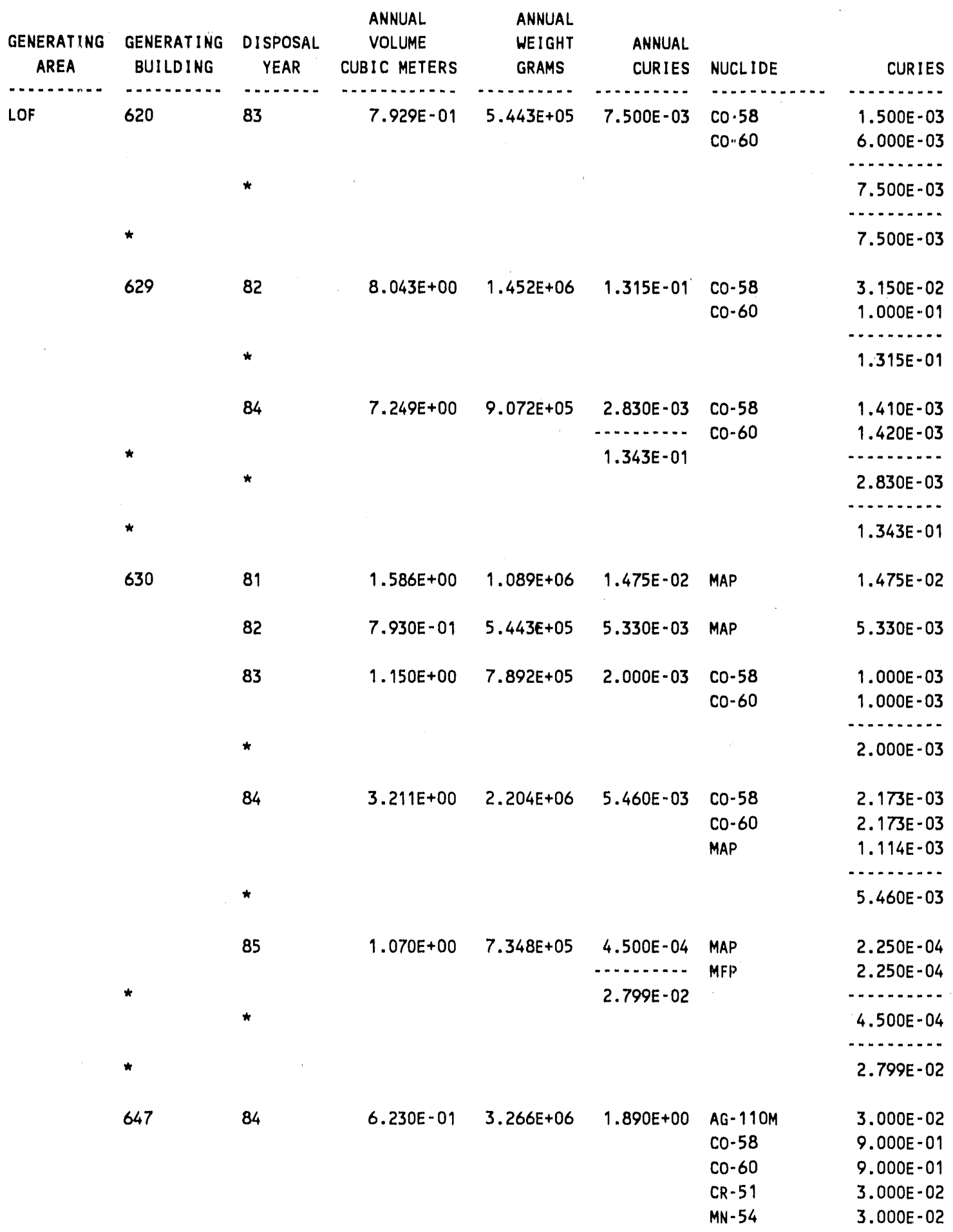


LOF

650

82

85

*

ANNIAL ANNUAL

VOLUME WEIGHT

GENERATING GENERATING DISPOSAL

AREA BUILDING

YEAR

CUBIC METERS

GRAMS

ANNUAL

CURIES NUCLIDE

CURIES

(...........

$1.890 \mathrm{E}+00$

..........

$1.890 E+00$

$6.380 E-03$

\begin{tabular}{|c|c|c|c|}
\hline $7.930 E-01$ & $5.443 E+05$ & $6.380 E-03$ & MAP \\
\hline $4.812 E+01$ & $2.525 E+07$ & $\begin{array}{r}5.523 E-01 \\
5.586 E-01 \\
2.618 E+00 \\
2.618 E+00\end{array}$ & $\begin{array}{l}\text { CO-58 } \\
\text { CO- } 60 \\
\text { CS- } 137 \\
\text { MAP } \\
\text { MFP }\end{array}$ \\
\hline
\end{tabular}

1.160E-01

$9.000 E-02$

5.000E-02

$1.248 \mathrm{E}-01$

1. 714 E-01

-........

5.523E- 01

5.586E- 01

-..........

$2.618 E+00$

...........

$2.618 E+00$ 


\begin{tabular}{|c|c|c|c|c|c|c|c|}
\hline $\begin{array}{l}\text { GENERATING } \\
\text { AREA }\end{array}$ & $\begin{array}{l}\text { GENERATING } \\
\text { BUILDING }\end{array}$ & $\begin{array}{l}\text { DISPOSAL } \\
\text { YEAR }\end{array}$ & $\begin{array}{c}\text { ANNUAL } \\
\text { VOLUME } \\
\text { CUBIC METERS }\end{array}$ & $\begin{array}{l}\text { ANNUAL } \\
\text { WEIGHT } \\
\text { GRAMS }\end{array}$ & $\begin{array}{l}\text { ANNUAL } \\
\text { CURIES }\end{array}$ & NUCLIDE & CURIES \\
\hline . & . & ............ & . & - n. & . & ……... & . \\
\hline \multirow[t]{24}{*}{ NRF } & NONE & 86 & $2.174 E+01$ & $1.049 E+07$ & $2.576 E-02$ & co-60 & $2.576 E-02$ \\
\hline & 000 & 61 & $7.580 E+02$ & $0.000 E+00$ & $1.097 E+04$ & $U N-I D-B+G$ & $1.097 E+04$ \\
\hline & & 62 & $8.360 E+02$ & $0.000 E+00$ & $1.230 E+04$ & $U N-I D-B+G$ & $1.230 E+04$ \\
\hline & & 63 & $1.173 E+03$ & $0.000 E+00$ & $2.126 E+04$ & $U N-1 D-B+G$ & $2.126 E+04$ \\
\hline & & 64 & $1.031 E+03$ & $0.000 E+00$ & $2.405 E+04$ & $U N-1 D-B+G$ & $2.405 E+04$ \\
\hline & & 65 & $1.553 E+03$ & $0.000 E+00$ & $5.007 E+05$ & $U N-1 D-B+G$ & $5.007 E+05$ \\
\hline & & 66 & $1.450 E+03$ & $0.000 E+00$ & $7.873 E+05$ & $U N-1 D-B+G$ & $7.873 E+05$ \\
\hline & & 67 & $1.385 E+03$ & $0.000 E+00$ & $8.011 E+05$ & $U N-1 D-B+G$ & $8.011 E+05$ \\
\hline & & 68 & $1.561 E+03$ & $0.000 E+00$ & $1.927 E+05$ & $U N-1 D-B+G$ & $1.927 E+05$ \\
\hline & & 69 & $1.812 E+03$ & $0.000 E+00$ & $6.440 E+05$ & $U N-I D-B+G$ & $6.440 E+05$ \\
\hline & & 70 & $1.932 E+03$ & $0.000 E+00$ & $1.010 E+05$ & $U N-1 D-B+G$ & $1.010 E+05$ \\
\hline & * & & & & $3.095 E+06$ & & $3.095 E+06$ \\
\hline & 601 & 71 & $2.592 \mathrm{E}+02$ & $2.659 E+07$ & $7.130 E-01$ & $\begin{array}{l}C 0-60 \\
I R-192\end{array}$ & $\begin{array}{l}7.127 E-01 \\
2.800 E-04\end{array}$ \\
\hline & & * & & & & & $7.130 E-01$ \\
\hline & & 72 & $3.845 E+01$ & $1.695 E+07$ & $3.196 E-01$ & co- 60 & $3.196 \mathrm{E}-01$ \\
\hline & & 73 & $4.757 E+00$ & $1.667 E+06$ & $1.235 E-02$ & 00.60 & $1.235 E-02$ \\
\hline & & 74 & $7.788 E+00$ & $5.557 E+06$ & $8.740 E-03$ & 00.60 & $8.740 E-03$ \\
\hline & & & & & & & 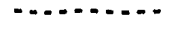 \\
\hline & & & & & & & $8.740 E-0 S$ \\
\hline & & 75 & $5.640 E+00$ & $1.044 E+06$ & $2.169 E-04$ & $00-60$ & $1.204 E-04$ \\
\hline & & & & & & $\begin{array}{l}\text { SR-90 } \\
U-238\end{array}$ & $8.000 E-05$ \\
\hline & & & & & & & ........... \\
\hline & & * & & & & & $2.169 E-04$ \\
\hline & & 76 & $8.496 E-01$ & $4.989 E+05$ & $1.000 \mathrm{E}-03$ & Co. 60 & $1.000 E-03$ \\
\hline
\end{tabular}




\begin{tabular}{|c|c|c|c|c|c|c|c|}
\hline & & & ANNUAL & ANNUAL & & & \\
\hline GENERATING & GENERATING & DISPOSAL & VOLUME & WEIGHT & ANNUAL & & \\
\hline AREA & BUILDING & YEAR & CUBIC METERS & GRAMS & CURIES & NUCLIDE & CURIES \\
\hline 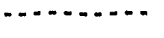 & 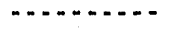 & , n....... & , n & . & .............. & - & - \\
\hline \multirow[t]{31}{*}{ NRF } & 601 & 77 & $2.354 E+01$ & $7.167 E+06$ & $1.038 E+00$ & $c 0-60$ & $1.038 E+00$ \\
\hline & & 78 & $2.082 E-01$ & $1.361 E+01$ & $9.249 E-02$ & co- 60 & $9.249 \mathrm{E}-02$ \\
\hline & & 79 & $9.912 E+00$ & $3.629 E+06$ & $5.000 E-02$ & Co- 60 & $5.000 E-02$ \\
\hline & & 81 & $7.250 E+00$ & $4.536 E+06$ & $1.200 E+00$ & CO-60 & $1.200 E+00$ \\
\hline & & 83 & $2.832 E+00$ & $1.406 E+06$ & $1.410 E+01$ & co- 60 & $1.410 E+01$ \\
\hline & & 84 & $7.957 E+00$ & $9.253 E+06$ & $5.584 E-02$ & co- 60 & $5.100 E-02$ \\
\hline & & & & & & Cs-15/ & $\begin{array}{r}4.84 \angle E-05 \\
\ldots . \ldots . \ldots . . .\end{array}$ \\
\hline & & * & & & & & $5.584 E-02$ \\
\hline & & 88 & $2.832 E+00$ & $6.804 E+06$ & $2.624 E+00$ & $c 0-60$ & $2.400 E+00$ \\
\hline & & & & & & FE-55 & $1.700 E-01$ \\
\hline & & & & & & $N I-63$ & $5.400 E-02$ \\
\hline & & * & & & & & $2.624 E+00$ \\
\hline & & 89 & $2.832 E+00$ & $4.989 E+06$ & $9.110 E+00$ & Co- 60 & $6.940 E+00$ \\
\hline & & & & & 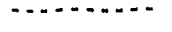 & FE-55 & $1.830 E+00$ \\
\hline & * & & & & $2.932 E+01$ & $k-40$ & $1.500 \mathrm{E}-01$ \\
\hline & & & & & & $M N-54$ & $8.000 E-02$ \\
\hline & & & & & & N1 -63 & $1.100 E-01$ \\
\hline & & * & & & & & $9.110 E+00$ \\
\hline & & & & & & & . \\
\hline & * & & & & & & $2.932 E+01$ \\
\hline & 613 & 79 & $2.574 E+02$ & $3.847 E+08$ & $4.161 \mathrm{E}-02$ & CS- 137 & $3.733 E-02$ \\
\hline & & & & & & $U-235$ & $5.983 E-05$ \\
\hline & & & & & & U-238 & $4.222 E-03$ \\
\hline & & * & & & & & (a) \\
\hline & & & & & & & ........... \\
\hline & * & & & & & & $4.161 E-02$ \\
\hline & 616 & 76 & $3.512 E+00$ & $4.536 \mathrm{E}+05$ & $4.000 E-02$ & $c 0-60$ & $4.000 E-02$ \\
\hline & & 77 & $3.398 E+00$ & $6.804 E+05$ & $3.000 E-03$ & $10-60$ & $3.000 \mathrm{E}-03$ \\
\hline & & 79 & $5.046 E+01$ & $2.123 E+07$ & $2.672 E-02$ & AM-241 & $1.600 \mathrm{E}-04$ \\
\hline & & & & & & $c 0.60$ & $2.643 E-02$ \\
\hline & & & & & & RA-226 & $1.320 \mathrm{E}-04$ \\
\hline
\end{tabular}




\begin{tabular}{|c|c|c|c|c|c|c|c|}
\hline & & & ANNUAL & ANNUAL & & & \\
\hline GENERATING & GENERATING & DISPOSAL. & VOLUME & WEIGHT & ANNUAL & & \\
\hline AREA & BUILDING & YEAR & CUBIC METERS & GRAMS & CURIES & NUCLIDE & CURIES \\
\hline . & $\ldots$ & $\cdots+\cdots$ & n & , n & . & n & n. \\
\hline & & $\star$ & & & & & $2.672 E-02$ \\
\hline \multirow[t]{31}{*}{ NRF } & 616 & 80 & $1.631 E+01$ & $2.059 E+06$ & $5.000 E-04$ & $C 0-60$ & $5.000 E-04$ \\
\hline & & 81 & $5.4 \zeta 1 E+01$ & $3.182 E+07$ & 4.206E-01 & $C 0-60$ & $4.206 E-01$ \\
\hline & & 82 & $1.237 E+01$ & $7.648 E+06$ & $9.800 E-04$ & Co- 60 & $9.800 E-04$ \\
\hline & & 83 & $5.729 E+01$ & $7.865 E+07$ & $3.757 E-04$ & Co. 60 & $3.757 E-04$ \\
\hline & & 89 & $4.531 E+00$ & $5.897 E+06$ & $2.999 E+01$ & $C 0-60$ & $9.840 E+00$ \\
\hline & & & & & - & CS- 137 & $3.000 \mathrm{E}-02$ \\
\hline & * & & & & $3.048 E+01$ & $F E-55$ & $1.654 E+01$ \\
\hline & & & & & & MAP & $6.000 E-02$ \\
\hline & & & & & & $M N-54$ & $2.550 E+00$ \\
\hline & & & & & & $N I-63$ & $9.400 E-01$ \\
\hline & & & & & & $S R-90$ & $3.000 E-02$ \\
\hline & & & & & & & - \\
\hline & & * & & & & & $2.999 E+01$ \\
\hline & * & & & & & & $3.048 E+01$ \\
\hline & 617 & 71 & $2.753 E+02$ & $1.324 E+08$ & $4.540 E+02$ & Co.58 & $1.100 E-01$ \\
\hline & & & & & & $C 0-60$ & $4.536 E+02$ \\
\hline & & & & & & CS- 134 & $9.900 \mathrm{E}-02$ \\
\hline & & & & & & CS -137 & $1.210 E-01$ \\
\hline & & & & & & MFP & $1.299 E-02$ \\
\hline & & & & & & $U-235$ & $1.327 E-06$ \\
\hline & & & & & & $U-238$ & $4.662 E-08$ \\
\hline & & & & & & & (n) \\
\hline & & ^ & & & & & $4.540 E+02$ \\
\hline & & 72 & $1.198 E+02$ & $3.056 E+07$ & $3.635 E+01$ & $\mathrm{CO}-60$ & $3.635 E+01$ \\
\hline & & & & & & MFP & $2.414 E-05$ \\
\hline & & & & & & U. 235 & $8.560 E-07$ \\
\hline & & $\star$ & & & & & $3.635 \mathrm{E}+01$ \\
\hline & & 73 & $3.360 E+01$ & $2.582 E+07$ & 4.236E- 01 & $c 0.60$ & $4.236 E-01$ \\
\hline & & 74 & $6.995 E+00$ & $7.258 E+06$ & $1.037 E-01$ & $C 0-60$ & $1.037 E-01$ \\
\hline & & 78 & $1.189 E+01$ & $1.483 E+07$ & $6.010 E-03$ & $C 0-60$ & $6.010 E-03$ \\
\hline & & 80 & $3.557 E+01$ & $1.250 E+07$ & $5.028 E+00$ & $C 0-60$ & $2.800 \mathrm{E}-02$ \\
\hline
\end{tabular}




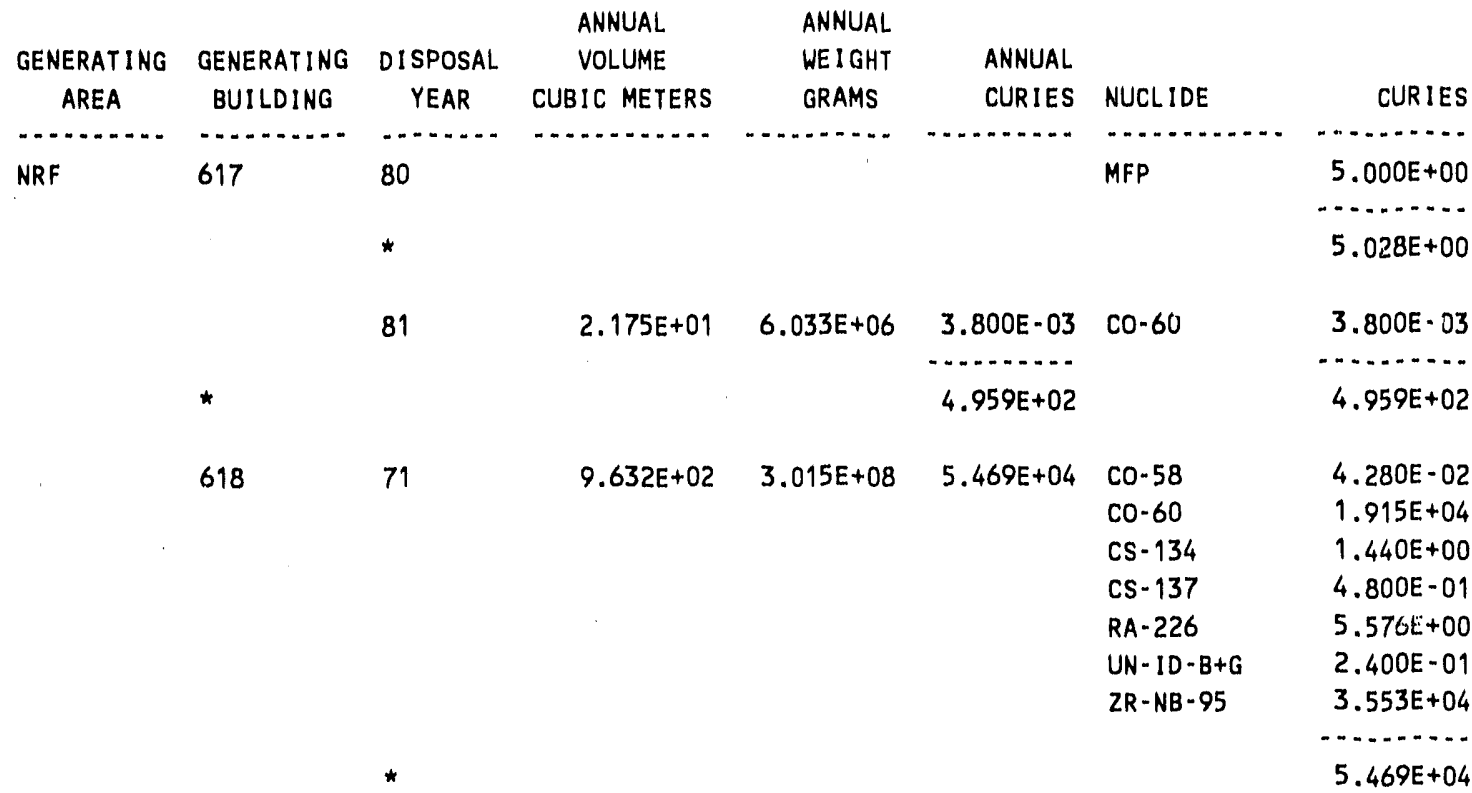

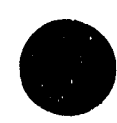

CE- 144

CO- 58

$\mathrm{CO}-60^{\circ}$

CS- 134

CS- 137

MFP

$U-235$

$U N-1 D-B+G$

*

73
CE- 144

CO- 60

CS- 134

CS- $\{37$

MFP

NP-23\%

PM- 147

PU-239

PU- 240

PU- 241

PU- 242

RU-106

SR-90

TH- 232

U-234

U-235

U-236
$9.990 \mathrm{E}-01$

2.534E-01

$1.079 E+04$

8.686E-01

$2.571 E+00$

$1.169 E+00$

$1.712 E-06$

$1.690 \mathrm{E}-01$

$1.080 E+04$

7.549E-01

9. $306 E+03$

5. 183E- 01

$1.753 E+00$

6.000E-01

$6.345 E-07$

$7.400 \mathrm{E}-01$

1.044E-05

$9.560 \mathrm{E}-06$

$6.720 \mathrm{E}-04$

$3.900 E-09$

1.300E-02

3. $800 E-01$

5. $450 \mathrm{E}-05$

$1.857 \mathrm{E}-05$

4.392E-07

2. $751 \mathrm{E}-06$ 


\begin{tabular}{|c|c|c|c|c|c|c|c|}
\hline $\begin{array}{c}\text { GENERATING } \\
\text { AREA }\end{array}$ & $\begin{array}{l}\text { GENERATING } \\
\text { BUILDING }\end{array}$ & $\begin{array}{c}\text { DISPO: AL } \\
\text { YEAR }\end{array}$ & $\begin{array}{c}\text { ANNUAL } \\
\text { VOLUME } \\
\text { CUBIC METERS }\end{array}$ & $\begin{array}{l}\text { ANNUAL } \\
\text { WEIGHT } \\
\text { GRAMS }\end{array}$ & $\begin{array}{l}\text { ANNUAL } \\
\text { CURIES }\end{array}$ & NUCL IDE & CURIES \\
\hline …… & . . . & .......... & ……….... & ........... & ……… & 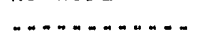 & .......... \\
\hline \multirow[t]{41}{*}{ NRF } & 618 & 73 & & & & $U-238$ & $3.664 E-05$ \\
\hline & & * & & & & & $9.311 E+03$ \\
\hline & & 74 & $2.513 E+02$ & $1.620 E+08$ & $5.814 E+03$ & Co- 60 & $5.754 E+03$ \\
\hline & & & & & & CS* 134 & $1.969 E+01$ \\
\hline & & & & & & CS -137 & $3.690 E+01$ \\
\hline & & & & & & PU-239 & $6.000 E-10$ \\
\hline & & & & & & SR-89-90 & $3.936 \mathrm{E}+00$ \\
\hline & & & & & & $U-233$ & $1.040 E-08$ \\
\hline & & & & & & $U-235$ & $5.121 E-07$ \\
\hline & & & & & & $U-238$ & $5.791 \mathbb{E}-09$ \\
\hline & & & & & & UN-ID-ALPHA & $3.936 E-03$ \\
\hline & & & & & & & . \\
\hline & & * & & & & & $5.814 E+03$ \\
\hline & & 75 & $2.200 E+02$ & $2.948 E+13$ & $5.067 E+03$ & co- 60 & $5.046 E+03$ \\
\hline & & & & & & $c s-134$ & $8.410 E+00$ \\
\hline & & & & & & Cs -137 & $1.141 E+01$ \\
\hline & & & & & & SR-90 & $1.430 \mathrm{E}-03$ \\
\hline & & & & & & $U N-1 D-B+G$ & $1.682 E+00$ \\
\hline & & & & & & & n. \\
\hline & & * & & & & & $5.067 E+03$ \\
\hline & & 76 & $2.821 E+02$ & $2.046 E+08$ & $7.369 E+04$ & $c 0-60$ & $2.141 E+04$ \\
\hline & & & & & & CS- 134 & $1.840 E+00$ \\
\hline & & & & & & CS- 137 & $1.065 E+01$ \\
\hline & & & & & & $F E=55$ & $2.576 E+04$ \\
\hline & & & & & & $N:-63$ & $1.472 E+03$ \\
\hline & & & & & & $S B-125$ & $1.399 E+04$ \\
\hline & & & & & & SN-119 & $3.680 E+03$ \\
\hline & & & & & & $S R-90$ & $9.800 E-09$ \\
\hline & & & & & & TC-99 & $3.961 E-07$ \\
\hline & & & & & & $U N-I D-B+G$ & $1.710 E+00$ \\
\hline & & & & & & $2 R-95$ & $7.361 E+03$ \\
\hline & & & & & & & , \\
\hline & & * & & & & & $7.369 E+04$ \\
\hline & & 77 & $1.762 E+02$ & $9.857 E+07$ & $1.447 E+05$ & $B A-133$ & $3.400 E-08$ \\
\hline & & & & & & Co- 57 & $3.360 \mathrm{E}-11$ \\
\hline & & & & & & co- 60 & $4.212 E+04$ \\
\hline & & & & & & CS- 137 & $8.200 E-08$ \\
\hline & & & & & & $F E-55$ & $5.059 E+04$ \\
\hline & & & & & & $N A-22$ & $1.050 E-08$ \\
\hline & & & & & & $N I-63$ & $2.891 E+03$ \\
\hline & & & & & & SB- 125 & $2.746 E+04$ \\
\hline
\end{tabular}




\begin{tabular}{|c|c|c|c|c|c|c|c|}
\hline GENERATING & GENERATING & DISPOSAL & ANNUAL & ANNUAL & ANNEAI & & \\
\hline AREA & BUILDING & YEAR & CUBIC METERS & GRAMS & CURIES & NUCL IDE & CURIES \\
\hline …….... & $\ldots \ldots \ldots$ & - & - & $\cdots$ & $\ldots$ & $\cdots$ & 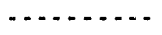 \\
\hline \multirow[t]{41}{*}{ NRF } & 618 & 77 & & & & $S N-119$ & $7.226 E+03$ \\
\hline & & & & & & TC- 99 & $3.200 E-09$ \\
\hline & & & & & & $2 R-95$ & $1.445 E+04$ \\
\hline & & & & & & & . \\
\hline & & $\star$ & & & & & $1.447 E+05$ \\
\hline & & 78 & $1.652 E+02$ & $1.225 E+08$ & $3.504 E+04$ & Co- 60 & $1.017 E+04$ \\
\hline & & & & & & $\mathrm{FE}-55$ & $1.226 E+04$ \\
\hline & & & & & & $N 1-63$ & $7.006 E+02$ \\
\hline & & & & & & SB-125 & $6.656 E+03$ \\
\hline & & & & & & $S N-119$ & $1.752 E+03$ \\
\hline & & & & & & $U-235$ & $1.000 E-09$ \\
\hline & & & & & & $U N-I D-B+G$ & $6.400 E-02$ \\
\hline & & & & & & $2 R-95$ & $3.503 E+03$ \\
\hline & & & & & & & . \\
\hline & & $\star$ & & & & & $3.504 E+04$ \\
\hline & & 79 & $1.494 E+02$ & $1.036 E+08$ & $1.092 E+05$ & $\mathrm{CO}-60$ & $3.167 E+04$ \\
\hline & & & & & & $F E-55$ & $3.820 E+04$ \\
\hline & & & & & & $\mathrm{NI}-63$ & 2. $183 E+03$ \\
\hline & & & & & & SB- 125 & $2.074 E+04$ \\
\hline & & & & & & $S N-119$ & $5.457 E+03$ \\
\hline & & & & & & $T C .99$ & $7.940 E-08$ \\
\hline & & & & & & $2 R-95$ & $1.091 E+04$ \\
\hline & & & & & & & 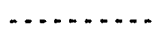 \\
\hline & & * & & & & & $1.092 E+05$ \\
\hline & & 80 & $2.331 E+02$ & $1.269 E+08$ & $3.923 E+04$ & $100-60$ & $1.139 E+04$ \\
\hline & & & & & & FE- 55 & $1.372 E+04$ \\
\hline & & & & & & $\mathrm{NI}-63$ & $7.843 E+02$ \\
\hline & & & & & & SB- 125 & $7.451 E+03$ \\
\hline & & & & & & $S N-119$ & $1.961 E+03$ \\
\hline & & & & & & $Z R-95$ & $3.921 E+03$ \\
\hline & & & & & & & . \\
\hline & & * & & & & & $3.923 E+04$ \\
\hline & & 81 & $1.613 E+02$ & $1.127 E+08$ & $1.932 E+04$ & $c 0.58$ & $6.186 E+02$ \\
\hline & & & & & & $c 0-60$ & $6.186 E+03$ \\
\hline & & & & & & $F E-55$ & $3.081 E+03$ \\
\hline & & & & & & $N 1-63$ & $9.435 E+03$ \\
\hline & & & & & & & (n) \\
\hline & & * & & & & & $1.932 E+04$ \\
\hline & & 82 & $1.819 E+02$ & $1.084 E+08$ & $9.048 \mathrm{E}+03$ & $C 0-58$ & $2.710 E+02$ \\
\hline & & & & & & $c 0.60$ & $2.904 E+03$ \\
\hline & & & & & & $F E-55$ & $1.446 E+03$ \\
\hline
\end{tabular}




\begin{tabular}{|c|c|c|c|c|c|c|c|}
\hline & & & ANNUAL & ANNUAL & & & \\
\hline $\begin{array}{l}\text { GENERATING } \\
\text { AREA }\end{array}$ & $\begin{array}{l}\text { GENERATING } \\
\text { BUILDING }\end{array}$ & $\begin{array}{c}\text { DISPOSAL } \\
\text { YEAR }\end{array}$ & $\begin{array}{l}\text { VOLUME } \\
\text { CUBIC METERS }\end{array}$ & $\begin{array}{l}\text { WEIGHT } \\
\text { GRAMS }\end{array}$ & $\begin{array}{l}\text { ANNUAL } \\
\text { CURIES }\end{array}$ & NUCL IDE & CURIES \\
\hline -.......... & n. & $\ldots . . .$. & - & …….... & - n. & ……...... & ............ \\
\hline \multirow[t]{39}{*}{ NRF } & 618 & 82 & & & & $N I-63$ & $4.427 E+03$ \\
\hline & & & & & & $U-235$ & $1.926 E-07$ \\
\hline & & & & & & & - \\
\hline & & $\star$ & & & & & $9.048 E+03$ \\
\hline & & 83 & $2.681 E+02$ & $2.201 \mathrm{E}+08$ & $3.904 E+04$ & $\mathrm{CO}-58$ & $1.169 E+03$ \\
\hline & & & & & & co- 60 & $1.254 E+04$ \\
\hline & & & & & & CS-134 & $1.500 E-02$ \\
\hline & & & & & & Cs -137 & 5.200E-02 \\
\hline & & & & & & $F E=55$ & $6.235 E+03$ \\
\hline & & & & & & $N I .63$ & $1.909 E+04$ \\
\hline & & & & & & $U-235$ & $1.365 E-05$ \\
\hline & & * & & & & & $3.904 E+04$ \\
\hline & & 84 & $3.220 E+02$ & $4.167 E+08$ & $3.651 E+05$ & $N / A$ & $0.000 E+00$ \\
\hline & & & & & & $\mathrm{Co}-58$ & $1.026 E+04$ \\
\hline & & & & & & $\operatorname{co-}-60$ & $1.173 E+05$ \\
\hline & & & & & & FE- 55 & $5.855 E+04$ \\
\hline & & & & & & $M N-54$ & $6.300 E+01$ \\
\hline & & & & & & $N I-63$ & $1.790 E+05$ \\
\hline & & & & & & PB-210 & $2.000 E-05$ \\
\hline & & & & & & ' & - \\
\hline & & * & & & & & $3.651 E+05$ \\
\hline & & 85 & $2.357 E+02$ & $1.753 E+08$ & $1.418 E+05$ & $\mathrm{CO}-58$ & $4.252 E+03$ \\
\hline & & & & & & $c 0-60$ & $4.537 E+04$ \\
\hline & & & & & & $F E-55$ & $2.268 E+04$ \\
\hline & & & & & & $N I-63$ & $6.945 E+04$ \\
\hline & & & & & & & 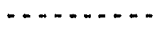 \\
\hline & & * & & & & & $1.418 E+05$ \\
\hline & & 86 & $1.725 E+02$ & $1.078 E+08$ & $3.593 E+04$ & co- 58 & $1.078 E+03$ \\
\hline & & & & & & $c 0-60$ & 1. $150 E+04$ \\
\hline & & & & & & FE-55 & $5.74 i E+03$ \\
\hline & & & & & & $N I-63$ & $1.760 E+04$ \\
\hline & & & & & & & . \\
\hline & & * & & & & & $3.593 E+04$ \\
\hline & & 87 & $1.167 E+02$ & $1.450 E+08$ & $2.966 E+04$ & Co-58 & $8.893 E+02$ \\
\hline & & & & & & $c 0-60$ & $9.507 E+03$ \\
\hline & & & & & & $F E-55$ & $4.743 E+03$ \\
\hline & & & & & & $N I-63$ & $1.453 E+04$ \\
\hline & & & & & & $U-238$ & $1.153 E-01$ \\
\hline & & * & & & & & $2.966 E+04$ \\
\hline
\end{tabular}




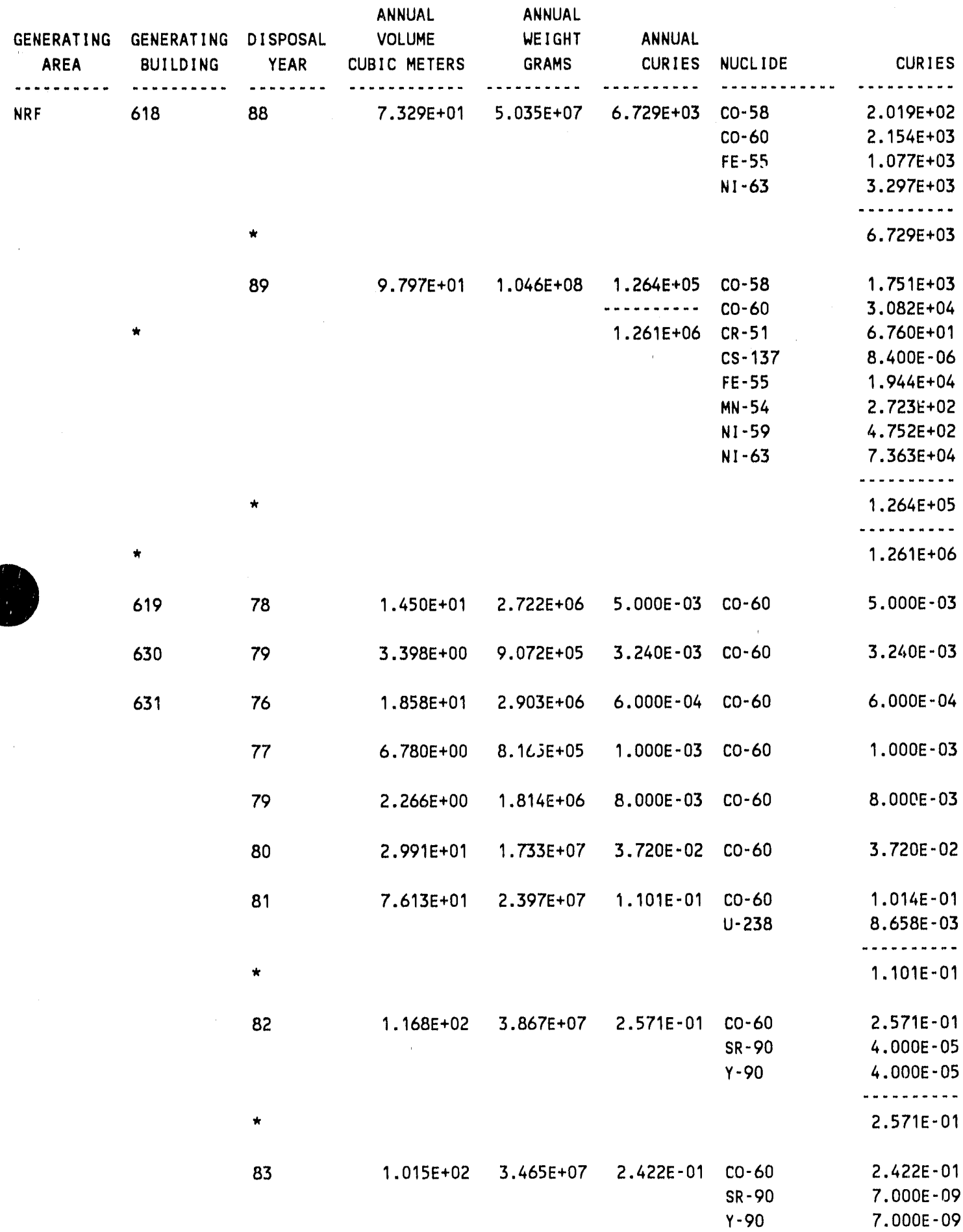




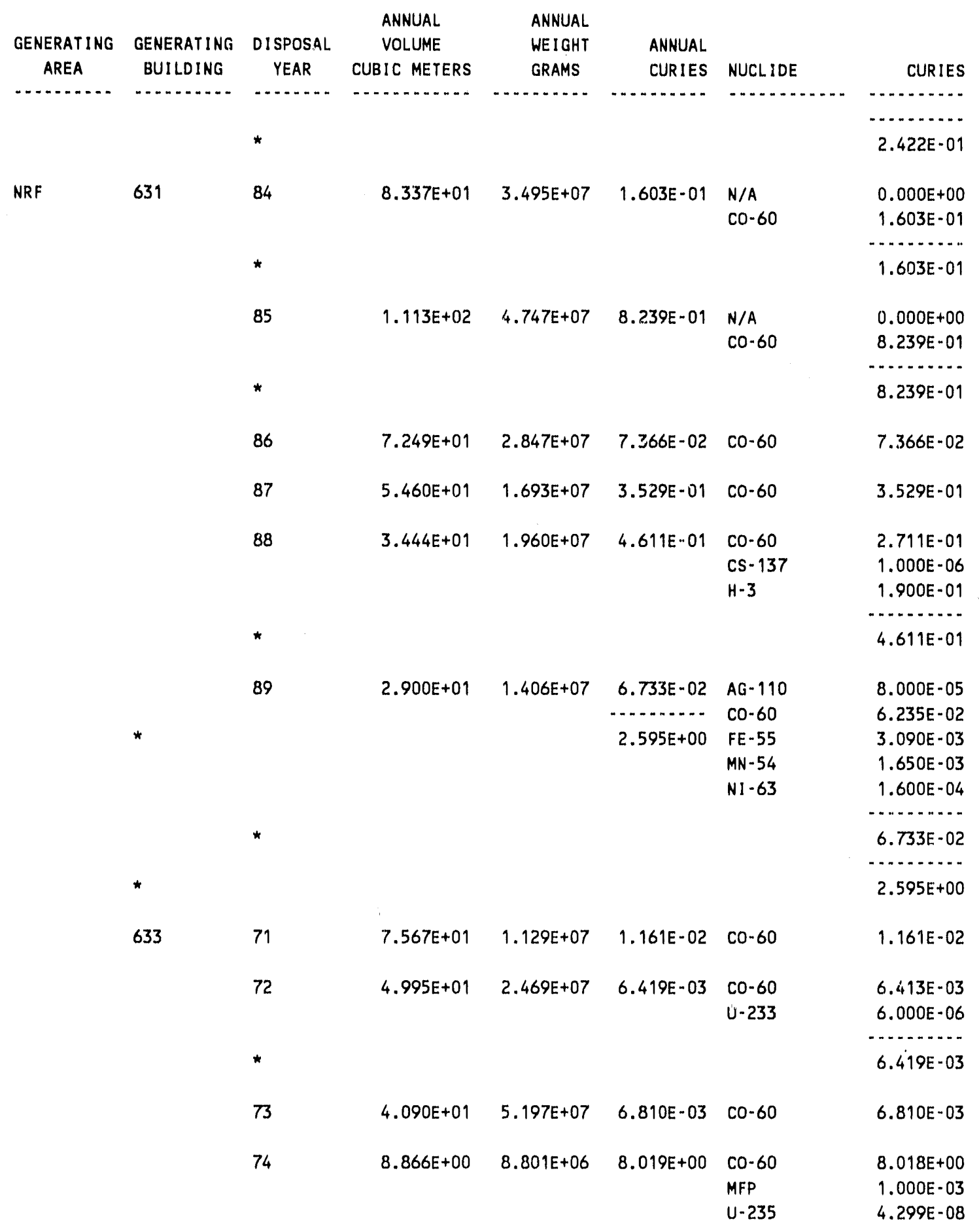




\begin{tabular}{|c|c|c|c|c|c|c|c|}
\hline $\begin{array}{l}\text { GENERATING } \\
\text { AREA }\end{array}$ & $\begin{array}{l}\text { GENERATING } \\
\text { BUILDING }\end{array}$ & $\begin{array}{c}\text { DISPOSAL } \\
\text { YEAR }\end{array}$ & $\begin{array}{c}\text { ANNUAL } \\
\text { VOLUME } \\
\text { CUBIC METERS }\end{array}$ & $\begin{array}{l}\text { ANNUAL } \\
\text { WEIGHT } \\
\text { GRAMS }\end{array}$ & $\begin{array}{l}\text { ANNUAL } \\
\text { CURIES }\end{array}$ & NUCLIDE & CURIES \\
\hline & (n... & * & - & 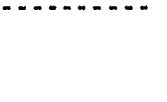 & , n & 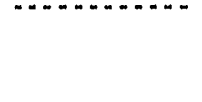 & $8.019 E+00$ \\
\hline \multirow[t]{12}{*}{ NRF } & 633 & 75 & $4.433 E+01$ & $5.120 E+07$ & $1.978 E-02$ & $10-60$ & $1.978 E-02$ \\
\hline & & 77 & $1.310 E+02$ & $7.775 E+07$ & 6.303E-02 & $10-60$ & $6.303 E-02$ \\
\hline & & 78 & $9.969 E+00$ & $2.381 E+06$ & $2.830 E-01$ & Co. 60 & $2.830 \mathrm{E}-01$ \\
\hline & & 83 & $3.993 E+00$ & $7.484 E+06$ & $8.400 E-01$ & $c 0-60$ & $8.400 E-01$ \\
\hline & & 84 & $2.662 E+00$ & $3.629 E+06$ & $1.238 \mathrm{E}+01$ & $C 0-60$ & $1.238 E+01$ \\
\hline & & 86 & $2.917 E+00$ & $7.257 E+06$ & $4.670 E+00$ & $c 0-60$ & $4.670 E+00$ \\
\hline & * & & & & $2.630 E+01$ & & $2.630 E+01$ \\
\hline & 636 & 79 & $7.250 E+00$ & $2.268 \mathrm{E}+06$ & $5.500 E-03$ & $20-60$ & $5.500 E-03$ \\
\hline & & 81 & $1.025 E+01$ & $1.542 E+06$ & $4.000 E-03$ & $00-60$ & $4.000 E-03$ \\
\hline & * & & & & $9.500 E-03$ & & $9.500 \mathrm{E}-03$ \\
\hline & & & & & $4.357 E+06$ & & $4.356 E+06$ \\
\hline & & & & & $457 F+06$ & & $4.356 E+06$ \\
\hline
\end{tabular}




\begin{tabular}{|c|c|c|c|c|c|c|c|}
\hline $\begin{array}{c}\text { GENERATING } \\
\text { AREA }\end{array}$ & $\begin{array}{l}\text { GENERATING } \\
\text { BUILDING }\end{array}$ & $\begin{array}{l}\text { DISPOSAL } \\
\text { YEAR }\end{array}$ & $\begin{array}{c}\text { ANNUAL } \\
\text { VOLUME } \\
\text { CUBIC METERS }\end{array}$ & $\begin{array}{l}\text { ANNUAL } \\
\text { WEIGHT } \\
\text { GRAMS }\end{array}$ & $\begin{array}{l}\text { ANNUAL } \\
\text { CURIES }\end{array}$ & NUCLIDE & CURIES \\
\hline . & - n............ & - n...... & - n. & …….... & - n. & - & …….... \\
\hline \multirow[t]{34}{*}{ PBF } & 601 & 84 & $1.603 E+02$ & $9.348 \mathrm{E}+06$ & $1.600 E-01$ & MAP & $8.000 E-02$ \\
\hline & & & & & & MFP & $8.000 E-02$ \\
\hline & & & & & & & …… \\
\hline & & $\star$ & & & & & $1.600 \mathrm{E}-01$ \\
\hline & & & & & & & (n) \\
\hline & * & & & & & & $1.600 \mathrm{E}-0 ?$ \\
\hline & 613 & 79 & $3.625 \mathrm{E}+00$ & $2.948 E+06$ & $1.000 E-06$ & MFP & $1.000 E-06$ \\
\hline & & 82 & $1.087 E+01$ & $1.406 E+06$ & $2.000 E-06$ & CS -137 & $1.000 \mathrm{E}-06$ \\
\hline & & & & & n. & MFP & $1.000 \mathrm{E}-06$ \\
\hline & * & & & & $3.000 E-06$ & & ............... \\
\hline & & * & & & & & $2.000 \mathrm{E}-06$ \\
\hline & & & & & & & 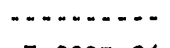 \\
\hline & * & & & & & & $3.000 E-06$ \\
\hline & 617 & 77 & $2.832 E-02$ & $4.536 E+02$ & $3.139 E-06$ & $U-235$ & $2.140 E-06$ \\
\hline & & & & & & $U-238$ & $9.990 \mathrm{E}-07$ \\
\hline & & & & & & & $\ldots$ \\
\hline & & * & & & & & $3.139 E-06$ \\
\hline & * & & & & & & $3.139 \mathrm{E}-06$ \\
\hline & 620 & 75 & $3.928 E+00$ & $2.722 E+05$ & $3.000 E-03$ & MAP & $2.85 C E-13$ \\
\hline & & & & & & MFP & $1.500 E-04$ \\
\hline & & & & & & & - n. \\
\hline & & * & & & & & $3.000 E-03$ \\
\hline & & 76 & $1.620 E+01$ & $2.041 E+06$ & $3.677 \mathrm{E}-01$ & MAP & $5.219 E-02$ \\
\hline & & & & & & MFP & $1.468 E-01$ \\
\hline & & & & & & $U N-1 D-B+G$ & $1.688 E-01$ \\
\hline & & * & & & & & $3.677 E-01$ \\
\hline & & 77 & $1.764 E+01$ & $5.398 E+06$ & $4.476 E-02$ & MAP & $9.111 E-03$ \\
\hline & & & & & & MFP & $3.565 E-02$ \\
\hline & & * & & & & & $4.476 E-02$ \\
\hline & & 78 & $2.392 E+01$ & $7.053 E+06$ & $8.789 E-02$ & MAP & $1.291 E-02$ \\
\hline & & & & & & MFP & $7.498 E-02$ \\
\hline & & * & & & & & $8.789 \mathrm{E}-02$ \\
\hline & & 79 & $1.095 E+02$ & $1.589 E+07$ & $1.848 E+00$ & MAP & $3.798 E-01$ \\
\hline & & & & & & MFP & $1.469 E+00$ \\
\hline
\end{tabular}




\begin{tabular}{|c|c|c|c|c|c|c|c|}
\hline & & & $\begin{array}{l}\text { ANNUAL } \\
\text { VOLUME }\end{array}$ & $\begin{array}{l}\text { ANNUAL } \\
\text { WEIGHT }\end{array}$ & & & \\
\hline $\begin{array}{c}\text { GENERAT ING } \\
\text { AREA }\end{array}$ & $\begin{array}{l}\text { GENERATING } \\
\text { BUILDING }\end{array}$ & $\begin{array}{l}\text { DISPOSAL } \\
\text { YEAR }\end{array}$ & $\begin{array}{l}\text { VOLUME } \\
\text { CUBIC METERS }\end{array}$ & $\begin{array}{l}\text { WEIGHT } \\
\text { GRAMS }\end{array}$ & $\begin{array}{l}\text { ANNUAL } \\
\text { CURIES }\end{array}$ & NUCLIDE & CURIES \\
\hline \multirow[t]{2}{*}{, non } & 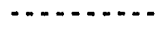 & .......... & - n. & ………… & - n. & . & n............. \\
\hline & & * & 11 & & & & $1.848 E+00$ \\
\hline \multirow[t]{31}{*}{ PBF } & 620 & 80 & $8.494 E+01$ & $1.694 E+07$ & $1.855 E+00$ & MAP & $2.033 E-01$ \\
\hline & & & & & & MFP & $1.652 E+00$ \\
\hline & & * & & & & & $1.855 E+00$ \\
\hline & & 81 & $1.222 E+02$ & $4.127 E+07$ & $2.517 E+00$ & MAP & $2.622 \mathrm{E}-01$ \\
\hline & & & & & & MFP & $2.254 E+00$ \\
\hline & & * & & & & & $2.517 E+00$ \\
\hline & & 82 & $4.378 E+01$ & $1.132 E+07$ & $4.328 E-01$ & MAP & $1.313 E-02$ \\
\hline & & & & & & MFP & 4.197E-01 \\
\hline & & * & & & & & $4.328 E-01$ \\
\hline & & 83 & $7.597 E+01$ & $2.336 E+07$ & $1.539 \mathrm{E}-01$ & MAP & $1.307 E-02$ \\
\hline & & & & & & MFP & $1.408 E-01$ \\
\hline & & $*$ & & & & & $1.539 E-01$ \\
\hline & & 84 & $4.250 E+01$ & $1.892 \mathrm{E}+07$ & $1.808 E+02$ & MAP & $9.079 E+00$ \\
\hline & & & & & & MFP & $1.717 E+02$ \\
\hline & & * & & & & & (1) \\
\hline & & & & & & & \\
\hline & & 85 & $1.206 \mathrm{E}+02$ & $8.851 E+07$ & $3.705 E+02$ & $N / A$ & $0.000 E+00$ \\
\hline & & & & & & $B A-L A-140$ & $1.000 E+00$ \\
\hline & & & & & & CS- 134 & $4.900 E+01$ \\
\hline & & & & & & Cs -137 & $3.170 E+02$ \\
\hline & & & & & & MAP & $3.630 E-01$ \\
\hline & & & & & & MFP & $3.148 E+00$ \\
\hline & & & & & & & (1) \\
\hline & & * & & & & & $3.705 E+02$ \\
\hline & & 86 & $3.625 E+00$ & $7.870 E+05$ & $2.525 E-03$ & MAP & $2.525 E-04$ \\
\hline & & & & & & MFP & $2.273 E-03$ \\
\hline & & & & & & & 25255003 \\
\hline & & & & & & & \\
\hline & & 87 & $4.467 E+01$ & $2.139 E+07$ & $1.054 E+01$ & CO- 60 & $8.000 E+00$ \\
\hline & & & & & & MAP & $5.100 E-02$ \\
\hline & & & & & & MFP & $2.488 E+00$ \\
\hline
\end{tabular}




\begin{tabular}{|c|c|c|c|c|c|c|c|}
\hline GENERATING & GENERAT ING & DISPOSAL & $\begin{array}{l}\text { ANNUALL } \\
\text { VOLUME }\end{array}$ & $\begin{array}{l}\text { ANNUAL } \\
\text { WEIGHT }\end{array}$ & ANNUAL & & \\
\hline AREA & BUILDING & YEAR & CUBIC METERS & GRAMS & CURIES & NUCL IDE & CURIES \\
\hline \multirow[t]{2}{*}{ - n } & 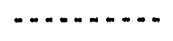 & . & - & and & . & מ & 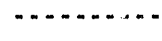 \\
\hline & & * & & & & & $1.054 E+01$ \\
\hline \multirow[t]{8}{*}{ PBF } & 620 & 88 & $2.900 E+01$ & $1.174 E+07$ & $3.272 E+00$ & $c 0-60$ & $9.665 E-01$ \\
\hline & & & & & (n) & MFP & $2.305 E+00$ \\
\hline & $\star$ & & & & $5.724 E+02$ & & ه \\
\hline & & * & & & , & & $3.272 E+00$ \\
\hline & & & & & & & . . . n n. n \\
\hline & * & & & & & & $5.724 E+02$ \\
\hline & 632 & 84 & $3.659 E+01$ & $2.268 E+06$ & $2.600 E-05$ & MAP & $1.300 E-05$ \\
\hline & & & & & . & MFP & $1.300 E-05$ \\
\hline \multirow[t]{5}{*}{ * } & & & & & $5.726 E+02$ & & 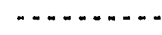 \\
\hline & & * & & & . & & $2.600 E-05$ \\
\hline & & & & & $3.726 E+02$ & & $\ldots$ \\
\hline & * & & & & & & $2.600 \mathrm{E}-05$ \\
\hline & & & & & & & $\cdots+n$ \\
\hline \multirow[t]{2}{*}{ * } & & & & & & & $5.726 E+02$ \\
\hline & & & & & & & $5.736 \mathrm{E}+02$ \\
\hline
\end{tabular}




\begin{tabular}{|c|c|c|c|c|c|c|c|}
\hline GENERATING & GENERATING & DISPOSAL & $\begin{array}{l}\text { ANNUAL } \\
\text { VOLUME }\end{array}$ & $\begin{array}{l}\text { ANNUAL } \\
\text { WEIGHT }\end{array}$ & ANNUAL & & \\
\hline AREA & BUILDING & YEAR & CUBIC METERS & GRAMS & CURIES & NUCL. IDE & CURIES \\
\hline (n) & . & $\ldots$ & - & . & n. & - & (n) \\
\hline \multirow[t]{27}{*}{ PER } & NONE & 71 & $6.117 E+00$ & $6.804 E+05$ & $2.090 E-01$ & MFP & $2.090 E-01$ \\
\hline & 000 & 61 & $5.000 E+00$ & $0.000 E+00$ & $5.000 E-04$ & $U N-1 D-B+G$ & $5.000 E-04$ \\
\hline & & 62 & $2.300 E+01$ & $0.000 E+00$ & $1.000 E+00$ & $U N-1 D-B+G$ & $1.000 E+00$ \\
\hline & & 63 & $1.900 E+01$ & $0.000 E+00$ & $5.000 E-04$ & $U N-1 D-B+G$ & $5.000 E-04$ \\
\hline & & 64 & $1.600 E+01$ & $0.000 E+00$ & $1.000 E+00$ & $U N-I D-B+G$ & $1.000 E+00$ \\
\hline & & 65 & $1.700 E+01$ & $0.000 \mathrm{E}+00$ & $1.300 E+01$ & $U N-1 D-B+C$ & $1.300 E+01$ \\
\hline & & 66 & $2.800 E+01$ & $0.000 E+00$ & $5.000 E-04$ & $U N-1 D-B+G$ & $5.000 E-04$ \\
\hline & & 67 & $2.500 E+01$ & $0.000 E+U 0$ & $5.000 E-04$ & $U N-1 D-B+G$ & $5.000 E-04$ \\
\hline & & 68 & $1.400 E+01$ & $0.000 E+00$ & $5.000 E-04$ & $U N-1 D-B+G$ & $5.000 E-04$ \\
\hline & & 69 & $1.600 E+01$ & $0.000 E+00$ & $5.000 E-04$ & $U N-1 D-B+G$ & $5.000 E-04$ \\
\hline & & 70 & $1.370 E+02$ & $0.000 E+00$ & $3.000 E+00$ & $U N-1 D-B+G$ & $3.000 E+00$ \\
\hline & * & & & & $1.800 E+01$ & & $1.800 E+01$ \\
\hline & 612 & 73 & $9.969 F+00$ & $9.299 E+05$ & $9.393 E-01$ & $R A-226$ & $2.299 E-01$ \\
\hline & & & & & & UN-ID-ALPHA & $1.000 E-08$ \\
\hline & & & & & & $U N-1 D-B+G$ & $7.094 E-01$ \\
\hline & & * & & & & & $9.393 E-01$ \\
\hline & & 89 & $6.289 E+00$ & $1.103 E \cdot+07$ & $3.000 E-05$ & MFP & $3.000 \mathrm{E}-05$ \\
\hline & $\star$ & & & & $9.393 E-01$ & & $9.393 \mathrm{E}-01$ \\
\hline & 613 & 71 & $5.155 \mathrm{E}+00$ & $6.849 E+05$ & $4.538 E+00$ & co- 60 & $4.500 E+00$ \\
\hline & & & & & & U.235 & $2.996 E-05$ \\
\hline & & & & & & $U-238$ & $4.329 E-05$ \\
\hline & & & & & & $U N-I D-B+G$ & $3.800 E-02$ \\
\hline & & * & & & & & $4.538 E+00$ \\
\hline & & 73 & $7.137 E+00$ & $9.072 E+05$ & $4.950 E-02$ & $U N-I D-B+G$ & $4.950 E-02$ \\
\hline & & 76 & $1.592 E+02$ & $3.613 E+06$ & $4.363 E-01$ & Co-60 & $4.345 E-01$ \\
\hline & & & & & & CS- 137 & $5.000 E-04$ \\
\hline & & & & & & MAP & $1.500 E-04$ \\
\hline
\end{tabular}


IDAHO OPETATIONS OFFICE

U.S. DEPARTMENT OF ENERGY

INEL WASTE MANAGEMENT INFORMATION SYSTEM

ANNUAL SUMMARY FOR PER
RUN DATE: 04/03/91

PAGE 120

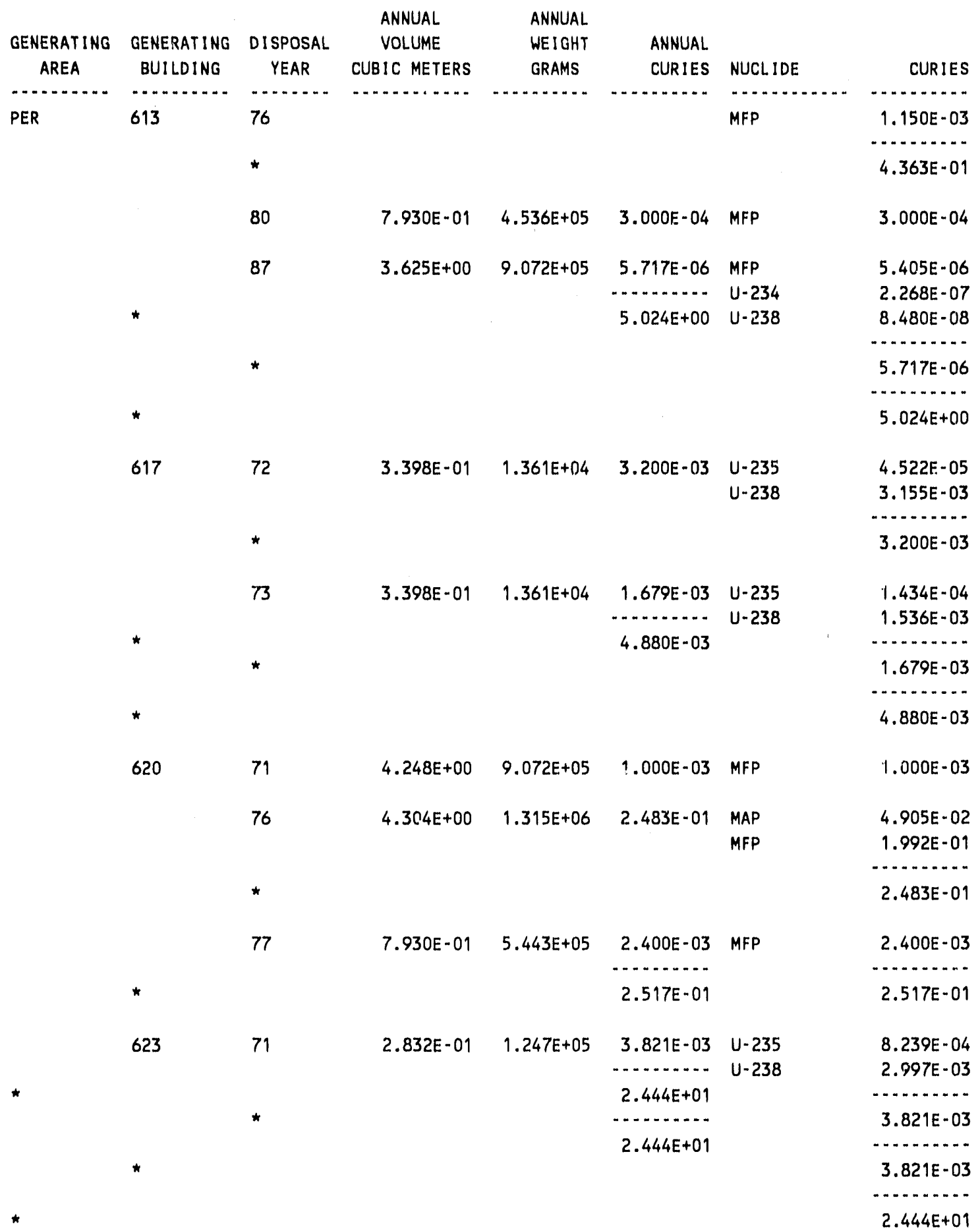




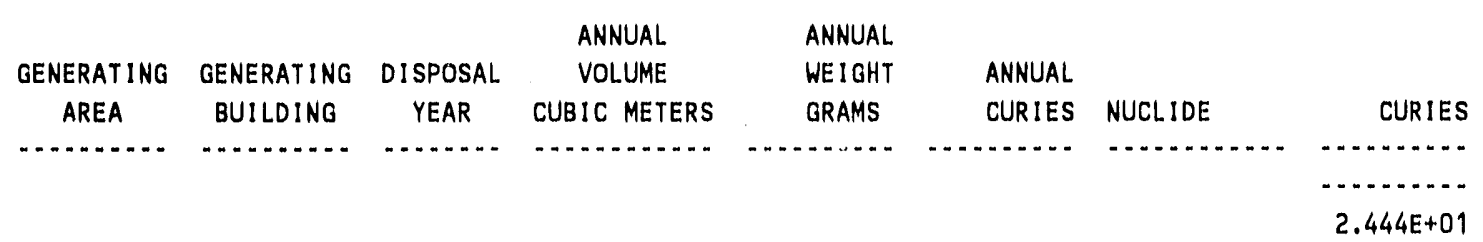




\begin{tabular}{|c|c|c|c|c|c|c|c|}
\hline GENERATING & GENERATING & DISPOSAL & $\begin{array}{l}\text { ANNUAL } \\
\text { VOLUME }\end{array}$ & $\begin{array}{l}\text { ANNUAL } \\
\text { WEIGHT }\end{array}$ & ANNUAL & & \\
\hline AREA & BUILDING & YEAR & CUBIC METERS & GRAMS & CURIES & NUCL IDE & CURIES \\
\hline 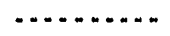 & $\ldots$ & $\ldots$ & $\ldots+\ldots+\ldots$ & 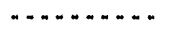 & $\ldots \ldots \ldots$ & 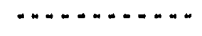 & n............ \\
\hline \multirow[t]{35}{*}{ RFO } & DOW & 71 & $7.530 E+02$ & $2.825 E+08$ & $7.825 E+00$ & U. 235 & $9.706 \mathrm{E}-02$ \\
\hline & & & & & & $U-238$ & $7.728 E+00$ \\
\hline & & $\star$ & & & & & $7825 \mathrm{E}+00$ \\
\hline & & 72 & $6.102 E+02$ & $2.525 \mathrm{E}+08$ & $5.623 \mathrm{E}+00$ & $U=235$ & $7.184 E-02$ \\
\hline & & & & & & $U-238$ & $5.551 E+00$ \\
\hline & & & & & & & . \\
\hline & & * & & & & & $5.623 E+00$ \\
\hline & & 73 & $2.083 \mathrm{E}-01$ & $1.225 E+06$ & $7.345 E+01$ & $c 0.60$ & $7.345 E+01$ \\
\hline & & & & & n............ & & ............. \\
\hline & * & & & & $8.690 E+01$ & & $8.690 E+01$ \\
\hline & 000 & 54 & $6.790 E+02$ & $0.000 E+00$ & $5.278 E+00$ & $A M-243$ & $2.800 E+00$ \\
\hline & & & & & & PU. 242 & $8.842 E-01$ \\
\hline & & & & & & $U-235$ & $1.594 E+00$ \\
\hline & & & & & & & n. \\
\hline & & * & & & & & $5.278 E+00$ \\
\hline & & 55 & $1.115 E+03$ & $0.000 E+(10$ & $1.373 E+01$ & $A M-243$ & $5.200 E+00$ \\
\hline & & & & & & $P U-242$ & $6.410 E+00$ \\
\hline & & & & & & U-235 & $2.117 E+00$ \\
\hline & & & & & & & $\cdots$ \\
\hline & & * & & & & & $1.373 E+01$ \\
\hline & & 56 & $1.184 E+03$ & $0.000 E+00$ & $1.764 E+01$ & $A M-243$ & $5.600 E+00$ \\
\hline & & & & & & PU-242 & $9.499 E+00$ \\
\hline & & & & & & $U-235$ & $2.538 E+00$ \\
\hline & & * & & & & & 1764501 \\
\hline & & & & & & & \\
\hline & & 57 & $1.891 \mathrm{E}+03$ & $0.000 E+00$ & $2.659 E+01$ & $A M-243$ & $8.600 E+00$ \\
\hline & & & & & & PU-242 & $1.335 \mathrm{E}+01$ \\
\hline & & & & & & $U-235$ & $4.642 E+00$ \\
\hline & & * & & & & & $2.659 E+01$ \\
\hline & & 58 & $1.649 E+03$ & $0.000 E+00$ & $3.941 E+01$ & $A M-243$ & $1.220 E+01$ \\
\hline & & & & & & $P U-242$ & $1.811 E+01$ \\
\hline & & & & & & $U-235$ & $9.102 E+00$ \\
\hline & & * & & & & & $3.941 E+01$ \\
\hline & & 59 & $2.082 E+03$ & $0.000 E+00$ & $4.065 E+01$ & $A M-243$ & $1.240 E+01$ \\
\hline & & & & & & PU-242 & $2.012 E+01$ \\
\hline
\end{tabular}




\begin{tabular}{|c|c|c|c|c|c|c|c|}
\hline $\begin{array}{c}\text { GENERAT ING } \\
\text { AREA }\end{array}$ & $\begin{array}{l}\text { GENERATING } \\
\text { BUILDING }\end{array}$ & $\begin{array}{c}\text { DISPOSAL } \\
\text { YEAR }\end{array}$ & $\begin{array}{c}\text { ANNUAL } \\
\text { VOLUME } \\
\text { CUB!C METERS }\end{array}$ & $\begin{array}{l}\text { ANNUAL } \\
\text { WEIGHT } \\
\text { GRAMS }\end{array}$ & $\begin{array}{l}\text { ANNUAL } \\
\text { CURIES }\end{array}$ & NUCL IDE & CURIES \\
\hline …….......... & n............. & $\ldots . . . .$. & .................... & ....... & ……… & - na & ................ \\
\hline \multirow[t]{36}{*}{ RFO } & 000 & 59 & & & & $U-235$ & $8.130 E+00$ \\
\hline & & * & & & & & $4.065 E+01$ \\
\hline & & 60 & $1.945 E+03$ & $0.000 E+00$ & $1.123 E+04$ & $A M=243$ & $9.200 E+00$ \\
\hline & & & & & & $P U-242$ & $1.491 E+01$ \\
\hline & & & & & & $U-235$ & $8.940 E+00$ \\
\hline & & & & & & $U N-I D-B+G$ & $1.120 E+04$ \\
\hline & & & & & & & n. \\
\hline & & * & & & & & $1.123 E+04$ \\
\hline & & 61 & $2.439 E+03$ & $0.000 E+00$ & $3.701 E+03$ & $A M=243$ & $1.400 E+01$ \\
\hline & & & & & & PU- 242 & $2.324 E+01$ \\
\hline & & & & & & $U-235$ & $9.342 E+00$ \\
\hline & & & & & & $U N-1 D-B+G$ & $3.654 E+03$ \\
\hline & & & & & & & $\ldots \ldots$ \\
\hline & & * & & & & & $3.701 E+03$ \\
\hline & & 62 & $2.755 E+03$ & $0.000 E+00$ & $3.851 E+03$ & $A M-243$ & $3.600 E+01$ \\
\hline & & & & & & PU-242 & 2. $170 E+01$ \\
\hline & & & & & & $U-235$ & $1.010 E+01$ \\
\hline & & & & & & $U N-I D \cdot B+G$ & $3.783 E+03$ \\
\hline & & * & & & & & $3.851 E+03$ \\
\hline & & 63 & $3.357 E+03$ & $0.000 E+00$ & $1.063 E+04$ & $A M-243$ & $4.080 E+01$ \\
\hline & & & & & & $P U-242$ & $6.689 E+01$ \\
\hline & & & & & & $U-235$ & $3.624 E+00$ \\
\hline & & & & & & $U N-I D-B+G$ & $1.052 E+04$ \\
\hline & & & & & & & .................. \\
\hline & & * & & & & & $1.063 E+04$ \\
\hline & & 64 & $3.764 E+03$ & $0.000 E+00$ & $1.240 E+04$ & AM- 243 & $4.760 E+01$ \\
\hline & & & & & & PU- 242 & $7.797 E+01$ \\
\hline & & & & & & $U-235$ & $2.910 E+00$ \\
\hline & & & & & & $U N-1 D-B+G$ & $1.227 E+04$ \\
\hline & & & & & & & 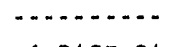 \\
\hline & & * & & & & & $1.240 E+04$ \\
\hline & & 65 & $3.454 E+03$ & $0.000 E+00$ & $1.722 E+04$ & $A M-243$ & $8.280 E+01$ \\
\hline & & & & & & PU-242 & $1.063 E+02$ \\
\hline & & & & & & $U-235$ & $9.230 E+00$ \\
\hline & & & & & & $U N-I D-B+G$ & $1.702 E+04$ \\
\hline & & * & & & & & $1.722 E+04$ \\
\hline
\end{tabular}




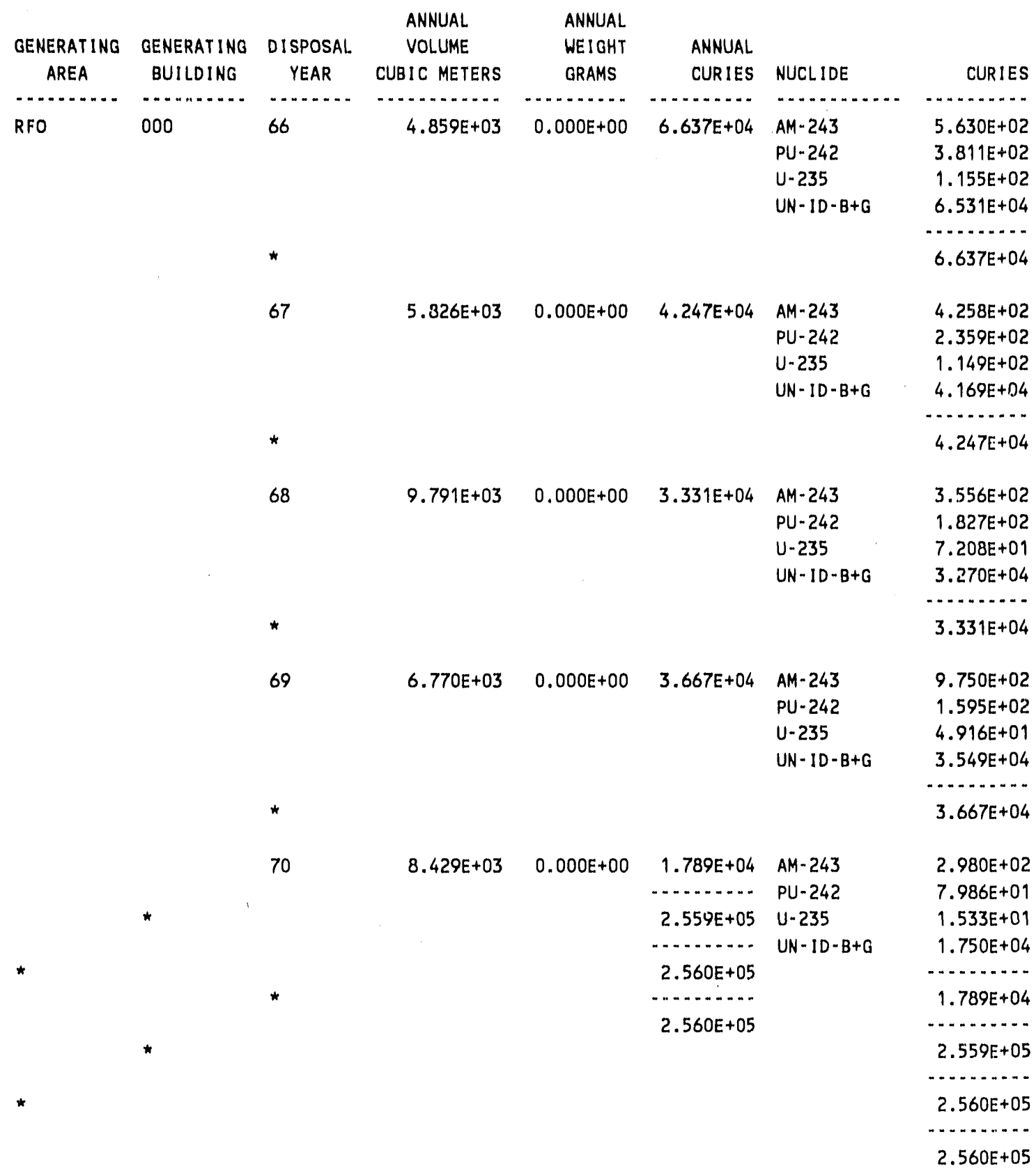




\begin{tabular}{|c|c|c|c|c|c|c|c|}
\hline GENERATING & GENERATING & DISPOSAL & $\begin{array}{l}\text { ANNUAL } \\
\text { VOLUUME }\end{array}$ & $\begin{array}{l}\text { ANNUAL } \\
\text { WE I GHT }\end{array}$ & ANNUAL & & \\
\hline AREA & BUILDING & YEAR & CUBIC METERS & GRAMS & CURIES & NUCLIDE & CURIES \\
\hline - & - & -....... & - & . & , n & - & - \\
\hline \multirow[t]{7}{*}{ SMC } & RWI & 86 & $4.274 E+01$ & $3.053 E+07$ & $5.100 E-03$ & $U-238$ & $5.100 \mathrm{E}-03$ \\
\hline & & 87 & $6.662 E+00$ & $1.428 E+07$ & $7.895 E-02$ & $U-238$ & $7.895 E-02$ \\
\hline & & 88 & $5.341 E+01$ & $9.075 E+07$ & $4.266 E-01$ & $U-238$ & $4.266 E-01$ \\
\hline & & 89 & 2.144E+01 & $4.517 E+07$ & $1.042 E+00$ & $U-238$ & $1.042 E+00$ \\
\hline & & & & & ……..... & & . \\
\hline & * & & & & $1.553 E+00$ & & $1.553 E+00$ \\
\hline & & & & & n.t.n. & & (n) \\
\hline \multirow[t]{3}{*}{ * } & & & & & $1.553 E+00$ & & $1.553 \mathrm{E}+00$ \\
\hline & & & & & n......... & & (n) \\
\hline & & & & & $1.553 E+00$ & & $1.553 E+00$ \\
\hline
\end{tabular}




\begin{tabular}{|c|c|c|c|c|c|c|c|}
\hline $\begin{array}{l}\text { GENERATING } \\
\text { AREA }\end{array}$ & $\begin{array}{l}\text { GENERAT ING } \\
\text { BUILDING }\end{array}$ & $\begin{array}{l}\text { DISPOSAL } \\
\text { YEAR }\end{array}$ & $\begin{array}{c}\text { ANNUAL } \\
\text { VOLUME } \\
\text { CUBIC METERS }\end{array}$ & $\begin{array}{l}\text { ANNUAL } \\
\text { WEIGHT } \\
\text { GRAMS }\end{array}$ & $\begin{array}{l}\text { ANNUAL } \\
\text { CURIES }\end{array}$ & NUCLIDE & CURIES \\
\hline - n n & - & n...... & - & n. & n. non. & - n. & ……..... \\
\hline \multirow[t]{31}{*}{ TAN } & DFN & 84 & $6.162 E+01$ & $1.789 \mathrm{E}+07$ & $4.608 E-02$ & $N / A$ & $0.000 E+00$ \\
\hline & & & & & & MFP & $4.608 E-02$ \\
\hline & & * & & & & & $4.608 E-02$ \\
\hline & & 87 & $4.712 E+01$ & $2.295 E+07$ & $9.767 E-01$ & MAP & $9.767 E-01$ \\
\hline & & & & & n................ & & n.......... \\
\hline & * & & & & $1.023 E+00$ & & $1.023 E+00$ \\
\hline & IET & 78 & $2.081 E+01$ & $4.083 E+06$ & $5.000 E+00$ & MFP & $5.000 E+00$ \\
\hline & LPT & 72 & $4.758 E+00$ & $3.175 E+05$ & $1.000 E-03$ & $U N-1 D-B+G$ & $1.000 E-03$ \\
\hline & & 76 & $3.407 E+01$ & $8.618 E+06$ & $1.100 E+00$ & MFP & $1.100 E+00$ \\
\hline & & 77 & $2.832 E-02$ & $2.268 E+03$ & $1.959 E-05$ & $11-235$ & $1.926 E-05$ \\
\hline & & & & & n. & $U-238$ & $3.330 E-07$ \\
\hline & * & & & & $1.101 E+00$ & & - n. \\
\hline & & * & & & & & $1.959 E-05$ \\
\hline & & & & & & & - \\
\hline & * & & & & & & $1.101 E+00$ \\
\hline & NONE & 71 & $1.790 E+01$ & $2.358 E+07$ & $2.790 E-01$ & MFP & $2.790 E-01$ \\
\hline & PM2 & 82 & $7.249 E+00$ & $5.443 E+06$ & $1.100 E-04$ & $\mathrm{co}-60$ & $1.000 E-05$ \\
\hline & & & & & & CS -137 & $1.000 E-04$ \\
\hline & & * & & & & & $100 E-04$ \\
\hline & & & & & & & ............... \\
\hline & * & & & & & & $1.100 E-04$ \\
\hline & TSF & 83 & $7.068 E+01$ & $8.645 E+07$ & $5.622 E-03$ & $00-60$ & $7.800 E-05$ \\
\hline & & & & & & CS- 137 & $2.772 E-03$ \\
\hline & & & & & & SR -90 & $2.772 E-03$ \\
\hline & & * & & & & & $5.622 E-03$ \\
\hline & & & & & & & - \\
\hline & * & & & & & & $5.622 E-03$ \\
\hline & 000 & 61 & $1.680 E+02$ & $0.000 E+00$ & $1.260 E+02$ & $U N-1 D-B+G$ & $1.260 E+02$ \\
\hline & & 62 & $2.670 E+02$ & $0.000 E+00$ & $1.600 E+04$ & $U N-I D-B+G$ & $1.600 E+04$ \\
\hline & & 63 & $3.460 E+02$ & $0.000 E+00$ & $3.671 E+04$ & $U N-1 D-B+G$ & $3.671 E+04$ \\
\hline & & 64 & $4.610 E+02$ & $0.000 E+\cap 0$ & $3.642 E+03$ & $U N-I D-B+G$ & $3.642 E+03$ \\
\hline
\end{tabular}




\begin{tabular}{|c|c|c|c|c|c|c|c|}
\hline GENERATING & GENERATING & DISPOSAL & $\begin{array}{l}\text { ANNUAL } \\
\text { VOLUME }\end{array}$ & $\begin{array}{l}\text { ANNUAL } \\
\text { WEIGHT }\end{array}$ & ANNUAL & & \\
\hline AREA & BUILDING & YEAR & CUBIC METERS & GRAMS & CURIES & NUCLIDE & CURIES \\
\hline ……....... & n............... & 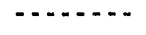 & (n) & n............... & 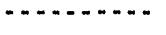 & n. & - \\
\hline \multirow[t]{31}{*}{ TAN } & 000 & 65 & $4.090 E+02$ & $0.000 E+00$ & $1.404 E+03$ & $U N-I D-B+G$ & $1.404 E+03$ \\
\hline & & 66 & $8.720 E+02$ & $0.000 E+00$ & $1.481 E+04$ & $U N-I D-B+G$ & $1.481 E+04$ \\
\hline & & 67 & $3.090 E+02$ & $0.000 E+00$ & $2.242 E+03$ & $U N-I D-B+G$ & $2.242 E+03$ \\
\hline & & 68 & $5.470 E+02$ & $0.000 E+00$ & $4.458 E+03$ & $U N-I D-B+G$ & $4.458 E+03$ \\
\hline & & 69 & 4.100E+02 & $0.000 E+00$ & $1.990 E+03$ & $U N-I D-B+G$ & $1.990 E+03$ \\
\hline & & 70 & $2.710 E+02$ & $0.000 E+00$ & $1.120 E+03$ & $U N-I D-B+G$ & $1.120 E+03$ \\
\hline & * & & & & $8.250 E+04$ & & $8.250 E+04$ \\
\hline & 330 & 83 & $1.450 E+01$ & $1.451 E+07$ & $1.420 \mathrm{E}-03$ & Co- 60 & $2.000 E-05$ \\
\hline & & & & & & CS- 137 & $7.000 E-04$ \\
\hline & & & & & & SR-90 & $7.000 E-04$ \\
\hline & & * & & & & & $1.420 \mathrm{E}-03$ \\
\hline & & & & & & & n.......... \\
\hline & & & & & & & $1.420 E-03$ \\
\hline & 603 & 71 & $2.163 E+01$ & $5.897 E+06$ & $2.000 E-03$ & MFP & $2.000 E-03$ \\
\hline & & 84 & $1.087 E+01$ & $4.740 E+06$ & $1.956 \mathrm{E}-02$ & MFP & $1.956 \mathrm{E}-02$ \\
\hline & & 86 & $7.248 E+00$ & $2.702 E+06$ & $2.000 E-06$ & MFP & $2.000 E-06$ \\
\hline & & 87 & $5.976 E+01$ & $3.710 E+07$ & $1.995 E-02$ & MFP & $1.995 E-02$ \\
\hline & * & & & & 4.151E-02 & & $4.151 E-02$ \\
\hline & 606 & 71 & $6.117 E+00$ & $2.268 E+05$ & $4.400 E-02$ & $U N-I D-B+G$ & 4.400E-02 \\
\hline & 607 & 71 & $2.231 E+02$ & $8.064 E+07$ & $1.036 E+03$ & CE -144 & $3.000 \mathrm{E}-01$ \\
\hline & & & & & & co-58 & $1.400 E-02$ \\
\hline & & & & & & $\operatorname{co-60}$ & $2.511 E+02$ \\
\hline & & & & & & CS- 134 & $6.000 E-02$ \\
\hline & & & & & & CS -137 & $5.344 E+01$ \\
\hline & & & & & & $F E-59$ & $2.250 E+02$ \\
\hline & & & & & & MFP & $1.472 E+00$ \\
\hline & & & & & & $\mathrm{NI}-59$ & $5.000 E+02$ \\
\hline & & & & & & RH-106 & $1.300 E+00$ \\
\hline & & & & & & RU-106 & $1.300 E+00$ \\
\hline & & & & & & $S R-90$ & $6.200 E-01$ \\
\hline & & & & & & $U N-I D-B+G$ & $9.327 E-01$ \\
\hline
\end{tabular}




\begin{tabular}{|c|c|c|c|c|c|c|c|}
\hline $\begin{array}{c}\text { GENERATING } \\
\text { AREA }\end{array}$ & $\begin{array}{l}\text { GENERATING } \\
\text { BUILDING }\end{array}$ & $\begin{array}{l}\text { DISPOSAL. } \\
\text { YEAR }\end{array}$ & $\begin{array}{c}\text { ANNUAL } \\
\text { VOLUME } \\
\text { CUBIC METERS }\end{array}$ & $\begin{array}{l}\text { ANNUAL } \\
\text { WEIGHT } \\
\text { GRAMS }\end{array}$ & $\begin{array}{l}\text { ANNUAL } \\
\text { CURIES }\end{array}$ & NUCL IDE & CURIES \\
\hline n. & . & ............ & , n & 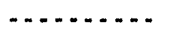 & n. & - nas & - \\
\hline \multirow[t]{41}{*}{ TAN } & 607 & 71 & & & & $Y-90$ & $6.200 E-01$ \\
\hline & & * & & & & & $1.036 E+03$ \\
\hline & & 72 & $1.524 E+02$ & $4.001 E+07$ & $2.365 E+03$ & $C E-144$ & $1.620 E+00$ \\
\hline & & & & & & $c 0.60$ & $4.968 E+02$ \\
\hline & & & & & & CS -134 & $2.020 E+00$ \\
\hline & & & & & & Cs -137 & $2.438 E+02$ \\
\hline & & & & & & FE-59 & $4.650 E+02$ \\
\hline & & & & & & $N 1-59$ & $1.095 E+03$ \\
\hline & & & & & & $R B-86$ & $4.210 E+00$ \\
\hline & & & & & & $R H-106$ & $3.200 E+00$ \\
\hline & & & & & & $R U=106$ & $6.830 E+00$ \\
\hline & & & & & & $S R=90$ & $1.693 E+01$ \\
\hline & & & & & & $U-235$ & $6.169 E-04$ \\
\hline & & & & & & $U-238$ & $7.909 E-04$ \\
\hline & & & & & & UN-ID-ALPHA & $1.020 E-01$ \\
\hline & & & & & & $U N-1 D-B+G$ & $2.130 E+01$ \\
\hline & & & & & & $Y-90$ & $8.040 E+00$ \\
\hline & & * & & & & & $2.365 E+03$ \\
\hline & & 73 & $1.551 E+02$ & $1.831 E+07$ & $1.962 E+03$ & $C E-144$ & $1.218 E+00$ \\
\hline & & & & & & $c 0-60$ & $4.700 E+02$ \\
\hline & & & & & & CS- 134 & $2.840 E-01$ \\
\hline & & & & & & CS -137 & $5.540 E+01$ \\
\hline & & & & & & FE-59 & $4.500 E+02$ \\
\hline & & & & & & MFP & $1.000 \mathrm{E}-02$ \\
\hline & & & & & & $N I-59$ & $9.700 E+02$ \\
\hline & & & & & & $R B-86$ & $4.160 E+00$ \\
\hline & & & & & & RH- 106 & $1.280 E+00$ \\
\hline & & & & & & $R U-106$ & $5.152 E+00$ \\
\hline & & & & & & $S R-90$ & $1.302 E+00$ \\
\hline & & & & & & $U N-1 D-B+G$ & $1.620 E+00$ \\
\hline & & & & & & $Y-90$ & $1.398 E+00$ \\
\hline & & & & & & & .............. \\
\hline & & * & & & & & $1.962 E+03$ \\
\hline & & 74 & $9.837 E+02$ & $4.504 E+07$ & $6.735 E+03$ & CE-144 & $1.411 E+01$ \\
\hline & & & & & & $\mathrm{CO}-60$ & $1.680 E+03$ \\
\hline & & & & & & CS- 134 & $3.212 E+00$ \\
\hline & & & & & & CS -137 & $2.242 E+02$ \\
\hline & & & & & & FE-59 & $1.430 \mathrm{E}+03$ \\
\hline & & & & & & $H F-181$ & $7.000 E-02$ \\
\hline & & & & & & MFP & $8.201 E-01$ \\
\hline & & & & & & $N]=59$ & $3.200 E+03$ \\
\hline
\end{tabular}




\begin{tabular}{|c|c|c|}
\hline GENERAT ING & GENERATING & DISPOSAL \\
\hline AREA & BUILDING & YEAR \\
\hline & , n & \\
\hline
\end{tabular}

$\begin{array}{cl}\text { ANNUAL } & \text { ANNUAL } \\ \text { VOLUME } & \text { WEIGHT } \\ \text { CUBIC METERS } & \text { GRAMS }\end{array}$

ANNUAL
CURIES
607

74

CUBIC METERS

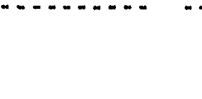

CURIES NUC

NUCLIDE

RB- 86

$R U=106$

$S R-90$

$U N-I D-B+C$

$Y-90$

CURIES

$6.322 E+01$

$5.920 \mathrm{E}+01$

$1.538 E+01$

$2.795 \mathrm{E}+01$

$1.679 \mathrm{E}+01$

$6.735 E+03$

75

$1.202 E+02$

$1.194 E+08$

$3.738 E+01$

CE- 144

CO- 60

CS- 134

CS -137

EU- 154

NN -54

RB- 86

$\mathrm{RU}-106$

$S R-90$

U. 235

$U-238$

UN-1D-ALPHA

$U N-1 D-B+G$

$Y=90$

$1.321 E+00$

$1.791 \mathrm{E}-02$

3.201E-01

$9.763 E+00$

$2.342 \mathrm{E}-03$

$6.888 \mathrm{E}-04$

$5.850 E+00$

$5.475 E+00$

$4.371 E+00$

2.140E-05

3.330E-07

$1.791 E-03$

$8.724 E+00$

$1.530 E+00$

$3.738 \mathrm{E}+01$

76

$9.075 E+02$

$9.938 E+08$

$3.222 E+02$

CE -144

CO- 60

CS- 134

CS- 137

EU- 154

MFP

$M N-54$

RU- 106

$S R-90$

U-238

UN-ID - AL.PHA

$U N-I D-B+G$

1. $811 E+00$

$6.778 E+00$

$2.169 E+00$

$1.672 \mathrm{E}+02$

3.801E-01

$4.101 E+00$

$2.066 E-01$

$1.627 E+00$

$2.992 E+01$

$2.431 E-05$

5.327E-03

$1.080 E+02$

3.........

77
Co. 58

CO- 60

CS- 134

CS -137

MAP

MFP
6.202E+02

$8.146 E+01$

$3.000 E+00$

$8.250 E+01$

2.652E+00

$1.124 E+01$ 


\begin{tabular}{|c|c|c|c|c|c|c|c|}
\hline $\begin{array}{c}\text { GENERAT ING } \\
\text { AREA }\end{array}$ & $\begin{array}{l}\text { GENERATING } \\
\text { BUILDING }\end{array}$ & $\begin{array}{l}\text { DISPOSAL } \\
\text { YEAR }\end{array}$ & $\begin{array}{c}\text { ANNUAL } \\
\text { VOLUME } \\
\text { CUBIC METERS }\end{array}$ & $\begin{array}{l}\text { ANNUAL } \\
\text { WEI GHT } \\
\text { GRAMS }\end{array}$ & $\begin{array}{l}\text { ANNUAL } \\
\text { CURIES }\end{array}$ & NUCL IDE & CURIES \\
\hline n........... & ............... & .......... & 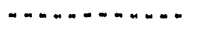 & - n...…… & - n. & 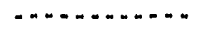 & - n. \\
\hline \multirow[t]{39}{*}{ TAN } & 607 & 77 & & & & $M N-54$ & $5.929 E+02$ \\
\hline & & & & & & $U N-1 D-B+G$ & $1.635 \mathrm{E}-02$ \\
\hline & & * & & & & & $1.394 E+03$ \\
\hline & & 78 & $1.774 E+02$ & $6.941 E+07$ & $3.012 E+03$ & $C 0-58$ & $1.258 \mathrm{E}+03$ \\
\hline & & & & & & $c 0-60$ & $2.650 E+02$ \\
\hline & & & & & & CS- 134 & $1.000 E+01$ \\
\hline & & & & & & CS -137 & $2.750 E+02$ \\
\hline & & & & & & MAP & $2.096 E+00$ \\
\hline & & & & & & MFP & $8.479 E+00$ \\
\hline & & & & & & $M N-54$ & $1.190 E+03$ \\
\hline & & & & & & $U N-1 D-B+G$ & $3.286 E+00$ \\
\hline & & & & & & & (1) \\
\hline & & * & & & & & $3.012 E+03$ \\
\hline & & 79 & $4.370 E+02$ & $1.602 E+08$ & $2.013 E+03$ & $C 0-58$ & $9.600 E+02$ \\
\hline & & & & & & $c 0-60$ & $4.000 E+01$ \\
\hline & & & & & & MAP & $5.300 \mathrm{E}-02$ \\
\hline & & & & & & MFP & $1.245 E+01$ \\
\hline & & & & & & $M N-54$ & $1.000 E+03$ \\
\hline & & & & & & $U N-1 D=B+G$ & $4.096 E-01$ \\
\hline & & & & & & & - \\
\hline & & * & & & & & $2.013 E+03$ \\
\hline & & 80 & $3.517 E+02$ & $1.394 E+08$ & $2.284 E+01$ & MAP & $2.000 E-03$ \\
\hline & & & & & & MFP & $2.284 E+01$ \\
\hline & & & & & & $P U-238$ & $3.733 E-06$ \\
\hline & & & & & & PU-239 & $1.818 E-05$ \\
\hline & & & & & & $U-234$ & $2.667 E-05$ \\
\hline & & & & & & $U-235$ & $1.380 E-06$ \\
\hline & & & & & & $U-236$ & $5.482 E-07$ \\
\hline & & & & & & $U=238$ & $1.218 \mathrm{E}-06$ \\
\hline & & & & & & & n........... \\
\hline & & * & & & & & $2.284 E+01$ \\
\hline & & 81 & $1.117 \mathrm{E}+02$ & $4.896 E+07$ & 5.892E-01 & MFP & $5.892 E-01$ \\
\hline & & 82 & $3.171 E+02$ & $1.427 E+08$ & $5.186 E+00$ & MAP & $6.000 E-02$ \\
\hline & & & & & & MFP & $5.126 E+00$ \\
\hline & & & & & & & n \\
\hline & & * & & & & & $5.186 E+00$ \\
\hline & & 83 & $1.993 \mathrm{E}+02$ & $6.893 E+07$ & $3.656 E+01$ & CS- 134 & $6.010 \mathrm{E}-01$ \\
\hline & & & & & & CS- 137 & $3.001 E+01$ \\
\hline & & & & & & MFF & $5.350 E+00$ \\
\hline
\end{tabular}




\begin{tabular}{|c|c|c|c|c|c|c|c|}
\hline & & & ANNUAL & ANNUAL & & & \\
\hline GENERATING & GENERATING & DISPOSAL & VOLUME & WEIOHT & ANNUAL & & \\
\hline AREA & BUILDING & YEAR & CUBIC METERS & GRAMS & CURIES & NUCL IDE & CURIES \\
\hline - n. & n. & ............... & 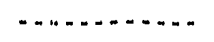 & n. nan. & n. nan. & ................ & n.......... \\
\hline \multirow[t]{40}{*}{ TAN } & 607 & 83 & & & & RH- 106 & $1.503 E-01$ \\
\hline & & & & & & $R U-106$ & $1.502 E-01$ \\
\hline & & & & & & $S R=90$ & $1.502 E-01$ \\
\hline & & & & & & $Y-90$ & $1.503 E-01$ \\
\hline & & & & & & & $\ldots$ \\
\hline & & * & & & & & $3.656 \mathrm{E}+01$ \\
\hline & & 84 & $1.431 E+02$ & $4.791 E+07$ & $2.085 E+00$ & N/A & $0.000 E+00$ \\
\hline & & & & & & MFP & $2.085 E+00$ \\
\hline & & & & & & & $\cdots$ \\
\hline & & * & & & & & $2.035 E+00$ \\
\hline & & 85 & $1.647 E+02$ & $5.395 E+07$ & $1.662 E+01$ & $N / A$ & $0.000 E+00$ \\
\hline & & & & & & MFP & $1.662 E+01$ \\
\hline & & & & & & & . \\
\hline & & * & & & & & $1.662 E+01$ \\
\hline & & 86 & $1.140 E+02$ & $3.991 \mathrm{E}+07$ & $1.438 E+01$ & MAP & $2.900 E-01$ \\
\hline & & & & & & MFP & $1.409 E+01$ \\
\hline & & & & & & & - n \\
\hline & & * & & & & & $1.438 \mathrm{E}+01$ \\
\hline & & 87 & $1.167 E+02$ & $4.431 E+07$ & $3.576 E+02$ & $10-60$ & $6.279 E+00$ \\
\hline & & & & & & CS -137 & $5.120 E+00$ \\
\hline & & & & & & MAP & $1.269 E-01$ \\
\hline & & & & & & MFP & $3.461 E+02$ \\
\hline & & & & & & $U-235$ & $6.500 E-06$ \\
\hline & & & & & & $U-238$ & $5.220 E-04$ \\
\hline & & & & & & & 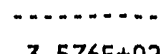 \\
\hline & & * & & & & & $3.576 E+02$ \\
\hline & & 88 & $5.585 E+01$ & $2.435 E+07$ & $1.169 E+00$ & $c 0-60$ & $4.373 E-03$ \\
\hline & & & & & & CS -137 & $5.894 E-04$ \\
\hline & & & & & & MAP & $1.750 E-03$ \\
\hline & & & & & & MFP & $1.163 E+00$ \\
\hline & & & & & & & a.t. \\
\hline & & * & & & & & $1.169 E+00$ \\
\hline & & 89 & $7.609 E+01$ & $2.499 E+07$ & $6.705 E+01$ & AM-241 & $7.101 E-02$ \\
\hline & & & & & (-) & CE- 144 & $1.200 E-01$ \\
\hline & * & & & & $1.940 E+04$ & CM-244 & $2.250 E-03$ \\
\hline & & & & & & $c 0-60$ & $2.878 E-01$ \\
\hline & & & & & & CS -134 & $4.252 E+00$ \\
\hline & & & & & & CS- 137 & $6.036 E+01$ \\
\hline & & & & & & MFP & $8.755 E-01$ \\
\hline & & & & & & PU-239 & $1.510 E-02$ \\
\hline
\end{tabular}




\begin{tabular}{|c|c|c|c|c|c|c|c|}
\hline $\begin{array}{c}\text { GENERATING } \\
\text { ARE }\end{array}$ & $\begin{array}{l}\text { GENERATING } \\
\text { BUILDING }\end{array}$ & $\begin{array}{c}\text { DISPOSAL } \\
\text { YEAR }\end{array}$ & $\begin{array}{c}\text { ANNUAL } \\
\text { VOLUME } \\
\text { CUB IC METERS }\end{array}$ & $\begin{array}{l}\text { ANNUAL } \\
\text { WEIGHT } \\
\text { GRAMS }\end{array}$ & $\begin{array}{l}\text { ANNUAL } \\
\text { CURIES }\end{array}$ & NUCI IDF & CUPIFS \\
\hline ........... & . ............ & ......... & CUDAC METEKSO & & CUKIES & NUCL IDE & CURIES \\
\hline \multirow[t]{32}{*}{ TAN } & 607 & 89 & & & & RU-106 & $8.000 E-02$ \\
\hline & & & & & & $S B-125$ & $1.700 E-01$ \\
\hline & & & & & & $S R=90$ & $8.158 E-01$ \\
\hline & & & & & & $U-235$ & $7.776 \mathrm{E}-07$ \\
\hline & & $\star$ & & & & & $6.705 E+01$ \\
\hline & & & & & & & . \\
\hline & * & & & & & & $1.940 E+04$ \\
\hline & 615 & 72 & $4.169 E+01$ & $2.903 E+06$ & $6.004 E-03$ & $U-235$ & $3.659 E-06$ \\
\hline & & & & & & $U N-1 D-B+C$ & $6.000 \mathrm{E}-03$ \\
\hline & & & & & & & 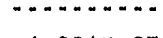 \\
\hline & & * & & & & & $6.004 E-03$ \\
\hline & & 73 & $1.424 E+01$ & $1.814 E+06$ & $1.900 E-02$ & U-235 & $6.099 E=07$ \\
\hline & & & & & - n & $U N-1 D-B+G$ & $1.900 \mathrm{E}-02$ \\
\hline & * & & & & $2.500 \mathrm{E}-02$ & & - L \\
\hline & & * & & & & & $1.900 E-02$ \\
\hline & & & & & & & 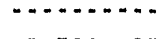 \\
\hline & * & & & & & & $2.500 E-02$ \\
\hline & 616 & 78 & $1.631 E+01$ & $2.368 E+07$ & $2.280 E-01$ & MFP & $2.280 E-01$ \\
\hline & 620 & 86 & $1.841 E+00$ & $5.400 E+05$ & $1.000 E-05$ & MFP & $1.000 E-05$ \\
\hline & 623 & 74 & $4.610 E+00$ & $1.633 E+06$ & $1.000 E-03$ & $U N=1 D-B+G$ & $1.000 E-03$ \\
\hline & & 84 & $3.625 \mathrm{E}+00$ & $2.404 E+06$ & $9.600 \mathrm{E}-04$ & MFP & $9.600 E-04$ \\
\hline & & 86 & $1.448 E+01$ & $1.208 E+07$ & $8.000 E-06$ & MFP & $8.000 E-06$ \\
\hline & & & & & 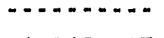 & & 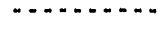 \\
\hline & * & & & & $1.968 E-03$ & & $1.968 \mathrm{E}-03$ \\
\hline & 629 & 72 & $7.052 E+00$ & $4.536 E+06$ & $1.000 E-03$ & MFP & $1.000 E-03$ \\
\hline & 630 & 79 & $5.115 E+00$ & $3.556 E+06$ & $3.517 E-03$ & MAP & $1.758 E-03$ \\
\hline & & & & & & MFP & $1.758 E-03$ \\
\hline & & * & & & & & $3.517 E-03$ \\
\hline & & 80 & $3.013 E+00$ & $2.068 E+06$ & $9.210 E-04$ & MAP & $9.210 E-04$ \\
\hline & & 81 & $9.119 E-01$ & $6.260 E+05$ & $7.500 E-07$ & MAP & $3.750 E-07$ \\
\hline & & & & & & MFP & $3.750 E-07$ \\
\hline & & * & & & & & $7.500 E-07$ \\
\hline
\end{tabular}




\begin{tabular}{|c|c|c|c|c|c|c|c|}
\hline $\begin{array}{l}\text { GENERATING } \\
\text { AREA }\end{array}$ & $\begin{array}{l}\text { QENERATING } \\
\text { BUILDING }\end{array}$ & $\begin{array}{l}\text { DISPOSAL. } \\
\text { YEAR }\end{array}$ & $\begin{array}{c}\text { ANNUAL } \\
\text { VOLUME } \\
\text { CUBIC METERS }\end{array}$ & $\begin{array}{l}\text { ANNUAL } \\
\text { WEIGHT } \\
\text { GRAMS }\end{array}$ & $\begin{array}{l}\text { ANNUAL } \\
\text { CURIES }\end{array}$ & NUCLIDE & CURIES \\
\hline 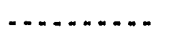 & $\ldots$ & ......... & 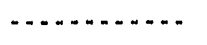 & n. & . n........... & …….......... & $\ldots$ \\
\hline \multirow[t]{33}{*}{ TAN } & 630 & 82 & $1.586 E+00$ & $1.089 E+06$ & $4.605 E-03$ & MAP & $2.250 \mathrm{E}-03$ \\
\hline & & & & & , n. & MFP & $2.355 E-03$ \\
\hline & * & & & & $9.044 E-03$ & & (n) \\
\hline & & * & & & & & $4.605 E-03$ \\
\hline & & & & & & & 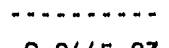 \\
\hline & * & & & & & & $9.044 E=03$ \\
\hline & 636 & 76 & $2.436 \mathrm{E}+01$ & $5.444 E+06$ & $4.000 E-03$ & MFP & $4.000 E-03$ \\
\hline & 640 & 74 & $7.958 E+00$ & $1.363 E+06$ & $1.000 E+00$ & $R A-226$ & $1.000 E+00$ \\
\hline & & & & & & $U-235$ & $5.350 E-07$ \\
\hline & & & & & & $U-238$ & $5.994 E-09$ \\
\hline & & & & & & & $\cdots+\cdots$ \\
\hline & & * & & & & & $1.000 E+00$ \\
\hline & & & & & & & 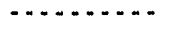 \\
\hline & * & & & & & & $1.000 E+00$ \\
\hline & 641 & 76 & $1.586 E+01$ & $5.443 E+05$ & $1.000 E-03$ & MFP & $1.000 E-03$ \\
\hline & 645 & 78 & $5.437 E+00$ & $3.175 E+05$ & $3.000 E-01$ & MFP & $3.000 E-01$ \\
\hline & 647 & 76 & $9.091 E+00$ & $1.361 E+06$ & $2.000 E-03$ & $U N-1 D-B+G$ & $2.000 E-03$ \\
\hline & & 82 & $1.475 E+01$ & $9.072 E+05$ & $1.100 E-04$ & $c 0-60$ & $1.000 E-05$ \\
\hline & & & & & & CS- 137 & $1.000 E-04$ \\
\hline & & $\star$ & & & & & $1.100 \mathrm{E}-04$ \\
\hline & & 83 & $1.133 E-01$ & $8.391 E+04$ & $4.068 E-04$ & MAP & $1.440 E-04$ \\
\hline & & & & & & MFP & $1.440 E-04$ \\
\hline & & & & & & U-235 & $7.900 E=07$ \\
\hline & & & & & & $U-238$ & $1.180 E-04$ \\
\hline & & * & & & & & $4.068 E-04$ \\
\hline & & 86 & $9.772 E+01$ & $1.029 E+08$ & $2.329 E+00$ & $c 0-60$ & $2.000 E-05$ \\
\hline & & & & & ……....... & CS- 137 & $1.121 \mathrm{E}+00$ \\
\hline & * & & & & $2.331 E+00$ & MFP & $1.207 \mathrm{E}+00$ \\
\hline & & & & & & & and \\
\hline & & 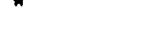 & & & & & $\begin{array}{r}2.329 E+00 \\
\ldots . . . \ldots . . . . .\end{array}$ \\
\hline & * & & & & & & $2.331 E+00$ \\
\hline & 668 & 85 & $7.249 E+01$ & $8.972 E+07$ & $7.805 E-01$ & $N / A$ & $0.000 E+00$ \\
\hline & & & & & & MFP & $7.805 E-01$ \\
\hline
\end{tabular}




\begin{tabular}{|c|c|c|c|c|c|c|c|}
\hline & & & ANNUAL & ANNUAL & & & \\
\hline GENERATINO & GENERATING & DISPOSAL. & VOLUME & WEIGHT & ANNUAL. & & \\
\hline AREA & BUILDING & YEAR & CUBIC METERS & GRAMS & CURIES & NUCLIDE & CURIES \\
\hline \multirow[t]{4}{*}{ n. } & ............... & $\cdots$ & . & , n & $\ldots, \ldots+\ldots$ & . & $\cdots+\ldots$ \\
\hline & & * & & & & & $7.805 E-01$ \\
\hline & & & & & & & . \\
\hline & * & & & & & & $7.805 E-01$ \\
\hline \multirow[t]{5}{*}{ TAN } & 711 & 74 & $4.164 E+00$ & $1.814 E+06$ & $1.000 E-03$ & $U N-1 D-B+G$ & $1.000 E-03$ \\
\hline & & & & & - & & - n. \\
\hline & & & & & $1.019 E+05$ & & $1.019 E+05$ \\
\hline & & & & & (n) & & $\cdots$ \\
\hline & & & & & $1.019 E+05$ & & $1.019 E+05$ \\
\hline
\end{tabular}




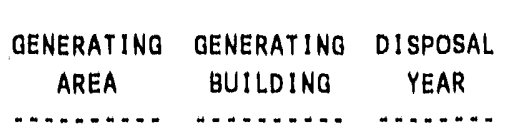

TRA

87
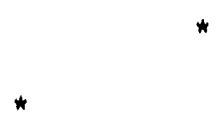

HT4

NONE
71

71

VOLUME CUBIC METERS

4.858 ....

$4.858 \mathrm{E}+0$

1

ANNUAL

WEIGHT aran

$1.955 E+07$

CURIES NUC

NUCL. IDE

CURIES

C0.60

CS- 137

n...........

U. 235

$1.3305-05$

$3.571 \mathrm{E}-04$

(............

$3.911 \mathrm{E}-04$

$3.911 \mathrm{E}-04$

$1.699 \mathrm{E}-01$

4.536E+04 1.000E-05 MFP

$1.000 E-05$

$1.577 E+02$

$2.170 E+07$

$2.886 \mathrm{E}+05$

$B A=L A-140$

CE- 141

Co. 58

$\mathrm{CO}-60$

CR-51

CS -137

FE- 59

$\mathrm{H}-3$

MFP

$M N-54$

RU-106

$T E-1 \cdot 132$

$\mathrm{TH}-232$

$\mathrm{U}-234$

U-235

$\mathrm{U}-236$

$U-238$

$1.352 E+00$

$1.113 E+00$

$5.638 \mathrm{E}+00$

$2.599 E+04$

$2.338 E+05$

$1.218 \mathrm{E}+00$

2. $886 E+0 !$

5. $000 \mathrm{E}-01$

$5.883 E+00$

$1.000 \mathrm{E}-01$

$1.216 \mathrm{E}-01$

3. $040 \mathrm{E}-01$

$1.090 E-04$

3.710E- 04

$3.456 E-04$

$1.584 \mathrm{E}-06$

$U N-10-8+Q \quad 8.343 E-04$

$2 N-65$

$1.600 E+00$

$2.886 E+05$

86

$3.790 E+00$

$3.175 E+06$

$9.284 E+00$
-2.20
$2.887 E+05$

CO- 60

$C R-51$

$1.240 E-01$

*

$$
2.887 E+05
$$

$U N-1 D-B+O$

$8.980 E+00$

$1.800 \mathrm{E}-01$

- ............

$9.284 E+00$

..........

$2.887 E+05$

NSA

85

$9.938 E+01$

$6.809 E+07$

$2.993 E-01$

N/A

$0.000 E+00$

$1.496 E-01$

$1.498 \mathrm{E}-01$

MFP

..........

2.993E-01 


\begin{tabular}{|c|c|c|c|c|c|c|c|}
\hline $\begin{array}{c}\text { OENERATINO } \\
\text { AREA }\end{array}$ & $\begin{array}{l}\text { QENERATING } \\
\text { BUILDING }\end{array}$ & $\begin{array}{l}\text { DISPOSAL } \\
\text { YEAR }\end{array}$ & $\begin{array}{c}\text { ANNUAL } \\
\text { VOLUME } \\
\text { CUBIC METERS }\end{array}$ & $\begin{array}{l}\text { ANNUAL } \\
\text { WEIGHT } \\
\text { GRAMS }\end{array}$ & $\begin{array}{l}\text { ANNUAL } \\
\text { CURIES }\end{array}$ & NUCL IDE & CURIES \\
\hline ............. & 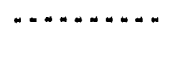 & $\cdots$ & $\ldots$ & …n...nn. & $\ldots \ldots+\ldots$ & - & (............. \\
\hline & * & & & & & & $2.993 E-01$ \\
\hline \multirow[t]{27}{*}{ TRA } & 000 & 61 & $9.280 E+02$ & $0.000 E+00$ & $1.220 E+05$ & $U N-1 D-B+O$ & $1.220 E+05$ \\
\hline & & 62 & $8.770 \mathrm{E}+02$ & $0.000 E+00$ & $8.210 E+04$ & $U N-1 D=B+Q$ & $8.210 E+04$ \\
\hline & & 63 & $9.570 E+02$ & $0.000 E+00$ & $1.777 E+05$ & $U N-1 D-B+0$ & $1.777 E+05$ \\
\hline & & 64 & $8.670 E+02$ & $0.000 E+00$ & $1.178 E+05$ & $U N-1 D-B+Q$ & $1.178 E+05$ \\
\hline & & 65 & $7.830 E+02$ & $0.000 E+00$ & $1.810 E+05$ & $U N-1 D-B+Q$ & $1.810 E+05$ \\
\hline & & 66 & $8.330 E+02$ & $0.000 E+00$ & $3.387 E+04$ & $U N-1 D-B+G$ & $3.387 E+04$ \\
\hline & & 67 & $9.280 \mathrm{E}+02$ & $0.000 E+00$ & $3.293 E+03$ & $U N-1 D-B+G$ & $3.293 E+03$ \\
\hline & & 68 & $7.650 \mathrm{E}+02$ & $0.000 E+00$ & $3.099 E+04$ & $U N-1 D-B+G$ & $3.099 E+04$ \\
\hline & & 69 & $1.170 E+03$ & $0.000 E+00$ & $2.410 E+05$ & $U N \cdot 1 D \cdot B+0$ & $2.410 E+05$ \\
\hline & & 70 & $6.410 E+02$ & $0.000 E+00$ & $3.782 E+05$ & $U N-1 D-B+Q$ & $3.782 E+05$ \\
\hline & * & & & & $1368 \mathrm{E}+06$ & & $1.368 E+06$ \\
\hline & 603 & 73 & $5.324 E+00$ & $2.268 \mathrm{E}+05$ & $1.000 \mathrm{E}-02$ & MFP & $1.000 \mathrm{E}-02$ \\
\hline & & 74 & $9.516 E+00$ & $1.588 E+06$ & $1.384 E-02$ & MAP & $9.688 E-03$ \\
\hline & & & & & & MFP & $4.152 E-03$ \\
\hline & & & & & & & n........... \\
\hline & & * & & & & & $1.384 E-02$ \\
\hline & & 75 & $1.020 E+00$ & $3.637 E+05$ & $1.376 E-02$ & MAP & $6.750 E-03$ \\
\hline & & & & & & MFP & $6.750 E-03$ \\
\hline & & & & & & $U-235$ & $3.201 \mathrm{E}-06$ \\
\hline & & & & & & $U-238$ & $2.531 E-04$ \\
\hline & & * & & & & & $1.376 \mathrm{E}-02$ \\
\hline & & 77 & $1.167 E+01$ & $1.905 E+06$ & $2.012 E+05$ & $c 0-60$ & $1.811 \mathrm{~F}+04$ \\
\hline & & & & & & $C R-51$ & $1.630 E+05$ \\
\hline & & & & & & $F E-59$ & $2.012 E+04$ \\
\hline & & & & & & MAP & $5.000 E-0.4$ \\
\hline & & & & & & MFP & $5.000 E-0.4$ \\
\hline & & * & & & & & $2.012 E+05$ \\
\hline
\end{tabular}




\begin{tabular}{|c|c|c|c|c|c|c|c|}
\hline $\begin{array}{l}\text { GENERATING } \\
\text { AREA }\end{array}$ & $\begin{array}{l}\text { GENERATING } \\
\text { BUI LDING }\end{array}$ & $\begin{array}{c}\text { DISPOSAL } \\
\text { YEAR }\end{array}$ & $\begin{array}{c}\text { ANNUAL } \\
\text { VOLUME } \\
\text { CUBIC METERS }\end{array}$ & $\begin{array}{l}\text { ANNUAL } \\
\text { WEIGHT } \\
\text { GRAMS }\end{array}$ & $\begin{array}{l}\text { ANNUAL } \\
\text { CURIES }\end{array}$ & NUCL.IDE & CURIES \\
\hline ….. & ........... & n......... & 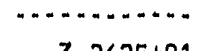 & 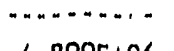 & (1) & $\ldots \ldots \ldots$, & ........... \\
\hline \multirow[t]{30}{*}{ TRA } & 603 & 79 & $3.262 E+01$ & $4.899 E+06$ & $6.003 E+00$ & $\begin{array}{l}\text { MAP } \\
\text { MFP }\end{array}$ & $\begin{array}{l}3.001 E+00 \\
3.002 E+00\end{array}$ \\
\hline & & & & & & $T H-232$ & $1.801 E-04$ \\
\hline & & * & & & & & $6.003 E+00$ \\
\hline & & 81 & $3.625 E+00$ & $9.072 E+05$ & $2.222 E-01$ & MAP & $1.025 E-01$ \\
\hline & & & & & & MFP & $1.025 E-01$ \\
\hline & & & & & & U-235 & $2.140 E-05$ \\
\hline & & & & & & $U-238$ & $1.717 E-02$ \\
\hline & & * & & & & & $2.222 E-01$ \\
\hline & & 82 & $3.625 \mathrm{E}+00$ & $6.804 E+05$ & $2.239 E-02$ & MAP & $1.052 E-02$ \\
\hline & & & & & & MFP & $1.052 E-02$ \\
\hline & & & & & & U. 235 & $2.140 \mathrm{E}-05$ \\
\hline & & & & & & $U-238$ & $1.326 \mathrm{E}-03$ \\
\hline & & * & & & & & $2.239 \mathrm{E}-02$ \\
\hline & & 83 & $5.663 E+00$ & $1.506 \mathrm{E}+07$ & $8.949 E+01$ & 100.60 & $8.948 E+01$ \\
\hline & & & & & & MAP & $5.000 E-03$ \\
\hline & & & & & & MFP & $5.000 E-03$ \\
\hline & & & & & & $U-238$ & $3.330 \mathrm{E}-04$ \\
\hline & & * & & & & & $8.949 E+01$ \\
\hline & & 84 & $2.341 E+01$ & $1.067 E+07$ & $8.808 E-01$ & MAP & $4.404 E-01$ \\
\hline & & & & & & MFP & $4.404 E-01$ \\
\hline & & * & & & & & $8.808 E-01$ \\
\hline & & 85 & $2.979 E+01$ & $1.505 E+07$ & $1.005 E+00$ & MAP & $5.023 E-01$ \\
\hline & & & & & & MFP & $5.0235 \cdot 01$ \\
\hline & & * & & & & & $1.005 E+00$ \\
\hline & & 86 & $2.896 E+01$ & $6.826 E+06$ & $4.940 \mathrm{E}-01$ & MAP & $2.470 E-01$ \\
\hline & & & & & & MFP & $2.470 E-01$ \\
\hline & & * & & & & & $4.940 \mathrm{E}-01$ \\
\hline & & 87 & $5.068 E+01$ & $1.336 E+07$ & $1.065 E+00$ & MAP & $5.323 E-01$ \\
\hline & & & & & & Mre & $\begin{array}{r}5.323 E-01 \\
-\ldots .\end{array}$ \\
\hline & & * & & & & & $1.065 E+00$ \\
\hline
\end{tabular}




\begin{tabular}{|c|c|c|c|c|c|c|c|}
\hline $\begin{array}{l}\text { GENERATING } \\
\text { AREA }\end{array}$ & $\begin{array}{l}\text { GENERATINO } \\
\text { BUILDING }\end{array}$ & $\begin{array}{l}\text { DISPOSAL } \\
\text { YEAR }\end{array}$ & $\begin{array}{c}\text { ANNUAL. } \\
\text { VOLUME } \\
\text { CUBIC METERS }\end{array}$ & $\begin{array}{l}\text { ANNUAL } \\
\text { WEIGHT } \\
\text { GRAMS }\end{array}$ & $\begin{array}{l}\text { ANNUAL } \\
\text { CURIES }\end{array}$ & NUCLIDE & CURIES \\
\hline n................ & ……....... & …........ & 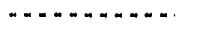 & 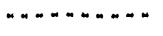 & n & 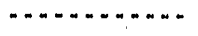 & ……… \\
\hline \multirow[t]{38}{*}{ TRA } & 603 & 88 & $8.374 E+01$ & $5.189 E+07$ & $4.149 E+00$ & $c 0-60$ & $6.100 E-03$ \\
\hline & & & & & & $C R-51$ & $1.000 E-03$ \\
\hline & & & & & & CS- 134 & $3.100 E-03$ \\
\hline & & & & & & CS -137 & $1.978 E-01$ \\
\hline & & & & & & MAP & $1.890 E+00$ \\
\hline & & & & & & MFP & $1.890 E+00$ \\
\hline & & & & & & $S R-90$ & $1.510 E-01$ \\
\hline & & & & & & $U N-1 D-B+Q$ & $1.010 E-02$ \\
\hline & & & & & & & 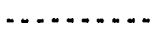 \\
\hline & & * & & & & & $4.149 E+00$ \\
\hline & & 89 & $2.862 E+01$ & $1.479 E+07$ & $1.031 E+00$ & $C R=51$ & $4.500 E-01$ \\
\hline & & & & & n. & MFP & $5.812 E-01$ \\
\hline & * & & & & $2.013 E+05$ & & 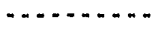 \\
\hline & & * & & & & & $1.031 E+00$ \\
\hline & & & & & & & (…… \\
\hline & $\star$ & & & & & & $2.013 E+05$ \\
\hline & 604 & 72 & $1.563 E+01$ & $9.163 E+05$ & $3.479 E-05$ & MFP & $1.500 E-05$ \\
\hline & & & & & & $U-235$ & $2.140 E-06$ \\
\hline & & & & & & $U=238$ & $1.765 E-05$ \\
\hline & & & & & & & (n) \\
\hline & & * & & & & & $3: 479 E-05$ \\
\hline & & 73 & $1.416 E-01$ & $6.804 E+04$ & $1.406 \mathrm{E}-03$ & $U \cdot 235$ & $3.221 E-06$ \\
\hline & & & & & & $U-238$ & $1.403 E-03$ \\
\hline & & & & & & & $\cdots$ \\
\hline & & * & & & & & $1.406 E-03$ \\
\hline & & 75 & $5.664 E-02$ & $9.979 E+03$ & $2.363 E-03$ & $U-235$ & $3.039 E-04$ \\
\hline & & & & & & $U-238$ & $2.060 E-03$ \\
\hline & & & & & & & $3<350 x$ \\
\hline & & * & & & & & $2.363 E-03$ \\
\hline & & 76 & $3.115 E-01$ & $1.366 E+05$ & $1.097 \mathrm{E}-02$ & MAP & $7.500 E-04$ \\
\hline & & & & & & MFP & $7.500 E-04$ \\
\hline & & & & & & $U-233$ & $9.470 E-03$ \\
\hline & & $\star$ & & & & & $1.097 E-02$ \\
\hline & & & & & & & \\
\hline & & 77 & $2.832 E-02$ & $2.000 E+02$ & $9.088 \mathrm{E}-07$ & $U=235$ & $8.988 E-07$ \\
\hline & & & & & & $U-238$ & $9.990 E-09$ \\
\hline & & 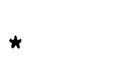 & & & & & $9.088 \mathrm{E}-07$ \\
\hline & & 82 & $1.470 E+02$ & $4.536 \mathrm{E}+07$ & $2.501 E+00$ & MAP & $1.250 E+00$ \\
\hline
\end{tabular}


1SCHEDULE NO. SUSS411

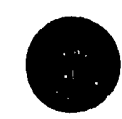

GLNERATING GENERATING DISPOSAL

AREA

TRA$$
B
$$$$
\text { ................ }
$$$$
604 \quad 82
$$$$
\text { * }
$$$$
83
$$

83

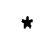

84

85

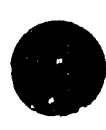

IDAHO OPERATIONS OFFICE

U.S. DEPARTMENT OF ENERGY

INEL WASTE MANAGEMENT INFORMATION SYSTEM

ANNUAL SUMMARY FOR TRA
RUN DATE: 04/03/91

PAGE 139

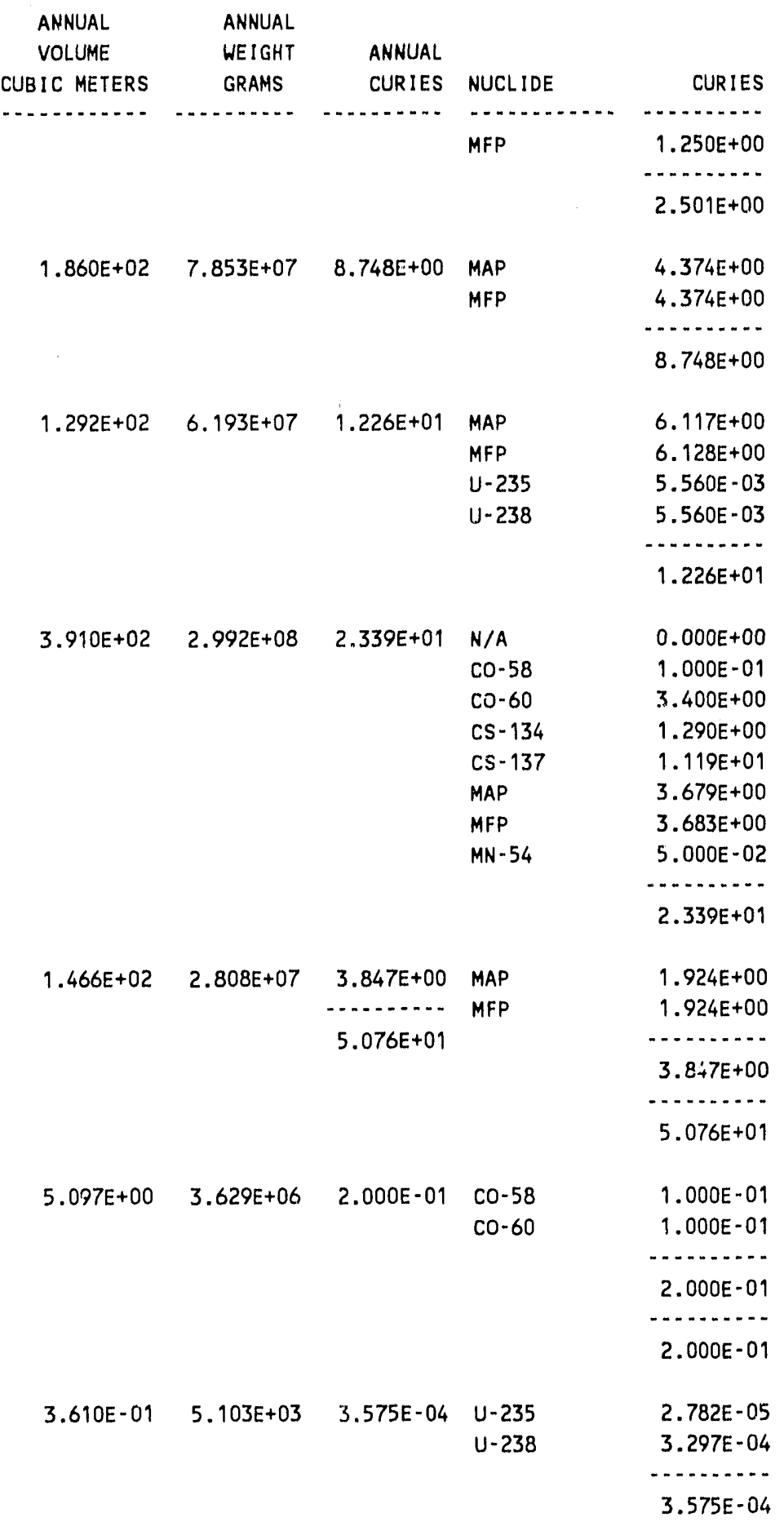




\begin{tabular}{|c|c|c|c|c|c|c|c|}
\hline $\begin{array}{l}\text { GENERATING } \\
\text { AREA }\end{array}$ & $\begin{array}{l}\text { GENERATING } \\
\text { BUILDING }\end{array}$ & $\begin{array}{l}\text { DISPOSAL } \\
\text { YEAR }\end{array}$ & $\begin{array}{c}\text { ANNUAL } \\
\text { VOLUME } \\
\text { CUBIC METERS }\end{array}$ & $\begin{array}{l}\text { ANNUAL } \\
\text { WE IGHT } \\
\text { GRAMS }\end{array}$ & $\begin{array}{l}\text { ANNUAL } \\
\text { CURIES }\end{array}$ & NUCLIDE & CUR!ES \\
\hline ................ & (.............. & .......... & (n) & - n. & . & n. nas & - n. \\
\hline \multirow[t]{36}{*}{ TRA } & 614 & 72 & $1.699 E+00$ & $1.225 E+05$ & $7.791 E-05$ & $U-235$ & $7.663 E-05$ \\
\hline & & & & & & $U-238$ & $1.273 E-06$ \\
\hline & & $\star$ & & & & & $7.791 E-05$ \\
\hline & & 73 & $1.164 E+01$ & $7.295 E+05$ & $3.096 \mathrm{E}-01$ & MAP & $3.000 E-02$ \\
\hline & & & & & & MFP & $2.775 E-01$ \\
\hline & & & & & . & $U-235$ & $7.289 E-05$ \\
\hline & & & & & & $U-238$ & $1.994 E-03$ \\
\hline & & & & & & & . \\
\hline & & * & & & & & $3.096 \mathrm{E}-01$ \\
\hline & & 74 & $1.699 E+00$ & $1.134 E+05$ & $1.197 E-04$ & $U-235$ & $1.087 E-04$ \\
\hline & & & & & & $U-238$ & $1.100 \mathrm{E}-05$ \\
\hline & & & & & & & . \\
\hline & & * & & & & & $1.197 E-04$ \\
\hline & & 79 & $5.098 E+00$ & $2.268 E+05$ & $3.000 E-02$ & MAP & $1.500 \mathrm{E}-02$ \\
\hline & & & & & - n. & MFP & $1.500 E-02$ \\
\hline & $\star$ & & & & $3.401 E-01$ & & 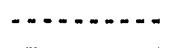 \\
\hline & & $\star$ & & & & & $3.000 E-02$ \\
\hline & t & & & & & & (2) \\
\hline & 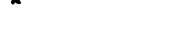 & & & & & & $3.401 E-01$ \\
\hline & 617 & 71 & $1.861 E+01$ & $2.517 E+07$ & $1.500 E-02$ & MFP & $1.500 E-02$ \\
\hline & 624 & 73 & $1.393 E+01$ & $4.718 E+06$ & $1.200 E-02$ & MAP & $6.000 E-03$ \\
\hline & & & & & & MFP & $6.000 E-03$ \\
\hline & & & & & & & n.......... \\
\hline & & * & & & & & $1.200 E-02$ \\
\hline & & 81 & $7.250 E+00$ & $3.629 E+06$ & $3.900 E-04$ & MAP & $1.950 E-04$ \\
\hline & & & & & (n) & MFP & $1.950 E-04$ \\
\hline & * & & & & $1.239 E-02$ & & 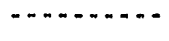 \\
\hline & & * & & & & & $3.900 E-04$ \\
\hline & * & & & & & & $1.239 \mathrm{E}-02$ \\
\hline & 626 & 76 & $1.893 E-02$ & $1.361 E+04$ & $2.731 E-04$ & U-235 & $1.712 E-04$ \\
\hline & & & & & & $U-238$ & $1.019 E-04$ \\
\hline & & & & & & & , n. \\
\hline & & * & & & & & $2.731 E-04$ \\
\hline & & 80 & $3.625 E+00$ & $9.072 E+05$ & $2.600 E-01$ & MAP & $2.598 E-01$ \\
\hline & & & & & $\ldots$ & $U-235$ & $5.157 \varepsilon-05$ \\
\hline & $\star$ & & & & $2.603 E-01$ & $U-238$ & $1.873 E-04$ \\
\hline
\end{tabular}


INEL WASTE MANAGEMENT INFORMATION SYSTEM

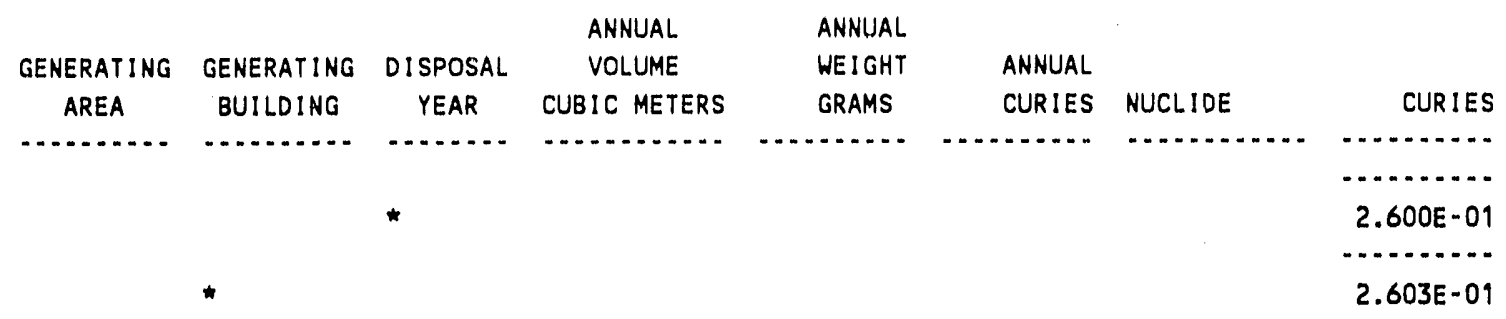

TRA

630

85

$2.082 E+00 \quad 1.796 E+06$

2.001E+01 MAP

$1.001 E+01$

1.001E+01

-........

$2.001 E+01$

$\star$

2.001E+01

632

72

$1.958 E+01 \quad 3.656 E+06$

$5.958 E+03$

CE -141

CO-60

$8.469 E+00$

CR -51

FE-59

MAP

$5.922 E+02$

MFP

$4.991 E+03$

$1.370 E+02$

$M N-54$

$7.875 E-03$

$M N-56$

2.625E-03

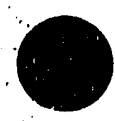

ॠ

NI -59

$3.500 E+00$

$\mathrm{RU}-103$

2.600E+01

$1.121 E+02$

U. 235

2.709E+00

$U-238$

5.778E-05

$U N-1 D-B+C$

$9.124 E-05$

$2 R-95$

5.397E+01

3.117E+01

$5.958 E+03$

73

$1.141 E+01 \quad 1.805 E+06$

$1.330 E+03$

BE- 10

$1.000 E+01$

CE-141

CO-60

$2.954 E+00$

CR-51

FE-59

MAP

$1.172 E+02$

$1.052 E+03$

$1.294 E+02$

MFP

5.500E-02

MN -54

$5.500 E-02$

NI -59

3.500E-02

RU -103

$1.330 E-01$

UN $-1 D-B+G$

$1.012 E+00$

$2 R-95$

$1.943 E+00$

$1.455 E+01$

$1.330 E+03$

74

$1.713 E+01 \quad 1.865 E+06$

$6.771 E+02$

CO- 60

$1.652 E+02$

CR- 51

$7.776 E+01$ 


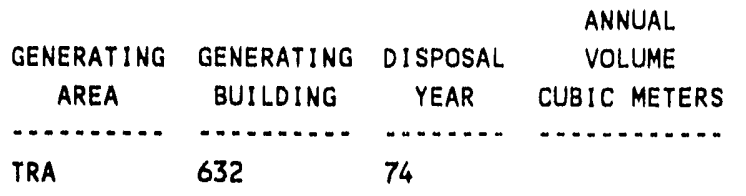

\section{ANNUAL \\ WEIGHT GRAMS}

ANNUAL

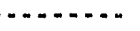

$-$

CURIES

NUCLIDE

(............

FE-59

MAP

MFP

$M N-54$

ZN-65

$\star$

75

$4.569 E+00$

$6.078 E+05$

$1.847 E+02$

CO- 60

$C R \cdot 51$

FE- 59

MAP

MFP

*

76

$1.889 E+00$

$4.617 E+06$

3. $270 E+02$

CO- 60

CR - 51

FE-59

MAP

MFP

U-235

U. 238

*

77

$1.593 E+01$

$2.005 E+06$

$8.589 E+01$

MAP

MFP

U-235

U- 238

78

3. 306E+01

$1.549 E+07$

$3.564 E+01$

MAP

MFP

U-235

U. 238

79
2.839E- 01
$2.454 E+05$
$2.700 E+0$

MAP

$U-235$

U-238
$9.600 E+00$

6.861E-01

4.059E-01

6.380E+01

$3.596 E+02$

6.771E+0

$6.771 E+02$

$1.656 E+01$

$1.490 E+02$

$1.840 E+01$

4.987E-01

2. $137 \mathrm{E}-01$

-.........

$1.847 E+02$

2. 250E+01

$2.025 E+02$

2.500E+01

$1.325 E+01$

$6.375 E+01$

3.638E-04

6.157E-04

-..........

$3.270 E+02$

$7.294 E+01$

$1.296 E+01$

2. $996 \mathrm{E}-05$

1.399E-05

-.........

$8.589 E+01$

$2.983 E+01$

$5.807 E+00$

$1.948 \mathrm{E}-06$

2.867E-05

..........

$3.564 E+01$

$1.910 E+01$

$7.900 E+00$

$6.420 E-06$

$2.331 E-05$

..........

$2.700 E+01$ 


\begin{tabular}{|c|c|c|c|c|c|c|c|}
\hline GENERATING & GENERATING & DISFOSAL & $\begin{array}{l}\text { ANNUAL } \\
\text { VOLUME }\end{array}$ & $\begin{array}{l}\text { ANNUAL } \\
\text { WEIGHT }\end{array}$ & ANNUAL & & \\
\hline AREA & BUILDING & YEAR & CUBIC METERS & GRAMS & CURIES & NUCLIIDE & CURIES \\
\hline - n.t. & n............... & - n. & - n. & n. & - noten & $\ldots . .$. & $\ldots$ \\
\hline \multirow[t]{2}{*}{ TRA } & 632 & 80 & $3.786 \mathrm{E}-02$ & $4.536 E+04$ & $2.000 E+00$ & MAP & $1.000 E+00$ \\
\hline & & & & & & MFP & $1.000 E+00$ \\
\hline
\end{tabular}

81

$1.136 E-01$

$1.633 E+05$

$6.756 E+03$

CE- 144

$5.587 E+02$

CO- 60

$2.878 E+02$

CS- 134

$8.479 E+02$

CS -137

$3.519 E+03$

NB-95

$7.817 E+02$

$U N-1 D-B+G \quad 3.594 E+02$

$2 R-95$

$4.013 E+02$

82

3.215E-01 1.368E+06

$5.039 E+03$

$6.756 E+03$
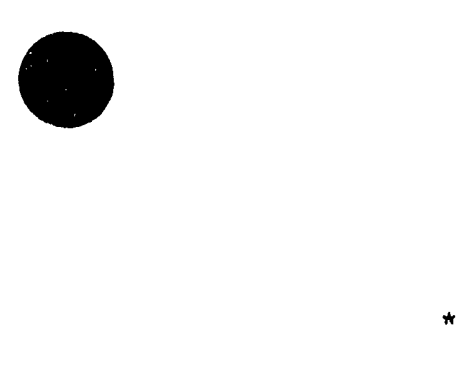

83

$3.218 E-01$

$3.538 E+05$

$8.316 E+01$

$C E-144$

CO-60

CS- 134

CS. 137

FE-59

MAP

MN-54

NB-95

UN-ID-B+G

$Z R-95$

2.808E+01

$1.894 E+03$

$4.263 E+01$

$1.768 E+02$

$1.880 E+03$

$9.000 E-04$

4.700E+02

$3.929 E+01$

$4.881 E+02$

$2.017 E+01$

$5.040 E+03$$$
\text { (2) }
$$

CO- 60

$6.878 E+00$

CS- 134

CS -137

NB - 95

PU-239

U-235

U -238

$3.543 E+00$

$1.044 E+01$

4. $332 E+01$

$9.622 E+00$

$4.798 \mathrm{E}-04$

UN- ID - B $+G$

$1.912 E-04$

ZR-95

$2.021 E-04$

$4.424 E+00$

$4.940 E+00$

$8.316 E+01$

84

$1.514 E-01$

2.132E+05

$2.527 E+02$

CE -144

1. $028 E+01$

CO- 60

$1.318 \mathrm{E}+02$

CS- 134

$1.988 \mathrm{E}+01$

CS- 137

$6.750 E+01$

NB- 95

2.310E+00 


\begin{tabular}{|c|c|c|c|c|c|c|c|}
\hline & & & ANNUAL & ANNUAL. & & & \\
\hline $\begin{array}{c}\text { GENERATING } \\
\text { AREA }\end{array}$ & $\begin{array}{l}\text { GENERATING } \\
\text { BUILDING }\end{array}$ & $\begin{array}{l}\text { DISPOSAL } \\
\text { YEAR }\end{array}$ & $\begin{array}{c}\text { VOLUME } \\
\text { CUB!C METERS }\end{array}$ & $\begin{array}{l}\text { WEIGHT } \\
\text { GRAMS }\end{array}$ & $\begin{array}{l}\text { ANNUAL } \\
\text { CURIES }\end{array}$ & NUCLIDE & CURIES \\
\hline ............. & ........... & ......... & - . - & - . - . - & - & - ………. & ........... \\
\hline \multirow{42}{*}{ TRA } & 632 & 84 & & & & $U-235$ & $2.782 E-04$ \\
\hline & & & & & & $U N-1 D-B+G$ & $1.497 E+01$ \\
\hline & & & & & & $2 R-95$ & $6.050 E+00$ \\
\hline & & & & & & & ( n............. \\
\hline & & * & & & & & $2.527 E+02$ \\
\hline & & 85 & $9.109 E+00$ & $1.191 E+06$ & $3.311 E+02$ & $C E-144$ & $1.549 E+01$ \\
\hline & & & & & & $\mathrm{CO}-58$ & $1.500 E-03$ \\
\hline & & & & & & $c 0-60$ & $1.436 E+02$ \\
\hline & & & & & & CS- 134 & $2.439 E+01$ \\
\hline & & & & & & CS. 137 & $8.842 E+01$ \\
\hline & & & & & & $M N=54$ & $2.200 E-03$ \\
\hline & & & & & & NB-95 & $1.157 E+01$ \\
\hline & & & & & & $U-238$ & $1.200 E-03$ \\
\hline & & & & & & $U N-1 D-B+G$ & $1.936 E+01$ \\
\hline & & & & & & ZR-95 & $2.826 E+01$ \\
\hline & & & & & & & n. \\
\hline & & * & & & & & $3.311 \mathrm{E}+02$ \\
\hline & & 86 & $3.092 E+01$ & $7.133 E+06$ & $1.951 E+02$ & CE -144 & $2.550 E+00$ \\
\hline & & & & & & $c 0.60$ & $1.054 E+02$ \\
\hline & & & & & ' & CS- 134 & $5.355 E+00$ \\
\hline & & & & & & Cs- 137 & $5.178 E+01$ \\
\hline & & & & & & MAP & $5.493 \mathrm{E}-01$ \\
\hline & & & & & & MFP & $5.493 E-01$ \\
\hline & & & & & & $U-238$ & $9.990 E-04$ \\
\hline & & & & & & $U N-1 D-B+G$ & $4.350 E+00$ \\
\hline & & & & & & $2 R-95$ & $2.452 E+01$ \\
\hline & & & & & & & . \\
\hline & & * & & & & & $1.951 E+02$ \\
\hline & & 87 & $2.549 E+01$ & $6.916 E+06$ & $1.798 \mathrm{E}+02$ & CE -144 & $3.100 E+00$ \\
\hline & & & & & ...n. & $c 0-60$ & $8.885 E+01$ \\
\hline & * & & & & $2.146 E+04$ & CS- 134 & $1.242 E+01$ \\
\hline & & & & & & CS -137 & $4.688 E+01$ \\
\hline & & & & & & EU-152 & $3.900 E+00$ \\
\hline & & & & & & $G D-153$ & $1.300 E+00$ \\
\hline & & & & & & IR-192 & $6.500 E-01$ \\
\hline & & & & & & MAP & $1.378 E+00$ \\
\hline & & & & & & MFP & $1.378 E+00$ \\
\hline & & & & & & $U N-I D-B+G$ & $5.900 E+00$ \\
\hline & & & & & & $2 R-95$ & $1.400 E+01$ \\
\hline & & & & & & & (n) \\
\hline & & * & & & & & $1.798 E+02$ \\
\hline & * & & & & & & $2.146 E+04$ \\
\hline
\end{tabular}




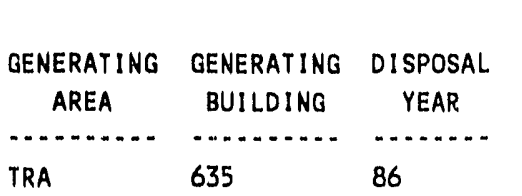

86

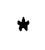

87

*

637

74

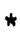

84
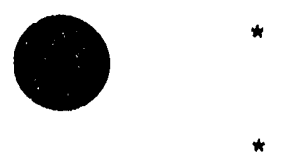

641

73

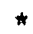

642
ANNUAL

VOLUME CUBIC METERS

$1.810 E+00$

.

...........

$1.770 E+06$

ANNUAL

WEIGHT

GRAMS

.

CURIES

7.500E-03

NUCLIDE

MAP

MFP

CURIES

-...........

3.750E-03

$3.750 E-03$

-.........

7.500E-03

$1.795 E-01$

1.795E-01

...........

3.590E-01

$3.665 E-01$

$1.050 E-04$

4.500E- 05

$1.500 E-04$

$9.000 E-02$

$9.000 \mathrm{E}-02$

...........

1.800E -01

1.801E-01

$3.225 \mathrm{E}-02$

$3.225 \mathrm{E}-02$

MFP

..........

6.450E-02

-...........

6.450E-02

1. $760 \mathrm{E}-01$

$5.280 E-02$

9.405E-01

$2.364 E+02$

$2.106 \mathrm{E}+03$

$2.600 \mathrm{E}+02$

2.805E-01

$1.406 E+00$

$5.280 \mathrm{E}-02$

$4.660 \mathrm{E}-01$

$3.045 \mathrm{E}+00$

$1.182 \mathrm{E}-01$

$1.485 E+00$

$M N-56$

UN-ID-B+G

$7.458 \mathrm{E}-01$ 
IDAHO OPERATIONS OFFICE

U.S. DEPARTMENT OF ENERGY

INEL WASTE MANAGEMENT INFORMATION SYSTEM

ANNUAL SUMMARY FOR TRA
RUN DATE: $04 / 03 / 91$

PAGE 146

\begin{tabular}{|c|c|c|c|c|c|c|c|}
\hline GENERATING & GENERATING & DISPOSAL & $\begin{array}{l}\text { ANNUAL } \\
\text { VOLUME }\end{array}$ & $\begin{array}{l}\text { ANNUAL } \\
\text { WEIGHT }\end{array}$ & ANNUAL & & \\
\hline AREA & BUILDING & YEAR & CUBIC METERS & GRAMS & CURIES & NUCLIDE & CURIES \\
\hline (n. & 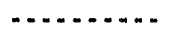 & $\ldots$ & - & n. & $\ldots+\ldots+\ldots$ & - & 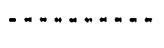 \\
\hline & & * & & & & & $2.611 E+03$ \\
\hline \multirow[t]{39}{*}{ TRA } & 642 & 72 & $2.061 E+02$ & $3.233 E+07$ & $1.204 E+01$ & $c 0-60$ & $6.750 E-01$ \\
\hline & & & & & & CS- 134 & $3.994 E-01$ \\
\hline & & & & & & CS -137 & $2.831 E-01$ \\
\hline & & & & & & $L A-140$ & $3.775 E-01$ \\
\hline & & & & & & MAP & $5.157 E+00$ \\
\hline & & & & & & MFP & $3.483 E+00$ \\
\hline & & & & & & $M N-54$ & 4.099E- 01 \\
\hline & & & & & & $R A-226$ & $1.250 E+00$ \\
\hline & & & & & & & , n \\
\hline & & * & & & & & $1.204 E+01$ \\
\hline & & 73 & $1.932 E+02$ & $3.352 E+07$ & $9.846 E+00$ & $C E-144$ & $1.213 E+00$ \\
\hline & & & & & & Co. 60 & $3.042 E-01$ \\
\hline & & & & & & $C R-51$ & $1.980 E+00$ \\
\hline & & & & & & CS- 134 & $1.116 E-01$ \\
\hline & & & & & & CS -137 & $1.555 E-01$ \\
\hline & & & & & & $F E-59$ & $2.445 E-01$ \\
\hline & & & & & & MAP & $2.643 E+00$ \\
\hline & & & & & & MFP & $2.929 E+00$ \\
\hline & & & & & & $R U-103$ & $6.405 E-02$ \\
\hline & & & & & & $U N-1 D-B+G$ & $1.665 E-01$ \\
\hline & & & & & & $2 R-95$ & $3.477 E-02$ \\
\hline & & & & & & & - \\
\hline & & $\star$ & & & & & $9.846 E+00$ \\
\hline & & 74 & $8.021 E+01$ & $1.296 E+07$ & $9.019 E+00$ & $C E-144$ & $3.471 E-02$ \\
\hline & & & & & & $c 0-60$ & $2.746 E+00$ \\
\hline & & & & & & $C R-51$ & $3.086 E+00$ \\
\hline & & & & & & CS -137 & $5.340 \mathrm{E}-02$ \\
\hline & & & & & & FE- 59 & $3.810 E-01$ \\
\hline & & & & & & MAP & $1.680 \mathrm{E}+00$ \\
\hline & & & & & & MFP & $8.595 E-01$ \\
\hline & & & & & & $M N-54$ & $7.209 E-02$ \\
\hline & & & & & & $2 N-65$ & $1.068 E-01$ \\
\hline & & & & & & & n........ \\
\hline & & * & & & & & $9.019 E+00$ \\
\hline & & 75 & $4.798 E+01$ & $1.191 \mathrm{E}+07$ & $3.726 E+00$ & CE- 144 & $1.500 E-01$ \\
\hline & & & & & & co-60 & $1.350 E+00$ \\
\hline & & & & & & MAP & $1.361 E+00$ \\
\hline & & & & & & MFP & $8.652 E-01$ \\
\hline & & * & & & & & $3.726 E+00$ \\
\hline
\end{tabular}




\begin{tabular}{|c|c|c|c|c|c|c|c|}
\hline GENERAT ING & GENERAT ING & DISPOSAL & $\begin{array}{l}\text { ANNUAL } \\
\text { VOLUME }\end{array}$ & $\begin{array}{l}\text { ANNUAL } \\
\text { WEIGHT }\end{array}$ & ANNUAL & & \\
\hline AREA & BUILDING & YEAR & CUBIC METERS & GRAMS & CURIES & NUCLIDE & CURIES \\
\hline 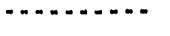 & (n) & .......... & 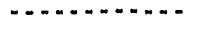 & (n) & 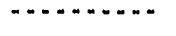 & (n) & 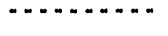 \\
\hline \multirow[t]{39}{*}{ TRA } & 642 & 76 & $2.571 E+01$ & $4.627 E+06$ & $1.432 E+00$ & MAP & $7.160 E-01$ \\
\hline & & & & & & MFP & $7.160 E-01$ \\
\hline & & & & & & & a.t. \\
\hline & & * & & & & & $1.432 E+00$ \\
\hline & & 77 & $4.917 E+01$ & $1.271 E+07$ & $2.878 E+05$ & $c 0-60$ & $2.590 E+04$ \\
\hline & & & & & & $C R-51$ & $2.331 E+05$ \\
\hline & & & & & & FE-59 & $2.878 E+04$ \\
\hline & & & , & & & MAP & $9.329 E-01$ \\
\hline & & & & & & MFP & $1.691 \mathrm{E}+00$ \\
\hline & & & & & & $U-235$ & $1.049 E-05$ \\
\hline & & & & & & $U-238$ & $1.199 E-07$ \\
\hline & & & & & & & 2. \\
\hline & & ${ }^{*}$ & & & & & $2.878 E+05$ \\
\hline & & 78 & $3.559 E+01$ & $1.271 E+07$ & $3.165 E+05$ & $c 0-60$ & $2.848 E+04$ \\
\hline & & & & & & $C R-51$ & $2.564 E+05$ \\
\hline & & & & & & FE-59 & $3.165 E+04$ \\
\hline & & & & & & MAP & $8.002 E-01$ \\
\hline & & & & & & MFP & $5.448 E-01$ \\
\hline & & & & & & $U-235$ & $1.027 E-04$ \\
\hline & & & & & & $U-238$ & $3.686 E-04$ \\
\hline & & & & & & & 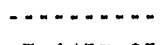 \\
\hline & & * & & & & & $3.165 E+05$ \\
\hline & & 82 & $7.590 E+00$ & $6.350 E+06$ & 4.846E-01 & CE- 144 & $1.055 E-02$ \\
\hline & & & & & (n) & $\mathrm{CO}-60$ & $3.278 \mathrm{E}-01$ \\
\hline & * & & & & $6.069 E+05$ & $C R-51$ & $3.086 E-02$ \\
\hline & & & & & & $M N=54$ & $1.434 E-02$ \\
\hline & & & & & & $S B-125$ & $3.300 E-04$ \\
\hline & & & & & & $U N-1 D-B+G$ & $4.813 E-02$ \\
\hline & & & & & & $2 N-65$ & $5.258 \mathrm{E}-02$ \\
\hline & & * & & & & & (2) \\
\hline & & & & & & & 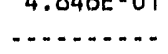 \\
\hline & $\star$ & & & & & & $6.069 E+05$ \\
\hline & 643 & 74 & $1.982 E+00$ & $1.361 E+06$ & $2.096 \mathrm{E}+01$ & CE-144 & $2.725 E-01$ \\
\hline & & & & & & $c 0-60$ & $1.886 E+01$ \\
\hline & & & & & & CS- 137 & $4.192 E-01$ \\
\hline & & & & & & $M N-54$ & $5.659 E-01$ \\
\hline & & & & & & $2 N-65$ & $8.384 E-01$ \\
\hline & & * & & & & & $2.096 E+01$ \\
\hline & * & & & & & & $2.096 \mathrm{E}+01$ \\
\hline
\end{tabular}




\begin{tabular}{|c|c|c|c|c|c|c|c|}
\hline QENERATING & GENERATI INO & DISPOSAL & $\begin{array}{l}\text { ANNUAL } \\
\text { VOLUUME }\end{array}$ & $\begin{array}{l}\text { ANNUAL } \\
\text { WEIGHT }\end{array}$ & ANNUAL & & \\
\hline AREA & BUILDING & YEAR & CUBIC METERS & ORAMS & CURIES & NUCL IDE & CURIES \\
\hline - n. & 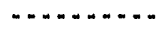 & …..... & . & 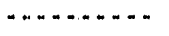 & - n. & …...... & 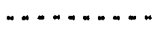 \\
\hline TRA & 644 & 71 & $5.679 E+00$ & $3.856 E+06$ & $4.118 E+00$ & $C 0.58$ & $1.272 E+00$ \\
\hline & & & & & & 00.60 & $1.590 E+00$ \\
\hline & & & & & & $1-132$ & $1.638 E-01$ \\
\hline & & & & & & $1-133$ & $3.276 E-01$ \\
\hline & & & & & & $1-135$ & 3.510E-02 \\
\hline & & & & & & $L A=140$ & $3.533 E-01$ \\
\hline & & & & & & $U N=10-B+Q$ & $3.765 E-01$ \\
\hline & & & & & & & (............... \\
\hline & & * & & & & & $4.118 E+00$ \\
\hline & * & & & & & & $4.118 E+00$ \\
\hline & & & & & & & \\
\hline & 647 & 71 & $4.486 E+01$ & $1.370 E+07$ & $2.247 E+00$ & MAP & $1.287 E-01$ \\
\hline & & & & & & MFP & $2.119 E+00$ \\
\hline & & & & & & & (n) \\
\hline & & * & & & & & $2.247 E+00$ \\
\hline & & 72 & $1.121 E+01$ & $2.268 E+06$ & $1.480 E-01$ & MAP & $7.400 E-02$ \\
\hline & & & & & & MFP & $7.400 E-02$ \\
\hline & & & & & & & . \\
\hline & & * & & & & & $1.480 E-01$ \\
\hline & & 74 & $3.172 E+00$ & $6.804 E+05$ & $4.500 E-01$ & MAP & $3.150 E-01$ \\
\hline & & & & & & MFP & $1.350 E-01$ \\
\hline & & & & & & & n \\
\hline & & * & & & & & $4.500 E-01$ \\
\hline & & 75 & $3.172 E+00$ & $6.804 E+05$ & $3.112 E-C 2$ & MAP & $1.556 \mathrm{E}-02$ \\
\hline & & & & & & MFP & $1.556 \mathrm{E}-02$ \\
\hline & & & & & & & (n) \\
\hline & & * & & & & & $3.112 E-02$ \\
\hline & & 76 & $1.745 E+02$ & $8.364 E+07$ & $1.832 E+01$ & MAP & $3.862 E+00$ \\
\hline & & & & & & MFP & $1.446 E+01$ \\
\hline & & & & & & & 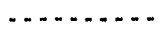 \\
\hline & & * & & & & & $1.832 E+01$ \\
\hline & & 77 & $2.020 E+02$ & $7.841 E+07$ & $4.123 E+04$ & $c 0-60$ & $3.709 E+03$ \\
\hline & & & & & & $C R=51$ & $3.338 E+04$ \\
\hline & & & & & & $F E-59$ & $4.121 E+03$ \\
\hline & & & & & & MAP & $6.917 E+00$ \\
\hline & & & & & & MFP & $1.374 E+01$ \\
\hline & & & & & & $T H-232$ & $1.613 E-07$ \\
\hline & & & & & & U. 235 & $1.991 \mathrm{E}-04$ \\
\hline & & & & & & $U-238$ & $7.250 E-04$ \\
\hline
\end{tabular}




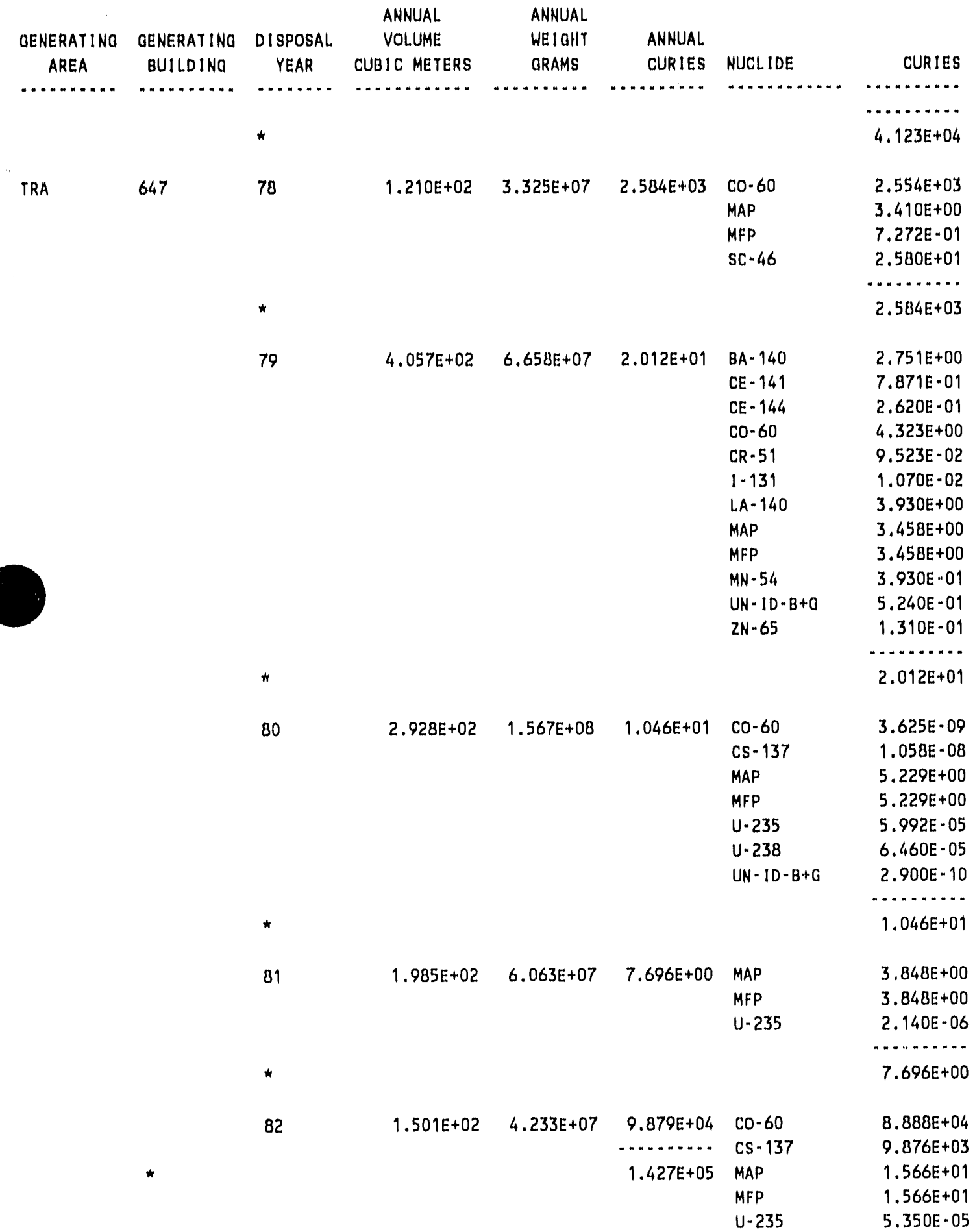




\begin{tabular}{|c|c|c|c|c|c|c|c|}
\hline $\begin{array}{c}\text { QENERATINO } \\
\text { AREA }\end{array}$ & $\begin{array}{l}\text { OENERATINQ } \\
\text { BUILDING }\end{array}$ & $\begin{array}{c}\text { DISPOSAL } \\
\text { YEAR }\end{array}$ & $\begin{array}{c}\text { ANNUAL } \\
\text { VOLUME } \\
\text { CUBIC METERS }\end{array}$ & $\begin{array}{l}\text { ANNUAL } \\
\text { WEI IHT } \\
\text { QRAMS }\end{array}$ & $\begin{array}{l}\text { ANNUAL } \\
\text { CURIES }\end{array}$ & NUCLIDE & CURIES \\
\hline n............. & n............. & ........ & 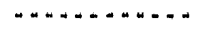 & n. & ……n. & - & 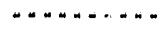 \\
\hline \multirow[t]{36}{*}{ TRA } & 647 & 82 & & & & $U-238$ & $3.230 \mathrm{~L}-05$ \\
\hline & & $\star$ & & & & & $9.879 E+04$ \\
\hline & & & & & & & $\ldots+\ldots$ \\
\hline & $\star$ & & & & & & $1.427 E+05$ \\
\hline & 652 & 71 & $1.416 \mathrm{E}-02$ & $1.361 E+04$ & $4.000 E+00$ & $\mathrm{co} \cdot 60$ & $4.000 E-02$ \\
\hline & & & & & & cs -134 & $5.200 E \times 01$ \\
\hline & & & & & & CS -137 & $3.080 E+00$ \\
\hline & & & & & & $U N=1 D-B+O$ & $3.600 E-01$ \\
\hline & & & & & & & $\ldots \ldots \ldots$ \\
\hline & & * & & & & & $4.000 E+00$ \\
\hline & & & & & & & (1) \\
\hline & * & & & & & & $4.000 E+00$ \\
\hline & 653 & 73 & $5.777 E+00$ & $6.804 E+05$ & $1.312 E+00$ & $\cos 60$ & $1.181 E-01$ \\
\hline & & & & & & $C R-51$ & $1.063 E+00$ \\
\hline & & & & & & $F E=59$ & $1.312 E-01$ \\
\hline & & * & & & & & 1,21050 \\
\hline & & $n$ & & & & & \\
\hline & * & & & & & & $1.312 E+00$ \\
\hline & 654 & 71 & $3.398 \mathrm{E}-02$ & $2.268 E+03$ & $6.917 E-05$ & $U-235$ & $3.039 E-06$ \\
\hline & & & & & & $U-238$ & $6.613 E-05$ \\
\hline & & * & & & & & $6.917 E-05$ \\
\hline & & 74 & $3.681 E-01$ & $2.313 E+04$ & $1.079 E-04$ & TH-232 & $1.916 E-05$ \\
\hline & & & & & & $U-235$ & $3.144 E-05$ \\
\hline & & & & & & $U-238$ & $5.730 E-05$ \\
\hline & & & & & & & n. \\
\hline & & * & & & & & $1.079 E-04$ \\
\hline & & 75 & $8.496 E-02$ & $6.352 E+03$ & $1.536 \mathrm{E}-03$ & $T H-232$ & $2.180 E-05$ \\
\hline & & & & & (n............ & $U-235$ & $9.206 E=05$ \\
\hline & * & & & & $1.713 E-03$ & $U-238$ & $1.422 E-03$ \\
\hline & & & & & & & . \\
\hline & & * & & & & & $1.536 E-03$ \\
\hline & * & & & & & & $1713 E-03$ \\
\hline & 657 & 72 & $3.398 E+00$ & $8.165 E+05$ & $1.950 E+05$ & $C E-141$ & $2.788 E+04$ \\
\hline & & & & & & $c 0.60$ & $2.437 E+03$ \\
\hline & & & & & & $R U=103$ & $9.555 E+03$ \\
\hline & & & & & & $U N-1 D-B+G$ & $1.774 E+04$ \\
\hline
\end{tabular}




\begin{tabular}{|c|c|c|c|c|c|c|c|}
\hline QENERATING & QENERATINO & DISPOSAL & $\begin{array}{l}\text { ANNUAL } \\
\text { VOLUME }\end{array}$ & $\begin{array}{l}\text { ANNUAL } \\
\text { WEIQHT }\end{array}$ & ANNUAL & & \\
\hline AREA & BUILDINO & YEAR & CUBIC METERS & GRAMS & CURIES & NUCL IDE & CURIES \\
\hline , n. & 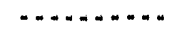 & $\ldots+\ldots$ & . & n. & (n. & . & - n \\
\hline \multirow[t]{36}{*}{ TRA } & 657 & 72 & & & & $2 R-95$ & $1.374 E+05$ \\
\hline & & * & & & & & $1050 E+05$ \\
\hline & & & & & & & \\
\hline & & 74 & $2.152 E+01$ & $2.268 \mathrm{E}+06$ & $1.717 \mathrm{E}+00$ & $c 0.60$ & $9.450 \mathrm{E}-02$ \\
\hline & & & & & & $C R=51$ & $8.505 E-01$ \\
\hline & & & & & & $F E=59$ & $1.050 E-01$ \\
\hline & & & & & & MAP & $5.244 E=01$ \\
\hline & & & & & & MFP & $1.428 \mathrm{E}-01$ \\
\hline & & & & & & & . \\
\hline & & * & & & & & $1.717 E+00$ \\
\hline & & 76 & $3.738 E+00$ & $4.082 E+04$ & $1.000 E-06$ & MFP & $9.000 E-07$ \\
\hline & & & & & & $U N-1 D-B+G$ & $1.000 E-07$ \\
\hline & & & & & & & n......... \\
\hline & & * & & & & & $1.000 E=06$ \\
\hline & & 81 & $1.699 E-01$ & $5.738 E+05$ & $5.000 E+00$ & $c 0-60$ & $2.500 E+00$ \\
\hline & & & & & (............ & CS -137 & $2.500 E+00$ \\
\hline & * & & & & $1.950 E+05$ & & (n) \\
\hline & & * & & & & & $5.000 \mathrm{E}+00$ \\
\hline & & & & & & & 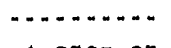 \\
\hline & * & & & & & & $1.950 E+05$ \\
\hline & 660 & 75 & $2.832 E-02$ & $1.361 E+03$ & $2.798 E-05$ & $U-235$ & $2.782 \mathrm{E}-05$ \\
\hline & & & & & & $U-238$ & $1.632 E-07$ \\
\hline & & * & & & & & $2.798 \mathrm{E}-05$ \\
\hline & & & & & & & ........... \\
\hline & * & & & & & & $2.798 \mathrm{E}-05$ \\
\hline & 661 & 71 & $3.540 E+00$ & $9.072 E+05$ & $1.000 E-02$ & MFP & $9.000 E-03$ \\
\hline & & & & & & $P U=240$ & $9.000 E-04$ \\
\hline & & & & & & $P U-241$ & $1.000 E-04$ \\
\hline & & & & & & & (1) \\
\hline & & * & & & & & $1.000 E-02$ \\
\hline & & 72 & $5.66,4 \mathrm{E}-0 ?$ & $2.268 E+04$ & $1.000 E-05$ & MFP & $1.000 E-05$ \\
\hline & & 73 & $4.531 \mathrm{E}-01$ & $9.072 E+05$ & $6.970 E-04$ & UN-ID - ALPHA & $6.960 E-04$ \\
\hline & & & & & & $U N-1 D-B+Q$ & $1.000 \mathrm{E}-06$ \\
\hline & & * & & & & & $6.970 E-04$ \\
\hline & & 75 & $1.171 E+01$ & $5.171 E+05$ & $9.360 E+00$ & $c 0-60$ & $1.000 E+00$ \\
\hline & & & & & & PU-239 & $2.300 E-04$ \\
\hline
\end{tabular}




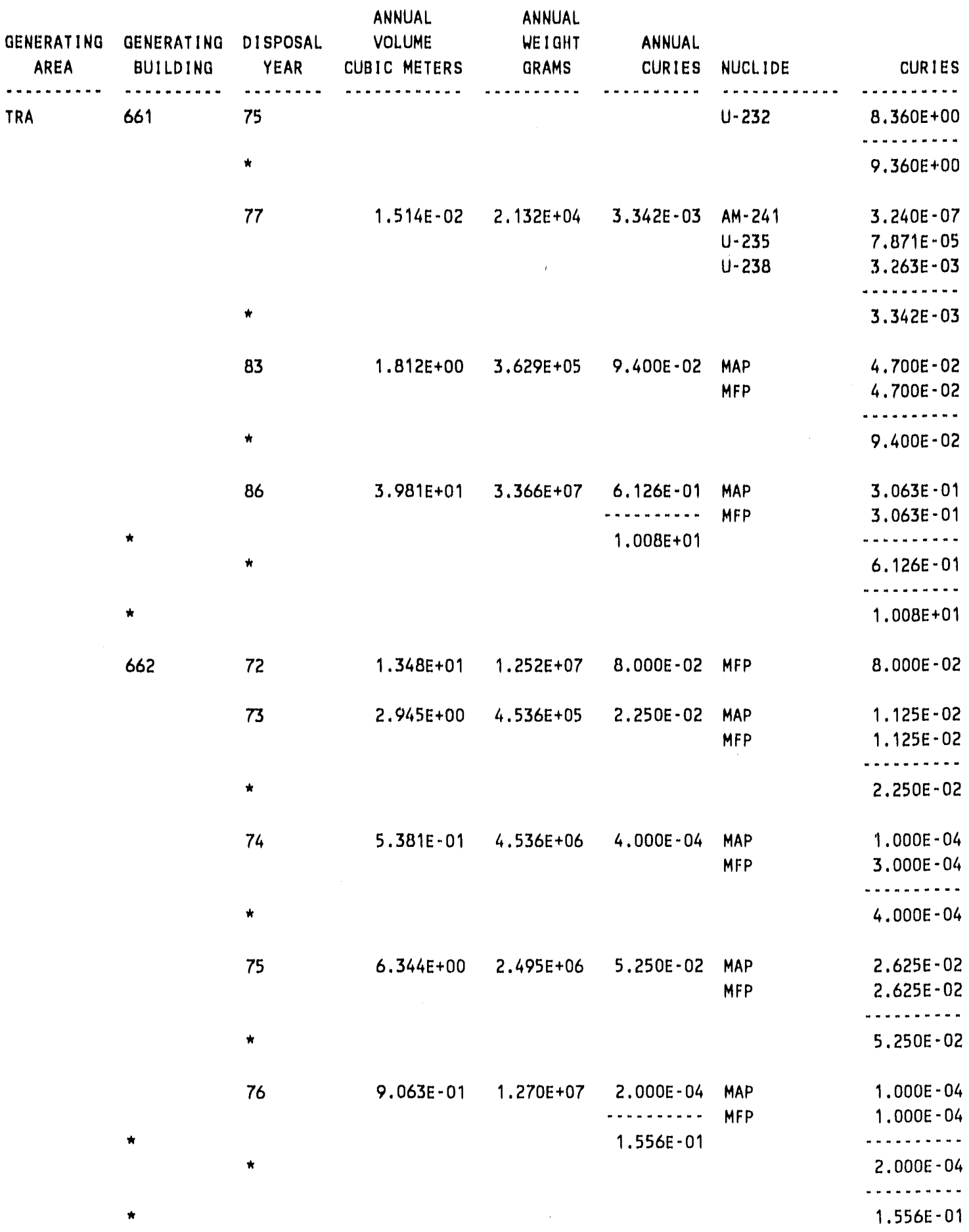




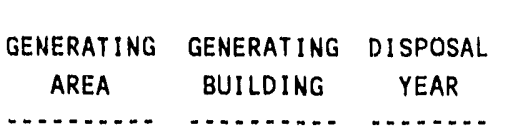

TRA 666

73

71

670
ANNUAL
VOLUME CUBIC METERS

5. $719 \mathrm{E}+00$

$2.719 \mathrm{E}+00$

ANNUAL

WEIGHT GRAMS

ANNUAL -.......... CURIES
C.......

NUCL IDE

MFP

$U-235$
$U-238$

$U-235$
$U-238$

DE

CURIES

7.500E-03

5. 179E-06

$3.660 E-03$

-.........

1. 117E-02

1.117E-02

$8.544 E+01$

$3.457 E+07$

$3.388 E+01$

BA-LA- 140

CE-141

CR-51

I -131

I-133

MAP

MFP

NA- 24

NA- 25

RU- 103

SC-46

TE-I- 132

U-235

UN- $1 D-B+G$

W- 187

ZR-NB- 95

ZR- 95

4. $944 E-01$

$6.190 E+00$

5. 189E+00

1. $624 E-01$

1.026E-01

3. 125E-01

$1.830 E+00$

$3.537 E+00$

1.270E- 01

2. 570E- 02

$4.948 \mathrm{E}+00$

4.800E-01

3. 100E-06

$3.173 E+00$

5. $298 \mathrm{E}+00$

$1.955 E+00$

5. 130E-02

$3.388 E+01$

72

$8.292 E+0$

$7.280 E+06$

$4.694 E+01$

BA-LA- 140

$8.629 E+00$

CE - 141

$5.692 E+00$

CO- 58

$5.049 E+00$

CO- 60

$1.712 E+01$

CR -1

MAP

MFP

$5.692 E+00$

1.699E-01

RU -103

8.716E-01

SC -46

5.967E-01

$3.121 E+00$

$4.694 E+01$

73

\begin{abstract}
$7.219 E+01$
\end{abstract}
5. 717E+O

7.51PE-02

$1.137 E+00$

$9.416 \mathrm{E} \cdot 07$

$6.657 E-04$

-........ 


\begin{tabular}{|c|c|c|c|c|c|c|c|}
\hline GENERATING & GENERATING & DISPOSAL & $\begin{array}{l}\text { ANNUAL } \\
\text { VOLUME }\end{array}$ & $\begin{array}{l}\text { ANNUAL } \\
\text { WEIGHT }\end{array}$ & ANNUAL & & \\
\hline AREA & BUILDING & YEAR & CUBIC METERS & GRAMS & CURIES & NUCLIDE & CURIES \\
\hline n' & n. & $\ldots$ & $\ldots$ & - n........... & (............... & . & - \\
\hline \multirow[t]{44}{*}{ TRA } & 670 & 74 & $7.332 E+01$ & $1.168 E+07$ & $2.713 E+01$ & $C E-141$ & $1.717 E+00$ \\
\hline & & & & & & CE- 144 & $2.625 E-01$ \\
\hline & & & & & & Co-58 & $2.079 E+00$ \\
\hline & & & & & & $C 0-60$ & $1.846 E+01$ \\
\hline & & & & & & Cs- 134 & $1.982 E-01$ \\
\hline & & & & & & CS -137 & $2.141 E+00$ \\
\hline & & & & & & MAP & $1.511 \mathrm{E}-01$ \\
\hline & & & & & & MFP & $1.845 E-01$ \\
\hline & & & & & & $M N-54$ & $1.514 E+00$ \\
\hline & & & & & & NB-95 & $3.188 E-01$ \\
\hline & & & & & & $R U=103$ & $9.644 E-02$ \\
\hline & & & & & & & (n) \\
\hline & & * & & & & & $2.713 E+01$ \\
\hline & & 75 & $4.020 E+01$ & $1.238 E+07$ & $1.009 E+02$ & $B A-140$ & $8.000 E-02$ \\
\hline & & & & & & CE- 144 & $2.300 E+00$ \\
\hline & & & & & & Co.58 & $4.537 E-02$ \\
\hline & & & & & & $c 0-60$ & $1.649 E+01$ \\
\hline & & & & & & $C R-51$ & $7.421 E+01$ \\
\hline & & & & & & CS- 134 & $1.270 E-01$ \\
\hline & & & & & & Cs -137 & $6.162 E-01$ \\
\hline & & & & & & FE-59 & $2.940 E-02$ \\
\hline & & & & & & $H F-181$ & $4.882 E-02$ \\
\hline & & & & & & $1-131$ & $8.167 E-03$ \\
\hline & & & & & & $L A-140$ & $2.813 E-02$ \\
\hline & & & & & & MAP & $3.500 E+00$ \\
\hline & & & & & & MFP & $1.571 E+00$ \\
\hline & & & & & & $M N-54$ & $1.414 E+00$ \\
\hline & & & & & & NB- 95 & $2.051 E-02$ \\
\hline & & & & & & $2 N-65$ & $4.000 E-01$ \\
\hline & & & & & & $2 R-95$ & $9.075 E-03$ \\
\hline & & & & & & & (n) \\
\hline & & * & & & & & $1.009 E+02$ \\
\hline & & 76 & $2.880 E+01$ & $1.909 E+07$ & $2.143 E+05$ & $A G-110 M$ & $2.180 E-01$ \\
\hline & & & & & & $B A-140$ & $4.018 E+01$ \\
\hline & & & & & & $C E-141$ & $2.881 E+01$ \\
\hline & & & & & & CE -144 & $3.873 E+01$ \\
\hline & & & & & & $\mathrm{Co-58}$ & $2.450 E+00$ \\
\hline & & & & & & $c 0-60$ & $4.449 E+04$ \\
\hline & & & & & & $C R-51$ & $1.510 E+05$ \\
\hline & & & & & & CS -134 & $1.279 E+00$ \\
\hline & & & & & & Cs- 137 & $2.900 E+00$ \\
\hline & & & & & & $F E-59$ & $1.863 E+04$ \\
\hline & & & & & & $H F-181$ & $7.310 E-02$ \\
\hline & & & & & & $1-131$ & $8.800 E-01$ \\
\hline
\end{tabular}




\begin{tabular}{|c|c|c|}
\hline GENERAT ING & GENERAT ING & DISPOSAL \\
\hline AREA & BUILDING & YEAR \\
\hline - nen & 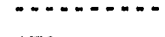 & $\cdots$ \\
\hline TRA & 670 & 76 \\
\hline
\end{tabular}

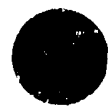

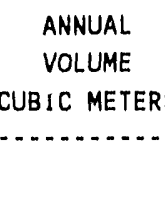

$7.988 E+01$

\section{$3.227 E+07$}

8. $993 \mathrm{E}+04$

$A G-110 M$

$C E-141$

CO-58

CO- 60

CR-51

CS- 134

CS -137

FE- 59

$H F-181$

$1-131$

MAP

MFP

$M N-54$

NB-95

RU- 103

$U N-I D-B+G$

ZN-65

$2 R-95$

78

$3.134 E+02 \quad 5.928 E+07$
$6.103 E+05$

AG- $110 \mathrm{M}$

CE-141

CE- 144

CO- 60

CR-51

CS- 134

CS -137

FE-59

HF -181

I -131
CURIES

$5.542 E+01$

4.135E-02

4.135E-02

$1.170 E+00$

$2.499 E+01$

$2.604 E+00$

7.310E-02

$3.302 E+00$

7.310E-02

2. $111 E+01$

$1.701 E+00$

$3.141 E+00$

$2.143 E+05$

5.960E-02

8. $940 E-02$

8.940E-02

$8.061 E+03$

$7.290 E+04$

2. $980 \mathrm{E}-02$

2.086E-01

$8.955 E+03$

5.960E-02

$5.500 E+00$

1. $670 \mathrm{E}-01$

1.670E-01

2. 980 E-02

8.940E-02

$2.980 E-02$

$8.979 E+00$

5.960E-02

$8.940 \mathrm{E}-02$

$8.993 E+04$

$2.583 E+00$

$1.698 \mathrm{E}+00$

$1.828 \mathrm{E}+00$

$5.958 E+04$

4. $702 E+05$

7.786E-01

$\% .064 E+00$

$6.050 E+04$

$1.032 \mathrm{E}+00$

$1.297 \mathrm{E}+00$ 


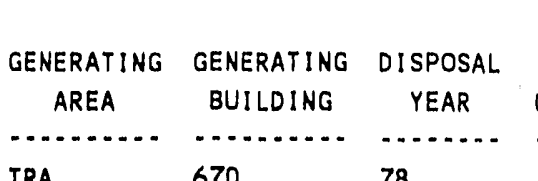

TRA 670

78

\begin{tabular}{|c|c|}
\hline ANNUAL & ANNUAL \\
\hline VOLUME & WEIGHT \\
\hline CUBIC METERS & GRAMS \\
\hline
\end{tabular}

\section{$1.041 E+02$}

79

80
9.271E+01

$7.908 E+07$

\begin{tabular}{l} 
ANNUAL \\
CURIES \\
\hline
\end{tabular}

\section{NUCL}

\section{MAP}

MFP

NB-95 5.700E-01

SC-46 5.160E+01

$U N-1 D-B+G \quad 8.433 E+00$

$2 \mathrm{~N}-65 \quad 7.828 \mathrm{E}-03$

ZR-95 $\quad 1.140 E-03$

..........

$6.103 E+05$

5.280E- 01

$5.722 E-01$

CE-141

CE -144

CO- 58

CO- 60

CR-51

CS- 134

CS- 137

$1-131$

$1-132$

$1-133$

LA- 140

MAP

MFP

NB-95

UN- ID-B+G

$2 R-95$

$1.186 E+01$

3.960E-01

1.332E+01

$7.284 E+02$

8.600E-02

2.580E- 01

$1.159 E+00$

8. $280 E-03$

2.898E-02

$7.920 E-01$

$9.084 E-02$

$1.059 E-01$

$4.800 E+00$

$1.277 E+09$

$1.380 E-03$

7...........

$9.334 E+00$

BA- 140

CE- 141

CE- 144

Co-58

C. -60

CR -51

CS -134

CS. 136

CS. 137

HF- 181

I-131

LA-140

MAP

MFP

MN-54

NB- 95
$4.462 E+00$

$3.889 E+00$

7.913E-01

$9.336 E+00$

$7.842 E+02$

$7.678 E-01$

$1.584 E-01$

$1.919 E+00$

$1.292 E-02$

1.072E-01

$1.213 E+01$

3.708E-02

2. 199E-02

$1.133 E-01$

3. 184E-01 


\begin{tabular}{|c|c|c|c|c|c|c|c|}
\hline $\begin{array}{l}\text { GENERATING } \\
\text { AREA }\end{array}$ & $\begin{array}{l}\text { GENERATING } \\
\text { BUILDING }\end{array}$ & $\begin{array}{l}\text { DISPOSAL } \\
\text { YEAR }\end{array}$ & $\begin{array}{c}\text { ANNUAL } \\
\text { VOLUME } \\
\text { CUBIC METERS }\end{array}$ & $\begin{array}{l}\text { ANNUAL } \\
\text { WEIGHT } \\
\text { GRAMS }\end{array}$ & $\begin{array}{l}\text { ANNUAL } \\
\text { CURIES }\end{array}$ & NUCL IDE & CURIES \\
\hline$\ldots$ & . & -.......... & -.............. & ......... & $\ldots+\ldots, \ldots$ & …..... & .............. \\
\hline \multirow[t]{37}{*}{ TRA } & 670 & 80 & & & & RU-103 & $1.258 E-01$ \\
\hline & & & & & & $U N-1 D-B+G$ & $1.859 E+01$ \\
\hline & & & & & & $2 N-65$ & $1.052 E-01$ \\
\hline & & & & & & $2 R-95$ & $2.521 E-01$ \\
\hline & & * & & & & & $8.467 E+02$ \\
\hline & & 81 & $8.201 E+01$ & $6.736 E+07$ & $8.512 E+02$ & $B A-140$ & $2.282 E+00$ \\
\hline & & & & & & CE-141 & $1.167 E+00$ \\
\hline & & & & & & CE- 144 & $6.776 E+00$ \\
\hline & & & & & & $C 0.58$ & $1.088 E+00$ \\
\hline & & & & & & 00.60 & $1.713 E+01$ \\
\hline & & & & & & CR-51 & $7.753 E+02$ \\
\hline & & & & & & CS- 134 & $5.010 E-02$ \\
\hline & & & & & & Cs. 137 & $6.501 E-01$ \\
\hline & & & & & & $H F-181$ & $1.820 E-01$ \\
\hline & & & & & & $L A-140$ & $2.513 E+00$ \\
\hline & & & & & & MAP & $8.653 E-02$ \\
\hline & & & & & & MFP & $8.653 E-02$ \\
\hline & & & & & & NB-95 & $8.960 E-02$ \\
\hline & & & & & & RU- 103 & $2.360 E-01$ \\
\hline & & & & & & $U N-I D-B+G$ & $4.243 E+01$ \\
\hline & & & & & & $2 N-65$ & $7.330 E-01$ \\
\hline & & & & & & $2 R-95$ & $4.537 E-01$ \\
\hline & & * & & & & & $8.512 E+02$ \\
\hline & & 82 & $8.888 E+01$ & $6.494 E+07$ & $1.259 E+05$ & $B A-140$ & $3.256 E+00$ \\
\hline & & & & & & CE-141 & $1.140 E+00$ \\
\hline & & & & & & CE-144 & $1.111 E+01$ \\
\hline & & & & & & Co.58 & $4.000 E-02$ \\
\hline & & & & & & $c 0-60$ & $1.852 E+04$ \\
\hline & & & & & & CR-51 & $7.978 E+02$ \\
\hline & & & & & & CS- 134 & $2.280 E-01$ \\
\hline & & & & & & Cs- 137 & $1.704 E+00$ \\
\hline & & & & & & FE-59 & $2.314 E+04$ \\
\hline & & & & & & $L A-140$ & $4.410 E+00$ \\
\hline & & & & & & MAP & $3.936 E+04$ \\
\hline & & & & & & MFP & $3.936 E+04$ \\
\hline & & & & & & NB-95 & $1.118 E+00$ \\
\hline & & & & & & $U N-I D-B+G$ & $4.713 E+03$ \\
\hline " & & & & & & $2 R-95$ & $1.306 E+00$ \\
\hline & & * & & & & & $1.259 E+05$ \\
\hline & & 83 & $8.417 E+01$ & $6.647 E+07$ & $7.845 E+02$ & $B A-140$ & $3.501 E+00$ \\
\hline
\end{tabular}




\begin{tabular}{|c|c|c|c|c|c|c|c|}
\hline & & & ANNUAL & ANNUAL & & & \\
\hline GENERAT ING & GENERATING & DISPOSAL & VOLUME & WEIGHT & ANNUAL & & \\
\hline AREA & BUILDING & YEAR & CUBIC METERS & GRAMS & CURIES & NUCLIDE & CURIES \\
\hline \multirow{45}{*}{ TRA } & and & 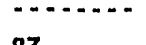 & 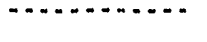 & - & n. & - & . \\
\hline & 670 & 83 & & & & CE- 141 & $9.256 \mathrm{E}-01$ \\
\hline & & & & & & CE- 144 & $1.988 E+00$ \\
\hline & & & & & & $\mathrm{CO} .58$ & $2.840 E-01$ \\
\hline & & & & & & $c 0.60$ & $2.167 E+01$ \\
\hline & & & & & & $C R-51$ & $6.644 E+02$ \\
\hline & & & & & & CS- 137 & $3.576 E-01$ \\
\hline & & & & & & $L A-140$ & $1.978 E+00$ \\
\hline & & & & & & MAP & $1.356 E+01$ \\
\hline & & & & & & MFP & $1.356 E+01$ \\
\hline & & & & & & $M N-54$ & $2.840 E-01$ \\
\hline & & & & & & NB - 95 & $2.840 E-01$ \\
\hline & & & & & & $U N-I D-B+G$ & $6.076 E+01$ \\
\hline & & & & & & $2 N-65$ & $3.576 E-01$ \\
\hline & & - & & & & $2 R-95$ & $5.680 E-01$ \\
\hline & & & & & & & - \\
\hline & & ^ & & & & & $7.845 E+02$ \\
\hline & & 84 & $1.019 E+02$ & $8.401 E+07$ & $8.315 E+02$ & $B A-140$ & $1.084 E+00$ \\
\hline & & & & & & CE- 141 & $1.038 E+00$ \\
\hline & & & & & & CE- 144 & $4.602 E+00$ \\
\hline & & & & & & $\mathrm{CO}-58$ & $7.905 E-01$ \\
\hline & & & & & & $c 0-60$ & $3.033 E+01$ \\
\hline & & & & & & $C R-51$ & $7.328 E+02$ \\
\hline & & & & & & CS- 134 & $4.133 E-01$ \\
\hline & & & & & & CS- 137 & $3.791 E-01$ \\
\hline & & & & & & $L A-140$ & $1.186 E+00$ \\
\hline & & & & & & MAP & $5.800 \mathrm{E}-02$ \\
\hline & & & & & & MFP & $5.800 E-02$ \\
\hline & & & & & & $M N-54$ & $2.385 E-01$ \\
\hline & & & & & & NB-95 & $7.520 E-01$ \\
\hline & & & & & & $U N-1 D-B+G$ & $5.617 E+01$ \\
\hline & & & & & & $Z N-65$ & $4.760 E-01$ \\
\hline & & & & & & $2 R-95$ & $1.128 E+00$ \\
\hline & & $\star$ & & & & & 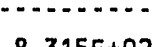 \\
\hline & & & & & & & \\
\hline & & 85 & $7.478 E+01$ & $5.465 E+07$ & $2.076 E+03$ & $B A-140$ & $7.800 E-02$ \\
\hline & & & & & & $C E-141$ & $3.800 E-01$ \\
\hline & & & & & & CE-144 & 5.100E-01 \\
\hline & & & & & & Co.60 & $1.944 E+01$ \\
\hline & & & & & & $C R-51$ & $2.019 E+03$ \\
\hline & & & & & & cs -134 & $1.400 E-01$ \\
\hline & & & & & & CS -137 & $1.250 E-01$ \\
\hline & & & & & & $H F-181$ & $2.832 E-01$ \\
\hline & & & & & & LA- 140 & $8.460 E-02$ \\
\hline & & & & & & MAP & $5.064 E+00$ \\
\hline
\end{tabular}


INEL WASTE MANAGEMENT INFORMATION SYSTEM
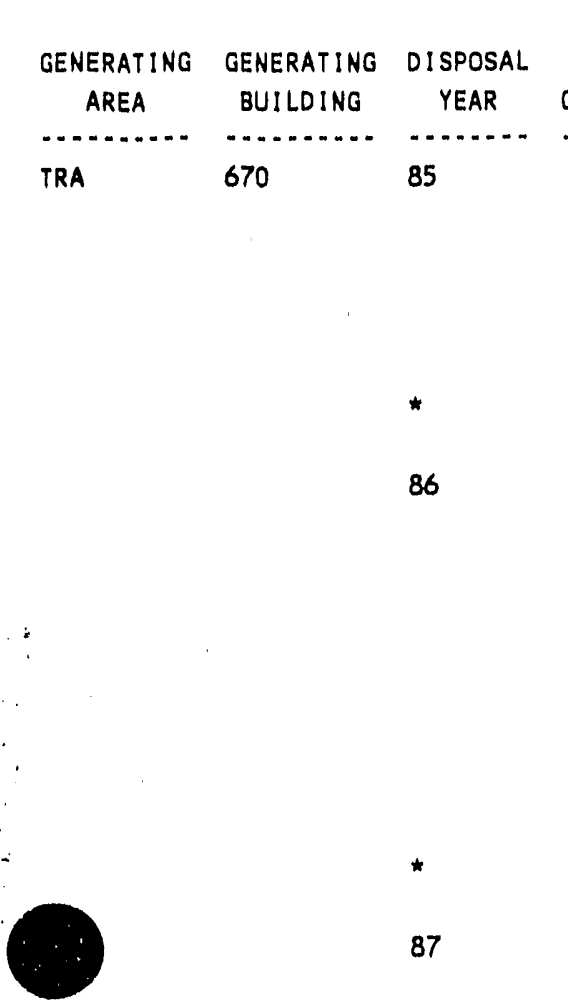

*

87
$8.678 E+01$

$1.352 E+02$

$7.910 E+07$

$1.044 E+03$

Co-58

CO- 60

CR-51

FE-59

MAP

MFP

MN-54

NA- 24

$U N-1 D-B+G$

MFP

$R U=106$

UN- $1 D-B+C$

$2 \mathrm{~N}-65$

CURIES

$5.064 \mathrm{E}+00$

5. $430 \mathrm{E}-01$

$1.380 E-01$

$2.477 \mathrm{E}+01$

3.264E-01

...........

$2.076 \mathrm{E}+03$

$8.678+01$

$4.780 E+07 \quad 1.145 E+0 /$

AG- $110 M$

CE- 141

CE-144

CO- 58

CO-60

$C R-51$

$H F-181$

MAP

MFP

$M N=54$

UN- ID-B+G

$2.717 E+00$

$1.048 E+01$

$1.019 E+03$

5.000E-02

$6.798 E-01$

$6.798 E-01$

7.200E-02

$2.200 E+00$

$8.531 E+00$

-..........

$1.044 E+03$

$2 \mathrm{~N}-65$

$1.913 E+00$

2.400E-02

$1.305 E+01$

2.569E+01

$5.732 \mathrm{E}+03$

$2.619 E+02$

$2.741 E+00$

$2.688 E+03$

$2.688 E+03$

$9.675 E+00$

$7.511 \mathrm{E}+00$

$1.948 \mathrm{E}+01$

$1.145 E+04$

88

$7.468 E+01$

$1.433 E+02$

$A G-110$

CE- 144

CO- 58

CO. 60

CR-51

CS- 137

HF- 181

MAP

MFP

MN-54

$U N-I D-B+G$
2.370E-02

2. 160E-01

8.340E-01

$2.231 E+00$

$1.346 E+02$

2. 200E-02

$7.570 \mathrm{E}-02$

5.574E-01

5.574E-01

$3.190 \mathrm{E}-01$

$3.585 E+00$ 


\begin{tabular}{|c|c|c|c|c|c|c|c|}
\hline GENERATING & GENERATING & DISPOSAL & $\begin{array}{l}\text { ANNUAL } \\
\text { VOLUME }\end{array}$ & $\begin{array}{l}\text { ANNUAL } \\
\text { WEIGHT }\end{array}$ & ANNUAL & & \\
\hline AREA & BUILDING & YEAR & CUBIC METERS & GRAMS & CURIES & NUCL IDE & CURIES \\
\hline . & …............. & ……. & 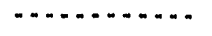 & ….......... & n. & - n & 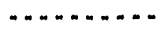 \\
\hline \multirow[t]{39}{*}{ TRA } & 670 & 88 & & & & $2 N-65$ & $2.480 E-01$ \\
\hline & & $\star$ & & & & & $1.433 E+02$ \\
\hline & & 89 & $3.330 E+01$ & $3.765 E+07$ & $7.587 E+01$ & CE- 144 & $1.520 E-01$ \\
\hline & & & & & 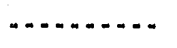 & CO.58 & $7.380 E-01$ \\
\hline & * & & & & $1.060 E+06$ & $c 0-60$ & $2.529 E+00$ \\
\hline & & & & & & $C R-51$ & $7.092 E+01$ \\
\hline & & & & & & $H F-181$ & $1.473 E-01$ \\
\hline & & & & & & MAP & $2.782 E-01$ \\
\hline & ' & & & & & MFP & $6.782 E-01$ \\
\hline & & & & & & $M N-54$ & $1.010 E-01$ \\
\hline & & & & & & $2 N-65$ & $3.250 E-01$ \\
\hline & & & & & & & . \\
\hline & & $\star$ & & & & & $7.587 E+01$ \\
\hline & & & , & & & & 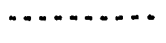 \\
\hline & * & & & & & & $1.060 E+06$ \\
\hline & 678 & 75 & $3.172 E+00$ & $4.536 E+05$ & $7.050 E+00$ & MAP & $3.525 E+00$ \\
\hline & & & & & & MFP & $3.525 E+00$ \\
\hline & & & & & & & .................. \\
\hline & & * & & & & & $7.050 E+00$ \\
\hline & & & & & & & . \\
\hline & $\star$ & & & & & & $7.050 E+00$ \\
\hline & 706 & 75 & $1.048 E+03$ & $1.731 E+08$ & $7.186 E+00$ & $\mathrm{CO}-60$ & $7.135 E+00$ \\
\hline & & & & & & $\mathrm{HAP}$ & $4.257 E-03$ \\
\hline & & & & & & MFP & $4.666 E-02$ \\
\hline & & & & & & & n. \\
\hline & & * & & & & & $7.186 E+00$ \\
\hline & & & & & & & a.s. \\
\hline & $\star$ & & & & & & $7.186 E+00$ \\
\hline & 730 & 73 & $2.945 E+00$ & $6.804 E+05$ & $7.500 E-03$ & MAP & $3.750 E-03$ \\
\hline & & & & & & MFP & $3.750 E-03$ \\
\hline & & & & & & & $\cdots$ \\
\hline & & $\star$ & & & & & $7.500 E-03$ \\
\hline & & & & & & & (1) \\
\hline & * & & & & & & $7.500 E-03$ \\
\hline & 732 & 74 & $3.398 \mathrm{E}+00$ & $4.536 E+05$ & $1.500 E-03$ & MAP & $1.050 E-03$ \\
\hline & & & & & & MFP & $4.500 E-04$ \\
\hline & & & & & & & . \\
\hline & & $\star$ & & & & & $1.500 E-03$ \\
\hline & & 76 & $6.741 E+00$ & $5.588 E+06$ & $1.350 E-03$ & MAP & $6.750 E-04$ \\
\hline
\end{tabular}




\begin{tabular}{|c|c|c|c|c|c|c|c|}
\hline & & & ANNUAL & ANNUAL & ANNUAL & & \\
\hline $\begin{array}{l}\text { GENERATING } \\
\text { AREA }\end{array}$ & $\begin{array}{l}\text { GENERATING } \\
\text { BUILDING }\end{array}$ & $\begin{array}{l}\text { DISPUSAL } \\
\text { YEAR }\end{array}$ & $\begin{array}{l}\text { VOLUME } \\
\text { CUBIC METERS }\end{array}$ & $\begin{array}{l}\text { WEIGHT } \\
\text { GRAMS }\end{array}$ & $\begin{array}{l}\text { ANNUAL } \\
\text { CURIES }\end{array}$ & NUCLIDE & CURIES \\
\hline . & . & $\ldots \ldots$ & 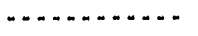 & 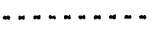 & - n.......... & 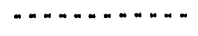 & ………. \\
\hline \multirow[t]{10}{*}{ TRA } & 732 & 76 & & & & MFP & $6.750 E-04$ \\
\hline & & * & & & & & $1.350 E-03$ \\
\hline & & 81 & $1.087 E+01$ & $2.268 E+06$ & $4.500 E-04$ & MAP & $2.250 E-04$ \\
\hline & & & & & & MFP & $2.250 E=04$ \\
\hline & & & & & & & $\ldots$ \\
\hline & & * & & & & & $4.500 E-04$ \\
\hline & & 85 & $7.249 E+00$ & $1.583 F+06$ & $1.000 E-04$ & MAP & $5.000 E-05$ \\
\hline & & & & & 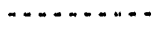 & MFP & $5.000 E-05$ \\
\hline & * & & & & $3.400 E-03$ & & 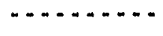 \\
\hline & & * & & & . & & $1.000 E-04$ \\
\hline \multirow[t]{3}{*}{ ^ } & & & & & $3.884 E+06$ & & ................ \\
\hline & * & & & & . & & $3.400 E-03$ \\
\hline & & & & & $3.884 E+06$ & & , n \\
\hline \multirow[t]{2}{*}{${ }^{*}$} & & & & & & & $3.883 E+06$ \\
\hline & & & & & & & $3.883 E+06$ \\
\hline
\end{tabular}




\begin{tabular}{|c|c|c|c|c|c|c|c|}
\hline $\begin{array}{l}\text { GENERATINO } \\
\text { AREA }\end{array}$ & $\begin{array}{l}\text { GENERATING } \\
\text { BUILDING }\end{array}$ & $\begin{array}{c}\text { DISPOSAL } \\
\text { YEAR }\end{array}$ & $\begin{array}{c}\text { ANNUAL } \\
\text { VOLUME } \\
\text { CUB IC METERS }\end{array}$ & $\begin{array}{l}\text { ANNUAL } \\
\text { WE IOHT } \\
\text { ORAMS }\end{array}$ & $\begin{array}{l}\text { ANNUAL } \\
\text { CURIES }\end{array}$ & NUCLIDE & CURIES \\
\hline ……....... & …........ & .......... & …........... & ............. & ........... & ............... & ............. \\
\hline \multirow[t]{33}{*}{ WER } & $\operatorname{com}$ & 87 & $1.087 E+02$ & $7.171 E+07$ & $1.167 E_{-01}$ & MAP & $5.835 \mathrm{E}-02$ \\
\hline & & & & & & MFP & $5.835 E-02$ \\
\hline & & * & & & & & $1.167 E-01$ \\
\hline & & 88 & $1.614 E+02$ & $1.065 E+08$ & $1.987 E-01$ & MAP & $9.935 E-02$ \\
\hline & & & & & & MFP & $9.935 E-02$ \\
\hline & & * & & & & & $1.987 E-01$ \\
\hline & & 89 & $2.778 E+02$ & $1.709 E+08$ & $1.925 \mathrm{E}-01$ & MAP & $9.626 \mathrm{E}-02$ \\
\hline & & & & & an. & MFP & $9.626 E-02$ \\
\hline & $\star$ & & & & $5.079 \mathrm{E}-01$ & & $\cdots$ \\
\hline & & * & & & & & $1.925 E-01$ \\
\hline & & & & & & & r........ \\
\hline & $\star$ & & & & & & $5.079 E-01$ \\
\hline & INC & 87 & $2.631 E+01$ & $2.695 E+07$ & $3.865 \mathrm{E}-02$ & MAP & $7.950 E-03$ \\
\hline & & & & & & MFP & $3.070 E-02$ \\
\hline & & $\star$ & & & & & $3,865 E-02$ \\
\hline & & 88 & $4.044 E+01$ & $3.617 E+07$ & $2.010 E-02$ & MAP & $1.005 E-02$ \\
\hline & & & & & & MFP & $1.005 E-02$ \\
\hline & & * & & & & & $2.010 \mathrm{E}-02$ \\
\hline & & 89 & $2.092 E+01$ & $2.445 E+07$ & $2.416 E-02$ & MAP & $1.208 E-02$ \\
\hline & & & & & (n. & MFP & $1.208 E-02$ \\
\hline & * & & & & $8.291 \mathrm{E}-02$ & & $\ldots$ \\
\hline & & * & & & & & $2.416 E-02$ \\
\hline & & & & & & & a.c.n. \\
\hline & $\star$ & & & & & & $8.291 E-02$ \\
\hline & MET & 85 & $1.924 E+02$ & $1.934 E+08$ & $2.305 E-01$ & MAP & $8.344 E-02$ \\
\hline & & & & & & MFP & $1.470 E-01$ \\
\hline & & * & & & & & $2.305 \mathrm{E}-01$ \\
\hline & & 86 & $1.992 E+02$ & $1.502 E+08$ & $1.664 E-01$ & MAP & $8.319 E-02$ \\
\hline & & & & & & MFP & $8.319 E-02$ \\
\hline & & & & & & & , \\
\hline & & " & & & & & $1.664 E \times 01$ \\
\hline & & 87 & $1.376 E+02$ & $1.126 E+08$ & $6.688 E-02$ & MAP & $3.344 E-02$ \\
\hline & & & & & & MFP & $3.344 E-02$ \\
\hline
\end{tabular}




\begin{tabular}{|c|c|c|c|c|c|c|c|}
\hline $\begin{array}{l}\text { OENERATINO } \\
\text { AREA }\end{array}$ & $\begin{array}{l}\text { GENERATING } \\
\text { BUILDING }\end{array}$ & $\begin{array}{l}\text { D1SPOSAL } \\
\text { YEAR }\end{array}$ & $\begin{array}{c}\text { ANNUAL } \\
\text { VOLUME } \\
\text { CUBIC METERS }\end{array}$ & $\begin{array}{l}\text { ANNUAL } \\
\text { WEIOHT } \\
\text { GRAMS }\end{array}$ & $\begin{array}{l}\text { ANNUAL } \\
\text { CURIES }\end{array}$ & NUCLIDE & CURIES \\
\hline …n-..... & …… & * & nacken. & n. & ................ & & $6.688 \mathrm{0} \cdot 02$ \\
\hline WER & MET & * & $5.256 E+01$ & $3.741 E+07$ & $1.013 \mathrm{E}-02$ & $\begin{array}{l}\text { MAP } \\
\text { MFP }\end{array}$ & $\begin{array}{r}5.065 E-03 \\
5.065 E-03 \\
\ldots \ldots \ldots \\
1.013 E-02\end{array}$ \\
\hline * & * & * & $2.900 E+01$ & $2.584 E+07$ & $\begin{array}{r}1.223 \mathrm{E}=02 \\
4.861 \mathrm{E}-01 \\
\cdots \\
1.077 \mathrm{E}+00 \\
\cdots \cdots \cdots \\
1.077 \mathrm{E}+0 .\end{array}$ & $\begin{array}{l}\text { MAP } \\
\text { MFP }\end{array}$ & 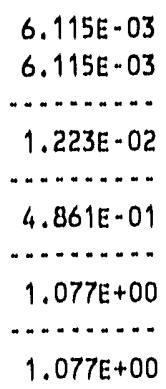 \\
\hline
\end{tabular}




\begin{tabular}{|c|c|c|c|c|c|c|c|}
\hline $\begin{array}{c}\text { QENERAT INO } \\
\text { AREA }\end{array}$ & $\begin{array}{l}\text { QENERATING } \\
\text { BUILDING }\end{array}$ & $\begin{array}{c}\text { DISPOSAL } \\
\text { YEAR }\end{array}$ & $\begin{array}{c}\text { ANNUAL } \\
\text { VOLUME } \\
\text { CUBIC METERS }\end{array}$ & $\begin{array}{l}\text { ANNUAL } \\
\text { WESOHT } \\
\text { ORAMS }\end{array}$ & $\begin{array}{l}\text { ANNUAL } \\
\text { CURIES }\end{array}$ & NUCLIDE & CURIES \\
\hline$\ldots$ & $\ldots \ldots$ & ......... & $\ldots \ldots+\ldots \ldots$ & …......... & …...... & .............. & ........... \\
\hline \multirow[t]{36}{*}{ WMC } & $E A D$ & 86 & $3.421 E+01$ & $4.536 E+06$ & $8.021 E-03$ & $A M-241$ & $8.021 E-03$ \\
\hline & & 87 & $1.550 E+02$ & $4.415 E+07$ & $1.260 \mathrm{E}=01$ & $A M-241$ & $1.260 E-01$ \\
\hline & & & & & . & & ............. \\
\hline & * & & & & $1.340 \mathrm{E}-01$ & & \\
\hline & $\mathrm{PO2}$ & 77 & $1.645 E+01$ & $6.659 E+06$ & $1.030 E-06$ & MFP & $1.030 E=06$ \\
\hline & T07 & 78 & $1.087 E+01$ & $1.306 E+07$ & $6.000 E+00$ & CS -137 & $1.200 E+00$ \\
\hline & & & & & & $S R=90$ & $4.800 E+00$ \\
\hline & & & & & & & $\ldots \ldots \ldots$ \\
\hline & & * & & & & & $6.000 E+00$ \\
\hline & & & & & & & 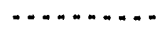 \\
\hline & * & & & & & & $6.000 E+00$ \\
\hline & WMO & 83 & $3.625 E+00$ & $3.629 E+05$ & $7.500 E-05$ & MAP & $3.750 E-05$ \\
\hline & & & & & & MFP & $3.750 E-05$ \\
\hline & & & & & & & a.s.......... \\
\hline & & * & & & & & $7.500 E-05$ \\
\hline & & & & & & & 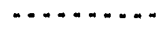 \\
\hline & * & & & & & & $7.500 E-05$ \\
\hline & 000 & 60 & $1.846 E+04$ & $0.000 E+00$ & $6.092 E+04$ & $U N-1 D-B+G$ & $6.092 E+04$ \\
\hline & 105 & 84 & $4.164 E-01$ & $2.722 E+05$ & $6.804 E-07$ & PU-239 & $6.804 E-07$ \\
\hline & 601 & 79 & $3.609 E+02$ & $6.327 E+08$ & $7.170 E-02$ & MAP & $1.000 E-04$ \\
\hline & & & & & & MrP & $1.000 \mathrm{E}-04$ \\
\hline & & & & & & $R A-226$ & $1.720 \mathrm{E}-02$ \\
\hline & & & & & & $T H-230$ & $1.789 E-02$ \\
\hline & & & & & & $T H-232$ & $3.339 E-04$ \\
\hline & & & & & & $U-234$ & $1.733 E-02$ \\
\hline & & & & & & $U-235$ & $9.136 \mathrm{E} \cdot 04$ \\
\hline & & & & & & $U-238$ & $1.783 \mathrm{E}-02$ \\
\hline & & & & & & & 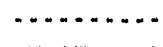 \\
\hline & & * & & & & & $7.170 \mathrm{E}-02$ \\
\hline & & 80 & $1.161 E+00$ & $1.814 E+05$ & $1.500 E-04$ & MAP & $7.500 E-05$ \\
\hline & & & & & & MFP & $7.500 E-05$ \\
\hline & & & & & & & $\ldots \ldots$ \\
\hline & & * & & & & & $1.500 E-04$ \\
\hline & & 81 & $3.625 E+00$ & $1.814 E+06$ & $1.500 E-04$ & MAP & $7.500 E \cdot 05$ \\
\hline & & & & & & MFP & $7.500 \mathrm{E}-05$ \\
\hline & & $\star$ & & & & & $1.500 E-04$ \\
\hline
\end{tabular}



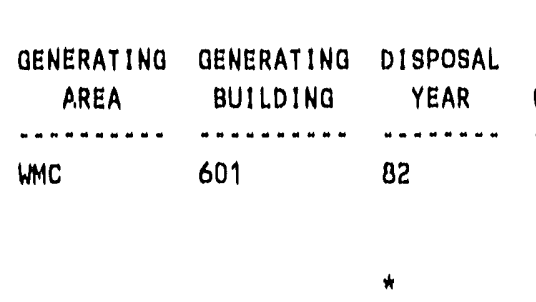

83

86

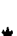

87

$\star$

*

602

78

*

79

*

80

$\star$

* 612

3

89

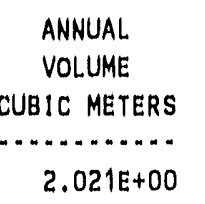

ANNUAL
WEIOHT
GRAMS
$1.842 E+06$

ANNUAL.

CURIES NUCLIDE C........

CURIES

2.000E-06 MAP

MFP

$1.000 E-06$

$1.000 E-06$

.............

$2.000 \mathrm{E}-06$

$4.313 E+02$

$6.477 E+07$

9.000E-03 MFP

$9.000 E-03$

$7.930 E-01$

$2.041 E+05$

5.200E-05 AM-241

PU- 239

$7.800 E-06$

$4.420 \mathrm{E}-05$

-.........

5.200E -05

4. 505E- 03

4. 505E-03

2. 200E- 07

*........ MFP

............

9.010E-03

$9.006 \mathrm{E}-02$

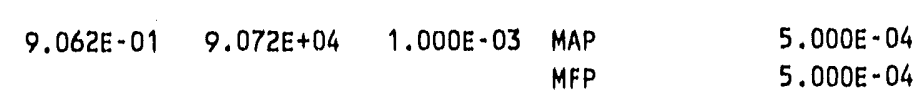

$1.000 \mathrm{E}-03$

$3.010 E-03$

$4.220 E+00 \quad 1.667 E+06 \quad 4.330 E-03$ MFP

UN-1D-B+G

$1.320 \mathrm{E}-\mathrm{U} 3$

$4.330 E-03$

$1.913 E-0.5$

$7.815 E-06$

$2.264 \mathrm{E}-04$

$5.583 E-03 \quad$ CS -137

$2.533 \mathrm{E}-04$

- . . . . . . . . .

$5.583 E-03$

$2.174 E+01 \quad 1.412 E+07$

$2.333 E-04$

PU- 238

PU- 239

PU -240

PU. 241

PU-242

8. $482 E-10$

2.328E-04

4. $114 E-07$

$2.403 E-08$

1.697E-09

$2.333 E-04$ 


\begin{tabular}{|c|c|c|c|c|c|c|c|}
\hline OENEDATINO & OFNFPAT INO & DISPOSAl & ANNUAL. & $\begin{array}{l}\text { ANNUAL } \\
\text { WE }\end{array}$ & ANNUAL & & \\
\hline AREA & BUILOINA & YEAR & CUAIC METERS & GRAMS & CURIES & NUCL IDE & CURIES \\
\hline \multirow[t]{2}{*}{ 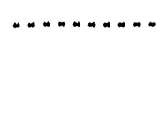 } & n. & .............. & . & ................ & 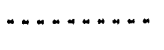 & . & $\ldots \ldots \ldots$ \\
\hline & * & & & & & & $2.333 \mathrm{E}-04$ \\
\hline \multirow[t]{8}{*}{ WMC } & 613 & 87 & $2.000 E+00$ & $9.072 E+03$ & $2.000 E-01$ & MAP & $1.000 \mathrm{E}-01$ \\
\hline & & & & & & MFP & $1.000 E-01$ \\
\hline & & & & & & & 2 \\
\hline & & * & & & & & $2.000 E-01$ \\
\hline & & 89 & $1.470 E+00$ & $1.414 E+06$ & $6.653 E-04$ & $A M=241$ & $2.852 E-05$ \\
\hline & & & & & . n. n & PU-239 & $6.368 E-04$ \\
\hline & * & & & & $2.007 E-01$ & & ............. \\
\hline & & * & & & n... & & $6.653 E-04$ \\
\hline \multirow[t]{3}{*}{ * } & & & & & $6.093 E+04$ & & .............. \\
\hline & * & & & & ............ & & $2.007 E-01$ \\
\hline & & & & & $6.093 E+04$ & & ............. \\
\hline \multirow[t]{2}{*}{ * } & & & & & & & $6.093 E+04$ \\
\hline & & & & & & & $6.093 E+04$ \\
\hline
\end{tabular}




\begin{tabular}{|c|c|c|c|c|c|c|c|}
\hline & & & ANNUAL & ANNUAL & & & \\
\hline $\begin{array}{l}\text { GENERATING } \\
\text { AREA }\end{array}$ & $\begin{array}{l}\text { GENERATING } \\
\text { BUILDING }\end{array}$ & $\begin{array}{l}\text { DISPOSAL } \\
\text { YEAR }\end{array}$ & $\begin{array}{c}\text { VOLUME } \\
\text { CUBIC METERS }\end{array}$ & $\begin{array}{l}\text { WEICHT } \\
\text { GRAMS }\end{array}$ & $\begin{array}{l}\text { ANNUAL } \\
\text { CURIES }\end{array}$ & NUCLIDE & CURIES \\
\hline ............... & $\ldots . . .6$ & ........ & . & ……. & ........... & . . . . . . . . & .......... \\
\hline \multirow[t]{8}{*}{$10 R$} & 000 & 61 & $2.680 E+02$ & $0.000 E+00$ & $3.000 E+00$ & $U N-1 D-B+G$ & $3.000 E+00$ \\
\hline & & 62 & $2.420 E+02$ & $0.000 E+00$ & $9.400 E+01$ & $U N-I D-B+G$ & $9.400 E+01$ \\
\hline & & 63 & $2.900 E+02$ & $0.000 E+00$ & $3.060 E+02$ & $U N-1 D-B+G$ & $3.060 E+02$ \\
\hline & & 64 & $7.100 E+01$ & $0.000 E+00$ & $2.000 E+01$ & $U N-1 D-B+G$ & $2.000 E+01$ \\
\hline & & 65 & $4.940 E+02$ & $0.000 E+00$ & $2.011 E+03$ & $U N-1 D-B+G$ & $2: 011 E+03$ \\
\hline & & & & & . & & . \\
\hline & * & & & & $2.434 E+03$ & & $2.434 E+03$ \\
\hline & & & & & 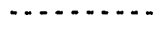 & & . \\
\hline \multirow[t]{3}{*}{ * } & & & & & $2.434 E+03$ & & $2.434 E+03$ \\
\hline & & & & & n. & & . \\
\hline & & & & & $2.434 E+03$ & & $2.434 E+03$ \\
\hline
\end{tabular}




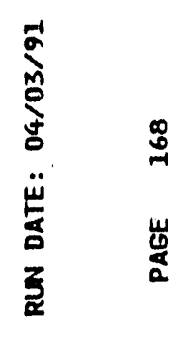

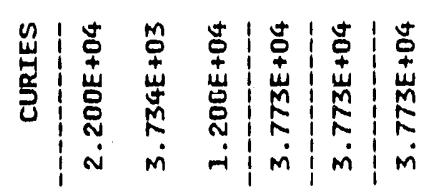

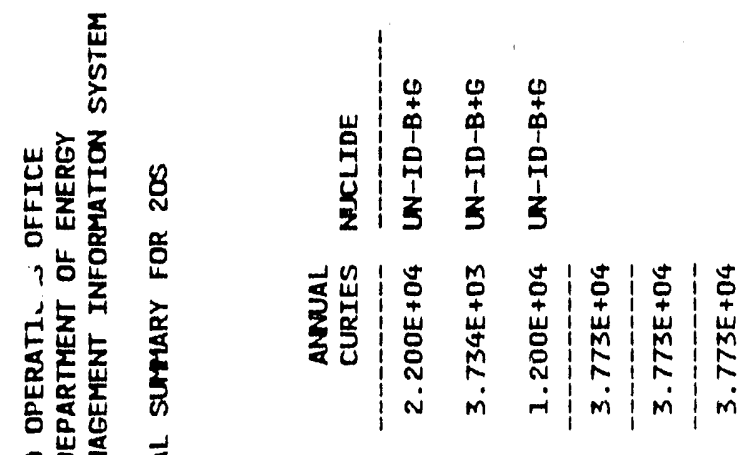

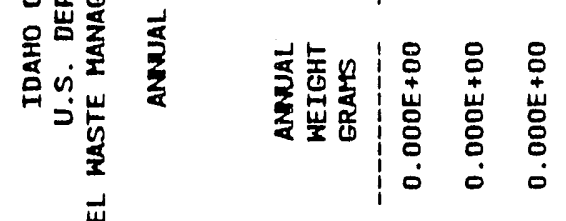

㞾

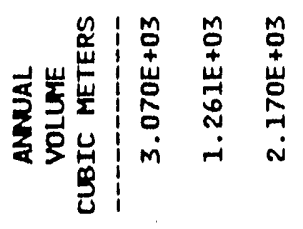
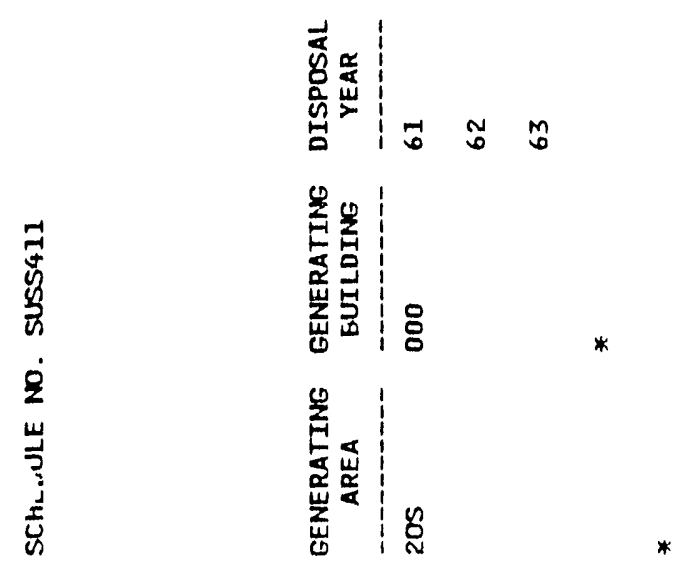



\section{APPENDIX C}

GENERATORS DISPOSING LLW IN THE RWMC SDA 
$\bullet$

-

-

C-2 


\section{APPENDIX C GENERATORS DISPOSING LLW IN THE RWMC SDA}

The following list of generators that have disposed radioactive waste in the RWMC SDA from 1952 to 1989. The INEL generators are given first along with the reactors which are, or have been, active at that generator or facility. Those noted below as closed have undergone or in the process of decontamination and decommissioning.

The onsite waste generators disposing waste at the RWMC known and documented in the Radioactive Waste Management Information System (RWMIS) are the following:

- $\quad$ ANLW (Argonne National Laboratory West)

Reactors: EBR-I (closed), EBR-II, TREAT, ZPPR

- NRF (Naval Reactor Facility) and ECF (Extended Core Facility)

Reactors: Information not available

- D\&D (Decontamination and Decommissioning)

- WERF (Waste Experimental Reduction Facility)

- $\quad$ PBF (Power Burst Facility)

Reactors: Refurbished Spert-1 Reactor

- $\quad$ PER or SPERT (Special Power Excursion Test Reactors 1-4

Reactors: SPERT-1, 2, 3 and 4; all closed except 1

- $\quad$ RWMC (Radioactive Waste Management Complex)

- $\quad$ CPP (Chemical Processing Plant)

- $\quad$ CFA (Central Facilities Area)

- $\quad$ TRA (Test Reactor Area)

Reactors: MTR (closed), ETR (closed), ATR, ARMF

- TAN (Test Area North)

- $\quad$ LOFT (or CTF - Containment of Fluids, or LOFT - Loss of Fluids Test)

Reactors - CTF/MTA, LOFT (closed)

ARA (Auxiliary Reactor Areas I - IV)

Reactors: ARA-1, ARA-2, ARA-3, ARA-4; all closed 
- SL-1 (U.S. Army Stationary Low Power Reactor)

Reactors: SL1; closed

Separate projects within the INEL include:

- ANP (Aircraft Nuclear Propulsion)

Reactors: (Listed under IET below)

- $\quad$ IET (Initial Engine Test)

Reactors: HTRE-1, HTRE-2, HTRE-3; closed

- $\quad$ NMEO (Nuclear Materials Evaluation Operations)

- SMC (Special Manufacturing Capability), contained in old LOFT facility

- $\quad$ SNAPTRAN (Space Reactor Research Program)

Reactors: SNAPTRAN-1, destroyed in final testing

- OMRE (Organic Moderated Reactor Experiment)

Reactors: OMRE; closed

- BORAX (Boiling Water Reactor)

Reactors: BORAX-1, 2, 3, 4 and 5; all closed

- GCRE (Gas Cooled Reactor Experiment)

Reactors: GCRE; closed - never used

The offsite waste generators in the RWMIS system are:

1. RFO (Rocky Flats Operations)

2. BEP/BAPL (Bettis Atomic Power Laboratory)

3. ANLE (Argonne National Laboratory East)

4. BCL (Battelle Columbus Laboratories)

5. MiL (Mound Laboratory)

Other external generators disposing radioactive waste in the RWMC SDA are:

1. BEN (Bendix Field Engineering) 
2. BNL (Brookhaven National Laboratory)

3. B\&W (Babcock and Wilcox)

4. MHD (Mountain States Energy); M-K (Morrison-Knutson)

5. MRC (Monsanto Research Corporation, no LLW)

6. The USAF (US Air Force, no LLW)

There have also been wastes received from some foreign and institutional locations. Generators disposing waste at the RWMC during the (Interim Burial Ground) IBG period (1961 to 1963) are documented in the report: Clements, Jr., T. L., "Buried Waste Classification: Nonradiological Hazards Study - Offsite Waste Generators," PR-W-80-027, October 1980. 
APPENDIX D

THE TRENCH AND PIT DISPOSAL LOCATIONS IN THE RWMC SDA

D-1 


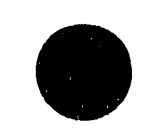

-

D-2 


\section{APPENDIX D \\ THE TRENCH AND PIT DISPOSAL LOCATIONS IN THE RWMC SDA}

Trench and Pit Wastes by Year

Table D-1 summarizes the trench and pit burial history at the P.WMC SDA. Table D-2 gives the opening and closing dates of the pits, trenches and soll vaults at the RWMC SDA. Table D.1 is subject to revision as new information may become avalable. This lable is a varlant of what is published by Card (1977). The date divisions have been chosen to match the key periods considered by the RWMC PA document. Certain disposal facillties overlap the time perlods shown in the table. 
Table D-1. Trench and Pit Waste Burlal History Summary.

\begin{tabular}{|c|c|c|c|c|}
\hline $\begin{array}{l}\frac{Y \operatorname{car}(\$)}{1952-} \\
1954\end{array}$ & 1 Trenches & Pils & $\begin{array}{l}\frac{\text { Waste Mix }}{\mathrm{LWW} \text { and on site }} \\
\text { TRU }\end{array}$ & Start of burlal in trenches \\
\hline $\begin{array}{l}1955- \\
1957\end{array}$ & 1 to 10 & 1 & $\begin{array}{l}\text { LLW and TRU in } \\
\text { trenches and pit } 1\end{array}$ & $\begin{array}{l}\text { LLW, onsite TRU and RFO } \\
\text { TRU mixed in trenches; start } \\
\text { of burlal in pits } 11 / 57\end{array}$ \\
\hline $\begin{array}{l}1958- \\
1959\end{array}$ & 10 to 17 & 1 and 2 & $\begin{array}{l}\text { LLW in trenches } 11 \text { to } \\
17 ; \text { LLW and TRU in } \\
\text { trench } 10 \text { and In pits } 1 \\
\text { and } 2\end{array}$ & \\
\hline $\begin{array}{l}1960- \\
1963\end{array}$ & 17 to 33 & 2 to 5 & $\begin{array}{l}\text { LLW in trenches } 17 \text { to } \\
33 ; \text { LLW and TRU in } \\
\text { pits } 2 \text { to } 5\end{array}$ & $\begin{array}{l}\text { Interim Burial Ground } \\
\text { (IBG) period (1961 TO } \\
\text { 1963) }\end{array}$ \\
\hline $\begin{array}{l}1964- \\
1970\end{array}$ & 33 to 54 & 4 to 12 & $\begin{array}{l}\text { LLW in trenches } 33 \text { to } \\
54: \text { LWW in pits } 7 \text { and } \\
8 ; \text { LLW and TRU in pits } \\
4,5,6,9,10,11 \text { and } 12\end{array}$ & Post IBG period \\
\hline $\begin{array}{l}1971- \\
\text { Now }\end{array}$ & 54 to 58 & 12 to 20 & $\begin{array}{l}\text { LLW trenches } 54 \text { to } 58 ; \\
\text { LLW in all pits, except } \\
\text { pit 12; TRU stored } \\
\text { above ground in the } \\
\text { transuranic storage area } \\
\text { (TSA) }\end{array}$ & $\begin{array}{l}\text { Trench burial used to } 1981 \text {, } \\
\text { soil vault rows started in } \\
1977 \text {. Pad-A used from } \\
1972 \text { to } 1978 \text { for non-TRU } \\
\text { uranium waste of activity } \\
\text { between } 0.1 \text { and } 10 \\
\text { nCl/gram }\end{array}$ \\
\hline
\end{tabular}




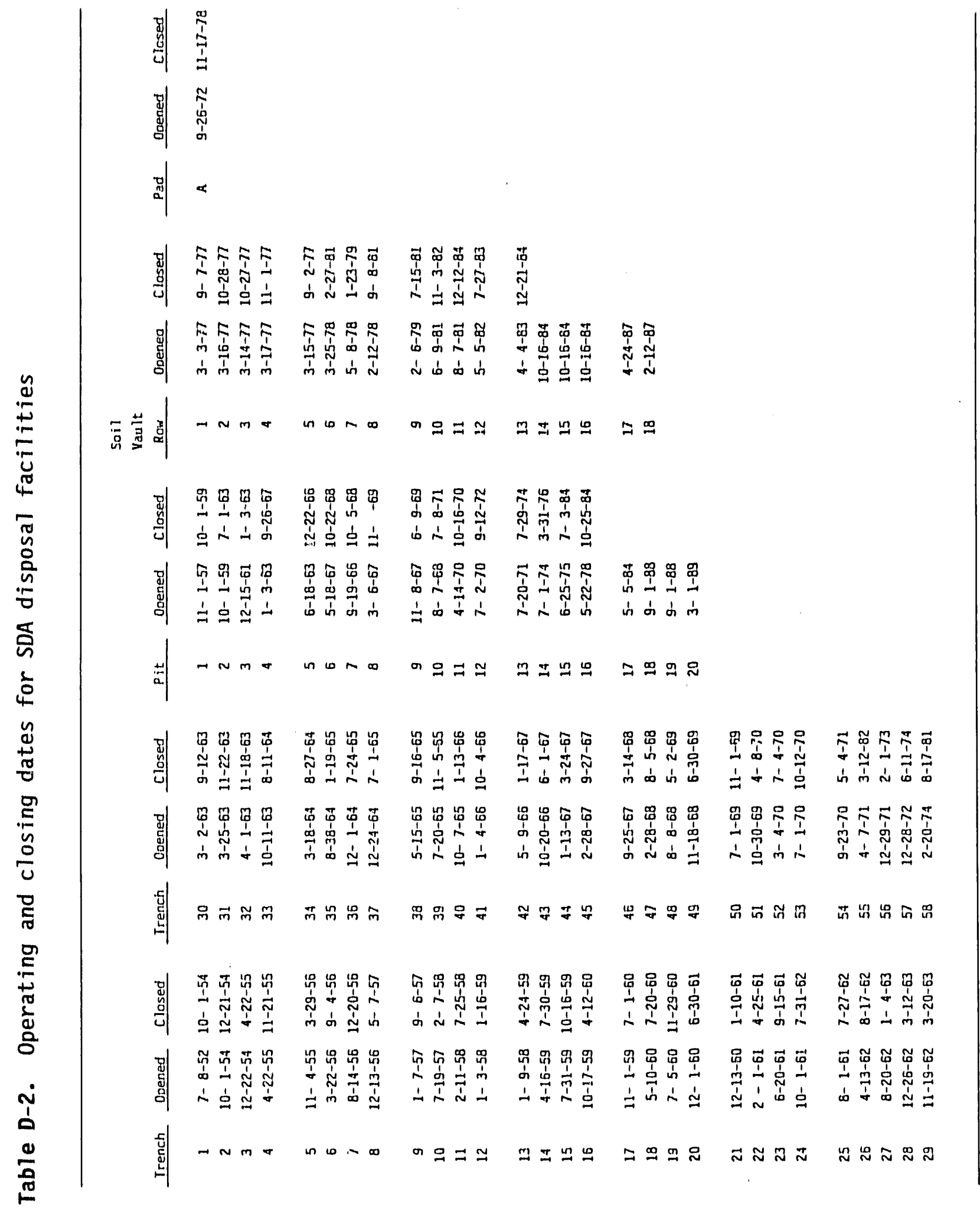


$\bullet$
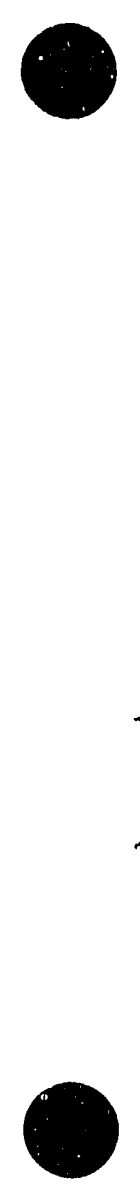

E-2 


\section{APPENDIX E THE GENERATOR QUESTIONNAIRE}

This generator questionnaire used in this study is given on the following pages. 
Apri1 25, 1991

\section{Distribution}

RADIOACTIVE WASTE MANAGEMENT COMPLEX (RWMC) LOW-LEVEL WASTE (LLW) INVENTORY FOR THE RWMC PERFORMANCE ASSESSMENT DOCUMENT - TLC-31-91

DOE Order 5820.2A, Chapter III, establishes the requirements for Performance Assessments for $L L W$ disposal sites, such as the Idaho National Engineering Laboratory (INEL) RWMC. The results from the Performance Assessment must meet the performance objectives defined in the order to continue disposal of LLW. A draft radiological Performance Assessment has been performed for the LLW that has been disposed at the RWMC, and indicates that the RWMC is currently in conformance with the performance objectives. During development of the RWMC Performance Assessment, the existing information concerning facility waste generation and radionuclides was used. This data generally only identified radionuclides as Mixed Fission Products and Mixed Activation Products. Conservative assumptions were used to bound the 1 imitations in the quantitative data available for performing the Performance Assessment. The intent of this waste inventory project is to improve on the existing data to increase the quality of the final Performance Assessment. Adequate data concerning specific radionuclide data for waste generated at your facilities is needed to increase the confidence in the current Performance Assessment results.

The purpose of this questionnaire is to obtain facility-specific data concerning specific radionuclides in LLW disposed at the RWMC between 19521990. This data is needed for use in the RWMC Radiological Performance Assessment, which analyzes the LLW radionuclide inventory (both $L L W$ disposed in the past and LLW planned to be disposed in the future) and its impact upon the environment and the public. The results from the Performance Assessment must meet the performance objectives defined in DOE Order 5820.2A to continue LLW disposal at the RWMC.

With your support, it may be possible to improve the LLW radionuclide inventory information used in the draft radiological Performance Assessment. Enclosed with this letter are graphs indicating annual volume of waste by facility and annual curies by facility, a questionnaire, and a detailed computer 1 isting from the Radioactive Waste Management Information System 
Distribution

Apri1 25, 1991

TLC-31-91

Page 2

(RWMIS) containing information about waste disposed at the RWMC by your facility since 1952. The computer listing is sorted by building and year, and contains annual volume, annual weight, annual curies, and annual curies by specific radionuclide (where known). Totals are indicated on the report by ' ${ }^{\prime \prime}$ '. Where specific radionuclides were not identified, the RWMIS

information contains Mixed Activation Products (MAP), Mixed Fission Products (MFP), Unidentified Beta-Gamma (UN-ID-B-G), and Unidentified Alpha (UN-IDALPHA).

I realize that information may be sketchy or unavailable on LLW sent from your facility to the RWMC for disposal, particularly during 1952-1970. However, I am requesting that you review the questionnaire and computer listing, noting your changes or additional information. Personnel from my staff are available to answer questions, provide additional information, or provide other assistance in completing this request. Please return the completed questionnaire and computer listing with your changes to

Ms. M. E. Sussman at Mail Stop 3950 by June 7, 1991.

Your help with this request is greatly appreciated. Please feel free to contact Ms. Sussman at (208) 526-4697 if you have any questions or need additional information or assistance.

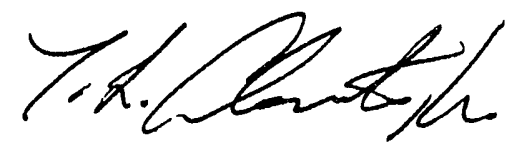

T. L. Clements, Jr., Manager

Waste Management Operations Technical Support

1 ap

Attach/Encl:

As Stated 
Distribution

Apri1 25, 1991

TLC-31-91

Page 3

\section{Distribution}

ANL-W

R. P. Grant, MS 6000

ANL-E

R. W. Ditch

EG\&G Idaho, Inc.

J. R. Bishoff, MS 4202

J. D. Bradford, MS 8101

D. W. Colling, MS 8103

S. J. Keating, MS 7107

D. K. Lainhart, MS 4109

R. H. Meservey, MS 1545

P. North, MS 3601

K. E. Streeper, MS 9208

L. J. Toomer, MS 7104

T. L. Trace, MS 9201

NRF

D. H. Haar, MS 6001

R. B. Newbold, MS 6001

J. C. Rushi, MS 6001

\section{WINCO}

J. D. Edelmayer, MS 5114

cc: (w/o Enclosure)

R. C. Cullison, DOE-IBO, 6001

D. G. Hinckley, DOE-ID, MS 1118

S. T. Hinschberger, DOE-ID, MS 1118

J. C. Okeson, EG\&G Idaho, (w/o Attach), MS 3601

J. P. Orr, DOE-ID, MS 1118

J. G. Podgursky, NRF, MS 6001

R. M. Srhiletter, ANL-E

D. W. Suthers, EG\&G Idaho, MS 7121

J. R. Wade, DOE-ID, MS 1118

L. C. Witbeck, ANL-W, MS 6000

J. 0. Zane, EG\&G Idaho, (w/o Attach), MS 3600 
bcc: (W/o Encl)

R. M. Brown, MS 3950

J. N. Davis, MS 3940

D. L. French, MS 4201

W. W. Gay, MS 7106

D. J. Harvego, MS 4156

W. F. Lewis, MS 7132

D. L. Litteer, MS 4110

S. J. Maheras, MS 2110

J. D. McKinney, MS 3950

T. B. McLaughl in, MS 8101

L. E. Plansky, MS 3950

J. D. Poole, MS 4118

A. S. Rood, MS 2110

D. M. Sherick, MS 7112

S. G. Stiger, MS 3900

M. E. Sussman, MS 3950

D. W. Suthers, MS 7121

K. R. Thurman, MS 9114

J. D. Wells, MS 4201

D. C. Wilkie, MS 7104

D. R. Wilkinson, MS 4201

Central Files, MS 1651

Technical Support File, MS 3950

T. L. Clements, Jr. File* 


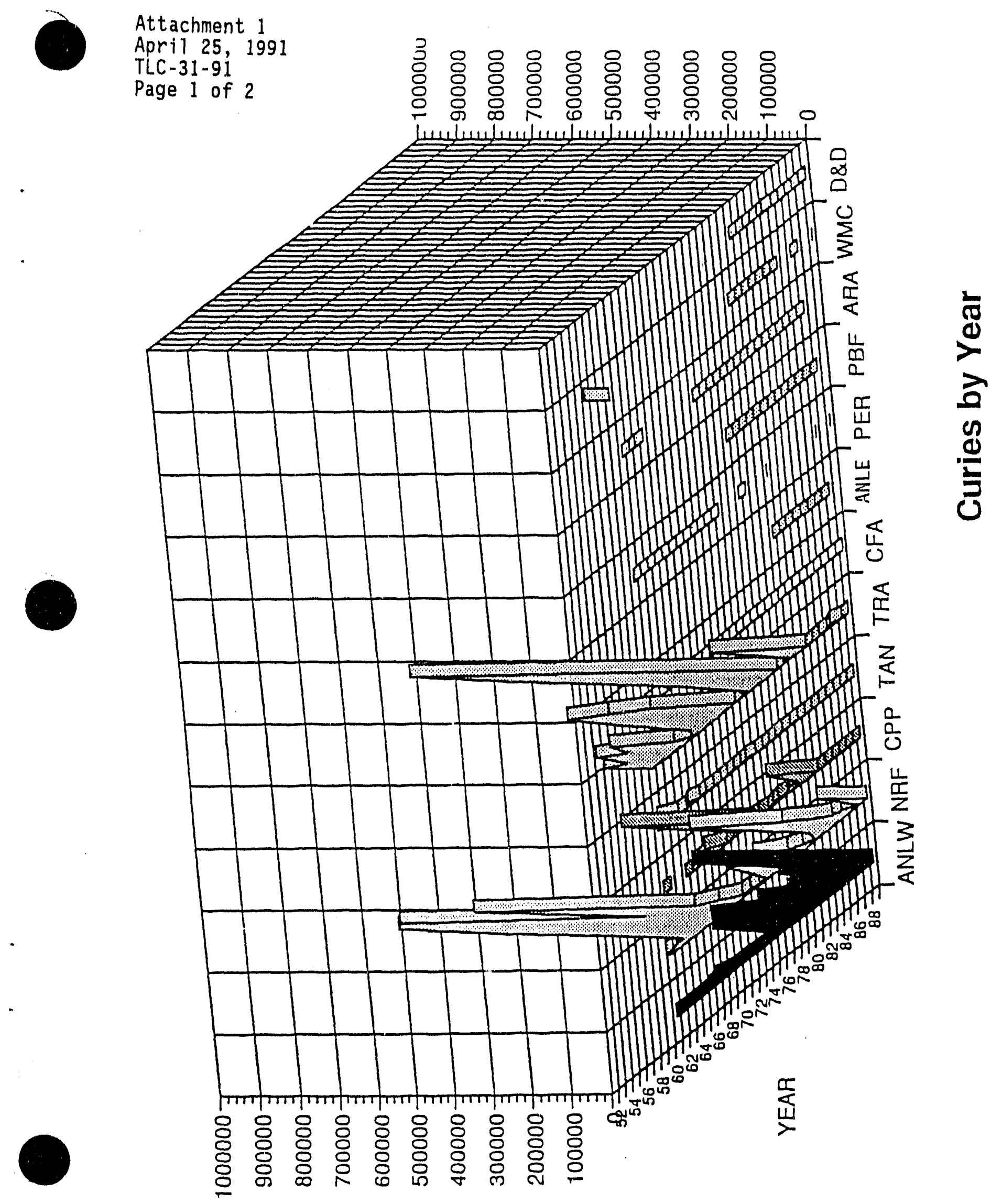


Attachment 1

April 25, 1991

TLC-31-91

Page 2 of 2

윰유유유 윰유 윰

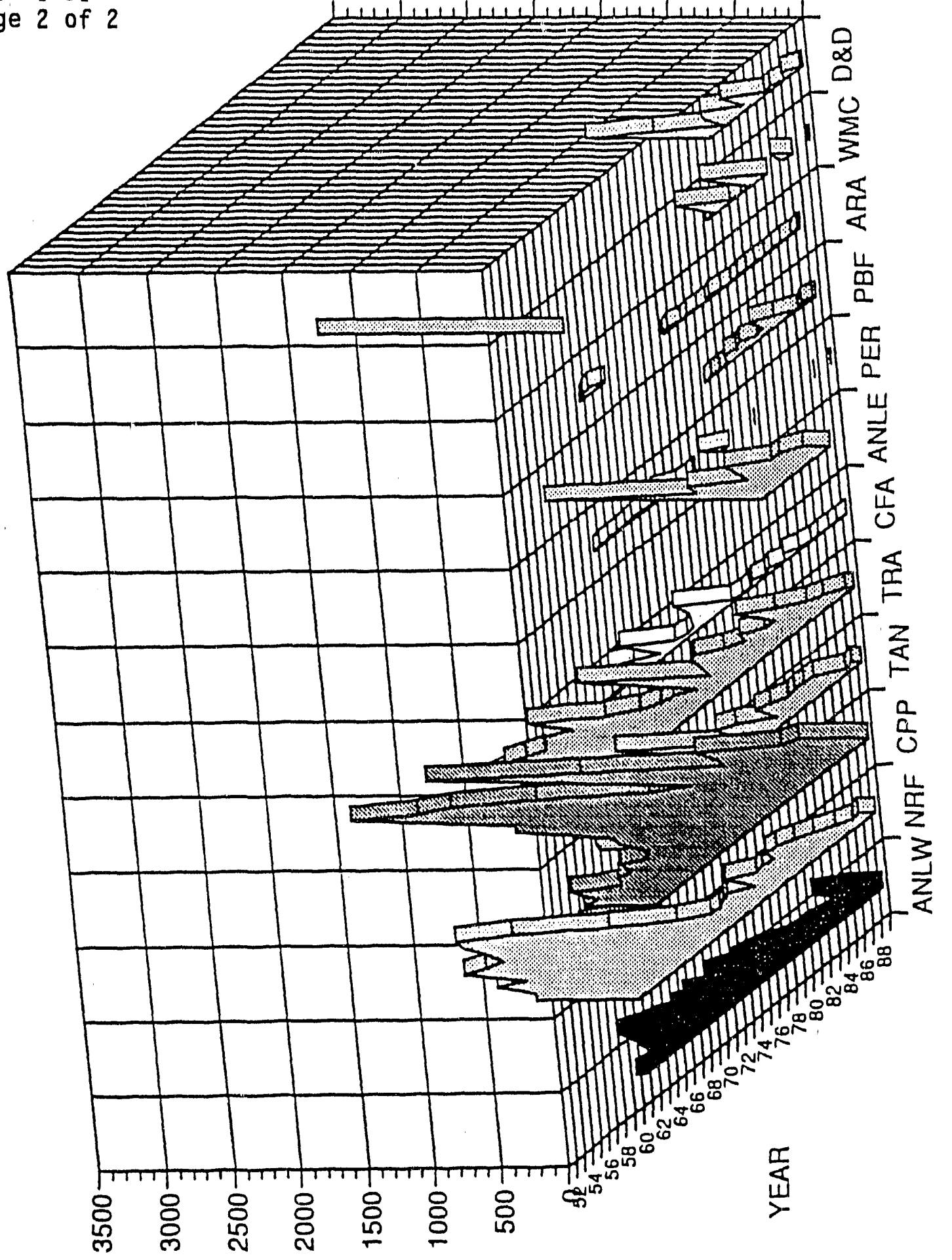

离 
Attachment 2

Apr 11 25, 1991

TLC-31-91

Page 1 of 5

RWMC LOW-LEVEL WASTE INVENTORY QUESTIONNAIRE

FOR THE RWMC PERFORMANCE ASSESSMENT

FACILITY:

NAME:

PHONE :

MAIL STOP:

The purpose of this questionnaire is to obtain facility-specific data concerning low-level waste (LLW) disposed at the RWMC between 1952-1990. This data is needed for use in the RWMC Radiological Performance Assessment, which analyzes the LLW radionuclide inventory (both LLW disposed in the past and LLW planned to be disposed in the future) and its impact upon the environment and the public. The results from the Performance Assessment must meet the performance objectives defined in DOE Order 5820.2A to continue LLW disposal at the RWMC. During development of the RWMC Performance Assessment, the existing information concerning facility waste generation and radionuclides was used. This data generally only identified radionuclides as Mixed Fission Products and Mixed Activation Products. Conservative assumptions were used to bound the limitations in the quantitative data available for performing the Performance Assessment. The intent of this waste inventory project is to improve on the existing data to increase the quality of the final Performance Assessment. Adequate data concerning specific radionuclide data for waste generated at your facilities is needed to increase the confidence in the current Performance Assessment results.

Enclosed with this letter is a listing from the INEL Radioactive Waste Management Information System (RWMIS) containing information about waste disposed at the RWMC from your facility since 1952. This information is sorted by building and year, and contains annual volume, annual weight, annual curies, and annual curies by specific radionuclide (where known). Totals are indicated on the report by $' * \prime$. Where specific radionuclides were not identified, the RWMIS information contains Mixed Activation Products (MAP), Mixed Fission Products (MFP), Unidentified Beta-Gamma (UN-ID-B-G), and Unidentified Alpha (UN-ID-ALPHA).

Please provide answers for the following questions and return the questionnaire and computer 1 isting to Ms. M. E. Sussman at Mail Stop 3950 by May 30,1991 . In addition to a review of the RWMIS records, reviews of waste shipment or disposal records and literature searches may be helpful in answering the questionnaire. If questions cannot be answered, so state and provide the reason why the information is not available. If you have questions or need additional information or assistance with questionnaire, please feel free to contact Ms. Sussman at (208) 526-4697. Your help in providing this information is greatly appreciated. 
Attachment 2

Apri1 25, 1991

TLC-31-91

Page 2 of 5

1. Are waste records, documents, or personnel avallable that may detafl LLW shipments to the RWMC?

A. If so, do the documents concur with the attached RWMIS information? If not, please mark corrections.

B. If so, where are the records or documents located, and can they be obtained by RWMC Low Level Waste Performance Assessment project personnel?

C. Is specific radionuclide inventory information present on the waste records or documents? Can you reconstruct or improve the accuracy of the waste radionuclide inventory information contained in the RWMIS?

D. If records or documents are not available, are other sources (letters, logbooks, etc.) available for detailing waste shipped to the RWMC?

E. Briefly describe the method used to determine the radionuclides identified in the waste packages shipped to the RWMC. 
Attachment 2

Apr 11 25, 1991

TLC-31-91

Page 3 of 5

II. For each major facility, project, bullding, or experiment that contributed to the waste stream packaged for shipment to the RWMC since 1952 (this should include facilities that were in operation in the past, but are no longer operating), provide the following information:

A. Please provide a brief description of the activities conducted by each facility/project/building/experiment, the basic types of waste processes, radionuclides generated, or other pertinent data that could lead to waste stream/radionuclide identification. The description may be by year or groups of years. (For example: "During 1952 - 1959, building 643 performed fuels tests, which produced I-129, Cs-137, and Sr-90 as waste).

B. Describe the waste physical forms (sludge, combustibles, metals, glass, etc.), waste chemical forms (oxide, nitrates, etc), and waste containers (steel drums, wooden boxes, etc.) used to package the waste, and approximate percentage of each type container by year. If internal shielding was used, indicate the type of shielding material. 
Attachment 2

Apr11 25, 1991

TLC-31-91

Page 4 of 5

C. Specific radionuclide information about the waste streams is needed to assess RWMC's compliance with the performance objectives of DOE Order 5820.2A. Much of the waste shipped to the RWMC in the early years did not contain specific radionuclide information, and was identified as Mixed Fission Products (MFP), Mixed Activation Products (MAP), UnidentifledBeta-Gamma (UN-ID-B-G), or Unidentified-Alpha (UN-ID-ALPHA). Please provide specific radionuclide information or estimates of the specific radionuclide distribution for waste that is identified as MAP, MFP, UN-ID-B-G, or UN-ID-ALPHA.

D. Are the disposal locations at the RWMC (pit or trench) of the wastes disposed before 1972 known? If so, please list each known disposal location with the volume, total activity, and radionuclide information associated with that location. 
Attachment 2

Apr 1 1 25, 1991

TLC - 31-91

Page 5 of 5

III. Please describe the chemicals that were included in waste packages shipped to the RWMC. This should include physical form of the chemical and any other information that you feel would be helpful in characterizing the waste.

IV. Were any potential nonradiological hazards (such as pressurized or partially pressurized gas cylinder, batteries, explosives or explosive mixtures) present in waste that may have been sent to the RWMC? If so, please describe.

v. Is there any other information that would be helpful to our understanding of low-level waste radionuclides disposed at the RWMC, particularly in the years 1954 - 1970? If so, please describe. 


\section{APPENDIX $F$ \\ ANALYSIS OF THE GENERIC RADIONUCLIDES}




\title{
APPENDIX F ANALYSIS OF THE GENERIC RADIONUCLIDES
}

\author{
INTRUDER DOSE CALCULATIONS FOR MIXED FISSION \\ PRODUCTS AND MIXED ACTIVATION PRODUCTS DISPOSED \\ OF AT THE RADIOACTIVE WASTE MANAGEMENT COMPLEX 1
}

Arthur S. Rood

Steven J. Maheras

Subsurface and Environmental Modeling Unit

May 1991

${ }^{1}$ Condensed version of original paper. 


\section{INTRODUCTI $\triangle N$ AND BACKGROUND}

Requirements for the management of low-level radioactive waste (LLW) at Department of Energy (DOE) facilities are given iī Chapter IIl of DOE Order5820.2A. Performance objective 3.a. of Chapter III states that the committer effective dose equivalent received by individuals who inadvertently intrude into the facility after the loss of active institutional control will not exceed 100 $\mathrm{mrem} / \mathrm{y}$ for continuous chronic exposure or $500 \mathrm{mrem}$ for a single acute exposure. DOE guidance on compliance with these performance objectives requires that a radiological performance assessment be performed using appropriate scerarios to estimate potential consequences to intruders who engage in activities on a closed site after institutional control has ceased.

Radioactive waste containing mixed activation products (MAP) and mixed fission products (MFP) has been disposed of at the Idaho National Engineering Laboratory (INEL) Radioactive Waste Management Complex (RWMC). Traditionally, MAP and MFP have been converted to radionuclides such as Co-60 and Cs-137. While this may be a reasonable conversion over the operational life of the RWMC, this conversion may not be appropriate for the extended time periods over which performance assessment analyses are typically performed. The purpose of this report is to provide a technical basis for the conversion of MAP and MFP to specific radionuclides that are reasonably conservative over performance assessment time frames. Implicit in this purpose is the desire to choose radionuclides that have a reasonable chance of being present in INEL waste.

LLW containing unidentified beta-gamma activity has also been disposed of in the RWMC. For the purposes of the RWMC performance assessment, it is assumed that the composition of unidentified beta-gamma activity is the same as MFP activity.

Inadvertent intruder dose calculations to determine waste classification limits for the RWMC have been performed using the PATHRAE (Rogers and Hung, 1987) and MICROSHIELD (Grove Engineering, 1988) computer codes. The calculations performed by Rood and Maheras (1990) used the methodology and parameter values that were reported in the RWMC Performance Assessment (Case et al., 1990) with the exception that the groundwater pathway was not evaluated. Computer codes (Baca et al., 1990) are currently being developed to evaluate the downward migration of radionuclides from the RWMC to the Snake River Plain Aquifer. These codes will be used to evaluate the groundwater pathway when completed. The source term for these calculations included the actinides Pu-242-238, U-238, U-235, U-233, and Am-241, C-14, I-129, and H-3. These calculations provided a means for identifying important transuranic, unidentified alpha-emitting nuclides and some fission products on the basis of waste concentration limits. A similar set of calculations are presented in this report for radioactivity classified as MAP and MFP. 


\section{TECHNICAL APPROACH}

To convert MAP and MFP to specific radionuclides, a representative suite of radionuclides must first be developed. For the purposes of this analysis, it was assumed that radionuclides contained in spent fuel would be representative of MFP and radionuclides contained in fuel disassembly hardware and control rod elements would be representative of MAP. The specific radionuclides evaluated in this analysis were derived from the Characteristics Data Base (CDB) developed by Oak Ridge National Laboratory (DOE, 1987). This data base contains the characteristics of spent fuel, high-level waste, and other radioactive waste that may require long-term isolation.

Radionuclide inventories contained in spent fuel, control rod elements, and fuel disassembly hardware were evaluated. The spent fuel inventory was derived for a pressurized water reactor with the maximum burn up of $60,000 \mathrm{MWD} / \mathrm{MTU}$ (megawatt days per metric ton of uranium). The inventory for fuel disassembly hardware and control rod elements was derived from a Westinghouse $17 \times 17$ fuel assembly. Radionuclides identified in the spent fuel inventory were primarily fission products. Radionuclides identified in control rod elements and fuel disassembly hardware were primarily activation products. Actinides, C-14, I-129, and H-3 were not considered in this analysis because these radionuclides were previously evaluated (Rood and Maheras,1990). Because the minimum time before intrusion is 100 years, nuclides with half-lives less than 10 years were also eliminated from consideration. Table 1 contains the radionuclides evaluated in this analysis.

After a representative radionuclide list was developed, each radionuclide was evaluated using inadvertent intruder scenarios and compared to the regulatory criteria in DOE Order 5820.2A for intruders (i.e., $100 \mathrm{mrem} / \mathrm{yr}$ for chronic exposures and $500 \mathrm{mrem}$ for acute exposures). Specifically, a unit concentration of each radionuclide was assumed to exist in the waste. The radionuclidespecific dose through each of the intruder scenarios was calculated and compared to the DOE Order $5820.2 \mathrm{~A}$ regulatory criteria by determining the concentration of each radionuclide that yielded the dose specified in the regulatory criteria. The radionuclides that exhibited the lowest concentrations were chosen as being conservative representations of MFP and MAP. This procedure is similar to the procedures used to determine waste classification limits. 
Table 1. MFP and MAP identified using the CDB for spent fuel, control rod elements, and fuel disassembly hardware.

\begin{tabular}{|c|c|c|c|c|}
\hline Nuclide & Progeny & MFP or MAP & Origin $^{\mathrm{a}}$ & Half-life (yr) \\
\hline${ }^{90} \mathrm{Sr}$ & ${ }^{90} \mathrm{Y}$ & MFP & SF & 28.6 \\
\hline${ }^{137} \mathrm{Cs}$ & $137 \mathrm{~m}_{\mathrm{Ba}}$ & MFP & SF & 30.2 \\
\hline${ }^{151} \mathrm{Sm}$ & & MFP & SF & 90.0 \\
\hline $93 \mathrm{~m}_{\mathrm{Nb}}$ & & MFP \& MAP & SF, CRE \& FDH & 14.6 \\
\hline $94 \mathrm{Nb}$ & & MFP \& MAP & SF, CRE \& FDH & $2.03 E+04$ \\
\hline $115_{\mathrm{In}}$ & & MAP & CRE & $4.60 \mathrm{E}+15$ \\
\hline${ }^{93} \mathrm{Zr}$ & $93 \mathrm{~m}_{\mathrm{Nb}}$ & MFP \& MAP & SF, CRE \& FDH & $1.53 \mathrm{E}+06$ \\
\hline${ }^{107} \mathrm{Pd}$ & & MAP & CRE & $6.50 \mathrm{E}+06$ \\
\hline${ }^{99} \mathrm{Tc}$ & & MFP \& MAP & SF \& FDH & $2.13 E+05$ \\
\hline${ }^{63} \mathrm{Ni}$ & & MAP & CRE \& FDH & 100 \\
\hline${ }^{10} \mathrm{Be}$ & & MAP & CRE \& FDH & $1.60 \mathrm{E}+06$ \\
\hline${ }^{36} \mathrm{Cl}$ & & MAP & CRE \& FDH & $3.01 \mathrm{E}+05$ \\
\hline${ }^{59} \mathrm{Ni}$ & & MAP & CRE \& FDH & $7.50 \mathrm{E}+04$ \\
\hline${ }^{93} \mathrm{Mo}$ & $93 \mathrm{~m}_{\mathrm{Nb}}$ & MAP & $\mathrm{FDH}$ & $3.50 \mathrm{E}+03$ \\
\hline${ }^{79} \mathrm{Se}$ & & MFP & $\mathrm{SF}$ & $6.50 \mathrm{E}+04$ \\
\hline $113 \mathrm{~m}_{\mathrm{Cd}}$ & & MFP & SF & 13.7 \\
\hline${ }^{126} \mathrm{Sn}$ & $126 \mathrm{~m}_{\mathrm{Sb}}$ & MFP & SF & $1.00 \mathrm{E}+05$ \\
\hline${ }^{135} \mathrm{Cs}$ & & MFP & SF & $2.30 \mathrm{E}+06$ \\
\hline
\end{tabular}

a. $S F=$ spent fuel

$\mathrm{CRE}=$ control rod elements

FDH $=$ fuel disassembly hardware 


\section{METHODOLOGY}

The assessment methodology and assumptions used in this analysis is described in detail in Waste Concentration Limits Based on the Inadvertent Intruder Protection Standards for the Radioactive Waste Management Complex (Rood and Maheras, 1990) and the RWMC Performance Assessment (Case et al., 1990). A brief description of the general methodology is presented below. Parameters that are specific to the nuclides examined in this analysis are listed in Table 2.

Table 2. Nuclide specific parameter values used in the intruder dose calculations for mixed activation and mixed fission products (from Baes et al.. 1984)

\begin{tabular}{|c|c|c|c|c|c|}
\hline Nuclide & $\begin{array}{l}\text { Soil to Plant } \\
\text { Uptake Factor } \\
\text { for Grain }\end{array}$ & $\begin{array}{l}\text { Soil to Plant } \\
\text { Uptake Factor } \\
\text { for Vegetables }\end{array}$ & $\begin{array}{l}\text { Forage to } \\
\text { Milk Uptake } \\
\text { Factor } \\
\end{array}$ & $\begin{array}{l}\text { Forage to } \\
\text { Beef Uptake } \\
\text { Factor }\end{array}$ & $\begin{array}{l}\mathrm{K}_{\mathrm{d}} \\
(\mathrm{mL} / \mathrm{g}) \\
\end{array}$ \\
\hline${ }^{90} \mathrm{Sr}$ & 0.25 & 2.5 & $1.5 \mathrm{E}-3$ & $3.0 \mathrm{E}-4$ & 35 \\
\hline${ }^{137} \mathrm{Cs}$ & 0.030 & 0.080 & $7.0 \mathrm{E}-3$ & 0.02 & 1000 \\
\hline${ }^{151} \mathrm{Sm}$ & $4.0 \mathrm{E}-3$ & 0.010 & $2.0 \mathrm{E}-5$ & $5.0 \mathrm{E}-3$ & 650 \\
\hline $93 \mathrm{~m}_{\mathrm{Nb}}$ & $5.0 \mathrm{E}-3$ & 0.020 & 0.020 & 0.25 & 350 \\
\hline${ }^{94} \mathrm{Nb}$ & $5.0 \mathrm{E}-3$ & 0.020 & 0.020 & 0.25 & 350 \\
\hline $115_{\text {In }}$ & $4.0 \mathrm{E}-4$ & $4.0 \mathrm{E}-3$ & $1.4 \mathrm{E}-4$ & $8.0 \mathrm{E}-3$ & 1500 \\
\hline${ }^{93} \mathrm{Zr}$ & $5.0 \mathrm{E}-4$ & $2.0 \mathrm{E}-3$ & $3.0 \mathrm{E}-5$ & $5.5 \mathrm{E}-3$ & 3000 \\
\hline${ }^{107} \mathrm{Pd}$ & 0.040 & 0.15 & 0.01 & $4.0 \mathrm{E}-3$ & 60 \\
\hline${ }^{99} \mathrm{Tc}$ & 1.5 & 9.5 & 0.01 & $8.5 \mathrm{E}-3$ & 1.5 \\
\hline${ }^{63} \mathrm{Ni}$ & 0.060 & 0.060 & $1.0 \mathrm{E}-3$ & $6.0 \mathrm{E}-3$ & 150 \\
\hline${ }^{10} \mathrm{Be}$ & $1.5 \mathrm{E}-3$ & 0.010 & $9.0 \mathrm{E}-7$ & $1.0 \mathrm{E}-3$ & 650 \\
\hline${ }^{36} \mathrm{Cl}$ & 70.0 & 70.0 & 0.015 & 0.08 & 0.25 \\
\hline${ }^{59} \mathrm{Ni}$ & 0.060 & 0.060 & $1.0 \mathrm{E}-3$ & $6.0 \mathrm{E}-3$ & 150 \\
\hline${ }^{93} \mathrm{Mo}$ & 0.060 & 0.25 & $1.5 \mathrm{E}-3$ & $6.0 \mathrm{E}-3$ & 20 \\
\hline${ }^{79} \mathrm{Se}$ & 0.025 & 0.025 & $4.0 \mathrm{E}-3$ & 0.015 & 300 \\
\hline $113 \mathrm{~m} C d$ & 0.15 & 0.55 & $1.0 \mathrm{E}-3$ & $5.5 E-4$ & 6.5 \\
\hline${ }^{126} \mathrm{Sn}$ & $6.0 \mathrm{E}-3$ & 0.030 & $1.0 \mathrm{E}-3$ & 0.080 & 250 \\
\hline${ }^{135} \mathrm{Cs}$ & 0.030 & 0.080 & $7.0 \mathrm{E}-3$ & 0.020 & 1000 \\
\hline
\end{tabular}


Intruder scenarios consistent with the scenarios defined by the U.S.Nuclear Commission were analyzed (Kennedy, 1988). These scenarios were modified to account for INEL-specific and RWMC-specific characteristics. Three intruder exposure scenarios were evaluated:

\section{Intruder agriculture}

\section{Intruder construction}

\section{Intruder drilling.}

All the intruder scenarios assume that the intruder occupies the waste site after the end of institutional control (100 years). The intruder agriculture scenario estimates chronic exposure and assumes that a home and water well are constructed and food is grown on the site. Pathways considered include dust inhalation; ingestion of contaminated food (meat, milk, and vegetables); water consumption; and external exposure. The intruder construction scenario estimates the acute exposure received by an individual during construction of the home. Pathways include dust inhalation and external exposure. The intruder drilling scenario estimates the acute exposure received by an individual while a well is being drilled. Only the external exposure pathway is considered. A detailed description of each exposure scenario can be found in Case et al. (1990).

The intruder agriculture scenario is a chronic exposure scenario; therefore, radionuclide concentrations are based on a $100 \mathrm{mrem} / \mathrm{y}$ dose limit. The intruder construction and drilling scenarios are acute scenarios; therefore, radionuclide concentrations are based on a 500 mrem dose limit.

Radionuclide concentrations were calculated for LLW using two different types of disposal technologies (pits and soil vaults). The LLW was assumed to be buried beneath 5 meters of cover. Pit dimensions were $257 \times 122$ meters and 6.1 meters deep. The volume was $1.91 \mathrm{E}+05 \mathrm{~m}^{3}$ and the cover thickness was $4.87 \mathrm{~m}$. The pit was assumed to be placed 2.38 meters below grade; thus, 2.49meters of cover would remain above ground and be susceptible to erosion. The cover was estimated to erode down to grade in 2900 years. Soil vault dimensions were $15.9 \times 15.9$ meters and 3.05 meters deep. The volume was $771 \mathrm{~m}^{3}$, and the cover thickness was $5.8 \mathrm{~m}$. The vault was assumed to be placed 3.2 meters below grade; thus, 2.6 meters of cover would remain above ground and be susceptible to erosion. The cover was estimated to erode down to grade in 3000 years.

Radionuclide concentraiions were calculated for $100,300,500$, and 1000 years following closure of the waste facility in accordance with the original intruder calculations (Rood and Maheras, 1990). An additional case was run for each disposal technology at a time that corresponded to the time of maximum erosion of the cover. 


\section{SUMMARY OF RESULTS}

The radionuclide concentrations that yield the intruder doses specified in DOE Order 5820.2A (100 mrem/yr for chronic exposures and $500 \mathrm{mrem}$ for acute exposure) are presented in Table 25 for pits and Table 26 for soil vaults. The radionuclide with the most stringent concentration was Nb-94 $\left(7.9 \mathrm{E}-7 \mathrm{Ci} / \mathrm{m}^{3}\right)$ for the pits through the construction scenario at 2900 years. The primary pathway of exposure was external gamma; thus, the highest dose occurred when shielding between waste and receptor was at a minimum. This corresponded to 2900 years, the time of maximum erosion and minimum shielding.

The identification of $\mathrm{Nb}-94$ as a key radionuclide for LLW disposal application is consistent with the U.S. Nuclear Regulatory Commission waste concentration limits in 10 CFR 61.55. For example, $\mathrm{Nb}-94$ has an extremely low Class $\mathrm{C}$ concentration limit, $0.2 \mathrm{Ci} / \mathrm{m}^{3}$.

Although $\mathrm{Nb}-94$ is primarily an activation product produced through the activation of stable Nb-93 contained in many alloys used in nuclear applications, it can also be produced through nuclear fission (mass numbers of 94 have thermal fission yields in the range of 4.4 to $6.8 \%$ ). Thus, $\mathrm{Nb}-94$ represents the nuclide with the most stringent standards for both MFP and MAP waste.

A conservative estimate for the purposes of performance assessment is to assume the entire inventory of MFP and MAP is Nb-94. If other pathways are considered other than the pathways evaluated in this study, then Nb-94 may not be the most conservative nuclide to assume in the waste inventory. 
Table 25. Bounding radionuclide concentrations for the pit geometry.

\begin{tabular}{lllll}
\hline Radionuclide & $\begin{array}{c}\text { Dose } \\
(\mathrm{mrem} / \mathrm{yr})\end{array}$ & $\begin{array}{c}\text { Radionuclide } \\
\text { Concentration } \\
\left(\mathrm{Ci} / \mathrm{m}^{3}\right)\end{array}$ & $\begin{array}{l}\text { Bounding } \\
\text { Scenario }\end{array}$ & $\begin{array}{c}\text { Time } \\
(\mathrm{yr})\end{array}$ \\
\hline${ }^{90} \mathrm{Sr}$ & $1.8 \mathrm{E}-03$ & $5.6 \mathrm{E}+04$ & Agriculture & 100 \\
$137 \mathrm{Cs}$ & $3.9 \mathrm{E}+00$ & $2.6 \mathrm{E}+01$ & Agriculture & 100 \\
$151 \mathrm{Sm}$ & $3.2 \mathrm{E}-04$ & $3.1 \mathrm{E}+05$ & Agriculture & 100 \\
$93 \mathrm{~m}_{\mathrm{Nb}}$ & $2.9 \mathrm{E}-04$ & $3.5 \mathrm{E}+05$ & Agriculture & 100 \\
${ }^{94} \mathrm{Nb}$ & $6.3 \mathrm{E}+08$ & $7.9 \mathrm{E}-07$ & Construction & 2900 \\
$115 \mathrm{In}$ & $9.6 \mathrm{E}+01$ & $1.0 \mathrm{E}+00$ & Agriculture & 2900 \\
$93_{\mathrm{Zr}}$ & $3.8 \mathrm{E}+01$ & $2.6 \mathrm{E}+00$ & Agriculture & 2900 \\
$107 \mathrm{Pd}$ & $7.1 \mathrm{E}+00$ & $1.4 \mathrm{E}+01$ & Agriculture & 2900 \\
$99 \mathrm{Tc}$ & $4.3 \mathrm{E}+03$ & $2.3 \mathrm{E}-02$ & Agriculture & 2900 \\
$63_{\mathrm{Ni}}$ & $4.3 \mathrm{E}-03$ & $2.3 \mathrm{E}+04$ & Agriculture & 100 \\
$10 \mathrm{Be}$ & $5.1 \mathrm{E}+00$ & $2.0 \mathrm{E}+01$ & Agriculture & 2900 \\
$36 \mathrm{Cl}$ & $3.7 \mathrm{E}+05$ & $2.7 \mathrm{E}-04$ & Agriculture & 2900 \\
$59 \mathrm{Ni}$ & $3.6 \mathrm{E}+00$ & $2.8 \mathrm{E}+01$ & Agriculture & 2900 \\
$93 \mathrm{Mo}$ & $5.0 \mathrm{E}+01$ & $2.0 \mathrm{E}+00$ & Agriculture & 2900 \\
$79 \mathrm{Se}$ & $1.1 \mathrm{E}+02$ & $9.5 \mathrm{E}-01$ & Agriculture & 2900 \\
$113 \mathrm{~m} \mathrm{Cd}$ & $7.4 \mathrm{E}-05$ & $1.4 \mathrm{E}+06$ & Agriculture & 100 \\
$126 \mathrm{Sn}$ & $6.3 \mathrm{E}+05$ & $1.6 \mathrm{E}-04$ & Construction & 2900 \\
$135 \mathrm{Cs}$ & $2.8 \mathrm{E}+02$ & $3.6 \mathrm{E}-01$ & Agriculture & 2900 \\
\hline
\end{tabular}


Table 26. Bounding radionuclide concentrations for the soil vault geometry.

\begin{tabular}{lllll} 
Radionuclide & $\begin{array}{c}\text { Dose } \\
(\mathrm{mrem} / \mathrm{yr})\end{array}$ & $\begin{array}{c}\text { Radionuclide } \\
\text { Concentration } \\
\left(\mathrm{Ci} / \mathrm{m}^{3}\right)\end{array}$ & $\begin{array}{l}\text { Bounding } \\
\text { Scenario }\end{array}$ & $\begin{array}{c}\text { Time } \\
(\mathrm{yr})\end{array}$ \\
\hline${ }^{9}{ }_{\mathrm{Sr}}$ & $9.4 \mathrm{E}-04$ & $1.1 \mathrm{E}+05$ & Agriculture & 100 \\
$137 \mathrm{Cs}$ & $1.9 \mathrm{E}+00$ & $5.3 \mathrm{E}+01$ & Agriculture & 100 \\
$151_{\mathrm{Sm}}$ & $1.6 \mathrm{E}-04$ & $6.3 \mathrm{E}+05$ & Agriculture & 100 \\
$93 \mathrm{~m}_{\mathrm{Nb}}$ & $1.4 \mathrm{E}-04$ & $7.1 \mathrm{E}+05$ & Agriculture & 100 \\
$94 \mathrm{Nb}$ & $2.1 \mathrm{E}+04$ & $2.4 \mathrm{E}-02$ & Construction & 3000 \\
$115 \mathrm{In}$ & $4.5 \mathrm{E}-02$ & $2.2 \mathrm{E}+03$ & Agriculture & 100 \\
$93 \mathrm{Zr}$ & $1.8 \mathrm{E}-02$ & $5.6 \mathrm{E}+03$ & Agriculture & 100 \\
$107 \mathrm{Pd}$ & $3.3 \mathrm{E}-02$ & $3.0 \mathrm{E}+03$ & Agriculture & 100 \\
$99 \mathrm{Tc}$ & $2.0 \mathrm{E}+00$ & $5.0 \mathrm{E}+01$ & Agriculture & 100 \\
$63 \mathrm{Ni}$ & $2.3 \mathrm{E}-03$ & $4.3 \mathrm{E}+04$ & Agriculture & 100 \\
$10 \mathrm{Be}$ & $2.4 \mathrm{E}-03$ & $4.2 \mathrm{E}+04$ & Agriculture & 100 \\
$36 \mathrm{Cl}$ & $1.8 \mathrm{E}+02$ & $5.6 \mathrm{E}-01$ & Agriculture & 100 \\
$59 \mathrm{Ni}$ & $1.7 \mathrm{E}-03$ & $5.9 \mathrm{E}+04$ & Agriculture & 100 \\
$93 \mathrm{Mo}$ & $4.1 \mathrm{E}-02$ & $2.4 \mathrm{E}+03$ & Agriculture & 100 \\
$79 \mathrm{Se}$ & $5.1 \mathrm{E}-02$ & $2.0 \mathrm{E}+03$ & Agriculture & 100 \\
$113 \mathrm{~m} \mathrm{Cd}$ & $2.2 \mathrm{E}-02$ & $4.5 \mathrm{E}+03$ & Agriculture & 100 \\
$126 \mathrm{Sn}$ & $2.3 \mathrm{E}+04$ & $2.2 \mathrm{E}-02$ & Construction & 3000 \\
$135 \mathrm{Cs}$ & $1.3 \mathrm{E}-01$ & $7.7 \mathrm{E}+02$ & Agriculture & 100 \\
\hline
\end{tabular}




\section{REFERENCES}

Baca, R. G., S. O. Magnuson, FLASH Computer Code Verification, Benchmarking and Validation Document in review, Draft Published in September, 1990.

Baes, C. F., R. D. Sharp, A. L. Sjoreen, R. W. Shor, A Review and Analysis of Parameters for Assessing Transport of Environmentally Released Radionuclides Through Agriculture, Oak Ridge National Laboratory, ORNL-5786, September 1984.

Case, M. J., S. J. Maheras, M. A. McKenzie-Carter, M. E. Sussman, P.Voilleque, Radioactive Waste Management Complex Performance Assessment, EGG-WM-8773, June 1990.

DOE (U. S. Department of Energy), Characteristics of Spent Fuel. High-Level Waste and Other Radioactive Wastes Which May Require Long-Term Isolation, DOE/RW-0184, 1987.

Grove Engineering Inc., Microshield Version 3, April 1988.

Kennedy, W. E. and R. A. Peloquin, Intruder Scenarios for Site Specific Low-Level Radioactive Waste Classification, U. S. DOE National Low Level Radioactive Waste Management Program, DOE/LLW71T, September 1988.

Rood, A. S. and S. J. Maheras, Waste Concentration Limits Based on the Inadvertent Intruder Protection Standards for the Radioactive Waste Management Complex, letter from A. S. Rood to M. E. Sussman, ASR-10-90, December 1990.

Rogers, V. C. and C. Hung, PATHRAE-EPA: A Low-Level Radioactive Waste Environmental Transport and Risk Assessment Code, Methodology and Users Manual, EPA-520/1-87-028, 1987. 


\title{
INTRUDER DOSE CALCULATIONS FOR UNIDENTIFIED ALPHA RADIONUCLIDES DISPCSED OF AT THE RADIOACTIVE WASTE MANAGEMENT COMPLEX
}

\author{
Steven J. Maheras \\ Arthur S. Rood \\ Subsurface and Environmental Modeling Unit
}

May 1991

\section{INTRODUCTION}

Radioactive waste containingy radionuclides designated as unidentified alpha radioactivity has been disposed of at the Idaho National Engineering Laboratory Radioactive Waste Management Complex (RWMC). Traditionally, unidentified alpha activity has been converted to radionuclides such as Pu-239 or Po-210. While this may be a reasonable conversion over the operational life of the RWMC, this conversion may not be appropriate for the extended time periods over which perfonnance assessment analyses are typically performed. The purpose of this report is to provide a technical basis for the conversion of unidentified alpha activity to specific radionuclides that are reasonably conservative over performance assessment time frames. Implicit in this purpose is the desire to choose radionuclides that have a reasonable chance of being present in INEL waste.

Inadvertent intruder dose calculations to determine waste classification limits for the RWMC have been perforined using the PATHRAE (Rogers and Hung, 1987) and MICROSHIELD (Grove Engineering, 1988) computer codes. The calculations performed by Rood and Maheras (1990) used the assumptions and parameter values that were reported in the RWMC Performance Assessment (Case et al., 1990). The radionuclides examined in Rood and Maheras (1990) included Pu-238, Pu239, Pu-240, Pu-241, Pu-242, Am-241, U-233, U-235, and U-238. The analyses presented in Rood and Maheras (1990) serve as the basis for the conversion of unidentified alpha activity to specific radionuclides.

Each radionuclide was evaluated using inadvertent intruder scenarios and compared to the regulatory criteria in DOEOrder5820.2A for intruders (i.e., $100 \mathrm{mrem} / \mathrm{yr}$ for chronic exposures and 500 mrem for acute exposures). Specifically, a unit concentration of each radionuclide was assumed to exist in the waste. The radionuclide-specific dose through each of the intruder scenarios was calculated and compared to the DOE Order 5820.2A regulatory criteria by determining the concentration of each radionuclide that yielded the dose specified in the regulatory criteria. The radionuclide that exhibited the lowest concentration was chosen as being a conservative representation of unidentified alpha activity. This procedure is similar to the procedures used to determine waste classification limits. The assessment methodology and assumptions used in this analysis is described in detail in Waste Concentration Limits Based on the Inadvertent Intruder Protection Standards for the Radioactive Waste Management Complex (Rond and Maheras,1990) and the RWMC Performance Assessment (Case et al., 1990).

Various times and cover thicknesses were evaluated in Rood and Maheras (1990). For the purpose of this analysis the maximum dose assuming erosion of cover down to grade (some cover remains over the waste) was used. The hypothetical case of erosion down to the waste (no cover remains over the waste) was not included. It should be noted that the time of maximum dose does not necessarily correspond to the time of maximum erosion, especially for the drilling scenario. 


\section{SUMMARY OF RESULTS}

The radionuclide concentrations that yield the intruder doses specified in DOE Order 5820.2A are presented in Table 1 for pits and Table 2 for soil vaults. The radionuclide with the most stringent concentration was U-235 (8.6E-03 Ci/m ${ }^{3}$ at 2900 years) for the pit case therefore U-235 was chosen as the radionuclide conversion for unidentified alpha activity. However, the bounding radionuclide concentrations for the pit geometry were quite close for $\mathrm{Pu}-239, \mathrm{Pu}-240, \mathrm{Pu}-242, \mathrm{U}-$ 233, U-235, and U-238, within about a factor of 10 . This same phenomenon was also seen for soil vaults. This gives added confidence that a representative suite of radionuclides has been evaluated for the conversion of unidentified alpha activity to a specific radionuclide. 
Table 1. Bounding radionuclide concentrations for pit geometry.

$\begin{array}{llll}\text { Radionuclide } & \begin{array}{l}\text { Radionuclide } \\ \text { Concentration } \\ \left(\mathrm{Ci} / \mathrm{m}^{3}\right)\end{array} & \begin{array}{l}\text { Bounding } \\ \text { Scenario }\end{array} & \begin{array}{l}\text { Time } \\ (\mathrm{yr})\end{array} \\ \mathrm{Pu}-238 & 5.7 \mathrm{E}+01 & \text { Agriculture } & 100 \\ \mathrm{Pu}-239 & 2.4 \mathrm{E}-02 & \text { Agriculture } & 2900 \\ \mathrm{Pu}-240 & 3.0 \mathrm{E}-02 & \text { Agriculture } & 2900 \\ \mathrm{Pu}-241 & 5.6 \mathrm{E}+01 & \text { Agriculture } & 2900 \\ \mathrm{Pu}-242 & 2.3 \mathrm{E}-02 & \text { Agriculture } & 2900 \\ \mathrm{Am}-241 & 1.9 & \text { Agriculture } & 2900 \\ \mathrm{U}-233 & 1.6 \mathrm{E}-02 & \text { Agriculture } & 2900 \\ \mathrm{U}-235 & 8.6 \mathrm{E}-03 & \text { Agriculture } & 2900 \\ \mathrm{U}-238 & 4.5 \mathrm{E}-02 & \text { Agriculture } & 2900\end{array}$

From Rood and Maheras (1990), Tables 3.16

Table 2. Bounding radionuclide concentrations for soil vault geometry.

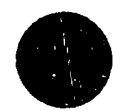

\begin{tabular}{ll}
\hline $\mathrm{Pu}-238$ & $1.1 \mathrm{E}+02$ \\
$\mathrm{Pu}-239$ & $4.7 \mathrm{E}+01$ \\
$\mathrm{Pu}-240$ & $4.7 \mathrm{E}+01$ \\
$\mathrm{Pu}-241$ & $1.5 \mathrm{E}+03$ \\
$\mathrm{Pu}-242$ & $5.0 \mathrm{E}+01$ \\
$\mathrm{Am}-241$ & $5.1 \mathrm{E}+01$ \\
$\mathrm{U}-233$ & $3.0 \mathrm{E}+01$ \\
$\mathrm{U}-235$ & 3.9 \\
$\mathrm{U}-238$ & 2.1
\end{tabular}

$\begin{array}{ll}\text { Agriculture } & 100 \\ \text { Agriculture } & 100 \\ \text { Agriculture } & 100 \\ \text { Agriculture } & 100 \\ \text { Agriculture } & 100 \\ \text { Agriculture } & 100 \\ \text { Construction } & 3000 \\ \text { Construction } & 3000 \\ \text { Construction } & 3000\end{array}$

From Rood and Maheras (100,0), Tables 3.34 


\section{REFERENCES}

Case, M. J., S. J. Maheras, M. A. McKenzie-Carter, M. E. Sussman, P.Voilleque, Radioactive Waste Management Complex Perfoimance Assessment, EGG-WM-8773, June 1990.

Grove Engineering Inc., Microshield Version 3, April 1988.

Rood, A. S. and S. J. Maheras, Waste Concentration Limits Based on the Inadvertent Intruder Protection Standards for the Radioactive Waste Management Complex, letter from A. S. Rood to M. E. Sussman, ASR-10-90, December 1990.

Rogers, V. C. and C. Hung, PATHRAE-EPA: A Low-Level Radioactive Waste Environmental Transport and Risk Assessment Code. Methodology and Users Manual, EPA-520/1-87-028, 1987. 


\section{APPENDIX G \\ STAFF CONTACTS, REVIEWERS AND SOURCES OF INFORMATION}


-

$M$

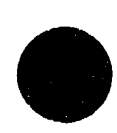

1

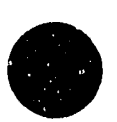

G-2 


\section{APPENDIX G \\ STAFF CONTACTS, REVIEWERS AND SOURCES OF INFORMATION}

The INEL staff contacts, reviewers and other sources of information are listed in this appendix.

Past and present staff of the INEL who have been contacted for information and/or document review are:

M. E. Sussman, Waste Management, project manager and reviewer

R. M. Brown, Waste Management, reviewer

R. B. Horton, Waste Management, reviewer

J. D. Wells, Waste Management, reviewer and source of information on RWMC

D. H. Rhodes, Waste Management, reviewer

S. J. Maheras, Performance Assessment Staff, reviewer

D. L. Litteer, Environmental Monitoring - coordinator of the RWMIS database, reviewer

T. Watanabe, Waste Management, worked on early RWMIS database, information source

G. B. Cassidy, WINCO, worked on early RWMIS database, information source

W. D. Mickesell, E.G.\&G. STD, worked on early RWMIS database, information source

J. W. Rodgers, E.G.\&G. TRA, nuclear engineer, source of information on TRA and early practices

J. F. Summers, E.G.\&G. TRA (retired), health physicist, source of information on TRA and early practices

H. Batchelder, Waste Management (past) managed early RWMIS database and data collection, information source

D. W. Colling, E.G.\&G. PBF, source of information on PBF

G. D. Gerber, E.G.\&G. PBF, review and source of information on PBF

J. D. Bradford, E.G.\&G. WERF, source of information WERF

R. F. Wasson, E.G.\&G. WERF, source of information WERF

D. K. Lainhart, E.G.\&G. CFA, source of information on CFA/ARA

D. J. Harvego, E.G.\&G. CFA, review and source of information on CFA/ARA 
R. H. Meservey, E.G.\&G. D\&D, review and source of information on D\&D

K. E. Streeper, E.G.\&G. TAN, review and source of information on TAN

I. G. Harrell, E.G.\&G. TAN, LLW shipping to the RWMC, source of information on TAN

S. J. Keating, E.G.\&G. TRA, LLW shipping to the RWMC, source of information on TRA

L. J. Toomer, E.G.\&G. TRA, source of information on TRA

J. D. Bishoff, E.G.\&G. RWMC, review and source of information on RWMC

L. C. Witbeck ANL-W, and source of information on ANL-W

J. D. Edelmayer, CPP, review and source of information on CPP

R. P. Grant, ANL-W, review and source of information on ANL-W

C. F. Walton, ANL-W, review and source of information on ANL-W

R. B. Allen, source of information on ANL-W, coordinated all ANL-W factilities and their response to the questionnaire

R. W. Ditch, ANL-E, source of information on ANL-E

R. B. Newbold, NRF (Westinghouse), review and source of information on NRF

J. F. Ruggiero, NRF (Westinghouse), source of information on NRF 

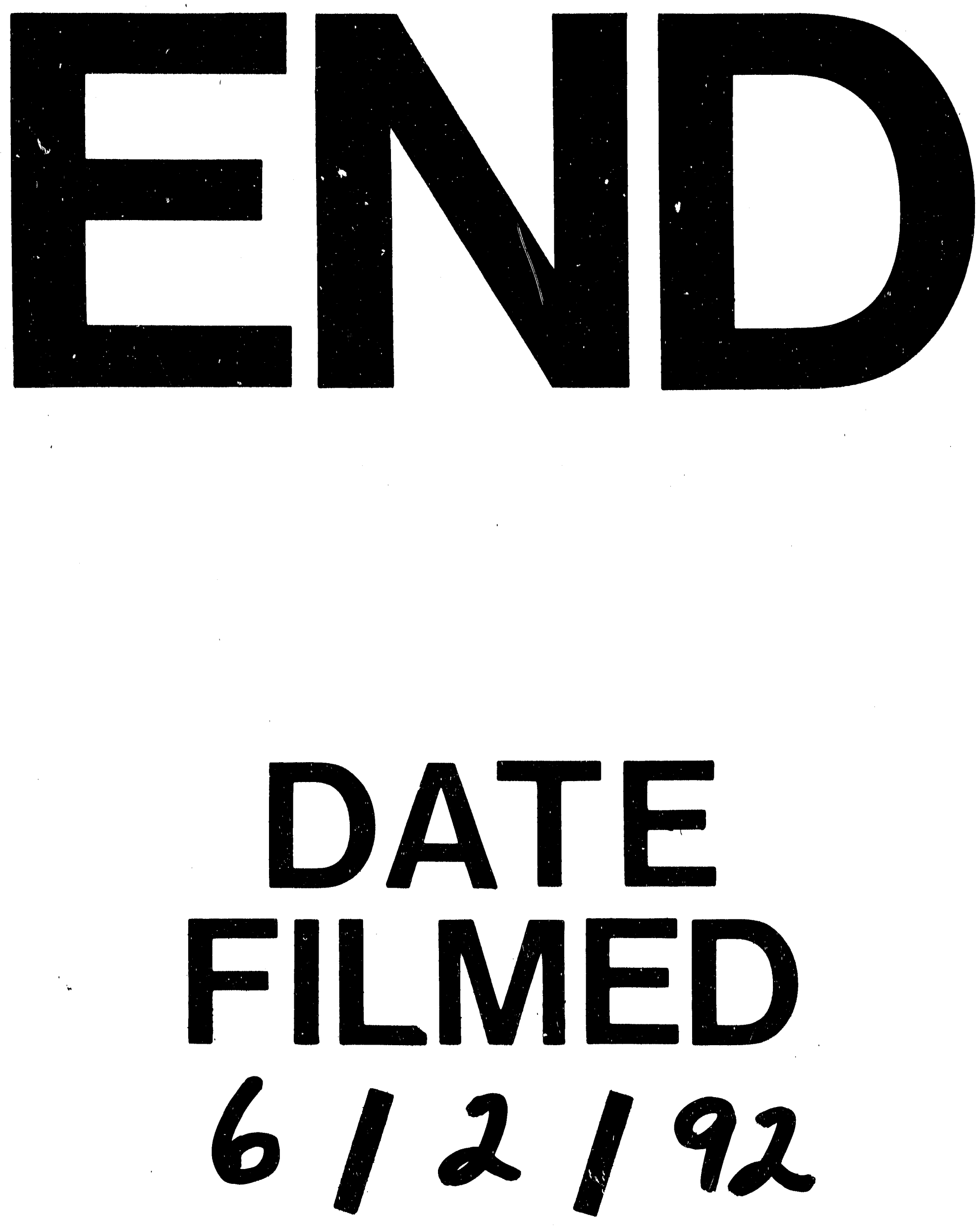

1 
